\title{
De benoeming van rechters : constitutionele aspecten van de toegang tot het rechtersambt in Nederland en in de Amerikaanse deelstaat New York
}

Citation for published version (APA):

de Werd, M. F. J. M. (1994). De benoeming van rechters : constitutionele aspecten van de toegang tot het rechtersambt in Nederland en in de Amerikaanse deelstaat New York. [Doctoral Thesis, Maastricht University]. Gouda Quint. https://doi.org/10.26481/dis.19940701mw

Document status and date:

Published: 01/01/1994

DOI:

10.26481/dis.19940701mw

Document Version:

Publisher's PDF, also known as Version of record

Please check the document version of this publication:

- A submitted manuscript is the version of the article upon submission and before peer-review. There can be important differences between the submitted version and the official published version of record.

People interested in the research are advised to contact the author for the final version of the publication, or visit the DOI to the publisher's website.

- The final author version and the galley proof are versions of the publication after peer review.

- The final published version features the final layout of the paper including the volume, issue and page numbers.

Link to publication

\footnotetext{
General rights rights.

- You may freely distribute the URL identifying the publication in the public portal. please follow below link for the End User Agreement:

www.umlib.nl/taverne-license

Take down policy

If you believe that this document breaches copyright please contact us at:

repository@maastrichtuniversity.nl

providing details and we will investigate your claim.
}

Copyright and moral rights for the publications made accessible in the public portal are retained by the authors and/or other copyright owners and it is a condition of accessing publications that users recognise and abide by the legal requirements associated with these

- Users may download and print one copy of any publication from the public portal for the purpose of private study or research.

- You may not further distribute the material or use it for any profit-making activity or commercial gain

If the publication is distributed under the terms of Article $25 \mathrm{fa}$ of the Dutch Copyright Act, indicated by the "Taverne" license above, 
De benoeming van rechters 
"Wat drommel! de regterlijke magt is uit ambtenaren zamengesteld en die ambtenaren zijn geene geheimzinnige symbolen, geene wijsgerige formulen; zij bestaan uit vleesch en beenderen gelijk wij, zij dwalen en begaan feilen gelijk wij, zij zijn even als wij rekenschap verschuldigd aan de openbare meening. Te vergeefs trachten zij zich te verschuilen achter den sluijer van dat groote woord: de regterlijke magt! Een regterlijk ambtenaar stelt evenmin de regterlijke magt daar als eene zwaluw de lente makkt. Neen; ongetwijfeld mag men niet te kort blijven in den eerbied, aan de regterlijke magt verschuldigd; ja, ongetwijfeld is de regterlijke magt het palladium onzer regten; gewis, de justitie is eene grootsche en schoone zaak, en het is de regterlijke magt, die haar vertegenwoordigt. De regterlijke magt; fiat.... het zij zoo....zeg ten haren voordeele zooveel gij wilt, kniel voor haar neêr, aanbid haar met het hoofd in het stof nedergebogen! Maar de regterlijke ambtenaren....O! deze behooren ons toe, wij kunnen de hand op hen leggen en in het openbaar hunne handelingen en hun geweten onderzoeken en doorgronden." Anonymus W 3206 (1870) 


\section{De benoeming van rechters}

Constitutionele aspecten van de toegang tot het rechtersambt in Nederland en in de Amerikaanse deelstaat New York

\section{Proefschrift}

ter verkrijging van de graad van doctor aan de Rijksuniversiteit Limburg te Maastricht, op gezag van de rector magnificus, Prof.dr. H. Philipsen, volgens het besluit van het College van Dekanen, in het openbaar te verdedigen op vrijdag 1 juli 1994 om 16.00 uur

door

Marcus Franciscus Johannes Maria de Werd

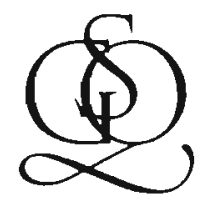

Gouda Quint bv

(S. Gouda Quint - D. Brouwer en Zoon)

Arnhem

1994 
Promotoren

Co-promotor

Beoordelingscommissie
: Prof.mr. F.A.M. Stroink

Prof.mr. C.A.J.M. Kortmann

: Mr. R.E. de Winter

: Prof.mr. E.C.M. Jurgens (voorzitter)

Prof.mr. J.C.M. Leijten

Prof.mr. N.H.M. Roos 
Voor Rob 


\section{Voorwoord}

"Et après ça il disait un grand ouf?" Bij die verzuchting - geleend uit het voorwoord van L. van Praag (Rechtspraak en voornaamste litteratuur op rechterlijke organisatie en daarmee verband houdende Wettelijke Bepalingen, 1906) - zou ik het willen laten, want, het is de laatste tijd vaker opgemerkt, er wordt al zoveel geklaagd door promovendi. Rest mij een welgemeend woord van dank aan mijn beide promotoren, Frits Stroink en Tijn Kortmann, voor het gedegen commentaar op, en de efficiënte afwikkeling van mijn onderzoek. In het bijzonder wil ik bedanken mijn co-promotor, Reiner de Winter, die tevens als begeleider optrad.

I am very much obliged to Walter Gellhorn (Columbia University School of Law in the City of New York) and to Elizabeth B. Hubbard (The Fund for Modern Courts) for their help during my stay in the United States. 

Deel I Object, probleemstelling en opzet van het onderzoek

\section{Hoofdstuk 1 Inleiding}

1.1 De benoeming van rechters 5

$\begin{array}{lll}1.2 & \text { Benoeming of selectie? } & 7\end{array}$

1.2.1 Selectie en de samenstelling van de rechterlijke macht $\quad 10$

1.2.2 De samenstelling van de rechterlijke macht als probleem van bevoegdheden 12

1.3 Perspectieven op de toegang tot het rechtersambt 15

$\begin{array}{lll}\text { 1.3.1 Selectiemethoden in het staatsrecht } & 17\end{array}$

$\begin{array}{ll}\text { 1.3.2 Het democratische perspectief } & 18\end{array}$

$\begin{array}{lll}\text { 1.3.3 Vraagtekens bij het democratische perspectief } & 20\end{array}$

$1.4 \quad$ Vraagstelling, opzet van het onderzoek en onderzoeksmethode 23

1.4.1 Waarschuwing vooraf 25

Deel II Het constitutionele kader

Hoofdstuk 2 De toegang tot het rechtersambt: het constitutionele kader

$2.1 \quad$ Inleiding

2.2 Het constitutionele kader 32

2.2.1 De begrippen 'benoeming' en 'aanwijzing' 33

$\begin{array}{ll}\text { 2.2.2 De benoeming voor het leven } & 33\end{array}$

2.2.2.1 De opheffing en ontbinding van gerechten 34

$\begin{array}{lll}2.2 .3 & \text { Vereiste van een wettelijke grondslag } & 38\end{array}$

2.2.3.1 Het begrip "inrichting van de rechterlijke macht" in
art. 116, tweede lid, GW

2.2.4 Delegatie 41 
2.3 De toegang tot het rechtersambt: de wettelijke regeling

2.3.1 Selectie: rechterlijke ambtenaren in opleiding

2.3.1.1 De raio-selectiecommissie

2.3.1.2 De Commissie aantrekken leden rechterlijke macht

2.3.2 Absolute en relatieve voorwaarden voor benoembaarheid

2.3.3 Benoemingen: algemeen

2.3.4 De procedure bij eerste benoemingen

2.3.5 De procedure bij verdere benoemingen

2.3.5.1 Benoeming van presidenten en vice-presidenten

2.3.5.2 De herziene benoemingsprocedure president rechtbank

2.3.6 Benoeming raadsheer Hoge Raad 53

2.3.6.1 Situatie sinds $1992 \quad 54$

2.3.6.2 Benoeming (vice-)president Hoge Raad 55

2.3.6.3 Keuzemogelijkheid $\quad 55$

2.3.7 Benoemingsnota, benoeming en beroep 56

$\begin{array}{lll}\text { 2.3.7. } & \text { Beroep } & 57\end{array}$

2.3.8 Benoeming in deeltijd 58

2.3.8.1 Deeltijd en anciënniteit 61

$2.4 \quad$ Vraagtekens bij de toegang tot het rechtersambt 63

2.4.1 Werving 63

2.4.2 Selectie en benoeming $\quad 64$

2.4.2.1 Gesloten circuits $\quad 65$

$\begin{array}{ll}2.4 .3 \quad \text { Benoembaarheidsvereisten } & 67\end{array}$

2.4.3.1 Aanvaarding van de benoeming: ambtseed 67

2.5 De toegang tot het rechtersambt: nabeschouwing 69

Deel III Historische grondslagen

Hoofdstuk 3 De toegang tot het rechtersambt:

historische grondslagen

3.1 Inleiding

3.2 Historische inspiratiebronnen

3.3 De Grondwet van 1814/1815: grondslag voor de rechterlijke organisatie

3.3.1 De voordracht als staatsrechtelijke anomalie $\quad 78$

3.3.1.1 De Grondwetscommissie $1814 \quad 80$

3.3.1.2 De Grondwet van $1815 \quad 82$

3.4 Totstandkoming en invoering van de Wet op de Regterlijke Organisatie 1827

3.4. I De aanbeveling 84

3.5 Benoembaarheidsvereisten: de Grondwet 1814 en $1815 \quad 86$ 
3.5.1 Wettelijke benoembaarheidsvereisten

3.5.2 Motivering van de bencembaarheidsvereisten

3.6 De rechterlijke organisatie in de periode 1838-1871

93

3.6.1 Aanscherping van de benoembaarheidsvereisten

95

3.6.1.1 De juridische opleiding

97

3.7 De aanhevelingslijsten

3.7.1 De interpellatie-Hoynck van Papendrecht

3.7.2 Verzet tegen de aanbevelingslijsten

100

3.7.2.1 Kritiek buiten de Tweede Kamer

102

3.7.3 Omslag. invloed van het ministerie van justitie

3.7.3.1 Brochures van Pols en Loke

103
104

3.7.3.2 Laatste poging tot afschaffing van de aanbevelingslijsten

106

3.7.3.3 Restauratie van het stelsel van aanbevelingen

108

3.8 Terug naar de voordrachten: periode 1840-1887

109

3.8.1 Preadviezen NJV 1883

111

3.8.1.1 Reacties op de preadviezen van Heemskerk en Tellegen

114

3.8.1.2 Negentiende-eeuwse perceptie van rechtersverkiezingen

115

3.8.2 De grondwetsherziening van 1887

116

3.8.3 Voorstel tot grondwetsherziening 1913 en het Genootschap voor den Rechtsstaat 1940

119

3.9 De benoembaarheid van vrouwen in de rechterlijke macht

122

3.9.1 Pleidooien van Simons voor de benoembaarheid van vrouwen

3.9.2 Wet Invoering kinderrechter 1921

124

3.9.2.1 De adviezen van de president van de Hoge Raad en de procureur-generaal bij de Hoge Raad

126

128

128

3.9.3 Initiatief-wetsvoorstel Marchant 1922

3.9.4 Preadviezen van Scheltema en Cluysenaer

3.9.4.1 Reacties op de preadviezen van Scheltema en Cluysenaer

3.9.4.2 Heymans over Heymans

3.9.5 Benoeming van J.C. Hudig tot kinderrechter

$3.10 \quad$ Nabeschouwing

Hoofdstuk 4 Benoeming en benoembaarheid: ontwikkelingen na de Tweede Wereldoorlog

4.1 Inleiding

4.2 De toegang tot het rechtersambt na de Tweede Wereldoorlog Commissie-Verdam Het Permanent College van advies

4.5.1 De publieke opinie over klassejustitie 
4.5.2 Rijksbegroting $1970 \quad 161$

$\begin{array}{lll}4.5 .3 & \text { Beeldvorming } & 162\end{array}$

4.6 Recrutering van buitenstaanders 166

4.6.1 De Commissie aantrekken leden rechterlijke macht 166

$\begin{array}{ll}\text { 4.6.2 Invoering gerechtsauditeurs } & 167\end{array}$

4.7 A.J. Cnoop Koopmans: Rechter en politiek 168

$\begin{array}{lll}4.8 & \text { Promotiefuncties } & 171\end{array}$

$\begin{array}{lll}\text { 4.8.1 Openstelling promotiefuncties } & 174\end{array}$

4.9 Benoembaarheidsvereisten 176

4.9.1 Het vereiste van het Nederlanderschap 176

$\begin{array}{ll}\text { 4.9.2 Het opleidingsvereiste } & 179\end{array}$

4.9.3 Incompatibiliteiten 181

4.9.3.1 Politieke nevenfunctie van A.J. Cnoop Koopmans 183

4.9.3.2 Kwestie-Van den Biesen 190

4.9.3.3 De NVvR over nevenfuncties 193

4.10 Recente ontwikkelingen 198

4.10.1 De kwestie-Van der Burg $1991 \quad 200$

4.10.1.1 Steun voor Van der Burg 205

4.10.1.2 Enquête Vrij Nederland $\quad 207$

4.10.2 De reorganisatie van de rechterlijke macht 209

4.10.2.1 De Raad voor de rechterlijke macht $\quad 210$

4.11 Nabeschouwing 213

4.11.1 Twee perspectieven 213

4.11.2 De rechterlijke organisatie in de toekomst 215

Deel IV Het democratische perspectief

Hoofdstuk 5 De toegang tot het rechtersambt in de Amerikaanse deelstaat New York

$5.1 \quad$ Inleiding

5.2 Rechterlijke organisatie in de staat New York 223

5.3 Rechtersverkiezingen in de staat New York 224

5.3.1 Kritiek op het verkiezingsproces 226

$\begin{array}{ll}5.3 .2 & \text { De nominatie } \\ 5.3 .3 & 228\end{array}$

$\begin{array}{ll}5.3 .3 & \text { Campagnevoering } \\ 5.3 .4 & 229\end{array}$

$\begin{array}{lll}5.3 .4 & \text { De verkiezing } & 232\end{array}$

5.3.5 Invloed van verkiezingen op vertegenwoordiging van vrouwen en minderheden $\quad 233$

5.3.6 Belang bij rechtersverkiezingen 234

5.4 Rechtershenoemingen in de staat New York 235

5.4.1 De Association of the Bar of the City of New York 238 
5.5 Rechtersverkiezingen: historische achtergronden 241

5.5.1 Invoering verkiezingsstelsel in New York $1846 \quad 244$

5.5.2 Rechtersverkiezingen in federaal perspectief

5.5.3 Problemen met rechtersverkiezingen: invloed van Tammany Hall

5.5.4 Oprichting van de Association of the Bar of the City of New York

$\begin{array}{lll}\text { 5.5.5 Onregelmatigheden bij rechtersverkiezingen } & 254\end{array}$

5.6 Voorstellen tot grondwetswijziging na $1846 \quad 258$

$\begin{array}{lll}5.7 & \text { Merit selection } & 261\end{array}$

$\begin{array}{lll}5.7 .1 & \text { Albert Kales-Plan } 1914 & 263\end{array}$

$\begin{array}{lll}\text { 5.7.2 California Court Plan } 1934 & 266\end{array}$

$\begin{array}{lll}\text { 5.7.3 Missouri Court Plan } 1940 & 267\end{array}$

$\begin{array}{lll}\text { 5.7.4 Ervaringen met het Missouri Court Plan } & 269\end{array}$

$\begin{array}{ll}\text { 5.7.5 Kritische kanttekeningen bij merit selection } & 270\end{array}$

$\begin{array}{lll}5.7 .5 .1 & \text { Citizen knowledge } & 271\end{array}$

$\begin{array}{lll}\text { 5.7.5.2 Selectiecriteria } & 273\end{array}$

$\begin{array}{lll}5.8 & \text { Recente ontwikkelingen: merit selection versus representatie } 274\end{array}$

5.8.1 Proefprocessen en voorstellen tot grondwetswijziging 278

$5.9 \quad$ Nabeschouwing

Hoofdstuk 6 Het democratische perspectief
$6.1 \quad$ Inleiding
6.2 De trias politica: machtenscheiding
6.3 De taak van de rechter versus de legitimatie van de rechterlijke macht: het toetsingsrecht
6.3.1 Het toetsingsrecht en de legitimatie van de rechter
6.3.2 Administratieve rechtspraak
6.4 De legitimatie van de rechter en de toegang tot het rechtersambt
6.4.1 Verkiezingen als referentiekader
6.4.1.1 Relativering van het referentiekader
6.4.1.2 De verkiezing versus de benoeming van rechters als schijncontroverse
6.5 Rechterlijk activisme
$\begin{array}{lll}6.5 .1 & \text { Analoge probleemstelling } & 302\end{array}$
$\begin{array}{lll}6.5 .2 & \text { Afspiegeling } & 303\end{array}$
$\begin{array}{lll}\text { 6.5.3 De onathankelijkheid van de rechter } & 305\end{array}$
6.6 Terug naar de eerste stap: machtenscheiding of evenwicht van machten? 
6.6.2 Evenwicht van machten en de samenstelling van de rechterlijke macht

6.6.2.1 Dissenting en concurring opinions

6.7 Nabeschouwing

\section{Deel V Slot}

\section{Hoofdstuk 7 Epiloog}

7.1 De toegang tot het rechtersambt: terugblik

7.2 Nabeschouwing

7.3 Slot

Bijlagen

Summary

Literatuurlijst

Zakenregister

Personenregister

Curriculum 


\section{Lijst van afkortingen}

$\begin{array}{ll}\text { AA } & \text { Ars Aequi } \\ \text { Awb } & \text { Algemene Wet Bestuursrecht } \\ \text { Bijl. Hand. I } & \text { Bijlage Handelingen Eerste Kamer } \\ \text { Bijl. Hand. II } & \text { Bijlage Handelingen Tweede Kamer } \\ \text { CRvB } & \text { Centrale Raad van Beroep } \\ \text { GW } & \text { Grondwet } \\ \text { KB } & \text { Koninklijk Besluit } \\ \text { MvA } & \text { Memorie van Antwoord } \\ \text { MvT } & \text { Memorie van Toelichting } \\ \text { NJB } & \text { Nederlands Juristenblad } \\ \text { NVvR } & \text { Nederlandse Vereniging voor Rechtspraak } \\ \text { OM } & \text { Openbaar Ministerie } \\ \text { OvW } & \text { Ontwerp van wet } \\ \text { RvS } & \text { Raad van State } \\ \text { Stb. } & \text { Staatsblad } \\ \text { VV } & \text { Voorlopig Verslag } \\ \text { W } & \text { Weekblad van het Recht } \\ \text { Wet AB } & \text { Wet Algemene Bepalingen } \\ \text { Wet RO } & \text { Wet op de Rechterlijke Organisatie }\end{array}$


Deel I

Object, probleemstelling en opzet van het onderzoek 


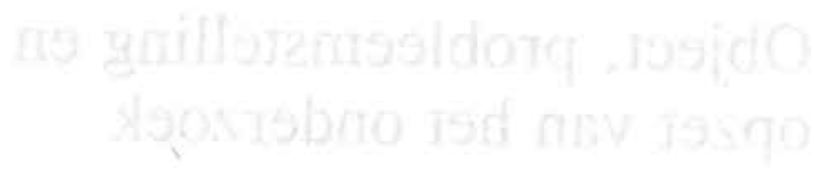




\title{
Inleiding
}

'Rechter getroffen door slagroomtaart', is de kop boven een klein maar intrigerend krantebericht op 17 januari 1992:

\begin{abstract}
"De fungerend president van de Amsterdamse rechtbank, mr. J.M. Vrakking is gisteren getroffen door een slagroomtaart. Na de behandeling van een kort geding over de ontruiming van een pand aan de Hobbemakade in Amsterdam, wierp een kraker een taart in de richting van de president. Deze wist het projectiel in een reflexbeweging te ontwijken, waarna het via zijn stoel terecht kwam op een muurschildering. Rondvliegende slagroom besmeurde de toga van de president, die niet onder de indruk was van de aanslag. (-) De krakers wilden met dit gebaar onderstrepen dat ze hun vertrouwen in de 'partijdige rechtspraak' hebben verloren. ${ }^{n 1}$
\end{abstract}

Het sweeping statement van de krakers is hier de metafoor voor wat elders wel de 'dynamiek in de trias' is genoemd. ${ }^{2}$ Het krantebericht weerspiegelt een controverse die de laatste jaren in de Tweede Kamer, in de rechtsliteratuur, en in de pers heeft plaatsgevonden over enerzijds de taak van de rechter in controversiële vraagstukken (hier: het kraken) en anderzijds de vraag naar de legitimatie van de rechterlijke macht. Die is, zoals F.A.M. Stroink in zijn oratie de klassieke opvatting weergeeft, 'immers' niet samengesteld met het oog op de beoordeling van dergelijke vraagstukken. "De wetgever, waarvan de rechtstreeks gekozen volksvertegenwoordiging deel uitmaakt, behoort het laatste woord te hebben. De rechter wordt benoemd en heeft derhalve geen enkele democratische legitimatie. ${ }^{3}$ Moeten rechters dan misschien gekozen worden, vraagt R.E. de Winter zich af, "Of moeten ze - net als in de Verenigde Staten publiekelijk gescreend worden". ${ }^{4}$ Onzin, meent C.A.J.M. Kortmann, de feilen van het huidige rechterlijke bestel zitten niet in de wijze van benoeming van

1. Rechter getroffen door slagroomtaan, NRC Handelsblad, 17 januari 1992

2. Vergelijk de congresbundel van het Raio-congres 1987 in Veldhoven: De rechter als dictator? Dynamiek in de trias. Verschuivingen in de verhouding regelgeving, bestuur en rechispraak, 1987

3. F.A.M. Stroink, De plaats van de rechter in het staatshestel, 1990, p. 15

4. Reiner de Winter, De overheid, 1991, p. 161 
rechters. ${ }^{5}$ Dat laatste zou ik, al was het maar om niet onmiddellijk al het gras voor mijn voeten te laten wegmaaien, nog even in het midden willen laten. Laten we het er, met een voorschot op de conclusies in hoofdstuk 4, voorlopig op houden dat het vraagstuk van de toegang tot het rechtersambt in de literatuur vrij beperkt aan bod komt, meestal in de afronding van een enkel betoog, en dan nog slechts naar aanleiding van een krantebericht.

Toch staan de organisatie, de samenstelling van de rechterlijke macht en de rechterlijke functie de laatste jaren in een groeiende wetenschappelijke belangstelling. Terecht, want men hoeft, zo bleek al, de krant maar open te slaan om te zien dat de rechterlijke macht, zoals De Montesquieu haar in 1748 voorstelde bepaald niet meer 'en quelque façon nulle ${ }^{*}$ is, en men kan ernstig betwijfelen of zij werkelijk nog steeds 'the least dangerous branch' is, zoals Publius (Alexander Hamilton) in 1787 beweerde. $^{7}$

"It is difficult to overestimate the significance of the judiciary in the Modern State. The work of the executive has become so vast, the powers delegated to it by the legislature are so wide, that judges are, perhaps more than at any previous time, the real safeguard of personal liberty. (-) Obviously, therefore, the method by which judges are appointed, the kind of men, further, it is customary to choose, these questions become a matter of the first importance",

aldus Harold J. Laski in $1926 .{ }^{8}$ Hij neemt die nieuwe taak als uitgangspunt voor een studie naar de Technique of judicial appointment, die samen met de ideeën van Albert Kales de grondslag legde voor de huidige discussie over merit selection in de Amerikaanse deelstaten. ${ }^{9}$ Hoewel ook in ons land de interesse voor de wijze van samenstelling van de rechterlijke macht groeit, ontbrak een uitgebreide studie over de toegang tot het rechtersambt tot nu toe. Dit boek poogt in die lacune te voorzien. Het onderwerpt het constitutionele kader van de toegang tot het rechtersambt aan een nader onderzoek, en beschrijft de parlementaire geschiedenis die aan de invoering en de verdere ontwikkeling van de benoembaarheid in, en de benoeming tot de rechterlijke macht ten grondslag heeft gelegen. Voorts poogt deze studie de relevante aspecten van de toegang tot het rechtersambt voor het moderne staatsrecht in kaart te brengen. Dit eerste hoofdstuk beoogt de reikwijdte van het vraagstuk

5. C.A.J.M. Kortmann, Redactionele kanttekeningen Reorganisatie van de rechterlijke macht?, RM Themis, 1991, p. 370

6. C.L. de Montesquicu. De l'Esprit des Lois, 1748, livre XI. ch. VI

7. The' Fetleralist Pupers, nr. 78

8. Harold J. Laski. The technique of judicial appointment, voor het eerst gepubliceerd in: Michigan Law Review, 1926, p. 539 e.v. Zie ook: Studies in law and politics, 1932. p. 163

9. Zic verder bij hoofdstuk 5 
van de toegang tot het rechtersambt aan te geven en bakent het onderzoeksterrein af.

\subsection{De benoeming van rechters}

De leden van de rechterlijke macht met rechtspraak belast en de procureurgeneraal bij de Hoge Raad worden bij koninklijk besluit voor het leven benoemd, aldus art. 117, eerste lid, GW. Volgens de Wet RO bieden de colleges waarin een vacature openvalt een aanbeveling van drie (bij de Hoge Raad: zes) personen aan de Koning (dat wil zeggen: aan de regering) aan, 'om daarop zodanig acht te slaan als Hij zal dienstig oordelen'. Bij de benoeming van een lid van de Hoge Raad zit tussen de aanbeveling van de Hoge Raad en de benoeming door de regering een extra stap. De Tweede Kamer maakt uit de aanbeveling van de Hoge Raad een voordracht op van drie kandidaten, waaruit de regering een keuze maakt. ${ }^{10}$

Over de eigenlijke benoeming door de regering komt weinig naar buiten. Duidelijk is wel dat het ministerie van justitie zich zeer sterk laat leiden door de aanbevelingen van de rechtbanken en de gerechtshoven, hetgeen misschien al blijkt uit de schaarse achtergrondinformatie (gemiddeld 10 regels) die het ministerie bij het opmaken van de benoemingsnota ter beschikking staat. Veel schijnt zo'n benoeming, waaraan een audiëntie - alleen de presidenten en vicepresidenten worden door de minister zelf ontvangen - vooraf gaat, niet om het lijf te hebben, want de gedoodverfde kandidaat staat binnen twintig minuten weer buiten. "Na zo'n 1000 benoemingen en 750 audiënties stel ik mijzelf de vraag: hoe vaak had je van de aanbeveling willen afwijken en hoe vaak heb je dat de Minister ook geraden? Het antwoord luidt: uiterst zelden. Bij eerste benoemingen bijna nooit, bij benoemingen in promotiefuncties zelden", aldus topambtenaar J. Demmink van het ministerie van justitie in 1993. ${ }^{11}$ J.L.R. van Vliet beaamt dit en zegt dat het ministerie zich zeer terughoudend opstelt bij benoemingen, zeker als het gaat om het inwinnen van extra informatie over de aanbevolen kandidaten: "Wij steken onze neus liever niet in andermans zaken", aldus Van Vliet. "Alleen als het gerechtshof, dat de aanbeveling van de rechtbank doorstuurt, een afwijkend advies geeft, is dat een signaal voor het ministerie om eens met de betreffende rechtbankpresident te bellen. "12

10. Zie voor een uitgebreide beschrijving van de wettelijke regeling: hoofdstuk 2

11. J. Demmink, Justitia zonder blinddoek: de rechterlijke benoeming, in: Kabaal in Holland, 1993, p. 109

12. Interview met J.L.R. van Vliet, Hoofd Onderafdeling Personeclsvoorziening en Administratief Beheer van de Hoofdafdeling Personeelszaken, Ministerie van Justitie, Den Haag, 25 juni 1991 
Maar of de regering van een aanbeveling afwijkt, laat staan waarom zij afwijkt, komt niet in de openbaarheid, want aanbevelingen worden sinds de jaren zeventig niet meer gepubliceerd. Daarvoor bestaat overigens een vrij triviale reden. "We kregen het op een gegeven moment nogal druk", aldus Van Vliet, "en tja, hoe gaan die dingen, het is er gewoon bij ingeschoten. Maar ja wie interesseert zich nou eigenlijk voor die aanbevelingen, dat gaat toch alleen de betrokkenen iets aan?" Dat het bij de publikatie van aanbevelingen om een klassiek staatsrechtelijk onderwerp gaat, waarover in de Tweede Kamer en in de literatuur in de vorige eeuw regelmatig werd gedebatteerd ${ }^{13}$, was men kennelijk vergeten. Dat is jammer, want mogelijke verdachtmakingen aan het adres van de regering, als zou zij bepaalde personen stelselmatig wel of niet benoemen, zouden zo ontzenuwd kunnen worden. Bovendien blijft nu de vraag, wie precies de hand heeft gehad in een bepaalde benoeming - de minister van justitie als politiek verantwoordelijk ambtsdrager of de rechterlijke macht zelf onbeantwoord. Inmiddels is de praktijk tot regel verheven, want de circulaires die sinds 1975 de selectie van presidenten en vice-presidenten regelen, vermelden uitdrukkelijk dat aanbevelingen niet gepubliceerd mogen worden. ${ }^{14}$

Toch komt een enkele maal, per ongeluk, een verschil van mening tussen het aanbevelende gerecht en het ministerie van justitie aan het licht. Zo was er in Alkmaar in 1993 enige consternatie, toen - zoals dat in jargon heet - een vacature president rechtbank openviel. De rechtbank Alkmaar maakte een aanbeveling van drie personen op, en zette een vrouw op de eerste plaats. De regering benoemde evenwel de nr. 2 op de aanbeveling, een man. Voldoende reden voor Nicoline Baartman om bij deze 'verdere benoeming' in de Volkskrant de vrouwvriendelijkheid van het ministerie van justitie in twijfel te trekken. "Wie dat hardop durft te zeggen, verdient een lintje", aldus Baartman. In een reactie zegt de vice-president van het gerechtshof Amsterdam, J. Willems-Morsink: "Als het om topfuncties in de rechterlijke macht gaat, gelden klaarblijkelijk andere normen. Een vrouw past niet in het plaatje, he. Ik word daar niet vrolijker van. Ik vind dat de minister iets heeft uit te leggen. " Zover kwam het echter niet, want om 'privacy-overwegingen' wilde het ministerie van justitie geen mededelingen over deze zaak doen. ${ }^{15}$

Maar niet alleen tussen het ministerie en de gerechten, ook tussen de leden van een rechtbank of een gerechtshof onderling bestaat - kennelijk - wel eens verschil van mening over de aan te bevelen kandidaten. Als de rechtbank Roermond in 1992 de burgemeester van het Limburgse Hunsel voor de vacature van rechter-plaatsvervanger op de aanbeveling plaatst, laat een minderheid van de

13. Zic hoofdstuk 3

14. Zic hoofdstuk 2

15. Nicolinc Baarman, Mevr. Justitia, de Volkskrant, 15 mei 1993 
rechters, die naar verluidt bestaat uit de helft min een, weten dat de rechtbankvergadering 'in beslotenheid de trias politica' heeft opgeheven. Zij vreest voor de onafhankelijkheid van de rechterlijke macht als een bestuurder uit hetzelfde rechtsgebied rechtsprekende taken kan uitoefenen. Maar het allerergste, zo leek het, was toch dat mededelingen over een besloten vergadering naar buiten waren gebracht. De president van de Roermondse rechtbank sprak van een 'ernstige zaak' ${ }^{\text {'6 }}$, en A.F.M. Brenninkmeijer spreekt na de consternatie in Alkmaar over een 'onfris mediarelletje'. ${ }^{17}$ Men vergat evenwel dat er ook positieve kanten aan deze openbaarheid zitten. Het is voor de burger immers een geruststellende gedachte te weten dat er in Roermond kennelijk zo scrupuleus over de rechtsstaat wordt gewaakt. ${ }^{18}$ Openheid over aanbevelingen en benoemingen van rechters is in de praktijk van het Nederlandse staatsrecht echter een heikel punt. Dat bleek ook toen het CDA-Tweede Kamerlid V.A.M. van der Burg eind 1991 pleitte voor 'meer inzicht' in de aanbevelingen van de Hoge Raad. De Tweede Kamer maakt immers uit de aanbeveling van de Hoge Raad een voordracht op van drie kandidaten. Van der Burg zei te vermoeden dat de Hoge Raad eenzijdig is samengesteld uit raadsheren met een 'nieuw-liberale' (lees: D66) levenshouding. Hij meende dat de Tweede Kamer, bij het opmaken van een voordracht voor de Hoge Raad, beter moet opletten dat de Hoge Raad een 'afspiegeling' van de samenleving vormt. Ook nu reageerde de rechterlijke macht als door een wesp gestoken, net als de media zèlf trouwens. NRC Handelsblad bijvoorbeeld verweet de 'grijpgrage' CDApolitici 'platvloers opportunisme' en het Utrechts Nieuwsblad noemde het plan een 'Onzalig idee'. ${ }^{19}$

\subsection{Benoeming of selectie?}

Inmiddels mag duidelijk zijn, dat wie over de toegang tot het rechtersambt spreekt, niet alleen het oog heeft (zou moeten hebben!) op het formele benoemingsbesluit van de regering, maar bijvoorbeeld ook op de aanbeveling en de voordracht van rechters. De benoeming van een rechter is immers slechts de allerlaatste - en minst interessante - fase in een lange reeks van selectiemomenten. Die reeks neemt goed beschouwd reeds een aanvang met de werving, rekrutering en selectie van de potentiële leden van de rechterlijke macht: de 'raio's' en de 'buitenstaanders'. Raio's (rechterlijke ambtenaren in opleiding) zijn juristen zonder praktijkervaring, die na de universitaire studie Nederlands

16. Marcel Haenen, Geschil over benoeming hurgemeester tot plaatsvervanger Conflict rechters Roermond, NRC Handelsblad, 8 oktober 1992

17. A.F.M. Brenninkmeijer, Talent gewogen, Trema, 1993-8, p. 306

18. Zie ook mijn bijdrage in NRC Handelsblad, Er is niets mis mee als burgemeester ook rechter is, 19 oktober 1992

19. Zie hoofdstuk 4 
Recht, de zesjarige raio-opleiding volgen. $\mathrm{Na}$ die opleiding worden zij benoemd als gerechtsauditeur bij een rechtbank, en later tot rechter, of - wanneer zij opteren voor een loopbaan bij het openbaar ministerie - tot substituutofficier van justitie. Het ministerie van justitie hanteert als beleidslijn dat de leden van de rechterlijke macht voor maximaal $50 \%$ worden gerecruteerd uit raic's, en voor minimaal $50 \%$ uit buitenstaanders. 'Buitenstaanders' zijn juristen met minimaal zes jaar praktijkervaring, die hetzij de 'overstap' naar de rechterlijke macht willen maken, hetzij vanuit hun huidige werkkring als rechter-plaatsvervanger benoemd willen worden. Behalve een opleidingsvereiste, geldt voor alle aspirant leden van de rechterlijke macht het vereiste van de Nederlandse nationaliteit en het verbod van bepaalde nevenfuncties. Raio's worden geselecteerd door de raio-selectiecommissie, buitenstaanders komen terecht bij de Commissie aantrekken leden rechterlijke macht (ook wel de Commissie-buitenstaanders.

Net als over de benoeming zèlf, komt weinig naar buiten over de gang van zaken bij de selectiecommissies. Dat is merkwaardig, want naar verluidt valt maar liefst drie kwart van alle kandidaten voor het rechtersambt af, hetzij bij de psychologische test, hetzij bij de selectiecommissies, of 'onderweg' bij de aanbeveling of de benoeming. Naarmate de samenstelling van de rechterlijke macht - zie hierboven bij de kwestie-Van der Burg - kennelijk belangrijker wordt, zou men verwachten dat het, bijvoorbeeld voor de Tweede Kamer, interessanter wordt juist de in- en doorstronm van rechters in de gaten te houden. Hoe is bijvoorbeeld de gang van zaken bij de selectiecommissies; wie selecteert en controleert de selecteurs, welke selectiecriteria hanteren de commissies, en welke kandidaten passeren de selectie wel (en welke niet) en waarom? Wie informeert bij RPD Advies, de instelling die kandidaten ten behoeve van de selectiecommissies een psychologische test afneemt, krijgt op ietwat schichtige toon te horen, dat over de selectie en zelfs over de objectieve selectiecriteria, geen mededelingen worden gedaan. Een interview - zo verzekert men met klem - heeft dan ook weinig zin. "Belt u maar eens met de Commissie-Buitenstaanders." Zoveel discretie is toch wel vreemd, want wie wil worden toegelaten tot bijvoorbeeld de raio-opleiding is mede afhankelijk van het eindrapport van RPD Advies. ${ }^{20}$ Opnieuw rijst de vraag wie de selecteurs selecteert, welk rechtersbeeld deze psychologen hanteren (en waarom), en aan de hand van welke criteria dat getoetst wordt.

De secretaris van de Commissie aantrekken leden rechterlijke macht, N.J. van der Lee, reageert duidelijk minder verkrampt op verzoeken om eens iets te vertellen over 'zijn' commissie. Geen wonder, want, zo zegt hij: "wij hebben 
hier niets te verbergen. ${ }^{21}$ De Commissie aantrekken leden rechterlijke macht, die zetelt in het Haagse Paleis van Justitie, bepaalt grotendeels zèlf haar samenstelling. Begonnen als een experiment in de jaren zeventig, heeft zij nu stilzwijgend een permanente status verkregen. Dat spreekt niet helemaal voor zich, want anders dan bij de raio-selectiecommissie, is over de samenstelling en de werkwijze van de Commissie Buitenstaanders vrijwel niets geregeld. ${ }^{22}$ Toch zegt de Commissie zeer tevreden te zijn. Het 'onderonsje' dat een rechtersbenoeming vroeger was, waarbij alles binnenskamers geregeld werd, is volgens Van der Lee, zelf kantonrechter te Haarlem, doorbroken. De rechtbanken vinden de Commissie dan ook wel eens 'lastig', met name als kandidaten, die door de rechtbanken 'gestuurd' zijn, door de Commissie worden afgewezen. "Ik vermoed daarom dat de meeste rechtbanken de selectie graag weer zelf zouden doen", glimlacht Van der Lee. Bij de beoordeling van de kandidaten is het 'geworteld zijn in de maatschappij' voor de Commissie een belangrijk criterium; 'kamergeleerden' worden niet op prijs gesteld. In het tweede gesprek met de kandidaat wordt daarom gevraagd naar activiteiten buiten de werkkring en naar hobby's. Inhoudelijke toetsing van de kandidaten geschiedt veelal aan de hand van actuele kwesties in de literatuur en in de jurisprudentie (euthanasie, gelijke behandeling). Naar politieke voorkeur en geloofsovertuiging wordt niet gevraagd. Niettemin kunnen bepaalde voorkeuren via een omweg aan de orde komen. Zo vraagt de Commissie bijvoorbeeld welke dag- en weekbladen de kandidaat leest. 'Linkse' of 'rechtse' georiënteerdheid werkt niet in het nadeel van kandidaten, eenzijdigheid wel. Ook bepaalde combinaties van persoonskenmerken kunnen problemen opleveren. Van der Lee noemt het voorbeeld van iemand die Jehova's getuige is, een zekere dwingendheid uitstraalt en van wie het RPD-rapport aangeeft dat hij slecht luistert. "In het betreffende geval rees bij de commissieleden de vraag of een zekere 'voet-tussen-de-deur'mentaliteit zich niet ook in zijn rechtspraak zou doorzetten", aldus Van der Lee.

De Commissie gaat ervan uit dat een kandidaat 'een maal in de fout' mag gaan - "winkeldiefstal, bepaalde jeugdzonden, het komt gelukkig niet veel voor" maar de marges zijn smal. Een niet te zware veroordeling (geen vrijheidsstraf) wegens rijden onder invloed bijvoorbeeld, levert niet noodzakelijk een bezwaar op voor een positief oordeel van de Commissie, maar weer wel indien dit minder dan twee jaar geleden is gebeurd, en de betreffende persoon in hetzelfde arrondissement benoemd wil worden. "Zo'n grens heeft natuurlijk altijd iets willekeurigs", geeft Van der Lee toe, die ook overigens enigszins sceptisch is over selectie, en vooral over het aandeel van de psychologische test daarin.

21. Interview met N.J, van der Lee, secretaris van de Commissie aantrekken leden rechterlijke macht, 15 maart 1993, Den Haag

22. Zie hoofdstuk 2 en 4 
"Selecteren is, net als solliciteren trouwens, mensenwerk. Is onze waarneming als selecteur deugdelijk? Hoe ziet de mens er van binnen uit? Is de 'foto' van de psychologen betrouwhaar?" 'Verkeerde mensen' zegt hij echter nauwelijks binnen te halen, al vindt hij het jammer dat sommige 'goede mensen' soms toch afgewezen worden, bijvoorbeeld omdat het gesprek niet goed loopt. Daarom willen sommige commissieleden, hij een stemverhouding 6-0 waarna geen revisie meer mogelijk is ${ }^{23}$, hun mening nog wel eens herzien.

\subsubsection{Selectie en de samenstelling van de rechterlijke macht}

Uit het bovenstaande blijkt dat selectiecommissies een nuttige functie vervullen, en een belangrijke stempel drukken op de samenstelling van de rechterlijke macht. Het is een geruststellende gedachte te weten, dat bijvoorbeeld de Commissie aantrekken leden rechterlijke macht alleen 'goede mensen' binnenhaalt en 'verkeerde mensen' buiten de deur houdt. Toch rijst de vraag wat eigenlijk goede en slechte rechters zijn. 'Goed' en 'slecht' in welk verband'? De feitelijke werkzaamheden van een rechter kunnen immers ver uiteen lopen, zeker naarmate hij ${ }^{24}$ verder opklimt in de rechterlijke hiërarchie. Praten we over de rechter als rechtspreker, of over de rechter-commissaris in het vooronderzoek'? Gaat het over collegiale of over unusrechtspraak? Moet een rechter, als president van een college, misschien typische managerskwaliteiten hebben' En tenslotte. in welke hoedanigheid treedt een rechter op; in de straf-, civicle- of bestuurssector"? "Bij een niet gering aantal collega s staat nog steeds vorop dat een goed civilist alles kan", zegt Van der Lee, die er echter van doordrongen is dat "een goed civilist wel eens een hele slechte strafrechter kan $-i j n$ ". En daarmee wordt de vinger op een zere plek gelegd, want bij de aanhangige reorganisatie van de rechterlijke macht, is het uitgangspunt dat rechters moeten rouleren in de verschillende kamers, en in de toekomst zullen rechters - uit overwegingen van kostenhesparing - zoveel mogelijk als 'unus' optreden.

Wie let op de problemen waarvoor selectiecommissies zich geplaatst zien, vraagt zich wellicht, net als Maurice Rosenberg (Columbia University), af: 'The qualities of justices- are they strainable?'. Rosenberg verhaalt van een selectiecommissie in New York, die het na 18 maanden vergaderen eens werd over de 'minimal standards' voor een goede rechter:

"Besides naming integrity, legal ability, "above-average legal experience", good health, industry, and diligence, the committee's report prescribed "judicial tem-

23. Zie Bijlage 2

24. 'Hij' is overigens, zoals Leijten al heeft opgemerkt, tegenwoordig vaak een 'zij' (al treft men vrouwen vooral nog in de lagere echelons van de rechterlijke macht aan; zie hoofdstuk 4). Jan Leijten, De rechter, in: Brullen als een nachtegaal, 1993, p. 11 
perament, " which it defined "as a condition of courtesy, dignity, patience, tact, humor, and a personality free from arrogance, pomposity, irascibility, impatience, loquacity, bias, prejudice and ability to listen and keep an open mind. " As a Florida journalist exclaimed upon hearing the bar committee's definition: "Why, that man was crucified 2,000 years ago! 'm2s

Wat de persoonskenmerken van een goede rechter zijn zal, zo is de boodschap van Rosenberg, wel altijd een probleem blijven. In elk geval zal het antwoord op die empirisch-sociologische vraag, niet van het staatsrecht komen, dat immers 'slechts' een poging is om de uitwendige voorwaarden te scheppen waarbinnen juiste beslissingen worden genomen. Toch bevat ook het staatsrecht - bewust of onbewust, dat valt hierna nog te bezien - een bepaald rechtersbeeld. Hiervoor zagen wij bijvoorbeeld dat de Grondwet en de Wet RO bepaalde voorwaarden voor benoembaarheid formuleren, die mogelijk niet alleen met de persoon maar ook met de persoonlijkheid van een kandidaat (kunnen) samenhangen: het vereiste van het Nederlanderschap, het verbod van bepaalde nevenactiviteiten en een juridische opleiding. Het is niet onwaarschijnlijk dat bijvoorbeeld de rechtenstudie, en later het rechtersambt, juist bepaalde mensen aantrekt en andere weer afstoot. Amerikaanse onderzoeken uit de jaren zeventig geven een weinig aantrekkelijk beeld van rechtenstudenten in die tijd: cynisch, agressief, zelfzuchtig, onzeker en nerveus. ${ }^{26}$ Dat is ongeveer de definitie die staatssecretaris Gabor in 1993 gaf voor het castreren en muilkorven van pitbulls. Dat een dergelijke studentenpopulatie en dito beroepsbevolking potentiële studenten zou kunnen afschrikken ligt voor de hand. Eenmaal de drempel van de opleiding genomen, rijst de vraag waarom sommige juristen wel en andere niet solliciteren naar het ambt van rechter. Staat de functie hun niet aan, wordt zij onvoldoende gehonoreerd, of spelen mogelijke reserves ten opzichte van een vermeend esprit de corps (een ons-kent-ons-sfeer) misschien (mede) een rol? C. de Gooijer, vice-president van het College van Beroep voor het Bedrijfsleven, wijst in een interview op de 'keurigheid' van rechters ('grijs met een streepje'). Met alle gevolgen van dien: "Na een vergadering kan niemand zijn regenjas meer terugvinden, ze zijn allemaal hetzelfde", aldus De Gooijer. ${ }^{2 ?}$

Het rechtersbeeld in het staatsrecht is niet alleen het gevolg van expliciete wettelijke vereisten, maar soms ook het resultaat van hepaalde 'vanzelfsprekendheden' in de samenleving. Het mannelijk geslacht hijvoorbeeld is nooit een

25. Maurice Rosenberg, The qualities of justices - are they strainable?. Texas Law Review, 1966, p. 1079

26. N.H.M. Roos, Juristerij in Nederland. 1981, p. $80-81$

27. Marc Josten en J. van Tijn, De rechterlijke macht van Nederland: een geruststellend gezelschap, Vrij Nederland. 2 november 1991, p. 42 
wettelijke voorwaarde voor benoembaarheid tot het rechtersambt geweest, maar de regering heeft tot 1947 - op advies van de procureur-generaal bij de Hoge Raad, Noyon - met succes volgehouden dat vrouwen 'juridisch' niet benoembaar zijn als rechter. Vrouwen zijn, zo meende Noyon, tijdens de menstruatie immers "niet normaal", en je zult als rechtzoekende maar net de pech hebben om een ongestelde rechter te treffen. ${ }^{28}$ Ook een bepaalde gelonfsovertuiging, het bezit van eigen kapitaal of volledige beschikbaarheid voor de rechterlijke functie behoorden lange tijd tot de vooronderstellingen voor een benoeming in de rechterlijke macht. ${ }^{29}$

\subsubsection{De samenstelling van de rechterlijke macht als probleem van bevoegdheden}

De samenstelling van de rechterlijke macht omvat, anders dan uit het voorgaande zou kunnen blijken, behalve de instroom van rechters, ook de door- en uitstroom uit de rechterlijke macht. Bij het probleem van de 'doorstroom' van rechters kan men denken aan de selectie die optreedt doordat rechters promotie maken (of juist niet) en met de jaren hoger in de hiërarchie komen, en daarmee - zoals Leijten schrijft - 'almaar machtiger' worden. ${ }^{30}$ Het probleem van de doorstroom vindt echter ook plaats door de interne selectie die optreedt door de vorming van enkel- en meervoudige kamers binnen de gerechten. Rechters die niet functioneren kunnen op een 'zijspoor' worden geplaatst; zij maken geen promotie, of worden - in het geval van rechters-plaatsvervangers - niet meer opgeroepen. Bij de uitstroom uit de rechterlijke macht kan worden gedacht aan de schorsing en het ontslag, maar ook aan vacatures die openvallen door het overlijden van een rechter.

Anders dan de in- en de doorstroom, wordt vooral de uitstroom van rechterlijke ambtenaren in de literatuur in verband gebracht met de 'onafhankelijkheid' van de rechter(lijke macht). Er is letterlijk geen handboek in het (staats)recht te vinden waarin de 'benoeming voor het leven' van rechters en de regeling van de rechtspositie en het ontslag 'op de gronden bij de wet bepaald', geen waarborgen voor de onafhankelijkheid van de rechter worden genoemd. In onze rechtsstaat zijn rechters, zo lijkt de boodschap, 'onafzetbaar'. Of toch niet? Er zijn tal van casusposities denkbaar waardoor de samenstelling van het

28. T.J. Noyon, Brief aan de Hoge Raad van 10 mei 1921, Bijl. Hand. II 1920-1921, nr. 75-13. Zie ook: hoofdstuk 3

29. Zie hoofdstuk 3 en 4

30. Hij voegt daar aan toe dat voor deze groep de 'verleiding om verschrikkelijk eigenwijs en behoudend te worden' bijna niet is te weerstaan. Jan Leijten, Kromme carrières (een wellicht onwelgevallig voarstel), in: De verschrikkelijke eenzaanheid van de inbreker, 1992, p. 93 
rechtersbestand verandert. Bevoegdheden, die niet voor dat doel zijn gegeven, kunnen een belangrijk selectie-effect in zich dragen. Het gevaar dreigt (in theorie) dat een 'belanghebbend' orgaan, (de wetgever, de regering of een minister) zo'n hevoegdheid zal misbruiken, en via een omweg zal pogen lastige rechters te verwijderen of monddood te maken.

Als afschrikwekkend voorbeeld geldt meestal een buitenlands voorheeld, namelijk het Court Packing Plan, dat in de jaren dertig in Amerika tegen het U.S. Supreme Court in stelling werd gebracht. Op het hoogtepunt van de recessie in 1933 stelde de Democratische president Roosevelt de New Deal voor, een reeks maatregelen die het hoofd moest bieden aan de toenmalige economische crisis. Het Supreme Court, dat op dat moment uit een conservatieve meerderheid bestond, verklaarde in een aantal opeenvolgende arresten de New Deal-wetgeving ongrondwettig. Gesterkt door zijn herverkiezing ontwikkelde Roosevelt in 1937 een plan om de rechtspraak van het Supreme Court te beïnvloeden. Door het aantal rechters in het Supreme Court uit te breiden, hoopte Roosevelt door de benoeming van een aantal nieuwe 'Democratische' rechters de koers van het Supreme Court te veranderen. Vór het zover kwam koos het Supreme Court echter eieren voor zijn geld, en ging in een aantal arresten wat betreft de $N c w$ Deal 'om'. ${ }^{31}$

Een andere manier om de omvang en de kwaliteit (type rechters: oud/jong) van het rechtersbestand te veranderen, en daarmee de koers van een rechtscollege te beïnvloeden, is het wijzigen van de leeftijdsgrens voor zittende rechters (thans zeventig jaar). Het is bepaald niet ondenkbaar dat rechtspolitieke of politieke argumenten, daarbij een rol spelen. In 1932 schrijft J.C. Van Oven over de "leiders der rechtsontwikkeling, deze rechtsvinders bij uitnemendheid" in de Hoge Raad:

"Mij dunkt, voor hen gelden de motieven voor een tijdig afscheid nog meer dan voor anderen. Laat ons niet in het abstracte blijven, maar een voorbeeld noemen: men leze eens de namen der raadsheeren die de arresten over art. 1401 B.W. geveld hebben in de jaren voor 1919, met die, welke het befaamde arrest van 31 Januari van dat jaar hebben gewezen, en beantwoorde dan de vraag of deze heilzame nieuwe rechtspraak, die a.h.w een nieuw hoofdstuk in de ontwikkeling van ons privaatrecht heeft geopend, niet 'n jaar of tien vroeger zou zijn aanvaard, indien voor den H.R. de 65-jarigen leeftijdsgrens had gegolden. ${ }^{n 32}$

31. Zie bijvoorbeeld: William Lasser, The limits of judicial power, 1988, p. 111 e.v.

32. J.C. van Oven, De leefiydsgrens: niel 70, maar 65, in: NJB, 1932, p. 633-637 Zie ook de reactie van V.D. Krone, die de juistheid van de opmerkingen van Van Oven betwijfelt. en wijst op de 'wonderen' die juist de oude rechter "rijp aan ervaring. volkomen op de hoogte van den eisch van het maatschappelijk verkeer" kan verrichten. 
De (zeventigjarige) leeftijdsgrens kwam er inderdaad, zij het niet om de rechtspraak te beïnvloeden, maar om een evenmin erg fraaie reden, nl. als bezuinigingsmaatregel. Door de invoering van een leeftijdsgrens, kon een groot aantal 'overtollige' rechters, worden ontslagen, en konden de gerechten inkrimpen. Niet voor niets noemde het Tweede Kamerlid Tilanus het ontwerp een 'crisiskindje ${ }^{33}$, iets wat de minister van justitie Donner niet tegensprak. ${ }^{34}$

Tenslotte zou men kunnen beslissen een gerecht met onwelgevallige of oude rechters maar helemaal op te heffen, een probleem dat in ons land nauwelijks wordt onderkend. Rechters zijn 'immers' onafhankelijk en onafzetbaar. Toch zullen bij de tweede fase van de aanhangige reorganisatie van de rechterlijke macht, de kantongerechten worden 'geïntegreerd' in de rechtbanken. Juridisch betekent deze 'integratie' echter niets anders dan de opheffing en ontbinding van de kantongerechten. De 'oude' kantonrechters zullen - zo schrijft de regering geruststellend - 'in beginsel' deel gaan uitmaken van de rechtbank nieuwe stijl, als betrof het hier een bijzondere gunst, en niet het uitvloeisel van een grondwettelijk beginsel. De gevaren die aan deze constructie kleven zijn evident, en roepen vragen op omtrent het waarborgkarakter dat wij in de benoeming voor het leven van rechters plegen te zien. ${ }^{35}$ Tevergeefs waarschuwt J.T. Buijs in 1884, in een vergelijkbaar geval, al dat de deur die men hier openstelt: "om aan het grondwettig gebod te ontsnappen, vroeger of later ook ten dienste [staat] van een minder gemoedelijken wetgever, wien het om eene zoogenaamde zuivering van de rechterlijke collegiën te doen mocht zijn. ${ }^{\text {"36 }}$

Toch zou het te gemakkelijk zijn om in de voorgaande gevallen zonder meer van misbruik van bevoegdheden te spreken. Wat de opheffing van de kantongerechten bij de aanstaande herziening betreft, wordt, zoals gezegd, mogelijk de deur opengezet voor politieke zuiveringen in de rechterlijke macht. Toch rijst de vraag of het - los van het feit of er werkelijk van ongrondwettigheid sprake is - zo onredelijk is dat een regering beleid wenst te ontwikkelen, en een verouderde organisatie van de rechterlijke macht wil verbeteren, zonder daarmee dertig jaar te wachten totdat de laatste kantonrechter de pensioengerechtigde leeftijd heeft gehaald. Kortom: weegt het uitgangspunt van de onafhankelijke positie van de rechter per se zwaarder dan het belang van de verdachte of de justitiabele, dat zijn rechtszaak tijdig wordt afgehandeld, of omgekeerd dan het belang van de samenleving dat misdadigers hun straf niet ontlopen omdat de redelijke termijn is overschreden?

in: NJB, 1932, p. $760-762$

33. Hand. II 1932-1933, p. 208

34. Hand. II 1932-1933, p. 211

35. Zie over deze kwestie verder in hoofdstuk 2

36. J.T. Buijs, De Grondwet toelichting en kritiek II, 1884, p. 480 
Eenzelfde probleem rijst bij de twee andere voorbeelden. Valt zelfs voor evident schurkachtige bedoelingen van regering en wetgever met de rechterlijke macht soms niet iets te zeggen? Was het, ten tijde van de New Deal, in morele maar ook in staatkundige zin, terecht dat het U.S. Supreme Court, bestaande uit negen rechters, het risico nam om een compleet werelddeel willens en wetens te laten afglijden in een economische recessie, tegen een uitdrukkelijke kiezersuitspraak in? Hadden president en Congres werkelijk lijdzaam moeten blijven toekijken, enkel omwille van de onafhankelijkheid van de rechterlijke macht? $\mathrm{Zo}$ ja, wat is dat dan voor principe waarin het doel alle middelen heiligt; welke visie op verdeling van verantwoordelijkheden in de staat steekt achter die conceptie van de onafhankelijkheid van de rechterlijke macht? Maar - en nu draai ik de zaak weer om - wat als president Eisenhower en het Congress in 1954, zelfs al was er sprake geweest van een kiezersuitspraak, door middel van een Court Packing Plan de uitspraak in Brown v. Board of Education (die een doorbraak betekende in de strijd tegen rassen-segregatie), nadelig ten opzichte van de zwarte burgers had willen beïnvloeden? Waarom ligt het - goddank - dan opeens weer 'anders'?

\subsection{Perspectieven op de toegang tot het rechtersambt}

Net als het probleem van de toegang tot het rechtersambt, strekt het probleem van de samenstelling van de rechterlijke macht veel verder dan een discussie over louter de benoeming van rechters. De samenstelling van de rechterlijke macht is immers het resultaat van veel meer selectiemomenten dan het enkele benoemingsbesluit. Sommige van die momenten zijn publiekrechtelijk geregeld, andere worden voorondersteld, weer andere zijn het gevolg van voor- of zelfselectie. Tenslotte kan de samenstelling van de rechterlijke macht gemanipuleerd worden door het oneigenlijk gebruik van bevoegdheden.

Gezien de gevoeligheid van een selectiesysteem voor kunstgrepen, en de gevolgen daarvan voor de samenstelling van de rechterlijke macht, rijst - en ik beperk mij nu verder tot de toegang tot het rechtersambt - de vraag welk perspectief op het aantrekken van rechters voorop moet staan. Het ligt in dit no nonsense-tijdperk voor de hand het vraagstuk van de toegang tot het rechtersambt allereerst op te vatten als een vraagstuk van personeelsvoorziening. In termen van personeelsmanagement is selectie een middel om te komen tot een adequate personeelsvoorziening, nl. zorgen dat op het gewenste tijdstip de juiste mensen aanwezig zijn om een organisatie naar behoren te laten functioneren. ${ }^{37}$ Daarbij geldt bovendien 'tijd is geld'. Om die reden adviseerde de Projectgroep werkbelasting gerechten in 1985, naar aanleiding van een advies 
van het organisatiebureau Berenschot, bij vacatures het wettelijke aanbevelingsrecht van rechters en Openbaar Ministerie maar te schrappen; dit leidt 'immers" alleen maar tot "overbodige tijdsbesteding en een verlenging van de benoemingsprocedure. ${ }^{138}$

Hoewel een zekere rationalisering tegenwoordig ook aan het rechtsbedrijf niet vreemd is, kunnen inzichten uit het personeelsmanagement toch niet zonder meer op de toegang tot het rechtersambt worden toegepast. Dat houdt verband met een eigenaardigheid van het publiekrecht. Daarbij springt allereerst in het oog dat de premisse voor het commerciële personeelsmanagement - het rationele beslissingsmodel dat grotendeels gebaseerd is op nutsmaximalisatie - niet het overheersende uitgangspunt mag zijn bij de selectie van publieke ambtsdragers. Minstens zo belangrijk als de keuze voor de 'right man in the right place', is de procedure die aan die keuze vooraf gaat. Deze mag bijvoorbeeld, op grond van art. $3 \mathrm{GW}$, dat bepaalt dat alle Nederlanders op gelijke voet benoembaar zijn in de openbare dienst, niet leiden tot willekeurige of krenkende ongelijke behandeling. ${ }^{39}$

De Grondwet kent ten aanzien van de toegang tot de daarin genoemde ambten een drietal basismethoden of principes purs ${ }^{40}$ : vererving (koningschap), verkiezing (Tweede en Eerste Kamer, Provinciale Staten, gemeenteraad) en benoeming (bijvoorbeeld: ministers, leden van de rechterlijke macht, Commissaris van de Koning en de burgemeester). Daarbinnen bestaat een aantal mengvormen. Voor de bezetting van rechterlijke ambten valt te denken aan de benoeming na aanbeveling en de benoeming na verkiezing (voordrachtsprocedure voor leden van de Hoge Raad). Dat de verschillende selectiemethoden in het staatsrecht (vererving, verkiezing, benoeming) net als in het personeelsmanagement berusten op een rationeel beslissingsmodel valt ernstig te betwijfelen; in de praktijk staat immers niets er aan in de weg dat volstrekt ongeschikten sleutelposities innemen in de staat (hoewel dat naar verluidt in het bedrijfsleven niet anders is). De verschillende selectiemethoden in het staatsrecht ontlenen hun bestaansrecht dan ook aan iets anders, namelijk aan de omstandigheid dat, afhankelijk van de betrokken selectiemethode, de kring van betrokkenen bij de aanstelling van ambtsdragers groter, en daarmee - kennelijk ${ }^{41}$ - meer of minder democratisch is. Op deze schaal lijkt helemaal links de directe verkiezing

38. Projectgruep werkbelasting gerechten, Onderacok functioneren rechterlijke organisalie. 29 januari 1985 , p. 4-5

39. Vergelijk C.A.J.M. Kormann, De grondwetsherzieningen 1983 en 1987,1987 , p. 72

40. De term is ontleend aan: Raoul de la Grasserie, De la justice en France et à l'élranger, 1914. p. 241

41. Op het verband tussen de legitimatie van de rechter, en de wijze waarop hij wordt angesteld, kom ik in hoofdstuk 6 uitgebreid terug. 
te staan, en verder naar rechts: de indirecte verkiezing, de benoeming, coöptatie, en vererving. Het feit dat een (selectie-)bevoegdheid berust op de Grondwet en niet op een wet, een algemene maatregel van bestuur, een ministerieel besluit, een circulaire, op jurisprudentie of gewoonte, is, zo is althans de hypothese, een zeer principiële keuze die teruggrijpt op fundamentele noties in onze staatsinrichting; welk orgaan beslist op basis van welke bevoegdheid over welk onderwerp, wie controleert dat en op basis van welke informatie kan men dat doen?

\subsubsection{Selectiemethoden in het staatsrecht}

Inmiddels is de vraag gesteld naar de historische keuze voor de factoren die de toegang tot het rechtersambt bepalen, en de relevantie van die keuze voor het hedendaagse staatsrecht. Historisch komt men zowel de benoeming, de verkiezing en de coöptatie van rechters, als de vererving van het rechtersambt tegen, al behoeft die laatste variant - zoals Laski al nors opmerkt - geen nadere studie, "Since (-) the thesis upon which the Western civilization is increasingly built is a denial of hereditary right". ${ }^{42}$ Daaruit blijkt al dat de keuze voor bepaalde selectiemethoden in het staatsrecht niet uit de lucht komt vallen. De gedachte aan een Koning bij beurtwisseling, een erfelijk parlement, een regering door loting ${ }^{43}$ of benoemde gemeenteraden, geeft reeds het gevoel dat de wijze van aanstelling van ambtsdragers in het (huidige) staatsrecht wel 'iets' met democratie, 'iets' met deskundigheid en 'iets' met taken en bevoegdheden te maken zal (zou moeten?) hebben. De ontwikkeling van de parlementaire democratie en de invoering van het algemeen kiesrecht voor de verkiezing van de leden van de Tweede Kamer lijken enig causaal verband te hebben. Maar hoe zit het met de aanstelling van andere publiekrechtelijke ambtsdragers, zoals ministers, leden van de Raad van State en van de Algemene Rekenkamer, rechters en burgemeesters, waarvan de benoemingsprocedure werd vastgesteld in een tijd waarin democratie nog een scheldwoord was? Al snel rijst het vermoeden dat het begrip toegang tot het rechtersambt, een moderne conceptie is, waar in de vorige eeuw niemand aan dacht, bijvoorbeeld omdat keuzes voor de hand lagen (familiebanden), uit hun aard beperkt waren (aanbod van juristen) of, gezien de taak van de rechter, van betrekkelijk belang waren (de nachtwakerstaat).

42. Laski, o.c. p. 164

43. J.H.A. Logemann noemt loting en beurtwisseling als historisch voorkomende methoden. Over de theorie van een stellig staatsrecht, 1948, p. 93 


\subsubsection{Het democratische perspectief}

Dat de huidige regeling van de aanstelling van veel publiekrechtelijke ambtsdragers samenhangt met de moderne opvattingen over hun functievervulling, taakuitoefening of bevoegdheid ligt niet voor de hand, maar zou het dan tenminste niet zo moeten zijn? Met een zekere regelmaat wordt dit wel beweerd ten aanzien van de - gewijzigde - taak van verschillende geprononceerde ambten in ons staatsbestel. J.P. Rehwinkel ziet in 1991 voor de veranderde functie van de minister-president een 'legitimatienoodzaak'; voor het aantreden en de ambtsvervulling dient de minister-president over een eigen legitimatie te beschikken, afwijkend van die van andere ministers, die in overeenstemming is met de zwaarte van zijn functie. ${ }^{44} \mathrm{Hij}$ stelt daarom de figuur van een gekozen minister-president voor ${ }^{45}$ Scherp treedt het conflict tussen de legitimiteit en (de uitoefening van) bevoegdheden naar voren in de discussie over de positie van de Eerste Kamer. Veelal wordt als hoofdbezwaar tegen een Eerste Kamer, die zich al te activistisch (d.i. een Eerste Kamer die het werk van de Tweede Kamer 'overdoet') opstelt, aangevoerd dat zij niet rechtstreeks gekozen wordt (een 'zwakkere legitimatie' heeft). ${ }^{46}$ Ook in de discussie over de benoemde of gekozen burgemeester staat de relatie tussen de wijze van aanstelling en bevoegdheid centraal. De burgemeester van Enschede, $\mathrm{H}$. Wierenga, brengt die legitimatie-noodzaak duidelijk onder woorden:

"Vanuit een principieel, democratisch standpunt moet de burgemeester gekozen worden. Als een democratie geacht wordt regulering van de volkswil te zijn, dun is een benoemde burgemeester daarmee in strijd. De legitieme basis voor de uitoefening van macht, de legitieme basis woor het maken van keuzes zijn democratische verkiezingen. Elke andere basis voor machtsuitoefening is ondemocratisch. En de burgemeester heeft macht, invloed. Zoals elk bestuursorgaan macht heeft. ${ }^{n 77}$

Een vergelijking tussen de taak, functie en bevoegdheden van de leden van de rechterlijke macht met die van de minister-president, de Eerste Kamerleden of een burgemeester ligt buiten het bereik van dit onderzoek. Ik stip deze discussies slechts aan om te laten zien dat de dominante probleemstelling voor de selectie van kandidaten voor publieke ambten in het staatsrecht zo op het eerste gezicht een transcendent karakter heeft. In essentie concentreert die probleemstelling zich in al deze kwesties steeds rond het thema 'bevoegdheid en demo-

44. J. P. Rehwinkel, De minister-president, Eerste onder gelijken of gelijke onder eersten?, 1991, p. 230

45. Rehwinkel, o.c. p. 240

46. H.R.B.M. Kummeling. De Nederlandse Eerste Kamer, 1992, p. 20

47. H. Wierenga, De gekozen burgemeester verdedigd' Een visie vanuit de praktijk van het openbaar bestuur, in: De benoemde of gekozen burgemeester, 1992, p. 148 
cratische legitimatie', waarbij legitimatie wordt vertaald in de wijze van aanstelling van publieke ambtsdragers (gedemocratiseerde benoeming, verkiezing).

In het debat over de benoeming van rechters is de laatste jaren in toenemende mate sprake van een analoge probleemstelling als voor andere ambtsdragers, die in hoofdstuk 6 het 'democratische perspectief' wordt genoemd. Al in 1973 zegt A.J. Cnoop Koopmans dat de ontwikkeling van de benoemingsprocedure voor rechters staatsrechtelijk is 'achtergebleven' bij die van de wetgevende en de uitvoerende macht; "benoemde parlementen, provinciale, en gemeenteraden zijn vervangen door gekozen colleges, benoemde ministers hebben plaats gemaakt voor door het parlement aangewezene." Slechts bij de Hoge Raad zou het anders zijn, omdat daar het beginsel van coöptatie "op gelukkige wijze" is gecombineerd met "democratische inspraak van de burgerij. ${ }^{n 48}$

Ook in onze tijd rijst de vraag naar de legitimiteit van de rechter in verband met zijn toegenomen rol bij de rechtsvorming. In zijn toespraak bij het jubileum van Koningin Beatrix in 1992, zegt de voorzitter van de Eerste Kamer, H.D. Tjeenk Willink:

\begin{abstract}
"Wie de gezagsverhoudingen binnen de Nederlandse Staat in de afgelopen twaalfeneenhalf jaar bekijkt, ontdekt dat de wetgever aan geloofwaardigheid heeft ingeboet, maar de rechter aan vertrouwen gewonnen. (-) Koningin en rechter, de een erfelijk aangewezen, de ander voor het leven benoemd. Is dat niet vreemd in een parlementaire democratie waarin toch de legitimatie door verkiezingen zo op de voorgrond staat $?^{49}$
\end{abstract}

Nee, dat is niet vreemd, is de strekking van het betoog van Tjeenk Willink, maar wie verwachtte - in aanwezigheid van de Koningin - ook iets anders op zo'n feestelijke dag. Over de legitimatie van de rechter laat hij zich trouwens niet uit. Dat gebeurt een jaar eerder wel door het CDA-Tweede Kamerlid Van der Burg, die - zo zagen we al - meer inzicht in de aanbevelingen van de Hoge Raad verlangt. Eensgezind had de Tweede Kamer zich in 1979 ook al eens zorgelijk uitgesproken over de 'gewichtige rol' van met name de Hoge Raad bij de rechtsvorming (destijds ging het vooral om legalisering van pornografie, abortus en staking). Men meende dat de Hoge Raad voor uitspraken in "maatschappelijk gevoelige kwesties" een bijzondere verantwoordelijkheid draagt. Omdat veel van de uitspraken van de Hoge Raad "kracht van materiële wetgeving" hebben, behoeft het "geen betoog dat het belang van dit soort uit-

48. A.J. Cnoop Koopmans, Rechter en politiek, NJB, 1973, p. 630-638

49. H.D. Tjeenk Willink, Inhoudelijk koningschap wardt op den duur kwetsbaar. NRC Handeisblad, 31 oktober 1992 
spraken nog eens een extra deskundigheid vergt van de producent van zo'n uitspraak. " 50

"In al die gevallen is het van groot belang, hoe individuele leden van de Hoge Raad aankijken tegen bepaalde maatschappelijke ontwikkelingen, maar wijkennen noch hun godsdienstige, geestelijke, levensbeschouwelijke of algemeen politieke achtergronden, noch hun maatschappelijke afkomst. Terwijl van het parlement, door verkiezingen tot stand gekomen, kan worden gezegd, dat het geacht kan worden de in de bevolking levende opvattingen in het algemeen te weerspiegelen, is dat van de Hoge Raad nog maar de vraag. Eigenlijk weten wij daar niets van." 51

Anders dan in 1979 gaat de Tweede Kamer in 1992 wel tot stappen over. Ondanks de eerdere, felle kritiek besluit de Vaste Kamercommissie voor Justitie in het voorjaar van 1992 namelijk om zonodig persoonlijke gesprekken te voeren met kandidaat-leden voor de Hoge Raad. ${ }^{52}$ Daaraan voorafgaand publiceerde Vrij Nederland in het najaar van 1991 een enquête, waaruit blijkt dat de rechterlijke macht inderdaad voor een groot deel bestaat uit D66-stemmende, NRC-lezende VPRO-leden. ${ }^{53} \mathrm{Al}$ eerder schreef de rechtssocioloog F. Bruinsma dat de belangstelling van de gekozen volksvertegenwoordigers de Hoge Raad "een klein beetje broodnodige legitimatie" verschaft. ${ }^{54} \mathrm{H}$. van Maarseveen noemde die belangstelling zelfs een "grondwettelijke plicht". ${ }^{55}$

\subsubsection{Vraagtekens bij het democratische perspectief}

"Democracy is an incredible powerful term in this society; it will be used repeatedly and always will be taken as the major premise in analysis", schrijft Erwin Chemerinsky in zijn artikel The vanishing Constitution. ${ }^{56}$ Chemerinsky bestrijdt dat het 'democratische perspectief' de dwingende premisse zou moeten zijn van waaruit de legitimatie van de rechter moet worden beredeneerd. Toch is Chemerinsky er niet op uit om de rechtsstaat om zeep te helpen. Integendeel, hij meent dat voor de veiligstelling van grondrechten en voor maatschappelijk kwetsbare groepen op lange termijn winst valt te boeken door de zeephel van schijn-democratie, die het beroep op de meerderheidsregel soms vormt, door

50. Nijpels, Hand. II $1978-1979$, p. 5269

51. Roethof, Hand. II $1978-1979$, p. 5268

52. Zie verder in de hoofdstukken 2 en 4

53. Marc Josten en J. van Tijn. De rechterlijke macht van Nederland: een geruststellemd gezelschap, Vrij Nederland, 2 november 1991

54. F. Bruinsma, Van aanbeveling naar voordracht, NJB, 18 juli 1991, p. 1083-1085

55. Henc van Maarseveen, Politiek en Hoge Raad, NJB, 18 juli 1991, p. 1087-1088

56. Enwin Chemerinsky, The vanishing Constitution. Harvard Law Revicw, november 1989 , p. 76 
te prikken. Dit inzicht lijkt in Amerika, waar het de directe verkiezing van rechters in de deelstaten betreft, terrein te winnen in brede lagen van de bevolking. Deze Amerikaanse inzichten, waarop in de hoofdstukken 5 en 6 uitgebreid wordt ingaan zijn, toegegeven, de wrange vrucht van langdurige ervaringen met een ander rechtsstelsel onder geheel andere omstandigheden. Niettemin vormen zij een uitdaging om in eigen land eens buiten de paden van de geijkte probleemstelling ten aanzien van het vraagstuk van de toegang tot het rechtersambt te treden. Want, wat wordt eigenlijk bedoeld met 'afspiegeling' in de rechterlijke macht? Afspiegeling van wie of van wat? Van de Staten-Generaal, die 'het Nederlandse volk vertegenwoordigen' (art. $50 \mathrm{GW}$ ), of - zoals politici graag stellen - van 'maatschappelijke stromingen'? Maar wat is dat, een 'afspiegeling' van de samenleving? Moet de rechterlijke macht systematisch ook worden samengesteld uit analfabeten, gedetineerden, niet-Nederlanders, kinderen, hoogbejaarden, anti-semieten en geestelijk gestoorden? En in welke sleutelverdeling? Zal de profielschets van een lesbische asielzoekster in een rolstoel, voor de functie van president van de rechtbank Zwolle, (tenminste) geen logistieke problemen gaan opleveren? Of heeft bij het begrip 'maatschappelijke stroming' allang een schifting plaatsgevonden door het politiek correcte forum? Is de ideale rechter inderdaad het NRC-lezende, D66-stemmende VPRO-lid $(\mathrm{M} / \mathrm{V})$ ? Een 'geruststellend gezelschap' zoals Vrij Nederland schreef, dat wel, maar een 'afspiegeling' van de samenleving?

Behalve ten aanzien van de probleemstelling en de begripsbepaling, rijzen vragen naar de effecten van een afspiegelingsbeleid. Allereerst is er natuurlijk het probleem dat Nederlandse rechters na hun benoeming voor het leven, binnen de rechterlijke macht carriere kunnen maken. Een evenwichtige 'spreiding' van rechters met verschillende eigenschappen/kenmerken over de verschillende rechtscolleges - en daarbinnen over de verschillende kamers - valt daardoor niet te realiseren; en wat te doen wanneer de samenstelling van de rechterlijke macht niet spoort met het landelijke beeld $?^{57}$ Verder is er de vraag of er wel een verband is tussen de 'kleur' van een rechter en zijn vonnissen. Freek Bruinsma signaleert in Nederland de 'paradox van de afspiegelingsbenoeming", dat wil zeggen dat "iemand meer kans maakt te worden benoemd naarmate zijn levensbeschouwing, sexe, huidskleur of een ander groepskenmerk in het college minder vertegenwoordigd is, maar eenmaal benoemd wordt het als volstrekt ongepast gezien wanneer hij zijn groepsbelang daadwerkelijk gaat behartigen. ${ }^{58} \mathrm{~W}$. van Gerven meent echter dat het probleem ingewikkelder

57. Vergelijk de uitslag van de Vrij Nederland-enquête over de politieke voorkeur van de rechterlijke macht.

58. Freek Bruinsma, Cassatierechtspraak in civiele zaken Een rechlssociologisch verslag, 1988 , p. 125 
ligt, en wijst op de persoonlijke keuzes die onbewust aan een rechterlijk oordeel vooraf gaan (de z.g. 'Vorentscheidung').

"In het licht van deze Vorentscheidung selecteert en interpreteert de rechter de feiten en de toepasselijke regel. waarna hij de gekozen oplossing door middel van een juridische motivering in het vigerende regelsysteem en het daaraan ten grondslag liggende waardensysteem inpast. ${ }^{m 59}$

Overigens lijkt de wens naar afspiegeling er wel wat erg makkelijk van uit te gaan dat maatschappelijke problemen zich eenvoudig laten opsplitsen naar politieke voorkeur, geloofsovertuiging, huidskleur of sexuele gerichtheid. Dat is echter een achterhaalde (verzuilde) visie op 'politiek' bedrijven, die voor veel zaken die voor de rechter komen, niet opgaat. Een discussie over 'afspiegeling' gaat bovendien voorbij aan een andere vraag, namelijk of wij het begrip 'minderheid' (c.q. bloedgroep, belangenbehartiger) wel willen introduceren in de rechterlijke macht. Zal bij 'afspiegeling' niet het gevaar dreigen dat sommige minderheden wèl, en andere niet aan bod zullen komen, bijvoorbeeld omdat zij nog niet helemaal salonfähig zijn (pedofielen?), of nog moeten worden uitgevonden (ageism, de sociaal-economische/culturele achterstelling van ouderen, is bijvoorbeeld pas recent geproblematiseerd). En hoe - maar dat probleem speelt elders ook - gaan we 'afspiegeling' positiefrechtelijk benaderen? Wat als bijvoorbeeld sexuele voorkeur een ziekte blijkt? Met een verdachte gedrevenheid is in naam van de wetenschap immers recent de jacht op het 'homogen' geopend. Of wat als de presidente van de rechtbank Zwolle alsnog besluit met een man door het leven te willen gaan? Wordt 'gewijzigde sexuele voorkeur' dan wellicht een officiële grond voor ontslag in de Wet RO?

Tenslotte, is er wel een verband tussen afspiegeling in de rechterlijke macht, en het vertrouwen van de burger in de rechter, want daar was het allemaal om begonnen. Gemakshalve gaan veel beschouwingen over 'democratisering' daar inderdaad van uit. Maar is dat terecht? Uit de eerdergenoemde enquête van Vrij Nederland uit 1991 hlijkt dat 37\% van de Nederlandse burgers, net als in de jaren zestig, meent dat de rechter 'met twee maten meet', terwijl $19 \%$ zegt het niet te weten. ${ }^{60}$ Een groot deel van de Nederlanders staat kennelijk nog altijd (uiterst) sceptisch ten opzichte van de rechterlijke macht. Tot een 'vertrouwenscrisis' en opschudding in het parlement heeft dat deze keer - anders dan in 1967 - niet geleid ${ }^{6}$. Toch geschiedt de benoeming van rechters formeel op dezelfde manier als in de jaren zestig. Uit het onderzoek van Vrij Nederland blijkt bovendien dat maar liefst 1 op de 5 Nederlanders denkt

59. W. van Gerven, De taak van de recher in de West-Europese democratie, 1977, p. 4

60. Vrij Nederland, o.c. p. 20

61. Zie ook: hoofdstuk 4 
dat rechters in ons land tijdens de rechtszitting pruiken dragen. ${ }^{62}$ Kent ú eigenlijk de naam van de kantonrechter en de president van de rechtbank in uw arrondissement, of van de president van de Hoge Raad? Nu reeds rijst de vraag of pleidooien voor alternatieve selectiemethoden voor de leden van de rechterlijke macht, althans waar het de burger betreft, hun doel niet voorbij schieten.

\subsection{Vraagstelling, opzet van het onderzoek en onderzoeksmethode}

Op dit punt is de wrevel bereikt die nodig is voor het schrijven van een boek. Van het kaliber bovenstaande vragen (ik tel er 173) - waarbij bewust gechargeerd wordt - valt zonder probleem een nieuw register open te trekken. Geen wonder, want het is een reactionair oude mannen-deuntje waarmee je, comfortabel achterover leunend tegen sigarenrook, álles wel kapot kunt relativeren. Toch vervullen zulke platvloerse vragen tot op zekere hoogte een nuttige functie. Ze geven aan hoe makkelijk een beschouwing, in dit geval over de toegang tot het rechtersambt (maar ze gaan ook op voor de Tweede Kamer of het burgemeesterschap), wegzakt in een zompig moeras van pseudo-juridisch gebabbel, over wat 'de' burger allemaal wel of niet zal denken, willen, voelen, en wat zich wel of niet verdraagt met 'de' democratie of 'de' rechtsstaat. Een hoogst emotioneel debat, waarbij de deelnemers, zoals we nog zullen zien, als het zo uitkomt schaamteloos graaien naar zeer selectieve 'argumenten' in de constitutionele grabbelton van de parlementaire geschiedenis, de sociologie en de psychologie. Weinig verheffende argumenten trouwens, waarmee onder de fraaie vlag van 'de onafhankelijkheid van de rechter', àlles beweerd wordt.

Intussen constateer ik met een zekere ongemakkelijkheid dat er slechts weinig onderwerpen zijn die hierboven niet overhoop worden gehaald. Dit boek zal echter veel beperkter en saaier (van opzet) zijn. Het bestudeert het probleem van de toegang tot het rechtersambt vanuit de institutionele optiek, dus voorzover het gaat om de drempels die door het positieve recht worden opgeworpen. Daarbij wordt uitgegaan van een tweetal hypothesen. De veronderstelling is 1) dat in ons staatsrecht sprake is van een samenhang tussen de verschillende factoren die de toegang tot het rechtersambt bepalen, en dat aan dit stelsel 2) zowel bij de totstandkoming als bij de latere ontwikkelingen een bepaalde visie bij de (grond)wetgever heeft voorgestaan. De hoofdstukken 2, 3 en 4 toetsen bovenstaande hypothesen op hun houdbaarheid. Daartoe moeten twee hoofdvragen worden beantwoord, te weten I) hoe is de toegang tot het rechtersambt feitelijk geregeld (hoofdstuk 2), en II) welke overwegingen hebben aan deze regeling ten grondslag gelegen (hoofdstukken 3 en 4)? Vervolgens wordt onder- 
zocht welke tendensen ten aanzien van het vraagstuk van de toegang tot het rechtersambt zijn waar te nemen en hoe deze moeten worden gewaardeerd (hoofdstukken 5 en 6).

Het onderzoeksobject van deze studie zal de toegang tot het 'gewone' rechtersambt zijn, dat wil zeggen de toegang tot de gerechten van de rechterlijke macht als bedoeld in art. 116, eerste lid, GW jo. art. 1 Wet RO. Daarbij gaat het om de benoembaarheid in, en de benoeming tot raadsheer in de Hoge Raad en in een gerechtshof, tot rechter in een rechtbank of (nog even, zie hiervoor) in een kantongerecht, en om de benoeming in (vice-)presidentsfuncties. De benoembaarheid en benoeming van administratieve rechters komt slechts - marginaal - aan de orde in hoofdstuk 6. Met de integratie van een belangrijk deel van de administratieve rechters in de 'gewone' rechterlijke macht, heeft deze discussie namelijk belangrijk aan relevantie ingeboet. Bovendien zal uit hoofdstuk 6 blijken dat de discussie over de benoeming en benoembaarheid van administratieve rechters bij de invoering van de administratieve rechtspraak slechts van (zeer) ondergeschikte betekenis is geweest.

Wat de bronnen voor dit onderzoek betreft ben ik, zowel in Nederland als in New York, grotendeels op dezelfde manier te werk gegaan. Primair heb ik mij geconcentreerd op de traditionele bronnen van het staatsrecht: de Handelingen en de Bijlagen van de Tweede en Eerste Kamer, en op de secundaire literatuur. Daarnaast heb ik gebruik gemaakt van informatie uit interviews met personen die direct of indirect betrokken zijn (geweest) bij de selectie en benoeming van rechters in Nederland en in de Verenigde Staten. In het bijzonder wil ik hier noemen de interviews met P.W.M. Broekhoven (president rechtbank Maastricht $)^{63}$, mevr. J.C. Hudig ${ }^{64}$, N.J. van der Lee (Commissie aantrekken leden rechterlijke macht) ${ }^{65}$, J.L.R. van Vliet (ministerie van justitie) ${ }^{66}$, Maurice Rosenberg en Hans Smit (Columbia University in the City of New York School of Law) ${ }^{6}$. Elisabeth Hubbard (Fund for Modern Courts New York) ${ }^{68}$, Maureen Moralla (New York City Bar Association) ${ }^{69}$, Stuart A. Summit (Commission on Judicial Nomination) ${ }^{70}$, John Carey en David Silverman (Westchester Supreme Court) ${ }^{71}$ en Bernard Harnmelburg. ${ }^{22}$ Bovendien heb ik veel gebruik

63. 16 maart en 2 april 1992, Maastricht

64. 8 juni 1993 , Zeist

65. 15 maart 1993, Den Haag

66. 25 juni 1991, Den Haag

67. Respectievelijk op 16 en 17 april 1992, New York

68. 6 mei 1992. New York

69. 8 mei 1992. New York

70. I mei 1992. New York

71. 10 april 1992. New York

72. 19 mei 1992. New York 
gemaakt van artikelen uit kranten en niet-juridische tijdschriften. Dit behoeft enige toelichting. Ik ben van mening dat de ontwikkeling van het recht veel minder 'academisch' van aard is dan wel eens wordt voorgesteld. De sturende kracht die bijvoorbeeld van 'de' media uitgaat op de rechtsontwikkeling, beschouw ik als een staatkundig relevante factor. Gebruikmaking van 'secundaire' bronnen was ook een noodzaak. Een belangrijk probleem is dat in ons land - anders dan in de Verenigde Staten - de feitelijke regeling van de selectieen benoemingsprocedure van rechters slechts moeizaam valt te achterhalen (zie hoofdstuk 2); omgekeerd zijn de handelingen van de wetgevers in de Amerikaanse deelstaten veelal incompleet.

\subsubsection{Waarschuwing vooraf}

Het onderzoeken van een onontgonnen rechtsgebied brengt, naast de vrijheid om het onderzoek naar eigen inzicht in te richten, toch vooral ook de plicht mee om dat gebied eerst in kaart te brengen. Daarom is een substantieel deel van mijn onderzoek voor een positiefrechtelijke en historische beschrijving ingeruimd. Daarbij geldt dat de argumentatiecultuur en de belevingswereld van een ander tijdsgewricht aan de hand van het positieve recht nooit (laat staan volledig) valt te achterhalen. Onze perceptie van het verleden behoeft - zoals Ira Gershwin het uitdrukt in zijn opera Porgy and Bess - dan ook "a grain of salt", want "It ain't necessarily so ${ }^{\prime 73}$ Gershwin zet terecht subtiele vraagtekens, bij de doodklap die Li'l David de reus Goliath kon toebrengen (1 Sam. 17:51), bij Jonas die drie dagen en drie nachten in een walvis zat (Jona. 1:17), en bij het leven van de 969-jarige Methusalach ('en hij gewon zonen en dochteren', Gen. 5: 25). Het is kortom niet aan ons om te bepalen wat in een ver verleden waarheid was en wat onwaarheid; immers, ooit zullen ook wij in een opera worden afgeschilderd als primitieven en fantasten.

Omgekeerd mogen wij niet zonder meer 'argumenten' aan de geschiedenis onttrekken. Karl. R. Popper gaat nog iets verder. In een historical note bij zijn boek The Poverty of Historicism, schrijft hij: "the belief in historical destiny is sheer superstition". ${ }^{74}$ Die waarschuwing is met name voor juristen bedoeld. Als zij over 'historische interpretatie' spreken, dan is dat meestal omdat zij er iets mee willen (verklaren, beweren, ontkrachten). Vanuit een calvinistische noodlotsgedachte worden 'lessen' getrokken uit een verleden, waarvan het maar de vraag is of het wel bestaan heeft. Dergelijke historische 'verwijzingen' zijn - zie de paragraaf in hoofdstuk 3 over de benoembaarheid van vrouwen in rechterlijke functies - ook niet altijd de gelukkigste exercities in het recht

73. Ira Gershwin/George Gershwin, Porgy and B̈Bss, 1935, Act 2 Scene 2

74. Karl R. Popper, The poverty of historicism, 1957 
geweest. Veel van die beschouwingen getuigen van een zekere drammerigheid, die vaak wordt verward met belezenheid.

Naast een rechtshistorisch deel bevat dit boek, als gezegd, ook een rechtsvergelijkende component. De keuze voor het rechtsvergelijkende gedeelte werd gemaakt na de afronding van het derde en vierde hoofdstuk. Deze hoofdstukken wijzen, zoals hiervoor ook al bleek, op een tendens in de literatuur om het vraagstuk van de toegang tot het rechtersambt vanuit het begrip 'representatie' of 'afspiegeling' te benaderen. Om een globale indruk te krijgen hoe incorporatie van zo'n uitgangspunt in een staatsbestel uitwerkt, althans zou kunnen uitwerken, en welke problemen daarbij kunnen rijzen, bekijk ik een selectiestelsel waarin het representatiebegrip par excellence lijkt te worden toegepast: de directe verkiezing van rechters, en wel in de Amerikaanse deelstaat New York. Rechtsvergelijking is echter - net als rechtshistorisch onderzoek - tricky business. Meer nog dan in eigen land moet men elders een glibberig pad bewandelen, waarbij tal van evidenties en gevoeligheden niet direct onderkend worden. De sociaal-culturele en economische verhoudingen in de Verenigde Staten bijvoorbeeld, zijn een uiterst belangrijke factor voor rechtsvergelijking. Men zal zich terdege bewust moeten zijn, dat voor de toegang tot het rechtersambt in Amerika geldt, dat - anders dan bij ons - schrijnende etnische tegenstellingen een acuut issue zijn voor de inrichting van de rechtspleging. Het laat zich bijvoorbeeld raden welke consequenties de rellen in Los Angeles, die uitbraken nadat een blanke jury op 30 april 1992 vier blanke politieagenten niet schuldig verklaarde aan de mishandeling van een zwarte arrestant, zullen hebben voor de rechterlijke organisatie in de Amerikaanse deelstaten. Constance B. Motley, rechter in het federale District Court in New York, meent dat deze zaak, die bekend werd als 'the beating of Rodney King' "grave implications for society as a whole" zal hebben, en hij trekt de lijn door naar de samenstelling van de rechterlijke macht. "Excluding minority candidates from judicial posts (-) breeds alienation. Alienation from government breeds the feeling on the part of the disenfranchised that government serves not to represent them but to control them. ${ }^{175}$

Heeft het, zo bezien, eigenlijk wel zin om een onderdeel (van een onderdeel) van je staatsbestel te 'vergelijken' met dat van een - zo is het vermoeden althans - heel andere (rechts-)cultuur? Th. de Boer vindt van niet. "Als ik mij", zo schrijft hij,

75. Constance B. Motley, U.S. Judge Speaks Out On Judicial Diversity, New York Law Journal, 28 juni 1993 
"tenslotte, tracht voor te stellen hoe rechtsvergelijking zou moeten worden bedreven vanuit Nederlands perspectief, dan laat zich uit het voorgaande de les trekken dat de onderzoeker zich in de eerste plaats zou moeten richten op landen waarvan de maatschappijstructuur vergelijkbaar is met die van Nederland en waar zich vergelijkbare maatschappelijke problemen voordoen. Binnen die kring zou vervolgens gezocht moeten worden naar rechtsstelsels waarvan te verwachten valt dat het probleem in kwestie daar is opgelost op een manier die past in de politieke, culturele, sociaal-economische en juridische traditie waarop het Nederlandse recht berust. ${ }^{m 76}$

Als het doel van 'een kijkje over de grens' zich beperkt tot een vraag-en-antwoord-spelletje, heeft De Boer natuurlijk gelijk. Toch zou het jammer zijn als rechtsvergelijking in de toekomst alleen nog maar gericht zou zijn op efficiënte conflictoplossing. Dat klemt te meer waar problemen niet geheel helder zijn, en waar de constitutionele grenzen van zo'n probleem nog moeten worden afgetast. Het vraagstuk van de toegang tot het rechtersambt is een voorbeeld van zo'n probleem. Juist het confronteren van - ogenschijnlijke! - extremen, kan leiden tot enige relativering en zelfinzicht. Of uit zo'n confrontatie tevens zwaarwegende 'conclusies' moeten worden getrokken, is een tweede. De Amerikaanse staatsrechtbeoefenaars zèlf tenslotte, lijken zich veel minder druk te maken over al deze problemen van rechtsvergelijking. Met een plezierig soort lichtvoetigheid wordt hier en daar de benoeming en verkiezing van Amerikaanse rechters geplaatst tegenover 'Judicial Selection Around the World'." "The Dutch constitution is similar to the French", las ik ergens over het Nederlandse staatsbestel. Iets meer kennis van zaken over en weer kan voorlopig dus geen kwaad.

76. Th.M. de Boer. Vergelijkenderwijs: de inspiratie van buitenlands recht, in: Weekblad voor privaatrecht, notariaat en registratie, 1992, p. 47

77. Zie bijvoorbeeld: E. Blythe Stason, Judicial selection around the world, in: Journal of the American Judicature Society, 1958, p. 134-141 

Deel II

Het constitutionele kader 


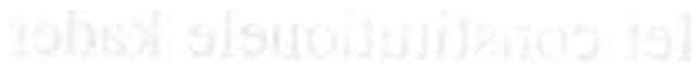




\section{De toegang tot het rechtersambt: het constitutionele kader}

\subsection{Inleiding}

Een (lichte) wrevel is soms nodig voor het schrijven van een boek, schreef ik in mijn inleiding. Dat geldt zeer zeker voor dit hoofdstuk, dat het constitutionele kader beschrijft van de factoren die samen de toegang tot het rechtersambt bepalen. Het bijeenschrapen van de regelingen over de werving, selectie, benoeming en promotie van rechterlijke ambtenaren (op het eerste gezicht toch een tamelijk eenvoudige klus, zou men denken) heeft meer tijd en moeite geknst dan welk onderdeel (het Amerikaanse incluis) van dit boek ook. "Bijgaand ontvangt $u$ een computeruitdraai met een overzicht van alle (onderstreping van mij, $M d W$ ) thans geldende circulaires van het Ministerie van Justitie", antwoordt de Afdeling Documentatie \& Archieven stoer. ${ }^{1}$ Toch ontbrcken op dit (overigens imposante) overzicht van 45 pagina's nagenoeg alle relevante circulaires voor dit onderzoek. En dat is natuurlijk merkwaardig in een rechtsstelsel waarin de toegankelijkheid van regelgeving traditioneel op een hoog plan staat. Met behulp van enig (voor staatsrecht-juristen althans) 'exotisch' bronnenmateriaal (brochures, interviews) ben ik een eind gekomen met het reconstrueren van de gang van zaken bij benoemingen, maar nog steeds word ik 's nachts angstig wakker, met het beeld voor ogen van een rechtbankpresident, die zich bulderend op de knieën slaat, omdat de hele zaak al sinds jaar en dag eigenlijk wordt geregeld door circulaire zus-en-zo - waar ik natuurlijk nooit van gehoord heb - 'maar dat dat er allemaal toch weinig toe doet', omdat de vergadering van rechtbankpresidenten al jaren geleden ook deze bemoeizuchtige regeling van de minister naast zich neer heeft gelegd. En dat brengt mij bij een ander probleem: de praktijk van de werving, selectie en benceming van rechters blijkt een stuk weerbarstiger dan de regelingen die erop worden losgelaten, terwijl die praktijk per arrondissement nogal eens wil verschillen. De onafhankelijkheid van de rechterlijke macht heeft zo haar prijs. Het - kennelijk - vertrouwelijke karakter van het onderwerp tenslotte, maakt dat essentiële stadia in het selectieproces niet openbaar zijn, zodat het uiteindelijk maar gissen blijft.

1. Brief van de Afdeling Documentatie \& Archieven van de Hoofdafdeling Documentaire Informatievoorziening, 15 juni 1993 
De toegang tot het rechtersambt in ons land wordt bepaald door een wirwar van regelingen, neergelegd in o.a. de Grondwet, de Wet op de Rechterlijke Organisatie, de Wet op het Nederlanderschap, de Wet betreffende de positie van Molukkers, de Eedswetten 1916 en 1971, de Wet op de bezoldiging van rechterlijke ambtenaren, het Reglement van Orde van de Tweede Kamer, diverse algemene maatregelen van bestuur, ministeriële besluiten, en circulaires. Geen wonder dat de wetgevers zèlf - zoals uit dit hoofdstuk zal blijken - het spoor inmiddels ook bijster zijn geraakt. Vitale onderdelen van ons staatsrecht staan bij nader onderzoek namelijk op gespannen voet met de Grondwet. Dit hoofdstuk heeft daarom allereerst tot doel de lezer een overzicht te bieden van de wettelijke regeling van het wervings-, selectie- en benoemingsvraagstuk ( $\$ 2.3$ ). Dergelijk overzichten zijn meestal weinig meeslepend, en daarom zijn - om hier en daar lange verhalen kort te houden - uitgebreide procedures verkort beschreven, of in een bijlage opgenomen. Voorafgaand aan deze beschrijving wordt de onderlinge systematiek van deze regelingen belicht $(\$ 2.2)$, en tenslotte worden enige vragen gesteld bij de toegang tot het rechtersambt in Nederland $(\S 2.4)$.

\subsection{Het constitutionele kader}

Art. 117, eerste lid, GW bepaalt dat de leden van de rechterlijke macht met rechtspraak belast en de procureur-generaal bij de Hoge Raad bij koninklijk besluit voor het leven worden benoemd. ${ }^{2}$ Ten aanzien van de leden van de Hoge Raad der Nederlanden bepaalt art. 118, eerste lid, GW dat zij worden benoemd uit een voordracht van drie personen, opgemaakt door de Tweede Kamer der Staten-Generaal. Deze twee grondwetsartikelen vormen het grondwettelijke kader waarbinnen de procedure voor de toegang tot het rechtersambt zich dient af te spelen. Dwingendrechtelijke elementen in deze procedure zijn: 1) soorten van ambten waarvoor de procedure geldt ('leden van de rechterlijke macht met rechtspraak belast' en de procureur-generaal bij de Hoge Raad), 2) aard van het benoemingsbesluit (koninklijk besluit) en impliciet: kwaliteit van het benoemende orgaan (regering: zie art. $47 \mathrm{GW}$ ), 3) termijn van de benoeming ('voor het leven', dat wil zeggen tot het zeventigste levensjaar') en 4) voor de Hoge Raad: eis van een voordrachtsprocedure.

2. Sinds de grondwetsherziening van 1983 spreekt de Grondwet niet meer over een benoeming door de Koning maar over benoeming bij koninklijk besluit.

3. Art. $116 \mathrm{GW}$ jo ant. 36 , tweede lid, 51 , eerste lid, 62 , eerste lid en 84 , eerste lid, Wet $\mathrm{RO}$ 


\subsubsection{De begrippen 'benoeming' en 'aanwijzing'}

Bij de benoeming van de leden van de rechterlijke macht met rechtspraak belast, zoals bedoeld in de artt. 117, eerste lid, en 116, eerste lid, GW jo. art. 1 Wet RO, gaat het om een benoeming van personen in een rechterlijk ambt. Men kan worden benoemd in het ambt van kantonrechter (art. 36a Wet RO), in het ambt van rechter in een arrondissementsrechtbank (art. 52 Wet RO), in het ambt van raadsheer in een gerechtshof (art. 63 Wet RO) of in het ambt van raadsheer in de Hoge Raad (art. 85, eerste lid, Wet RO). Het begrip 'benoeming' moet worden onderscheiden van het begrip 'aanwijzing'. Het belang van dat onderscheid ligt daarin, dat na de wervings-, selectie en benoemingsprocedure, nog een interne selectie binnen de gerechten zelf plaatsvindt, waarbij de feitelijke werkzaamheden worden verdeeld. Noch de Grondwet, noch de Wet RO c.a. maken echter een duidelijk onderscheid tussen de benoeming en de aanwijzing van rechters. Bij een aanwijzing is geen sprake van een benoeming in een rechterlijk ambt in de zin van art. 117, eerste lid, GW (de aangewezen of aan te wijzen persoon is reeds in een rechterlijk ambt benoemd) maar van de samenstelling van enkelvoudige en meervoudige kamers. Het gaat daarbij om de aanwijzing in functies in enkelvoudige kamers, als die van politierechter, kinderrechter of rechter-commissaris (het ambt is rechter in een rechtbank), of in functies in meervoudige kamers (de straf-, civiele--, administratieve-, belasting- of ondernemingskamer). ${ }^{4}$

\subsubsection{De benoeming voor het leven}

De leden van de rechterlijke macht, zo stelt art. 117, eerste lid, GW worden bij koninklijk besluit 'voor het leven' benoemd. De benoeming voor het leven wordt door nagenoeg de hele literatuur als een waarborg voor de onafhankelijkheid van de rechter(lijke macht) beschouwd. Toch moet het waarborgkarakter van deze bepaling om tenminste twee redenen worden gerelativeerd. Allereerst:

4. Aanwijzingen vindt men in de Wet van 3 juni 1992, Stb. 278. Op voorstel van de president zullen de arrondissementsrechtbankenenkelvoudige en meervoudige burgerlijkeen strafkamers vornen (art. 49 en 57 Wet RO), alsmede enkelvoudige kamers voor de behandeling en beslissing van kinderzaken (art. 58a Wet RO) en wijzen zij op voorstel van de president, de hoofdofficier van justitie gehoord, rechters-commissarissen aan. Zie voor de vorming van enkelvoudige en meervoudige kamers voor burgerlijke en strafzaken bij de gerechtshoven: art. 70 Wet RO. en voor de aanwijzing van de kamers voor belastingzaken en ondernemingszaken, resp. artt. 71 en 72 Wet RO. Zie voor andere. aanwijzingen, de samenstelling van bijzondere kamers, voortvloeiende uit: de Wet op de: overgang bijzondere rechtspleging; de Wet. op de economische delicten (art. 39); de Ambtenarenwet (art. 4); de Militaire Ambtenarenwet (art. 5); de Algemene militaire pensioenwet (art. Vii en W1 en W3); de Algemene burgelijke pensioenwet (art. S2) en de Beroepswet (art. i). 
dient men in de gaten te houden dat de Grondwet rechters geen absolute 'aanspraak' geeft op een levenslange aanstelling, en dat ook nooit gedaan heeft. De Grondwet van 1814 bevatte reeds de bepaling dat "Geen regter gedurende de tijd zijner bediening van zijn post [mag] worden ontslagen, dan op eigen verzoek of bij regterlijk vonnis. " ${ }^{5}$ Bij de grondwetswijziging van 1922 werd in de Grondwet expliciet de mogelijkheid geopend dat de leden van de rechterlijke macht op een bij de wet te bepalen leeftijd ontslag wordt verleend. ${ }^{6}$ Sinds 1932 voorziet de Wet RO inderdaad in die mogelijkheid. ${ }^{7}$ Rechters worden thans bij het bereiken van het zeventigste levensjaar ontslagen. ${ }^{8}$ Overigens is de constitutionaliteit van de invoering van de leeftijdsgrens tot aan de invoering van de Wet van 3 december 1932, Stb. 576 steeds (fel) bestreden. ${ }^{9}$

\subsubsection{De opheffing en ontbinding van gerechten}

De waarborg van art. 117, eerste lid, GW is ook om een andere reden problematisch. In hoofdstuk 1 werd er reeds op gewezen dat de kantongerechten bij de tweede fase van de reorganisatie van de rechterlijke macht zullen worden 'geïntegreerd' in de rechtbanken 'nieuwe stijl'. De voorgestelde 'integratie' is juridisch echter niets anders dan de opheffing en de ontbinding van de bestaande kantongerechten; het nieuwe ambt wordt rechter in een arrondissementsrechtbank, en voor de - zoals art. 29 Wet RO het zegt - inbedieningtreding zullen de 'oude' kantonrechters opnieuw bij koninklijk besluit benoemd, en vervolgens geïnstalleerd en beëdigd moeten worden. Deze kwestie werpt de vraag op hoe de opheffing van een gerecht - vooropgesteld dat dit al mogelijk is - zich verhoudt tot de bepaling in art. 117, eerste lid, GW dat de leden van deze gerechten 'voor het leven' worden benoemd. Wordt het de wetgever nu niet erg gemakkelijk gemaakt, om zich via de omweg van de opheffing van gerechten, van lastige rechters te ontdoen? De grondwetgever leek in 1983 het probleem zelfs niet eens te zien waar hij stelt dat:

"de Grondwet geen onnodige hinderpaal vormt (moet vormen?, MdW) voor ontwikkelingen op het terrein van de rechtspraak. Binnen het kader, dat in onze opzet de Grondwet aangeeft voor de bevoegdheid en de inrichting van de rechterlijke macht, wordt de wetgever de mogelijkheid gelaten verschuivingen in de bevoegdheid van de gerechten die deel uitmaken van het orgaan-complex rechterlijke

5. Art. $113 \mathrm{GW} 1814$

6. Art. 167 GW 1922

7. Vergelijk de Wet van 3 december 1932, Stb. nr. 576

8. Zie artt. 36. tweede lid, 51. eerste lid, 62, eerste lid. en 84, tweede lid, Wet RO

9. Vergelijk de discussie over de invoering van het opleidingsvereiste en van de (wettelijke) incompatibiliteiten in $\$ 2.4 .3$ 
Over de opheffing en de ontbinding van gerechten in het algemeen is (grond)wettelijk weinig geregeld. Art. 116, eerste lid, GW stelt dat de wet de gerechten aanwijst die behoren tot de rechterlijke macht. Die gerechten zijn thans genoemd in art. 1 Wet RO, en omvatten de Hoge Raad, de gerechtshoven, de rechtbanken en (nog even) de kantongerechten. Art. 116, eerste lid, GW impliceert mijns inziens dat de wetgever niet alleen gerechten kan instellen, maar ook dat hij deze gerechten weer kan opheffen. Hoe dat moet gebeuren is echter onduidelijk.

Al in de vorige eeuw stuitte men op het probleem dat een strikte uitleg van de benoeming voor het leven zich niet verhoudt met een flexibele inrichting van de rechterlijke organisatic, in het bijzonder niet met de inkrimping van het aantal gerechten, bijvoorbeeld als gevolg van bezuinigingen. Anders dan nu, zag de Tweede Kamer er toen geen been in om dagenlang te debatteren over de constitutionaliteit van de opheffing van bijvoorbeeld de rechthank Zierikzee. ${ }^{11}$ Naarstig werd gezocht naar een mogelijkheid om de benoeming voor het leven te relativeren, zodanig dat enerzijds de waarborg voor de onafhankelijkheid van de rechter gegarandeerd was, maar anderzijds de wetgever niet al w: zeer belemmerd werd bij de inrichting van de rechterlijke organisatie. De voorstellen die aan de hand werden gedaan, struikelden meestal over hun eigen ingewikkeldheid, of leidden anderszins tot onwenselijke uitkomsten. J.P. Veri. ren hijvoorbeeld koppelde de benueming voor het leven aan het hestaan van een gerecht. Een college had volgens hem zijn 'rechtsbestaan" te danken "aan de v'et die zijn bestaun voorschrijft en zijn feitelijk bestaan aun de uitvoerende macht dic het in leien roept en houdt. "12 Houdi de taak van een college op te bestaan, dan kan het college opgeheven en het personeel ontbonden worden. Wel moet men volgens Verloren waken voor schijnvertoningen. Een gerecht dat onder een andere naam dezelfde werkzaamheden krijgt, houdt niet op te bestaan. ${ }^{13}$ Later, in 1950, stelt ook G. van den Bergh dat de waarborg van de benoeming voor het leven is gerelateerd aan het bestaan van het gerecht. ${ }^{14}$ Voor het 'bestaan' van een gerecht onderscheidt hij tussen de rechterlijke taak die uit zijn aard aflopend is (het betrof in casu de afdeling Rechtspraak van de

10. MvT, Bijl. Hand. Il 1979-1980, 16 162, nr. 3, p. 2

11. Vergelijk het verhandelde rond de Wet van 9 april 1877 . Stb. nr. 76

12. J.P. Verloren, Over am. 163 van de Grondwet, in: Themis Regtsioundig Tijdschrift, 1877, p. 174

13. Zie in gelijke zin J.T. Buijs, De Grondwet Toelichting en kritiek II, 1884, p. 478-480

14. G. van den Bergh, De Rechterlijke Macht als grondwettelijk begrip, NJB, 1950 , p. $193-412$ 
Raad voor het Rechtsherstel), en die welke dat niet is. In het eerste geval valt de benoeming voor het leven samen met de uitvoering (tot aan de voltooiing) van de rechterlijke taak,

"Ongrondwettig ware het daarentegen, wanneer men rechters in de arrondissementsrechtbanken zou benoemen voor de duur van het bestaan dezer colleges, en dan later alle rechtbankzaken naar de Hoven zou overbrengen, de Rechtbanken zou opheffen en tegelijkertijd de functie dezer arrondissementsrechters als leden van de rechterlijke macht als geëindigd zou beschouwen. ${ }^{m 15}$

Anders dan Verloren lijkt Van den Bergh niet te menen dat de ontbinding van de gerechten de opheffing ervan in de weg staat, hetgeen bij hem leidt tot de merkwaardige, puur academische situatie dat gewezen rechters toch (onbezoldigd?) lid van de rechterlijke macht blijven. C.W. van der Pot heeft overigens, in zijn nogal scherpe reactie op het artikel van Van den Bergh, diens visie op het 'bestaan' van gerechten goeddeels overeind gelaten. ${ }^{16}$

Zowel in de visie van Verloren als in die van Van den Bergh (instemmend Buijs en Van der Pot) staat de aangekondigde 'integratie' van kantongerechten en arrondissementsrechtbanken, op (zeer) gespannen voet met de Grondwet. Recent hebben A.F. Th Snelders en A.L.R. Melens geconcludeerd dat een kantonrechter die dat niet wenst, zonder grondwetswijziging 'die het mogelijk maakt een rechter tegen zijn wil te benoemen in een ander ambt', geen rechter in de rechtbank 'nieuwe stijl' zal worden. ${ }^{17}$ Die conclusie lijkt mij echter zowel onjuist, onlogisch als onwenselijk; 1) onjuist omdat een benoeming tot rechter tegen iemands wil onder de huidige Grondwet zeer wel mogelijk (zij het ondenkbaar) is, 2) onlogisch omdat een (grond)wetgever geen (apert) absurde regelgeving pleegt voort te brengen, en de regering (zie 1) een kanton-

15. Van den Bergh, o.c. p. 198

16. C.W. van der Pot. Wie behoren tor de "rechterlijke macht"?. NJB, 1950, p. 358 De praktijk bleef trouwens, zoals de regering in 1932 zelf al opmerkte, 'een andere': "de Grondwet [is] geen contract tusschen den staat en de leden van de rechterlijke macht; wilde de Grondwetgever de onafzetbaarheid van de rechterlijke mach geheel opheffen, dan zou een rechter aan een vroegere Grondwel het recht kunnen ontleenen om levenslang in functie te blijven. De bedoeling van deze onafzetbaarheid is slechts geweest, een waarborg te geven voor de onafhankelijkheid onzer rechterlijke macht door onmogelijk te maken, dat de regeering willekeurig ontslag kan verleenen, niet om aan de individueele rechters een subjectief recht op levenstange ambtsvervulling te geven. "NV, Bijl. Hand. II 1932-1933, 138, nr. 4, p. 3) "Ware hier sprake van een voor den wetgever onaantastbaar subjectief recht, dan zou hel zelfs ongeoorloofd wezen eenig gerecht op te heffen; het recht van den voor het leven benoemde zou zich daartegen verzetten! De praktijk is echter te recht steeds anders geweest." (MvA. Bijl. Hand. 1932-1933, 138. nr. 5, p. 5)

17. A.F.Th. Snelders en A.L.R. Melens, De afhankelijke kantonrechter, NJB, 1994, p. 60 
rechter die dat niet wil bij voorkeur niet in de rechtbank nieuwe stijl zal benoemen (de rechterlijke macht heeft op dit moment al problemen genoeg), en 3) onwenselijk omdat in de visie van Snelders en Melens (kanton)gerechten redelijkerwijs niet opgeheven en ontbonden kunnen worden. Dat laatste lijkt mij (ook in historisch perspectief) onaanvaardbaar omdat het instituut van de benoeming voor het leven daarmee zijn doel voorbij schiet. Waar op regelmatige wijze een rechtsingang of een gerecht verdwijnt, vervalt mét het belang van de burger ook de ratio om voor een (niet-bestaande) rechtsingang de waarborgen voor onafhankelijkheid te continueren.

Het venijn zit 'm echter - Buijs, Verloren, Van der Pot en Van den Berg waren het dár in elk geval over eens - in die 'regelmatige' opheffing van een rechtsingang of een gerecht. Hoe wordt gewaarborgd dat onwelgevallige rechters via een achterdeur hun ambt niet wordt ontnomen? Het ontslag biedt voor de opheffing en ontbinding van gerechten in elk geval geen soelaas, omdat ontslag volgens de Grondwet slechts op een drietal gronden mag geschieden: op eigen verzoek, wegens het bereiken van een bij de wet te bepalen leeftijd en in de gevallen bij de wet bepaald. ${ }^{18}$ Wat die laatste categorie betreft: de Wet RO voorziet niet in de mogelijkheid van ontslag wegens de opheffing van een gerecht. ${ }^{19}$ Het is echter de vraag of men dit principiële probleem bevredigend kan oplossen door de Wet RO uit te breiden met een ontslagmogelijkheid wegens - bijvoorbeeld - 'reorganisatie' (wat dat ook moge zijn). Wil de benoeming voor het leven een serieuze waarborg zijn tegen chicanes tnet de rechterlijke macht, dan lijkt het bon vouloir van de wetgever niet de aangewezen weg (vergelijk de perikelen rond het in hoofdstuk I genoemde Court Packing Plan).

Een oplossing die enerzijds ruimte biedt aan de wetgever bij het instellen en opheffen van gerechten, en anderzijds de rechterlijke macht beschermt tegen ongewenste invloeden van de kant van de wetgever, zou gevonden kunnen worden door de bevoegdheid tot opheffing en ontbinding van gerechten te splitsen, en te verdelen over twee organen: de wetgever en de rechterlijke macht zèlf. De wetgever blijft, vergelijk art. 116, eerste lid, GW bevoegd tot de opheffing van gerechten, maar voordat tot opheffing kan worden overgegaan, worden de betrokken gerechten door de Hoge Raad ontbonden. De waarborg tegen het oneigenlijk gebruik van de opheffing van gerechten ligt in de omstandigheid dat de Hoge Raad kan beslissen de betrokken rechterlijke ambtenaren, op grond van kennelijk misbruik van art. 116, eerste lid, GW door de wetgever, niet te ontslaan. Voor de ontbindingsbevoegdheid van de Hoge Raad zou kunnen worden aangesloten bij de discretionaire ontslagbevoegdheid

18. Vergeiijk art. 117, tweede en derde lid, GW

19. Vergelijk artt. 11 en 12 Wet RO 
die de Hoge Raad nu reeds toekomt op grond van art. 117, GW, jo. art. 11 Wet RO. Dit systeem - dat bij voorkeur een grondwettelijke grondslag zou krijgen - is overigens niet waterdicht, omdat (in theorie) chicanes van de zijde van de Hoge Raad niet zijn uit te sluiten (wat als ook de Hoge Raad - niet op juridische maar op beleidsgronden - van mening is dat continuering van de kantongerechten gewenst is?), maar dat is de prijs die voor de onafhankelijkheid van de rechter betaald wordt. Het zal er in elk geval toe leiden dat de regering haar voorstellen uitgebreid zal motiveren, en dat niet - zie de huidige reorganisatie achteloos aan vitale onderdelen van ons staatsbestel wordt voorbijgegaan.

\subsubsection{Vereiste van een wettelijke grondslag}

De Grondwet dwingt, afgezien van het hepaalde in de artt. 117, eerste lid (benoeming voor het leven bij koninklijk besluit) en 118 , eerste lid (voordracht), niet tot een (bepaalde) aan de benoeming vooratgaande wervings-, selectie- en benoemingsprocedure. De bevoegdheid tot instelling van een dergelijke procedure komt toe aan de wetgever op grond van art. 116, tweede lid, GW. Dit stelt voor deze onderwerpen het vereiste van een wettelijke grondslag, maar laat overigens delegatie toe (zie hierna). Met name ten aanzien van de selectie door de Commissie aantrekken leden rechterlijke macht, en met betrekking tot de benoemingsprocedure voor sommige promotiefuncties (president en vice-president rechtbank en gerechtshof) rijst - in verband met het ontbreken van een wettelijke grondslag van die procedures - een niet onbelangrijk grondwettelijk probleem.

\subsubsection{Het begrip "inrichting van de rechterlijke macht" in art. 116, tweede lid, GW}

Het vereiste van een wettelijke grondslag voor het wervings-, selectie- en benoemingsvraagstuk ex art. 116, tweede lid, GW behoeft enige toelichting. De wervings-, selectie- en benoemingsprocedure worden, naast het algemene benoemingsbesluit van art. 117, eerste lid, GW en de bijzondere benoemingsprocedure voor leden van de Hoge Raad (art. I18, eerste lid, GW), immers niet apart door de Grondwet genoemd. Wel bepaalt art. 116, tweede lid, GW dat de formele wetgever de inrichting. samenstelling en bevoegdheid van de rechterlijke macht regelt. Wat in de Grondwet is bedoeld met 'inrichting', 'samenstelling' en 'bevoegdheid', is op het eerste gezicht echter niet duidelijk. Deze zinsnede is afkomstig uit de Proeve, maar wordt daar nauwelijks toegelicht. Volgens de Proeve ligt in het artikel "het beginsel besloten dat de wet de rechters moet aanwijzen en dat de rechtspraak geschiedt krachtens wettelijke 
opdracht. ${ }^{120}$ Men moet aannemen dat het aanwijzen van rechters (thans de 'inrichting van de rechterlijke macht' in art. 116, tweede lid, GW) behalve de benoeming, ook de werving en selectie van rechterlijke ambtenaren omvat. De Staatscommissie van Advies inzake de Grondwet en de Kieswet behandelt namelijk. in haar Eindrapport (Hoofdstuk VII $\$ 4$ Inrichting der rechterlijke macht) de wijze van benoeming van de leden van de rechterlijke macht (genoemd worden onder meer rekrutering, aanbeveling, benoeming en promotie) als een van de drie ${ }^{21}$ vraagstukken die met de "inrichting van de rechterlijke macht" samenhangen. ${ }^{22}$ De regering nam deze bepaling - en kennelijk ook de lezing van deze bepaling - over. ${ }^{23}$ Overigens ziet ook de Staatscommissie Herziening Rechterlijke Organisatie in 1985 de werving, selectie, opleiding en eerste en verdere benoemingen als samenhangende onderwerpen. ${ }^{24}$

Men zou nog kunnen tegenwerpen dat de bestaande wervings-, selectie en benoemingsprocedures niet onder art. 116, tweede lid, GW maar onder art. 117, eerste lid, GW (kwaliteit van het benoemingsbesluit) vallen, en aldus tot de bevoegdheid van de regering behoren. Die uitleg lijkt mij echter onjuist. Systematisch is art. 117, eerste lid, GW namelijk een beperking van de algemene inrichtingsbevoegdheid van de wetgever ex art. 116, tweede lid, GW. Volgens de regering komt de wetgever terzake van de benoeming ex art. 117, eerste lid, GW geen regelgevende bevoegdheid toe. ${ }^{25}$ Aanname van het vereiste van een wettelijke grondslag voor de wervings, selectie- en benoemingsprocedure ligt ook voor de hand, omdat het beter past in het systeem van de Grondwet. Zo merkt de regering bij de grondwetsherziening 1983 op dat voor de "meest relevante bepalingen" van het hoofdstuk over de rechtspraak geen delegatiemogelijkheid bestaat (genoemd worden onder meer benoeming en ontslag):

20. Proeve van cen nieuwe Grondwet, 1967, p. 171

21. De andere twee zijn de positie van het Openbaar Ministerie en de deelneming van leken aan de rechtspraak.

22. Einalrapport van de Staatscommissie van Advies inzake de. Grondwet en de Kieswet, 1971 , p. 245.249

23. Bijl. Hand. II. 1979-1980, 16162 nr. 3 p. 17

24. Eindrapport van de Staatscommissie Herziening Rechterlijke Organisatie, deel II, 1985. p. 2 e.v.

25. "Art. 6.5, eersie tol en mel derde lid (thans an. 117, eerste tol en mel het derde lid, $\left.G W_{i}^{\prime} M^{\prime} d W\right)$, bevat voorschriften omtrent benoeming en ontslag van de leden van de rechierlijke macht met rechtspraak belast, welke voorschriften in de Grondwet zelf vasigelegd zullen zijn, en waarbij slechts op onderdelen de formele wetgever, wederom: bij witsluiting, ingeschaketd wordt ter nadere bepaling. "Nota naar aanleiding van het eindverslag, Bij1. Hand. II 1980-1981, 16162 , nr. 11, p. 1-2 
"De hier genoemde grondwetsbepalingen scheisen duidelijk een systeem, waarbij in de Grondwet zelf voorschriften zijn verankerd en waarbij, waar zulks niet hel geval is, de formele wetgever (accentuering van mij, MdW) zonder delegatiemogelijkheid geroepen wordt tot vaststelling van onderdelen. ${ }^{126}$

Omgekeerd kan men daaruit afleiden dat voor de overige, met benoeming en ontslag samenhangende onderwerpen delegatie weliswaar mogelijk is, maar dat dit tevens het vereiste van een wettelijke grondslag voor deze onderwerpen impliceert.

Inmiddels valt het niet mee om aan te geven welke onderwerpen die de toegang tot het rechtersambt bepalen, tot de reikwijdte van art. 117, eerste lid, GW moeten worden gerekend en welke niet. Hier wreekt zich de situatie dat - zoals in het eerste hoofdstuk werd gesteld - de bevoegdheden tot werving en selectie weliswaar van grote (zo niet doorslaggevende) invloed zijn op de uiteindelijke benoeming van een rechter, maar dat deze begrippen staatsrechtelijk nauwelijks ontwikkeld zijn. Terwijl de Staatscommissie en de regering - zie boven - er van uit gaan dat 'rekrutering' en 'promotie' onderdeel uitmaken van het begrip 'inrichting van de rechterlijke macht' ex art. 116, tweede lid, GW, worden deze begrippen niet uitgewerkt. Omvat 'rekrutering' zowel de wervingsfase als de werkzaamheden van de selectiecommissies? En wat is staatsrechtelijk precies een 'promotie'? Het antwoord op deze vragen is niet onbelangrijk. Neemt men aan dat (onderdelen van) de recrutering en promotie van rechterlijke ambtenaren inderdaad een wettelijke grondslag vereisen - en daarvoor zijn (zacht gezegd) goede gronden -, dan voert dit onvermijdelijk tot de conclusie dat belangrijke onderdelen van ons staatsrecht in strijd zijn met de Grondwet. Immers, zowel bij de werving, als bij de instelling en werkwijze van de Commissie aantrekken leden rechterlijke macht, en de selectie van presidenten en vice-presidenten, ontbreekt een wettelijke grondslag. ${ }^{27}$

Overigens vloeit, behalve uit art. 117, eerste lid, GW mogelijk ook uit art. 6 EVRM de eis van een wettelijke grondslag voor de werving, selectie en promotie van rechterlijke ambtenaren voort. Art 6 EVRM bepaalt immers dat een ieder bij het vaststellen van zijn burgerlijke rechten en verplichtingen of bij het bepalen van de gegrondheid van een tegen hem ingestelde strafvervolging, recht heeft op een eerlijke en openbare behandeling van zijn zaak, binnen een redelijke termijn, door een onafhankelijke en onpartijdige rechterlijke instantie welke bij de wet is ingesteld. Hoewel art. 6, eerste lid, eerste volzin, EVRM zich niet expliciet uitlaat over de werving, de selectie of de benoeming van rechters, stelt de Commissie in de Zand-zaak "It is the object and purpose of

26. Nota naar aanleiding van het eindverslag, Bijl. Hand. II 1980-1981, 16 162, nr. 11, p. 2

27. Zie $\$ 2.3 .5$ 
the Clause in Article 6 (1) requiring that the courts shall be "established by law" that the judicial organization in a democratic society must not depend on the discretion of the Executive, but that it should be regulated by law emanating from Parliament. ${ }^{128}$ Delegatie van bevoegdheden aan een lagere wetgever is volgens de Commissie voor bepaalde onderwerpen echter toegestaan: "Article 6 (1) does not require the legislature to regulate each and every detail in this field by formal Act of Parliament, if the legislature establishes at least the organizational framework for the judicial organization. "29 Wat evenwel nog 'framework' is, en wat 'detail' laat de Commissie in het midden. ${ }^{30}$

\subsubsection{Delegatie}

Terwijl ook voor de werving, selectie- en bevordering van rechterlijke ambtenaren op grond van het bepaalde in art. 116, tweede lid, GW moet worden uitgegaan van het vereiste van een wettelijke grondslag, blijkt uit de term 'regelt' in art. 116, tweede lid, GW dat delegatie terzake is toegestaan. De reikwijdte van die delegatie is, zo blijkt uit de grondwetsherziening van 1983 , beperkt tot het centrale overheidsverband. ${ }^{31}$ Van deze delegatiebevoegdheid is - zie $\$ 2.3$ - op ruime schaal gebruik gemaakt. Uit de grondwetsherziening 1983 blijkt niet dat aan deze constellatie een (enige) principiële gedachtengang ten grondslag ligt. Terwijl de regering in het algemeen een beschouwing over de toegang tot het rechtersambt achterwege laat, merkt zij over art. $116 \mathrm{GW}$ op dat dit de basis vormt voor de onafhankelijkheid van de rechterlijke macht, die haar leden beoogt te beschermen tegen "ongewenste beïvloeding". Overigens is "de onafhankelijkheid van de rechterlijke macht" volgens de regering geen zaak van "louter" grondwetsbepalingen: "de geest waarin de rechterlijke macht haar arbeid verricht is in de praktijk het belangrijkste aspect. Deze mentaliteit zou echter onvoldoende geruggesteund worden, indien niet de Grondwet de benoeming voor het leven zou waarborgen. " De ruime delegatie- (en subdelegatie)bevoegdheden bij de toegang tot het rechtersambt lijkt de regering in het geheel niet als een probleem te zien. Integendeel, zij stelt juist dat de terminologie 'de wet regelt' de wetgever "een voldoende mate van vrijheid geeft":

28. Rapport van 12 oktober i978, Zand, D\&R 15 (1979) p. 70 (79-81)

29. Rapport van 12 oktober 1978 , Zand, D\&R 15 (1979), p. 80

30. Wel stelt zij in de Zand-zaak dat het begrip "bij de wet ingesteld". "envisages the whole organizational set-up of the couns, including not only the matters coming within the jurisdiction of a certain category of courts, but also the establishment of the individual courts and the determination of their local jurisdiction. " Rapport van 12 oktober 1978. Zand, D\&R 15 (1979), p. 80

31. Zie: Nota naar aanleiding van het eindverslag, Hand. II 1980-1981, 16162 , nr. 11, p. 2. Zie ook: C.A.J.M. Kortmann, De grondwetsherzieningen 1983 en 1987, 1987, p. 327 
"De mogelijkheid van delegatie in het tweede lid is onder meer gegeven om het de wetgever mogelijk te maken de huidige praktijk dat binnen en door de gerechten alsmede door de Minister van Justitie, de taakverdeling wordt vastgesteld, te behouden. Bovendien is het gewenst om in de Grondwet de mogelijkheid open te houden dat het aantal rechters van een gerecht of bijvoorbeeld de territoriale competentie der gerechten anders dan bij formele wet worden vastgesteld. ${ }^{\prime 32}$

\subsection{De toegang tot het rechtersambt: de wettelijke regeling}

\subsubsection{Selectie: rechterlijke ambtenaren in opleiding}

De leden van de rechterlijke macht worden gerecruteerd uit twee groepen: de raio's en de buitenstaanders. Alvorens te worden benoemd tot rechter, dienen kandidaten voor een rechterlijke functie een selectieprocedure te doorlopen, hetzij bij de raio-selectiecommissie hetzij bij de Commissie aantrekken leden rechterlijke rnacht. Ambieert men een functie bij de rechterlijke macht en heeft men reeds minimaal zes jaar juridische praktijkervaring, dan komt men terecht bij de Cornmissie aantrekken leden rechterlijke macht; zo niet dan dient men eerst de zesjarige raio-opleiding te doorlopen. Volgens art. 59i, eerste lid, Wet RO kunnen personen die de graad of hoedanigheid bezitten als bedoeld in art. 48, eerste lid, Wet RO, door de minister van justitie worden aangesteld als rechterlijk ambtenaar in opleiding. Rechterlijke ambtenaren in opleiding (raio's) worden opgeleid voor de zittende of staande magistratuur. Na het met gunstig resultaat dooriopen van de raio-opleiding worden zij eerst aangesteld als gerechtsauditeur of als substituut-officier van justitie bij een arrondissementsrechtbank. Na verloop van enige tijd kan een gerechtsauditeur worden benoemd tot rechter-plaatsvervanger. De substituut-officier van justitie kan na enige tijd in aanmerking komen voor benoeming tot arrondissementsofficier van justitie. Bij algennene maatregel van bestuur worden voorschriften gegeven met betrekking tot de selectie, de aanstelling, de opleiding en andere aangelegenheden, alsmede de rechtspositie van deze ambtenaren. ${ }^{33}$

\subsubsection{De raio-selectiecommissie}

Ten aanzien van de toelating tot de opleiding bepaalt het Besluit opleiding rechterlijke ambtenaren dat er een selectiecommissie is. ${ }^{34}$ De selectiecommissie is volgens art. 17 Besluit samengesteld uit a) een president van een arrondissementsrechtbank en drie andere voor het leven benoemde leden van gerechten belast met de berechting van geschillen over burgerlijke rechten,

32. MvT, Bijl. Hand. II 1979-1980, 16162 , nr. 3, p. 17

33. Zie: art. $59 \mathrm{i}$, tweede lid, Wet RO jo. KB van 24 oktober 1985, Stb. 555

34. $\mathrm{KB}$ van 24 oktober 1985 , Stb. 555 
voorts b) een officier van justitie, hoofd van een arrondissementsparket en twee andere leden van het openbaar ministerie, c) een voorzitter van een raad van beroep $^{35}$ en een ander voor het leven benoemd lid van een gerecht, uitsluitend belast met geschillen die niet uit burgerlijke rechtsbetrekkingen zijn ontstaan; d) drie personen, niet behorend tot de vorige groepen en niet werkzaam bij het ministerie van justitie, en e) drie ambtenaren van het ministerie van justitie. ${ }^{36}$ Volgens art. 18, vijfde lid, Besluit legt de commissie al wat tot haar werkwijze behoort neer in een reglement van orde dat de goedkeuring van de minister behoeft. Als voorwaarden voor de toelating tot de opleiding stelt het Besluit dat de kandidaten de graad of hoedanigheid bezitten zoals genoemd in art. 48 , eerste lid, Wet RO (opleidingsvereiste) en dat zij niet ouder zijn dan dertig jaar. De minister kan, de selectiecommissie gehoord, ontheffing verlenen van de leeftijdseis. De minister beslist omtrent toelating van de kandidaten na advies van de selectiecommissie. Hij laat geen kandidaten toe dan op aanbeveling van de selectiecommissie. ${ }^{37}$

\subsubsection{De Commissie aantrekken leden rechterlijke macht}

De selectie van buitenstaanders voor de functies van rechter in een arrondissementsrechtbank en kantonrechter geschiedt door de Commissie aantrekken leden rechterlijke macht. Met de selectie van kandidaten voor andere colleges houdt de Commissie aantrekken leden rechterlijke macht zich niet bezig. Zo werven en selecteren de gerechtshoven bijvoorbeeld zelf hun kandidaten, een situatie die, volgens de secretaris van de Commissie. N.J. van der Lee, "niet allerwegen wordt toegejuicht." ${ }^{38}$ De term 'buitenstaanders' is overigens verwarrend: het kan daarbij gaan om personen die over minstens zes jaar elders opgedane juridische ervaring beschikken, en de 'overstap' naar de rechterlijke macht willen maken, dan wel om personen die van uit hun huidige werkkring als rechter-plaatsvervanger willen worden benoemd, en die niet van plan zijn full time over te stappen naar de rechterlijke macht. Voor de eerste categorie geldt een 'normale' selectieprocedure, voor de tweede een verkorte procedure. ${ }^{39}$ De Commissie aantrekken leden rechterlijke macht werd ingesteld bij

35. Thans een voorzitter van de bestuurssector van een rechțank.

36. De onder a) tot en met d) bedoelde leden worden voor vier jaar benoemd door de minister van justitie, die met betrekking tot de onder a), bj en c) bedoelde leden advies inwint van de Nederlandse Vereniging voor Rechtspraak. De onder e) bedoelde leden worden voor onbepaalde tijd benoemud. Elk jaar treden drie van de onder a) tot en met d) bedoelde leden af. Zij zijn niet aansluitend herbenoembaar. Uit de leden wijst de minister een voorzitter aan (art. 17 Besluit).

37. Art. 16 Besluit. Zie voor een beschrijving van de selectieprocedure: Bijlage 2

38. Bron: interview met N.J. van der Lee, secretaris van de Commissie aantrekken leden rechterlijke macht, 15 maart 1993, Den Haag

39. Zie voor een beschrijving: Bijlage 2 
ministerieel besluit van 16 april $1970 .{ }^{40}$ Reden voor instelling van de Commissie was dat zich volgens de minister voor vacatures in de zittende magistratuur te weinig juristen met een elders verkregen praktijkervaring aanmeldden. Met de instelling van de Commissie hoopte de minister de belangstelling van ervaren buitenstaanders voor een loopbaan bij de rechterlijke macht te stimuleren. ${ }^{41}$ Sinds de jaren zestig hanteert het ministerie de beleidslijn dat de rechterlijke macht voor ten hoogste $50 \%$ wordt samengesteld uit raio's en voor tenminste $50 \%$ uit leden die tevoren een heel andere carrière hebben gevolgd, hijvourbeeld in de advocatuur, het bedrijfsleven, het wetenschappelijk onderwijs of bij de overheid. ${ }^{42}$

\subsubsection{Absolute en relatieve voorwaarden voor benoembaarheid}

$\mathrm{Na}$ de selectieprocedure bij de Commissie aantrekken leden rechterlijke macht, kunnen buitenstaanders (oud-raio's worden eerst als gerechtsauditeur aangesteld) worden benoemd tot rechter-plaatsvervanger in een arrondissementsrechtbank. ${ }^{43}$ Daarbij wordt overigens nog onderscheiden tussen honoraire rechter-plaatsvervangers (de buitenstaander maakt geen 'overstap' naar de rechterlijke macht), en het rechter-plaatsvervangerschap als opleidingsfunctie. Teneinde in aanmerking te kunnen komen voor een eerste of verdere benoeming, dient de kandidaat te voldoen aan een aantal (grond-)wettelijke eisen voor benoembaarheid in de rechterlijke macht. Ik onderscheid tussen absolute en relatieve voorwaarden voor benoembaarheid. De absolute voorwaarden voor benoembaarheid gelden steeds voor de benoeming in een rechterlijk ambt; de relatieve voorwaarden gelden slechts voor de benoeming in een bepaald coll'ge, maar staan een benoeming in de rechterlijke macht overigens niet in de weg. De absolute voorwaarden voor benoembaarheid zijn het bezit van de Nederlandse nationaliteit ${ }^{44}$ en een bepaalde juridische opleiding. ${ }^{45} \mathrm{Bij}$ de rela-

40. Besluit van 16 april 1970 Hoofdafdeling R. O. nr. 735 P 870

41. Besluit van 16 april 1970 Hoofdafdeling R.O. nr. 735 P 870. Zie voor een beschrijving van de selectieprocedure: Bijlage 2

42. Zie hoofdstuk 4

43. De toetreding lot de rechterijke macht via de Commissie aantrekken leden rechterlijke mach, brochure 1993, p. 11

44. Art. 29a Wet RO Een uitzondering op de regel van art. 29a Wet RO vormen overigens de niet-Nederlandse Molukkers, die door de zorg van de Nederlandse regering in 1951 of 1952 in groepsverband naar Nederland zijn overgebracht, en die op bet tijdstip van het in werking treden van de Wet van 9 september 1976 Stb. 468 (Wet betreffende de positic van Molukkers) in Nederland woonplaats of werkelijk verblijf hadden. Zij worden bij de toepassing van de Nederlandse wetgeving behandeld als Nederlander, en zijn in tegenstelling tot andere niet-Nederlanders, tot iedere openbare dienst benoembaar, met uitzondering van de krijgsmacht. Zie: art. 1 van de Wet van 9 september 1976. Stb. 468. Ook het vereiste van het Nederlanderschap dat art. 29 Wet RO als voor- 
tieve voorwaarden voor benoembaarheid gaat het om het verbod van nevenfuncties ex art. 8 Wet RO), en het verbod voor de leden van de Hoge Raad om lid te zijn van de Staten-Generaal. ${ }^{46}$ Deze incompatibiliteiten zijn echter geen beletsel voor de benoembaarheid in de rechterlijke macht of in een bepaald college. Wel dient een rechter, na de aanvaarding van zijn ambt, zijn onverenigbare functie neer te leggen. De leden van de rechterlijke macht welke voor het leven zijn benoemd, die ambten of betrekkingen aanvaarden die volgens de wet onverenigbaar zijn met de door hen beklede functie, worden door de Hoge Raad ontslagen. ${ }^{47}$

\subsubsection{Benoemingen: algemeen}

De leden van de rechterlijke macht worden (zie hiervoor) gerecruteerd uit twee groepen: de raio's en de 'buitenstaanders'. Noch het met gunstig resultaat afleggen van de raio-opleiding, noch het positieve oordeel van de Commissie aantrekken leden rechterlijke macht, garanderen een benoeming tot de zittende of stitande magistratuur. Na de raio-opleiding kan de oud-raio tot gerechtsauditeur worden henoemd, en daarna tot rechter in een arrondissementsrechtbank; voor de buitenstaanders geldt, als gezegd, dat na het fiat van de Commissie aantrekken leden rechterlijke macht een benoeming tot rechter in een arrondissementsrechtbank mogelijk is. In de praktijk worden buitenstaanders echter eerst als rechter-plaatsvervanger bij een rechtbank, en in een enkel geval tot gerechtsauditeur benoemd. Overigens is de rechterlijke loopbaan wettelijk niet geregeld.

Voor een rechter in een arrondissementsrechtbank staan in de praktijk drie promotie-richtingen open, namelijk de functies van vice-president van een rechtbank, van raadsheer in een gerechtshof en van kantonrechter. Van daaruit kan verdere promotie worden gemaakt. Voor de vice-presidenten van een rechtbank is dit hetzij een benoeming tot raadsheer in een gerechtshof, hetzij een benoeming tot rechtbankpresident. Voor de raadsheren is dit doorgaans een benoeming tot vice-president gerechtshof met daarna nog de mogelijkheid om tot president gerechtshof te worden benoemd. Ook de overstap naar een groter

waarde stelt voor de benoembaarheid tot rechterlijk ambtenaar geldt niet voor deze categorie niet-Nederlanders. Zie verder: hoofdstuk 4

45. Art. 35, eerste lid, 48 cerste lid, 64 en 86 Wet R.O. Overigens geldt dat de leden van de rechterlijke macht bij het bereiken van het zeventigste levensjaar ontslag wordt verleend. Daamee is (theoretisch) tevens de maximale leeftijd gegeven waarop men benoemd zou kunnen worden. Zie: artt. 36, tweede lid, 51 , eerste lid, 62 , eerste lid en 84 , eerste lid, Wet RO

46. Art. 57, tweede lid, GW jo. an. 9 Wet RO

47. Art. 12, eerste lid, sub c, Wet RO 
kanton, of een groter arrondissement wordt als een promotie beschouwd. ${ }^{48}$ Het begrip 'carrière-rechter' dat wel voor ons promotiestelsel wordt gehanteerd is trouwens verwarrend. Met carriere-rechter (career judges) wordt in de (veelal Amerikaanse) literatuur meestal bedoeld degene die voor een onbepaalde ambtstermijn ('voor het leven') is aangesteld (in tegenstelling tot rechters die voor een bepaalde termijn worden benoemd of gekozen). Met carrièrerechters wordt in ons land echter bedoeld, degene die voor een loopbaan in de rechterlijke macht kiest (dus de oud-raio, of de buitenstaander die de 'overstap' naar de rechterlijke macht maakt, niet: de rechter-plaatsvervanger).

\subsubsection{De procedure bij eerste benoemingen}

De eerste stap in de rechterlijke loopbaan is (behoudens het gerechtsauditeurschap) de benoeming tot rechter(-plaatsvervanger) in een arrondissementsrechtbank. Daartoe dient eerst een vacature 'open te vallen'. Het verzoek tot het openstellen van de vacature wordt gedaan door de rechtbank; de beslissing daarover (vaststelling dat voldoende formatieruimte beschikbaar is) gebeurt door het ministerie van justitie. Daarna wordt o.a. in het Nederlands Juristenblad een advertentie geplaatst, waarin kandidaten worden opgeroepen te solliciteren. ${ }^{49}$ Met betrekking tot de werving van (kandidaat) rechterlijke ambtenaren bevat de Wet RO geen voorschriften. De werving van raio's geschiedt door het ministerie van justitie, evenals de werving voor promotiefuncties; de werving van 'buitenstaanders' geschiedt door de Commissie aantrekken leden rechterlijke macht. De werkwijzen van het ministerie en van de Commissie lopen niet ver uiteen. Uitgangspunt vormen de advertenties die op gezette tijden in zowel juridische bladen als in een aantal landelijke dagbladen

48. De toetreding tot de rechterlijke macht via de Commissie aantrekken leden rechterlijke macht, brochure 1993 , p. 14

49. Tegen deze sollicitatie-'plicht' rees in de jaren vijftig met name van de kant van kandidaat rechter-plaatsvervangers bezwaar. Een dergelijke benoeming, waarbij het veelal ging om personen die 'algemeen geacht en gezien' waren, werd beschouwd als "een eer waarvoor men niet pleegt te solliciteren. Bovendien is het niet denkbeeldig te achten, dat, speciaal zij, die in het maatschappelijk leven een vooraanstaande positie bekleden of reeds een eervolle carrière achter de nug hebben, zullen aarzelen -ook al worden zij door president of kantonrechter uitgenodigd-te solliciteren wanneer zij niet de zekerheid hebben te worden henoemd." (Briế van de minister van justitie van 12 januari 1955. nr. P. 800/059) Om die reden werd de publikatie van vacatures voor rechter-plaatsvervangers in het Nederlands Juristenblad gestaakt, en werd de werving en recrutering van de plaatsvervangers weer overgelaten aan de rechtscolleges zelf. Een rechtscollege kon in een dergelijk geval volstaan met een aanbeveling van slechts een kandidaat. Vacatures rechter-plaatsvervanger worden tot op heden niet gepubliceerd. 
en tijdschriften van uiteenlopende signatuur worden geplaatst. ${ }^{50}$ Voor vacatures raadsheer Hoge Raad geldt een uitzonderingssituatie; daarvoor wordt niet geadverteerd. In het verleden werden kandidaten zelfs niet gevraagd, maar eenvoudig op de aanbeveling geplaatst. Tegenwoordig worden potentiële kandidaten door de Hoge Raad zelf 'gepolst'. ${ }^{51}$ Dit laatste kornt trouwens ook voor bij de 'lagere' functies; zo gebeurt het - naar verluidt - regelmatig dat een president van een college of een kantonrechter, iemand die hij bijzonder geschikt acht voor het rechtersambt - veelal gaat het dan om advocaten - aanmoedigt om te solliciteren.

Het ministerie zendt de binnengekomen sollicitatierekesten met een verzamellijst door aan de desbetreffende rechtbank, die een aanbeveling opmaakt. De aanbevelingsvergadering bestaat (bij vacatures rechter arrondissementsrechtbank) uit de president van de betrokken rechtbank, de leden van de rechtbank en de officier van justitie die is benoemd tot hoofd van het betrokken arrondissementsparket. ${ }^{52}$ In het algemeen wordt voor het opstellen van de aanbeveling een vergadering belegd waaraan alle leden van het betreffende college kunnen deelnemen. Om een oordeel te kunnen krijgen over de geschiktheid van de kandidaten wordt het veelal nodig geacht dat met ieder van hen wordt kennis gemaakt. Vaak vindt zo'n gesprek plaats met aile leden van het college afzonderlijk. Soms echter geschiedt de kennismaking en het opstellen van de aanbeveling door het presidium van het betrokken college. De aanbeveling vermeldt in alfabetische volgorde de namen van drie ${ }^{53}$ kandidaten, zodat door de rechtbank geen voorkeur wordt uitgesproken. Na vaststelling van de lijst van aanbeveling wordt de lijst om commentaar gezonden aan de procureur-generaal bij het gerechtshof. Het openbaar ministerie conformeert zich nagenoeg altijd aan de aanbeveling. Ook de bijdrage van de president van het gerechtshof, aan wie de aanbeveling wordt voorgelegd, is praktisch zeer gering. ${ }^{\text {s4 }}$ Het gerechtshof stuurt de aanbeveling, al dan niet voorzien van commentaar, door aan het

50. Werving door de selecticcommissies geschiedt door advertenties in: het Nederlands Ju* ristenblad, Internediair, en enkele landelijke dagbladen.

51. P.J. van Koppen en J. ten Kate, Tol raadsheer benoemd Anderhalve eeuw benoemingen in de Hoge Raad der Nederlanden, 1987, p. 99

52. Art. 52 Wet RO

53. In het verleden bleek echter dat rechtbanken, bij gebrek aan geschikte kandidaten, niet zelden minder dan 3 kandidaten op de aanbeveling plaatsten, dit tot ergernis van het ministerie van justitie. Zie de brief van de minister van justitie van 6 juli 1953, nr. P. $8000 / 059$

54. Bron: Projectgroep Werkbelasting Gerechten, rapport: Onderzoek functioneren rechterlijke macht, 1985, p. 3-4 
ministerie van justitie. ${ }^{55}$ Daarna wordt op het ministerie van justitie een 'benoemingsnota' opgesteld. Met uitzondering van kandidaten voor de vacatures van president of voorzitter van colleges zullen de aanbevolen kandidaten bij ontstentenis van de minister door de secretaris-generaal worden ontvangen. Indien de kandidaat minder dan twaalf maanden geleden in verband met een sollicitatie is ontvangen, wordt van audiëntie afgezien. ${ }^{56}$ Tenslotte volgen het benoemingsbesluit door de regering en de installatie en beëdiging van de rechter. Overigens is de duur van de aanbevelings- en benoemingsprocedure, die voorheen gemiddeld 7 tot 9 maanden bedroeg, sinds september 1992 aanzieniijk bekort. $^{57}$

\subsubsection{De procedure bij verdere benoemingen}

In het systeem van de Grondwet en van de Wet RO is niet voorzien in een (duidelijke) promotieregeling voor rechterlijke ambtenaren. ${ }^{58}$ Wat de presidents- en vice-presidentsfuncties bij de rechtbanken en de gerechtshoven betreft, valt dit te verklaren uit de omstandigheid dat voor die benoemingen van oudsher de (overigens: ongeschreven) anciënniteitsregel gold. Slechts voor de benoeming van de leden van de Hoge Raad vinden we een vage vingerwijzing voor bevorderingen; de Hoge Raad dient bij het opmaken van de aanbeveling 'de leden der Hoven en der arrondissementsrechtbanken, mitsgaders de leden van het openbaar ministerie, welke deze hun ambtsbedieningen met lof en ijver hebben waargenomen, meer bijzonderlijk' in aanmerking te nemen. ${ }^{59}$ Ook de benoeming tot kantonrechter, raadsheer gerechtshof en president en vicepresident rechtbank en gerechtshof, moet - zoals hiervoor al bleek - worden

55. Vergelijk art. 52 Wet RO. De praktijk wisselt per hofressort. Sommige gerechtshoven ontvangen de aanbevolen kandidaten zelf. Naar verluidt voegt het gerechtshof Den Haag standaard een eigen advies bij de aanbeveling van de rechtbank.

56. Circulaire van 17 juni 1992 , nr. $213188 / 892$

57. Circulaire van 17 juni $1992, \mathrm{nr} .213188 / 892$. De benoemingsprocedure voor de vacature van rechter/ondervoorzitter/kantonrechter zal na verzoek tot openstelling tot aan de installatie 5 maanden ( 19 weken) in beslag nemen, de vacature van raadsheren bij de gerechtshoven: 4 maanden (17 weken), van vice-presidenten van rechtbanken en gerechtshoven: 5 maanden (19 weken) en van rechter/ondervoorzitter/raadsheer/kantonrechter-plaatsvervanger: 3 maanden ( 11 weken). De benoeming van een gerechtsauditeur tot rechter zal 3 maanden ( 11 weken) duren en die van een buitenstaander tot gerechtsauditeur 2 maanden ( 9 weken).

58. Strikt genomen kan men zich zelfs afvragen of wel van een 'promotic' gesproken kan worden, omdat een duidelijke hiërarchie tussen rechters ontbreekt.

59. Art. 85. tweede lid, Wet RO. De Wet RO 1827 kende overigens wel een zekere carrièreplanning voor rechters; de rechters van de rechtbanken werden bij voorkeur uit de kantonrechters gekozen (art. 52), de raadsheren in de gerechtshoven uit de leden van de rechtbanken (art. 67), en de raadsheren in de Hoge Raad uit de leden van de rechtbanken en de gerechtshoven (art. 87). 
heschouwd als een verdere henoeming. Benoeming in deze functies geschiedt hij koninklijk besluit. ${ }^{60}$

\subsubsection{Benoeming van presidenten en vice-presidenten}

De artikelen 51 , eerste lid, en 62, eerste lid, Wet RO bepalen onder meer dat de presidenten en vice-presidenten rechtbank en gerechtshof door de Koning ${ }^{01}$ worden aangesteld. Over een bijzondere procedure voor henoeming in deze functies zwijgt de wet. Ten aanzien van de benoeming van presidenten en vicepresidenten rechtbank en gerechtshof gold vroeger - als gezegd - het anciënniteitsprincipe, waardoor bij een presidentsvacature in een rechtbank of een hof de oudste vice-president - en bij een vice-presidentsvacature de oudste rechter/raadsheer - werd benoemd. Van dit anciënniteitsprincipe, dat geen wettelijke grondslag had, werd enkel afgeweken indien de betrokkene niet voor een benoeming in aanmerking wenste te komen, of in zeer bijzondere gevallen (gezondheid/aperte ongeschiktheid). ${ }^{\text {i? }}$ Later werden deze benoemingen, met uitzondering van vacatures president en vice-president Hoge Raad, z.g. 'keuzebenoemingen' van de regering." Thans wordt voor (sommige) promotiebenoemingen (president en vice-president arrondissementsrechtbank en gerechtshof) een bijzondere selectieprocedure gehanteerd. Deze procedure berust op een viertal circulaires, die in de periode 1975-1992 tot stand zijn gekomen. ${ }^{64}$ Een wettelijke grondslag voor deze procedures ontbreekt (overigens ten onrechte; zie hiervoor $\$ 2.2 .3$ ). Omdat de procedures voor verdere benoemingen grotendeels overeenkomen, volsta ik hieronder met de bespreking van de jongste procedure voor vacatures president rechtbank van 24 november 1992. ${ }^{65}$ Bij de benoeming van de president van de rechtbank Amsterdam, R. Gisolf, in 1992 is deze procedure voor het eerst toegepast, en gedocumen-

60. Zie hierover de opmerkingen van de regering bij de a!gehele grondwetsherziening 1983. Hand. II 1980-1981. p. 3319

61. N.B. art. $117 \mathrm{GW}$ spreekt over een benoeming bij koninklijk besluit

62. P.R. Smits, Enige kanthekeningen bij de huidige procedure van benoeming van presidenten en vice-presidenten bij rechibanken en hoven, in: Trema, 1989, p. 168

63. Het precieze moment is niet gedocumenteerd.

64. Benoemingsprocedures: president rechtbank: circulaire van 19 november $1985 \mathrm{nr} .2168$ P 885 (gewijzigd bij circulaire van 24 november 1992 nr. 26366/892; vice president rechtbank: circulaire van 3 januari $1975 \mathrm{nr}$. 2284 P 874: president gerechtshof: circulaire van 1 juli $1987 \mathrm{nr}$. 1271 P 887; vice-president gerechtshof: circulaire van 1 juli $1987 \mathrm{nr}$. 1271 P 887. Zie verder hoofdstuk 4 en Bijlage 1

65. Circulaire van 24 november $1992 \mathrm{nr}$. 263662/892. Overigens werd mij door het Ministerie van Justitie meegecleeld dat ten aanzien van de benoemingsprocedures op korte termijn geen veranderingen zijn te verwachten. Brief van 29 oktober 1993. 
teerd door een lid van het betreffende afspiegelingscollege ${ }^{66}$, hetgeen een mogelijkheid biedt theorie en praktijk van presidentsbenoemingen naast elkaar te leggen. ${ }^{67}$

\subsubsection{De herziene benoemingsprocedure president rechtbank}

Bij verdere benoemingen ${ }^{6 x}$ is net als bij eerste benoemingen sprake van een wervings-, aanhevelings- en benoemingsfase, maar is met name de aanbevelingsfase nader uitgewerkt. Terwijl de aanbeveling bij eerste benoemingen wordt opgemaakt door de rechtbank en de hoofdofficier van justitie in het betrokken arrondissement, is bij verdere benoemingen sprake van een 'commissie van aanbeveling', van z.g. 'insprekers', en - voor vacatures president rechtbank en gerechtshof - van een 'afspiegelingscommissie'. Anders dan bij eerste benoemingen is de aanbevelingsvergadering bij verdere benoemingen niet (alleen) samengesteld uit de leden van de betrokken rechtbank of het betrokken gerechtshof, maar hebben daarin ook externe leden zitting. ${ }^{69} \mathrm{De}$ bevoegdheden van de commissie van aanbeveling worden in de verschillende circulaires meer of minder omschreven. De jongste regeling op dit punt, nl. de nieuwe benoemingsprocedure voor presidenten rechtbank, is het meest gedetailleerd. ${ }^{70}$ Het zwaartepunt lijkt te liggen bij de commissie van aanbeveling; deze 'kleine commissie', bestaande uit de president van het betrokken college en twee presidenten van buiten, wint inlichtingen in, maakt zonodig (indien er zeer veel sollicitanten zijn) een voorselectie, en hoort de kandidaten.

66. P. Ingelse. Op zoek naar een nieuwe president Verslag van het Amsterdamse afspiegelingscollege. in: Trema 1993-7, p. 294-298

67. Hoewel ten tijde van de vacature van Gisolf formeel nog de oude circulaire (circulaire van 19 november $1985 \mathrm{nr} .2168 \mathrm{P} 885$ ) gold, is in Amsterdam de herziene procedure reeds toegepast.

68. N.B. de benoeming tot kantonrechter en raadsheer gerechtshof -beide worden eveneens als een verdere benoeming beschouwd-blijven hier buiten beschouwing. De betreffende regelingen zijn grotendeels identiek aan een cerste benoeming. Zie voor een beschrijving van de betrokken regelingen Bijlage 1

69. Zo hebben in de commissie van aanbeveling voor presidentsfuncties rechtbank de president van het gerechtshof en twee ad hoc door de vergadering van rechtbankpresidenten aangewezen rechtbankpresidenten zitting (circulaire van 24 november $1992 \mathrm{nr}$. 263658/892). Bij vacatures president gerechtshof zijn dit een door de vergadering van hofpresidenten aan te wijzen president van een gerechtshof, en twee door de vergadering van rechtbankpresidenten aan te wijzen rechtbankpresidenten (circulaire van 1 juli 1987 nr. 1271 P 887). Bij de vacatures vice-president rechtbank en hof is de commissie van aanbeveling -anders dan bij vacatures president-mede samengesteld uit de zittende presidenten: circulaires van 25 januari $1989 \mathrm{nr} .142$ P 889/21 februari $1989 \mathrm{nr} .307$ P 889 (vacatures vice-president gerechtshof) en 3 januari 1975 nr. 2284 P 874 (vacatures vicepresident rechtbank). Zie Bijlinge 1

70. Circulaire van 24 november $1992 \mathrm{nr}$. 263658/892. Zie Bijlage 1 
De rechtbank waarin de vacature bestaat stelt voordat de vacature wordt opengesteld een profielschets op en doet deze aan de commissie van aanbeveling toekomen. Voor de totstandkoming van die profielschets bevat de circulaire geen richtlijnen. Bij de recente benoeming van de president van de rechtbank Amsterdam, werd de profielschets pas opgesteld nadat de sollicitatierekesten waren binnengekomen. Daarbij had het college de gewenste eigenschappen onderscheiden in 'juridische kwaliteiten', 'managementkwaliteiten' en 'overige eisen'. ${ }^{71}$ De commissie van aanbeveling wint vervolgens inlichtingen in, bij voorkeur volgens een vast stramien, met een vaste vraagstelling en beperkt tot bepaalde functionarissen, zoals de president van de rechtbank waaraan de sollicitant verbonden is en eventueel de president van het hof indien het een raadsheer betreft. Indien de adviezen daartoe aanleiding geven, staat het de commissie van aanbeveling vrij nadere inlichtingen in te winnen. De voorzitter van de commissie van aanbeveling stuurt een afschrift van de binnengekomen inlichtingen naar de overige leden van de commissie alsmede aan de voorzitter van een delegatie van in beginsel 5 personen uit de rechtbank "die het vertrouwen heeft van dit college en welke als een afspiegeling daarvan kan worden aangemerkt" (het afspiegelingscollege), die deze stukken vertrouwelijk onder zich houdt en ze na het uitbrengen van het advies aan de voorzitter van de commissie van aanbeveling terugzendt. Niet duidelijk is overigens hoe dit vertrouwen wordt vastgesteld. Om daadwerkelijk het college te "weerspiegelen", achtte men het in Amsterdam noodzakelijk om de rechtbank in al haar geledingen (bestuurs-, civiele- en strafsector, kort-geding-sector, jeugd- en familieunit) te vertegenwoordigen, zodat het afspiegelingscollege niet uit vijf maar uit tien leden bestond (drie vice-presidenten en zeven rechters). ${ }^{2}$ De leden van het afspiegelingscollege en de overige hierna te noemen insprekers kunnen bij de voorzitter van het afspiegelingscollege inzage in de binnengekomen inlichtingen verkrijgen. De sollicitant heeft het recht kennis te nemen van de zakelijke inhoud van de inlichtingen. Het afspiegelingscollege onthoudt zich van het inwinnen van schriftelijke inlichtingen.

De circulaire maakt, afgezien van het verbod voor het afspiegelingscollege om schriftelijke inlichtingen in te winnen, geen melding van een bevoegdheid voor het afspiegelingscollege om sollicitanten te ontvangen. In Amsterdam hield het afspiegelingscollege uitvoerige gesprekken met drie kandidaten, waarbij het college zich in drie groepen had gesplitst, die elk een onderwerp (juridische, management- of persoonlijke aspecten) voor hun rekening namen, en elk gedurende drie kwartier met de drie kandidaten spraken. Met een der kandidaten werd nog een tweede gesprek gevoerd. Het afspiegelingscollege maakte daarbij

71. Ingelse, o.c. p. 294

72. Ingelse, o.c. p. 294 
gebruik van vragenlijsten, die als losse leidraad voor de gesprekken werden gehanteerd. ${ }^{73}$ De commissie van aanbeveling heeft overigens het recht om, indien haar dit in bijzondere omstandigheden gewenst voorkomt, bijvoorbeeld omdat zich zeer veel sollicitanten hebben gemeld, uit de sollicitanten een voorselectie te maken van degenen die naar haar mening voor de vervulling van de vacature in aanmerking komen. De commissie hoort in ieder geval alle sollicitanten indien deze dat wensen, behoudens wanneer een kandidaat niet aan de formele vereisten voor de benoeming voldoet. $\mathrm{Zij}$ geeft de namen van alle sollicitanten, alsmede de eventueel door haar gemaakte voorselectie, door aan de insprekers.

Insprekers zijn het afspiegelingscollege, de hoofdofficier van justitie, de directeur gerechtelijke ondersteuning (D.G.O.), het hoofd gerechtelijke ondersteuning (H.G.O.) en de deken van de orde van advocaten in het arrondissement. Op welke wijze de D.G.O. en het H.G.O. hun inspraakrecht uitoefenen staat te hunner beoordeling. Zij kunnen dit gezamenlijk doen, maar het is ook mogelijk dat het H.G.O. zich aansluit bij het afspiegelingscollege. Iedere inspreker moet contact kunnen hebben met de kandidaten. Het afspiegelingscollege heeft binnen een door de commissie gestelde termijn het recht de commissie te laten weten dat het ook andere dan de voorgeselecteerde sollicitanten in de verdere selectie wil betrekken. De commissie kan hierover met het afspiegelingscollege in overleg treden. Indien dit zijn wens handhaaft, worden bedoelde sollicitanten in de verdere selectie betrokken. Vervolgens bericht de commissie aan de sollicitanten die niet in de verdere selectie zijn betrokken dat aan hun sollicitatie geen verder gehoor zal worden gegeven. Voorts bericht de commissie de overige sollicitanten en de insprekers welke sollicitanten nog als zodanig zullen optreden. De insprekers brengen op verzoek van de commissie van aanbeveling hetzij schriftelijk hetzij mondeling advies uit, maar hebben steeds de bevoegdheid schriftelijk te adviseren en, indien schriftelijk advies is uitgebracht, een mondelinge toelichting daarop aan de commissie van aanbeveling te geven. Het afspiegelingscollege adviseert zonder last of ruggespraak. De adviezen zijn strikt vertrouwelijk en blijven voor de sollicitanten en de andere insprekers geheim, behoudens de vrijheid van de commissie van aanbeveling om met toestemming van de betrokken inspreker de inhoud ervan met andere insprekers en/of sollicitanten te bespreken wanneer de adviezen daartoe aanleiding geven.

Ook de aftredende of afgetreden president geeft ten behoeve van de commissie van aanbeveling een kenschets van de door hem (te) verlaten rechtbank en brengt deze in relatie met bovengenoemde profielschets. Voorts kan hij inlich-

73. Ingelse, o.c. p. 295 
tingen verstrekken omtrent de sollicitanten die aan de door hem (te) verlaten rechtbank verbonden zijn. Hij onthoudt zich echter van een advies of aanbeveling. De aanbeveling bevat zo mogelijk meer dan een naam. met een maximum van drie, opgemaakt in volgorde van voorkeur. De commissie van aanbeveling zendt de aanheveling en een toelichting op de aanbeveling aan het ministerie van justitie. Niet duidelijk is wie beslist over de plaatsing van kandidaten (en de volgorde van voorkeur daartussen) op de aanbeveling. In dit verband is niet onbelangrijk dat de commissie van aanbeveling bij de aanbeveling alle overige bescheiden (de originele rekesten, de binnengekomen adviezen en de overige inlichtingen) voegt, en deze uiterlijk drie maanden na sluiting van de sollicitatietermijn aan het ministerie van justitie zendt. Aan de sollicitanten en aan de insprekers wordt bericht hoe de aanbeveling, inclusief volgorde van voorkeur, luidt. De aanbeveling wordt niet gepubliceerd.

\subsubsection{Benoeming raadsheer Hoge Raad}

De benoeming van een lid van de Hoge Raad neemt tussen de verdere benoemingen een bijzondere positie in. Het gaat daarbij niet om een promotie die thuishoort in het reguliere carriereperspectief van een rechter. Vacatures president, vice-president of raadsheer in de Hoge Raad worden in de praktijk niet opengesteld voor sollicitatie. Art. 118, eerste lid, GW bepaalt dat de leden van de Hoge Raad der Nederlanden worden benoemd uit een voordracht van drie personen, opgemaakt door de Tweede Kamer der Staten-Generaal. Op zijn beurt biedt de Hoge Raad een aanbeveling van zes personen aan de Tweede Kamer aan. ${ }^{74}$ Volgens art. 85 , tweede lid, Wet RO zal de Hoge Raad bij het opmaken van de aanbeveling de leden der hoven en der arrondissementsrechtbanken, alsmede de leden van het openbaar ministerie bij deze colleges, die hun ambtsbediening 'met lof en ijver' hebben waargenomen, in het bijzonder in aanmerking laten komen. Niets is in art. $118 \mathrm{GW}$ bepaald omtrent het orgaan dat de leden van de Hoge Raad benoemt en/of over de aard van het besluit wadrbij de benoeming plaatsvindt. ${ }^{75}$ Naast de hoofdregel van art. 117 , eerste lid, GW achttc de regering een vermelding, dat de leden van de Hoge Raad bij koninklijk besluit voor het leven worden benıemd, vanuit een oogpunt van systematiek, alsmede van een beknopte opzet van de nieuwe Grondwet, niet nodig. ${ }^{76}$ Volgens de regering kon er geen misverstand over bestaan dat de waarborgen, die in artikel 117, eerste lid, GW voor de leden van de rechterlijke macht met rechtspraak belast worden gegeven, eveneens zullen gelden voor de leden van de Hoge Raad; zij was van mening dat in de toekomst grond-

74. Art. 85, eerste lid, Wet RO

75. Volgens art. 84 Wet RO worden de raadsheren bij koninklijk besluit voor hun leven angesteld.

76. MvA, Bijl. Hand. II 1980-1981, 16163 (R1146), nr. 8, p. 2 
wettelijk zou zijn vastgelegd dat de leden van de Hoge Raad bij koninklijk besluit worden benoemd. ${ }^{77} \mathrm{Bij}$ de algehele grondwetsherziening van 1983 werd de voordrachtsprocedure overigens, overeenkomstig het advies van de Staatscommissie van advies inzake de Grondwet en de Kieswet, in grote trekken gehandhaafd. ${ }^{78}$ Sinds de grondwetsherziening van 1983 bepaalt de Grondwet - anders dan art. $177 \mathrm{GW} 1972$ - in art. 118, eerste lid niet langer dat door de Hoge Raad van een voorgevallen vacature kennis wordt gegeven aan de Tweede Kamer der Staten-Generaal. De kennisgeving van de Hoge Raad, die volgens art. 85 , eerste lid, Wet RO gepaard gaat met het inzenden door de Hoge Raad van een lijst van aanbeveling van zes personen aan de Tweede Kamer, heeft daardoor haar grondwettelijke grondslag verloren.

\subsubsection{Situatie sinds 1992}

Naar aanleiding van de eerdergenoemde kwestie-Van der Burg ${ }^{79}$ geldt sinds 19 februari 1992 bij de inzending van de aanbeveling van kandidaten voor de Hoge Raad een nieuw regime. De Hoge Raad stuurt de curricula van de kandidaten op de aanbevelingslijst in gestandaardiseerde vorm voorzien van informatie naar de Tweede Kamer. De president van de Hoge Raad voorziet iedere aanbevelingslijst van een aparte toelichting. In die toelichting zet hij uiteen wat de motieven zijn van de Raad om te komen tot de aanbeveling. De aanbevelingslijst, de curricula en de toelichting worden gelijktijdig gestuurd aan de voorzitter van de Tweede Kamer en de voorzitter van de Vaste Kamercommissie voor Justitie. Indien de lijst of de toelichting aanleiding vormen tot het vragen van nadere inlichtingen, dan zal de Vaste Kamercommissie voor Justitie een gesprek kunnen aangaan met de president en de procureur-generaal. Spreekt de Vaste Kamercommissie voor Justitie daartoe de wens uit, dan kan zij daarna een gesprek voeren met een of meer kandidaten, in het bijzonder met de personen die voor het eerst op de aanbevelingslijst zijn opgevoerd. ${ }^{80} \mathrm{De}$ door de Hoge Raad aanbevolen kandidaten worden, anders dan de kandidaten voor de andere rechtscolleges, niet voor een gesprek uitgenodigd op het ministerie van justitie.

77. Nota naar aanleiding van het eindverslag, Bijl. Hand. II 1980-1981, 16163 (R 1146) nr. 12, p. 1

78. Vóór de algehele grondwetsherziening van 1983 bepaalde de Grondwet in art. 177: Van een voorgevallen vacalure word door de Hoge Raad aan de Tweede Kamer der StatenGeneraal kennis gegeven die, ter vervulling daarvan, een voordracht van drie personen aan de Koning aanbied, ten einde daaruit een keuze te doen.

De Koning benoemi de president en de vice-president uit de leden van de Hoge Raad.

79. Zie hoofdstukken 1 en 4

80. Brief van de vaste Commissie voor Justitie, Bijl. Hand. II 1991-1992, $22300 \mathrm{VI}$, nr. 37 herdruk, p. 1-2 


\subsubsection{Benoeming (vice-)president Hoge Rad}

Voor de volledigheid zij hier nog gewezen op de vacatures president en vicepresident Hoge Raad. Ten aanzien van deze functies geldt in beginsel nug steeds de anciënniteitsregel, al worden hierop wel uitzonderingen gemaakt. ${ }^{.1}$ V6or de grondwetsherziening van 1983 bepaalde de Grondwet in art. 177, tweede lid, dat de president en de vice-president van de Hoge Raad door de Koning uit de leden van de Hoge Raad worden benoemd. In navolging van de Proeve, het voorstel van de Staatscommissie van Advies inzake de Grondwet en de Kieswet en het advies van de Hoge Raad, werd in de Grondwet in art. 118 geen bepaling opgenomen dat de president en de vice-president van de Hoge Raad uit de leden van de Hoge Raad worden benoemd. De bepaling was volgens de regering 'niet nodig' naast art. 6.5 ontwerp (thans: art. 117, eerste lid, GW) dat bepaalde dat de leden van de rechterlijke macht met rechtspraak belast bij koninklijk besluit voor het leven worden benoemd. Het achterwege laten van een bepaling over de benoeming van de president van de Hoge Raad lag volgens de regering 'in de lijn' van het voorgestelde hoofdstuk 4 van de herziene Grondwet, waarin evenmin een afzonderlijke bepaling over de benoeming van de vice-president van de Raad van State en de president van de Algemene Rekenkamer is opgenomen. ${ }^{82}$

\subsubsection{Keuzemogelijkheid}

Sinds de grondwetsherziening van 1983 is in de bepaling over de voordrachtsbevoegdheid van de Tweede Kamer voor de leden van de Hoge Raad, de passage weggevallen dat de Tweede Kamer een voordracht van drie personen aan de regering aanbiedt, 'ten einde daaruit een keuze te doen' (art. $177 \mathrm{GW}$ 1972). Daardoor zou de vraag kunnen rijzen of de regering ook een lid van de Hoge Raad buiten de voordracht van de Tweede Kamer om mag benoemen. Hoewel art. 118, eerste lid, GW spreekt van een benoeming 'uit' de voordracht van de Tweede Kamer, is de geschiedenis van de grondwetsherziening op dit punt niet helder. ${ }^{83}$ Uit de memorie van toelichting blijkt dat de regering de oude voordrachtsprocedure van art. 177 GW 1972, die een keuzevrijheid voor

81. Van Koppen en Ten Kate, o.c. p. 45

82. MvT, Bijl. Hand. II 1979-198016163 (R1146), nr. 3, p. 4 De schrapping van de bepaling heeft overigens nog enige aanleiding tot discussie gegeven. Zo noemden de leden van de CDA-fractie de motivering vour het niet meer benoemen door de Koning van de president en de vice-president van de Hoge Raad 'onvoldoende', en zagen zij het verband tussen art. 6.5 ontwerp en het daardoor overbodig worden van de benoeming van de president en de vice-president van de Hoge Raad door de Koning niet. VV, Bijl. Hand. II 1980-1981, 16163 (R 1146), nr. 6, p. 2

83. Vergelijk C.A.J.M. Kortmann, De grondwetsherzieningen 1983 en 1987, 1987, p. 330 
de regering inhield tussen de voorgedragen kandidaten, onder de nieuwe grondwet wenste te handhaven. ${ }^{84}$ Opmerkelijk is overigens dat de regering er herhaaldelijk op heeft gewezen dat de voordracht van de Tweede Kamer voor haar een 'bindend karakter' heeft ${ }^{85}$, waarmee gedoeld wordt op de praktijk van benoemingen, die sinds 1852 zo is geweest dat de no. 1 op de voordracht van de Tweede Kamer door de regering wordt benoemd. ${ }^{86}$ 'Bindend' is de voordracht slechts voorzover het de keuze van de regering tussen de voorgedragen kandidaten betreft. Zou men echter de bevoegdheid van de regering zo uitleggen, dat zij enkel de no. 1 op de voordracht van de Tweede Kamer mag benoemen, dan dient het opmaken van een voordracht van drie personen door de Tweede Kamer geen enkel doel meer.

\subsubsection{Benoemingsnota, benoeming en beroep}

Uit hoofdstuk 1 bleek reeds dat over de gang van zaken bij de benoeming van rechters weinig bekend is. Op het ministerie van justitie wordt, naar aanleiding van de aanbeveling een benoemingsnota opgesteld, ter voorbereiding van de audiëntie. De aanbevolen kandidaten worden uitgenodigd voor een gesprek met de minister of met de secretaris-generaal van het departement. De literatuur neemt aan dat de regering bij aanbevelingen niet verplicht is de no. 1 op de aanbeveling te benoemen en dat zij hevoegd is om zelfs buiten de aanbeveling te benoemen. ${ }^{87}$ Het voorschrift in artt. 36a, 52 en 63 Wet RO om bij bepaalde eerste en verdere benoemingen de aanbeveling in alfabetische volgorde op te maken, vormt een aanwijzing voor de keuzevrijheid van de regering. Overigens moet men zich van die 'vrijheid' niet al te veel voorstellen; uit hoofdstuk 1 bleek reeds dat de regering zeer sterk leunt op de aanbevelingen van de rechtscolleges. Bij sommige verdere benoemingen dient in de aanbeveling wel een volgorde van voorkeur te worden aangebracht (vacatures president en vicepresident rechtbank en hof). Voor de Hoge Raad ontbreekt het voorschrift van de alfabetische aanbeveling.

84. MvT, Bijl. Hand. II 1979-1980, 16163 (R 1146), nr. 3, p. 3

85. MvA. Bijl. Hand. II 1980-1981 16163 (R 1146), nr. 8 p. 2 Zie ook het Tweede Kamerlid V.A.M. van der Burg (CDA) die meent dat het 'van belang' is dat de voordracht voor de regering een bindend karakter draggt (Hand. II 1980-1981, p. 3252). Ook elders, bij de benoemingsprocedure van de leden van de Raad van State, herhaalt de regering met nadruk dat de voordracht die de Tweede Kamer voor benoemingen in de Hoge Raad doet, anders dan de aanbevelingen die de Raad van State doet voor staatsraden, voor haar een 'bindend karakter' heeft (MvA, Bijl. Hand. II, 16040 (R 1141), nr. 8, p. 16).

86. Van Koppen en Ten Kate, o.c. p. 38

87. Zie hoofdstuk 3 


\subsubsection{Beroep}

Zowel bij eerste als bij verdere benoemingen is sprake van een besluit, en wel een heschikking, als bedoeld in art. 1:3, tweede lid, Awb. Het gaat bij de benoeming en bevordering van de leden van de rechterlijke macht bij koninklijk besluit immers om een schriftelijke beslissing van een bestuursorgaan, inhoudende een publiekrechtelijke rechtshandeling, die niet van algemene strekking is. ${ }^{88}$ Dit betekent dat de hoofdstukken 1 tot en met 5 Awb van toepassing zijn. Uit art. 8:4 Awb sub d. volgt o.a. dat beroep kan worden ingesteld bij de rechtbank tegen een besluit tot benoeming of aanstelling van een ambtenaar als bedoeld in art. 1 Ambtenarenwet. De nieuwe ambtenarenwet zal - anders dan de huidige ${ }^{89}$ - ook van toepassing zijn op de leden van de rechterlijke macht, met uitzondering van titel III (Bepalingen van materieel recht). ${ }^{90}$ Dit betekent dat ten aanzien van verdere benoemingen wel en ten aanzien van de meeste eerste benoemingen geen beroep openstaat. ${ }^{91} \mathrm{Bij}$ eerste benoemingen is immers niet voldaan dan het vereiste van het begrip ambtenaar uit art. 8:4 sub d. Awb. Volgens de regering zou:

"het belang van een potentiële ambtenaar (-) nauwelijks worden gediend met de mogelijkheid van beroep tegen dit soort besluiten in het algemeen (bedoeld zijn besluiten tot benoeming en aanstelling dan wel de weigering daarvan, MdW). Waar het gaat om de beoordeling van specifieke onderdelen van het aanstellingsbeleid, zoals de vraag of wordt voldaan aan de wettelijke eisen van gelijke behandeling, is reeds voorzien in rechterlijke toetsing. Overigens bepaalt een veelheid van redenen veelal de voorkeur van de werkgever voor de one boven de andere kandidaat. Deze lenen zich niet of nauwelijks voor rechterlijke toetsing. ${ }^{m 2}$

Gelet op de verhoudingen binnen de rechterlijke macht, achtte de regering het wenselijk in de Wet op de bezoldiging van rechterlijke ambtenaren een speciale rechtsgang te creëren, en beroep in te stellen tegen een besluit tot benoeming (of aanstelling op de Centrale Raad van Beroep. ${ }^{93}$ Het begrip 'belanghebbende'

88. Vergelijk: artt. 1:1-1:3 Awb

89. Volgens art. 2, tweede lid, sub c, Ambtenarenwet is deze wet niet van toepassing op krachtens de Grondwet of wet voor hun leden aangestelde ambtenaren.

90. Ontwerp-art. 2, sub c, Ambtenarenwet

91. Een uitzondering wordt gemaakt voor rechterlijke ambtenaren in opleidingen; vergelijk ontwerp-art. 9a Wet op de bezoldiging van de rechterlijke ambtenaren dat voor deze categorie een beroepsrecht bij de Centrale Raad van Beroep in het leven roept.

92. MvT, Bijl. Hand. II 1991-1992, 22495, nr. 3, p. 104

93. Zie: MvT, Bijl. Hand. Il 1992-1993, 22 495, nr. 12, p. 58-59 
is daarbij beperkt tot de rechterlijke ambtenaar als zodanig of de rechterlijk ambtenaar in opleiding. ${ }^{94}$

\subsubsection{Benoeming in deeltijd}

Sinds de Wet van 28 september 1989, Stb. 420 bevat de Wet op de Rechterlijke Organisatie een voorziening die het mogelijk maakt dat de leden van de rechterlijke macht in deeltijd worden aangesteld. Conform art. $7 \mathrm{~b}$, eerste lid, Wet RO worden de rechterlijke ambtenaren, de plaatsvervangers uitgezonderd, aangesteld voor het vervullen van een volledige of een gedeeltelijke werktijd. De volledige werktijd komt overeen met die welke geldt voor de burgerlijke rijksambtenaren, werkzaam bij de ministeries. De gedeeltelijke werktijd kan niet minder zijn dan de helft van de volledige werktijd en kan niet anders worden vervuld dan door wekelijks gemiddeld gedurende de in het aanstellingsbesluit genoemde werktijd werkzaamheden te verrichten. Op verzoek van de rechterlijke ambtenaar kan bij koninklijk besluit een aanstelling voor een volledige werktijd worden gewijzigd in een aanstelling in hetzelfde ambt voor een gedeeltelijke werktijd of een aanstelling voor een gedeeltelijke werktijd worden gewijzigd in een aanstelling voor een andere gedeeltelijke werktijd of voor een volledige werktijd. Op verzoeken tot wijziging van de werktijd als hierboven vermeld, wordt niet beslist, dan nadat daarover het advies is ingewonnen van het betrokken college of parket. ${ }^{95}$

V6́́r 1989 werd in de praktijk deeltijd mogelijk gemaakt door gebruikmaking van een regeling die, voor oorspronkelijk andere doeleinden, was neergelegd in de artt. 2 en 4 a van de Wet op de bezoldiging van rechterlijke ambtenaren. Op grond van art. 2 kon een raadsheer-, rechter- of kantonrechter-plaatsvervanger bij koninklijk besluit worden aangewezen om in de functie waarin hij optrad een deel van de gewone taak dan wel deze taak in zijn geheel te vervullen en daarvoor een bezoldiging te ontvangen. De aanwijzing vond slechts plaats op verzoek van de plaatsvervanger en na raadpleging van het betreffende college of kantongerecht. ${ }^{96}$ Volgens art. 2, derde lid, Wet op de bezoldiging

94. Het ontwerp-art. 9a Wet op de bezoldiging van de rechterlijke ambtenaren luidt:

1. Een belanghebbende kan tegen een besluil of een andere handeling ten aanzien van een rechterlijk ambtenaar als zodanig of een rechterlijk ambtenaar in opleiding als zodanig, hun nagelaten betrekkingen of hun rechtverkrijgenden, beroep instellen bij de Centrale Raad wan Beroep.

2. Geen beroep kan worden ingesteld tegen een besluit tot benoeming of aanstelling, tenzij beroep wordt ingesteld door een rechterlijk ambtenaar als zodanig of een rechterlijk ambtenaar in opleiding als zodanig, hun nagelaten betrekkingen of hun rechrverkrijgenden. Zie: Bijl. Hand. 1, 1992-1993, 22 495, nr. 310

95. Art. 7b, vierde lid sub a $t / m$ g. Wet RO

96. Art. 2, tweede lid, Wet op de bezoldiging van rechterlijke ambtenaren 
van rechterlijke ambtenaren geschiedde de aanwijzing voor een bepaalde tijd, maar voor ten hoogste vijf jaar. Wie na vijf jaar niet opnieuw werd aangewezen bleef weliswaar lid van de rechterlijke macht, maar werd de facto werkloos. ${ }^{97}$ In de praktijk werkte dit stelsel met name nadelig ten aanzien van vrouwen. ${ }^{98}$ Op 15 december 1980 bracht de Staatscommissie herziening rechterlijke organisatie een nota uit inzake de deeltijdarbeid bij de rechterlijke macht, waarin zij in navolging van de interdepartementale werkgroep 'Emancipatie en deeltijdarbeid als aspecten van het overheidsbeleid' het uitgangspunt huldigt dat iedere overheidsfunctie in beginsel in deeltijdarbeid moet kunnen worden vervuld, en dat de rechtspositie van de deeltijdwerkers waar mogelijk gelijk dient te zijn aan die van werkers in een volledige taak. De Staatscommissie spreekt als haar oordeel uit dat in beginsel ieder ambt in de zittende magistratuur en het openbaar ministerie in deeltijd moet kunnen worden vervuld, en adviseert een zodanige regeling van deeltijdarbeid bij wet vast te stellen, dat de rechtspositie van de deeltijdwerkers gelijk wordt aan die van de volledig werkenden. ${ }^{99}$

Sinds de Wet van 28 september 1989. Stb. 420 bevat de Wet RO, als gezegd, een regeling die het mogelijk maakt dat de leden van de rechterlijke macht in deeltijd worden aangesteld. Toch hebben emancipatoire overwegingen bij deze regeling niet voorop gestaan. Volgens de regering lag dat gezien het 'relatief grote aantal' vrouwen dat binnen de rechterlijke macht werkzaam is, ook niet voor de hand. ${ }^{100}$ De nieuwe regeling is onderdeel van het regeringsbeleid om zoveel mogelijk de gelegenheid te scheppen dat arbeid in deeltijd kan worden verricht. ${ }^{101}$ In beginsel kan onder het nieuwe stelsel elke functie bij de zittende en staande magistratuur in deeltijd worden vervuld. Hoewel de regering meent dat er functies zijn die niet in deeltijd kunnen worden verricht, acht zij het bezwaarlijk bij wet functies te noemen die van vervulling in deeltijd

97. Zit hierover ook: F. A.M. Stroink, Rechterlijke arganisatie en rechtspraak in beweging. 1993. p. 77 e.v.

98. Zic hierover: D.F.M. Twaalfhoven. De part-lime leden van de rechterlijke macht, NJB 1985, p. 347 e.v.

99. MvA, Bijl. Hand. II 1982-1983, 17600 hoofdstuk VI, nr. 11, p. 6

100. Die redenering spreekt overigens niet helemaal vanzelf, want mannen en vrouwen zijn zeer ongelijk verdeeld over de hogere en lagere rechtscolleges. Zo zijn vrouwen met name vertegenwoordigd in de laagste echelons van de rechterlijke macht. Zie hoofdstuk 4

101. MvA, Bijl. Hand. II 1988-1989, 20301 , nr. 5, p. 3-4 Merkwaardig is echter dat de regering daaraan toch tocvoegt dat de nieuwe regeling met name van helang is voor vrouwen, die reeds in decltijd werken binnen de rechterlijke macht. en vour vrouwen die dat in de toekomst wensen te gaan doen. 
worden uitgesloten. ${ }^{102}$ Of functies al dan niet in deeltijd kunnen worden verricht hangt af van omstandigheden zoals de organisatorische situatie, aard en omvang van de plaatselijke bezetting en de omvang van de gewenste deeltijd. Bovendien kan voor functies waarvoor deeltijd in het algemeen onwenselijk is, in concrete gevallen wegens persoonlijke, gezins- of familieomstandigheden deeltijd toch worden toegestaan. ${ }^{103}$ De gedeeltelijke werktijd - die wekelijks moet worden vervuld ${ }^{104}$ - zal echter niet minder mogen zijn dan de helft van de volledige werktijd. Als bezwaar tegen een kleine deelbetrekking noemt de regering dat dan veelal elders een andere betrekking zal worden vervuld, waardoor het 'gevaar' dreigt dat de rechterlijke functie als 'nevenbetrekking' wordt opgevat. Bij (beginnende) deeltijdwerkers die minder dan de helft van de volledige werktijd werkzaam zijn, zou de ervaring dan te langzaam worden opgebouwd, hetgeen onder meer als nadeel heeft dat een andere dan een beperkte voorziening in de sfeer van de anciënniteit moet worden getroffen. ${ }^{105}$

Volgens de regering zal in de praktijk zo soepel mogelijk met de verzoeken om in deeltijd te werken worden omgegaan. Er is echter geen sprake van een 'recht' op deeltijd. Steeds zal na afweging van de omstandigheden moeten worden bepaald of deeltijdwerk mogelijk is. Aan het oordeel van de autoriteit die plaatselijk verantwoordelijk is voor het goed functioneren van zijn dienst-

102. Hiertoe had de Staatscommissie Herziening Rechterlijke Organisatie ook al geadviseerd: zij nam als criterium aan dat het 'belang van de rechtspraak' zich niet tegen deeltijd mag verzetten. Dit zou het geval kunnen zijn bij vervulling in deeltijd van bepaalde functies, zoals die van president van een college. MvT, Bijl. Hand. II 1987-1988. 20 301, nr. 3. p. 17-21. In gelijke zin: het advies van de emancipatieraad. De emancipatieraad wenste bij de persoonlijke omstandigheden ook het dragen van gezinsverantwoordelijkheid genoemd te zien. De emancipatieraad meent dat er niet gemakkelijk van uit mag worden gegaan dat functies niet in deeltijd kunnen worden vervuld; de raad meent dat de minister per geval dient te bezien of vervulling in deeltijd mogelijk is, en dat de minister een afwijzing dient te beargumenteren (MvT. Bijl. Hand II 1987-1988. 20301 , nr. 3, p. 22-24). Anders: de commentaren van rechterlijke colleges: men meent dat de functies van president bij een gerechtshof, voorzitter van cen raad van beroep en van de Centrale Raad van Beroep en van griffier bij dat college, en van kantonrechter oudste in rang van benoeming bij kantongerechten met meer dan vijf kantonrechters niet in deeltijd dienen te worden uitgeoefend (MvT. Bijl. Hand. II 1987-1988, 20301, nr. 3, p. 2-3).

103. De regering noemt het voorbeeld van een wat oudere president van een rechtbank die het in de resterende jaren van zijn loopbaan wat rustiger aan moet doen, en zijn dagelijkse arbeidstijd met een uur wenst te verminderen. MvA, Bijl. Hand. II 19881989,20301 , nr. 5, p. 4

104. MvT, Bijl. Hand. II $1987-1988,20301$, nr. 3, p. 6

105. MvA, Bijl. Hand. Il 1988-1989, 20 301. nr. 5, p. 5 
eenheid zal daarom een zwaarwegende betekenis worden toegekend. ${ }^{106}$ Tegen de afwijzing van een verzoek kan door de rechterlijke ambtenaar die niet voor het leven is benoemd, beroep worden ingesteld bij het Ambtenarengerecht. Volgens de regering hebben de voor het leven benoemde rechterlijke ambtenaren, uit hoofde van het bepaalde in art. 2, tweede lid, Ambtenarenwet 1929 (Stb. 530), die beroepsmogelijkheid niet, maar hier ligt in de toekomst mogelijk een taak voor de Centrale Raad van Beroep. ${ }^{107}$ Het afwijzen van een verzoek geschiedt niet bij koninklijk besluit. Volstaan wordt met een besluit van de minister van justitie, daartoe gemachtigd door de Koningin. ${ }^{108}$

\subsubsection{Deeltijd en anciënniteit}

Vóór 1989 bestond bij de diverse rechtbanken verschil van opvatting over, en in de hantering van de anciënniteitsregeling ten aanzien van de deeltijdrechters. In sommige rechtbanken had de deeltijdrechter geen enkel 'recht', waardoor hij niet deelnam aan rechtbankvergaderingen, 'jongste rechter' bleef en geen sollicitanten ontving. In andere rechtbanken nam hij wel deel aan rechtbankvergaderingen, genoot hij anciënniteit naar datum van zijn benoeming, en ontving hij wel sollicitanten. Tussen deze uitersten waren er rechtbanken waar de deeltijdrechter weer wel deelnam aan rechtbankvergaderingen maar zonder stemrecht. De kwestie van de anciënniteit is thans geregeld in art. 7a, vijfde lid, Wet RO. Wat de rang van benoeming betreft is er geen onderscheid tussen rechterlijke ambtenaren die zijn aangesteld voor het vervullen van een volledige werktijd en zij die zijn aangesteld voor het vervullen van een gedeeltelijke werktijd, met dien verstande dat voor de rechterlijke ambtenaar die gedurende de vier dienstjaren, onmiddellijk volgend op de eerste aanstelling, een gedeeltelijke werktijd vervult of heeft vervuld, als benoemingsdatum wordt aangemerkt de datum die wordt gevonden door bij zijn werkelijke benoemingsdatum op te tellen een termijn, overeenkomend met de helft van de binnen die vier jaar vallende periode die hij in gedeeltelijke werktijd heeft doorgebracht. ${ }^{109}$

In het voorontwerp had de regering geen voorziening voor de anciënniteit opgenomen. Zij achtte dit onnodig indien de minimum-deeltijd op de helft van

106. MvA, Bijl. Hand. II 1988-1989, 20301 , nr. 5, p. 5

107. Vergelijk het ontwerp-art. 9a Wet op de bezoldiging van rechterlijke ambtenaren

108. MvA. Bijl. Hand. II 1988-1989, 20301 , nr. 5, p. 6-7

109. De Commissie gelijke behandeling van mannen en vrouwen bij de arbeid oordeelde op 30 september 1993 dat de minister van justitie indirect onderscheid makt jegens vrouwen, in strijd met art. la Wet gelijke behandeling, door als bevoegd gezag de regeling betreffende de rangorde van benoeming voor leden van de rechterlijke macht toe te passen op rechters. Gepubliceerd in: Tijdschrift voor ambtenareurecht, 1994. nr. 22 
de volledige werktijd zou worden bepaald. Daardoor zouden de deeltijdwerkers op gelijke wijze als volletijdwerkers anciënniteit opbouwen. In haar advies op het wetsvoorstel meende de Nederlandse Vereniging voor Rechtspraak echter dat bij het bepalen van de anciënniteit 'op enigerlei wijze' rekening moest worden gehouden met de verhouding parttime/fulltime. Ook de presidenten van de gerechtshoven en de voorzitter van de Centrale Raad van Beroep menen in hun advies dat men het vraagstuk van de anciënniteit 'niet te licht' moet nemen. ${ }^{110} \mathrm{Het}$ advies van de Emancipatieraad stelt zich daarentegen op het standpunt dat het opbouwen van ervaring vaak meer afhankelijk is van de inzet van de betrokkene en de wijze waarop deze opgedane kennis toepast dan van de hoeveelheid verricht werk. ${ }^{111}$ In weerwil van de adviezen vanuit de rechterlijke macht meent de regering evenwel dat het niet onredelijk is om de deeltijdwerker in het begin van zijn loopbaan enigszins te beknotten in de opbouw van anciënniteit. Deze beknotting geldt echter slechts beperkte tijd, en moet eenvoudig en helder geregeld worden. De anciënniteit zal geen 'bijzondere' betekenis hebben voor de salariëring en het promotiebeleid, omdat wettelijke voorschriften dienaangaande ontbreken, en de anciënniteit volgens de regering "al lang niet meer het eerste criterium voor de beslissing" is. "Slechts indien uit gelijk geschikten onder de gegadigden voor de vervulling van een bepaalde vacature een keuze moet worden gemaakt, wordt de anciënniteit nog wel als bepulende factor gehanteerd. "12 De anciënniteitsregel heeft thans nog slechts betekenis voor vervanging van de oudstbenoemde raadsheer of rechter (art. 7 Wet RO), voor de hoofdelijke omvraag (art. 26 Wet RO) en voor de vervanging van de kamervoorzitter (art. 21 Reglement 1). ${ }^{113}$

110. MvT, Bijl. Hand. II 1987-1988, 20301 , nr. 3, p. 3

111. MvT, Bijl. Hand. II 1987-1988, 20301 , nr. 3. p. 24

112. Anders dan de regering meende de CDA-fractie dat de anciënniteit nog als een 'belangrijk principe' binnen de rechterlijke macht werd gezien; zij vroeg zich af of er problemen zouden rijzen met de full-time rechters indien de part-time rechters met terugwerkende kracht anciënniteit kregen toegekend. De PvdA fractie noemde de oplossing van het anciënniteitsvraagstuk een 'redelijk compromis'. De VVD-fractie zei slechts 'schoorvoetend' in te stemmen met de door de regering voorgestelde anciënniteitsregeling. Met de regering was de VVD van mening dat de pro rata-regeling tot nogal wat ingewikkelde regelingen zou leiden, welke niet opwogen tegen het belang van de anciënniteitsregeling. die immers niet de materiële rechtspositie van rechters betreft, maar de interne organisatie van de gerechten. (Wiebenga, Hand. II 31 mei 1989. p. 81-6292) Ook de D66-fractie kon instemmen met de 'pragmatische oplossing' die voor het vraagstuk gevonden was (VV, Bijl. Hand. II 1987-1988, 20 301, nr. 4 , p. 2-5).

113. MvT, Bijl. Hand. Il 1987-1988, 20301 , nr. 3, p. 10-11. Zie: Wet van 28 september 1989, Stb. 420 


\subsection{Vraagtekens bij de toegang tot het rechtersambt}

Terwijl uit $\S 2.3$ blijkt dat de werving, selectie en benoeming van rechters in ons land is toevertrouwd aan een groot aantal instanties, volgt uit $\$ 2.2$ dat het maar de vraag is of de betreffende regeling wel in overeenstemming is met het grondwettelijke en verdragsrechtelijke kader. Een duidelijk antwoord op die vraag is echter niet mogelijk, omdat niet helder is wat precies onder 'werving' en 'selectie' verstaan moet worden. Die onduidelijkheid is geen toeval, maar kenmerkend voor het Nederlandse staatsrecht op dit punt, dat - en ik neem daarmee een voorschot op de conclusies in de hoofdstukken 3 en 4 - de factoren die samen de toegang tot het rechtersambt bepalen niet als samenhangende onderwerpen behandelt. Het vraagstuk van de toegang tot het rechtersambt, blijkt (zie hoofdstuk 1) inderdaad een moderne conceptie, die niet ten grondslag ligt aan het huidige benoemingsstelsel. Afgezien van de vraag of deze constellatie historisch verklaarbaar is - daarover gaan de hoofdstukken 3 en 4 -, rijst de vraag of zij ook wenselijk is.

\subsubsection{Werving}

Hiervoor werd er op gewezen dat de Wet RO geen voorschriften bevat met betrekking tot de werving van rechterlijke ambtenaren, terwijl de werving van raio's, buitenstaanders en van kandidaten voor promotiefuncties grotendeels aan de praktijk is overgelaten. Onduidelijk is wie $\mathrm{mag} /$ moet werven ${ }^{114}$, op welke wijze (in welk medium) en wanneer dit moet geschieden. ${ }^{115}$ Meer in het algemeen is er geen enkele (wettelijke) garantie dat geworven wordt, laat staan dat 'breed' geworven wordt. Elders (in het bedrijfsleven) wordt werving als zodanig niet als een noodzaak gezien. Integendeel, werving wordt optioneel gehanteerd, "wanneer te verwachten valt dat het spontane (aktuele) aanbod van sollicitanten onvoldoende zal zijn om toekomstige of reeds aanwezige vacatures te vervullen. "16 De keuze voor werving wordt in het bedrijfsleven bovendien gerelateerd aan rendementsverwachtingen omtrent de betreffende wervingsmethodiek. Dit leidt tot ingewikkelde berekeningen van de 'optimale selektieratio', het 'bruto-' en netto-rendement', de kosten van werving en selectie per sollicitant, de 'lineaire utiliteit' en 'prediktorskores'. 117

114. In 1993 begon de rechtbank Amsterdam middels advertenties in landelijke dagbladen zelf met de werving van buitenstaanders, om het tekor aan rechters in de hooldstad aan te vullen. Zie bijvoorbeeld de advertentic in NRC Handelsblad, 23 januari 1993

115. Zo nemen sommigen aan dat het gerecht zelf kan bepalen in welk medium geadvertecrd wordt. Zie bijvoorbeeld: Ingelse, o.c. p. 295

116. R.A. Roe, Grondslagen der personeelsselectie, 1983, p. 273-274

117. Roe, o.c. p. 608 e.v. 
Toch is het de vraag of deze rendementsgedachten zonder meer op de werving van publieke ambtsdragers, zoals rechters mogen worden toegepast; in hoofdstuk 1 werd er immers al op gewezen dat voor een 'rationele personeelsvoorziening' in het publiekrecht slechts beperkt plaats is. Dat komt omdat de aanstelling van publieke ambtsdragers verbonden is met fundamentele noties in het staatsrecht. Zeker zo belangrijk als de uiteindelijke keuze voor een kandidaat, is de wijze waarop die keuze plaatsvindt. In dit verband zitten ook aan het vraagstuk van werving principiële kanten. Immers, de keuze voor het medium voor werving heeft belangrijke consequenties voor de kwaliteit en de kwantiteit van de groep sollicitanten waaruit geselecteerd wordt, en daarmee voor bijvoorbeeld de diversiteit in de samenstelling van de rechterlijke macht. Zou het ministerie van justitie - bij een eerste of verdere benoeming - bijvoorbeeld om bezuinigingsredenen of uit rendementsverwachtingen, de algemene advertentieronde mogen overslaan, en kunnen putten uit een reeds aanwezige pool bij de betrokken rechtbank of het betrokken gerechtshof? Hoe zou dat liggen bij het aantrekken van nieuwe raio's of buitenstaanders? Zou daarvoor (bijvoorbeeld om een 'ondervertegenwoordiging' van bepaalde groepen weg te werken), uitsluitend geworven mogen worden in lokale dagbladen, in gespecialiseerde vakbladen, of in dagbladen van bepaalde 'linkse', 'rechtse', katholieke of protestantse signatuur of in typische vakbonds- of vrouwenbladen? Kan (om een vacature op te vullen) naast of in plaats van met advertenties ook gewerkt worden met headhunters, advies- of arbeidsbureaus? Reeds een vluchtige blik in de keuken van het personeelsmanagement - meer dan dat valt buiten het hereik van deze studie - leert dat werving, selectie en loopbaanplanning zich elders hebben ontwikkeld tot een heus métier, dat - zo vinden de beoefenaars zelf - zwaar onderschat wordt. In het publiekrecht lijkt het belang van het vraagstuk van de werving echter niet te worden onderkend. Hoewel art. $3 \mathrm{GW}$ bepaalt dat alle Nederlanders op gelijke voet in openbare dienst benoembaar zijn, vloeit hieruit - kennelijk - geen aansporing voor de wetgever uit voort om te zorgen dat bij vacatures bij de overheid bijvoorbeeld sprake is van een evenwichtig aanbod van kandidaten.

\subsubsection{Selectie en benoeming}

In hoofdstuk 1 werd nog verondersteld dat het neerleggen van taken en bevoegdheden in een wet, in een algemene maatregel van bestuur, een ministerieel besluit, een circulaire, of in gewoonte, een zeer principiële keuze is, die teruggrijpt op fundamentele noties in onze staatsinrichting: welk orgaan beslist op basis van welke bevoegdheid over welk onderwerp; wie controleert dat, en op basis van welke informatie kan het dat doen? Reeds bij de voorafgaande, eerste verkenning van de feitelijke regeling van de werving, selectie, benoeming en bevordering van rechterlijke ambtenaren, blijkt echter dat die veronderstelling, voor het vraagstuk van de toegang tot het rechtersambt, waar- 
schijnlijk niet op gaat. De afstemming van deze onderwerpen met het constitutionele recht is immers niet zonder problemen. In hoofdstuk 1 is reeds gewezen op het verschil tussen eigenlijke en oneigenlijke selectie, en op nagenoeg ongrijphare mechanismen als voor-en zelfselectie. Maar zelfs als we het hegrip 'selectie' beperken tot de werkzaamheden van de selectiecommissies en tot de procedures voorafgaande aan eerste en verdere benoemingen, blijkt selectie een tamelijk complex, diffuus begrip. Hiervoor bleek immers al dat het alantal actoren in het selectieproces veel groter is dan het enkele benoemingsbesluit van de regering. Opmerkelijk is dat 'zware' bevoegdheden in het selectieproces zijn gelegd bij relatief 'lichte' selectiecommissies, waarover weinig tot niets bekend is. Het gunstige advies van RPD Advies bijvoorbeeld, geldt praktisch als een voorwaarde voor toelating tot de raio-opleiding; hetzelfde geldt mutatis mutandis voor het positieve advies van de Commissie aantrekken leden rechterlijke macht bij eerste benoemingen. Beide instellingen, die elk voor de helft de instroom in de rechterlijke macht (mede) bepalen, vervullen kortom vitale functies voor ons staatsrecht. Bovendien valt op dat naarmate een vacature 'belangrijker' is, zie bijvoorbeeld de selectie van presidenten en vice-presidenten, de juridische grondslag op grond waarvan de selectie geschiedt een lagere is of zelfs geheel ontbreekt. Het valt moeilijk te verdedigen dat het formele benoemingshesluit met grondwettelijke waarborgen moet worden omkleed, terwijl de stadia waarin de feitelijke keuze valt, grotendeels buiten beschouwing blijven.

\subsubsection{Gesloten circuits}

Afgezien van de vraag naar de constitutionele systematiek, is in het recente verleden gebleken dat de bestaande situatie van selectie, benoeming en bevordering van rechters ook praktisch niet onproblematisch is. Zo is vooral de geslotenheid van het selectie- en benoemingsproces, dat zich voornamelijk afspeelt tussen de regering en de rechterlijke macht, gecombineerd met de lage wettelijke status van deze procedure, bij herhaling gehekeld in de literatuur (zie onk hoofdstuk 4). Daarbij gaat het meestal om de dreiging dat het ministerie van justitie zijn invloed op het selectieproces steeds verder zal uitbreiden. Uit de status van de betrokken regelingen (ministeriële besluiten en circulaires) blijkt overigens al dat de minister van justitie deze bevoegdheden niet zozeer gekregen, als wel genomen heeft. De oud-president van de Hoge Raad, H.E. Ras, nam onder meer dit probleem als uitgangspunt voor zijn afscheidsrede in 1989:

"we hebben hier te maken met onderwerpen - selectie en opleiding - waarbij de constitutionele positic van de rechterlijke macht weliswaar niet rechtstreeks in het geding is, maar die toch voor de kwaliteit, de taakopvatting en het functioneren van toekomstige rechters van wezenlijke betekenis is. Zij liggen in een met het oog op de onafhankelijkheid van de rechterlijke macht gevoelige zone en er bestaat be- 
hoefte om hier een op terughoudendheid van de uitvoerende macht gericht systeem op te bouwen. " Over de regeling van de promotiebenoemingen zegt Ras: "Het thans gehanteerde systeem berust op ministeriële circulaires. Dat is aanvaardbaar in een aanloopfase, als nog ervaring met de regeling moet worden opgedaan en aanpassingen nodig kunnen blijken. Maar er komt een stadium waarin het systeem moet worden vastgelegd, zij 't dat ook dan flexibiliteit gewenst kan zijn. ${ }^{m 18}$

Ook de Staatscommissie Herziening Rechterlijke Organisatie wijst er in 1985 op dat de uitvoerende macht, in het bijzonder de minister van justitie, formeel een 'overheersende' invloed op de benoeming en bevordering van rechters heeft. Hoewel de Staatscommissie geen enkele aanwijzing heeft "dat het benoemingsbeleid ook maar enigszins tendeert in de richting dat door het bestuur rechters worden benoemd of bevorderd, van wie te verwachten of gebleken is, dat zij de door het bestuur gestelde doelen niet zullen tegenwerken", acht zij het wenselijk dat het bestuur een minder overheersende invloed krijgt op de benoeming van leden van de zittende magistratuur. ${ }^{119}$

Behalve door het ministerie van justitie, en de daaronder ressorterende selectiecommissies, wordt blijkens het bovenstaande de werving, selectie en benoeming van rechterlijke ambtenaren evenzeer 'gedomineerd' door de rechterlijke macht zelf. Weliswaar zijn de hevoegdheden in het selectieproces formeel verschoven van de rechtbanken naar het ministerie van justitie, materieel bepaalt de rechterlijke macht grotendeels 'zelf' wie in haar midden benoemd wordt. De rechterlijke macht is immers (sterk) vertegenwoordigd in de beide selectiecommissies, stelt bij een vacature zelf de aanbevelingen op en heeft de selectie voor promotiefuncties grotendeels zelf in handen. Het is trouwens opmerkelijk dat het overwicht van de rechterlijke macht in het selectieproces de laatste jaren - anders dan in de jaren zeventig - in de literatuur duidelijk minder als een probleem wordt gezien dan het overwicht van de uitvoerende macht. ${ }^{120}$

Overigens moet de vrees voor de overheersende invloed van zowel het ministerie van justitie als de rechterlijke macht bij de selectie en benoeming van rechters, worden genuanceerd. De indruk wordt al snel gewekt dat sprake is van één selectiemoment, op één niveau door één centraal orgaan ('het' ministerie van justitie of 'de' rechterlijke macht). In werkelijkheid is, zoals we al

118. H.E. Ras, De onafhankelijkheid van de rechterlijke machi, afscheidsrede, gepubliceerd in NJB 1989, p. 1242-1244

119. Eindrappont van de Staatscommissie Herziening Rechterlijke Organisatie, deel II, 1985, p. 7-10

120. Zie hierover: J. ter Heide, De onafhankelijkheid van de rechterliike macht, 1970, p. 18 en: J.C.M. Leyten, De rechter op de schopstoel, 1970, p. 23 Zie verder $\$ 4.5$ 
zagen, het tegendeel het geval, en is bij de benoeming of bevordering van rechters steeds sprake van een groot aantal selectiemomenten, die zowel naar tijd (fase in de selectieprocedure), plaats (aanheveling door de lokale gerechten) en functionele geleding (orgaan dat advies/aanbeveling geeft, type functic waarvoor het advies/de aanheveling/de henoeming bedoeld is) wisselen. Een helangrijk (zij het waarschijnlijk niet heoogd) gevolg (voordeel) van deze situatie is, dat er weinig 'systeem' in zit, en dat het voeren van één centraal selectie- of benoemingsbeleid praktisch onmogelijk is.

\subsubsection{Benoembaarheidsvereisten}

Hiervoor werd opgemerkt dat voor alle kandidaten voor een rechtersfunctie geldt 1) dat zij, om benoembaar te zijn, moeten voldoen aan de (grond-)wettelijke vereisten van de Nederlandse nationaliteit en een afgeronde universitaire opleiding Nederlands Recht en 2) dat geen sprake is van een onverenigbaarheid van de hoofdbetrekking met eventuele nevenfuncties. Zoals art. 116, tweede lid. GW de inrichting van de werving en selectie van rechterlijke ambtenaren overlaat aan de formele wetgever, zo is ook het stellen van benoembaarheidsvereisten - kennelijk - een zaak van de wetgever. Met uitzondering van de onverenighaarheid voor de leden van de Hoge Raad zegt de Grondwet immers niets over deze voorwaarden voor benoembaarheid. Het is echter de vraag of invoering van wettelijke beperkingen die de toegang tot het rechtersambt frustreren. terwijl daarin niet door de Grondwet is voorzien, tot de bevoegdheid van de wetgever behoort. Men zou dergelijke voorwaarden voor benoembaarheid $\mathrm{nl}$. negatief kunnen omschrijven als een beperking die de wetgever - anders dan de grondwetgever - stelt aan de toegang tot het rechtersambt. In de vorige eeuw werd de vraag naar de constitutionaliteit van zulke voorwaarden voor benoembaarheid inderdaad gesteld, en deed toen veel stof opwaaien. Met name bij de invoering van de opleidingseis en de onverenigbaarheden meende de Tweede Kamer dat het stellen van dergelijke vereisten in de Wet RO in strijd was met de grondwettelijke regeling, die een dergelijke eis niet stelde (zie $\$ 3.5$ ). Bij de grondwetsherziening 1983 valt van deze discussie echter niets meer terug te vinden. De grondwetgever maakte zich, integendeel, juist bezorgd over de vraag of de wetgever bij de inrichting van de rechterlijke macht wel "een voldoende mate van vrijheid" toekomt (zie $\S 2.2 .4)$.

\subsubsection{Aanvaarding van de benoeming: ambtseed}

Anders dan voor de andere takken van staatsmacht (wetgevende en uitvoerende macht) heeft de eedsverplichting voor de leden van de rechterlijke macht geen grondwettelijke grondslag. Art. 29 Wet RO bepaalt dat de leden van de rechterlijke macht, alvorens in bediening te treden, elk naar de wijze zijner godsdien- 
stige gezindheid, de eed (belofte) afleggen. Volgens de tekst van art. 29 Wet RO wordt de eed afgelegd door de 'leden van de rechterlijke macht' en niet door de beoogde leden van de rechterlijke macht. Blijkbaar onderscheidt de Wet RO op dit punt tussen ambtsbekleding en functievervulling. De wijze van eedsaflegging voor rechterlijke ambtenaren is geregeld in het koninklijk besluit van 14 september 1838 Stb. $36 .^{121}$ De vorm van de eed, belofte of bevestiging, die ter uitvoering van een wettelijk voorschrift moet worden afgelegd, is sinds 1911 door de wetgever dwingend voorgeschreven. ${ }^{122}$

Het valt in onze dagen moeilijk voor te stellen dat een betrekkelijke 'formaliteit' als het afleggen van de ambtseed een selectieaspect in zich zou kunnen dragen. Dat is echter wel eens anders geweest. "De eedsziekte", zo schrijft Taverne in een noot in 1921, is "een vrijwel ongeneeslijke kwaal van onze rechtspleging. "123 Het eeds-vraagstuk heeft aan het einde van de vorige en in het begin van deze eeuw dan ook voor grote beroering gezorgd. Vór de Eedswet van 1916 was er geen vrije keuze tussen eed of belofte; een eedplichtige zwoor, tenzij zijn geloof hem het zweren verbood. 'Geloof' werd echter eng uitgelegd, want enkel Doopsgezinden kwamen met een beroep op het Nieuwe Testament (Matt. 5; 33-37) in aanmerking voor de belofte. Anderen, zelfs niet-gelovigen, waren verplicht de eed te zweren. De formule in art. 29 Wet RO bedoelt daarom naar de letter zeker niet dat de eed en de belofte facultatief mogen worden afgelegd.

Het eedsvraagstuk is inmiddels, na een roerige geschiedenis in wetgeving en rechtspraak, van alle scherpe kanten ontdaan. Sinds de Eedswet 1916 wordt de keuze tussen eed, belofte dan wel bevestiging ter vrije keuze van de betrokkene gelaten. Sinds de Eedswet 1971 geldt ook voor alle andere eedplichtigen een keuzevrijheid tussen eed, belofte of bevestiging. Sinds een uitspraak van de Hoge Raad uit 1989 is het afleggen van de eed bovendien 'vormvrij' geworden. ${ }^{124}$ De weg van het ontduiken van de bepalingen inzake meineed is daarmee nagenoeg ${ }^{\mathrm{i} 25}$ afgesneden. Het selectie-aspect dat de rechterlijke ambtseed ex art. 29 Wet RO in potentie in zich draagt, is daarmee praktisch verdwenen, en de ambtseed zal niet snel een drempel opwerpen tegen de toegang tot het

121. Voor het laatst gewijzigd bij koninklijk besluit van 16 december 1987, Stb. 596

122. Art. 1 Wet van 17 juli 1911 , Stb. 215

123. HR 23 mei 1921, NJ 1921 p. 600. Bij: Joan van Baars. Het Ontwerp Eedswet 1969 en de Eedsvorm. NJB. 1970, p. 634

124. HR 19 april 1988, NJ 1989 nr. 140

125. A.C. 't Hart noemt er in zijn noot onder HR 19 april 1988. NJ 1989 nr. 140 toch nog een: wat te doen met iemand die meent verplicht te zijn tot het doen van de eed, en daarvoor gesecondeerd moet worden door een lokale medicijnman uit het Andesgebergte? 
rechtersambt. Daarmee rijst de vraag naar de functie van deze nagenoeg uitgeholde wetsbepaling. De voorkeur voor het al dan niet handhaven van de ambtseed is een kwestie van persoonlijke smaak, geloofs- of levensovertuiging. De aansluiting die de Nederlandse (geseculariseerde) overheid -bij het afleggen van de eed althans- zoekt met het mystieke doet wat wonderlijk aan, maar dat is misschien ook wel de charme ervan. Anderen echter, wezen lang geleden al op het beledigende karakter van de rechterlijke ambtseed: "Moet dat eeuwig en herhaaldelijk zweren, dat men een fatsoenlijk man zal zijn, dan nog altijd blijven bestaan? Ik weet niet, er mocten gewis wel gewigtige redenen bij te brengen zijn, waarom men den regterlijken ambtenaar al dadelijk twijfelen doet aan de waarde v'un zijnen regtsregel: dat iemand voor goed moet gehouden worden, zoolang niet van het tegendeel blijkt (-)?"126

\subsection{De toegang tot het rechtersambt: nabeschouwing}

De toegang tot het rechtersambt in ons land, zo blijkt uit het voorgaande, is f'itelijk zeer fragmentarisch geregeld, terwijl de bevoegdheden in het wervings-, selectie- en benoemingsproces, - ogenschijnlijk zonder veel systematiek - her en der verspreid zijn over een groot aantal publiekrechtelijke en privaatrechtelijke instellingen. Bovendien staan belangrijke onderdelen van die regeling, in het bijzonder de regeling van de werving, de selectie en de bevordering van rechterlijke ambtenaren, op gespannen voet met het vereiste van een wettelijke grondslag in art. 116, tweede lid, GW. De ourzaak hiervoor ligt - zo werd met een voorschot op de hoofdstukken 3 en 4 gesteld - in de omstandigheid dat de factoren die samen de toegang tot het rechtersambt bepalen, in het staatsrecht niet als samenhangende vraagstukken worden behandeld. Dat het ontbreken van die samenhang niet alleen vanuit constitutioneel opzicht problematisch is, maar ook praktisch tal van vragen opwerpt, werd in dit hoofdstuk betoogd. De bestaande situatie kan intussen historisch worden verklaard doordat het bestaande 'stelsel' in de loop der jaren stukje bij beetje is opgebouwd, waarbij het verband met het grote geheel - zacht gezegd - niet de eerste prioriteit kreeg. In hoofdstuk $3 \mathrm{zal}$ dit voor wat betreft het ontstaan, en in hoofdstuk 4 voor wat de verdere ontwikkeling van het vraagstuk van de toegang tot het rechtersambt aangaat, aan de hand van de parlementaire geschiedenis worden gedemonstreerd. In deze hoofdstukken wordt bovendien gezocht naar tendensen die ten aanzien van het vraagstuk van de toegang tot het rechtersambt zijn waar te nemen. 



\section{Deel III}

Historische grondslagen 


\section{De toegang tot het rechtersambt: historische grondslagen}

\subsection{Inleiding}

In een beroepskeuze-gids voor juristen uit het hegin van deze eeuw: Het ambt van den rechter, schrijft de president van de Haagse Krijgsraad, G. van Slooten:

"Verdwaasde ouders, in bewondering voor hun kroost verzonken, plegen de toekomstige roemrijke loopbanen hunner jongens, wier wenschen voor het heden zich tot het ambt van tramconducteur beperken, te voorspellen uit hun tegenwoordige hebbelijkheden. "Es krïmmt sich bei Zeiten, was ein Haken werden will." Zoo zeggen zij, dat Fritsje, die den keukenwekker geopend en naar alle winden verstrooid heeft, werktuigbounkundige moet worden; dat Pietie, betrapt op vivisectie van de lievelingspop zijner zuster, als chirurg zijn ontstellende rekeningen zal schrijven; en dat Jantje, die zoo vlot liegen kan, voor advocaat in de wieg is gelegd. Zoo zijn er, die, amper zindelijk, reeds zijn voorbestemd tot dominees, generaals of zeekapiteins. Kindermeisjes en helpsters ter bewaarschool, gebannen in gelijk hevige, maar tegen-overgestelde subjectiviteit, houden aan deze veelbelovende voorwerpen harer verpleging galg en rad als eindpunt hunner carrière voor. Maar nog nimmer is mij rechtstreeks of van terijde ter oore gekomen, dat iemand in de schuldelooze misdragingen van zijn nakroost de kiemen van de rechterlijke waardigheid heeft gespeurd, of dat meer of min ongevoelige buitenstaanders morsboezelaars dan wel slabbetjes visionnair zagen omgetooverd in fluweelen tabbaarden en smetteloozen beffen. ${ }^{m 1}$

Uit dit eitaat blijkt dat men vroeger dacht dat iedereen wel voor iets deugde, al waren de vooruitzichten voor jongens wel een stuk spannender dan die voor meisjes. Van Slooten baseerde zich, zo weten we inmiddels, op het 'traditionele selectieparadigma', dat uityaat van 'the right man in the right place'. Geschiktheid was vroeger een kwestie van het bezitten van de eigenschappen die een beroep vereiste. "Uit iemands eigenschappen kon worden afgeleid voor welk beroep hij geschikt was, resp. of hij voor een bepaald beroep al dan niet seschikt was. "Ook de Wet RO hanteert het geschiktheidscriterium voor de

1. G. van Slooten, Het ambt van den rechter, serie beroepskeuze voor den jurist, 1921, p. 5

2. Zie ook R.A. Roe. Konte geschiedenis van de personeelsselektie, 1982, p. 12-13 
toegang tot het rechtersambt. Om benoembaar te zijn in de rechterlijke macht dient de kandidaat te beschikken over de Nederlandse nationaliteit en over een universitaire juridische opleiding, en moeten bepaalde incompatibiliteiten vermeden worden. Toch zou het onjuist zijn om er van uit te gaan dat dit de enige, of zelfs maar de belangrijkste selectiecriteria zijn geweest voor rechterlijke functies. De belangrijkste criteria die tot ver in onze eeuw hebben gegolden voor de toegang tot het rechtersambt - het eigen vermogen en de mannelijke sekse - werden immers nooit door de Wet RO genoemd. Vaak wordt ook kerkelijke gezindte als ongeschreven selectiecriterium voor leden in de Hoge Raad genoemd. Van Koppen en Ten Kate wijzen er op dat tussen 1838 en 1960 er 'scherp' op werd gelet tot welke godsdienst een raadsheer behoorde, waarbij met name de verhouding katholieken en niet-katholieken van belang was. ${ }^{3}$ Opmerkelijk genoeg vindt men in de vorige eeuw over alle selectiecriteria voor rechters vrij veel literatuur, behalve over de kerkelijke gezindte. De vraag rijst daarom of rond de z.g. kwaliteitszetels in de Hoge Raad - net zoals dat met het Amerikaanse Supreme Court is gebeurd - niet een zekere mythe is gegroeid, waarbij toeval een grotere rol gespeeld heeft dan wij nu willen aannemen. ${ }^{4}$

De enkele benoembaarheid geeft in ons staatsrecht (en voorzover mij bekend ook elders) geen enkele aanspraak op een benoeming in de rechterlijke macht. Uit hoofdstuk 2 bleek reeds dat het enkel voldoen aan de formele benoembaarheidsvereisten (nationaliteit, opleiding, onverenigbaarheden) pas de eerste van vele hobbels is op de weg naar een benoeming in de rechterlijke macht. Voor de toegang tot het rechtersambt is, naast de benoembaarheidsvereisten, het benoemingsstelsel van groot belang. De kandidaat moet zien dat hij op een aanbeveling terechtkomt (voor een benoeming in de Hoge Raad: op de aanbeveling en de voordracht). Daaraan voorafgaand worden kandidaten geselecteerd door de raio-selectiecommissie of de Commissie aantrekken leden rechterlijke macht. De hypothese is (zie hoofdstuk 1) dat er een samenhang bestaat tussen al deze factoren die samen de toegang tot het rechtersambt bepalen, en dat daardan zowel bij de invoering als bij de verdere ontwikkeling van het stelsel, een bepaalde visie heeft voorgestaan bij de (grond-)wetgever. Dit hoofdstuk toetst die hypothese, voor wat betreft het ontstaan van de benoembaarheidsvereisten en het benoemingsstelsel, op haar houdbaarheid.

3. Overigens wordt uit het onderzock van Van Koppen en Ten Kate niet duidelijk wie deze verhoudingen in de gaten hield (de Hoge Raad, de Tweede Kamer, de regering, de pers?) en welk beleid daarbij werd gevoerd. Het 'consequente beleid' waarover gesproken wordt bestond kennelijk enkel daaruit dat katholieken door katholieken, en niet-katholieken door niet-katholieken werden opgevolgd; van een evenredige verdeling was -kennelijk- geen sprake. Van Koppen en Ten Kate, Tot raadsheer benoemd, 1987, p. 73-78

4. Zie hierover B.A. Perry, A "Representative" Supreme Court? The impact of race, religion, and gender on appointments, 1991 


\subsection{Historische inspiratiebronnen}

De discussie over de benoeming en de benoembaarheid van rechters in de periode tussen de totstandkoming van het Koninkrijk in 1813 en de Wet RO 1835, kan moeilijk worden geïsoleerd van de daaraan voorafgaande periode. Als inspiratiebronnen voor de toegang tot het rechtersambt na 1813, gelden immers zowel de rechtspleging ten tijde van de Republiek als de (verschillende vormen van) organisatie van de rechterlijke macht tijdens de Franse bezetting (1795-1813). Beide bronnen staan echter op gespannen voet met elkaar, hetgeen tot uitdrukking kwam in de grondwetgevende vergadering van 1813. Nog tijdens de bezetting in 1812 had Van Hogendorp, die als de leidende figuur wordt beschouwd bij het herwinnen van de onafhankelijkheid in 1813, een Schets van eene Grondwet voor de Vereenigde Nederlanden ontworpen, waarvan de derde, herziene versie als uitgangspunt fungeerde voor de grondwetscommissie, die haar beraadslagingen begon op 21 december 1813. Sommige opvattingen in de Schets staan haaks op de ideeën die bij andere leden in de grondwetscommissie, zoals Elout, Van Maanen en Roëll leefden. Terwijl Van Hogendorp zoveel mogelijk de restauratie van instellingen uit de Republiek wenste (dus gedecentraliseerd bestuur), wilde met name Van Maanen juist gecentraliseerd bestuur met de concentratie van alle macht bij de Souvereine Vorst. ${ }^{5}$ Met name op het punt van de justitie liepen de opvattingen in de commissie ver uiteen. Kenmerkend is dat Van Hogendorp de rechtspleging na 1813 "op den ouden voet" (dus zoals in de provincies onder de Republiek) wilde herstellen, om "den geest der nieuwigheden, die ons land bedorven heeft, zooveel mogelijk uitteroeijen. ${ }^{6}$, terwijl Van Maanen juist spreekt over "de verkeerdheden en dwaasheden (-) welke bij de oude regtspleging, inzonderheid ten platte lande, alwaar hier en daar de bespottelijkste inrigtingen bestonden, plaats hadden "17 Op het punt van de rechtspleging lijkt Van Hogendorp het pleit enigszins te hebben verloren, want op zijn verzoek werd het hoofdstuk Van de justitie uiteindelijk geredigeerd door Elout en Van Maanen, en op geen punt week de redactie van de Grondwet 1814 uiteindelijk zo sterk af van de Schets als in dit hoofdstuk. ${ }^{8}$

Hoewel de organisatie van de rechtspraak in de Grondwet en de Wet RO overduidelijk de sporen draagt van het centralistische Franse systeem, zijn er - wat

5. G.W. Bannier, Grondwetten van Nederland, 1936, p. 254

6. H.T. Colenbrander, Ontstaan der Grondwet, deel I, p. 75

7. Colenbrander, o.c. p. 250 Elout meent dat "terwijl wij met dankbaarhid moeten terugzien op hetgeen onze voorvaderen daarstelden, wij echter de ogen niet voor alle nieuwe licht sluiten, maar verbeteren moeten wat te verbeteren is". Colenbrander, o.c. p. 250 Zie ook: "Elout over de rechterlijke macht", Colenbrander, o.c. p. 512-514

8. B.D.H. Tellegen, Overzicht van het tol stand komen der Grondwet van 1814,1912, p. 95 
de benoeming van rechters betreft - ook in de huidige Wet RO nog altijd resten te vinden van de staatsinrichting van de Republiek. De huidige voordrachtsbevoegdheid van de Tweede Kamer voor vacatures in de Hoge Raad bijvoorbeeld, is zeer waarschijnlijk terug te voeren op de benoemingsprocedure van de leden van de Provinciale Gerechtshoven tijdens de Republiek (zie §3.3.1). Wat de toegang tot het rechtersambt tijdens de Republiek betreft, is overigens vrij weinig bekend. ${ }^{9}$ Volgens Hermesdorf moest een gezagdrager in de Middeleeuwen beschikken over een zekere welstand, opdat hij zijn ambt onafhankelijk en onpartijdig kon uitoefenen. ${ }^{10}$ Bovendien diende hij een zekere geestelijke rijpheid te hebben, die werd aangenomen rond het vijfentwintigste levensjaar. Daarnaast moest een rechter bekend zijn met de plaatselijke gewoonten en gebruiken, en daarom gold veelal het vereiste dat hij geboren poorter was, of tenminste een bepaald aantal jaren in een plaats of streek had gewoond." Overigens was tot het einde van de achttiende eeuw van enige professionalisering bij de lagere rechtbanken nog geen sprake. In de landelijke gebieden was de positie van rechter gekoppeld aan de status die iemand had in de agrarische samenleving (eigenerfde of bezitter van een bepaalde hoeveelheid land). Benoeming geschiedde door de stadhouder voor een bepaalde tijd. Het ambt was veelal onbezoldigd, en juridische kennis ontbrak veelal bij deze rechters; in moeilijke gevallen werden daarom rechtsgeleerden geconsulteerd. ${ }^{12}$ De enige professionele rechtscolleges tijdens de Republiek waren de Provinciale Hoven, waarvan de leden (juristen) voor het leven werden benoemd. ${ }^{13}$ Voor de ontwikkeling van de rechterlijke organisatie in de periode 1795-1811 zij hier verwezen naar het onderzoek van M.W. van Boven, De rechterlijke instellingen ter discussie. Hier zal verder slechts worden gerefereerd aan het ontwerp van de Commissie-Farjon, die in 1808 een Wetboek voorbereidde, dat van grote invloed is geweest op de inrichting van de rechterlijke organisatie in de Grondwet 1814 en de Wet RO 1827. Het huidige stelsel van aanbevelingen, en de eisen voor benoembaarheid in de rechterlijke macht, zijn grotendeels tot dit ontwerp te herleiden.

9. Zie hierover: M.W. van Boven, De rechterlijke instellingen ter discussie De geschiedenis van de wetgeving op de rechterlijke organisatie in de periode 1795-1811, 1990. p. 9

10. B.H.D. Hermesdorf, Rechtsspiegel Een rechtshistorische terugblik in de Lage Landen van het herfstij. 1980, p. 108

11. Hermesdorf, o.c. p. 136 e.v. Zie ook Van Boven, o.c. p. 23

12. Van Boven, o.c. p. $25-26$

13. Van Boven, o.c. p. 23-24 
Hoewel de Wet op de Rechterlijke Organisatie pas in 1838 in werking trad, en tot die tijd de rechterlijke instellingen bleven vourthestaan die ouk tijdens de Franse bezetting hadden gefunctioneerd, bevat de Grondwet reeds vanat 1814/ 1815 een grondslag voor de rechterlijke macht. Zo vourziet de Grondwet 1814 in een Opperste Geregtshof genaamd Hoge Raad der Verenigde Nederlanden $^{14}$, dat cordeelt over ambtsmisdrijven en over zaken waarin het Koninklijk Huis of de Staat worden gedaagd, en dat het toezicht heeft op de rechtspraak van de lagere gerechten. ${ }^{15}$ In elke provincie is volgens de Grondwet een Provinciaal Geregtshof; daarnaast is voorzien in een Hoog Militair Geregtshof ${ }^{16}$ De wet bepaalt welke overige gerechten er zijn. ${ }^{17}$ Over de wijze van henoeming van de leden van de rechterlijke macht bevat de Grondwet - tot aan de dag van vandaag - afgezien van de bepaling over de benoeming voor het leven door de Koning (thans: "bij koninklijk besluit'), slechts voorschriften voor de Hoge Raad. Volgens art. $113 \mathrm{GW} 1814$ worden de leden en 'ministers" van de Hoge Raad en de Procureur-Generaal bij de Hoge Raad voor het leven benvemd; de termijn van aanstelling van alle andere rechters wordt door de wet bepaald. ${ }^{18}$ Bij een vacature in de Hoge Raad madkt de (na 1815: 1weede Kamer der) Staten-Generaal cen nominatie van drie personen op en hiedt dece aan de Souvereine Vorst (na 1815: de Kuning) aan, die daaruit een keuze doet. ${ }^{19}$ Bij een vacature in een Geregtshof makt de Vorst een keuze uit een nominatie van drie personen, opgemaakt door de Provinciale Staten. ${ }^{20}$ De

14. Art. $102 \mathrm{GW} 1814$, resp. art. $175 \mathrm{GW} 1815$

15. Artt. 104, 106 en $107 \mathrm{GW} 1814$, resp. artt. 177,179 en $180 \mathrm{GW} 1815$

16. Art. $115 \mathrm{GW} 1814$, resp. art. $188 \mathrm{GW} 1815$

17. Art. $112 \mathrm{GW} 1814$, resp. art. $185 \mathrm{GW} 1815$

18. Art. $113 \mathrm{GW} 1814$, resp. art. $186 \mathrm{GW} 1815$

19. Art. $103 \mathrm{GW} 1814$ : "Van eene voorgevallene vacaure wordt door den Hoogen Raad aan de Staten-Generaal kennis gegeven, die, ter vervulling van dezelve, eene nominatie van drie personen aan den Souvereinen Vorst aambieden, ten einde daaruit eene keuze te doen. De Souvereine Vorst heeft de directe aanstelling van de Procureur-Generaal bij den Hoogen Raad."

A $\overrightarrow{11} .176 \mathrm{GW}$ i815: "Van eene voorgevallene vacature, wordl door den Hoogen Raad aan de tweede kamer der Staten-Generaal kennis gegeven, die, ter vervulling van dezelve, eene nominatie van drie personen aan den Koning zal aanbieden, ten einde daaruit eene keuze te doen. De Koning benoemt den President uit de leden van de Hoogen Raad, en heeft de directe aanstelling van de Procureur-Generaal."

20. Art. 109 GW 1814: "Er zal zijn in elke Provincie of Landschap één Geregtshof, ten ware bij de wel een. Hof over meer dan eene Provincie of Landschap mogi worden. gesteld. Van eene voorgevallene vacature wordt door het Hof kennis gegeven aan de Provinciale Staten, die, ter vervulling van dezelve, eene nominatie van drie personen aan den Souvereinen Vorst aambieden, ten einde daaruit de keuze te doen." 
presidenten van de Hoge Raad en van de Hoven worden uit de leden benoemd. ${ }^{21}$ De Procureur-Generaal bij de Hoge Raad en die bij de Hoven wordt zonder nominatie door de Vorst benoemd. ${ }^{22}$ Tot 1848 bevatte de Grondwet de bepaling dat de leden van de Hoge Raad 'zoo veel mogelijk uit alle de Provincien " worden genomen."

\subsubsection{De voordracht als staatsrechtelijke anomalie}

Over de oorsprong van de voordrachtsbevoegdheid van de (na 1815: Tweede Kamer der) Staten-Generaal voor vacatures in de Hoge Raad, bestaat in de literatuur geen duidelijkheid. Hoewel de inrichting van de rechterlijke organisatie in de Grondwet 1814 in grote lijnen overeen komt met het ontwerp van de Commissie-Farjon uit april $1808^{24}$, komt een voordracht in dit ontwerp niet voor. ${ }^{25}$ De voordracht voor de Hoge Raad in art. 109 van de Grondwet 1814 vertoont echter grote gelijkenis met art. 6 van de Schets van Van Hogendorp. ${ }^{26}$ Volgens de $S c h e t s$ zou de Souvereine Vorst alle leden en ministers van dit college aanstellen uit een voordracht van drie personen, opgemaakt door de Staten-Generaal. ${ }^{27}$ Waarschijnlijk heeft Van Hogendorp deze voordrachtsprocedure ontleend aan de voordrachten van de provinciale staten onder de Republiek voor de vervulling van vacatures in de toenmalige Provinciale Hoven. Deze voordrachtsprocedure werd volgens Thorbecke in de Grondwet van 1814 hersteld voor de nieuwe Provinciale Hoven, en daarna overgeplant op de Hoge Raad:

"Men volgde cene aanleiding, zonder juist het oog te hebben op een beginsel. De inrigting der voormalige Republiek gaf regtsreeks geen voorbeeld. Maar Hogendorp ontleende van haar het regt van voordragt, dat de provinciale Staten zouden hebben voor benoemingen in de provinciale Hoven. Ging dat denkbeeld door, dan

21. Art. 176 GW 1815 N.B. de bepaling over de president van de Hoge Raad werd geschrapt bij de grondwetsherziening van 1983.

22. Art. 103 en $109 \mathrm{GW} 1814$

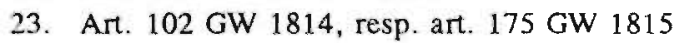

24. Van Boven, o.c. p. 264

25. Art. 24 ('Van het Hoog Nationaal Geregtshof") van het ontwerp-Farjon luidt: "De Prefident wordt onmiddellijk door den Koning aangefteld. Bij eene andere vacalure, zenden de overige Leden van hel Hof eene nominatie van drie Perfonen aan het Wetgevend Ligchaam, het welk daar uit de verkiezing van een Lid voor dat Geregtshof doet. "

26. Art. $109 \mathrm{GW} 1814$

27. Art. 6 Schets van Hogendorp: "De Souvereine Vorst stelt aan alle de Leden en Ministers van de Hoge en Provintiale Geregtshoven, uit nominatiën van drieën, door de Staten Generaal en Provintiaal respective gemaakt, om te dienen voor hun leven, en niel onislagen te worden dan op hun cigen verzoek, of bij vormis van de Hogen Raad der Nederlanden, onder het welk alleen zij in hunne amptsverrigtingen te regt staan." 
was het onvermijdelijk, aan de Statengeneraal eene tusschenkomst te verleenen bij benoemingen in den Hoogen Raad. De Souvereine Vorst of de Koning gebonden ten aanzien der provinciale Hoven, en niet gebonden ten aanzien van den Hoogen Raad, dit was niet vereenigbaar. ${ }^{28}$

De nieuwe constructie verdiende echter geen schoonheidsprijs. De voordrachtsbevoegdheid die de Grondwet van 1814 in art. 109 aan de Provinciale Staten toekent, bij de benoeming van de leden van de Provinciale Hoven, was immers niet langer een provinciale zaak zoals onder de oude Republiek, maar eene algemeene landszaak": "Hogendorp ontwaarde niet, dat hij oude vormen, die in hun tijd een goeden grond hadden, zonder dien grond en op een zeer verschillend wezen overdroeg. ${ }^{29}$

Bij de keuze voor de voordrachtsprocedure voor de Hoge Raad dient men de discussie over het herstel van de Provinciale Hoven in de Grondwet van 1814 in het oog te houden. Roel Pieterman beschrijft hoe door het behoud van deze Provinciale Gerechtshoven na 1814 aristocratische machtsposities uit de Republiek werden bestendigd. Door in iedere provincie een gerechtshof te plaatsen kon, ondanks de vestiging van een eenheidsstaat in 1814 , de provinciale autonomie in hoge mate worden gecontinueerd, doordat de Provinciale Staten zelf via een voordracht aan de Koning, de vacatures vervullen. ${ }^{30}$ Als de grondwettelijke grondslag voor de Provinciale Hoven in 1848 vervalt, en deze rechtscolleges in 1875 uit de Wet RO wordt geschrapt, vervalt daarmee tevens de ratio voor de voordrachten van de Tweede Kamer voor de Hoge Raad.

Het is overigens de vraag of men de gewraakte bepaling over de voordrachten uit de Schets van Van Hogendorp, uitsluitend kan afdoen als een reactionaire flirt met de Republiek. De belangstelling van Van Hogendorp voor de federalisatie van de Amerikaanse staten, en zijn bewondering voor De Montesquieu, roepen een heel ander beeld op. In 1783-1784 maakte hij een reis van zeven maanden door Amerika, en ontmoette Abraham Lincoln, George Washington,

28. J.R. Thorbecke, Aanteekening op de Grondwet, 1843, p. 171-172 Zie in gelijke zin, J.T. Buijs: "Hel denkbeeld van de bedoelde woordracht is van Hogendorp afkomstig, die zich ook hier veel meer heeft laten leiden door zijne voorliefde voor het staatsrecht van de oule Republiek dan door de vraag: welke regelen al of niet natuurlijk pasten in de nieuwe orde van zaken, welke hij hielp voorbereiden." J.T. Buijs, De Grondwet, Toelichting en kritiek, tweede deel, 1884, p. 436. Zie ook: de toespraak van de minister van justitie Du Tour van Bellinchave, Hand. II 1886-1887, p. 1604

29. J.R. Thorbecke, Aameekening op de Grondwet, tweede uitgave, tweede deel, 1843, p. 195-196 Zie in gelijke zin: A. de Pinto. Handleiding tot de Wet op de Regterlijke Organisatie en het beleid der justitie, 1844, p. 151

30. Roel Pieterman, De plaats van de rechter in Nederland Politiek-juridische ideeënstrijd over de scheiding van machten in de staat, 1990 
de federalist Alexander Hamilton en de anti-federalist Thomas Jefferson. Jefferson raakte goed bevriend met Van Hogendorp. Later zou Van Hogendorp een langdurige correspondentie met Jefferson voeren. ${ }^{31}$ De interesse van Van Hogendorp voor de Amerikaanse Constitutie stond niet op zichzelf. Vóor 1795 was in ons land, zowel bij de voorstanders van een federatie, als bij degenen die een eenheidsstaat voorstonden, de belangstelling voor de uitwerking van de machtenscheiding op federaal niveau in de Verenigde Staten, en vooral voor de positie van de Amerikaanse rechterlijke macht groot, al bleef de invloed daarvan op onze rechterlijke organisatie uiteindelijk beperkt. ${ }^{32}$ Daarom vertoont de in de Schets voorgestelde voordrachtsprocedure voor de Hoge Raad, niet alleen overeenkomsten met de Republiek (waar voor de souvereine provincies overigens geen overkoepelend rechtscollege bestond) maar juist ook met het Amerikaanse Supreme Court. De structuur van de Amerikaanse federale rechtersbenoemingen - eén hoogste gerechtshof voor de souvereine staten -, en de verdeling van benoemingsbevoegdheden tussen staatshoofd en volksvertegenwoordiging (nominatie door de president, goedkeuring door de Senaat), roept op zijn minst de vraag op of Van Hogendorp bij het schrijven van de Schets, bewust of onbewust, niet (ook) ideeën over machtenscheiding in het algemeen, en over de federale verhoudingen in Amerika in het bijzonder, in het achterhoofd heeft gehad.

\subsubsection{De grondwetscommissie 1814}

De grondwetscommissie van 1814 nam de bepalingen uit de Schets van Van Hogendorp over de Hoge Raad, en over de wijze van benoeming van de leden van de Hoge Raad (en van de Provinciale Gerechtshoven) grotendeels over. Anders dan Van Hogendorp had voorgesteld in art. 6 van zijn Schets, beperkt art. $103 \mathrm{GW} 1814$ zich tot de benoeming van de leden van de Hoge Raad; de aanstelling van de procureur-generaal bij de Hoge Raad geschiedt, buiten medewerking van de Staten-Generaal, direct door de Koning. Het mag inmiddels duidelijk zijn, dat het niet vanzelf spreekt dat de grondwetscommissie juist deze bepaling over de voordracht van de Staten-Generaal - die door Thorbecke als een terugkeer naar de Republiek beschouwd werd - overnam. Toch blijkı uit de aantekeningen van Van Maanen dat het voorstel van Van Hogendor over de voordrachten aanvankelijk ongewijzigd werd overgenomen. Als de grondwetscommissie echter besluit om voor benoemingen in de Provinciale Gerechtshoven, behalve door Provinciale Staten ook door het Provinciale Hoff een nominatie te laten opmaken, stelt Heerkens voor om, naar analogie, ouk bij vacatures in de Hoge Raad, zowel door de Staten-Generaal als door de

31. H.L.T, de Beaufort, Gijsben Karel van Hogendorp Grondlegger van hel Koninkrijk. 1979. p. 73-101

32. Van Boven, o.c. p. $56-59$ 
Hoge Raad zelf een nominatie op te laten opmaken. ${ }^{33}$ De Vorst vreest echter 'wrijving' tussen de Staten en de Hoven, resp. de Hoge Raad en de StatenGeneraal, wanneer uit de nominatie van een van beide wel of niet gekozen wordt, en daarop verdwijnt de dubbele aanbeveling weer (men vergelijke het stelsel van aanbevelingen in de Wet RO 1827). ${ }^{34}$ Een voorstel van Van Maanen om de voordracht voor de Hoge Raad en de Provinciale Hoven op te laten maken uit een gros van deze colleges zelf haalt het niet. ${ }^{35}$

Wat nu precies de overweging is geweest van de grondwetscommissie van 1814 om de bepalingen over de voordracht van de Staten-Generaal uit de Schets over te nemen blijft onduidelijk. Thorbecke wijst (zie boven) op de symmetrie tussen de voordrachtsbevoegdheid van de Provinciale Staten en van de StatenGeneraal. Indien juist, dan werd dat denkbeeld (blijkbaar) niet door alle leden van de grondwetscommissie gedeeld; zo is in de concept-artikelen, die Elout en Van Maanen, op verzoek van Van Hogendorp, ten behoeve van de grondwetscommissie opstellen, wèl voorzien in een voordrachtsbevoegdheid voor de Staten-Generaal voor vacatures in de Hoge Raad, maar niet in een soortgelijke bevoegdheid voor de Provinciale Staten voor vacatures in de Provinciale Hoven. ${ }^{36}$ Zelf heeft Van Hogendorp later geschreven dat de reden van de voordrachtsbevoegdheid voor vacatures in de Hoge Raad en de Hoven, is gelegen in "de meerdere zekerheid" dat er "bekwame en deugdzame mannen" benoemd zullen worden. ${ }^{37}$ Thorbecke meent echter dat de "beslissende reden" voor de instelling van de voordracht wordt gevonden: "in het verlangen, om een waarborg te hebben voor de persoonlijke onafhankelijkheid der leden. De Kroon, alleen meesteres, zou eenzijdige, administratieve inzigten kunnen volgen, en

33. Colenbrander, o.c. p. 332

34. Colenbrander, o.c. p. 402

35. Colenbrander, o.c. p. 403; zio ook: B.D.H. Tellegen, Overzicht van het tot stand komen der Gromdwet van 1814. 1912, p. 100

36. Concept artikelen van de Heeren Elout en Van Maanen betreffende de Justitie: Ari. 11: "Van eenige voorgevallene vacalure wordt door den Hogen Raad kennis gegeven aan de Staten. Generaal die ter vervulling van de vaceerende plaats een nominatie van drie personen aan den Souvereinen Vorst aanbiedt, ten einde daar uit eene keuze te doen.

De Souvereine Vorst heeft de directe aanstelling van den Procureur-Generaai bij den Hogen Raad."

Art. 17: "Er zal zijn in elke Provintie of Landschap een Geregtshof ten ware bij de wet een Hof over meer dan eene Provintie of Landschap mogt worden gesteld. "

37. "Men mag bij de nationale vertegenwoordiging de kennis aan zulke lieden onderstellen, zoodat zij diegenen op de nominatie zullen brengen, welke het meest als zoodanig bekend staan. Maar dan blijven er nog omstandigheden over, welke den een meer geschikt maken dan den anderen, om de opengevallen plaats te vervullen. Hieromtrent is het oordeel overgelaten aan de kroon." G.K. van Hogendorp, Bijdragen tot de huishouding van de staal in het Koningrijk der Nederlanden, 1855, p. 377 
door de hoop op plaatsing in den Hoogen Raad velen, inzonderheid ook leden of ambtenaren der regterlijke magt, aan zich verbinden. ${ }^{138}$

\subsubsection{De Grondwet van 1815}

In de Grondwet van 1815 wordt de voordrachtsbevoegdheid van de StatenGeneraal gewijzigd in een voordrachtsbevoegdheid voor de Tweede Kamer der Staten-Generaal. ${ }^{39}$ De nieuwe Eerste Kamer, die na de samenvoeging met de Belgen in 1815 ontstaat, wordt zodoende buiten de nominatie gehouden. Van Hogendorp meent bij de grondwetsvergadering dat de nominatie voor de leden van de Hoge Raad, evenals van andere colleges waarvan de Staten-Generaal de benoeming hebben, het beste door de Tweede Kamer kan gebeuren, en dat de zaak "niet van genoegzaam belang" is om beide Kamers te verenigen, terwijl de kwestie "meer eigenaardig" bij de Kamer der Representanten behoort, omdat in die kamer, in tegenstelling tot de Eerste, gedeputeerden uit alle provinciën zitting hebben ${ }^{40}$ Thorbecke noemt dit laatste echter "de minst waarschijnlijke aller denkbare redenen". Hij verklaart de uitsluiting van de Eerste Kamer uit het feit dat haar leden door de Koning benoemd worden, en doordat het opmaken van een voordracht door twee Kamers tot praktische problemen leidt. ${ }^{41}$ Hoewel de grondwetscommissie van 1815 inmiddels overtuigd is van het nut van de voordrachtsregeling ${ }^{42}$, heeft zij geen duidelijke voorkeur voor de Tweede of de Eerste Kamer, en neemt zij het standpunt van Van Hogendorp over. ${ }^{43} \mathrm{Na}$ een opmerking van de Koning wordt op 13 juli 1815 bepaald dat de Koning de presidenten van de Hoge Raad en de Provinciale Hoven uit de leden van deze colleges benoemt. ${ }^{44}$ Veel later zal de Tweede Kamer haar keuze voor de voordrachten betreuren. Zo zegt het liberale

38. J.R. Thorbecke, Aanteekening op de Grondwet, 1843, p. 173

39. Art. $176 \mathrm{GW}$ 1815: "Van eene voorgevallene vacature wordt door den Hoogen Raad aan de tweede kamer der Staten-Generaal kennis gegeven, die, ter vervulling van dezelve, eene nominatie van drie personen aan den Koning zal aanbieden, ten einde daaruit eene keuze te doen. De Koning benoemt den President uit de leden van den Hoogen Raad en heeft de directe aanstelling van de Procureur-Generaal."

40. C.F. Van Maanen, Aanteekeningen van het verhandelde over de Grondwet van 1814 gehouden door C.F. Van Maanen, 1886, p. 189

41. J.R. Thorbecke, Aanteekening op de Grondwet, 1843, p. 171

42. Op de vraag van Van Lijnden ("waarom moeten de Staten-Generaal de nominatie hebben"), zegt Elout: "om eene garantie tegen al te groot Koninklijk gezag te verzekeren": bij Van Maanen, o.c. p. 110

43. Bij Van Maanen lezen we: "De President: welke kamer zal de nominatie hebben. Dotrenge: beide. Leclerc: ieder afzonderlijk. de Conick: ita, en bovendien ook het Hof zelve. Lijnden: zonder nominatie, of het hof alleen; - het is voor de Staten Generaal eene ijdele gloriole. "Van Maanen, o.c. p. 110-111

44. J.T. Colenbrander, o.c. p. 501 en 545 
Tweede Kamerlid Van Houten, onder verwijzing naar benoemingen in het Amerikaanse federale Supreme Court, in 1887: "Indien men de novo een Staatswezen had op te bouwen, zou ik er de voorkeur aan geven, om den invloed der Staten-Generaal op de rechterlijke macht bij de Eerste Kamer te brengen, daarmede den gedachtengang volgende van de Amerikaansche Constitutie, die de approbatie op de regeeringsbenoemingen aan de Senaat geeft. ${ }^{m 45}$ Van het politieke steekspel, dat van de voordrachtsprocedure kan uitgaan, is de grondwetscommissie zich in 1815 echter nog niet bewust (evenmin als Van Houten zich in 1887 trouwens bewust is van de conflicten die het Amerikaanse nominatie-stelsel in potentie in zich draagt).

\subsection{Totstandkoming en invoering van de Wet op de Regterlijke Organisatie 1827}

Hoewel de Grondwet sinds 1814 een grondslag bevat voor de invoering van een rechterlijke organisatie, blijft ook na de Franse bezetting in 1813 tot aan de inwerkingtreding van de Wet RO in 1838 de Franse wetgeving van kracht, evenals het overgrote deel van de door de Fransen ingevoerde rechterlijke organisatie. ${ }^{46}$ Het ontwerp voor een (nieuwe) rechterlijke organisatie dateert van 1820 , de Wet RO kwam echter pas tot stand na een tweede ontwerp in 1827. ${ }^{47}$ De invoering van de Wet RO, die had moeten plaatsvinden op 1 februari $1831^{48}$, wordt echter doorkruist door de Belgische afscheiding in 1830 , waardoor een herziening noodzakelijk wordt. ${ }^{49}$ De gewijzigde Wet RO wordt afgekondigd op 28 april $1835^{50}$, en treedt uiteindelijk op 1 oktober 1838 in werking. ${ }^{51}$ Omdat er veel kritiek bestaat op de Wet RO 1835 is in de periode 1851-1871 tot zeven maal toe - vergeefs - getracht een algehele wijziging van de Wet RO te bewerkstelligen. ${ }^{52}$ De poging in 1861 resulteerde weliswaar in een wet ${ }^{53}$, maar de invoering van deze wet wordt herhaaldelijk uitgesteld ${ }^{54}$, totdat de invoering uiteindelijk door de Tweede Kamer wordt verworpen. ${ }^{55}$

45. Hand. II $1886-1887$. p. 1610

46. KB van 11 december 1813 , Stb, nr. 10

47. Wet van 28 april 1827 op de samenstelling van de regterlijke magt en het beleid der justitie, Stb, nr. 20

48. $\mathrm{KB}$ van 5 juli 1830 . Stb. nr. 41

49. KB van 24 februari 1831 , Stb. nr. 1

50. $\mathrm{KB}$ van 28 april $1835, \mathrm{Stb}, \mathrm{nr} .10$

51. KB van 10 april 1838, Stb. nr. 10. Zie uitgebreider bij A. de Pinto, Handleiding tot de Wet op de Regterlijke Organisatie en het beleid der Justitie, 1844, p. 12 e.v.

52. Namelijk in $1851,1853,1855,1857,1859.1860$, en 1871

53. Wet van 31 mei 1861 , Sib. nr. 49

54. Wet van 17 december 1861 , Stb. nr. 125: Wet van 27 juni 1863 , Stb. nr. 85 en Wet van 8 juni 1864 , Stb. nr. 69

55. Zitting van 23 juni 1870 
Het zal daarna meer dan honderd jaar duren voordat opnieuw een algehele herziening van de Wet RO ter hand wordt genomen.

\subsubsection{De aanbeveling}

De Wet RO 1835 voorziet, naast de grondwettelijk voorgeschreven Hoge Raad en de Provinciale Hoven ${ }^{56}$, in 'arrondissements-regtbanken' en 'kantongeregten'. Ten aanzien van de benoeming van de leden van de Hoge Raad bepaalt art. 66 Wet RO 1835 dat de Hoge Raad, inclusief de procureur-generaal, bij meerderheid van stemmen een aanbeveling van zes kandidaten opmaakt. De leden van de Provinciale Gerechtshoven, van de rechtbanken en van het Openbaar Ministerie die hun 'ambtsbedieningen met lof en ijver' hebben waargenomen, komen daarvoor in het bijzonder in aanmerking. ${ }^{57}$ Een soortgelijke regeling geldt voor de Provinciale Gerechtshoven; bij een vacature zendt het Hof, inclusief de procureur-generaal, een aanbevelingslijst van zes kandidaten aan de Provinciale Staten, die eveneens bij meerderheid van stemmen wordt opgemaakt. Ook hier komen de leden van de rechtbanken en de officieren van justitie in het bijzonder in aanmerking. Bij een vacature van rechter, rechterplaatsvervanger, griffier of kantonrechter, wordt de aanbevelingslijst opgemakt door de rechtbank, inclusief de officier van justitie. De rechters en officieren van justitie worden bij voorkeur gekozen uit de substituut-officieren, griffiers en plaatsvervangers, of uit de kantonrechters en hun plaatsvervangers, voorzover deze laatsten tenminste hun werkzaamheden gedurende vijf jaar 'met lof en ijver' hebben waargenomen. ${ }^{58}$ De leden van de Hoge Raad en de Hoven worden conform art. $186 \mathrm{GW} 1815$ voor het leven benoemd, evenals de leden van de rechtbanken. Overigens worden de kantonrechters(-plaatsvervangers) van $\mathbf{1} 838$ tot $1989^{59}$ slechts voor een periode van vijf jaar benoemd, en komen daarna voor een herbenoeming in aanmerking.

56. N.B. De Provinciale Hoven werden bij Wet van 10 november 1875. Stb. nr. 204 opgeheven en vervangen door de huidige gerechtshoven

57. Art. 87 Wet RO 1835: "Wanneer eene plaats van Raadsheer in den Hoogen Raad openvali, zal de Hooge Raad daarvan kennis geven aan de Tweede Kamer der StatenGeneraal, en daarbij inzenden eene door dien Raad, de Procureur-Generaal daaronder begrepen, bij besloten briefjes en met meerderheid van stemmen opgemaakte aambevelingslijst van zes kandidaten, waarop de Tweede Kamer bij het maken van hare nominatie zoodanig acht zal slaan als zij zal dienstig oordelen.

De leden der provinciale hoven, der criminele regtbank en der arrondissementsregthanken, mitsgaders de leden van het openbaar ministerie bij dezelve, welke deze hunne ambisbedieningen met lof en ijver hebhen waargenomen, zullen bij het opmaken dier lijst meer bijzonderlijk in aanmerking komen. "

58. Art. 52 Wet RO 1835

59. Wet van 28 september 1989 , Stb. nr. 420 
Hoewel reeds het ontwerp-Farjon - dat de inspiratiebron vormt voor de huidige Wet RO - bij vacatures een nominatiebevoegdheid geeft aan het Hoog Nationaal Geregtshof, de Departementale Geregtshoven, de Hooge Vierscharen en de Civiele Regtbanken ${ }^{(x)}$, ontbreekt een analoge bevoegdheid aanvankelijk nog in het eerste ontwerp van de Wet RO in 1820 . Voor de benoeming van de leden van de Hoge Raad volstaat dit ontwerp met de mededeling dat de raadsheren worden aangesteld op de wijze zoals voorgeschreven door art. $176 \mathrm{GW}$ $1815 .{ }^{61} \mathrm{Bij}$ een vacature geeft de Hoge Raad kennis aan de 'Tweede Kamer die, ter vervulling van die vacature, een 'nominatie' van drie personen aan de Koning aanbiedt teneinde daaruit een keuze te doen. De Koning benoemt de president uit de leden van de Hoge Raad en heeft de directe aanstelling van de procureur-generaal. Volgens het ontwerp benoemt de Koning behalve de president $^{62}$, ook de vice-president van de Hoge Raad. De regering wilde met deze regeling een tweespalt in de Hoge Raad voorkomen; "La différence de l'émolument, et quelques fois des vues d'ambition, exciteraient les passions et sèmeraient peut être la mésintelligence et la désunion parmi les membres, ce qu'il faut prévenir. ${ }^{163}$

De lijsten van aanbeveling zoals wij die thans kennen, worden pas geïntroduceerd in het ontwerp van $1827 .{ }^{64}$ In constitutioneel opzicht is het stelsel van aanbevelingen eigenlijk merkwaardig, omdat de grondwetscommissie van 1814, op aanraden van Willem I, een dergelijke 'dubbele aanbeveling' voor vacatures in de Hoge Raad en in de Provinciale Hoven nog van de hand had gewezen. Het voorlopig verslag beperkt zich in 1827 echter slechts tot marginale kanttekeningen; vindt de een dat de aanbevelingslijsten "geene genoegzame nuttigheid" hebben, en de grondwettelijke keuzevrijheid van de Koning belemmeren, de meerderheid meent toch dat het 'heilzaam' is om het eerste - niet verbindende - initiatief te geven aan diegenen die het meeste belang hebben bij een goede keuze (de rechterlijke macht). De enige twee suggesties uit de Tweede Kamer - een voorschrift om de aanbevelingslijst voor Provinciale Gerechtshoven alfabetisch in te richten ${ }^{65}$, en het voorstel om een "vertegenwoordigend ligchaam" aan te wijzen voor de aanbevelingen ${ }^{66}$ - legt

60. Art. 24, 39, 48, 61 Ontwerp-Farjon

61. OvW, Bijl. Hand. II 1819-1820, nr. XXVI-2

62. Daartoe verplichtte immers art. $176 \mathrm{GW} 1815$

63. MvA, Bijl. Hand. II 1819-1820, nr. XXVI-3

64. Bijl. Hand. II 1826-1827, nr. XIII-C

65. Bijl. Hand. II 1826-1827, nr. XIII-3a

66. Bijl. Hand. II 1826-1827, nr. XIII-3A 
de regering ongemotiveerd naast zich neer. ${ }^{67}$ Van belang is wel dat de enige aanwijzing voor bevorderingen die de Wet RO kent, wordt ingevoerd door de wijzigingswet van 1835, die aan de inwerkingtreding van de Wet RO 1827 vooraf ging. ${ }^{6}$ Daarin is bepaald dat de leden van het openbaar ministerie die hun ambtsbediening "met lof en ijver" hebben waargenomen voor de post van raadsheer in de Hoge Raad in het bijzonder in aanmerking komen; een soortgelijke bepaling wordt ook opgenomen voor de Provinciale Hoven.

\subsection{Benoembaarheidsvereisten: de Grondwet 1814 en 1815}

De voorwaarden voor benoembaarheid zijn - net als het 'stelsel' van aanbevelingen en voordrachten - een voor een ingevoerd. Een duidelijke motivering om het ene onderwerp wel en het andere niet in de Grondwet of in de Wet RO te regelen ontbreekt. De grondwettelijke onverenigbaarheden en het nationaliteitsvereiste dateren van 1814 , de wettelijke incompatibiliteiten en het opleidingsvereiste van 1827 . Wat de grondwettelijke onverenigbaarheden betreft, verklaart de Grondwet 1814, op voorspraak van Van Lynden, het lidmaatschap van de Staten-Generaal onverenigbaar met dat van de rechterlijke macht. ${ }^{69}$ De grondwettelijke onverenigbaarheden worden in de grondwetsvergadering van 1814 door Van Lynden voorgesteld voor de leden van de Provinciale Hoven, die naar zijn zeggen niet in hun colleges gemist kunnen worden. ${ }^{70}$ Van Hogendorp ${ }^{71}$ en Elout ondersteunen dit voorstel ${ }^{72}$, evenals de

67. Hier zij voor de volledigheid nog gewezen op het initiatief-ontwerp Wet RO van Barthelemy uit 1829. De bepaling over de aanbevelingslijsten van de Hoge Raad in dit wetsontwerp is gelijkluidend an art. 88 van de Wet van 1827 . Stb. nr. 20 (zie: art. 80 OvW, Bijl. Hand. II 1828-1829, nr. XVIII-2A) Ook ten aanzien van de aanbevelingslijsten voor de Provinciale Hoven, de arrondissementsrechtbankenen de kantongerechten wijkt het ontwerp van 1829 niet af van de Wet van 1827 (zie: art. 62 en 52 OvW. Bijl. Hand. II 1828-1829. nr. XVIII-2a). De Tweede Kamer nam het initiatief-ontwerp aan op 9 mei 1829, maar de Eerste Kamer verwierp het ontwerp op 19 mei 1829.

68. Wet van 28 april 1835 . Stb. nr. 10

69. Art. 60, eerste lid, GW 1814: "De leden der Staten Generaal kunnen niet te gelijk zijn leden van eenig regterlijk kollegie of van de Rekenkamer, noch ook eenige aan den Lande comptabelen post bekleeden."

70. N.B. Deze incompatibiliteit ontbreekt in de derde Schets van Van Hogendorp. Art. 38 van de derde Schets van Hogendorp luidt: "Alle de leden van de Vergadering der Staaten-Generaal kunnen teffens Raadpensionaris, hoofd' van een ministerieel Departement, Staaisraad, Gezant buiten 's lands, Groot-Officier van het huis van den vorst, Lid van een der hoge Gerechtshoven, Lid van een Provintiaal Geregtshof, en Staf-Officier op de vloot en in de armee zijn." In de eerste en tweede Schets van Van Hogendorp vindt men deze incompatibiliteit. wel.

71. Colenbrander, o.c. p. 156 (zie ook p. 532)

72. Elout, Bedenkingen op de schets der grondwet, bij: Colenbrander, o.c. p. 506 
Souvereine Vorst. ${ }^{73}$ Bij de grondwetsherziening van 1815 komt De Coninck echter op de kwestie van de incompatibiliteiten terug. Hij vraagt dan waarom de leden van de magistratuur uitgesloten zijn "van het eerwaardig voorregt" der Staten-Generaal: "die vergadering kan geen beter leden hebben; -waarom zal men de magistratuur zoo avilisseeren?" Elout merkt echter op: "regters moeten independent zijn; -men heeft er iets wanvoegelijks in gevonden, dat zij die de wet moesten toepassen, tevens de wet zouden kunnen maken." Hoewel De Coninck wordt bijgevallen door Van Maanen, Leclerc, Dotrenge en Raepsaet, zijn alle andere leden aanvankelijk van mening dat het artikel moet blijven. ${ }^{74}$ In de vergadering van donderdag 25 mei 1815 komt de vergadering echter alsnog terug op haar standpunt. De leden van de grondwetgevende vergadering blijken zich inmiddels te hebben aangesloten bij de overwegingen van De Coninck ${ }^{75}$, en in de Grondwet 1815 komt de incompatibiliteit voor de leden van de rechterlijke macht, die slechts een jaar heeft bestaan, weer te vervallen. ${ }^{76}$

Het nationaliteitsvereiste voor de leden van de rechterlijke macht dateert van $1815 .{ }^{77}$ Over de motieven voor de invoering van de nationaliteitseis als selectiecriterium is niets bekend. Reeds het ontwerp van de commissie-Farjon stelt in art. 19 deze eis. Zeer waarschijnlijk heeft het in 1814 voor zich gesproken dat dragers van (hoge) publieke ambten over de Nederlandse nationaliteit ${ }^{78}$

73. Colenbrander, o.c. p. 439

74. Colenbrander, Ontstaan der Grondwet II p. 168

75. De handelingen vermelden: "les membres des cours et des tribunaux peuvent en faire partie; sans cela, ce serait une espèce d'humiliation pour les magistrats, et l'on exclurait les hommes les plus capables et les plus propres pour la confection des lois". Colenbrander, Onistaan der Grondwet II p. 245

76. Art. 92 GW 1815 luidt: "De leden der Staten-Generaal kunnen niet le getijk zijn, leden van de Rekenkamer, noch eenigen aan den lande comprabelen post bekleeden."

77. Artt. 7 en 8 van de Grondwet 1840 (artt. 8 en 9 GW 1815):

Art. 7. Tot leden der Staten-Generaal, hoofden of leden van departementen van alge. meen bestuur, leden van den Raad van State, Commissarissen des Konings in de Provincien, en leden van den Hoogen Raad, kunnen alleenlijk benoemd worden Nederlandsche ingezetenen, geboren binnen het Rijk of deszelfs buitenlandsche bezittingen, uit ouders aldaar gevestigd.

Die uit zoodanige ouders, ler oorzake van 's lands dienst afwezend, of anderszins op reis zijnde, buiten het Rijk geboren zijn worden met de vorige gelijk gesteld.

Art. 8. Tot alle andere bedieningen zijn alle de ingezetenen, zonder onderscheid, benoembaar, welke geboren Nederlanders zijn, of het zij door wel-duiding, het zij door naturalisatie daar voor gehouden.

78. Voor het lidmaatschap van de Hoge Raad was in 1815 de Nederlandse nationaliteit overigens niet voldoende; men moest tevens geboren Nederlander zijn. Zie art. 9 GW 1815 
beschikken. Bij de grondwetsherziening van 1848 stelt de grondwetscommissie bijvoorbeeld:

"Vreemdelingen moeten geen zoogenaamd actief burgerschapsregt kunnen witoefenen. Maar ten aanzien van benoembaarheid tot landsambten komt het ons voor, dat de poort die art. 8 der Grondwet (van 1840) aan vreemdelingen geheel sluit, in het belang der algemeene dienst moet kunnen worden geopend voor onderscheidene betrekkingen, waar wij het talent van bekwame vreemdelingen behoeven. ${ }^{179}$

\subsubsection{Wettelijke benoembaarheidsvereisten}

In het ontwerp Wet RO van 1820 en in de Wet RO 1827 worden de benoembaarheidsvereisten, die tot dan toe nog slechts bestaan uit een (grondwettelijk) nationaliteitsvereiste, aangevuld met een incompatibiliteitenregeling, een opleidings- en een leeftijdsvereiste. Reeds in het ontwerp van de Commissie-Farjon uit 1808 worden deze eisen gesteld voor de leden van het Hoog Nationaal Geregtshof, de Departementale Geregtshoven, de Hoge Vierscharen en de Civiele Regtbanken. ${ }^{80}$ Omdat de grondwettelijke onverenigbaarheden in 1815 alweer zijn afschaft, verbaast het niet dat tegen een (wettelijke) incompatibiliteitenregeling in de ontwerpen voor een Wet op de Rechterlijke Organisatie in 1820 en 1827, het bezwaar van de ongrondwettigheid van de voorgenomen regel rijst. Art. 92 GW 1815 verbiedt immers niet de cumulatie van het lidmaatschap van de Staten-Generaal met dat van de rechterlijke macht. De regering is echter van mening dat de onderhavige regeling geheel in overeenstemming met de Grondwet is, en zelfs de "voeu national" uitdrukt:

"Le législateur se trouve donc dans la nécessité, que lui impose son devoir et son serment, d'avoir soin que toutes les dispositions de la Loi fondamentale soient religieusement observées. Or, il est physiquement impossible, que le même individu siège simultanément dans l'Assemblée des Etats-Généraux et dans la Haute Cour. En admettant que ses fonctions puissent être cumulées, on déclarerait virtuellement que l'impossible est possible: l'individu pourrait, à la véritê, porter le titre de membre des Etats-Généraux et de la Haute Cour, mais ou, sa place dans la Chambre, ou son fauteuil dans la Cour resterait non occupé; et par conséquent il négligerait soit les intérets de la nation, soit ceux des justiciables, et la Chambre serait par là réduite à un nombre inférieur au voeu exprimé par la nation. Une province perdrait le nombre de ses représentants, ou bien la marche des affaires. portées devant la Haute Cour, pourrait être paralisée, et ce corps se trouver hors 
d'état d'administrer la justice et d'exercer les fonctions que la Loi fondamentale lui a attribuées. ${ }^{" 81}$

Men kan zich echter afvragen of het niet aan de grondwetgever is, in plaats van aan de wetgever, om de "voeu national" in dezen te bepalen. Dat is blijkbaar ook de mening van de vele kamerleden in 1820 die "twijfelachtig" blijven omtrent de grondwettigheid van het verbod om rechterlijke en wetgevende betrekkingen te verenigen. ${ }^{82}$ In het gewijzigd voorstel van wet komt de regering deels aan de bezwaren van de tegenstanders van het artikel tegemoet; zij laat de incompatibiliteit overeind, maar creëert voor de betrokkene een keuzemogelijkheid tussen het rechtersambt en het lidmaatschap van het college waarin hij gekozen is. ${ }^{83}$ Lang zal de kwestie over de (vermeende) inconstitutionaliteit van het lidmaatschap van de Staten-Generaal met dat van de rechterlijke macht - althans met dat van de Hoge Raad - trouwens niet duren, want in 1848 krijgt de onverenigbaarheid met het lidmaatschap van de Hoge Raad - opnieuw - een grondwettelijke grondslag. ${ }^{\text {st }}$

\subsubsection{Motivering van de benoembaarheidsvereisten}

Net als voor de aanbevelingslijsten, ontbreekt voor de voorwaarden voor benoembaarheid grotendeels een motivering. Wat de onverenigbaarheid van het lidmaatschap van de Hoge Raad met de Staten-Generaal ${ }^{85}$ betreft, meent de regering in 1827 dat deze bepaling "op zeer goede gronden" ook op alle andere leden van de rechterlijke macht van toepassing kan zijn. Het verbod wordt echter tot de Hoge Raad beperkt, omdat anders teveel geschikte personen worden uitgesloten van het lidmaatschap van de Staten-Generaal. Een ander argument om juist de raadsheren in de Hoge Raad niet tot de Tweede Kamer

81. MvA, Bijl. Hand. Il 1819-1820, ar. XXVI-3

82. Bijl. Hand. II 1819-1820, nr. XXVI-6

83. Ontwerp-art. 3, tweede alinea, Wet RO: "Indien zij tot leden van de Siaten-Generaal, of van de Provinciale Siaten mogien geroepen worden, of wel, indien de leden van de Staten-Generaal, of Provinciale Staten, tol het ambt van raadsheer in den Hoogen Raad inogten worden gekozen, zullen de benoemden tusschen hel voorgeschreven lidmaatschap en het regterambt moeten kiezen, en alzoo van een of ander afstand doen. "Bijl. Hand. Il 1819-1820, nr. XXVI-5

84. Art. 91 GW 1848/1884, voorzover relevant, luidt: "De leden der Staten-Generaal kunnen niet te gelijk zijn leden of procureur-generaal van den Hoogen Raad, noch leden van de Rekenkamer, noch commissaris des Konings in de provincien, noch geestelijken, noch bedienaren van de godsdienst."

85. Ontwerp-art. 12 Wet RO: "De leden van den Hoogen Raad zullen niet tevens mogen zijn leden van de Tweede Kamer der Siaten-Generaal.

De leden van de provinciale geregtshoven zullen niet tevens mogen zijn leden van de provinciale staten." Bijl. Hand. II 1826-1827, nr. XIII-2 
toe te laten, ligt in de taak van de Hoge Raad bij ambtsmisdrijven. Het is volgens de regering "ten hoogste onvoegzaam" dat een Tweede Kamerlid, dat (mede) toestemming geeft tot vervolging, tevens over die misdrijven kan oordelen. "En hoezeer in zoodanig geval de regter zich in een der beide collegien zoude kunnen wraken, zoo is het echter in eene materie van dien teederen aard onvoegzaam voorgekomen, dat die beide hoedanigheden in één en dezelfde persoon zouden kunnen worden vereenigd. ${ }^{\$ 86}$ Een ander bezwaar tegen de cumulatie van het lidmaatschap van de Hoge Raad en van de Tweede Kamer, ligt in de nominatiebevoegdheid van de Tweede Kamer voor de Hoge Raad. De regering acht het "wederom onraadzaam om die beide hoedanigheden te vereenigen. ${ }^{\text {" } 77}$ Op voorstel van de Tweede Kamer wordt de onverenigbaarheid voor de leden van de Hoge Raad "uithoofde van de toepasselijkheid derzelfde beginselen" in de Wet RO 1835 uitgestrekt tot de leden van de Eerste Kamer. $^{88}$

De Wet RO 1827 verbiedt behalve bepaalde nevenfuncties ${ }^{89}$, ook het bloedverwantschap en zwagerschap tussen rechters, ambtenaren van het openbaar ministerie en griffiers in dezelfde rechtbank of in hetzelfde hof tot in de vierde graad. ${ }^{90}$ In het ontwerp van de Commissie-Farjon is in art. 19 in een soortgelijke regeling voorzien. Reeds in het voorstel uit 1820 maakt de regering onderscheid tussen de verwantschap die was ontstaan vór en die welke was

86. MvA, Bijl. Hand. II 1826-1827, nr. XIII-3b

87. MvA, Bijl. Hand. II 1826-1827, nr. XIII-3b

88. Art. 9 Wet RO 1835: "De leden van den Hoogen Raad, zullen niet tevens mogen zijn leden van de Staten-Generaal

De leden van de provinciale hoven en der criminele regtbank zullen niet tevens mogen zijn leden van de provinciale staten."

89. Art. 8 Wet RO 1835: "De leden van de regterlijke magt (met uitzondering van de regters-plaatsvervangers) kunnen niet tevens zijn advocaat, procureur, notaris of solliciteur, of eenig ambt bekleeden aan hetwelk eene vaste wedde is verbonden.

Zij zullen echter tevens mogen zijn, leden van de stedelijke of gemeente-raden, leden en secretarissen van hoogheemraadschappen, dijk- en polderbesturen, curatoren van hooge en andere scholen, leden van de cominissien van openbaar onderwijs of van alle inrigtingen, welke niet als eigenlijk bezoldigde ambten kunnen worden beschouwd.

Ingeval van wilfel of eenige openbare betrekking van laatstgenoemde aard, met hel lidmaatschap der regterlijke magt hestaanbaar zij, zal zulks door den Koning worden beslist."

90. Art. 10 Wet RO 1835: "Bloedvenwanten of aanverwanten tot den derden graad ingesloten, kumnen niet te zamen zijn raadsheren, regters, ambtenaren van het openbaar ministerie en griffiers in den Hoogen Raad, of in hetzelfde hof, of in dezeljde regtbank. Indien de zwagerschap eerst mogt zijn ontstaan na de benoeming, zal degeen die dezelfde heeft aangegaan, zijn ambt niet kunnen blijven behouden, zonder vergunning van den Koning.

Deze wetsbepaling is niet toepasselijk op de substituut-griffiers. " 
ontstaan na de benoeming. ${ }^{91}$ Afhankelijk van het aantal leden van een rechtscollege, en ook om andere redenen, kan de Koning evenwel dispensatie van het verbod van bloedverwantschap en zwagerschap verlenen. Later is deze dispensatiebevoegdheid van de Koning overigens veelvuldig door de Tweede Kamer bekritiseerd. Het zou veelal om een "bloot gunstbetoon" gaan, "dat aan den een gegeven, aan den ander onthouden kan worden. Zij kan haren grond niet anders vinden dan in het meerder of minder vertrouwen op het karakter van den betrokken persoon, dat in den regel niet aan de Regering bekend kan zijn. " 92

De derde voorwaarde voor benoembaarheid in de Wet RO 1827 is het opleidingsvereiste, dat voor alle rechterlijke ambtenaren, behalve voor de kantonrechters gesteld wordt. ${ }^{93}$ In het ontwerp van 1820 onderstreept de regering reeds het belang van een opleidingsvereiste voor de leden van de Hoge Raad. Het behoeft geen betoog aldus de regering:

"dat het hoogst belang der maatschappij daarin bestaat, om de regterlijke posten aan waardige en deskundige personen toe te vertrouwen; waartoe geen beter en geschikter middel aanwezig is, dan om de voorwerpen in mindere regterlijke collegien te zoeken, ten einde de verkiesbare tot den kring van personen te brengen, in wier mogelijke benoeming de maatschappij reeds voorafeen steun en waarborg

91. Onwwerp-art. 2 Wet RO: "In geen reglerlijk collegie zullen de leden, openbare aanklagers en griffiers, of derzelve substituten, elkander onderling mogen bestaan, tot in den vierden graad van bloedverwantschap of zwagerschap.

Indien de verwantschap door huwelijk eerst mogt ontstaan zijn, na de benoeming, zal degeen, welke helzelve heeft aangegaan, zijne ambtsverrigtingen niet mogen blijven uitoefenen, zonder daarloe de vergunning van den Koning te hebben bekomen." Bijl. Hand. II 1819-1820, nr. XXV-2

92. Bijl. Hand. II 1860-1861, nr. XI-3. Art. 10 Wet RO is bij Wet van 3 juni 1992, Stb. nr. 278 komen te vervallen.

93. Art. 51 Wet RO 1827: De regters van de arrondissements-regtbanken, de officieren van justitie, de griffiers en de regters plaatsvervangers moeten, onverminderd de vereischten bij de grondwet voorgeschreven, den graad van meester of licentiaat in de regten bekomen hebben, op eene van 's Rijks hooge scholen, en den vollen ouderdom van 25 jaar bereikt hebben.

Art. 68 Wet RO 1827: Onverminderd de vereischten bij de Grondwet gevorderd, zullen de raadsheeren, procureurs-generaal, advocaten-generaal, en griffiers der provinciale geregtshoven, moeten: 10 Sedert ten minsten vijf jaren zijn meesters of licentiaten in de regten op eene van 's Rijks hooge scholen. 20 Den ouderdom van 30 jaren ten vollen hebben bereikt.

Art. 88 Wet RO 1827: De hoedanigheden vereischt, om Raadsheer, ProcureurGeneraal, Advocaat-Generaal of Griffier bij den Hoogen Raad te zijn, behalve die bij den grondwet gevorderd, zijn: lo Sedert den tijd van ten minste tien jaren den graad van meester of licentiaat in de regten, op eene van's Rijks hooge scholen verkregen te hebben: 20 De volle ouderdom van vijfendertig jaren. 
vindt, dat hare teederste belangen aan goede handen zullen worden toevertrouwd. ${ }^{94}$

Tot 1877 stelt de Wet RO, als gezegd, voor de benoembaarheid tot kantonrechter geen opleidingsvereisten (voor de kantonrechter-plaatsvervangers zou dat tot 1972 duren). ${ }^{95}$ Op voorstel van de Tweede Kamer ${ }^{96}$ verschijnt in de Wet RO van 1827 de bepaling dat de kantonrechters en de assessoren uit "de kundigste, bekwaamste, gegoedste en meest geachte ingezetenen" gekozen worden en dat in handel- of fabriekssteden de assessoren van de kantonrechter voor een gedeelte uit kooplieden of fabrikanten zullen bestaan. ${ }^{97}$ Overigens blijkt nit dat er veel verzet bestond tegen het ontbreken van een opleidingsvereiste voor de kantonrechters. Een belangrijke overweging om voor de kantonrechters geen opleidingseis te stellen, was dat men vreesde dat zich te weinig kandidaten voor een kantonrechtersfunctie zouden aanmelden. Na 1838 zal de kritiek op deze regeling echter toenemen (zie ook hierna). Zo verzet De Pinto zich in 1844 tegen de gedachte dat rechtskennis voor een rechter van ondergeschikt belang is:

"moeijelijk is het te begrijpen, hoe een regter goed zal kunnen regt spreken, die de wet en het regt niet kent; en die kennis, welke men voorzeker niet de minste reden heeft om te vooronderstellen bij den niet-gegradueerden bewoner van het platte land, is juist voor den kantonregter misschien veel meer onontbeerlijk dan voor ieder ander regter, omdat hij het voorregt mist om, zoo noodig, de voorlichting te kunnen inroepen van meer kundige regtsgeleerde ambigenooten. Aan de magtspreuk, dat een gezond verstand en een helder oordeel voldoende zijn, om in zaken van minder aangelegenheid regt te spreken, gelooft in onze dagen wel niemand meer". 98

94. Bijl. Hand. II, 1819-1820, XXVI, ar. 3

95. Wet van 9 april $1877 \mathrm{Sib} . \mathrm{nr} .73$

96. "On observe, qu'il conviend rait d'établir dians cet articlê, que le licencié, ou le docteur en droit, alura toujours la préférence pour oblenir ia place "lors qu'il sera en concurrence avec un candidat, qui n'aura pas cette qualité; et qu'après dix ams, il faudra êre licencié, ou docteur en ároil, pour obtenir la place du juge de canton; l'importance de ses attributions exige cette disposition. "Eerste Afdeling, Bijl. Hand. II 1826-1827, XII$3 \mathrm{a}$

97. Art. 35: De kanton-regters en assessoren moeten, onverminderd de vereischen bij de grondwet voorgeschreven, den vollen ouderdom van 25 jaren bereikt hebben.

Zij worden uit de kundigste, bekwaamste, gegoedste en meest geachte ingezerenen, bij voorkeur uit meesters of licentiaten in de reglen gekozen.

In handei of fabrijksteden zullen de assessoren van den kanion-regter voor een gedeelle uit kooplieden of fabrijkanten bestaan.

N.B. Deze vereisten werden niet gesteld in het ontwerp-Wet RO van 25 april 1820

98. A. de Pinto, o.c. 1844, p. $88-90$ 


\subsection{De rechterlijke organisatie in de periode $1838-1871$}

$\mathrm{Na}$ de inwerkingtreding van de Wet RO in 1838 zal de discussie over het benoemingenstelsel - als we de berichten mogen geloven - beheerst worden door een litanie van verwijten, waarin de rechterlijke macht, de regering en de Tweede Kamer elkaar over en weer van willekeur, incompetentie, machtsmisbruik en nepotisme beschuldigen. Een belangrijke oorzaak voor de onvrede met de benoemingen is, behalve in het benoemingsstelsel (zie hierna), gelegen in de rekrutering van rechterlijke ambtenaren. Daarbij moet worden bedacht dat na 1838 niet iedereen staat te dringen om een positie bij de rechterlijke macht. Zeker voor de afgelegen gebieden blijkt het moeilijk om kandidaten te vinden. Bovendien wordt al vanaf de invoering van de Wet RO geklaagd over de lage bezoldiging van het rechtersambt. ${ }^{99}$ Met name in de jaren zestig en zeventig van de vorige eeuw, verschijnen over de rechtspositie bij herhaling boze brieven in de juridische pers. Een anonymus in 1862:

"Een zeer redelijke en billijke wensch is deze: dat voortaan de Wet waarheid en geene onwaarheid spreke, dat zij niet langer bezoldiging noeme wat volstrekt geene bezoldiging, maar slechts eene tegemoetkoming is, - en dat, naar waarheid, onder de vereischten voor het lidmaatschap van de Regterlijke Magt ook dit genoemd worde "bezit van genoegzaam eigene geldelijke middelen. " Een Regtersbenoeming is nu toch werkelijk een van Regeringswege verstrekt certificaat, dat de benoemde tot de Nederlandsche geld-aristocratie behoort, - eene aristocratie, die eenmaal. "de leelijkste van alle aristocratiën genoemd is. "n00

Met grote regelmaat wordt in de vorige eeuw gewaarschuwd tegen de kwalijke gevolgen die een te lage bezoldiging op de rekrutering van rechters kan hebben; "Zoolang het Nederlandsche volk het onnoodig acht aan zijne regterlijke ambtenaren goede bezoldigingen te geven, heeft het geen regt zich t' beklagen over hunne mindere bruikbaarheid. Men krijgt nu eenmaal geene goede waar om niet. ${ }^{101}$ En de Rotterdamse advocaat W. Siewertsz. van Reesema in 1853:

"Het valt niet te ontkennen, dat die bezoldigingen niet voldoende zijn, eensdeels, om aan personen, die daartoe geschikt zijn, lust en opwekking te geven tot het zoeken dier betrekkingen, en dat zij aan den anderen kant niet overeenkomen met

99. Zie bijvoorbeeld $W 137$

100. Regtsgeleerd Bijblad behoorende tot de nieuwe bijulragen voor regtsgeleerdheid en wetgeving, 1862 , p. 784

101. De S. L., Verdediging van het vonnis der Goesche regthank, en van de voordragten van de regiscollegien in Nederland, tegen den aanval van den heer J.E.G. le L,W 3204 
de waardigheid dezer Magistratuur. Het onderwerp is van te teederen aard, om daarover uit te weiden,; maar zoo veel is zeker, men onderwerpe de aanstaande regters aan staats-examina, zoo veel men maar wil, - zonder verhooging der bezoldigingen loopt men gevaar, in de plaats van goede - geene regters in genoegzaam aantal te vinden. De half bekwamen, die nu geplaatst worden, omdat zij s. r., Mrs. in de regten zijn, zullen op uwe strenge staats-examina - druipen, en de bekwamen zullen - wegblijven, en de carrière van Advocaat verkiezen. ${ }^{\text {mog }}$

De gevolgen van de slechte bezoldiging moeten, als we de berichten mogen geloven, soms schrijnend zijn geweest. Een - opnieuw anonieme - schrijver meent dat er weliswaar ook bekwame rechterlijke ambtenaren zijn, "Im/aar, dat er Edelachtbare, EdelGrootachtbare, ja zelfs EdelHoogachtbare heeren gevonden worden, die daartoe de noodige kennis missen, kan alleen ontkend worden door hen, qui oculos habent et non vident."

"Namen moeten niet genoemd worden, nam nomina sunt odiosa, maar zij zijn met den vinger aan te wijzen, de regters en raadsheeren, ja zelfs hier en daar de voorzitters, die geen flaauw begrip van regt hebben, noch stijl, noch taal kennen, $j a$, wat meer is, nu en dan door hunne handelingen of door hunne snuggere aanmerkingen den schijn moeten doen geboren worden, dat het hun aan gezond verstand hapert. Niet lang geleden was zekere correctionnele Regtbank, op zekere zitting, uitsluitenduitde jongste regters en regters-plaatsvervangers zamengesteld, die, toen zij zich op hunnen zetel hadden nêergevleid, bij den aanvang der debatten elkander als de augures aankeken en met hunne eigen onbedrevenheid schenen verlegen te zijn, zoodanig dat daardoor de hilariteit onder de balie en zelfs onder het publiek werd opgewekt. Het is meer dan tijd, dat men op middelen bedacht zij om aan dien treurigen toestand een einde te maken, en meer en meer begint zich de wensch te openbaren dat, behalve de voordragten, ook andere redenen mogen verdwijnen, die maar al te dikwijls goede benoemingen in de weg. staan. ${ }^{m 103}$

Bij de klachten over de bezoldiging in de vorige eeuw gaat het overigens om een relatief probleem, dat veroorzaakt wordt doordat een rechter maatschappelijk tot een zekere 'stand' verplicht is. Vergelijkt men de salarissen van rechterlijke ambtenaren in de jaren veertig van de vorige eeuw met salarissen die elders bij de Hoge Colleges van Staat worden verdiend, dan steken de bezoldigingen voor rechters inderdaad wat bleekjes af. ${ }^{104}$ Zet men de rech-

102. W. Siewertsz. van Reesema, in: Nieuwe Bijdragen voor regtsgeleerdheid en wetgeving. i853, p. 166

103. W 3210

104. In 1841 is de bezoldiging van de president van de Hoge Raad per jaar $8000,-$, van een raadsheer in de Hoge Raad: $4500,-$, van een president Hof: gemiddeld $3000,-$, van een raadsheer Hof: gemiddeld $2500,-$, van een president rechtbank: gemiddeld $2000,-$, en 
terssalarissen echter af tegen de bedragen die op de justitiebegroting worden uitgetrokken voor een cipier, een bakker, een knecht of de 'linnenmeid' van de huizen van bewaring, dan verdient de karigst betaalde rechter (met uitzondering van een kantonrechter) toch nog altijd het achtvoudige. ${ }^{105}$ De betrekkelijkheid van de lage rechterlijke bezoldiging wordt overigens ook in de vorige eeuw al onderkend, vooral wanneer het inkomen van de rechters en raadsheren wordt afgezet tegen de lage output van de gerechten. De 34 rechtbanken houden gemiddeld 1.5 zitting per week ${ }^{106}$, en wijzen in de periode $1850-1860$, met een bezetting van een president en negen leden, gemiddeld 64 vonnissen per jaar; de 11 hoven wijzen gemiddeld slechts 16 arresten per jaar, en de Hoge Raad 30. ${ }^{107}$ Niet voor niets spreekt de Amsterdamse advocaat J. Pinner in 1851 voor rechters dan ook van een "dolce far niente", en verdedigt hij een kleiner aantal gerechten met een hogere bezoldiging voor de leden. ${ }^{108}$

\subsubsection{Aanscherping van de benoembaarheidsvereisten}

Hoewel de hoogte van de rechterssalarissen in de vorige eeuw tot een rekruteringsprobleem leidt, en vooral wervingskracht uitoefent op de tweede garnituur onder juristen, is het geboden salaris nauwelijks relevant voor het vraagstuk van de toegang tot het rechtersambt. De groep personen waaruit gekozen kan worden blijft immers beperkt, ook al had men de salarissen verdubbeld. Voor de toegang tot het rechtersambt is immers een afgeronde juridische opleiding vereist, en die eis sluit het overgrote deel van de bevolking uit van een functie bij de rechterlijke macht. De universiteit is immers - tot na de Tweede Wereldoorlog - voor de cipier, de bakker en de knecht, laat staan voor de linnenmeid, nog een sociaal en economisch onneembare vesting. Per definitie is men in de vorige eeuw bij de recrutering van rechterlijke ambtenaren aangewezen op een betrekkelijk kleine kring van kapitaalkrachtigen. Dat laatste wordt overigens lang niet door iedereen als een bezwaar gezien. Integendeel; de wetgever bepaalt in 1827 expliciet dat de kantonrechters, van wie om strategische redenen

van een rechter: gemiddeld $1500,-$. De bezoldiging van een kantonrechter varieert tussen de 600 ,- en $1200,-$, maar dat is exclusief de emolumenten die voor deze functie golden. Een minister verdient in 1841 12.000,-, de vice-president van de Raad van State: 12.000. - de leden van de Algemene Rekenkamer 4000, Eerste Kamerleden ontvangen 3000,- en Tweede Kamerleden 2.500,- Gegevens: Wetien van 26 mei 1841 Stb. nr. 16, 17 en 18. De plaatsvervangers verrichtten gratis arbeid, maar dat werd gerechtvaardigd doordat het plaatsvervangerschap werd gezien als cen "nuttige leerschool $^{n}$ voor jeugdige rechtsgeleerden. A. de Pinto, o.c. p. 121

105. Een bakker verdient in $1841280,-$, een knecht 250 ,- en de linnenmeid: $230,-$. Gegevens: Staatsbegroting 1844-1845, Bijl. Hand. II 1842-1843, nr. X, hoofdstuk IV

106. J. Pinner, Bijdrage lot de reorganisatie der regterlijke magl, 1851, p. 38

107. Zie W. Wintgens, Redevoeringen over regterlijke organisatie, 1861, p. 16 e.v.

108. Pinner, o.c. p. 42 
geen opleiding geëist kan worden, uit de 'kundigste, bekwaamste, gegoedste en meest geachte ingezetenen' voortkomen. ${ }^{109}$ In die visie geldt eigen kapitaal als een waarborg voor onafhankelijkheid, net zoals dat bij de schepenen in de Republiek het geval was, die uit de "voornaamste familien" voortkomen en zoals Van Hogendorp stelt, "door hunne denkwijze, door hunne opvoeding en bezittingen, boven alle omkooping verheven" zijn. ${ }^{110}$

Uitgaande van dit beperkte recruteringsperspectief, worden na de invoering van de Wet RO in 1838 voorstellen gedaan om het aanzien en de kwaliteit van de rechterlijke macht op peil te brengen en te houden, door aanvullende eisen te stellen voor nevenfuncties, en door het professionaliseren van de juridische opleiding. Wat de nevenfuncties betreft, staat in de literatuur, en bij de herzieningen van de Wet RO tussen 1851 en 1871, in het bijzonder een viertal beroepen ter discussie: de advocatuur, de handel, het lidmaatschap van waterschaps-, dijk- en polderbesturen, en (voor de leden van de Hoge Raad) het lidmaatschap van de Staten-Generaal. Het bezwaar tegen de cumulatie van de advocatuur met het rechter-plaatsvervangerschap wordt al door De Pinto in 1844 genoemd. Hij meent dat er iets "zonderlings, ja iets aanstootelijks in gelegen is, denzelfden persoon, die heden als advokaat voor eene regtbank pleit, of als procureur postuleert, morgen in diezelfde regtbank als regter te zien zitting nemen, om vonnis te vellen met hen, die op eenen volgenden dag geroepen zullen zijn om over zijne zaken te oordelen. "11 Toch erkent ook De Pinto dat men de onbezoldigde rechter-plaatsvervangers moeilijk een rechtspraktijk kan verbieden. Dat ligt anders bij de uitoefening van een commercieel bedrijf door rechterlijke ambtenaren. Uit het oogpunt van de "achtbaarheid der justitie", acht de regering het in 1853 wenselijk dat een einde komt aan de situatie dat een rechter een bedrijf uitoefent, of zelfs in faillissement verkeert. De herzieningsontwerpen tussen 1853-1871 verbieden daarom de cumulatie van de rechterlijke functie met een dergelijk beroep, en deze voorstellen kunnen steeds rekenen op ruime bijval van de zijde van de Tweede Kamer. Vooral na 1857 wordt het bestuurslidmaatschap van een waterschap, waaraan dikwịls aanzienlijke bezoldigingen zijn verbonden, als een onwenselijke nevenbetrekking voor een rechter beschouwd. Dat geldt ook voor het lidmaatschap van een gemeenteraad. De Tweede Kamer acht het onjuist dat een rechter oordeelt over de verbindende kracht van reglementen waaraan hijzelf - zij het in een andere hoedanigheid - heeft meegewerkt. ${ }^{112}$ De regering ziet echter geen reden de vele leden van de rechterlijke macht "die weinig werk en tijd te over hithon"

109. Ar. 33 Wet RO 1841

110. G.K. van Hogendorp. Bijdrage tot de huishouding van staat in het Koninkrijk di'r Nederlanden, deel V. 1854, p. 50

111. A. de Pinto, o.c. p. 56

112. VV, Bijl. Hand. II 1856-1857, nr. LXXIV-6 
te verbieden hun tijd nuttig te besteden aan ondernemingen van nijverheid of in de betrekkingen bij de gemeente- of polderbesturen. Voor het lidmaatschap van een gemeenteraad volgt de regering eenzelfde redenering. Men zou, vooral in kleine plaatsen, deze raden "van zeer geschikte leden berooven". ${ }^{113}$

Over de verenigbaarheid van het lidmaatschap van de rechterlijke macht en de Hoge Raad met dat van de Staten-Generaal zijn de meningen verdeeld. De argumenten lijken opnieuw door praktische en niet door principiële overwegingen te worden ingegeven. Zo twijfelen de voorstanders van een dergelijke onverenigbaarheid in 1857 aan de mogelijkheid van een gelijktijdige, behoorlijke waarneming van beide betrekkingen. ${ }^{134}$ Dit argument zien we terug in 1871, als sommige leden opmerken dat de "gestadige absentien" schadelijk werken op de rechtsbedeling. Anderen erkennen dit 'ongerief' maar menen dat juist de leden van de rechterlijke macht nuttig werkzaam kunnen zijn bij de wetgeving; bovendien acht men het raadzaam de kiezers niet meer dan nodig is te beperken in hun keuze van volksvertegenwoordigers. ${ }^{115}$

\subsubsection{De juridische opleiding}

Tegenover de problemen met de rekrutering van rechters staat het probleem van de juridische deskundigheid van de rechters. In het eerste ontwerp van 1851 wordt daarom, voor het eerst (en, naar later zou blijken, voor het laatst) een radicale verandering van het bestaande stelsel voorgesteld. Volgens het ontwerp-Nedermeijer van Rosenthal leggen kandidaten voor rechterlijke betrekkingen een staatsexamen af. Ook voor de kantonrechters voorziet dit ontwerp in een opleidingsvereiste. Het ontwerp-Nedermeijer introduceert bovendien een nieuwe opleidingsfunctie, die van de 'referendaris'. Bij alle rechtscolleges kunnen volgens het ontwerp twee of meer onbezoldigde referendarissen worden geplaatst, die niet bevoegd zijn hun stem in de raadkamer uit te brengen, maar die wel de zittingen en beraadslagingen kunnen bijwonen, en aan wie bepaalde werkzaamheden kunnen worden opgedragen. ${ }^{116}$

113. MvA, Bijl. Hand. II 1856-1857, nr. LXXIV-9

114. VV, Bijl. Hand. II 1871-1872, ar. 90-6

115. VV, Bijl. Hand. II 1871-1872, nr. 90-6

116. Ontwerp-art. 103 Wet RO. "Bij alle regterlijke collegien, de kantongeregten daaronder begrepen, kunnen twee of meer onbezoldigde referendarissen worden geplaatst, die, zonder tot het uitbrengen eener stem bevoegd te zijn, de zittingen en beraadslagingen bijworten, en aan wie eenige bepaalde werkzaamheden kunnen worden opgedragen." Ontwerp-art. 104 Wet RO. "Deze referendarissen worden door den Minister van Justitie gekozen uit hen, die aan eene van 's Rijks hoogescholen den graad van meester in de regten hebben verkregen.

Alvorens die belrekking te aanvaarden, leggen zij in handen van den kantonregter of van de voorzitter van het collegie waarbij zij geplaatst zijn, den eed van geheimhou- 
"Het doel dier instelling, die, ofschoon gewijzigd, ook in andere landen bestaat, is de vorming van bekwame regterlijke ambtenaren en de verschaffing van eenen nuttigen werkkring aanjongelieden die de hoogescholen hebben verlaten en tegenwoordig dikwerf niet weten hoe zij hunnen beschikbaren tijd en verkregene kennis nuttig zullen besteden. Deze instelling hangt dus ten naauwste te zamen met de inrigting van het hooger onderwijs. Zij opent eene nuttige oefenschool voor hen, die, na den doctoralen graad verkregen te hebben, zich tot het afleggen van een staats-examen moeten voorbereiden, waardoor hun alleen de weg tot het dingen naar openbare regterlijke betrekkingen kan worden geopend. ${ }^{\text {117 }}$

De Tweede Kamer vreest echter dat het stelsel van referendarissen met name aantrekkingskracht zal uitoefenen op de tweede garnituur onder juristen. ${ }^{118}$ Binnen de rechterlijke macht bestaat evenmin consensus over de referendarissen. Terwijl sommigen liever zien dat kandidaten pas benoemd worden na enige jaren praktijkervaring in de advocatuur, "met opgave van het aantal zaken, en of de uitkomst daarvan gunstig of ongunstig was", juichen anderen het voorstel echter toe. ${ }^{119}$ Ook het openbaar ministerie is verdeeld over het stelsel van referendarissen. ${ }^{120}$ Het voorgestelde staatsexamen vindt daarentegen, zowel in de Tweede Kamer als bij de leden van de rechtscolleges en de ambtenaren van het openbaar ministerie, algemeen bijval.

Het stelsel van referendarissen, zoals dat door de regering in 1851 is voorgesteld, ontbreekt in de daaropvolgende zeven herzieningsontwerpen. Dat geldt ook voor het staatsexamen, hetgeen merkwaardig is omdat dit voorstel eerder zo enthousiast ontvangen werd. ${ }^{121} \mathrm{Na} 1851$ blijft de Tweede Kamer er dan

ding, ten aamzien der door hen te behandelen zaken en bij te wonen beraadslagingen, af.

Zij, die gedurende twee jaren in deze betrekking zijn werkzaam geweest, worden tol het staats-examen toegelaten, na welks gunstigen afloop zij tot regterlijke ambten benoembaar zijn." Bijl. Hand. II 1850-1851, LIII, nr. 2

1i7. MvT, Bijl. Hand. II 1850-1851, LIII, nr. 3, p. 314

118. Verslag, Bijl. Hand. II 1851-1852, XXX, nr. 2, p. 435: "Zij (de commissie, MdW) konde zich niet overtuigen, dat het door de Regering voorgestelde referendariaat eene goede kweekschool voor regterlijke amblenaren zou wezen; zij vreesde integendeel, dal eene dergelijke instelling aan hen, die de hoogeschool hebben verlaten, en die, bij gemis aan bekwaamheden of ijver, op geene andere wijze eene cervolle maatschappelijke betrekking kunnen verwerven, de gelegenheid zal aanbieden tot een surnumerairschap in het regterlijk ambt, waaruit zij later, in weêrwil van mindere geschiktheid, aanspraak op een definitive aanstelling zullen ontleenen."

119. Bijl. Hand. II 1851-1852, XXX, p. 450

120. Bijl. Hand. II 1851-1852, XXX, nr. 6, p. 473

121. Een toelichting op het besluit om, behalve het stelsel van referendarissen, ook het staatsexamen uit het ontwerp te schrappen laat de regering in het opvolgende ontwerp van 1853 achterwege. 
ook bij herhaling bij de regering op aandringen een staatsexamen voor kandidaten voor rechterlijke betrekkingen in te voeren. De scepsis over het niveau van de afgestudeerde juristen, zoals we die hiervoor in de pers tegenkwamen, hoort men nu ook in de Tweede Kamer. ${ }^{122}$ Zo wordt "de ernstige klagt geuit, dat, ten gevolge van de inrigting der akademische lessen en examina, de meestergraad tot nog toe zeer weinig grond voor vertrouwen op kunde en geschiktheid oplevert." De regering erkent in 1856 volmondig de problemen rondom de juridische opleiding, maar, anders dan in 1851, deelt zij niet langer de suggestie van een staatsexamen voor rechterlijke ambtenaren.

"Dat de promotie aan de hoogeschool voldoenden waarborg aanbiedt van bekwaamheid zal zeker de Regering niet beweren. Maar maatregelen te nemen om haar daartoe weder te maken, of door een anderen waarborg te vervangen, dit behoort zeker niet in de wet. Verder wordt nevens die bekwaamheid ook nog geschiktheid vereischt voor de betrekking die zal worden vervuld. En daarvoor is geen andere waarborg te vinden, dan in de naauwgezette pligtsbetrachting van allen die tot de benoeming medewerken. ${ }^{123}$

\subsection{De aanbevelingslijsten}

De problemen met de rechterlijke macht in de vorige eeuw, kunnen niet alleen aan de kwaliteit van het aanbod van de kandidaten worden geweten, ook aan de zorgvuldigheid van de benoemingen schort het in ruime mate. In de eerste jaren na 1838 komen de klachten over het gevoerde benoemingsbeleid met name van de kant van de rechterlijke macht zelf. Vooral De Tijdgenoot klaagt erover dat kunde en geschiktheid bij rechtersbenoemingen zo vaak het onderspit moeten delven. In het bijzonder de minister van justitie Van Hall wordt "familiezucht" bij benoemingen verweten. ${ }^{124}$ Overigens blijkt daaruit, dat de invloed van de minister van justitie op benoemingen in de rechterlijke macht, ook vóor de invoering van de ministeriële verantwoordelijkheid in 1848, groot is. Maar al snel keert het tij zich tegen de rechterlijke macht, in het bijzonder tegen de aanbevelingen van de gerechten aan de regering, en dat zal tot 1871 zo hlijven. "In het algemeen ligt daarin (in de aunbevelingen, $M d W$ ) de verkeerde strekking, dat het aanhevelend collegie zich zelf helpt aanvullon, waurdoor de aanbevelingen meestal een te localen geest ademen en niet zelden het uitvloeisel zijn van bijzondere voorliefde, ook van transactie", zo blijkt uit het voorlopig verslag van de Tweede Kamer uit het ontwerp-Wet RO 1855. Bij die gelegenheid keert de 'grote' meerderheid van de Tweede Kamerleden zich dan

122. VV, Bijl. Hand. Il 1855-1856, XXXVIII, nr. 7

123. MvA, Bijl. Hand. II 1856-1857, LXXIV, nr. 9

124. Zis: $D e$ Tijdgenoot 1841, p. 14-15, 1842, p. 59-60; 1842, p. 208 en 1843, p. 601-602 
ook tegen het stelsel van aanbevelingen. ${ }^{125}$ Door het aftreden van de minister, en het intrekken van het wetsvoorstel, blijft de kritiek echter onbeantwoord, maar niet onopgemerkt. In het ontwerp van 1857 vervallen namelijk, tot groot genoegen van de Tweede Kamer ${ }^{126}$, de aanbevelingslijsten voor alle rechtscolleges, met uitzondering van die voor de Hoge Raad. De regering heeft - zo zegt zij over de aanbevelingen - inmiddels andere middelen om zich te doen voorlichten, "die minstens even goed te achten zijn als eene voordragt van het betrokken collegie ${ }^{\text {"27 }}$, en doelt daarmee waarschijnlijk op de informatie van de parketten bij de gerechten.

De aanbevelingslijsten voor de Hoge Raad blijven in het ontwerp van 1857 echter gehandhaafd, onder uitbreiding van het aantal aan te bevelen kandidaten tot tien. Anders dan een minister, is de Tweede Kamer voor haar informatie uitsluitend op dergelijke aanbevelingen aangewezen, zo is de motivering van de regering. ${ }^{128}$ Dat is ook de mening van de meerderheid van de Tweede Kamer, die bovendien als bijzonder voordeel van de aanbeveling ziet, dat de Hoge Raad zo speciale personen kan aanwijzen wanneer volgens hem een bepaald deel van de rechtswetenschap aanvulling behoeft. Op verzoek van de Kamer bepaalt het gewijzigd ontwerp dat de aanbevelingslijst van de Hoge Raad in alfabetische orde wordt opgemaakt en dat deze een getal van zes personen bevat. ${ }^{129}$ Ook dit ontwerp wordt echter ingetrokken.

\subsubsection{De interpellatie-Hoynck van Papendrecht}

Het valt te betwijfelen of het voorlopig verslag bij het ontwerp van 1855 , voor de regering de enige reden is geweest, om in 1857 de lijsten van aanbeveling voor de rechtbanken en de hoven te schrappen. In een brochure uit 1876 noemt J. Pols, de interpellatie-Hoynck van Papendrecht de directe aanleiding. ${ }^{130}$ Bij deze interpellatie, gehouden op 20 november 1856, stelt het Tweede Kamerlid Hoynck van Papendrecht een circulaire van de minister van justitie van 20 februari 1856 ter discussie. ${ }^{131}$ Deze circulaire, gericht aan de gerechtshoven, de rechtbanken en de ambtenaren van het openbaar ministerie, bevat het dringende verzoek om de aanbevelingslijsten voortaan geheim te houden. De publikatie in de dagbladen zou in strijd zijn met de 'eerbied' aan de Koning.

125. VV, Bijl. Hand, II i855-1856, nr. XXXVIII-7

126. VV. Biil. Hand. II 1856-1857, nr. LXXIV-6

127. MvT, Bijl. Hand. Il 1856-1857, nr. LXXIV-3

128. MvT, Bijl. Hand. II $1856-1857$, nr. LXXIV-3

129. Ontwerp-art. 10 Wet RO, Bijl. Hand. II 1856-1857, nr. LXXIV-10

130. J. Pols, Over het wetsvoorstel tot verandering in de wije van benoeming wan leden der regterlijke magt, 1876, p. 10

131. Hand. II 1856-1857, p. 141-155 
Zij zou bovendien de vrijheid van de betrokken colleges beperken, en "wekt ontijdig verwachtingen op, vermeerdert naijver en teleurstelling, en maakt zonder noodzaak de taak der Regering, met opzigt tot de benoemingen, ten laatste tot eene der moeijelijkste die op haar rusten", aldus de circulaire. ${ }^{132}$ Anders dan de minister meent Hoynck van Papendrecht echter dat er hoogst wenselijke motieven zijn om de aanbevelingen openbaar te maken. Doordat de aanbevelingen bij openbaarmaking aan de "publieke oordeelvelling" bloot staan, is 'de eer van een rechterlijk college' ermee gemoeid, "te zorgen dat zoodanige aanbeveling zoo worde ingerigt dat er geene aanmerkingen op te maken zijn, en dat dus met opoffering van alle persoonlijke consideratien, alleen zulke personen worden aambevolen, die uit hoofde van hunne geschiktheid en bekwaamheden, met volle regt in aanmerking kunnen komen. ${ }^{133}$ De Kamerleden Dullert, Van Akerlaken en Van Eck vallen Hoynck bij in zijn kritiek op de circulaire. Zelfs Godefroi - zeker geen voorstander van de aanbevelingslijsten (in $1861 \mathrm{zal} \mathrm{hij} \mathrm{als} \mathrm{minister} \mathrm{van} \mathrm{justitie} \mathrm{de} \mathrm{aanbevelingslijsten} \mathrm{zelfs}$ afschaffen) - ziet in het stelsel toch nog het nut dat het de aanbevelingen van de rechterlijke macht onderwerpt aan de controle van de publieke opinie, "die, preventief werkende, welligt van menige min goede aanbeveling kan terughouden. Want dat altijd bij de regterlijke collegien het opmaken van nominatien beheerscht wordt door het besef van den pligt om alleen de geschiktsten aan te bevelen, zou ik niet zoo onvoorwaardelijk durven verzekeren. ${ }^{134}$ De minister volhardt echter in zijn standpunt en onderstreept dat de geheimhouding in het belang is zowel van de regering, het aanbevelende rechtscollege als de kandidaat, "omdat het gewis voor hem veel aangenamer is, ingeval hij niet gekozen

132. "Meer en meer heeft men in lateren tijd kunnen waumemen, dat de lijsten van aanbeveling of voordragten, ter voorziening in besiaande vacatures bij de regterlijke magt, door middel der dagbladen ruchibaarheid erlangen, terwijl deze stukken ò in raadkamer òf in een overleg tusschen de heeren voorzitters van en de procureurs-generaal of officieren van justitie bij de regterlijke colleges opgemaakt, veeleer als van geheimen aard te beschouwen zijn. Neemt men toch in aanmerking, dat deze stukken inderdaad bestemd zijn voor Zijne Majesteit den Koning, om daarop bij de benoeming, welke door Hoogsudenzelve geschiedi, zoodanig achl te geven als Zijne Majesteil zal vermeenen te behooren, dan vermeen ik te mogen zeggen, dat de openhaarmaking dezer stukken is in strijd met derzelver eigenlijke bestemming en met den eerbied, aan hel Hoofi van den Siaat verschuldigd. Zij heperkı daarenboven de vrijheid der betrokkene collegien en autoriteiten, wekt ontijdig verwaching en op, vermeerdent naijver en teteurstelling, en maakt zonder noodzaak de taak der Regering: met opzigt tot de benoemingen, ten laaiste tot eene der moeijelijkste die op haar risten. $l k$ heb derhalve de eer $u$ te verzoeken, om wel te willen toezien, dat de bedoelde aanbevelingen of voordragten voonaan geheim worden gehouden. "Voorgelezen door de minister van justitie Van der Brugghen, Hand. II 1856-1857, p. 143-144

133. Hand. II $1856-1857$, p. $143 \mathrm{Zie}$ in gelijke zin een anonymus in W 1727

134. Hand. II 1856-1857, p. 147-148 Zie ook de Tweede Kamerleden Van Akerlaken, p. 147 en Hoynck van Papendrecht, p. 152 
wordt, dat iedereen daar geen kennis van draagt, daar er vele redenen, onafhankelijk van en volstrekt buiten den aangewezen persoon, kunnen zijn, om een ander te benoemen. ${ }^{135}$

\subsubsection{Verzet tegen de aanbevelingslijsten}

Na 1857 neemt het verzet tegen de aanbevelingslijsten toe. Net als de ontwerpen van 1857 en $1859^{136}$ beoogt ook het zesde ontwerp van 6 mei 1860 de lijsten van aanbeveling van alle rechtscolleges, met uitzondering van die van de Hoge Raad, af te schaffen. ${ }^{137}$ De kritiek op de aanbevelingen is slechts meer van hetzelfde. Enkel de toon wordt scherper. Opmerkelijk is wel, dat het in 1860 juist de regering is die fel uithaalt naar de aanbevelingen. Godefroi, inmiddels minister van justitie, en als mede-benoemende autoriteit dus goed op de hoogte van de bestaande praktijk, fulmineert: "Ik heb dikwijls in de nominatien - behoudens menige gunstige uitzondering - meer gezien eene zucht om te believen, dan wel het streven om de meest geschikten voor te dragen. Ik heb in die nominatien ook meermalen bespeurd het product van een dikwerf beperkten gezigteinder. " De oorzaak van de problemen legt Godefroi in het "karakter" van het aanbevelingenstelsel zelf, "in die collegiale verantwoordelijkheid, die dikwijls op niets nederkomt, in het gemis van eene naar buiten toe werkende individuele verantwoordelijkheid." ${ }^{138}$ Dit probleem wordt volgens Godefroi veelal niet ondervangen door de verantwoordelijkheid van ministers; met name voor "een zwakken Minister, die niet uit eigen oogen ziet zijn nominatien zeker een uitmuntend hulpmiddel, want zij ontheffen hem van de moeite om te zoeken. ${ }^{\text {139 }} \mathrm{Om}$ die reden acht de minister het "oneindig nuttiger, dat de Minister bij het doen van zijne voordragt aan den Koning zelsstandig zij, dat hem geene gelegenheid worde gegeven op aanbevelingen te leunen en daarin een schild te vinden voor zijne eigen verantwoordelijkheid. " ${ }^{140}$ Het kost Godefroi geen enkele moeite om de Tweede Kamer te overtuigen, want bijna unaniem (met 61 tegen 4 stemmen) neemt zij het voorstel aan. ${ }^{141}$

135. Van der Brugghen, Hand. II 1856-1857, p. 144

136. Ontwerp van Wet op de zamenstelling der Regterlijke Magt en het beleid der Justitie van 4 februari 1859, Bijl. Hand. II 1858-1859, nr. LXVIII-2 Het ontwerp van 1859 wordt ingetrokken, nadat het strandt op het onderdeel dat de cassatietaak van de Hoge Raad beoogt af te schaffen. Hand. II 1858-1859. p. 1048

137. Art. 9: "De leden der regterlijke magt worden door Ons benoend." Bijl. Hand. II 1860-1861, nr. XI-5

138. Hand. II $1860-1861$, p. 169

139. Hand. II $1860-1861$, p. 169

140. Men zie ook de opmerkingen van de Tweede Kamerleden De Brauw en Cool, die in de aanbevelingen wel enige waarborg zien, met name tegen de invloed van de officier van justitie bij benoemingen. Hand. II 1860-1861, p. 169

141. Hand. II 1860-1861, p. 169 
Zoals bij alle herzieningsvoorstellen, blijft ook nu in het wetsvoorstel de aanbevelingslijst voor de Hoge Raad behouden. Anders dan in 1857 kan de Tweede Kamer de regering hierin in 1860 niet meer volgen. Volgens het voorlopig verslag zijn de gevoelens van de Kamer over de aanbevelingen van de Hoge Raad inmiddels 'overbekend'. Het kamerlid Van Eck stelt daarom een amendement voor, waarin ook de aanbevelingslijst voor de Hoge Raad vervalt. Zoals de anbeveling de verantwoordelijkheid van de minister ondervangt, zo ondervangt de aanbeveling van de Hoge Raad de verantwoordelijkheid van de Tweede Kamer, redeneert Van Eck. ${ }^{142}$ Een zwakke Tweede Kamer zal net als een zwakke minister op de aanbeveling kunnen leunen, meent hij. Bovendien is het een 'algemeen beginsel' dat geen lichaam zichzelf kiest, en hoewel de aanbeveling volgens Van Eck geen echte verkiezing is, meent hij toch dat het 'een begin van keuze' is. ${ }^{143}$ Godefroi blijft niettemin bij zijn standpunt dat het de Kamer aan voldoende informatie ontbreekt en handhaaft zijn voorstel. ${ }^{144}$ De Tweede Kamer - kennelijk niet overtuigd - neemt het amendement-Van Eck met 36 tegen 29 stemmen aan. ${ }^{145}$ De invoering van deze wet wordt echter herhaaldelijk uitgesteld, ${ }^{146}$ en tenslotte op 23 juni 1870 door de Tweede Kamer verworpen.

\subsubsection{Kritiek buiten de Tweede Kamer}

De meningen over de aanbevelingen zijn in 1860 duidelijk verdeelder dan in 1857. Zo staat de stemming in de Tweede Kamer over de afschaffing van de aanbevelingen van de Hoge Raad ( 36 tegen 29 stemmen) en van de overige rechtscolleges (61 tegen 4 stemmen) in schril contrast met de gevoelens in de Eerste Kamer over dit onderwerp. Daar vrezen 'niet weinige' leden dat het voorgestelde "nog meer dan het bestaande tot kuiperijen" aanleiding zal geven. ${ }^{147}$ Kritische geluiden over de aanbevelingslijsten zijn in de tweede helft van de vorige eeuw met grote regelmaat ook te horen in het Weekblad van het Regt. Zo leest men bijvoorbeeld na de 'Goesche zaak' - een geruchtmakende strafzaak waarbij de rechtbank Goes twee kinderen van negen en vijf jaar wegens diefstal tot zeveneneenhalf jaar gevangenisstraf veronrdeelde - in 1870: "dat het stelsel van rechterlijke aanbevelingen in waarheid nicts anders is dan een stelsel van indirecte cooptatie (-) en, in zijn werking, aan kundige mannen,

142. Hand. II $1860-1861$, p. 170

143. Hand. II 1860-1861, p. 170

144. Hand. II $1860-1861$, p. 170

145. Hand. II 1860-1861, p. 170 De Eerste Kamer nam het ontwerp met 25 tegen 11 stemmeu alan. Zie: Wet van 31 mei 1861, Stb. nr. 49

146. Wetten van 17 december 1861 , Stb. nr. 125, 27 juni 1863 , Stb. nr. 85 en 8 juni 1864 . Sth. nr. 69

147. Verslag der Commissic der Rapporteurs van 22 mei, Bijl. Hand. I 1860-1861 
die niet tot de bevoorrechte familien behooren, en die zich in geene uitgebreide relatien mogen verheugen, den toegang tot de rechterlijke macht lichtelijk kan versperren." Naar aanleiding van 'De Goesche zaak' pleit Goudsmit voor afschaffing van de aanbevelingslijsten, omdat zij, hoewel zij de minister tot "leiddraad" moeten strekken, in wezen "dwaalsterren" zijn. "In het algemeen toch wordt daarbij gelet op hoedanigheden, die met die, voor den rechterlijken ambtenaar vereischt, niets gemeens hebben. Den een strekt tot aanbeveling zijne politieke of godsdienstige richting, den ander een schoone familie-naam, een derde zijn behagelijk uiterlijk of de meerdere of mindere gemakkelijkheid" ${ }^{148}$ Een anonymus valt Goudsmit bij in zijn kritiek:

"Er zijn ons regterlijke colleges bekend, die gewoon zijn goede vrienden en kameraadjes voor te stellen, en de vraag, of hunne candidaten de noodige geschiktheid bezitten, als een punt van ondergeschikt belang schijnen te beschouwen, en er bestaat ergens in Nederland zoodanig collegie, waarin schier uitsluitend personen zetelen, die, wel is waar, niet in den verboden graad van bloed-en aanverwantschap, maar toch zoo naauw aan elkander verbonden zijn, dat het doorgaans in loco met den naam van familieregering wordt bestempeld. Somtijds vindt men onder de leden, die te zamen van het Hof en van de Regtbank deel maken, een primus inter pares, die, wat meer verstand hebbende dan zijne medeleden (in het land der blinden is éénoog koning), dezen als het ware weet te beheerschen en, gewoon zijnde zijn haan koning te zien kraaijen, den zoodanigen tracht te weren, die hem zouden kunnen overtreffen, en den lievelings-candidaat aan zijne moutons de Panurge weet op te dringen. Intriguanten met een innemend voorkomen, of zeker flux de bouche of bevalligheid in de zamenleving hebbende, mais de cervelle...point. Hij, die gehoord en gadegeslagen heeft wat er zoo al omgaat, en soms door de voorstellers zelven in societeiten en koffijhuizen, dan eens dom-naïef, dan eens onvoorzigtig verteld wordt, wanneer er candidaten te kiezen zijn, kan getuigen, dat veeltijds, ja schier in den regel (er is geene regel zonder uitzondering) op alles, behalve op geschiktheid en bekwaamheid, gelet wordt, en het is niet noodig om in den raadkamer te hebben doorgedrongen, om in dit opzigt met hare arcana bekend te zijn. Een meêgaand mensch, een charmante jongen, al is hij ook al niet heel knap, schijnt het ideaal voor een regter te zijn. en het is alsof men zich aan döodzonde zoude schuldig maken, zoo men zich in de pépinière der advocatie een degelijk practicus ging zoeken. ${ }^{\text {149 }}$

\subsubsection{Omslag: invloed van het ministerie van justitie}

Omdat de Wet van 1861 nooit wordt ingevoerd, volgt nog een ontwerp tot herziening van de Wet RO, dat - naar later zal blijken - eveneens vergeefs is. In 1871 wordt opnieuw voorgesteld de aanbevelingslijsten, onder verwijzing naar

149. W 3210 
de argumenten die hiervoor genoemd zijn - af te schaffen. In 1871 doet zich echter - net zoals dat in 1855 gebeurt - een radicale omslag voor, deze maal dus niet ten nadele maar juist ten gunste van de aanbevelingslijsten. Zo is de vrees voor nepotisme bij de rechtbanken en de hoven in 1871 weliswaar niet weggenomen $^{150}$, maar deze wordt - kennelijk - overschaduwd door de nog grotere angst voor de invloed van de uitvoerende macht op de rechterlijke colleges. Men moet daarbij in het achterhoofd houden dat in deze periode de ontwikkeling van de politieke partijen een aanvang neemt, terwijl eerder - in 1848 - de ministeriële verantwoordelijkheid (ook voor benoemingen in de rechterlijke macht) is ingevoerd. J.J. Loke, lid van het Gerechtshof 's-Gravenhage, schrijft later over de afschaffing van de aanbevelingen in 1861:

"Wijhadden destijds een minister, die niet tot de partijmannen behoorde (-). Maar de toestanden zijn veranderd en de ondervinding heeft geleerd, dat bij die verandering eene afschaffing van de aanbevelingen hoogst onraadzaam is te noemen. (-) Het is zeker geen van de gelukkigste gevolgen van de invoering van de Grondwet van 1848, dat zij eene zoo vermeerderde groeikracht heeft gegeven aan den partijgeest, die voor Nederland zoo dikwerf de oorzaak van een te laat opkomend berouw geweest is. ${ }^{n 151}$

Thans is een minister volgens Loke een 'zetbaas' van zijn partij geworden. "Een minister van justitie in den tegenwoordigen tijd kan geen vakman zijn; hij moet mede im Strudel en hij mist de vrijheid, die noodig is, om zijne aansprakelijkheid voor de door hem geprovoceerde benoemingen te kunnen gevoelen. "152 En zo ziet de Tweede Kamer het in 1871 ook. 'Zeer veel leden' achten het niet te laat om terug te komen op de huns inziens "verkeerde beslissing" van 1861 om de aanbevelingslijsten af te schaffen. Zij vrezen dat de leden van de jongere magistratuur in de onmiddellijke afhankelijkheid van het uitvoerend gezag worden geplaatst, en dat degenen die in of in de nabijheid van de residentie wonen veel voor zullen hebben op hen die in de provincie wonen. Het gevaar dreigt dat bij de aldus aangekweekte magistratuur de "geest van zelfstandigheid" ontbreekt. ${ }^{153}$ De regering handhaaft echter haar standpunt ten aanzien van de aanbevelingen. Het probleem zou niet liggen bij de benoemingen maar bij de aanbevelingen, die het aanbod van kandidaten belemmeren: "Bekwame en geschikte jongelieden, maar wien het aan betrekkingen of vrienden ontbreekt, die hen bij de leden van eenig regterlijk collegie kunnen aanbevelen, ondervinden soms de grootste moeite om op eenige voordragt eenige

150. Zie: VV, Bijl. Hand. II 1871-1872, nr. 90-6, p. 2144-2145

151. J.J. Loke, Ook een woard voor het behoud der aanbevelingen bij vacaturen in de regterlijke magt, Rotterdam, 1876, p. 5

152. Loke, o.c. p. 6-7

153. VV, Bijl. Hand. II 1871-1872, nr. 90-6, p. 1250 
gunstige plaats te krijgen", zo stelt de regering. ${ }^{154}$ Hoewel de Tweede Kamer inmiddels terug is gekomen op haar bezwaren ten aanzien van de aanbevelingen in het algemeen, bestaan bij sommigen tegen de aanbeveling van de Hoge Raad nog steeds belangrijke bezwaren. Opnieuw is het Van Eck die een amendement voorstelt om de bepaling over de aanbevelingslijst ${ }^{155}$ van de Hoge Raad te schrappen. ${ }^{156} \mathrm{Hij}$ herhaalt zijn argumenten uit 1860 , en wijst op de "onvoegzame sollicitatien" waartoe de aanbevelingslijsten hebben geleid; "ieder van ons zou toch brieven van solicitanten kunnen toonen en verklaringen kunnen afleggen omtrent persoonlijke sollicitatien. Ik weet dat deze ook bij den Hoogen Raad gedaan worden. ${ }^{157}$ Deze maal heeft hij echter geen succes, want de Tweede Kamer verwerpt het amendement Van Eck met een ruime meerderheid (44 tegen 21).

\subsubsection{Brochures van Pols en Loke}

De zorgen van de Tweede Kamer in de jaren zeventig van de vorige eeuw over de invloed van het ministerie bij benoemingen en bevorderingen, worden gedeeld door de rechterlijke macht. Naar aanleiding van het wetsontwerp van 1876 verschijnen twee invloedrijke brochures van J. Pols en J.J. Loke, waarin een krachtig pleidooi voor het behoud van de aanbevelingslijsten wordt gehouden. ${ }^{158}$ Zowel Pols als Loke zien in de aanbevelingslijsten een belangrijke bron van informatie en een controlemogelijkheid voor het publiek, iets waarop bij de interpellatie-Hoynck van Papendrecht ook al is gewezen:

"Juist in die openbaarmaking, en de dientengevolge daarover geroepen wordende openbare meening, veel meer nog dan in het aanzien van het regterlijk Collegie. dat de candidatenlijst opmaakt, schuilt het gezag der aanbevelingen, en van daar ook dat deze bij uitnemendheid passen in eenen constitutioneelen staat, waar alle

154. MvT, Bijl. Hand. II $1872-1873$, nr. 60-1, p. 3

155. Art. 10 ontwerp-Wet RO is inmiddels gewijzigd en luidt: "Van het onistaan eenet vacature in den Hoogen Raad wordı door dien Raad aan de Tweede Kamer der SiathGeneraal kennis gegeven, die ter vervulling daarvan eene nominatie van vïf personen aan Ons caanbiedi, ten einde daaruit eene keuze te doen.

Bij die kennisgeving biedt de Hooge Raad aan de Tweede Kamer eene lijst let aanbeveling van minstens zes personen aan, in alphabetische orde gerangschikt. "Bij1. Hand. II 1872-1873 nr. 60-12

156. Hand. II $1872-1873$, p. 1244

157. Hand. II $1872-1873$, p. 1246

158. J. Pols, Over het wetsvoorstel tot verandering in de wijze van benoeming van leden der regterlijke magt, $1876 \mathrm{en}$ J.J. Loke, Ook een woord voor hes behoud der aanbevelingen bij vacaturen in de regterlijke magt, 1876 
regeringshandelingen de toets der openbare meening moeten kunnen doorstaan. ${ }^{n 159}$

Zonder aanbevelingslijsten zal de regering zijn aangewezen op het oordeel van met name de hoofden en andere leden van de parketten, en hen acht Pols, rechter in de arrondissementsrechtbank te Rotterdam, minder dan ooit de aangewezen personen daarvoor:

"Inzonderheid waar het Openbaar Ministerie in strafzaken als vervolgende partij tegen een beklaagde optreedt, moet de Regter, op een onzijdig standpunt tusschen beiden geplaatst, meer dan eens weigeren aan het verlangen dier ambtenaars gevolg te geven. Wie nu begrijpt niet dadelijk, hetgeen bijkans aan ieder regterlijk ambtenaar bij ondervinding bekend zal zijn, dat bij de meest mogelijke humaniteit en zucht tot zamenwerking over en weder, er ligt van tijd tot tijd verschil van gevoelen, en bij herhaald voorkomen hiervan eene minder gemakkelijke verhouding tusschen het een of ander lid van het openbaar ministerie, en dat van een regtscollegie of een kantonregter. In elk geval zal reeds het bewustzijn, dat het officie bij het collegie te zijner tijd geroepen zal worden om de Minister te adviezeren omtrent iemands geschiktheid, zelfs den meest onafhankelijken regter in eene voor zijn gevoel valsche verhouding tegenover dat officie brengen ". ${ }^{160}$

Pols verwacht dat bij de afschaffing van de aanbevelingslijsten, de officier van justitie ten behoeve van het college informatie zal inwinnen bij zijn ambtgenoten in andere arrondissementen, hetgeen zal leiden tot "eene verzameling van informatiën", die ook bij andere vacatures gebruikt wordt: "Wee het lid der magistratuur dat nog jong, en niet buiten zijn dagelijkschen werkkring bekend, wee zelfs den overigens goed bekende, die minder gunstig onder die informatiën van het parket mogt voorkomen; en hoe ligt is het toch mogelijk dat eenig lid van het officie, volkomen te goeder trouw, iemands verdiensten verkeerd beoordeelt?"161

In een artikel in Themis ${ }^{162}$ verzet $A$. Heemskerk, de latere minister van justitie, zich sterk tegen het door Pols voorgestane behoud van de aanbevelingen, en sluit hij aan bij de in 1860 genoemde bezwaren. Dat een minister zonder aanbeveling is aangewezen op de adviezen van het openbaar ministerie lijkt Heemskerk overdreven: "In een landje als het onze is het solliciterend regtsgeleerd personeel niet zób talrijk of een actief Minister kan er wel oog op houden. Bovendien belet niets hem, ook b.v. bij regters of hoogleeraren adviezen in te

159. Pols, o.c. p. 14

160. Pois, o.c. p. 18

161. Pols, o.c. p. 18-19

162. A. Heemskerk, Boekbeoordelingen en verslagen Nederlandsche litteratuur. Themis, 1876, p. $454-460$ 
winnen. ${ }^{163}$ Juist dat laatste schiet echter bij de tweede auteur, J.J. Loke, in het verkeerde keelgat:

"Zij, die eenige ondervinding hebben, weten met mij tot welke grove misbruiken juistdat raadplegen van professoren over benoemingen heeft geleid; zij herinneren het zich, dat er tijden geweest zijn, waarop deze of gene hooggeleerde van de éene universiteit op schier iedere benoeming gehoord werd, terwijl zijne collega's aan andere hoogescholen immer te vergeefs op een verzoek om informatiën bleven wachten; zij weten het, hoe aangenaam die Heeren professoren het vonden om bekend te zijn als 'bij justitie invloed te hebben' (-) zij weten het, hoe dikwerf die recommendatiën later gebleken zijn, van niet zoo heel deugdelijken aard te zijn geweest. ${ }^{164}$

Loke, raadsheer in het gerechtshof 's Gravenhage, sluit zich overigens aan bij de brochure van Pols die "door bijna de geheele magistratuur met ingenomenheid" is begroet. ${ }^{165}$ Die magistratuur - zo lijkt Loke te willen zeggen - heeft inmiddels flink haar bekomst gekregen van de politieke inmenging bij benoemingen, en Loke doet het pleidooi van Pols nog eens dunnetjes over: "Hij, die de magistratuur kent, weet dat de Nederlandsche regterlijke ambtenaren 0 ! zoo blij zijn, dat zij geheel buiten dat politieke gehaspel zijn gesteld, en dat eene geprononceerde politieke kleur, in welke rigting ook, voor een sollicitant altijd is geweest eenen reden van achteruitstelling, veeleer dan eene recommandatie om eene plaats op eene lijst van aanbeveling in te nemen. ${ }^{" 166}$

\subsubsection{Laatste poging tot afschaffing van de aanbevelingslijsten}

Hoewel in 1871 in de Tweede Kamer inmiddels een omslag heeft plaatsgevonden, en ook de publieke opinie inmiddels weer op handhaving van de aanbevelingslijsten aandringt, komt de regering in 1876 opnieuw met een wetsontwerp om de lijsten van aanbeveling voor vacatures in kantongerechten en rechtbanken af te schaffen. ${ }^{167}$ Deze maal betreft het geen algehele herziening van de Wet RO, maar een verlate reactie op de grondwetsherziening van 1848 , toen de Provinciale Hoven - die nog herinneren aan de Republiek - werden afgeschaft, en vervangen door de huidige gerechtshoven. Mèt het afschaffen van de oude Hoven in 1848 hadden - uiteraard - ook de aanbevelingslijsten voor die Hoven moeten worden geschrapt, maar het zal tot 1875 duren voordat dit ge-

163. Heemskerk, o.c. p. 459

164. Loke, o.c. p. 9

165. Loke, o.c. p. 3

166. Loke, o.c. p. 11

167. OvW, Bijl. Hand. II 1875-1876, nr. 147-2 
beurt. ${ }^{168}$ Deze merkwaardige situatie had - maar dit terzijde - in elk geval nog het voordeel dat juristen hun scherpzinnigheid konden botvieren op de vraag, of de nieuwe gerechtshoven na 1848 bij een vacature nu wel of niet een aanbevelingslijst (bedoeld voor de Provinciale Hoven) moeten opmaken. ${ }^{169}$ Wat daar ook van $z \mathrm{ij}^{170}$, in 1875 meent de regering dat, met het verdwijnen van de aanbevelingen voor de gerechtshoven, ook de gelijksoortige bepalingen voor de rechtbanken en de kantongerechten moeten vervallen. ${ }^{171}$

De regering voert in 1875 echter een achterhoedegevecht, hoewel uit het voorlopig verslag toch blijkt dat "Im/et beroep van weêrszijden op de verschillende, dikwijls herhaalde argumenten" nog een "levendige strijd" wordt gevoerd over de al dan niet wenselijkheid van de afschaffing van de aanbevelingslijsten. ${ }^{172}$ Tijdens de openbare beraadslaging stelt het Tweede Kamerlid Lenting echter in een amendement voor de lijsten van aanbeveling te handhaven. Nu de publieke opinie zich niet meer zo ongunstig over de aanbevelingen uitlaat meent Lenting dat tal van redenen voor het behoud van de aanbevelingen pleiten, waarbij hij rechtstreeks uit het werk van Pols en Loke voordraagt. ${ }^{173}$ De Tweede Kamer neemt het amendement Lenting, gewijzigd op voorstel van Verniers van der Loeff, met 34 tegen 31 stemmen aan. ${ }^{174}$ Het wetsontwerp wordt uiteindelijk echter verworpen, zodat per saldo de bestaande situatie werd gecontinueerd.

\subsubsection{Restauratie van het stelsel van aanbevelingen}

De restauratie van het stelsel van aanbevelingen - die zich in 1871 en 1876 aftekent - zet door. Zo wordt in 1885 ook voor de nieuwe gerechtshoven het stelsel van aanbevelingslijsten opnieuw ingevoerd. In 1875 zijn immers de bepalingen in de Wet RO, die nog betrekking hadden op de Provinciale Hoven, waaronder die over de aanbevelingslijsten - zonder veel tegenwerking van de Tweede Kamer - weggenomen. ${ }^{175}$ Deze situatie zal echter niet lang duren. Op

168. Wet van 10 november 1875 , Stb. nr. 204

169. Zie bijvoorbeeld: W 1165. Voordragt en benoeming van ledent voor de Provinciale Geregtshoven

170. De regering meent achteraf dat die plicht niet bestond, zie. MvT, Bijl. Hand. II 18741875, nr. 121-3

171. MvT. Bijl. Hand. II 1875-1876, nr. 147-3

172. VV, Bijl. Hand. II $1875-1876$, nr. $147-25$, p. 153

173. Hand. II $1876-1877$, p. 985

174. Hand. II 1876-1877, p. 991

175. Ontwerp-art. 62 Wet RO: "De presidenten, vice-presidenten en raadsheeren worden door den Koning voor hun leven aangesteld.

De ambtenaren van hei openbaar ministerie, de griffiers, en hanne substituten worden insgelijks door den. Koning aangesteld, doch rot wederopzeggens ioe." 
21 juli 1884 biedt de regering een ontwerp van wet aan de Tweede Kamer aan om ook voor de gerechtshoven aanbevelingslijsten in te voeren. ${ }^{176} \mathrm{Er}$ is $-\mathrm{zo}$ heet het nu- een anomalie in de wet ontstaan, ten gevolge waarvan voor de benoeming van een lid van de Hoge Raad, van een rechtbank en van een kantongerecht wel een aanbeveling is vereist, maar voor de benoeming van een lid van een gerechtshof niet. Deze situatie acht de minister niet verdedigbaar. Het argument (de geconstateerde anomalie) is echter nogal selectief; even goed had men aan het ontbreken van een aanbeveling voor de gerechtshoven een argument voor de afschaffing van de aanbevelingen voor de overige gerechten kunnen ontlenen (iets wat in 1876 ook gebeurd is). Opnieuw wordt - zij het met steeds minder overtuiging - gewezen op het feitelijk ontbreken van de ministeriële verantwoordelijkheid voor benoemingen door de semi-bindendheid van de aanbevelingen, op het gevaar van nepotisme, en, zo meent het Tweede Kamerlid De Vos van Steenwijk geheimzinnig...

"...dan is er nog een factor: het is de invloed van het vrouwelijk element. Hierbij heb ik nu niet op het oog het geval, dat alhier gememoreerd is, toen het bekende amendement-Lenting werd behandeld, dat namelijk eene rechtbank bij het opmaken van de aanbeveling reeds dadelijk alle sollicitanten, die ongehuwd waren, buiten aanmerking stelde, omdat men voor de conversatie in het kleine stadje een gehuwd paar verlangde. Ik bedoel ook niet het geval dat mij eens is ter oore gekomen, dat een rechter, bijna rijp voor pensioen, en vader van eenige ongehuwde dochters, enkel op de ongehuwde sollicitanten acht sloeg. Maar ik bedoel den invloed van 's rechters vrouw. Ook bij haar wordt gesolliciteerd, ook zij heeft hare sympathie; zij het niet voor den eenen of anderen candidaat, dan althans voor diens echtgenoote, en nu is het lichtelijk te begrijpen, dat zij, die dag en nacht het oor van haar man heeft, in staat is invloed uit te oefenen. Moet men de gewichtige benoeming van leden der rechterlijke macht aan die gevaren blootstellen $?^{n 177}$

De minister van justitie Du Tour van Bellinchave wil dit laatste trouwens niet tegenspreken, en hekelt de geringe informatie van de gerechten: "Is er bijv. een vacature in het hof van Gelderland, dan verneemt de Minister hoe noodzakelijk

Ontwerp-art 63 Wet RO: "De leden der geregtshoven worden bij voorkeur gekozen wit de leden van en ambtenaren van het openbaar ministerie bij de arrondissementsregtbanken, die hunne bediening met lof en ijver hebben waargenomen." Bijl. Hand. II 1874-1875, nr. 121-6

176. Achter art. 62 Wet RO zou de volgende bepaling worden ingevoegd: -Wanneer eene plaats van raadsheer openvalt, maakt het hof, de procureur-generaal daaronder begrepen, eene lijst van aanbeveling van vijf candidaten op, welke lijst, alphabetisch ingerigt, aan den Koning wordt aangeboden, om daarop zoodanig acht te slaan als Hij zal dienstig oordelen." Bijl. Hand. II 1883-1884 nr. 247-2

177. Hand. II 1884-1885, p. 975 
de Geldersche lucht is voor mevrouw en de kinderen van den sollicitant die raadsheer wil worden. En is er een vacature bij het hof 's Gravenhage, dan verneemt de Minister hoe noodzakelijk de frissche Scheveningsche lucht is om de geschokte gezondheid van een huisgezin te herstellen. Maar inlichtingen omtrent de bekwaamheid en ijver, zij blijven veelal achterwege. "178 Toch hebben deze argumenten tegen de aanbevelingen, die de laatste 30 jaar herhaaldelijk voor het voetlicht zijn gebracht, in 1885 in de Tweede Kamer sterk aan gewicht verloren. Het zwaartepunt van de argumentatie ligt inmiddels bij iemand als De Savornin Lohman, die de invoering van de aanbevelingslijsten van de gerechtshoven met vuur verdedigt. Sprekend uit een persoonlijke ondervinding van twintig jaar, wijst hij op het praktische belang om rechtscolleges zelf inspraak te geven bij benoemingen. Hij neemt daarbij geen blad voor de mond:

"Men denke daarover niet licht, want men vergete niet dat in een rechtscollege, ook in de gewichtigste zaken, zulke onbekwame menschen den doorslag kunnen geven. Zitten er in een college twee nullen tegen een bekwaam man, dan is dat nog zoo erg niet, want die twee zullen die eenen bekwaamen volgen; maar de toestand wordt zeer ongelukkig, als tegenover twee bekwame menschen een nulstaat. Men kan dan even goed de zaak doen beslechten door een dubbeltje op zijn kant te doen staan. Ik heb een college gekend, waarin iemand gezeten was wiens verstand verbijsterd was, maar die nog niet onder curateele stond en toch zitting wilde hebben, zoodat de president en de tweede rechter, die wel bij hun verstand waren, moesten afspreken, dat, bij verschil van opvatting, de jongste rechters zich steeds zouden voegen naar het oordeel van den president, ten einde gewaarborgd te zijn dat de beslissing niet zou afhangen van de stem van een krankzinnige! "179

De Tweede Kamer neemt het wetsontwerp met overgrote meerderheid (46 tegen 10) aan. ${ }^{180}$

\subsection{Terug naar de voordrachten: periode 1840-1887}

Terwijl in de periode 1838-1876 ten aanzien van de lijsten van aanbevelingen het rumoer aanzwelt (en weer afneemt), blijft het tot 1887 ogenschijnlijk lange tijd stil rond de voordrachten. Toch is er tussen 1840 en 1887 forse kritiek np de (praktijk van de) voordrachten van de Tweede Kamer voor de Hoge Raad, en het is de vraag in hoeverre de discussie over de aanbevelingen nict beïn-

178. Hand. II $1884-1885$, p. 980

179. Hand. II 1884-1885, p. 977

180. Hand. II 1884-1885, p. 982 N.B. een amendement-Ruys van Beerenbrouck wijzigt het aantal kandidaten op de aanbeveling van vijf in drie. In de praktijk zou het volgens hem ondoenlijk zijn vijf (bij een dubbele vacature: tien) geschikte kandidaten te vinden die beschikbaar zijn voor de vacature. Zie thans art. 63 Wet RO 
vloed is door wat zich elders, bij benoemingen in de Hoge Raad afspeelt. In 1871 bijvoorbeeld ontleent de minister van justitie Godefroi (toch zeker geen voorstander van de aanbevelingen) aan de voordracht een van zijn belangrijkste argumenten om de aanbevelingslijsten voor de Hoge Raad toch te handhaven. Deze voordrachten noemt hij een "allerongelukkigste" bepaling, en - veel voorzichtiger dan menig bewindsman op justitie na hem zal doen - zegt hij:

"Vraagt men nu of die bepaling hier goed heefi gewerkt, dan is mijn antwoord, dat er zaken zijn waarover men hier in het openbaar moeijelijk kan spreken, en die men beter in de coulissen behandelt. Maar niet ligt zal iemand, die langen tijd lid der Kamer was, beweren dat nooit de politiek invloed heeft gehad op de voordragt van leden van den Hoogen Raad; dat nooit favoritisme, nooit redenen, vreemd aan de zaak, op het opmaken dier nominatien hebben gewerkt. ${ }^{n 181}$

Al eerder, bij de grondwetsherzieningen 1840 en 1848 , en bij het initiatiefvoorstel van de Negenmannen in 1844, is getracht de voordrachtsbevoegdheid van de Tweede Kamer af te schaffen. ${ }^{182}$ Aanvankelijk komen de bezwaren tegen de voordracht niet goed uit de verf. In het initiatief-voorstel van de Negenmannen bijvoorbeeld houdt de afschaffing verband met de invoering van een nieuw 'Hof van Staat'. Dit Hof van Staat is belast met de berechting van ambtsmisdrijven gepleegd door leden van de Staten-Generaal, en de Hoofden der departementen van algemeen bestuur. ${ }^{183}$ Daarmee verviel volgens de Negenmannen de "hoofdgrond om het regt van benoeming tusschen de Tweede Kamer en den Koning te verdeelen". En dan, zo staat in de memorie van toelichting (die door Thorbecke was opgesteld), "hernemen de redenen, welke het onraadzaam maken, de vrijheid der Kroon te beperken, eene talrijke vergadering tot dergelijk ambt mede te laten benoemen, en de Staten-Generaal in de

181. Hand. II $1872-1873$, p. 1246

182. Zie ook D. Donker Curtius, Proeve eener nieuwe grondwet, 1840 , waar in art. 158 wordt voorgesteld de Koning een keuze te laten doen uit een lijst van zes personendie de Hoge Raad ter vervuliing van een vacature opmaakt. De voorzitter worcit door de Koning uit de leden benoernd, en de Koning heeft de vrije aanstelling van de procureurgeneraal en de advocaten-generaal.

183. Ontwerp-art. $128 \mathrm{Wet}$ RO: "De leden der Staten-Generaal en de hoofden der departementen van algemeen bestuur staan, uit hoofde van amblsmisdrijven, ter vervolging. hetzij van Koningswege hetzij vanwege de Tweede Kamer, te regt voor een Hof van Staat, telkens ten behoeve van zoodanige vervolging bijeen te roepen. Het wordt, naar de bepalingen der wet, zamengesteld uit vijf leden van de Hoogen Raad, twee van de Eerste Kamer en twee van den Raad van State. Zij benoemen den voorzitter uit hun midden." Bijl. Hand. II 1844-1845, nr. XX-2, p. 448 
verantwoordelijkheid voor de gedane keuze in te wikkelen, de bovenhand. "184 Ook in 1848 zijn de bezwaren tegen de voordrachtsprocedure nog niet erg duidelijk, wanneer de regering schrijft: "[e]ene tienjarige ondervinding heeft de noodzakelijkheid der voordragten of nominatien niet zò̀ bevestigd, dat men het beginsel, hetwelk in de meeste constitutionnele landen ten aanzien der regtstreeksche benoeming heerscht, hier niet zou moeten aannemen"185 Met het laten vervallen van de nominatie wil de regering bovendien de macht van de Koning versterken, "zonder die op eene, voor 's lands vrijheden en voor de onafhankelijkheid der regterlijke macht schadelijke wijze uit te breiden. ${ }^{1186}$ De 'grote meerderheid' van de Tweede Kamerleden is echter tevreden over de tot dan toe gevolgde praktijk bij Hoge Raadbenoemingen, en vreest overigens dat de Hoge Raad te zeer afhankelijk van de regering zal worden. ${ }^{187}$ Erg zwaar lijkt de voordracht voor de regering niet te wegen, want in het gewijzigd ontwerp wordt zij gehandhaafd. ${ }^{188}$

184. MvT, Bijl. Hand. II 1844-1845, nr. XX, p. 461 Vergelijk zijn Aanteekening op de' Grondwel, waarin hij de voordracht, gezien de taak van de Hoge Raad bij de berechting van ambtsmisdrijven, "dubbel gewigtig " noemt. en die. "al maakle men een nieuve" Grondwet, het behoud van de medewerking der Statengeneraal sou aanraden." J.R. Thorbecke, Aanteekening op de Grondwel, 1843, p. $173 \mathrm{Hct}$ voorstel van de Negenmannen haalde het overigens niet; de grote meerderheid van de Twcede Kamerleden verklaarde zich tegen het nieuwe Hof van Staat en tegen het wegvallen van de vourdrachtsbevoegdheid van de Tweede Kamer (VV, Bijl. Hand. II 1844-1845, nr. XX, p. 474-475). Hel initiatief-voorstel werd op 30 mei 1845 door de Tweede Kamer verworpen.

185. MvT, Bijl. Hand. II 1847-1848, nr. XILX-11, p. 350

186. MvA, Bijl. Hand. II 1847-1848, XLIX-27, p. 577

187. VV, Bijl. Hand. II 1847-1848, XLIX-26, p. 485

188. Twee minder vergaande voorstellen van de regering haalden het overigens wel; tegen de zin van de Tweede Kamer in, werd de voordracht uitgebreid van drie naar vijf kandidaten met het doel de keuzemogelijkheid van de Koning te vergroten (MvA, Bijl. Hand. II 1847-1848, p. 577), hoewel de Tweede Kamer meende nu soms al moeite te hebben om drie geschikte kandidaten aan te wijzen voor bet hoogste rechterlijke college. Dit voorstel was trouwens nogal merkwaardig, gelet op de inmiddels gegroeide praktijk, waarbij de Koning (na 1848: de regering) sinds 1840 steeds de no. 1 op de voordracht had benoemd. Ook werd in 1848, tegen de zin van de Tweede Kamer, de bepaling geschrapt dat de leden van de Hoge Raad zoveel mogelijk uit de verschillende provinciën worden benoemd. Zie art. $158 \mathrm{GW} 1848$ : "Van eene voorgevallene vacature wordt door den Hoogen Raad aan de Tweede Kamer der Staten-Generaal kennis gegeven, die, ter vervulling daarvan, eene nominatie van viff personen aan den Koning aanbiedt, ten einde daaruit eene keuze te doen. De Koning benoemt den President uit de leden van den Hoogen Raad heeft en heeft de regtstreeksche aanstelling van de Procureur-Generaal." 


\subsubsection{Preadviezen NJV 1883}

Na 1848 neemt de kritiek op de voordrachten, net zoals dat na 1838 gebeurde voor de aanbevelingen, sterk toe. Van de 48 benoemingen in de periode 1839 . 1887 zal slechts in 24 gevallen de no. 1 op de voordracht van de Tweede Kamer gelijk zijn aan de no. 1 op de aanbeveling van de Hoge Raad. Daarentegen benoemt de Koning (na 1848: de regering) nagenoeg steeds de no. 1 op de voordracht van de Tweede Kamer. ${ }^{189}$ Het verbaast dan ook niet dat de twee preadviseurs, Heemskerk en Tellegen, op de 14e vergadering van de NJV in 1883 (thema: 'Welke bepalingen omtrent de justitie zijn in de Grondwet onmisbaar?') aandacht besteden aan de merites van de voordrachtsprocedure. ${ }^{100}$ Heemskerk bepleit in zijn preadvies o.a. de afschaffing van de voordracht. Hij noemt de verplichte voordracht van de Tweede Kamer 'afkeurenswaardig'. ${ }^{191}$ Bovendien meent Heemskerk dat de historische grond waarop de voordracht steunt - de regeringsvorm van vór 1795, toen de scheiding tussen staatkundige en rechterlijke macht zeer onvolkomen was - niet meer bestaat. $\mathrm{Nu}$ 'de geheele wetgeving' is doortrokken van de rechterlijke en de staatkundige bevoegdheden, acht hij een 'politieke vergadering' niet geschikt voor de keuze van de leden van het hoogste rechtscollege. De aanbevelingen daarentegen doen "niets te kort aan de onafhankelijkheid van 's Konings keuze en aan de volle verantwoordelijkheid des Ministers, die de benoeming contrasigneert." Neemt men deze 'primae linae' tot grondslag, dan acht Heemskerk het voldoende dat de Grondwet, met betrekking tot rechterlijke benoemingen slechts bepaalt dat alle leden van de rechterlijke macht worden benoemd door de Koning. ${ }^{192}$

De andere preadviseur, Tellegen, staat in het algemeen een verkiezing voor het leven van de leden van de rechterlijke macht door vertegenwoordigende lichamen (Staten-Generaal, provinciale staten en gemeenteraden) voor. Hij verdedigt de voordracht van de Tweede Kamer voor vacatures in de Hoge Raad. Het lidmaatschap van de Hoge Raad is immers "de Maarschalksstaf der Rechterlijke Macht", en dat men "om dien te erlangen, door het meer invloedrijke deel der Vertegenwoordiging daartoe geschikt moet worden geacht, zal de Koning $u$ kunnen benoemen", kan volgens Tellegen "den bedervenden invloed

189. In de periode $1839-1887$ zal dit bij 43 van de 48 benoemingen het geval zijn. Zie: Van Koppen en Ten Kate, o.c. p. 40

190. 1. Heemskerk Azn, preadvies, Handelingen der Nederlandsche Juristen-Vereeniging, 1883 p. $34-80$ en B.D.H. Tellegen, preadvies, Handelingen der Nederlandsche Juristen-Vereeniging. 1883, p. 81-128

191. Heemskerk, o.c. p. 71

192. Heemskerk, o.c. p. 72 
van de zucht naar bevordering temperen, zoo niet weren. ${ }^{m 193}$ Iets dergelijks zullen de liberale Tweede Kamerleden Van Houten en De Ranitz in 1887 zeggen: "de hoogste uiting van de volksmeening, de Vertegenwoordiging en het orgaan van het Nederlandsche Volk, moet medewerken tot de samenstelling van een college, dat ook geroepen kan worden in zaken van politieken aard recht te spreken. ${ }^{" 194}$ Over de nadelen van een rechtersverkiezing, in het bijzonder dat "politieke redenen" invloed op de keus kunnen hebben, zegt Tellegen: "bestaat er bij den Minister niet het nog grooter gevaar, dat de teedere banden van bloed- en aanverwantschap hem bij het doen der keuze verstrikken? Iets waarvoor men bij de Tweede Kamer minder vrees behoeft te koesteren. ${ }^{195}$ Tellegen erkent overigens dat bij een verkiezing de waarborg van de ministeriële verantwoordelijkheid niet bestaat, en dat het stelsel van keuze "een grooten invloed zoude inruimen aan plaatselijke en provinciale invloeden." Marar, ook de ministeriële verantwoordelijkheid belet de minister niet "aan familiebetrekking, zoowel als aan politieke consideratien bij de benoeming het oor te leenen". ${ }^{\text {Wo }}$ Overigens meent hij dat een groot deel van de hezwaren tegen de verkiezing van rechters kan worden weggenomen, door een verkiezing voor het leven door gemeenteraden, provinciale staten of Staten-Generaal.

\subsubsection{Reacties op de preadviezen van Heemskerk en Tellegen}

De reacties op de preadviezen van Heemskerk en Tellegen, zijn op het punt van de voordracht gelijkluidend, zij het dat men vanuit andere, soms zelfs tegengestelde redeneringen, tot eenzelfde uitkomst komt. A.F.L. Gregory wijst er op dat alleen 'rechtschapenheid en bekwaamheid' bij een benoeming tot de rechterlijke macht in aanmerking komen, politiek moet daaraan geheel vreemd zijn. Wanneer de Tweede Kamer de nominatie opmaakt valt volgens hem te duchten dat de heersende politieke opinie beslist, en dat op de lijst slechts namen van personen komen die behoren tot de politieke meerderheid. Gregory stelt daarom voor de aanbeveling van de Hoge Raad te laten vervallen, en de voordrachtshevoegdheid van de Tweede Kamer over te dragen aan de Hoge Raad zelf. Alleen de Hoge Raad is z.i. in staat zich officieel te doen inlichten omtrent de geschiktheid van de kandidaat; bovendien is hij het best op de hoogte van hetgeen wordt gevorderd om "eene waardige plaats in zijn college in te nemen". ${ }^{197}$ Ook Levy is voorstander van de afschaffing van de voordrachtsbevoegdheid van de Tweede Kamer, zij het om heel andere redenen dan

193. Tellegen, o.c. p. 105

194. Hand. II 1886-1887, p. 1606

195. Tellegen, o.c. p. 106

196. Tellegen, o.c. p. 103-104

197. A.F.L. Gregory, Verslag van de veertiende jwristen-vergadering, donderdag 30 augustus 1883, p. $8-11$ 
Gregory. ${ }^{198}$ Uitgangspunt voor de samenstelling van de rechterlijke macht, zou juist moeten zijn 'geen benoeming zonder aanbeveling'. Hij wijst op het belang van de openbaarheid van de aanbeveling, iets waar hij in 1877 ook al eens op heeft gewezen, en waarop ook de interpellatie Hoynck van Papendrecht in 1857 over was gegaan. ${ }^{199}$

"Eene krachtige Regeering schuwt de openbaarheid der aanbeveling niet. Integendeel zoekt zij voorlichting, omdat het bewustzijn zelfstandig hare plicht te vervullen, haar fier en sterk maakt. Eene krachtige Vertegenwoordiging, ontwijkt de openbaarheid der aanbeveling evenmin. Zij ziet in deze een waarborg tegen misbruik van gezag, dat, hoe men over personen denke, tot de mogelijkheden blijf behooren. ${ }^{300}$

De suggestie van Gregory om een stelsel van assumptie aan te nemen voor de Hoge Raad noemt Levy het 'allergevaarlijkste middel' dat men bedenken kan: "Wil men van den Hoogen Raad maken een familieraad, neem dan aan het middel van assumptie; stelt gij er echter prijs op dat ons hoogste rechtscollegie blijve wat het is, laat dan de leden door den Koning benoemd worden, en omring 's Konings keuze van zoodanige waarborgen, dat gij alle voordelen hebt van de benoeming en geen der nadeelen van de keuze. ${ }^{\prime 201}$

\subsubsection{Negentiende-eeuwse perceptie van rechtersverkiezingen}

Het pleidooi van Tellegen in 1883 voor rechtersverkiezingen is - gezien het tijdsgewricht - een interessant waagstuk, maar roept - wellicht omdat het zo bizar is - geen reacties op. De publieke opinie - de rechtsliteratuur - is in de jaren zestig en zeventig van de vorige eeuw immers sterk tegen zulke verkiezingen gekant, met name onder invloed van alarmerende berichten uit de Verenigde Staten. Van de bewondering die tijdens de Republiek nog vrij algemeen wordt gekoesterd voor de Amerikaanse (federale) rechterlijke organisatie, is na de invoering van de rechtersverkiezingen in 1846 in de deelstaat New York, niets meer over. Niet voor niets refereert Heemskerk in zijn preadvies aan de "wrange vruchten" die men in New York van zulke verkiezingen heeft moeten

198. J.A. Levy, Verslag van de vecriende juristen-vergactering, donderdag 30 augustus 1883 , p. 12-20

199. Levy, o.c. p. 15-16 In gelijke zin: N.F. van Nooten, Verslag van de veertiende juristen-vergadering, donderdag 30 augustus 1883, p. 20-22

200. J.A. Levy, De rechter, zelfstandig drager der koninklijke rechtsmacht (rechterlijke aanbevelingen), in: Nieuwe Bijdragen voor rechisgeleerdheid en wetgeving, nieuwe reeks, derde deel, 1877 , p. 146

201. Levy, o.e. p. 20 
smaken. ${ }^{202}$ Inderdaad culmineren juist in deze jaren in die staat de problemen met rechtersverkiezingen (zie $\S 5.5 .3$ ). Berichten daarover zijn al in een vroeg stadium in de Nederlandse rechtsliteratuur doorgedrongen, en roepen vragen op met brandende kwesties als de (on)wenselijkheid van het (algemeen) kiesrecht hier te lande. B.C.J. Loder, later raadsheer in de Hoge Raad, schrijft in 1873: "wie durft de deugdzaamheid vol te houden van de ambtenaren onder het opzicht van het souvereine volk, in een tijd waarin de handigheid van een Tammany-Ring is aan het licht gekomen, en waarin de veilheid der rechters van New York spreekwoordelijk werd. "203 En het Tweede Kamerlid Beelaerts van Blokland schrijft in 1869:

"Het is bekend, dat diefstal en omkooping de hoofdbezigheid uitmaakt van het New Yorksche gemeentebestuur ("the forty thieves"). (-) Door de volkskeuze zijn de rechters meer dan ooit politieke personen geworden, verkozen door en uit de partij welke de meerderheid heefi; hun ambrelijke levensduur is afhankelijk van het aantal en het goedvinden hunner partijgenooten. (-) Een rechterambt, dat van dergelijke partijbedoelingen afhankelijk is, kan niet geëerbiedigd worden, en hoewel het in hooge mate onbillijk ware, dit New-Yorksche voorbeeld op al de andere Staten toe te passen, toch is het niet tegen te spreken, dat ook elders soortgelijke zaken soortgelijke gevolgen te weeg brengen, en dat in de geheele Unie het vertrouwen op de onpartijdigheid der meeste State Courts, door de handelingen der rechters bij volkskeuze aanmerkelijk is geschokt. "204

Hierna zullen we nog zien dat Beelaerts van Blokland in 1887 aan de ontwikkeling van de Amerikaanse democratie een argument ontleent om de voordrachtsbevoegdheid van de Tweede Kamer voor vacatures in de Hoge Raad af te schaffen. Maar ook elders in Europa (Frankrijk, Engeland, Zwitserland) wordt met ontzetting naar de Verenigde Staten gekeken. De Zwitser Rüttimann citeert in 1867 schrijvers als De Toqueville en Duvergier om zijn afkeer van rechtersverkiezingen kracht bij te zetten ${ }^{205}$, en de Engelse auteur Anthony Trollope rapporteert in 1862: "At present even a few visits to the courts

202. J. Heemskerk Azn., Welke bepalingen omtrent de justitie zijn in de Grondwet onmisbaar, preadvies, NJV, 1883, p. 70

203. B.C.J. Loder, De leer der volkssonvereiniteil, 1873, p. 157-158

204. G.J.Th. Beelaerts van Blokland, De bevoegdheid van den amerikaanschen rechter 10 t ongrondwettigverklaring eener wet, in: Niellwe Bijdragen voor Rechtsgeleerdheid en Wetgeving, 1869, p. 41-43

205. Rüttiman, p. 337 e.v. Aardig is het citaat van Laboulane: "Les élections populaires ont des résultats détestables (-) Le candidat se trouve exposé anx propositions les plus étranges. Ainsi vous savez qu'il y a dans certains Etats une loi, qui défend l'usage de tout spirinuetox. Cette loi est très désagréable à certaines parties de la population, notamment aux gens d'origine allemande. Eh bien, on y a dit aux juges: "Oui, nous vous nommerons, mais à la condition que vous n'appliquerez pas la loi." 
constituted in this manner (door verkiezing, MdW) will convince an observer that the judges on the bench are rather inferior than superior to the lawyers before them. The manner of address, the tone of voice, the lack of dignity in the judge, and the assumption by the lawyer before him of a higher authority than his, all tell this tale. "206 Dergelijke kritiek komt overigens hard aan in de Verenigde Staten. D.B. Eaton schrijft aan de vooravond van het referendum over rechtersverkiezingen in New York in 1873 (zie $\$ 5.6$ ):

"Our most intelligent friends in other countries, as well as candid observers at home, have noticed the decay and the disgrace into which our judicial reports have fallen, and such reports are the barometers of our judicial affair. In all European countries where our reports are quoted, the decisions prior to 1846 (i.e. het jaar dat rechtersverkiezingen in New York werden ingevoerd, MdW) are of higher authority than those made during the last ten or fifteen years, and no New York lawyer would care more than once to refer to the later jurisprudence of his State in the presence of a well-read foreign jurist. ${ }^{\text {n203 }}$

Tellegen is zich in 1883 deze kritiek terdege bewust, maar meent toch dat hier met twee maten wordt gemeten:

"Niets is gemakkelijker dan de schaduwaijde van den rechter door keuze in 't licht te stellen, daar zij meer in 't oog springt dan de nadeelen aan de Koninklijke benoeming verbonden. Niemand ziet er eenig bezwaar in kritiek en scherpe kritiek wit te oefenen over den gekozen rechter, de ondervinding echter leert, dat bij de door den Koning benoemde rechters de kritiek zich niet luide laat hooren. Wanneer de eerste het aanhooren der pleidooien tot verlenging der nachtrust mocht willen gebruiken, het zoude den volgenden dag in de dagbladen komen; doet het de tweede, men zal er zich wellicht binnen's kamers boos over maken; wellicht als op iets komieks er onder elkander op wijzen. ${ }^{\text {m208 }}$

En daar heeft hij niet geheel ongelijk in. De enkele verwijzing naar het Amerikaanse 'schrikbeeld' van rechtersverkiezingen zal, tot in onze tijd, als een - nogal gemakkelijk - argument gelden tegen 'politieke' benoemingen, maar de tegenstanders (en dat is nagenoeg iedereen) zullen steeds minder moeite doen om hun afkeer te beargumenteren, laat staan om het Amerikaanse verkiezingsstelsel serieus in studie te nemen.

206. Anthony Trollope, North America II, 1987 (voor het eerst gepubliceerd in 1862), p. 338

207. D.B. Eaton, Should judges be elected? Or the experiment of an elective judiciary in New York, pamflet, 1873, p. 20

208. Tellegen, o.c. p. 103 
Anders dan in 1840 en 1848, wil de regering in 1887 de voordrachtsprocedure voor de Hoge Raad handhaven. ${ }^{209}$ Dit vindt, aldus de regering een "rechtvaardiging in de speciale bevoegdheid van dat lichaam, bepaaldelijk door de voorschriften, omtrent de vervolging van Ministers wegens ambtsmisdrijven. ${ }^{210}$ Zij stelt bovendien dat: "Idloor de voordracht van de Tweede Kamer voor de benoeming der leden van den Hoogen Raad te behouden, wordt erkend dat de Volksvertegenwoordiging op de keuze een bepaalde invloed mot uitosfenen. ${ }^{1211}$ In het ontwerp tot grondwetsherziening is het aantal namen op de voordracht verminderd van vijf tot drie, omdat men een bezwaar ziet om vijf (of bij een dubbele vacature: tien) juristen op één ogenblik aan te wijzen, die zowel geschikt als genegen zijn om in de Hoge Raad zitting te nemen. ${ }^{212}$

Het spreekt - om tenminste twee redenen - niet vanzelf dat de voordrachten in 1887 worden gehandhaafd. Na de afschaffing van de Provinciale Hoven in de Grondwet van 1848 is immers de historische grondslag aan de voordrachtsbevoegdheid van de Tweede Kamer ontvallen. Bovendien had de indiener van het ontwerp, Heemskerk, zich in 1883 in zijn preadvies voor de NJV nog scherp gekant tegen de voordracht, en betoogd dat een "politiıke vergadering" niet geacht kan worden het meest geschikt te zijn voor de keuzen van het hoogste rechtscollege. Daar schrijft hij immers nog: "Reeds het denkbecld (wanneer dit algemeen ingang vindt) dat men bekend moet zijn als voorstander van het een of ander ' $t$ welk de meerderheid in een politiek lichaam op prijs. stelt, of dat men > tot de vrienden" moet behooren, om tot hoogere rechterlijke betrekkingen te geraken, werkt nadeelig op de onafhankelijkheid van zwakke karakters, zooals er in iedere magistratuur, met hoeveel zorg ook samengesteld,

209. Ontwerp-art. $158 \mathrm{GW}$ : "Van eene voorgevallene vacalure wordt door den Hoogen Raad a an de Tweede Kamer der Staten-Generaal kennis gegeven die, ter vervulling daarvan, eene vordragt van drie personen aan den Koning aanbiedt, ten einde daaruit eene keuze te doen.

De Koning benoemt den president en den vice-president uit de leden van den Hougen Raad. "OvW, Bijl. Hand. II 1884-1885, nr. 111-14 N.B. door de Statscommissic was geadviseerd de bestaande regeling te handhaven. Bijl. Hand. II 1884-1885, nr. 111-29

210. MvT, Bijl. Hand. II 1884-1885, nr. 1I1-15. Zie ook de rede van de minister van justitie Du Tour de Bellinchave bij de openbare heraadslaging van het voorstel tot grondwetsherziening: "Het is toch volkomen waar, dat de man, die misschicn kan terechtstaan voor den Hoogen Raad, de leden van dal rechtscollege niet aan zich moet hebben kunnen verplichten. Hij moet terechtstaan voor een college in alle opzichten geheel onafhankelijk en waarkan de leden noch door hem, noch door zijne voorgangers tot die hooge betrekking geroepen zijn." Bijl. Hand. II 1886-1887, p. 1605

211. MvT, Bijl. Hand. II 1884-1885, nr. 111-15

212. MvT, Bijl. Hand. I] 1884-1885, nr. I11-15 
worden gevonden. ${ }^{1213}$ Die opvatting valt moeilijk te rijmen met de opmerking in de memorie van antwoord dat "fe/ene langdurige ondervinding heeft bewezen, dat de Kamer tot behoorlijke vervalling van die taak niet ongeschikt is. "2la

Op de jaarvergadering van de NJV in 1883 was reeds gebleken dat - onder juristen althans - het behoud van de voordrachten niet op brede steun berustte (33 tegen, 18 voor en 11 onthoudingen). In de Tweede Kamer liggen de verhoudingen echter anders. Uit het voorlopig verslag blijkt dat 'verscheidene' leden, anders dan de regering, de voordracht voor vacatures in de Hoge Raad wensen te laten vervallen. Volgens deze leden ligt het minder op de weg van een politiek lichaam om de juridische verdiensten van de kandidaten voor het hoogste rechterlijke college te beoordelen. Vele andere leden menen echter dat het bestaande stelsel goed gewerkt heeft en dat behoud van de voordracht noodzakelijk is om de onafhankelijkheid van de Hoge Raad tegenover de regering te waarborgen. ${ }^{215} \mathrm{Het}$ is de liberaal Greeve die - zeer tegen de zin in van zijn liberale achterban - in een amendement voorstelt de voordrachtsbevoegdheid van de Tweede Kamer te laten vervallen. ${ }^{216}$ Greeve beroept zich met name op de historische anomalie van de voordrachten, waar Thorbecke in 1844 ook al op heeft gewezen, en noemt het voordrachtsrecht "een adat, eene overlevering waaraan men zeer gehecht is en die men niet gaarne zou willen prijsgeven. ${ }^{1217}$ Vooral de liberale voorman Van Houten trekt fel van leer, en verwijt Greeve dat hij zich heeft afgescheiden van de grote meerderheid van zijn partij, en zich heeft verenigd met een "gevoelen van de overzijde" (te weten de anti-revolutionairen), zonder zich te bekommeren om de "lijn der liberale beginselen". ${ }^{218}$

Men moet hierbij in het achterhoofd houden, dat op de achtergrond van dit debat de kwestie-Van Eyssell speelt. Als in 1886 in de Hoge Raad de vacature van F.C. Donker Curtius openvalt, plaatst de Hoge Raad de anti-revolutionair P.J. van Swinderen als eerste op zijn aanbeveling. De Tweede Kamer, die op dat moment is samengesteld uit een liberale meerderheid, passeert echter Van Swinderen ten gunste van de liberaal Van Eyssell. ${ }^{119}$ Het verbaast dus niet

\section{Heemskerk, preadvies. NJV o.c. p. 71}

214. MvA. Bijl. Hand. II 1885-1886, nr. 34-19

215. VV. Bijl. Hand. II 1884-1885, nr 111-38

216. Amendement-Greeve: "Art. 158 der Grondwet wordt gelezen als volgt: "Wanneer eent plaats van raadsheer in den Hoogen Raad openvall, maakl de Hooge Raad, de procureur-generaal daaronder begrepen, cene lijst van aanbeveling van vijf candidaten op, welke lijst, alphabetisch ingerigt, aan den Koning wordt aangeboden om daarop zoodanig acht te slaan als Hij zal dienstig oordelen." Hand. II 1886-1887, p. 1593

217. Hand. II $1886-1887$, p. 1593

218. Hand. II $1886-1887$, p. 1600

219. Zie ook Van Koppen en Ten Kate, o.c. p. 41 
echt dat met name de anti-revolutionairen in 1887 het amendement van de liberaal Greeve ondersteunen. Zij menen dat de Tweede Kamer als "politiek lichaam" wel als laatste geroepen is om leden van de Hoge Raad voor te dragen: "IN]og onlangs toonde de Hoge Raad zijne onpartijdigheid door als no.I op de aanbevelingslijst een anti-revolutionnair te plaatsen. Wat deed toen de Kamer? Daar zij niet van zich kan afschudden dat zij een politiek lichaam is, werd numero éen voorbijgegaan en numero twee een liberaal, gekozen. ${ }^{220}$ Naast de ongeschiktheid van de Tweede Kamer voor het opmaken van voordrachten - A. Blussé wijst er op dat de Kamer bij voordrachten "nog al wel opkomt ${ }^{\prime 221}$ - wordt er door verschillende kamerleden op gewezen dat een voordracht door de Tweede Kamer een kwestie van "goed geloof" en "toeval" is. De meeste Tweede Kamerleden zijn volgens Blussé onbekend met de "juridische grootheden", en zijn voor hun informatie afhankelijk van van hun rechtsgeleerde vrienden. De nominatie zèlf noemt hij een "loterij". ${ }^{222}$ Dat is ook de mening van A.F. de Savornin Lohman, die aanvoert dat op het opmaken van een voordracht geen peil te trekken is: "[H]oe gaat dat? 's Avonds of een paar dagen te voren komt er op de agenda: Voordracht voor den Hoogen Raad. Vele leden vragen eerst op den dag der stemming aan dezen en genen: op wien stemt gij, en bij verdeeldheid van gevoelen hangt het resultaat der stemming geheel af van de toevallige omstandigheid, wat op een gegeven oogenblik zekeren club dien dag wil. ${ }^{\prime 223}$ Dergelijke praktische bezwaren tegen de voordracht wegen in 1887 echter niet op tegen de principiële belangen die met de voordrachtsbevoegdheid worden gediend. De liberaal Van Houten:

"het is de zelfstandigheid van de rechterlijke macht in ons constitutioneel stelsel. Maakt men de gehele rechterlijke macht afhankelijk van de Regeering. laat men daarop niet den minsten invloed van de Vertegenwoordiging toe, dan is daarmede de rechterlijke macht uit de drieëenheid van de machten in het constitutioneele stelsel verdwenen, en is zij een onderdeel van de regeermacht geworden. ${ }^{224}$

Ook de liberaal S.M.S. de Ranitz doet een duit in het zakje: "De Hooge Raad behoort niet te zijn eene coterie, die geheel staat buiten het volk; tusschen dat volk en dien Ruad moet een band zijn, die Raad mag niet geheel vreemd blijven aan hetgeen in de natie omgaat. Eenige terugslag van hetgeen in het volk leeft en werkt, mag niet gemist worden in het hoogste rechterlijk college. "?" Daar is echter lang niet iedereen van overtuigd. Beelaerts van Blokland, die zich

220. Hand. II $1886-1887$, p. 1598

221. Hand. IJ $1886-1887$, p. 1599

222. Hand. II 1886-1887, p. 1598

223. Hand. II 1886-1887, p. 1604

224. Hand. Il $1886-1887$, p. 1600

225. Hand. II $1886-1887$, p. 1606 
eerder zeer negatief heeft uitgelaten over het Amerikaanse rechterlijk toetsingsrecht en over rechtersverkiezingen in New York, stelt dat "in de tegenwoordige omstandigheden, die van de democratische invloeden" het "dubbel nodig" is dat de rechterlijke macht "in al haar vertakkingen" volkomen onafhankelijk is van de "Vertegenwoordiging".

"Mag ik den geachten afgevaardigde (Van Houten, MdW) verzoeken om zijn blik eens naar Amerika te wenden; daar zal hij zien dat de gevaren, die ook aan democratische regeeringsvormen eigen zijn, naar het oordeel van de beste en kundigste staatslieden het doeltreffendst ontweken worden door ijverig te zorgen voor de volkomen onafhankelijkheid van de rechterlijke macht, terwijldaarentegen de volksmenners en demagogen alles doen om die rechterlijke macht afhankelijk te maken van de Vertegenwoordiging en van de kiezers. (-) Een rechterlijke macht buiten alle invloed van volk en van Vertegenwoordiging, ziedaar een dringende eisch des tijds. ${ }^{\text {"2zG }}$

Toch heeft het pleidooi van Beelaerts van Blokland niet het gewenste effect. Met een krappe meerderheid van 39 tegen 36 stemmen, wordt het amendementGreeve op 10 mei 1887 verworpen."

\subsubsection{Voorstel tot grondwetsherziening 1913 en het Genootschap voor den Rechtsstaat 1940}

Tot omstreeks 1920 zou de Tweede Kamer een belangrijke rol blijven spelen bij benoemingen in de Hoge Raad. In de periode 1887-1917 plaatste de Kamer in negen van de 27 gevallen een ander als eerste op de voordracht dan door de Hoge Raad was aanbevolen. ${ }^{228} \mathrm{Om}$ die reden wenste de regering in 1913 de voordracht af te schaffen. In de praktijk hadden de voordrachten geleid tot een benoeming door de Tweede Kamer, en een politiek lichaam achtte de regering vonr een dergelijke benoeming niet het meest aangewezen orgaan. Een andere reden um de voordrachtsprocedure af te schaffen, zag de regering in het feit dat de Hoge Raad na 1887 niet langer het forum privilegiatum was voor de berechting van de Koning. de leden van het Koninklijk Huis en de staat. ${ }^{229}$ De voorstellen tot grondwetswijziging werden echter niet in behandeling genomen en nog hetzelfde jaar ingetrokken. Na 1913 nam de bemoeienis van de Tweede

226. Hand. II 1886-1887. p. 1603

227. Hand. II 1886-1887, p. 1613

228. Van Koppen en Ten Kate, o.c. p. 40-41

229. Ontwerp-art. $163 \mathrm{GW}$ : "Wanneer eene plaats van lid in den Hoogen Raad openvalt, maakl de Hoge Raad, de procureur-generaal daaonder begrepen, eene lijst van drie personen op, die alphabetisch ingericht, aan den Koning wordt toegezonden, om daarop zoodanig achl te staan als hij zal dienstig oordelen. "Bijl. Hand. II 1912-1913, nr. 25015 
Kamer met benoemingen in de Hoge Raad sterk af, en verdween ook de kritiek op de voordrachten. Van de 24 benoemingen in de periode 1917-1940 werd in 21 gevallen de no. 1 op de aanbeveling van de Hoge Raad door de Tweede Kamer op de eerste plaats van de voordracht gezet; in 18 gevallen was de voordracht conform de volgorde van de eerste drie kandidaten op de aanbeveling. ${ }^{230}$

Na de Tweede Wereldoorlog zou de bemoeienis van de Tweede Kamer met benoemingen in de Hoge Raad nagenoeg ${ }^{231}$ geheel verdwijnen. ${ }^{232}$ Toch waren de bezwaren tegen de voordracht nog niet bij iedereen weggenomen. Het Genootschap voor den Rechtsstaat riep tijdens de Tweede Wereldoorlog, in 1940, een commissie in het leven met de opdracht om een rapport samen te stellen omtrent alle hervormingen op staatkundig gebied, welke na de oorlog wenselijk werden geacht "teneinde den arbeid van politieke toenadering, welke juist tegen het uitbreken van den oorlog vruchtdragend begon te worden, voort te zetten". ${ }^{233}$ Deze commissie stelde voor de voordrachtsbevoegdheid van de Tweede Kamer te vervangen door een bindende 'voordracht' door de Hoge Raad: "Daartoe worde bepaald, dat het de Regeering niet vrij staat een benoeming buiten de voordracht om te doen, tenzij het betreft de benoeming van iemand, die tot dusver geen deel uitmaakte van eenig rechterlijk college en de voordracht uitsluitend bestaat uit leden der Rechterlijke Macht, de plaatsvervangers daaronder begrepen." Deze restrictie was volgens de commissie noodzakelijk om te voorkomen, dat de Hoge Raad buitenstaanders ("die somtijds, vooral in den Hoogen Raad, een gelukkige aanvulling geven") de toegang tot het rechtersambt zou afsnijden. "Onder deze omstandigheden vervalt vanzelfsprekend de bemoeiing van de Tweede Kamer met de benoeming van de leden van den Hoogen Raad. "234 Ook dit voorstel heeft niet geresulteerd in de afschaffing van de voordrachtsprocedure.

230. Van Koppen en Ten Kate, o.c. p. 40

231. Een uitzondering vonnt de voordracht van 22 januari 1975. De Tweede kamer zette toen de enige vrouw. Van den Blink, die op de zesde plaats van de aanbevcling van de Hoge Raad stond, op de tweede plaats. Van Koppen en Ten Kate, o.c. p. 97

232. Zic evenwel de nieuwe situatie sinds 1992 bij het opmaken van de voordracht door de Tweede Kamer $(\$ 2.3 .6 .1)$ en de achtergronden daarvan $(\$ 4.10 .1)$

233. Staukundige hervormingen, rapport uitgebracht aan het Genootschap voor den Rechtsstaat, 1946, p. 5

234. Staatkundige hervormingen, o.c. p. 5 


\subsection{De benoembaarheid van vrouwen in de rechterlijke macht}

Terwijl in ons land al na 1887 de aandacht van de (grond)wetgever voor het vraagstuk van de toegang tot het rechtersambt wegebt (om pas na de Tweede Wereldoorlog terug te keren), doen zich juist in die jaren in Europa en in de Verenigde Staten, belangrijke ontwikkelingen voor op dat punt, met name wat de benoembaarheid van vrouwen in de rechterlijke macht betreft. Een oekaze van de Russische keizer uit 1876 verbiedt vrouwen expliciet de toegang tot het rechtersambt, en ook de hoogste rechtscolleges in Zwitserland, Turijn, Denemarken en Brussel ontzeggen vrouwen de toegang tot het rechtersambt. ${ }^{235} \mathrm{Al}$ leen in de Verenigde Staten worden vrouwen sinds 1870 benoemd in de rechterlijke macht. ${ }^{236}$ Toch heeft ook daar niet altijd consensus bestaan over de wenselijkheid van vrouwelijke rechters. In zijn concurring decision in Bradwell $v$. Illinois, schrijft Justice Bradley in 1873:

"Civil law, as well as nature herself, has always recognized a wide difference in the respective spheres and destinies of man and woman. Man is, or should be, woman's protector and defender. The natural and proper timidity and delicacy which belongs to the female sex evidently fits it for many of the occupations of civil life. The constitution of the family organization, which is founded in the divine ordinance, as well as in the nature of things, indicates the domestic sphere as that which properly belongs to the domain and functions of womanhood. The harmony, not to say the identity, of interests and views which belong, or should belong, to the family institution is repugnant to the idea of a woman adopting a distinct and independent career from that of her husband. (-) This is the law of the Creator. (-) It is the prerogative of the legislator to prescribe regulations founded on nature, reason and experience. ${ }^{n 237}$

In ons land begint de discussie over de benoembaarheid van de vrouw in de rechterlijke macht rond $1915 .^{238}$ Op 8 januari 1915 wordt Anna Maria Elza-

235. R. de la Grasserie, De la justice en France el à l'étranger au XXé sięcle, 1914, p. 792

236. De eerste vrouwelijke rechter in de Verenigde Staten was Esther Williams, die in 1870 in Wyoming tot justice of the peace werd benoemd. Men leze over dit onderwerp bij: Susan Carbon. Women in the judiciary: an introduction, in: Judicature The Journal of The Judicature Society, 1982, p. 285

237. Concurring opinion van Justice Bradley bij: Bradwell v. Illinois, 83 U.S. 130. 21 L.F.d 442 (1873)

238. Ik wijs evenwel op de discussie in 1901 naar aanleiding van het amendement-Van Helsdingen op het ontwerp-Beroepswet. In het amendement wordt de benoembaarheid van de vrouw in de raden van beroep bepleit (Hand. II 1900-1901 p. 1659 e.v.). Het amendement haalde het overigens niet; de Wet van 8 december 1902 tot uitvoering van artikel 75 der Ongevallenwet 1901, Stb. nr. 208 bepaalt in art. 10 o.a. dat alleen mannelijke ingezetenen benoembaar zijn tot de raden van beroep. 
bee Post, op requisitoir van de officier van justitie bij de rechtbank Winschoten, bij beschikking van die rechtbank, benoemd tot 'klerk ter griffie' en als zodanig bij deze rechtbank beëdigd. Tegen deze benoeming, die direct een 'stout stuk' ${ }^{239}$ wordt genoemd, lijkt aanvankelijk geen wettelijk beletsel te bestaan. De Wet RO stelt op dat moment immers slechts als enige voorwaarde voor een griffier dat deze de leeftijd van 23 jaar bezit. ${ }^{240}$ Tegen de beschikking van de rechtbank Winschoten, tot toelating van de betreffende vrouw tot de beëdiging, tekent de officier van justitie van de rechtbank Winschoten echter beroep aan bij het gerechtshof Leeuwarden. Het Hof acht de beëdiging van Post in strijd met de wet en vernietigt de beschikking van de rechthank voorzover het betreft de toelating tot het afleggen van de eed. Het Hof overweegt daarbij onder meer:

"dat naar onze staatsinstellingen de staatsmacht (behoudens de Koninklijke waardigheid en het Regentschap) wordt uitgeoefend door mannen; dat men het blijkbaar onnoodig heeft geacht in de Grondwet en in de organieke wetten dit met ronde woorden uit te spreken, daar tijdens het vaststellen dier wetten daaromtrent bij niemand twijfel bestond; $O$. dat intusschen wel uit tal van bepalingen blijkt, dat men de mogelijkheid om vrouwen met de staatsmacht re bekleeden geheel heeft uitgesloten geacht; dat dit in het bijzonder ten aanzien van de rechterlijke macht blijkt uit art 10 al. 1 R. O., waarbij is bepaald, dat bloed-en aanverwanten geen deel mogen uitmaken van eenzelfde rechtscollege, doch warbij van echtgenooten geen melding wordt gemaakt, en uit al. 4, zooals dit bij de Wet van 9 April 1877 aan dit artikel is toegevoegd, bepalende: "zwagerschap houdt op door het overlijden van de vrouw die haar veroorzaak". ${ }^{241}$

De Hoge Raad casseert het arrest van het Hof, conform de conclusie van de procureur-generaal, overwegende dat een beëdigde klerk geen lid is van de rechterlijke macht en dat het antwoord op de vraag of een vrouw tot lid van de rechterlijke macht benoembaar is voor de wettigheid van de gewraakte beschikking van de rechtbank Winschoten niet beslissend kan zijn. Aan een principieel antwoord, te weten of de vrouw benoembaar is in de rechterlijke macht, komt de Hoge Raad niet toe. ${ }^{242}$ De visie van de rechtbank Winschoten wordt overigens niet door iedereen gedeeld. In 1921, komt de Raad van Justitie te Padang, op grond van hetzelfde wetshistorische materiaal, namelijk tot een tegenovergestelde redenering als de rechtbank Winschoten in 1915:

"Nu de wet geene uitdrukkelijke verbodsbepaling inhoudt, mag, al mocht het waurschijnlijk de bedoeling van den wetgever zijn geweest om de vrouw uit te

239. D. Simons, W 9773

240. Art. 47a Wet RO

241. Gerechtshof Leeuwarden, 21 april 1915, NJ 1915 p. $405-407$

242. HR 17 december 1916, NJ 1916, p. 161-163 
sluiten van de rechterlijke macht, in verband met de gewijzigde behoeften en inzichten, waarmee bij de uitlegging der wet mag worden rekening gehouden, worden aangenomen, dat de vrouw als zodanig niet is uitgesloten van de rechterlijke macht. ${ }^{\text {m43 }}$

\subsubsection{Pleidooien van Simons voor de benoembaarheid van vrouwen}

Naar aanleiding van de kwestie in Winschoten, houdt D. Simons in de periode 1915-1930 in het Weekblad van het Recht een drietal pleidooien voor de benoembaarheid van de vrouw in de rechterlijke macht. ${ }^{244}$ In twee artikelen uit 1915 bespreekt hij de juridische aspecten van de benoembaarheid van de vrouw in de rechterlijke macht, alsmede de geschiktheid van de vrouw voor het rechterlijke ambt en de maatschappelijke wenselijkheid dat zij in de rechterlijke macht haar intrede zal doen. Simons gaat er van uit dat de wetgever bij de totstandkoming van de Wet op de Rechterlijke Organisatie (1827) aan de benoeming van vrouwen tot rechter niet gedacht heeft: "Iw/are die gedachte wel bij hem opgekomen, hij zou haar als de ongerijmdheid zelve hebben verworpen. ${ }^{1245}$ Onk bij de totstandkoming van art. 10 Wet RO in 1877 zou de wetgever stilzwijgend verondersteld hebben dat alleen mannen tot rechterlijke functies kunnen worden geroepen. Niettemin meent Simons dat de Wet R0 thans niet zo mag worden uitgelegd dat de benoeming van vrouwen tot rechterlijke ambten niet is toegestaan. Nu art. 5 van de Grondwet bepaalt dat iedere Nederlander in elke landsbediening benoembaar is, meent Simons dat, om de vrouw van een landsbediening uit te sluiten, de wetgever daartoe zijn wil uitdrukkelijk moet uitspreken. 246

243. Vonnis van de Raad van Justitie te Padang van 13 juli 1921 (bekrachtigd door het Hooggerechtshof van Nederlands-Indië bij vonnis van 28 september 1921) en gepubliceerd in W 10818

244. Zie: W 9773 en W. 9775, Vrouwen bij de rechterlijke macht I en II, W 9773-9775. W 12135. Vrouwen in de rechterlijke macht

245. Uit de memorie van toelichting bij het ontwerp van wet van 1 maart 1876 , nr. 147 blijkt inderdaad dat de regering de kwestie van de benoembaarheid van de vrouw in de rechterlijke macht geheel terzijde heeft gelaten.

246. Simons, W 9773; men vergelijke de visie van het gerechtshof Leeuwarden (21 april 1915. NJ 1915 p. 407) ten aanzien van de door het hof voorgestane methode van wetsinterpretatie; "O. ten aanzien daarvan, dat het Hof van oordeel is, dal de verschillende lakken van wetgeving, in verband met den aard van hun onderwerp, verschillende regelen van interpretatie medebrengen; dat het burgerlijk recht wordt geformuleerd in verband met bepaalde feitelijke toestanden en heerschende opvattingen, een zekert plooibaarheid eischt met het oog op in den loop der tijden intredende veranderingen in toestanden en opvattingen, terwijl de rechterlijke macht is aangewezen als een zelfstandig onafhankelijk staatsorgaan, om bij de rechtsontwikkeling leidend op te treden; $O$. dat de regelen, welke moeten gelden ten aanzien van de burgerlijke wetgeving ( $B . W$., W.v.K. enz.) uit den aard der zaak verschillen van de regelen, welke toepassing moeten 
Over de geschiktheid van de vrouw voor het rechtersambt merkt Simons op dat er geen enkele reden is om te veronderstellen, dat de grondige kennis van recht en wet, die nodig is voor een rechterlijke functie, niet bij vrouwen aanwezig is. Wat de objectiviteit en de onbevangenheid van het vrouwelijk oordeel aangaat, sluit Simons aan bij de bevindingen van de psycholoog Heymans. De conclusie van Heymans over de gerechtigheidszin van de vrouw noemt Simons belangrijk:

"Iolok hierbij vertoont zich dezelfde eigenaardigheid; de vrouw houdt meer rekening met het bijzondere geval, de paragrafen van de wet imponeeren haar slechts in geringe mate (..) Voor hen dus, die gerechtigheid verkiezen boven het streng luisteren naar de uitspraak van den wetgever, zou de vrouw de ideale rechter moeten wezen. Eene aan het leven vreemde rechtspraak, zich vastklemmende aan de letter, kan van haar niet worden verwacht. ${ }^{247}$

Simons meent dat het oordeel van de vrouw met name op het terrein van het familierecht niet gemist mag worden; "Iallles wat betreft het huwelijksleven en de rechten ten aanzien van de kinderen mag toch niet eenzijdig van het mannelijk standpunt worden gewaardeerd en berecht. Het is billijk en rechtvaardig, dat de stem van het vrouwelijk gevoel en van de vrouwelijke rechtsovertuiging daarbij mede gehoord worden." 248 Vijftien jaar later, in 1930, herhaalt Simons zijn argumenten voor de wenselijkheid van het benoemen van vrouwen in de rechterlijke macht, maar zwakt hij zijn standpunt iets af, omdat "in den laatsten tijd, ook ten onzent, het rechterlijk ambt aan beteekenis heeft gewonnen; bij vergelijking van wetgever en rechter wint de laatste het tegenover vroeger. Het lijkt onnoodig dit nader uiteen te zetten. (..) De meerdere macht, door den mannelijken rechter verkregen, zal vanzelf ook aan de vrouwelijke collega toevallen. Is zij rijp die grootere verantwoordelijkheid te dragen, mag zij op hare schouders worden gelegd?"249 De pleidooien van Simons roepen in de literatuur betrekkelijk weinig weerstand op. Slechts een enkeling merkt in het Weekblad van het Recht over vrouwen op: "al is het gemakkelijk spreken haar van nature meer eigen dan den man, (radheid van tong is haar wel eens verweten) daarmede - $U$ wilt dit wel toegeven - is allerminst aangetoond, dat zij "in

vinden bij de explicatie van wellen, waarbij een deel der slaalsmacht aan bepaalde auloriteiten wordt opgedragen; dat daarbij in veel meerdere male de wet en de bedoeling van den wetgever als eenig richtsnoer naar voren treden en in veel meerdere mate iedere verandering vereischt een beslist ingrijpen van den wetgever; $O$., dat bij de vraag, of vrouwen tot rechterlijke ambten benoemhaar zijn, moet worden vastgehouden aan hetgeen de bedoeling van den wetgever en de slrekking van de wet moet worden geacht;"

247. Simons, W 9775

248. Simons, W 9775

249. Simons, W 12135 
het algemeen" niet alleen de bekwaamheid, maar in het bizonder de geschiktheid bezit voor het moeilijk rechter-ambt (over de vervulling waarvan door mannen uw oordeel algemeen wel zal gedeeld worden). "1250

\subsubsection{Wet Invoering kinderrechter 1921}

Tot een principieel debat in de Tweede Kamer over de benoembaarheid van de vrouw komt het in 1921, bij het voorstel van wet tot Invoering van den kinderrechter en van de ondertoezichtstelling van minderjarigen. ${ }^{251}$ Blijkens de memorie van toelichting is de vraag of aanstelling van vrouwen als kinderrechter wenselijk is, 'ernstig overwogen'. De minister van justitie, Heemskerk, wenst echter eerst het oordeel van de Staatscommissie voor de Grondwetsherziening over de grondwettigheid van een dergelijke aanstelling af te wachten. ${ }^{252}$ In een afzonderlijke nota, gevoegd bij het voorlopig verslag noemt het Tweede Kamerlid Dresselhuys de uitsluiting van de vrouw van het rechterlijk ambt, en met name van de functie van kinderrechter, een 'anachronisme'. Juist de vrouw is als pedagoog en psycholoog geroepen om 'het verwaarloosde of misdadige meisje' en het 'zeer jeugdige mannelijke kind' op het juiste spoor te zetten. ${ }^{253}$ Nadat de Staatscommissie in de benoembaarheid van de vrouw in de rechterlijke macht geen grondwettelijk bezwaar ziet, sluit de regering zich bij deze zienswijze aan. ${ }^{254}$ Toch meent de minister dat het vraagstuk 'met grote omzichtigheid' moet worden benaderd. Een nader onderzoek is daarom noodzakelijk. ${ }^{255}$ In antwoord op de nota-Dresselhuys zegt de minister van justitie dat hij geen principieel bezwaar heeft de benoembaarheid van de vrouw op een of andere manier in de wet vast te leggen. Wel wijst hij op het bezwaar dat art. 10 Wet RO wel van bloedverwantschap en zwagerschap spreekt, maar niet rept van een verbod voor gehuwden. ${ }^{256}$

\subsubsection{De adviezen van de president van de Hoge Raad en de procureur-generaal bij de Hoge Raad}

Bij de algemene beraadslaging in de Tweede Kamer op 20 mei 1921 over het wetsvoorstel, dient Dresselhuys een amendement in waardoor de Wet RO zich althans tegen de benoeming van een vrouw als plaatsvervangend kinderrechter

250. B. Denekamp, W 9778 Zie in gelijke zin W 9778

251. OvW, 18 maart 1920. Bijl. Hand. II 1919-1920, nr. 409-2

252. MvT, Bijl. Hand. II 1919-1920, nr. 409-3

253. Nota Dresselhuys, Bijl. Hand. II 1920-1921, nr. 75-1

254. MvA. Bijl. Hand. Il 1920-1921, nr. 75-2

255. MvA, Bijl. Hand. II 1920-1921, nr. 75-2

256. Antwoord Nota Dresselhuys, Bijl. Hand. II 1929-1921, nr. 75-2 
niet verzet. ${ }^{257}$ Naar aanleiding van het amendement-Dresselhuys, dat al op 21 februari is ingezonden, verzoekt de minister van justitie de Hoge Raad en het parket bij de Hoge Raad om advies omtrent de grenzen waarbinnen de benoembaarheid van vrouwen in rechterlijke functies gewenst is, en tot welke wijzigingen in de Wet RO een en ander moet leiden. ${ }^{258}$ Hoewel de Hoge Raad in de wet geen beletsel ziet voor de toelating van vrouwen tot de rechterlijke macht, zijn er volgens hem wel bepaalde bezwaren tegen vrouwelijke rechters. De Hoge Raad betwijfelt met name of een vrouw, als ambtenaar van het openbaar ministerie, wel met kracht en gezag kan optreden. Als rechter zou de vrouw bovendien geconfronteerd worden met zaken van 'uiterst kieschen aard'. Ook vreest de Hoge Raad dat een gehuwde vrouw niet al haar tijd en aandacht aan de werkzaamheden van het ambt zou kunnen geven en dat daardoor het werk voor de andere leden bleef liggen en zich zou ophopen. Het is echter onredelijk, aldus de Raad, om aan deze bezwaren, die ook voor andere ambten gelden, met betrekking tot het rechtersambt beslissende invloed toe te kennen. Vrouwen moeten zelf beoordelen aan welke onaangename ervaringen zij zich willen blootstellen. Overigens verwacht de Hoge Raad dat een gehuwde vrouw, 'de onverenigbaarheid van ambt en moederschap inziende', haar ambt zal neerleggen. ${ }^{259}$

Bepaald minder positief over de benoembaarheid van vrouwen is het advies van het parket bij de Hoge Raad, gevat in een afzonderlijke nota, en meegedeeld door de procureur-generaal bij de Hoge Raad Noyon. ${ }^{260}$ De procureurgeneraal meent, net als de president van de Hoge Raad, dat voor de beantwoording van de vraag naar de geschiktheid van de vrouw in de eerste plaats deskundigen in de psychologie en de biologie in aanmerking komen. Wel wijst hij op het zijns inziens wetenschappelijk vastgestelde feit "dat de vrouw, in bepaalde tijdperken, die der zwangerschap en der menstruatie, dikwijls niet normaal is en zonder dat zij zelve zich daarvan bewust is of het voor anderen kan blijken, onderhevig kan zijn aan waanvoorstellingen, en zoo dit al niet het geval is, toch kan leiden aan ongewone prikkelbaarheid; zoodat twijfel of zij in dic tijdperken wel over de voor het uitoefenen van een rechterlijk ambt noodige onhevangenheid en onpartijdigheid beschikt, gerechwaardigd is. ${ }^{261}$ Over de bekwaamheid van de vrouwelijke rechter schrijft Noyon dat de ervaring heeft geleerd dat "in het algemeen, door de vrouwen, die zich aan de rechtspraktijk

257. Toelichting Amendement Dresselhuys, ingezonden 21 februari 1921. Bijl. Hand. II 1920-1921, nr. 75-7

258. Brief aan de Hoge Raad, Bijl. Hand. II 1920-1921, nr. 75-12

259. Brief aan de minister van justitie van 17 mei 1921, Bijl. Hand. J1 1920-1921, nr. 75-1.8

260. T.J. Noyon, Brief aan de Hoge Raad van 10 mei 1921, Bijl. Hand. II 1920-1921, nr. 75-13

261. Noyon, o.c. 
wijden, niet veel wordt gepraesteerd; op eene zeer enkele uitzondering na hebben zij zich niet boven de middelmaat weten te verheffen." Met name functies bij het openbaar ministerie en het rechter-commissariaat in strafzaken dienen volgens de p-g voor de vrouw gesloten te blijven in verband met haar 'kieschheidsgevoel'; "Terwijl de vraag naar het openstellen van den toegang tot betrekkingen, die vroeger alleen door mannen vervuld werden, voor de vrouw beoogt het opheffen van haar uit eene door ongelijkheid ontstaande minderwaardige plaats in de maatschappij, zou het waarnemen van de bedoelde functiën haar juist omlaag halen." De bijzondere geschiktheid van de gehuwde vrouw als kinderrechter kan Noyon niet inzien. Overigens meent hij dat de krachten van een vrouw in de eerste plaats dienstbaar moeten zijn aan haar gezin. $^{262}$

Naar aanleiding van de nota van de Hoge Raad neemt de Tweede Kamer - op voorstel van Kleerekoper - een motie aan (met 33 tegen 29 stemmen), waarin de Tweede Kamer uitspreekt dat het gewenst is vrouwen tot het rechterlijk ambt toe te laten en warin de regering wordt uitgenodigd ten spoedigste wettelijke voorzieningen te treffen om de toelating van vrouwen tot de rechterlijke macht mogelijk te maken. Volgens Kleerekoper is door de nota van de Hoge Raad de 'legende' over de grondwettige of wettelijke bezwaren weggenomen. ${ }^{263}$

Bij de heraadslaging over het amendement-Dresselhuys voeren sommige tegenstanders van de benoeming van vrouwen tot rechter aan dat de gehuwde vrouw thuishort in het gezin; een ander ziet in het amendement:

"de steeds meer en meer voortwoekerende epidemie in het maatschappelijk leven, waardoor men het verschil in aanleg en roeping tusschen man en vrouw geheel uit het oog verliest. (..) Wanneer dan ook de vrouw haar eigen eigenschappen uit het oog gaat verliezen, dan zien wij, dat zich juist in haar optreden het tegenovergestelde openbaart: dan zien wij dat zij juist wordt koud, haatdragend, bedilziek en soms gevoelloos. Ik zeg, dat een vrouw, die haar vrouwelijke eigenschappen verliest, zich kenmerkt door eigenschappen, welke de vrouw niet sieren, maar haar ontaarden. Het is dan ook om die reden, dat de vrouw ongeschikt is voor de positie van kinderrechter. ${ }^{264}$

262. Noyon, פ.c.

263. Hand. II $1920-1921$, p. 2518-2519

264. Scheurer, Bijl. Hand. II 1920-1921, p. 2521 
De eerlijkheid gebiedt te vermelden dat volgens de Handelingen op dat moment 'tumult' uitbreekt in de Kamer, en de voorzitter de overige leden maant om Scheurer zijn gedachten te laten uitspreken. Nadat de minister van justitie, in weerwil van het advies van de Staatscommissie en van de Hoge Raad, heeft betoogd dat het amendement strijdig is met art. 10 Wet RO wordt het door Dresselhuys zodanig gewijzigd dat het enkel de benoembaarheid van de vrouw als plaatsvervangend kinderrechter mogelijk maakt. ${ }^{265}$ De Tweede Kamer verwerpt het amendement echter met 42 tegen 31 stemmen. ${ }^{365}$

\subsubsection{Initiatief-wetsvoorstel Marchant 1922}

Een jaar later, op 6 maart 1922, dient het Tweede Kamerlid Marchant een initiatief-wetsvoorstel in tot wijziging van art. 10, vierde lid, Wet RO ${ }^{267}$ Het enige wettelijke voorschrift dat de benoembaarheid van vrouwen in rechterlijke ambten volgens de indieners in de weg kan staan, wordt daardoor uit de weg geruimd. In het voorlopig verslag wordt met name als bezwaar genoemd dat de gehuwde vrouw, die belast is met de zorg voor de huishouding, niet meer de geschiktheid voor het ambt bezit. Daarom kan volgens het voorlopig verslag het wetsvoorstel moeilijk los worden gezien van een wijziging van de Grondwet (benoemen van de vrouw voor bepaalde tijd) of uitbreiding van de gronden voor ontslag door de Hoge Raad (ontslag na huwelijk). Bovendien wordt als bezwaar tegen dit wetsvoorstel gevoeld dat de voorgestelde wijziging van art. 10 Wet RO er toe leidt dat een rechter wel met zijn vrouw, doch niet met de zuster van zijn vrouw in hetzelfde college kan zitten. ${ }^{26}$ Tijdens de openbare beraadslaging worden grotendeels dezelfde bezwaren herhaald die reeds zijn geuit tegen het amendement-Dresselhuys. De Tweede Kamer verwerpt het initiatief-voorstel van Marchant op 22 februari 1922 met 39 tegen 35 stemmen. ${ }^{269}$

265. "Een vrouw kan worden benoemd tol plaatsvervangend lid van een arrondissementsrechtbank, doch alleen mel aanwijzing ter vervanging van den kinderrechter in aangelegenheden betreffende meisjes en jeugdige mannelijke kinderen. " $\mathrm{H}$ and. II $1920-$ 1921 , p. 2530

266. Bijl. Hand. II $1920-1921$, p. 2531

267. "Het vierde lid van art. 10 van de Wet op de regterlijke orgamisatie en het beleid der justitie wordt gelezen als volgl: "De zwagerschap houdl op door hel overlijden van wie haar veroorzaakte. "OvW, Bijl. Hand. II 1921-1922, nr. 445

268. VV, Bijl. Hand. II 1921-1922, nr. 445

269. Hand. II 1922-1923, p. 1624 


\subsubsection{Preadviezen van Scheltema en Cluysenaer}

Ruim tien jaar later, in $1933^{270}$, brengt de Nationale Vrouwenraad een tweetal preadviezen uit rond het thema: De geschiktheid van de vrouw voor de rechterlijke macht. ${ }^{271}$ O.J. Cluysenaer, de president van de rechtbank Winschoten (dezelfde rechtbank die in 1915 een vrouwelijke griffier benoemd had!), noemt in zijn preadvies zowel juridische als psychologische bezwaren tegen de benoembaarheid/benoeming van vrouwen in de rechterlijke macht. Hij meent dat niet te ontkennen valt dat de wetgeving niet is ingericht op de benoeming van vrouwen tot rechterlijk ambtenaar. Argumenten daarvoor ontleent hij aan het recent verworpen wetsvoorstel van Marchant met betrekking tot art. 10, vierde lid, Wet RO en aan het ontbreken van de grondwettelijke bevoegdheid van de wetgever om te bepalen dat de vrouw na huwelijk ontslagen zou kunnen worden." Belangrijker echter dan de juridische onmogelijkheid om vrouwen te benoemen, acht Cluysenaer de onwenselijkheid dat de vrouw haar intrede in het corps van de magistratuur zal doen. Hij herhaalt de bezwaren die eerder in het parlement en daarbuiten zijn genoemd, en wijst op de diverse werkzaamheden die niet thuis kunnen worden verricht, op het 'natuurlijke schaamtegevoel' van de vrouw in zaken van delicate aard en op bezwaren van 'intersexueel psychologischen aard' bij de collegiale rechtspraak. ${ }^{273}$ Maar ook al zouden al deze bezwaren niet bestaan, dan nog moet het rechterlijk ambt volgens Cluysenaer voor de vrouw gesloten blijven "omdat (-) de gemiddelde vrouw door het wezen van haar psyche, inzonderheid door haar grootere emotionaliteit, bij den gemiddelden man ten achter staat. ${ }^{274}$ Ook Cluysenaer heeft, net als destijds Simons en Noyon (gedeelten uit) het boek Die Psychologie der Frau van de psychuloog Heymans gelezen. Opvallend is dat dezelfde passages die Simons in 1915 in zijn artikelen in het Weekblad van het Recht ten gunste van de benoeming van vrouwen aanvoert, door Cluysenaer ten nadele van een dergelijke benoeming worden opgevoerd. Cluysenaer citeert Heymans waar deze meende dat het voor veel vrouwen:

"bijna onmogelijk [is] aan een bespreking over eenige haar interesseerende vraag deel te nemen, zonder van den beginne af daarin partij te kiezen; reeds de eenvoudige vraagstelling veroorzaakt emotioneele reacties, doet het eene antwoord

270. Ik wijs er op dat vrouwen al sinds 1929 benoembaar zijn in het ambt van ambtenarenrechter. Zie MvT, Bijl. Hand. II 1928-1929, 91, nr. 2, p. 10

271. De geschiktheid der vroww voor de rechterlijke macht, preadviezen van Prof. Mr. F.G. Scheltema en Mr. O. J. Cluysenaer voor de Nationale Vrouwenraad van Nederland, 1933

272. Cluysenaer, o.c. p. 27

273. Cluysenaer, o.c. p. 28-29

274. Cluysenaer, o.c. p. 30 
sympathiek het andere antipathiek schijnen; en daarmee is niet zelden de zaak reeds beslist. Van dit oogenblik af voelt de betrokken vrouw zich niet meer als rechter, maar als advocaat; zij heeft de waarheid niet meer te vinden, maar nog slechts te verdedigen, en wanneer zij naar gronden zoekt, geschiedt dit minder, om eigen twijfel op te lossen, dan om de bedenkingen van anderen te kunnen weerleggen. ${ }^{\text {m275 }}$

Het positieve recht boezemt de vrouw weinig ontzag in, zo meent Cluysenaer bij Heymans te lezen, want de vrouw zal zich richten naar het bijzondere geval en niet naar de algemene regel. Onafhankelijk van het geldende recht zal een vrouw bij strijdige rechtsaanspraken ertoe neigen volgens haar eigen mening te kiezen. Cluysenaer vraagt zich dan ook af hoe een dergelijke sterke, emotionele partijkeuze te rijmen is met de opdracht van art. 11 Wet Algemene Bepalingen: 'De regter moet volgens de wet regt spreken; hij mag in geen geval de innerlijke waarde of billijkheid van de wet beoordelen.'

De andere preadviseur, Scheltema, ziet echter -zoals dat gaat bij preadviezengeen juridische bezwaren tegen de benoembaarheid van de vrouw in de rechterlijke macht. Noch art. 5, eerste lid, GW noch art. 10, vierde lid, Wet RO verzetten zich zijns inziens tegen een dergelijke benoeming. Ook aan de psychologie kunnen zijns inziens geen argumenten tegen de geschiktheid van de vrouw worden ontleend. Hoewel Scheltema op grond van psychologisch onderzoek verwacht dat het percentage vrouwen dat geschikt is voor het bekleden van het rechterlijk ambt geringer is dan dat van mannen, meent hij toch dat ten aanzien van dat deel der vrouwen dat wèl geschikt is voor de rechterlijke macht het ambt moet open staan. ${ }^{276}$

\subsubsection{Reacties op de preadviezen van Scheltema en Cluysenaer}

Blijkens het verslag van de op 22 april 1933 gehouden Algemeene Vergadering van de Nationale Vrouwenraad, gaf het onderwerp De geschiktheid van de vrouw voor de Rechterlijke Macht aanleiding 'tot een zeer levendige en vaak amusante gedachtenwisseling', waarbij de deelnemers zich - gezien de samenstelling van het gezelschap niet geheel verwonderlijk (aan de discussie werd volgens het verslag, behalve door de voorzitter C. Frida Katz, deelgenomen door vijf vrouwen en twee mannen) - over het algemeen aan de zijde van Scheltema scharen. ${ }^{277}$ Kritiek wordt door de deelnemers met name geleverd op de door de preadviseurs geciteerde, psychologische onderzoeken, die zij als 'niet meer van den laatsten tijd' kwalificeren. De Vrouwenraad weerlegt het

275. Geciteerd bij Cluysenaer, o.c. p. 32

276. F.G. Scheltema, o.c. p. 3-13

277. D.R.E. Oppenheimer-Belinfance, W 12591 
bezwaar dat het rechtersambt ook voor de vrouw werkzaamheden buitenshuis vordert, door er op te wijzen dat dit bezwaar ook geldt voor vele andere beroepen waarvoor de vrouw wel geschikt wordt geacht. Het 'intersexueel psychologische' bezwaar waar Cluysenaer op had gewezen - te weten: de vrees dat de rechter in raadkamer 'onder de bekoring eener lieftallige collega' zijn plicht zal verwaarlozen -, gaf volgens het verslag 'ruimschoots stof tot bestrijding en hilariteit', en werd gepareerd met de overigens weinig elegante opmerking "dat als vrouwelijke rechters zeker geen jeugdige schoonen zouden worden aangesteld, maar oudere vrouwen, die reeds door jarenlange rechtspractijk hare sporen verdiend hadden. 278

\subsubsection{Heymans over Heymans}

De leden van de Nationale Vrouwenraad zouden er goed aan hebben gedaan het boek van Heymans er zelf eens bij te pakken. In zijn boek waarschuwt deze namelijk uitdrukkelijk voor de 'rechtlijnigheid' van zijn theorie, en voor de 'gebrekkigheid 'van het wetenschappelijk onderzoek terzake. Heymans voorziet bovendien dat veel en selectief geciteerd zal worden uit zijn boek ten behoeve van 'staatkundige beschouwingen', 'wie diejenigen des Frauenstudiums, des Fruuenwahlrechts, der Berechtigung der Frau zum Bekleiden öffentlicher Amter':

"denn überall, wo starke praktischen Interessen walten, entkommt die Wissenschaft schwerlich der Gefahr, sich durch dieselben in eine oder die andere Richtung vom geraden Wege ablenken zu lassen. Darum wünsche ich nachdrücklich zu betonen, daß in diesem Buche zur "Frauenfrage" in keiner Weise Stellung genommen werden soll. Vielleicht wird man demselben Gründe für eine oder die andere der sich gegenüberstehenden Meinungen entnehmen können; ich kan nur bezeugen. daß angesichts der uneheueren Komplikation der Frage diese Gründe mir nahezu nirgends stark genug erscheinen, um für sich allein eine Entscheidung zu tragen. ${ }^{279}$

Heymans voelt bovendien het spanningsveld tussen de maatschappelijke wenselijkheid en de juridische mogelijkheid van de benoembaarheid van vrouwen in publieke ambten feilloos aan, als hij schrijft (en ik maak nu, net als de meeste critici van Heymans' boek, gebruik van de vertaling) dat "de maatschappelijke verhoudingen voor een hoogere ontwikkeling van het vrouwelijk verstand beslist ongunstig zijn.

278. Oppenleimer-Belinfante, o.c

279. G. Heymans, Die Psychologie der Frauen, 1910, p. 4-5 
"Reeds de jeugd-opvoeding en het school-onderricht is bij de meisjes veel minder dan bij de jongens er op gericht, wetenschappelijke neigingen te ontwikkelen of een wetenschappelijke denkwijze te bevorderen; inplaats van in de diepte te gaan, blijft men zooveel mogelijk aan de oppervlakte, en hecht meer waarde aan aesthetische en gemoeds-vorming, misschien zelfs aan het aanleeren van bloote beleefdheids-vormen, dan aan de ontwikkeling van het verstand. Is het meisje eenmaal volwassen, dan vond het tot voor korten tijd, en vindt het hier en daar nog, de poorten der hoogere onderwijs-inrichtingen voor zich gesloten; en daar buitendien tot de meeste ambten, voor welker vervulling academische opleiding vereischt wordt, alleen mannen worden toegelaten, ontbreekt bij de vrouwen een der belangrijkste motieven, die genen tot geestelijk werk aansporen. Komen er dan tenslotte de nog altijd niet verdwenen vooroordeelen tegen de "geleerde vrouw" bij, die in elk geval de maatschappelijke positie van het studeerend meisje niet aangenamer maken, en misschien zelfs haar kansen op een gelukkiger huwelijk beslist verminderen, dan zou men het ook bij volkomen gelijkheid van den oorspronkelijken aanieg bijna een wonder moeten noemen, indien de vrouwen in een of andere wetenschap evenveel tot stand gebracht hadden als de mannen. ${ }^{280}$

\subsubsection{Benoeming van J.C. Hudig tot kinderrechter}

Het mag terecht cynisch genoemd worden dat het boek van Heymans de zaak er voor vrouwen bepaald niet beter op maakte, maar integendeel de bestaande vooroordelen bevestigde. Nog bij het laatste, principiële debat in de Tweede Kamer over de benoembaarheid van de vrouw in de rechterlijke macht in 1946 , wordt op grond van 'zijn' bevindingen de wenselijkheid van de vrouwelijke rechter betwist. In september 1946, voorafgaand aan de openbare behandeling van de Rijksbegroting, constateert de regering dat omtrent de vraag of de rechterlijke macht voor vrouwelijke functionarissen toegankelijk dient te zijn "de meeningen vrij scherp tegenover elkander" staan. ${ }^{281}$ Volgens de regering kan men niet voorbijzien aan het feit "dat het gevoelsleven bij de vrouw in het algemeen sterker ontwikkeld was dan bij de man en dat bij den man het gevoelsleven meer onder contrôle van de verstandelijke opvattingen staat dan bij de vrouw. "282 Met name tegen de benoeming van vrouwen als rechtercommissaris, en bij het Openbaar Ministerie, bestaan bezwaren bij de regering. ${ }^{283}$ Een en ander neemt echter niet weg dat de vrouw voor bepaalde

280. G. Heymans, Psychologie der vrouwen, 1920, p. 118-119 Zie ook Heymans, Die Psychologie der Frauen, o.c. p. 108-109

281. MvA, Bijl. Hand. II 1946-1947, nr. 213-6

282. Van Maarseveen. Hand. II 1946-1947. p. 21

283. "De taak van den Officier van Justitie toch, aan de hand van wiens bevelen de politie haar opsporingstaak heeft te verrichten en die vaak in het opsporingsonderzoek handelend dient op te treden - men denke b.v. aan huiszoekingen en d'e daarmee gepaard gaande aanhoudingen van verdachten en inbeslagnemingen - is nies geschiks om door 
functies, met name voor die van kinderrechter, bij uitstek zeer geschikt wordt geacht. ${ }^{284}$ Daartegen bestaat echter weer het bezwaar dat ook de kinderrechteĩ voor het leven wordt benoemd, hetgeen de regering voor gehuwde vrouwen ongewenst voorkomt:

"De rechterlijke functie eischt den geheelen mensch. Hij die tot rechter benoemd wordt, moet zich geheel aan de rechterlijke functie kunnen wijden, niet alleen overdag, maar ook des avonds, wanneer hij zijin litteratuur en vakwetenschap moet bestudeeren. Wanneer nu de vrouw door het huwelijk een andere roeping krijgt. die haar verhindert met al haar kracht haar taak als rechter te blijven vervullen, dan kan de vrouw toch ook na haar huwelijk deze functie blijven waarnemen, hoewei zij na haar huwelijk minder geschikt wordt, die functie te vervullen. ${ }^{2285}$

Bij de openbare beraadslagingen over de gezamenlijke vaststelling van de Rijksbegroting 1946 en 1947 wordt de wens van de benoeming van vrouwen in de rechterlijke macht met name verwoord door de Tweede Kamerleden Wttewaal van Stoetwegen en Tendeloo. Wttewaal van Stoetwegen meent dat het werk van vrouwen in de voogdijraden niet zo veel verschilt van wat er op dat gebied gebeurt door de officier van justitie en de rechter-commissaris. Bovendien acht zij het vanuit het standpunt van de vrouwelijke verdachte gewenst dat zij door een vrouw wordt verhoord. ${ }^{286}$ Anderen wijzen er op dat in Nederlands-Indië sinds jaar en dag vrouwen worden benoemd bij de Raden van Justitie en bij het Hooggerechtshof ${ }^{287}$ De bezwaren tegen vrouwelijke rechters zijn grotendeels dezelfde gebleven. Genoemd worden het juridische beletsel van art. 10 Wet RO, de grondwettelijke onmogelijkheid van ontslag van de vrouw na huwelijk, en het feit dat de vrouw na benoeming voor alle rechterlijke ambten, dus niet alleen voor het ambt van kinderrechter, in aanmerking komt. $\mathrm{Zij}$ zal zodoende belast kunnen worden met de behandeling van strafzaken, of deel moeten nemen aan de berechting van ernstige zedendelicten, hetgeen volgens sommigen (Terpstra) in verband met de "grotere emotionaliteit van de vrouw" onwenselijk is. Uitgebreid verwijzen de tegenstanders naar de onderzoeken van Heymans. ${ }^{288}$ In haar memoires biedt C.W.I. Wttewaal van Stoetwegen in 1973 de histoire intime van dit debat:

"Bij de eersivolgende begroting van Justitie kwam Corry Tendeloo naar me toe en vertelde dat zij ging spreken over het benoemen van vrouwen als rechter. Want die waren er nog niet. 't Zou leuk zijn als jij er ook iets over zei.' Ik vroeg aan de

een vroww te worden verricht. "MvA, Bijl. Hand. IJ 1946-1947, 2. IV. nr. 8, p. 44

284. Van Maarseveen, Hand. II 1946-1947, p. 22

285. Hand. II 1946-1947. p. 22

286. Hand. Il 1946-1957. p. 329-330

287. Hand. II $1946-1947$, p. 336

288. Hand. II 1946-1947. p. 333-334 
heer Tilanus, wat hij er van vond als ik daarover in voorzichtige bewoordingen sprak. Na enig nadenken zei hij: 'Och ja, doe het maar. het is toch niet tegen te houden!' Toen ik aan 't woord kwam vroeg ik dus de mimister hoe hij er over dacht vrouwen als rechter te benoemen. Ik liet duidelijk merken dat mijn fractie achter me stond. In de pauze hoorde ik mr. J. Terpstra zeggen: 'Ja, ik moet daar wel tegenin gaan!' Ik was zo onnozel om niet eens te begrijpen dat dat over mijn speech ging. Maar jawel, daar kwam het: de vrouw was volgens prof. Heymans, de psycholoog, te emotioneel voor het rechterschap. (..) Ik moest, toen ik dit alles in ernst hoorde zeggen, zo lachen dat ik naar Corry Tendeloo toeliep en een beetje met haar zat na te grinniken. Niet om de heer Terpstra, die ik bijzonder waardeerde, te hinderen maar om het idee dat er in 1947 nog zulke opvattingen bestaan. In de verdere discussie werden ook door mejuffrouw Tendeloo de door de heer Terpstra gebruikte percentages in twijfel getrokken. Ik zelf nam aan de verdere discussies geen deel, ik had m'n zegje gezegd en de bres ter rechterzijde was geslagen omdat de betrokken bewindsman, Van Maarseveen, wist dat Tilanus het goed vond. Benoeming van vrouwen tot rechter werd toegezegd. De eerste vrouwelijke rechter werd mevrouw mr. J.C. Hudig. ${ }^{m 289}$

Inderdaad weegt het argument van de vermeende emotionaliteit van de vrouw voor de minister niet langer erg zwaar, ook al bestaat daarvoor een nogal dubieuze reden. Van Maarseveen wijst immers op een recent artikel in het Nederlands Juristenblad van H.R. de Zaaijer ${ }^{200}$, waarin deze het begrip 'politieke delinquenten' relativeert, en enig begrip vraagt voor de verschillende gradaties waarin 'landverraad' zich tijdens de bezetting heeft voorgedaan. Enigszins ongelukkig redeneert Van Maarseveen dat, nu "mannelijke rechterlijke ambtenaren zoo dikwijls hun hart laten schreeuwen in plaats van hun verstand te laten spreken", het bezwaar van de grotere emotionaliteit van de vrouw veel aan overtuigingskracht verloren heeft. ${ }^{291}$

J.C. Hudig zal de eerste vrouw zijn die door een rechtbank op de aanbeveling wordt geplaatst. Tijdens haar verblijf in Chicago wordt zij in 1946 per telegram gepolst door de vertrekkende Rotterdamse kinderrechter, Overwater. Tijdens haar sollicitatie bij de toen als vooruitstrevend bekend staande rechtbank Rotterdam, wordt haar met nadruk gevraagd of zij ook bereid is andere taken op zich te nemen dan het kinderrechterschap. En hoewel het punt tot dan toe in de Tweede Kamer en in de literatuur niet is aangeroerd, blijkt de rechthank ook geïnteresseerd in de vermogenspositie van de kandidate. "Misschien waren ze bang dat ik mij zou laten omkopen", aldus Hudig in 1992. Hoewel er "aanvankelijk door de oudere leden van de rechtbank nog wel raar werd opgekeken tegen een vrouw als rechter", wordt Hudig unaniem donr de rechtbank

289. C.W.I. Wttewal van Stoetwegen, De freule vertelt, 1973, p. 289-291

290. H.R. de Zaaijer, Oordeel des onderscheids, NJB 1946, p. 146-148

291. Hand. II 1946-1947, p. 1341 
aanbevolen. Toch zal de minister van justitie Van Maarseveen haar eerst een functie als griffier aanbieden. Hudig weigert echter en wordt - tot haar eigen verbazing - toch tot rechter in Rotterdam benoemd. ${ }^{292}$

Het feit dat met de benoeming in 1947 van de eerste vrouwelijke (kinder)rechter, het pleit over de benoembaarheid van de vrouw lijkt beslecht, neemt niet weg dat sommige, grondwettige bezwaren tegen de gehuwde, vrouwelijke rechter volgens de regering overeind blijven. Op de opmerking van het Tweede Kamerlid Tendeloo in 1948, dat, mocht Hudig in het huwelijk treden, "men het gerust en in vol vertrouwen aan haar zou kunnen overlaten om te beslissen of zij twee verantwoordelijkheden naast elkaar kan aanvaarden, zonder dat de ene wordt opgeofferd aan de andere ${ }^{203}$, reageert de minister in 1947:

"Men zou dit mijns inziens alleen kunnen doen, wanneer het hier ging om particuliere belangen. Het gaat hier echter ook om het Rijksbelang. Daarom is het, naar mijn oordeel, minder gewenst, dat vrouwelijke rechters gehuwd zijn. Ik heb reeds vroeger tot de geachte afgevaardigde gezegd, dat ik eigenlijk op ruimere schaal de benoeming van vrouwelijke rechters zou bevorderen, wanneer het grondwettelijke bezwaar van haar onafzetbaarheid bij huwelijk niet bestond. ${ }^{224}$

Inderdaad is de wenselijkheid van de benoeming van vrouwen in de rechterlijke macht in deze jaren nog geen gemeengoed geworden. In 1950 meent een commissie van het centrum voor staatkundige vorming nog: "Bij de vrouw spelen (-) door haar natuur, psychische en physieke factoren een rol, welke onder omstandigheden te kort kunnen doen aan de onbezonnen objectiviteit, welke voor de rechter een eerste vereiste is. "295 Ook de wettigheid van de benoeming van vrouwen is, zelfs na de benoeming van Hudig in 1946, tot twee maal toe bij de Hoge Raad betwist, op grond van art. 10 , vierde lid, Wet RO. ${ }^{296}$ In 1948 spreekt de Hoge Raad echter expliciet uit dat geen enkele wettelijke bepaling de aanstelling van vrouwen tot leden van de rechterlijke macht belet. ${ }^{297}$ Pas in 1956 wordt de Wet RO gewijzigd om aan alle misverstanden omtrent de benoembaarheid van de vrouw een einde te maken. ${ }^{208}$

292. Bron: Interview met J.C. Hudig, 8 juni 1992, Zeist

293. Hand. II, 3 december 1947

294. Hand. II, 3 december 1947

295. Reorganisatie van rechtspraak in Nederland, Centrum voor staatkundige vorming. 1950. p. 9. Men zie in dit verband ook: L.W.M.M. Drabbe, De vrouw in de rechterijke macht, in: Themis, 1963 , p. 532 e.v.

296. HR 15 oktober 1946, NJ 1947 nr. 18 en HR 1 juni 1948, NJ 1948 nr. 502

297. HR 1 juni 1948, NJ 1948 nr. 502 De annotator W. Pompe ziet in de toekomst naast de raadsheer ook de 'raadsdame' zitting nemen in de Hoge Raad.

298. Bij Wet van 28 juni $1956 . \mathrm{Stb} .377 \mathrm{kwam}$ het laatste lid van art. 10 Wet RO te luiden: "De zwagerschap houdt op door de ontbinding van het huwelijk dat haar veroorzaakte." 


\subsection{Nabeschouwing}

Dit hoofdstuk onderzocht de veronderstelling uit hoofdstuk 1 dat er een historische samenhang bestaat tussen de factoren uit het positieve recht die samen de toegang tot het rechtersambt bepalen, t.w. de benoembaarheidsvereisten en het benoemingsstelsel. De conclusie moet zijn dat een dergelijke samenhang in constitutioneel opzicht ontbreekt. De huidige voordrachtsbevoegdheid van de Tweede Kamer voor de Hoge Raad, werd 'geleend' van de staatsinrichting van de Republiek, en hoorde niet thuis in een eenheidsstaat. Het enige motief dat haar bestaan kon rechtvaardigen (namelijk het herstel van de Provinciale Hoven in 1814), verviel met het wegvallen van deze hoven in 1848. De invoering van de aanbevelingslijsten stond - althans wat de Hoge Raad en de Provinciale Hoven betreft - haaks op de ideeën die daarover ontwikkeld waren in de grondwetscommissie 1813, en de ministeriële verantwoordelijkheid werd pas veel later, namelijk in 1848, onder het benoemingsstelsel 'gelegd'. De benoembaarheidsvereisten en later (zie $\S 2.2 .2$ ) de invoering van de leettijdsgrens, konden slechts onder protest en op gespannen voet met de Grondwet worden ingevoerd. Dat het vraagstuk van de toegang tot het rechtersambt een moderne conceptie is en geen historische notie, wordt onderstreept door het feit dat de twee belangrijkste factoren die de toegang tot het rechtersambt tot in deze eeuw bepaalden: het eigen vermogen en de mannelijke sekse, nooit in de (Grond-)wet genoemd zijn. De vraag rijst, nu aan het ontstaan van het benoemings- en benoembaarheidsstelsel geen principiële visie op de toegang tot het rechtersambt ten grondslag ligt, of dat bij de verdere ontwikkelingen wel het geval is geweest. Die vraag komt in het vierde hoofdstuk aan de orde. Bovendien wordt gepoogd tendensen te signaleren met betrekking tot het vraagstuk van de toegang tot het rechtersambt. 


\section{Benoeming en benoembaarheid: ontwikkelingen na de Tweede Wereldoorlog}

\subsection{Inleiding}

In zijn boek De laatste eer - grafreden, fingeert de Nederlandse romancier Ferdinand Bordewijk in 1935 de figuur van Jhr. mr. Digitalis, president in een gerechtshof. ${ }^{1}$ Bij diens verscheiden geeft Bordewijk, die behalve schrijver ook advocaat is, een karakteristiek van een lid van de rechterlijke macht, dat hij in zijn rechtspraktijk misschien wel eens is tegengekomen:

"De goede zede der nederlandse magistratuur wil dat zij zich van het gewoel des dagelijksen levens verre houdt, zal door de duwen en elleboogstoten van het maatschappelijk verkeer de balans der gerechtigheid in haar handen niet wankelen. Jhr. Mr. Digitalis was van deze zede wel een overtuigd drager. Hij vond dat zijn omgang met anderen beperkt hoorde te blijven tot zijn eigenlijke ambtgenoten. Zelfs met de overige organen die het recht dienen, het openbaar ministerie en de balie, had hij generlei contact. Ja, de vreze zijn evenwicht te schokken weerhield hem een huiselijke haard te ontsteken en zich aan haar veelszins weldadig vuur te warmen, - hij was celibatair, minder misschien uit natuurlijke geaardheid dan uit beroepsdunk.

Gezellig aangelegd weigerde hij niettemin ieder verkeer met anderen dan 's hofs raden. Hij zeide mij eens te vrezen dat hij als rechter tegenover vrienden zou komen te staan en hun belangen. Hij vreesde voor zichzelf partijdigheid van opvatting, maar het typeerde hem dat, gelijk hij daarbij voegde, hij die partijdigheid bij zichzelf niet vreesde ten gunste van zijn vrienden, - neen, omgekeerd, was hij bevreesd dat hij uit overmaat van voorgenomen ònpartijdigheid, en om elke schiin van het tegendeel te vermijden, juist zijn vrienden eer dan vreemden in het ongelijk stellen zou. Het past ons zoveel scrupule als een hoge karakterkwaliteit op te dragen."

Het beeld dat Bordewijk in 1935 niet zonder ironie schetst is meer dan louter fantasie. "Een broodje eten in een broodjeszaak doe ik in Amsterdam wél, in Haarlem niet, zegt de president van de Haarlemse rechtbank, F.P.E. Bloemarts in 1969, "in de wet staat uitdrukkelijk dat een rechter zich niet met de partijen mag inlaten. In cafe of broodjeswinkel kun je altijd een partij van nu, morgen 
of overmorgen tegenkomen. "2 Maar ook in 1993 nog meent de scheidende vice-president van de rechtbank Maastricht, J. Wortmann: "Rechters stappen zelden spontaan een cafe binnen. Stel je voor dat ze een maand later oog in oog met een drinkebroer zitten. Wij zijn nogal huiselijk ingesteld. ${ }^{\prime 3}$

De tijd dat potentiële verdachten zich enkel in tweede of derde klas rijtuigen ophielden, ligt echter achter ons, en ook het pathetische beeld van de schichtige president die, verstoken van huiselijke haard, - in Amsterdam wél, in Maastricht niet - een kroketje (of erger) uit de muur 'trekt', heeft plaats moeten inruimen voor de banaliteit van alledag. Tegenwoordig wordt - niet in het minst door de magistraten zelf - om het hardst betoogd dat rechters toch vooral 'gewone' mensen (moeten) zijn, die fouten maken 'als iedereen'. Typerend is de beschrijving van de oud-president van de rechtbank Rotterdam, F.J.M. Nivard in 1991: "Rechters functioneren binnen de maatschappij en zullen dus met de in die maatschappij levende opvattingen en ontwikkelingen rekening moeten houden willen hun uitspraken en beslissingen in die maatschappij weerklank vinden en aanvaard worden. ${ }^{\prime 4}$ Het 'gewoon zijn' is niet alleen tot norm verheven, het is kennelijk ook een bittere noodzaak geworden. Maar nog altijd ligt er volgens Nivard gevaar op de loer van "allerhande invloeden van buiten", zoals van pressiegroepen, pers en andere media, die de onafhankelijkheid van de rechter dreigen te corrumperen. Veel keuze lijkt er echter niet te zijn. "Wie de Scylla van deze beïnvloeding vermijdt moet dan wel oppassen dat hij niet komt vast te zitten op de Charibdis van de algehele afzijdigheid van het maatschappelijk gebeuren." Nivard zet daarmee de toon voor een uiterst behoedzaam laveren tussen twee kwaden, in de zeeëngte die de rechtspraak kennelijk is; wie niet verslonden wil worden door het monster in de straat van Messina moet tegelijk zorgen dat hij niet terecht komt in de klauwen van de zeskoppige hond met de twaalf poten. Het is een haast moedeloos makende opdracht, want het verhaal wil dat zelfs Odysseus zijn zes beste makkers verloor aan een van beide. De prijs die betaald moet worden voor het 'gewoon zijn' is dus - net als die voor de ultieme distantie van weleer - hoog gebleven.

En daarmee zijn we terug bij de grafrede van Bordewijk op de eenzame jonkheer. Digitalis mag dan zijn begraven, het dilemma van Digitalis - het vermijden van zelfs maar de schijn van rechterlijke partijdigheid - is springlevend en actueler dan ooit. Het Europese Hof voor de Rechten van de Mens hanteert voor de uitleg van het begrip 'onafhankelijke en onpartijdige' rechter in art. 6 EVRM de 'objective approach'. Rechters moeten niet alleen onpartijdig zijn,

2. Bij: F. Kuitenbrouwer, Participatie houdt rechter op de hougte, NRC Handelsblad 4 oklober 1984

3. Engclien Beker, "Een rechter lijkt op een chirurg", de Limburger 3 juli 1993

4. F.J.M. Nivard, De goede rechter, in: G.P. Hoefnagels, De goede jurist, 1991, p. 17 
ze moeten ook de schijn vermijden dat ze partijdig zouden kunnen lijken. In dit hoofdstuk, dat de verdere ontwikkeling van het vraagstuk van de toegang tot het rechtersambt beschrijft, zal blijken dat met name dat laatste aspect van onpartijdigheid, na de Tweede Wereldoorlog sterk aan belang heeft gewonnen.

\subsection{De toegang tot het rechtersambt na de Tweede Wereldoorlog}

Vanaf de vorige eeuw tot in de jaren vijftig werden rechterlijke ambtenaren gerecruteerd uit de substituut-griffiers bij de rechtbanken (c.q. de griffiers en de substituut-griffiers bij de kantongerechten) en uit buitenstaanders. De recrutering, selectie en opleiding van rechterlijke ambtenaren was een zaak die vrijwel geheel berustte bij de rechterlijke macht. De jonge jurist werd na zijn afstuderen eerst als volontair zonder enige vergoeding bij de griffie van een rechtbank geplaatst. Na enkele jaren als waarnemend-griffier dienst te hebben gedaan, werd hij tot substituut-griffier benoemd, en dan volgde, tenzij bleek dat hij daarvoor apert ongeschikt was, de benoeming tot rechter. Tegen het volontairstelsel bestonden in de Tweede Kamer reeds voor de oorlog grote bezwaren. Men meende dat van de tientallen volontairs, die gedurende een groot aantal (vijf à zes, soms langer) jaren een volledige dagtaak verrichtten in de hoop op een benoeming tot rechter, misbruik werd gemaakt. Het substituutgriffierschap bood bovendien onvoldoende kwaliteitswaarborgen. ${ }^{5}$ De regering had immers de "morele verplichting" om ook "middelmatige krachten" tot rechter te benoemen. ${ }^{6} \mathrm{Zij}$ wenste overigens geen verantwoordelijkheid te dragen voor dergelijke slechte benoemingen, en schoof het probleem van de volontairs door naar de rechtscolleges, die zij voor de aanstelling van de volontairs verantwoordelijk achtte. ${ }^{7}$

Het mag niet verbazen dat het recruteringsstelsel - dat uitging van de vooronderstelling van eigen kapitaal van de kandidaat - leidde tot een - naar herkomst - eenzijdig samengestelde rechterlijke macht. Die eenzijdigheid werd, behalve door het volontairstelsel, veroorzaakt doordat de universitaire studie praktisch slechts toegankelijk was voor een bovenklasse uit de samenleving. Het volontair-stelsel vormde daarom een gemakkelijk doelwit voor verdachtmakingen in de gevoelige periode vlak na de Tweede Wereldoorlog. "Verscheidene leden" van de Tweede Kamer, zo staat in het voorlopig verslag bij de Rijksbegroting 1946, meenden,

5. Zie bijvoorbeeld een anonymus in NJB, 1929, De samenstelling onzer Rechterlijke Macht, p. $550-552$

6. Zie bijvoorbeeld het voorlopig verslag van de Tweede Kamer bij de begroting voor 1934 , Bijl. Hand. II 1933-1934, Bijlage A, 2, IV, 7, p. 7

7. MvA, Bijl. Hand. II 1937-1938, Rijksbegroting 1938, p. 27 
"dat huns inziens in de practijk bepaalde groepen der bevolking nog te veel van het rechtersambt zijn uitgesloten. Sommigen hunner waren van oordeel, dat dit er mede toe heeft bijgedragen, dat de rechterlijke macht zich gedurende de bezetting te veel heeft gedragen als een onaandoenlijke en afgesloten kaste, die in den strijd tegen den bezetter onvoldoende heeft meegeleefd. Ook meenden zij, dat dit uitspraken, zooals er den laatsten tijd verscheidene gevallen zijn, die den indruk wekken van een zekere "klassejustitie" (-), bevordert. ${ }^{\text {8 }}$

De gewijzigde economische verhoudingen na de Tweede Wereldoorlog brengen echter verandering in het traditionele selectiepatroon, als een tekort dreigt aan rechterlijke ambtenaren." "Niet langer is de vraag alleen maar: "Hoe krijgen wij de besten?", zij zal weldra zijn: "Hoe krijgen wij er genoeg?" en daardoor meer dan ooit: "Hoe trekken wij van ieder het best partij?", aldus G.E. Langemeijer in 1945 in het Nederlands Juristenblad. ${ }^{10}$ Konden rechterlijke ambtenaren voorheen nog "aan eigen vermogen een zekere onverschilligheid voor hun salaris (-) ontleenen", onder de nieuwe omstandigheden verwacht Langemeijer niet langer dat men bereid is 'te beleggen' in eigen werkkring. Langemeijer baseert zijn verwachting, op de bezoldigingsstructuur en de verminderde aantrekkingskracht van het rechtersambt. De 'pijnlijkste' reden is echter het gedaalde aanzien van de rechterlijke macht. De verwijten die tijdens en na de oorlog naar de rechterlijke macht zijn geslingerd, hebben volgens Langemeijer weinig overgelaten van het hoge voetstuk van de 'noblesse de robe'. ${ }^{11}$ Daarnaast is het rechterswerk volgens Langemeijer ook 'relatief onbelangrijker', en daardoor minder aantrekkelijk geworden: "Het tempo der wetgeving is stormachtig geworden, haar omvang onvergelijkbaar grooter dan vroeger, het practische en principieele belang van de beslissingen der administratie en haar vrijheid daarbij zijn sterk vermeerderd. (..) Op tal van plaatsen kan de jurist zich meer in het centrum van het rechtsgebeuren voelen dan in de rechtszaal. "12 De door Langemeijer geschetste problematiek, is echter - zoals hijzelf ook aangeeft - betrekkelijk. De bezoldiging van substituut-griffiers en de overige leden van de rechterlijke macht is weliswaar lager dan wat in het bedrijfsleven verdiend kan worden, maar vaak toch nog vele malen hoger dan wat

8. VV. Bijl. hand. II 1946-1947, Rijksbegroting 1946, hoofdstuk IV, p. 23 Zie ook de voorstellen van het Genootschap voor den Rechtsstaat uit 1940 voor het aantrekken van buitenstaanders voor de Hoge Raad $\$ 3.9$

9. Zie het voorlopig verslag bij de Rijksbegroting 1956, Bijl. Hand. II, 1955-1956, p. 24

10. G.E. Langemeijer, De toekomst van de rechterlijke macht, NJB, 1945, p. 281

11. Zie hierover P.E. Mazel, In naam van het recht De Hoge Raad en de Tweede Wereldoorlog, 1984

12. Langemeijer, o.c. p. 284 
elders in overheidsdienst verdiend wordt. ${ }^{13}$ Ook het recruteringsprobleem is betrekkelijk. Terecht werpt men Langemeijer tegen dat hij niet gedacht heeft aan de grote categorie vrouwelijke juristen die op dat moment nog niet voor benoeming in de rechterlijke macht in aanmerking komt (zie $\$ 3.9) .{ }^{14}$

\subsection{Commissie-Verdam}

De regering deelt de gedachte van Langemeijer, dat met betrekking tot de selectie, de opleiding en de verdere voorbereiding van rechterlijke ambtenaren nieuwe wegen moeten worden ingeslagen. De bestaande opleiding acht zij niet veelzijdig genoeg; gezocht moet worden naar een verruiming van de 'gezichtskring' van betrokkenen. De regering stelt voor om aankomende rechterlijke ambtenaren bij de griffie en het OM te detacheren, om een diepere kennismaking omtrent inrichting en werkwijze van politie, gevangeniswezen, reclassering en kinderbescherming te verwezenlijken. Ook wenst de regering greep te krijgen op de selectie van rechterlijke ambtenaren; onvoldoende was in het verleden de "beslissende invloed van de autoriteit, die in een later stadium voor de verschillende benoemingen staatsrechtelijk verantwoordelijk" verzekerd geweest. ${ }^{15}$ Bij besluit van de minister van justitie van 19 december 1949 wordt de commissie-Verdam ingesteld, die tot taak krijgt het opleidingsvraagstuk te onderzoeken. ${ }^{16}$ Bij de installatie van de commissie, neemt haar voorzitter reeds een voorschot op de uitkomst van het rapport. Verdam benadrukt de maatschappelijke vorming van de rechterlijke ambtenaar, die moet worden gerealiseerd als onderdeel van de ambtelijke loopbaan. "Magistraat zijnde neemt hij zelf weinig actief deel aan het maatschappelijk leven. Krijgt hij de gelegenheid om zich gedurende enige tijd volop in te leven in dat maatschappelijk leven als zelfstandig werker, dan kan dit - vooral nu het geschiedt kort na zijn universitaire studie - aan zijn vorming een bepaalde richting geven. ${ }^{\prime 17}$ De commissie-Verdam zal uiteindelijk verbeteringen zoeken in twee hoofdrichtingen: in de selectie van rechterlijke ambtenaren en in de scholing die de gekozenen zullen ondergaan. Opvallend is de voorkeur van de commis-

13. Op de Rijksbegroting voor 1940 wordt voor een substituut-griffier genaiddeld 5000 .- per jaar uitgetrokken, voor een rechter arrondissementsrechtbank $6000,-$, voor een raadsheer gerechtshof 7000.-. De directeur van een strafgevangenis daarentegen verdiende in 1940 $3000,-$, een huismeester $1700,-$ en een kok 1400,-

14. Zie: E.C. Simons, De toekomst van de rechterlijke macht. NJB, 1946. p. 222 Overigens reageert Langemeijer hierop met het verweer dat hij het denkbeeld van het benoemen van vrouwen weliswaar toejuicht, maar het onder de huidige omstandigheden nog niet realistisch vindt. G.E. Langemeijer, NJB, 1946, p. 222

15. Rede van de minister van justitie, gehouden bij de installatie op 9 februari 1950 van de commissie-Verdam, gepubliceerd in NJB, 1950, p. 209.210

16. Besluit van 19 december 1949,8 e afdeling B, Kabinet No. $6810, T 16$

17. Installatierede, o.c. p. 210 
sie voor 'buitenstaanders' in de rechterlijke macht: "De allerbeste candidaat voor het rechtersambt is zeker hij, die in de volle strijd des levens tegelijkertijd de rijkdom aan ervaring heeft weten op te doen en de zuiverheid en vastheid van karakter heeft weten te bewaren, die voor het rechtersambt wenselijk zijn. ${ }^{m 18}$

De commissie-Verdam doet een reeks voorstellen om aan de geschetste problematiek tegemoet te komen. Door voor het griffiersambt niet langer de rechtenstudie te eisen, zou een groot aantal rechtersvacatures ontstaan, die kunnen worden opgevuld met advocaten en juristen uit de overheidssector en het hedrijfsleven. Ook stelt de commissie een bijzondere pensioenregeling voor buitenstaanders voor, die personen uit het bedrijfsleven of uit vrije beroepen de mogelijkheid biedt een behoorlijk pensioen op te bouwen. Nieuw is het voorstel van de commissie voor een specifieke opleiding voor rechterlijke ambtenaren. Pas afgestudeerde juristen, die voor een benoeming bij de rechterlijke macht in aanmerking wensen te komen en die 'op grond van de universitaire gegevens' geschikt schijnen, zullen worden aangenomen als rechterlijke ambtenaar in opleiding, en afwisselend te werk worden gesteld op een griffie of parket. Ondanks de voorkeur van de commissie-Verdam voor rechterlijke ambtenaren die met twee benen in het maatschappelijk leven staan, bestaat er bij de commissie duidelijk koudwatervrees voor haar eigen voorstellen, met name wat betreft het aantrekken van buitenstaanders, "omtrent wie het Departement van Justitie moeilijk betrouwbare gegevens zal kunnen verkrijgen. Het gevaar bestaat dan, dat aanbeveling bij voorbeeld door politieke relaties of zelfs door chefs, die zelf van de betrokkenen ontslagen wensen te worden, kortom aanbevelingen uit onzakelijke motieven veel vaker dan thans zullen voorkomen."

\subsection{Het Permanent College van advies}

Het rapport van de commissie-Verdam ligt aan de basis van de Nota inzake de rechterlijke macht uit $1953 .{ }^{19} \mathrm{Hierin}$ worden met name voorstellen gedaan met betrekking tot de rekrutering van rechterlijke ambtenaren. Als richtsnoeren voor het toekomstig beleid noemt de regering hierin onder andere de verminde-

18. Tweede rapport-Verdam, Bijl. Hand. II 1953-1854, 3200, hoofdstuk IV, nr. 8, p. 56

19. Nota inzake de rechterlijke mach, Bijl. Hand. II 1953-1854, 3200, hoofdstuk IV, nr. 8. Ik wijs hier nog op het rapport van de werkgroep-Langemeijer die tot taak kreeg een technische uitwerking in details te zoeken voor de voorstellen van de commissieVerdam. Ik zie af van een bespreking van het rapport-Langemeijer, dat het overgrote deel van de desiderata van de commissie-Verdam deelt. Zie: rapport van de werkgroepLangemeijer, Bijl. Hand. II 1953-1954, 3200, hoofdstuk IV, nr. 8, p. 31 e.v. 
ring op korte termijn van het aantal substituut-griffiers en gegradueerde waarnemende griffiers, het regelen van de ambtelijke status van de secretaris van de rechter en het regelen van de ambtelijke status van de jonge rechterlijke ambtenaren in opleiding. Deze Nota resulteert in 1954 in een wetsvoorstel dat onder andere de mogelijkheid opent voor een meer doeltreffende opleiding van rechterlijke ambtenaren. ${ }^{20}$ De twee wegen die traditioneel naar het rechtersambt leidden (via de griffie en als buitenstaander), blijven onder het nieuwe stelsel bestaan, maar de selectie en de opleiding van de toekomstige substituutgriffiers zal verbeterd worden. Daartoe acht de regering het allereerst noodzakelijk dat het aantal juristen op de griffie wordt verminderd. Indien de vooruitzichten voor een benoeming tot rechter na een loopbaan ter griffie zeer gering zijn, zal de aantrekkingskracht van de griffie-functies op de bekwamen volgens haar klein zijn. ${ }^{21}$ Voorts stelde de regering voor, in aansluiting op de bevindingen van de Nota inzake de rechterlijke macht, een tweetal nieuwe rangen in te voeren, die van gerechtssecretaris bij de arrondissementsrechtbanken en de kantongerechten, en die van secretaris bij een arrondissementsparket. ${ }^{22}$ De regering beoogt hiermee in de wet bepaalde mogelijkheden te openen inzake de opleiding van jonge juristen. De gerechtssecretaris zal - anders dan door de commissie-Verdam is voorgesteld - ambtenaar in tijdelijke dienst zijn. Pas na een benoeming als substituut-griffier kan een vast dienstverband worden aangegaan. De uiteindelijke vormgeving van de opleiding zou naderhand "geleid door practische ervaring" bij algemene maatregel van bestuur worden vastgesteld. ${ }^{23}$

Typerend voor de houding van de Tweede Kamer ten aanzien van het opleidings- en selectievraagstuk in de jaren vijftig, is, zo zal hieronder blijken, dat dergelijke onderwerpen volgens haar allereerst thuishoren bij de rechterlijke macht zelf. Als de Tweede Kamer zich enkele jaren later, in 1967, beklaagt over het gebrek aan inzicht in, en informatie over de samenstelling van de rechterlijke macht, vergeet zij dat zijzelf in de eerste plaats verantwoordelijk is geweest voor die situatie. In 1954 staat voor de Tweede Kamer voorop, dat gegadigden moeten worden opgeleid in "eendrachtige samenwerking met", en "in de geest en in de sfeer van" de rechterlijke macht. Waarschijnlijk om enige vaart te zetten achter die eendrachtige samenwerking tussen regering en rechterlijke macht, stelt de Tweede Kamer een bij de wet geregeld adviescollege voor, dat bij de selectie een 'belangrijke', en bij de opleiding een 'overwegende

20. MvT, Bijl. Hand. II 1954-1955, 3705, nr. 3, p. 5

21. MvT, Bijl. Hand. II 1954-1955, 3705, nr. 3, p. 7

22. Ontwerp-art. 59d Wet RO: "Onze Minister van Justitie kan gerechissecretarissen bij een arrondissements-rechtbank of kantongerecht en secretarissen bij een arrondissementsparket benoemen. " Bijl. Hand. II 1954-1955, 3705, nr. 2

23. MvT, Bijl. Hand. II 1954-1955, 3705, nr. 3, p. 8 
invloed' heeft, en dat geheel of voor het grootste deel, uit leden van de rechterlijke macht is samengesteld. Op de instelling van een dergelijk college is eerder aangedrongen door de Nederlandse Vereniging voor Rechtspraak. ${ }^{24}$ Bij Nota van wijzigingen volgt de regering de suggestie van een in te voeren Permanent College van advies. ${ }^{25}$ Dit College, waarvan de leden door de regering worden benoemd, is gevestigd in Den Haag, en adviseert de minister van justitie op diens verzoek of ambtshalve inzake de rechterlijke organisatie. De regering benadrukt dat het College slechts een adviserende bevoegdheid zal toekomen. "De uiteindelijke verantwoordelijkheid voor het benoemings- en het personeelsbeleid - $n l$. de individuele keuze van de te benoemen ambtenaar en bepaling van de totale bezetting - is (-) een zaak van de Regering. "26

Problemen rijzen in de Tweede Kamer als een amendement-Van Rijckevorsel voorstelt de benoeming van de leden van het College niet door de Kroon maar door de Hoge Raad te laten geschieden. ${ }^{27}$ De voorstellers van het amendement achten het beter de gehele wijze van benoeming en samenstelling van het College aan de rechterlijke macht over te laten. In hoofdzaak gaat het er volgens hen om dat de adviezen komen van een college dat het vertrouwen van

24. VV, Bij1. Hand. II 1954-1955, 3705, nr. 4. p. 2

25. Na artikel $59 \mathrm{e}$ Wet RO wordt ingevoegd:

"Art. 59j. Er is een Permanent College van advies in zake de rechterlijke organisatie, gevestigd te 's-Gravenhage.

Art. $59 \mathrm{~g}$. Het College bestaat uit tenminste elf en ten hoogste vijftien leden.

De leden worden door Ons benoemd en ontslagen. De meerderheid van de leden bestaat uit leden van de Hoge Raad, de gerechtshoven en de arrondissementsrechtbanken en uit kantonrechters. Een van deze leden wordt door Ons tot voorzitter aangewezen.

Aan het College kan door Onze Minister van Justitie een secretaris worden toegevoegd. Art. 59h. Het College dient Onze Minister van Justitie op diens verzoek of ambtshalve van advies in zake de rechterlijke organisatie.

Het College wordt gehoord over de vastsielling van een algemene maatregel van beshur, bedoeld in ant. 59e."

Nota van wijzigingen, Bijl. Hand. II 1954-1955, 3705, nr. 7

26. MvA, Bijl. Hand. II 1954-1955، 3705, nr. 5. p. 4

27. Amendement-Van Rijckevorsel op ontwerp-art. 59 h Wet RO:

1. Het College bestaat uit tenminste elf en ten hoogste vifftien leden, die door de Hoge Raad der Nederlanden worden benoemd en ontslagen.

2. De meerderheid van de leden hestaat uit raadsheren van de Hoge Raad, raadsheren van de gerechtshoven, rechters van de arrondissements-rechtbanken en kantonrechters. Een van deze leden wordt door Ons tot voorzitter benoemd.

3. Het College komt tenminste eenmaal 's jaars in vergadering bijeen en doet vóór I april aan Onze Minister van Justitie verslag van zijn werkzaamheden. Onze Minister brengt dit verslag ter kennis van beide Kamers der Staten-Generaal. Bijl. Hand. II 19541955, 3705, nr. 13. N.B. het derde lid wordt in een tweede amendement-Van Rijckevorsel ingetrokken; Bijl. Hand. II 1954-1955, 3705, nr. 14 
de rechterlijke macht zelf heeft. ${ }^{28}$ Waarschijnlijk wordt hiermee tegemoetgekomen aan bezwaren uit de rechterlijke macht, die de Nota niet onverdeeld gunstig ontvangen heeft. De minister van justitie (Donker) ontraadt het amendement echter ernstig. Volgens hem moeten in het College, naast leden van de rechterlijke macht, ook vertegenwoordigers van de rechterlijke macht 'in ruime zin' worden opgenomen. Hij denkt daarbij aan vertegenwoordigers van het openbaar ministerie, van de griffie, van de advocatuur en van het ministerie van justitie. Donker noemt het 'onredelijk' dat de Hoge Raad ook de benoeming van deze leden wordt opgedragen, te meer omdat zo'n benoeming niet onder de ministeriële verantwoordelijkheid valt. Tenslotte acht de minister het onjuist dat het College in de zin van het amendement adviezen aan de beide kamers uitbrengt; een verschil tussen een advies van het college en een besluit door de regering zou dan in het openbaar ter discussie kunnen komen. ${ }^{29}$ De bezwaren van de regering mogen echter niet baten. De Tweede Kamer neemt het amendement aan met 44 tegen 28 stemmen. ${ }^{30}$ Ook het tweede amendement-Van Rijckevorsel, dat het College van advies de bevoegdheid geeft om adviezen te geven aan de Staten-Generaal ${ }^{31}$, en dat eveneens door de minister is ontraden, wordt aangenomen, met 44 tegen 26 stemmen. ${ }^{32}$ De wijzigingen wegen echter zo zwaar voor de regering dat zij enige tijd later het gehele wetsontwerp, dat inmiddels bij de Eerste Kamer ligt, intrekt.

\subsubsection{Afspiegeling}

Het debat over de samenstelling en de bevoegdheden van het Permanent College van advies, kan niet goed worden begrepen los van de discussie die op dat moment speelt over de afspiegeling van verschillende politieke en religieuze stromingen in de rechterlijke macht. Al voor de oorlog komt men in de Rijksbegroting klachten tegen over de 'ondervertegenwoordiging van katholieken en socialisten in de magistratuur. ${ }^{33}$ In 1955 houdt het Nederlands Juristenblad een pleidooi voor een evenwichtige en evenredige verdeling van verschillende richtingen; "wie zich met open oor in verschillende kringen beweegt, weet van

28. Van Rijckevorsel, Hand. II 1954-1955, p. 2916

29. Hand. II $1954-1955$, p. 2918

30. Hand. II 1954-1955, p. 2920 N.B. van de aanwezige leden van de vaste Kamercommissie stemmen vijf voor en twee tegen het amendement.

31. Amendement-Van Rijckevorsel op ontwerp-art. 59h Wet RO: "Het College kan zijn adviezen ter kennis brengen van de beide kamers der Staten-Generaal. "Bijl. Hand. II 1954-1955, 3705, nr. 14 Dit amendement wijkt overigens af van het oorspronkelijke: "Het College komt tenminste eenmaal 's jaars in vergadering bijeen en doet vóór 1 april aan Onze Minister van Justitie verslag van zijn werkzaamheden. Onze Minister brengt dit verslag ter kennis van beide Kamers der Stalen-Generaal."

32. Hand. II 1954-1955, p. 2921

33. Zie bijvoorbeeld: VV, Bijl. Hand. II 1934-1935, nr. 2, IV 8, p. 10 
hoeveel belang dit vraagstuk is, enerzijds voor het vertrouwen in de rechterlijke macht, anderzijds voor de gevoelshouding van de leden der rechterlijke macht tegenover de andere staatsorganen. ${ }^{134}$ In dit verband kan het stelsel van aanbevelingen tot een beperktheid van blik leiden, waardoor "traditie, sfeer en stijl (..) een enkele maal tot een wat uiterlijke beoordeling van een persoonlijkheid kunnen leiden, nauwe persoonlijke aanraking tot enige overwaardering van anciënniteit." Het voorgestelde College van Advies wijst het NJB daarom af. In plaats daarvan dient de minister van justitie, die door zijn functie "allicht meer geneigd [is] oog te hebben voor vertegenwoordiging van richtingen", op het aanbevelingenstelsel een correctie te brengen. "Het is een labiel evenwicht dat aldus ontstaat, maar een dat elk ogenblik in de parlementaire verantwoordelijkheid tegenover wisselende meerderheden ruime correctiemogelijkheden bevat. ${ }^{135}$

De redactie van het NJB loopt in 1955 met haar pleidooi voor een actief benoemingsbeleid ver vooruit op een discussie die eigenlijk pas in onze tijd van de grond komt. Maar ook het benoemingsperspectief waartegen zij dat beleid afzet, is opvallend modern. Juridische en politieke vraagstukken zijn volgens haar geen tegenstellingen, maar juist sterk verweven, en daarom heeft het NJB een voorkeur voor rechters,

"die nog andere inspiratie hebben dan alleen de bedoeling van de wetgever (-) benoeming zonder politieke invloed betekent niet benoemden zonder politieke overtuiging. (-) Recht en politiek hebben de moeilijkste twisturagen gemeen. Het is ondenkbaar dat iemand voor het rechterschap in aanmerking zou komen, die ten aanzien van die vragen niet innerlijk partij zou hebben gekozen, al moge hij dan de uiterlijke vormen der politiek nog zo ver van zich wijzen. ${ }^{n 36}$

Het probleem van de afspiegeling, zoals dat door het Nederlands Juristenblad wordt voorgesteld, komt bij de Rijksbegroting voor 1956, niet uitdrukkelijk ter sprake. Juist het tegenovergestelde, de toenemende invloed van het departement van justitie op de organisatie van rechtspraak en de rechterlijke macht, wordt gehekeld. "Er is (..) een algemeen streven merkbaar om de macht van ambtenaren uit te breiden. Bemoeit de minister zich niet te veel met de afzonderlijke colleges? (..) Men schijnt op het Departement de rechterlijke macht weleens als een "buitendienst" van het Departement te beschouwen. ${ }^{37}$

34. De vastgelopen herziening van de rechterlijke organisatie, redactioneel, NJB, 1955. p. $641-652$

35. Redactioneel NJB 1955, o.c. p. 647

36. Redactioneel NJB 1955, o.c. p. 647

37. VV, Bijl. Hand. II 1955-1956, 4100, nr. 9, p. 2 
Een vrijwel identiek wetsvoorstel, nu zonder het Permanent College van advies, passeert in 1956 de beide kamers. ${ }^{38} \mathrm{Bij}$ de beraadslaging over dit voorstel in de Tweede Kamer dreigt - alweer - een amendement-Van Rijckevorsel roet in het eten te gooien. Het amendement beoogt onder andere de bepaling over de amvb met de voorschriften voor de opleiding (en vorming) van de (gerechts)secretarissen te schrappen. ${ }^{39}$ Volgens Van Rijckevorsel zijn er onvoldoende waarborgen dat de rechterlijke macht in de toekomst invloed heeft op de selectie en opleiding van kandidaten ${ }^{40}$, en hij vreest dat de regering met de amvb de administratie, opleiding en vorming van de rechterlijke macht naar zich toe zal trekken. ${ }^{41}$ De minister van justitie (Van Oven), beducht voor de gevoeligheid van de Kamer op dit onderdeel, weet na een schorsing het verzet tegen het gewraakte artikel in de kiem te smoren, door het afleggen van een verklaring waarin hij de voorgenomen amvb toelicht. ${ }^{42}$ Kandidaten zullen in de toekomst met advertenties worden opgeroepen te solliciteren, en op aanbeveling van de rechtbanken worden geselecteerd voor de opleiding. Na een proeftijd van zes maanden bij de zittende en staande magistratuur beslist een selectiecommissie of de betrokkenen tot de opleiding worden toegelaten. Daarna

38. Wet van 28 juni 1956 , houdende wijziging in de rechterlijke organisatie, Stb. $1956 \mathrm{nr}$. 377: voorzover hier relevant:

Art. 59d. Onze Minister van Justitie kan gerechtssecretarissen bij een arrondissementsrechtbank of kantongerecht en secretarissen bij een arrondissementsparket benoemen. Art. 59e. Bij algemene maatregel van bestuur kunnen voorschriften worden gegeven met betrekking tot de opleiding en vorming van de in artikel 59 genoemde amblenaren, die de graad of hoedanigheid bezitten als bedoeld in artikel 48.

Onze Minister van Justitie is bevoegd hun ten behoeve van die opleiding en vorming verlof met behoud van bezoldiging te verlenen voor ten hoogste twee jaren.

N.B. In art. $59 \mathrm{e}$ Wct RO wordt thans van 'opleiding en vorming' gesproken. De achtergrond hiervan is tamelijk prozaïsch. Het voorstel van wet nr. 3705 sprak oorspronkelijk alleen van 'opleicling'. Een amendement Van-Rijckevorsel (3705 nr. 14) wijzigt dit in 'vorming', opdat in de wet beter tot uitdrukking komt dat goede rechters niet worden gevormd 'door zich getrouwelijk aan bepaalde stelsels van opleiding' te 'onderwerpen', maar door 'zelfwerkzaambeid'. De Tweede Kamer nam het amendement zonder hoofdelijke stemming aan, ondanks kritiek dat het begrip 'vorming' een exclusief rooms-katholieke betekenis heeft, die niet geldt voor protestanten en niet-gelovigen (Tendeloo) en dat beide begrippen moeilijk te karakteriseren zijn (minister Donker). In het nieuwe voorstel van wet (4244) is in ar. 59e blijkbaar gekozen voor de oer-Hollandse compromisgedachte door 'opleiding en vorming' naast elkaar te noemen, waarbij men de aldus geconstrueerde contradictie (onderwerping door zelfwerkzaamheid, zelfwerkzaamheid door onderwerping?) blijkbaar voor lief heeft willen nemen.

39. Bijl. Hand. II 1955-1956, 4244, nr. 7

40. Hand. II 1955-1956, p. 2614

41. Hand. II 1955-1956, p. 2615

42. Hand. II 1955-1956, p. 2616 
volgt een aanstelling tot gerechtssecretaris voor een periode van twee jaar en vervolgens plaatsing als secretaris op het parket bij een officier van justitie voor twee jaar. Na deze diensttijd van vier jaren volgt een stage. ${ }^{43}$ Zonder hoofdelijke stemming wordt het voorstel daarop door de Tweede Kamer aangenomen. ${ }^{43}$

Tot dan toe heeft de Eerste Kamer nog geen gelegenheid gehad zich uit te spreken over het selectie- en opleidingsvraagstuk. Zij laat zich, anders dan de Tweede Kamer, niet meteen overtuigen door de toelichting van de minister over de voorgenomen amvb. Anders dan in de Tweede Kamer komt in de Eerste Kamer de gedachte van een afspiegeling in de rechterlijke macht - zoals die eerder door het Nederlands Juristenblad onder woorden is gebracht - wel aan de orde. Terwijl sommigen menen dat de invloed van de rechterlijke macht op de opleiding van jonge juristen onvoldoende is verzekerd, zien anderen juist nadelen in die invloed, omdat het esprit de corps in de weg kan staan aan een veelzijdige benoemingspolitiek. Voor hen is niet aan de orde de vraag "of men meent met een gegadigde tot een aangename samenwerking te komen" maar vooral of bij de samenstelling van de rechterlijke macht voldoende rekening wordt gehouden met "de eisen van het maatschappelijk leven en van een rechtvaardige verdeling van de ambten". Daarom dient het zwaartepunt bij benoemingen bij de centrale overheid te liggen. De voorgestelde regeling voor de rechterlijke macht zou volgens hen slechts leiden tot een afgezonderde, gesloten kaste van specialisten, die het contact met de maatschappij ontbeert. ${ }^{45}$ Diepenhorst zegt hierover bij de beraadslaging:

"Specialisten menen vaak alles te weten. Ieder kent wel uit eigen ervaring moeilijk genoeg te waarderen figuren, die echter voor een bepaalde werkzaamheid volledig onbruikbaar zijn, omdat zij, hun kennis met klokkende adamsappel er als het ware uitspetterend, slechts één kant en niet meer dan één kant van de zaak zien. (..) Tegen enige kennis van het gevangeniswezen, van de psychiatrische behandeling van delinquenten, of, omiets geheel anders tenoemen, van het forceren van brandkasten of van het plegen van schriftvervalsing - natuurlijk moet het in de laatste gevallen een kennis met mate zijn - heb ik geen enkel gevaar. Kennis van het maatschappelijk leven, van de handel, van hetgeen in bepaalde kringen economisch gebruikelijk is, zij dient er zelfs overvloedig te zijn. ${ }^{n 46}$

43. Hand. Il 1955-1956, p. 2616

44. Hand. Il 1955-1956, p. 2617

45. VV. Bijl. Hand. 1 1955-1956, 4244, nr 200, p. 2

46. Diepenhorst, Hand. I, p. 2396. 
Ondanks haar twijfels neemt de Eerste Kamer het wetsvoorstel op 26 juni 1956 zonder hoofdelijke stemming aan. ${ }^{47}$ Enige maanden later verschijnt het Opleidings- en vormingsbesluit R.O. ${ }^{48}$ Dit besluit brengt, zoals te verwachten, weinig nieuws omdat de hoofdlijnen reeds door de minister van justitie aan de Tweede Kamer (zie hiervoor) zijn meegedeeld. Zes jaar later echter, in 1962 wordt het Besluit ingrijpend gewijzigd. ${ }^{49}$ In grote lijnen kan men zeggen dat het besluit van 1962 de procedure van 1956 niet alleen vereenvoudigt, maar dat ook de invloed van de rechterlijke macht enigszins ten opzichte van het ministerie van justitie vermindert. In zoverre is de vrees van de Tweede Kamer terecht gebleken. Sinds 1984 bepaalt art. 59i Wet RO dat personen die de graad of hoedanigheid bezitten als bedoeld in artikel 48, eerste lid, Wet RO door de minister van justitie kunnen worden aangesteld als rechterlijk ambtenaar in opleiding. Volgens het tweede lid van art. 59i Wet RO kunnen bij algemene maatregel van bestuur voorschriften worden gegeven met betrekking tot de selectie, de aanstelling, de opleiding en andere aangelegenheden, de rechtspositie van de rechterlijke ambtenaren in opleiding betreffende. Het wetsvoorstel werd in 1984 door de Tweede en Eerste Kamer zonder beraadslaging aangeno$m \mathrm{n}^{50}$, en dat was - vergeleken met de commotie die eerder ontstond rondom de wetsvoorstellen voor de functies van (gerechts-)secretaris (zie hiervoor) opvallend, te meer daar art. 59i tweede lid, Wet RO de gehele inrichting van de raio-recrutering, selectie en opleiding expliciet overlaat aan de regering. ${ }^{51}$

\subsection{Vertrouwenscrisis rechterlijke macht}

Bij de omschrijving van haar voorgeschiedenis stelt de Staatscommissie Herziening Rechterlijke Organisatie in 1984 tamelijk voorzichtig dat deze is gelegen "in de kritick die zich in de jaren zestig en zeventig luider dan voorheen liet horen op het functioneren van de rechterlijke macht", een verschijnsel dat volgens haar "mogelijk samenhing met de algemene geneigdheid bestaande waarden en duarop gebaseerde maatschappijstructuren en gezagsverhoudingen ter discussie te stellen." 52 De kritiek op de rechtspleging in het algemeen, en op de (eenzijdige) samenstelling van de rechterlijke macht is in de jaren zestig

47. Hand. I 1955-1956, p. 2407. Zie Wet van 28 juni 1956. Stb. 377

48. Besluit van 21 december 1956 , betreffende opleiding en vorming van gerechtssecretarissen en van secretarissen bij arrondissementsparketten, Stb. $1956 \mathrm{nr} .643$

49. Besluit van 19 oktober 1962 tot wijziging van het Opleidings- en Vormingsbesluit R.O., Stb. $1962, \mathrm{nr} .407$

50. Hand. II 1984, p. 4748 en Hand. I 1984, p. 1259

51. Het Besluit opleiding rechterlijke ambtenaren (KB 24 oktober 1985, Stb. 555) verving, in 1985 het Opleidings- en Vormingsbesluit 1962, en bicdt de structuur voor de huidige raio-opleiding.

52. Eindrapport van de Staatscommissie Herziening Rechterlijke Organisatic (deel I), 1984, p. 1 
echter niet nieuw (zie de verwijten aan het adres van de rechterlijke macht voor de oorlog). H.J.A. Hofland situeert de eerste tekenen van verzet tegen het Bestel' in het midden van de jaren vijftig, bij het begin van het verval van de welvaartsstaat. De kritiek betreft overigens niet alleen de rechterlijke macht, maar geldt de 'arrogantie' van het hele centrale en lokale bestuur jegens de 'simpele kiezer', die "het gevoel had dat hij afgebluft werd door de deskundigen, dat hij er voor het plezier van de politie was, dat het niets uitmaakte of hij links of rechts binnen het Bestel koos, dat zijn parlementariërs toch niet of onbegrijpelijk uit hun woorden kwamen en dat alles buiten hem om geregeld werd.

In 1958 wordt, in het rapport van R. Rijksen Meningen van gedetineerden over de strafrechtspleging, verslag gedaan van de wijze waarop de strafrechtspleging door de (passieve) betrokkenen wordt ervaren. In dit rapport, dat lange tijd niet mag worden gepubliceerd omdat het te controversieel is, worden klachten geuil over de denigrerende houding van rechters op de zitting. Ongevraagd verklaren gedetineerden het onbegrip van rechters over verdachten uit de (vermeende) afkomst van de eersten, die:

"geen snars begrip hebben wat er in die mensen leeft. omdat de heren van justitie bijna allen uit 'n geheel andere gesloten kring komen als de gewone man. (die overigens niets béter is als die gewone mensenkring!)" "Waarom bestaat een rechbank uit Baron die en die, en jonkheer zus en zo? Deze mensen, die allen met een geldzak om hun hals geboren werden, moeten zich de omstandigheden voorstellen, waartoe een gewone mens uit de arbeidersklasse tot zijn misdrijf kwam. Dat bestaat éénvoudig niet." "Hoe zal 'n baron of een jonkheer ooit kunnen begrijpen hoe ' $n$ arbeider leeft en denkt?' Is het niet veel gemakkelijker om eerlijk te blijven als men in overvloed baadt en nooit tegenslag of ellende heeft gekend nog ontmoet, als wanneer men niets anders heeft als armoede en tegenspoed zoals zoo velen van ons gevangen ? $^{m 4}$

In 1967 treedt de kritiek op de (vermeende) eenzijdige samenstelling van de rechterlijke macht echter sterker op de voorgrond dan voorheen, als het weekblad Revu twee enquêtes publiceert waaruit blijkt dat de helft van de Nederlandse bevolking meent dat de rechter 'met twee maten' meet. ${ }^{55}$ De uit-

53. H.J.A. Hofland, Tegels lichten, 1972, p. 169-171 Zie verder over deze periode: A.C. 't Har, Openbaar Ministerie en rechtshandhaving, 1994, p. 15-84

54. R. Rijksen, Meningen van gedetineerden over de strafrechtspleging, 1958, p. 106, 112 , 129 en 137

55. Eerste Revu-enquête (1-1-1967) Op de vraag: "Vindt U dat de Nederlandse rechter ieder met gelijke maat meet?" antwoordt $45 \%$ van de Nederlandse bevolking: nee, $38 \%$ : ja en $17 \%$ : weet niet. Dat de rechter met gelijke maat meet vindt $51 \%$ van de VVDstemmers, $48 \%$ : KVP, $46 \%$ : CHU, $36 \%$ : PvdA, 35\%: ARP, $29 \%$ : BP en $11 \%$ : KVP. 
slag van deze enquête wordt in de publieke opinie onmiddellijk uitgelegd in termen van klassejustitie. ${ }^{56} \mathrm{Na}$ de publikatie van de tweede Revu-enquête op 21 november 1967 komt het onderwerp klassejustitie in de Tweede Kamer ter sprake. Bij de vaststelling van de Rijksbegroting 1968 zegt het Tweede Kamerlid Singer-Dekker (PvdA) ervan overtuigd te zijn dat met de wijd verbreide mening over klassejustitie aan de samenleving de rekening wordt gepresenteerd van "alle onredelijke verschillen naar rang en stand", die nog steeds worden gemaakt. Om de beeldvorming van de rechterlijke macht te verbeteren, en het vertrouwen van het publiek te versterken, stelt zij een sociologisch onderzoek voor naar de samenstelling van de rechterlijke macht. "[D]e rechterlijke macht wordt vaak beschreven als een aantal deftige heren, die niets begrijpen van hetgeen er in de maatschappij omgaat. I $k$ weet niet, of dit allemaal waar is, maar laten wij dit punt dan eens wetenschappelijk laten bestuderen. Ik wil wel eens weten uit welke milieus de rechters komen, van welke levensbeschouwelijke en politieke richtingen zij zijn en of deze richtingen wel evenredig over de colleges zijn verdeeld. "57 Volgens Singer-Dekker is het benoemingsbeleid voor het publiek niet doorzichtig genoeg. Voor het vertrouwen van het publiek is het daarom goed als er een adviserend lichaam komt voor de selectie van rechters, dat onder andere is samengesteld uit vertegenwoordigers van verschillende delen van de bevolking. ${ }^{58}$ Kritiek op de samenstelling van de rechterlijke macht komt, behalve van de PvdA en D 66 , ook van de PSP, de CPN en de

Dat de rechter niet met gelijke mat meet vindt $33 \%$ van de CHU-stemmers, 34\%: KVP, 37\%: VVD, 49\%: ARP, 51\%: PvdA, 59\%: BP en 84\%: PSP. Tweede Revuenquête (21-11-1967) Op de vraag of men denkt dat de Nederlandse rechter ieder met gelijke maat meet, antwoordde $50 \%$ van de Nederlandse bevolking: nee, $38 \%$ : ja en $17 \%$ : weet niet. Op de vraag: Kunt u daarvan voorbeelden noemen?, antwoordt $28 \%$ : Baarnse moordzaak, $9 \%$ : beter gesitueerden, rijken krijgen lichtere straffen, positie speelt rol e.d., $9 \%$ : ervaringen uit eigen omgeving, $2 \%$ Tres-affaire, $2 \%$ andere antwoorden, 5\%: geen antwoord. Op de vraag: Aan gevangenen kunnen bepaalde gunsten en vrijheden worden toegestaan, afhankelijk van de omstandigheden. Meent u dat het bij de toekenning van deze gunsten en vrijheden in het algemeen eerlijk toegaat of denkt $u$ dat er onredelijke verschillen in de behandeling van de gevangenen zijn?, antwoordt $43 \%$ : onredelijke verschillen, $27 \%$ : in het algemeen eerlijk, $30 \%$ : geen antwoord. Op de vraag: Kunt u daarvan voorbeelden noemen, antwoordt $34 \%$ : Baarnse moordzaak, $4 \%$; beter gesitueerden, rijken hebben meer vrijheden, positie speelt een rol e.d., $3 \%$ : ervaringen uit eigen omgeving, $1 \%$ : Tres-affaire (roetkappenzaak), $2 \%$ : andere antwoorden, 3\%: geen antwoord.

56. Zie bijvoorbeeld: M. Ruyter, 'T gaat om 't effect van 't recht Mr Stheeman: uitslag revu-enquête teleurstellend, de Volkskrant dinsdag 3 januari 1967; zie ook het redactioneel van het Nederlands Juristenblad 1967 p. 467-469, dat de enquête "enquetelechnisch zeer ongenuanceerd" noemt, en meent dat de wetenschappelijke waarde van de opiniepeilingen kwestieus is

57. Hand. II 1967-1968, p. 672

58. Hand. II 1967-1968, p. 672-673. Zie ook: Goudsmit (D'66) Hand. II 1967-1968, p. 680 
Boerenpartij. Wolff (C.P.N.) brengt het begrip klassejustitie in verband met "ondernemers die van de rechter bescherming van hun belangen tegen de arbeiders vragen en door de op deze manier tot stand komende inmenging van de justitie, in arbeidsconflicten en stakingen ". ${ }^{59}$ Diepenhorst (A.R.P) spreekt daarentegen van een "voortreffelijke rechtspraak" en merkt op zelf "ook wel eens voor een overheidsloket te zijn afgesnauwd. "\$\$O

De minister van justitie (Polak) hoort het allemaal gelaten aan, en reageert met een Judaskus op het betoog van Singer-Dekker, dat hij 'zeer wijs' noemt, maar dat volgens hem 'niet erg diep' gaat,

"Voorts vraag ik mij af, of de verontrusting, die hierover vaak wordt geuit, niet mede is ingegeven door de hier en daar speciaal vaak nog bij juristen levende opvatting van de geweldige hoogheid van het rechtersambt. De rechter is echter in onze tijd niet meer een hoog boven zijn medemensen tronend onaantastbarefguur, waartegen iedereen eerbiedig moet opzien en wiens woorden, daden en uitspraken men bewonderend en deemoedig heeft teaanvaarden. (..) Dit houdtechter ook in. dat de rechters, net als ieder, die belangrijk en hoogst verantwoordelijk werk doet, meer in de publieke belangstelling staan en dat hun gedrag, wijze van optreden en uitspraken de aandacht trekken en commentaren uitlokken, ook wel eens ongunstige. Ongunstige commentaren worden soms terecht gemaakt, omdat de rechters net als ieder ander mens ook wel eens fouten maken. Die kritiek is niet altijd even prettig, maar kritiek is nooit prettig; zij wordt ook uitgeoefend op kamerleden, ministers en werkgevers. ${ }^{n 1}$

Met de grootste nadruk verzekert Polak dat de selectie-commissie voor de opleiding in het geheel niet let op klasse, geloof of politieke overtuiging. Wel beaamt hij dat met het beperkte aanbod van kandidaten rekening moet worden gehouden, en daarom wordt volgens hem getracht zoveel mogelijk buitenstaanders te winnen voor de rechterlijke macht. Een sociologisch onderzoek naar de samenstelling van de rechterlijke macht acht Polak echter schadelijk. ${ }^{62}$ Ook de door Singer-Dekker gesuggereerde Conseil de la Magistrature wijst hij van de hand, omdat het meer dan het Nederlandse aanbevelingenstelsel coöptatie in de hand werkt. De adviezen van de rechterlijke macht bij benoemingen werken volgens Polak goed: "Iw]anneer er bij de minister vragen rijzen - dit komt nugul eens voor - voor of nadat hij de aanbevolenen heeft ontvangen, kan hij de rechterlijke macht nadere vragen stellen en nagaan of de adviezen inderdaad

59. Hand. II $1967-1968$, p. 684

60. Hand. II 1967-1968, p. 682-684. Zie over het "corrupte beeld" van de rechterlijke macht ook Brongersma (PvdA) Hand. I 1967-1968, p. 389 en Van Wijk (P.S.P) Hand 1 1967-1968, p. 402

61. Hand. II $1967-1968$, p. 700

62. Hand. II 1967-1968, p. 700-701: zie ook Hand. I 1967-1968, p. 444 
met de vereiste zorgvuldigheid zijn opgesteld. Het feit dat de minister en het departement degenen, die de aanbevelingen doen, kennen vormt soms een nutiig gegeven bij de beoordeling van aanbevelingen."

Een jaar later, bij de interpellatie-Wolff over het vervolgingsbeleid van het openbaar ministerie bij de Maagdenhuisbezetting, laat Polak echter doorschemeren de Conseil de la Magistrature, althans voor het aantrekken van buitenstaanders, toch in onderzoek te hebben. ${ }^{63}$ Inderdaad rapporteert de Staatscommissie van Advies inzake de Grondwet en de Kieswet in 1971 over de Franse Conseil Supérieur de la Magistrature, maar zij ziet als bezwaar tegen een "geïnstitutionaliseerde inspraak in het benoemings- en promotiebeleid" van de Franse Conseil, de grote rol die anciënniteit daarin speelt, met als doel "het euvel van politieke benoemingen en promoties te keren. In Nederland is dit vrijwel onbekend. "164

Hoewel nagenoeg alle fracties zich in de kritiek op de rechterlijke macht kunnen vinden, wordt het verlangen van D'66 en de PvdA naar een breed samengestelde Conseil de la Magistrature niet gedeeld. Naar aanleiding van het rapport-Witsen-Elias over het aantrekken van buitenstaanders (zie hierna) ontspint zich bij de Rijksbegroting van 1970 een discussie over de samenstelling van een z.g. Raad van Advies. (Deze Raad van Advies beoogt het solliciteren naar het rechterschap te vergemakkelijken voor buitenstaanders, en niet zoals de voorstellen voor een Conseil de la Magistrature een democratisering van de rechterlijke macht.) Volgens het voorlopig verslag menen 'zeer vele leden' dat de meerderheid van de raad deel moet uitmaken van de zittende magistratuur, en dat geen ministerieel vertegenwoordiger lid moet kunnen zijn van de Raad. ${ }^{65}$ Eerder had D. Giltay Veth in het Nederlands Juristenblad in 1970 zijn ongenoegen geuit over de plannen van de commissie-Witsen Elias, en deze in verband gebracht met de ideeën van Singer-Dekker en Goudsmit voor een Conseil de la Magistrature. ${ }^{66}$ Giltay Veth meent dat de rechterlijke macht niet de veranderde opvattingen dient weer te geven die bij het Nederlandse volk leven, "behalve natuurlijk wanneer de wetgever zelf hem een marge heeft gelaten."

63. Hand. Il $1968-1969$, p. 3517

64. Eindrapport van de Staatscommissie van Advies inzake de Grondwet en de Kieswet, 1971, p. 245-246

65. VV, Bijl. Hand. Il 1970-1971, 10808 , nr. 6. p. 8. Zie ook: Eindrapport van de Staatscommissie van advies inzake de Grondwet en de Kieswet, 1971, p. 245-246 waarin de staatscommissie als bezwaar tegen een 'geïnstitutionaliseerde inspraak in het benoemings- en promotiebeleid' van de Franse Conseil Supérieur de la Magistrature noemt de grote rol die anciënniteit daarin speelt.

66. D. Giltay Veth, De rapporten-Bloemarts en-Witsen Elias, deel 1 en 2, NJB, 1970, resp. p. 1061-1072 en 1120-1131 
Benoeming van rechters op grond van 'politieke overwegingen' ziet Giltay Veth als "de ergst denkbare aanslag op het gehalte van onze rechterlijke macht", en hij twijfelt er niet aan dat de voorstellers pleiten voor rechters die er over abortus, druggebruik en pornografie "uitgesproken moderne opvattingen" op na houden. Natuurlijk prikkelen de uitspraken van Giltay Veth het Tweede Kamerlid Singer-Dekker (PvdA) tot tegenspraak ${ }^{67}$. Kort zet zij in een reactie haar bedoelingen met een Conseil de la Magistrature nog eens uiteen, en onderstreept zij dat haar voorstel voor een Raad van Advies geen pleidooi is voor een Raad met een linkse of links-extremistische signatuur. "Het gaat er mij slechts om zo goed mogelijke waarborgen te scheppen dat mensen met bepaalde politieke of levensbeschouwelijke overtuiging, ondanks voldoende bekwaamheid, niet geweerd worden. "168

\subsubsection{De publieke opinie over klassejustitie}

Het verwijt van klassejustitie leidt - met enige vertraging - in 1969 en 1970 tot een betrekkelijk groot aantal bijdragen over de selectie van rechterlijke ambtenaren. Belangrijker echter dan de uitslag van de Revu-enquêtes in 1967 , lijkt het massaproces dat in juni 1969 door de politierechters G.H. Nomes en A. Oosterbaan wordt gehouden na de ontruiming van het bezette bestuursgebouw van de UvA (Maagdenhuis) waarbij, zoals de fractievoorzitter van de PvdA J.M. den Uyl het noemt, sprake is van een 'snelrechtpsychose'. ${ }^{69}$ In 12 dagen behandelen de beide politierechters ruim 500 zaken. In het bijzonder het vermeende politieke karakter van de vervolgingen en de aard van sommige opgelegde straffen wordt als onrechtvaardig ervaren (ontzetting uit het kiesrecht was na de oorlog alleen aan NSB-ers en landverraders opgelegd).

Niet altijd is echter duidelijk tot wie de kritiek zich richt ('justitie'), en wat precies onder 'klassejustitie' moet worden verstaan. Terecht tracht A.J. Cnoop Koopmans, rechter in Amsterdam, in 1969 in een artikel in het Nederlands Juristenblad enige duidelijkheid te brengen in de discussie over klassejustitie. Hij onderscheidt drie vormen van klassejustitie, en meent dat de derde vorm, t.w. 'establishmentsjustitie', zich in de laatste jaren hier en daar plotseling heftig heeft voorgedaan. Van establishmentsjustitie is sprake wanneer staande en zittende magistratuur zich in overheersende mate laten leiden door het verlangen de maatschappelijke orde en de bestaande (maar niet algemeen aan-

67. H. Singer-Dekker, Het voordrachten- en benoemingsbeleid bij de rechterlijke mach. NJB. 1971 , p. $68-73$

68. Men zie in gelijke zin: D.H.W. de Jong, Mr. D. Giltay Veth en de rechershenoemingen, NJB, 1970, p. 1371-1372 en J.C.M. Leyten, De rechlerlijke organisatie I, NJB. 1971, p. 634-636. Anders: G.E. Langemeyer, NJB, 1970, p. 1373-1374

69. Den Uyl heefi bezwaar tegen massa-proces, de Volkskrant, 14 juni 1969 
vaarde) morele waarden te handhaven en te conserveren en onvoldoende openstaan voor optredende maatschappelijke veranderingen. Als uitingsvormen van deze establishmentsjustitie noemt Cnoop Koopmans hooghartige, geïrriteerde of neerbuigende behandeling van langharigen of anderen met afwijkend uiterlijk, zware bestraffing op het gebied van marihuana-roken en erotische geschriften en extra zware bestraffing van overtredingen tegen de openbare orde, met name deelname aan niet toegestane demonstraties, delicten met een politieke achtergrond en belediging van overheidsfunctionarissen. ${ }^{70}$ Niet iedereen onderschrijft trouwens de constatering van klassejustitie van Cnoop Koopmans. A.J. Hoekema spreekt voorzichtig van 'discriminerende justitie', en constateert dat ten onrechte nooit onderzoek is verricht naar het esprit de corps en de herkomst van rechters, en de invloed die dit kan hebben op het doen en laten van de leden van de rechterlijke macht; "achterwege laten zal dit ongunstige gevolg hebben, dat zowel de mythe van de volstrekte objectiviteit der rechtspleging als de mythe van de volstrekte klassegebondenheid ervan, ongestoord kunnen blijven bestaan. ${ }^{711}$ In een sociologische analyse van de Revu-enquêtes concludeert Hoekema in 1971 dat de onderzoeksresultaten niet mogen worden geïnterpreteerd als een teken van massale verwerping en een aantasting van het justitieel (moreel) gezag, of als teken van een wijd verbreide gezagscrisis. Een interpretatie in termen van klassejustitie gaat Hoekema helemaal te ver. ${ }^{72}$

Net als in de Tweede Kamer wordt ook daarbuiten een verband gelegd tussen het aanbevelingenstelsel en de (vermeende) eenzijdige samenstelling van de rechterlijke macht. Die eenzijdigheid valt volgens P.H. Hugenholz terug te voeren op het feit dat het benoemings- en promotiebeleid is gebaseerd op het oordeel van een in-crowd. "De leden van de rechterlijke macht maken onderling uit wie zij in een vakature bij hun college benoemd willen zien. Er moet wel iets heel bijzonders aan de hand zijn wil de minister van die voordracht

70. Als de twee andere vormen van klassejustitie noemt Cnoop Koopmans klassejustitie in de oorspronkelijke of klassieke vorm waarvan sprake is als in een maatschappij twee klassen bestaan waarvan de ene (de heersende of bezittende) de voorrechten en machtsmiddelen in handen heeft en de andere niet, terwijl het justitiële apparaat gebruikt en beheerst wordt door de bezittende klasse ter handhaving van haar bevoorrechte positie. Een meer subtiele vorm van klassejustitie is de "ondemocratische of selectiejustitie", waarvan sprake is wanneer de leden van justitiële organen bij uitsluiting of bij voorkeur worden geselecteerd uit bepaalde bevolkingsgroepen en weinig of niet uit andere groepen, en wanneer bovendien de leden van die andere groepen daarvan hinder ondervinden bij de rechtspraak. A.J. Cnoop Koopmans, Vormen van klassejustitie, NJB, 1969, p. 421-423

71. A.J. Hoekema, Opstellen en stellingen over klassejustitie. 1969. p. 4

72. A.J. Hoekema, Vertrouwen in de justitie resultaten van een vergelijkend onderzoek, 1971, p. 100 
afwijken". Het benoemingsstelsel zou 'dubbel selektief' werken: andersdenkenden worden niet op de aanbeveling geplaatst, maar willen ook niet meer solliciteren. Het resultaat van een en ander is een "apparaat van nogal uniforme samenstelling in die zin dat de componenten geneigd zullen zijn tot een zeker conservatisme ${ }^{\prime 7}{ }^{73}$ Het esprit de corps, wordt niet alleen door Hugenholz als een probleem ervaren. J. ter Heide bepleit in zijn oratie de 'zelfstandigheid van de magistraat in zijn systeem', en wijst op het "gevaar dat ieder systeem bedreigt dat door coöptatie tot stand komt, n.l. dat alleen zij in aanmerking komen die zich wensen te conformeren aan de referentiekaders en codes van degenen die benoemen." Door het esprit de corps wordt de onafhankelijkheid van de rechterlijke macht meer bedreigd dan vanuit het parlement, "omdat het gewenste conformisme krachtige mensen met frisse nieuwe ideeën kan afschrikken van een loopbaan waar dat selectiecriterium wordt gehanteerd. In een tijd van supersnelle veranderingen, die ook aan de opvatting van het recht niet voorbijgaan, kan dit een groot gevaar betekenen voor het aanzien van de rechtspraak. Neofilie en conformisme zijn onverenigbaar. ${ }^{174}$ Ook J.C.M. Leijten waarschuwt in 1970 in zijn oratie voor het esprit de corps:

"Het is minder belangrijk nu, dat rechterlijke colleges een team vormen, dat in vriendschap en homogeniteit samenwerkt - hoezeer dit waarden zijn, ook voor de rechtspraak, die ik hogelijk heb gewaardeerd - dan dat het rechterlijk college in zich die conflicterende waarden aanwezig vindt, die in het maatschappelijk bestel om voorrang en dus harmonisatie strijden. (-) Theoretisch is het niet noodzakelijk, dat men deze waarde - een passend en homogeen team - op moet geven, als men het maatschappelijk conflict binnen het rechtscollege voet aan wal laat zetten in ruimer mate dan nu gebeurt. Het lijkt voorts duidelijk, dat dit tengevolge van de onvermijdelijke vernieuwing gelijdelijk aan toch zal gebeuren. Maar de rechterlijke benoemingsvoordrachten, diezich op het standpunt van het homogene team stellen, zullen, zolang zij de feitelijke invloed behouden, die zij thans bezitten, toch wel een duidelijk remmend effect hebben op deze vernieuwing. ${ }^{m 5}$

Tegenover de kritiek op het benoemingsbeleid en het benoemingsstelsel staan opvattingen als die van bijvoorbeeld G.E. Langemeijer. Hij verklaart het verwijt van klassejustitie vooral uit een communicatie-tekort tussen rechter en justitiabele. Bijna 25 jaar na zijn artikel in het Nederlands Juristenblad over het dreigende tekort aan rechterlijke ambtenaren, moet hij nu opnieuw constateren dat het aanhod van geschikte kandidaten maar net groot genoeg is: "Dat zich

73. P.H. Hugenholz, Klassejustitie, realiteit!. Intermediair, 1969, p. 3-7

74. J. ter Heide, De onafhankelijkheid van de rechterlijke macht, een functioneel-analytische beschouwing, 1970, p. 18

75. J.C.M. Leyten, De rechter op de schopstoel, 1970, p. 23 Zie ook: C. Gutter, Ons strafrecht, verkenting van en achtergebleven gehied, 1969, p. 136-137, en L.H.C Hulsman, Onbehagen over het recht, de Gids 9 oktober 1967, p. 266 
voor een benoeming tot rechter velen zullen aanmelden, die daarnaast nog de aanleg van de maatschappijhervormer en een ruime dosis sociologische en psychologische kennis hebben aan te bieden lijkt me niet zo waarschijnlijk, nu nog afgezien van het stempel dat de uitoefening van welk beroep ook op den duur op een ieder drukt. ${ }^{m / 6}$ Overigens gelooft Langemeijer niet dat de selectiecommissie in de richting van een 'klassegeest' werkt; over het conservatisme in de rechterlijke macht merkt hij op: "Toch is het zeker dat in vele zaken - ik denk aan de berechting van zedenmisdrijven - de rechters meer revolutionair zijn dan het grote publiek. Wanneer hier jury-rechtspraak zou zijn, vielen er zwaardere straffen, daar ben ik zeker van. Het grote publiek is dikwijls heel wat conservatiever dan de rechterlijke macht. Voor democratie is in onze rechtspleging geen plaats. ${ }^{177}$ Anders dan Leijten en Ter Heide ziet Langemeijer daarom weinig bezwaar in het esprit de corps. ${ }^{78} \mathrm{M}$. Knap hekelt het spookbeeld van een zichzelf 'coöpterende en inteeltplegende' rechterlijke macht, en wijst er op dat de Tweede Kamer nooit gebruik heeft gemaakt van haar bevoegdheid om een minister voor een benoeming ter verantwoording te roepen. De bestaande aanbevelingsprocedure acht hij dan ook bevredigend, omdat het zittende college het best in staat is om de geschiktheid van een kandidaat te beoordelen. Openbaarheid van de rechtbankvergadering zou er volgens Knap slechts toe leiden dat de openhartigheid van spreken wordt aangetast. ${ }^{79}$

\subsubsection{Rijksbegroting 1970}

Na de openlijke aanval op de rechterlijke macht in de publieke opinie, besteedt de Tweede Kamer in 1969 opnieuw veel aandacht aan het verschijnsel klassejustitie. ${ }^{80}$ Opnieuw brengt zij het verschijnsel in verband met het stelsel van aanbevelingen. De toonzetting is evenwel minder voorzichtig dan twee jaar eerder. Zo merkt Van Schaik (KVP) op:

"Het is vanzelfsprekend dat op de voordrachten van een rechtbank niet gauw namen zullen prijken van diegenen, die andere opvattingen huldigen dan de leden van deze rechtbank zelf en dit kan tot gevolg hebben dat andersdenkenden niet op

76. Langemeijer, Opstellen en stellingen over klassejustitie, 1969, p. 8

77. Haagsche Post, Klassejustitie in Nederland: ja of nee?, 24 mei 1969, p. 5

78. G.E. Langemeijer, De' onafhankelijke rechter op de schopstoel, NJB, 1971, p. 811-812

79. M. Knap, Worden rechters wel op "democratische wijze" benoemd?, NJB, 1969, p. 1079-1082. Zie ook J. de Ruiter, die warschuwt tegen het denkbeeld dat bij het selectiebeleid 'politick getinte motieven' een rol zouden mogen spelen. J. de Ruiter, Oude en nieuwe taken van de burgerlijke rechter, Calvinistische Juristen Vereniging, 1970, p. 17

80. Zie ook het voorlopig verslag bij de Rijksbegroting 1969, waarin gesproken wordt over een 'maatschappelijk ivoren toren' waarin sommige leden van de zittende en staande magistraruur lijken te zitten. Bijl. Hand. II 1968-1969, 9800, hoofdstuk VI, nr. 12, p. 11 
de voordracht komen, terwijl andersdenkenden zelf geneigd zullen zijn, als zij weinig karakter hebben zich te conformeren, dan wel, als zij wèl karakter hebben. een dergelijke functie niet te ambiëren. Het resultaat is een apparaat van eenvormige, en uniforme samenstelling met een zekere neiging tot behoudendheid en - wat nog erger is - geen aspiranten voor de bestaande vacatures, om de reden, dat zij ervoor passen om deel uit te maken van een college dat soms blind is, althans de indruk maakt blind te zijn, voor maatschappelijke ontwikkelingen. (..) De rechters wonen en werken in een samenleving die bepaalde groeperingen van onze maatschappij niet kent, die haar volkomen vreemd zijn. En toch, mijnheer de Voorzitter, komen uit deze groeperingen juist bijzonder velen met deze rechter in aanraking en dat dit tot een behandeling en een uitspraak kan leiden die men als klasse-justitie zal kwalificeren, is dan niet te verwonderen. ${ }^{m 81}$

Anders dan twee jaar eerder reageert de regering duidelijk defensiever (maar ook informatiever) op de beschuldigingen. Om de Kamer zo goed mogelijk in te lichten, verschaft de minister van justitie een overzicht van gegevens die het Centraal Bureau voor de Statistiek heeft verzameld over de sociale milieus waaruit de rechtenstudenten afkomstig zijn. Daaruit blijkt dat van alle rechtenstudenten, ingeschreven in het studiejaar 1964-1965, $61 \%$ voortkomt uit de z.g. 'hogere' milieus, $25 \%$ uit de middelbare milieus en $4 \%$ uit de lagere milieus. Polak meent dat, als een verband tussen de functieuitoefening en het milieu waaruit men komt al bestaat, het probleem niet ligt bij de rechterlijke macht, maar bij de toegang tot het wetenschappelijk onderwijs. Iets dergelijks zal de Staatscommissie van Advies inzake de Grondwet en de Kieswet in 1971 ook zeggen:

"Naarmate de toegang en de toeloop tot het wetenschappelijk onderwijs worden verbreed, zal ook de samenstelling van de rechterlijke macht een grotere schakering kumnen vertonen. Het lijkt wenselijk dat het benoemingsbeleid hierop ook bewust wordt gericht. Zulks kan het vertrouwen in de wijze van samenstelling vam de rechterlijke macht verstevigen, dat thans, blijkens een weer oplevende discussie over het voorkomen van een z.g. klasse- of establishmentjustitie, door sommigen wordt aangevochten. ${ }^{n 2}$

\subsubsection{Beeldvorming}

De kritiek op de rechterlijke macht, leidt in 197I tot de instelling van een werkgroep (naar zijn voorzitter: werkgroep-Wiersma). ${ }^{83}$ Deze heeft tot doel

81. Hand. II 1969-1970, p. 379-380

82. Eindrapport van de Staatscommissie van Advies inzake de Grondwet en de Kieswet, 1971. p. 246

83. Werkgroep organisatie rechterlijke macht ingesteld bij beschikking van de Minister van Justitie van 23 december 1971, Stert 29 december 1971, nr. 253 
de minister van justitie van advies te dienen over de taakomschrijving van een in te stellen Staatscommissie, die voorstellen moet doen over vernieuwing van de wetgeving betreffende de rechterlijke organisatie (de latere Staatscommissie Herziening Rechterlijke Organisatie). De werkgroep hoort in 1971 en 1972 een groot aantal personen en instanties, die direct of indirect bij de rechtspleging betrokken zijn. In 1972 resulteren de werkzaamheden van de werkgroep-Wiersma in een lijvig rapport, Gedachten over de toekomst van de rechtspleging. ${ }^{84}$ $\mathrm{Na}$ bestudering van het binnengekomen materiaal, geeft de werkgroep de regering in overweging om de herziening van de rechterlijke organisatie te funderen op de resultaten van een onderzoek naar de rol van de rechter in de samenleving. Als een van de principiële vragen die in een dergelijk onderzoek aan de orde moeten komen, rekent de werkgroep de benoemingsprocedure van rechterlijke ambtenaren. Deze suggestie resulteert in 1973 en 1977 in weer twee andere rapporten onder dezelfde naam: De rol van de rechter in de samenleving. ${ }^{85}$ Ik zie af van een integrale bespreking van beide rapporten, maar wijs op een van de centrale onderwerpen die daarin ter sprake komen, namelijk de beeldvorming van de rechterlijke macht. Deze beeldvorming laat - zo stellen beide rapporten het voor - mede door toedoen van de media ernstig te wensen over. In dit verband signaleert men het probleem dat de meeste burgers vrijwel nooit rechtstreeks met de rechtspraak in contact komen, terwijl de verslaggeving door de media slechts 'zelden' een representatief beeld van de rechtspraak geeft. Om die reden wordt voorgesteld om de voorliching aan her publiek systematisch aan te pakken.

Kritiek op de (vermeende) tendentieuze berichtgeving door de media valt in deze jaren natuurlijk allereerst binnen de rechterlijke macht zelf te beluisteren. Reeds bij zijn installatie in 1956 als president van de rechtbank Amsterdam, spreekt U.W.H. Stheeman de aanwezigen waarschuwend toe: "Ik bet juist terug van een vakantie in de bergen en ik zou slechts cen fritite was sat vertrouwen willen genieten, dat wij stelden in onze berggids. ${ }^{*}$ Stheeman. ooit zowel de 'meest bekritiseerde' als de 'allerbeste kortgedingrechter' na de Tweede Wereldoorlog genoemd, wordt het in de daarop volgende saren docer de media niet gemakkelijk gemaakt. In zijn afscheidsrede in 1973 hekelt hil of bittere wijze de verhouding pers-rechtspraak, en meent hij dat de pers "in

84. Gedachten over de toekomst van de rechtspleging. Rapport wan de werkgroes hersiening rechterlijke organisatie ingesteld bij beschikking van de Minister van Justitie van $\mathbb{Z}$ december 1971, Staatsuitgeverij. 's-Gravenhage, 1972

85. Ministerie van Justitie, Wetenschappelijk Voorlichtings- en documentatiecentrurat, $D$ : rol van de rechter in de samenleving, een beschrijvend literatuurappori, 1973 en 18 rol van de rechter in de samenleving, een aanvullend hteratumapport 1977

86. U.W.H. Stheeman, rede uitgesproken bij zijn installatic als president van de rechibank Amsterdam op 2 augustus 1956 
overtreding van de democratische gedragsregels, wet en recht naar haar zin tracht te verbuigen door beïnloeding van de rechter met de middelen van intimidatie, van kritiek niet uit rechtskundige maar uit politieke hoek". Instemmend citeert Stheeman de Nijmeegse hoogleraar Nouwen, na kritiek op een vonnis van Stheeman in kort geding, tussen werkgevers en werknemers in de metaalindustrie:

"Willen wij ons overbevolkt landje leefbaar houden, dan zullen wij met grote zorgvuldigheid ons milieu moeten bewaken, waarbij belangrijker nog dan lucht, water en aarde, de rechtssfeer is waarin wij moeten ademen. Te hopen is dat wijze leiders de onzorgvuldigheid bij de kritiek tegen rechterlijke vonnissen weten in te tomen. Zo niet, dan zou de rechtsstaat wel eens plaats kunnen maken voor de machtsstaat, beheerst door een of andere oncontroleerbare pressiegroep. Het leed van andersdenkenden is dan niet te overzien."

Bepaald onkies is de oproep van Stheeman tot een tweede perszuivering, als hij spreekt over een "[v]ervuiling van de rechtssfeer in ons land, welke ons opnieuw aan een grote schoonmaak toe doet zijn. "In navolging van Nouwen ${ }^{\text {" }}$ spreekt Stheeman de hoop uit "dat onze leiders de wijsheid en de nodige moed zullen tonen, die sfeer te zuiveren en zuiver te houden. ${ }^{188}$ De uitspraken van Stheeman zijn echter zeker niet representatief voor de hele rechterlijke macht. In zijn rede bij de installatie van J. Schaafsma, de nieuwe president van de rechtbank Arnhem, haalt de vice-president van de rechtbank Arnhem, B.W. van Houten in 1973 fel uit naar zijn Amsterdamse collega:

"Ik herken (..) de reactie van mensen die zich bedreigd gevoelen. Ik herken de afweer van bevoorrechten die in onaantastbaarheid hebben geleefd en die zich wellicht zonder het zelf te merken te veel verwijderd hebben van alles wat zich uitkristalliseert in de maatschappij waarbinnen zij hun taak hebben uit te oefenen. (..) Maar ik wil nu graag heel duidelijk zeggen dat het mij juist voorkomt dat de rechter in deze tijd de ivoren toren verlaat en dat hij (..) plaats neemt in het glazen huisje dat men voor hem gereed heeft staan. ${ }^{m 9}$

87. De Gelderlander, 19 februari 1972

88. Afscheidsrede gepubliceerd in NJB. 1973, p. 17-18. De uitspraken van Stheeman ontlokten vanzelfsprekend heftige reacties. Zie: Het Parool, 30 mei 1973, 'Pers vernill bij ons rechtssfeer'. de Volkskrant, 1 juni 1973, Rechter Stheeman acht pers schuldig aan vervuiling rechtssfeer; Jac. van Veen, Mr Stheemans griezelig beroep op 'onze leiders' wie dit dan ook mogen zijn, Het Parool, 2 juni 1973.

89. Gepubliceerd in: NJB, 1973, p. 18: zie ook: de Volkskrant, 5 juni 1973, Mr Stheemam krijgt kritiek van collega. De woorden van Van Houten waren blijkbaar (ook) letterlijk bedoeld.

Zo heeft de Amsterdamse wethouder Han Lammers over het Arnhemse Paleis van Justitie, dat zeer veel glas bevat, eens gezegd: "Dat is dan eindelijk wat meer openheid: je kan er helemaal doorheen kijken, het lijkt waarachtig wel een echt democratisch gé- 
Jac. van Veen, rechtbankverslaggever van het Parool, beschrijft in 1979 de veranderende houding van de pers ten opzichte van de rechterlijke macht. Vóor het midden van de jaren zestig ziet de 'zeer gezagsgetrouwe pers' de magistraten als 'strenge, maar rechtvaardige figuren', maar in de zestiger jaren wordt dat anders:

"Bewegingen als Provo, de Kabouterpartij, de opstand der studenten, de Vietnamdemonstraties en de kraakacties hebben het wereldje binnen de paleizen van justitie niet onberoerd gelaten. Toen (..) het Maagdenhuisproces begon waren politierechter en verdachte daar voor de pers niet meer een bron van burgerlijk, oubollig amusement, maar hoogst boeiende exponenten van volstrekt tegengestelde opvattingen over recht en maatschappij. Een enkele reporter van de oude garde koos op traditionele manier de kant van het gezag door in zijn blad op te merken, dat 'de politierechter het langharig element op de verdachtebank zeer terecht berispte vanwege zijn brutale mond', maar de meerderheid zag het toen al duidelijk anders. (..) Het Maagdenhuisproces was weliswaar a-typisch voor het Nederlandse strafproces, maar het heeft wel cen aantal journalisten geprikkeld om de handel en wandel van vertegenwoordigers der zittende en staande magistratuur ook onder normale omstandigheden eens wat nauwkeuriger onder de loupe te leggen. Wat daarbij de eerstvolgende jaren zichtbaar werd was het bij herhaling falen in de communicatie met verdachten en vaak ook met getuigen, wanneer ook die niet afkomstig waren uit kringen, waarin rechters zichzelf gewoonlijk bewegen. Soms ergerlijke gevallen van onwellevendheid; geen uitleg in normaal Nederlands wat een vonnis betekent, als er al een motivering werd gegeven. ""90

De regering trekt zich deze kritiek aan, en de suggestie om de voorlichting over de rechtspleging aan het publiek systematisch aan te pakken resulteert in 1972 in de aanstelling bij het ministerie van justitie van een voorlichtingsconsulent voor de rechterlijke macht met als taak het verstrekken van faciliteiten aan de pers. Ook binnen de rechterlijke macht wordt structureel over hetere voorlichting nagedacht. Bij de rechtbank Dordrecht bijvoorbeeld treedt sinds 1973 een van de rechters uit het college op als 'contactpersoon voor de publiciteitsmedia'. Soortgelijke initiatieven volgen in de jaren daarna bij de rechtbanken van Den Haag en Rotterdam, waar contactpersonen en z.g 'persofficieren' worden aangesteld.

botw. " Bij: Jac. van Veen, De rechten van de mens de mensen van het rechl, 1971 , p. 93

90. Jac. van Veen, De kriliek in de pers op de strufrechlsple'ging, in: De magistruat in de' st(r)aat, 1979, p. 115-123 


\subsection{Recrutering van buitenstaanders}

\subsubsection{De Commissie aantrekken leden rechterlijke macht}

Hoewel uit het rapport van de commissie-Verdam en de Nota inzake de rechterlijke macht uit 1953 al blijkt dat de regering een grote voorkeur had voor het aantrekken van buitenstaanders, blijven concrete voorstellen voor de recrutering van buitenstaanders lange tijd uit. De discussie over de (vermeende) eenzijdige samenstelling van de rechterlijke macht heeft dit proces echter aanzienlijk versneld. Het aantrekken van buitenstaanders geschiedde vóor 1970 via de gerechten zelf. Belangstellenden wendden zich tot een gerecht, met het verzoek hen bij de minister van justitie aan te bevelen voor een benoeming tot rechterplaatsvervanger. Een probleem was echter dat zich te weinig buitenstaanders aanmeldden; het streven van de regering om de helft van de leden van de rechterlijke macht uit buitenstaanders te recruteren kon (bij lange na) niet worden gehaald. Om die reden werd in 1968 de commissie-Witsen Elias ingesteld, die moest adviseren over de mogelijkheden van het aantrekken van meer buitenstaanders. Volgens deze commissie was de wijze van solliciteren een bezwaar voor de leden van de balie om te solliciteren; zij moesten enige tijd als rechterplaatsvervanger optreden, zonder verzekerd te zijn van een benoeming tot rechter. In geval van mislukking was de weg terug voor een advocaat moeilijk, en liep hij het risico van een terugslag in zijn praktijk. Oudere advocaten vonden het bovendien onaantrekkelijk om als jongste rechter in een college te worden benoemd. Voor alle advocaten gold tenslotte het bezwaar dat zij, om een hoger salaris te kunnen verwerven, promotie moesten maken, terwijl het antwoord op de vraag of en wanneer zij daarvoor in aanmerking kwamen onzeker was. ${ }^{9 !}$

De commissie-Witsen Elias meent dat er behoefte bestaat aan een Raad van Advies voor de Zittende Magistratuur, een centrale instantie tussen het bestuur en de zittende magistratuur, waar buitenstaanders zich kunnen aanmelden. De Raad adviseert de minister van justitie omtrent bekwaamheid en geschiktheid van gegadigden voor de rechterlijke macht door persoonlijke gesprekken waarin de nadruk wordt gelegd op 'inzicht in maatschappelijke en menselijke verhoudingen' en door toetsing van de juridisch-technische vaardigheid van kandidaten. Aldus ontstaat een fonds van potentiële kandidaten, waardoor vacatures in de rechterlijke macht sneller vervuld kunnen worden. De Raad zal ook een taak krijgen inzake de verdere carrière van de leden van de zittende magistra-

91. Rapport-Witsen Elias, Bijl. Hand. Il 1969-1970, 10300, nr. 15, p. 15 
tuur. ${ }^{92}$ Behalve een Raad van Advies voor de Zittende Magistratuur, bepleit de commissie-Witsen Elias de invoering van de functie van rechter-auditeur. Deze functie is bedoeld als opleidingsfunctie voor buitenstaanders die 'nog niet ten volle de geschiktheid' hebben om tot rechter te worden benoemd. Met de functie van rechter-auditeur zou de kloof in de salarisstructuur van de rechterlijke macht kunnen worden overbrugd.

Bij de Rijksbegroting voor 1970 kondigt de regering aan de suggestie van de commissie-Witsen Elias voor een Raad van Advies in hoofdzaak over te zullen nemen. Overigens meent de regering, anders dan de commissie-Witsen Elias, niet dat de aanbevelingsbevoegdheid van de rechterlijke colleges dient te verdwijnen. In beginsel moet 'een zekere invloed' van de gerechten blijven bestaan; de aanbevelingsprocedure draagt bovendien bij tot de openbaarheid van het benoemingsbeleid. ${ }^{93}$ De regering acht het echter te vroeg nu reeds over te gaan tot de instelling van een dergelijke Raad van Advies. Teneinde eerst de noodzakelijke, praktische ervaring op te doen, stelt zij de Commissie aantrekken leden rechterlijke macht (naar haar voorzitter: Commissie-Dubbink) in die zal trachten te bevorderen dat onder juristen die buiten de rechterlijke macht werkzaam zijn (bijvoorbeeld in de advocatuur), meer kandidaten voor het aanvaarden van een functie in de zittende magistratuur bereid worden gevonden. $^{24}$

\subsubsection{Invoering gerechtsauditeurs}

Conform het advies van de Commissie-Witsen Elias stelt de regering in 1970 een afzonderlijke aanvangsfunctie voor de zittende magistratuur voor, die enerzijds een opleidingsplaats is voor buitenstaanders die nog niet geheel geschikt zijn om tot rechter te worden benoemd, en die anderzijds dient als een voortgezette opleiding voor de rechterlijke ambtenaren in opleiding..$^{95}$ Deze z.g. gerechtsauditeurs zijn niet met rechtspraak belast, en hebben in hoofdzaak een

92. In de visie van de commissie-Witsen Elias is de Raad samengesteld uit zes leden; drie leden zijn afkomstig uit de rechterlijke macht, een lid vertegenwoordigt de minister van justitie en twee leden zijn afkomstig uit 'belangrijke maatschappelijke groeperingen' (genoemd wordt de Orde van Advocaten).

93. Brief van de minister van justitie, Bijl. Hand. II 1969-1970, 10300 , nr. 15, p. 1-2

94. Besluit van 16 april 1970, HDORR no. 735 P 870

95. Ontwerp-artikel 108 Wet RO: "Wij kunnen bij de Hoge Raad, een gerechtshof, een arrondissements-rechtbank of een kantongerecht gerechtsauditewrs benoemen.

De gerechtsauditeurs zijn toegevoegd aan de president van het betrokken college onderscheidenlijk de kantonrechter, oudste in rang van benoeming, bij het betrokken kantongerecht.

Onze Minister van Justitie doet Ons de voordrach tot hun benoeming na overleg met de presiden! onderscheidenlijk de kantonrechter aan wie zij zullen zijn toegevoegd." 
assisterende taak, bijvoorbeeld bij het opstellen van concept-vonnissen en nota's over juridische vragen. ${ }^{96}$ De Vaste Kamercommissie voor Justitie van de Tweede Kamer reageert echter buitengewoon sceptisch op de plannen van de regering, die het voor met name oudere, ervaren advocaten met een ruime praktijkervaring, eerder minder dan meer aantrekkelijk maakt om naar de zittende magistratuur over te stappen. Reden daarvoor is het 'matig interessante werk' dat zij gedurende een lange reeks van jaren moeten verrichten, tegen een aanzienlijk lagere honorering dan zij elders kunnen verwerven. ${ }^{97}$ Ook bij de openbare behandeling krijgt het wetsvoorstel bepaald geen warm onthaal in de Tweede Kamer. Men verwacht niet dat de nieuwe functie grote werfkracht op buitenstaanders zal uitoefenen. Daarvoor acht men de functie van 'documentalist' of 'hulpje' te 'pover'. ${ }^{88}$ Toch neemt de Tweede Kamer het voorstel aan. ${ }^{99}$ Ook de Eerste Kamer, waar evenmin veel enthousiasme bestaat voor het wetsvoorstel, neemt het voorstel aan (indachtig de weinig inspirerende woorden 'baat het niet dan schaadt het niet' van minister van justitie Van Agt).

\subsection{A.J. Cnoop Koopmans: Rechter en politiek}

Het geruchtmakendste artikel dat in de jaren zeventig over het onderwerp rechtersbenoemingen is geschreven, is zonder twijfel dat uit 1973 geweest van de Amsterdamse rechter A.J. Cnoop Koopmans: Rechter en politiek. ${ }^{100}$ De commotie in 1973 is echter opmerkelijk. Op 22 maart 1972 schrijft Cnoop Koopmans immers al een brief aan de werkgroep-Wiersma, waarin hij stelt dat de rechterlijke macht wat herkomst en sociaal-politieke oriëntering betreft een 'uitermate eenzijdig samengestelde groep' is. Als ingrijpende maar noodzakelijke maatregel ziet hij dan ook dat de selectic en benoeming van rechterlijke ambtenaren in handen wordt gegeven van breder samengestelde colleges. ${ }^{10 t}$ In een onderhoud met de commissie-Wiersma stelt hij zich een van de administratie onafhankelijk, niet politiek verantwoordelijk orgaan voor, dat belast is

96. Ontwerp-artikel 110 Wet RO: "De gerechtsauditeurs staan hel gerech in zijn wertzaamileden bij.

Zij kumen de terechtziltingen en andere gerechtelijke verrichtingen, alsmede bijeenkomsten in raadkamer van het college of kantongerecht, waarbij zij zijn benoemd, bijwonen, tensij de president onderscheidenlijk de kantonrechter, oudste in rang van benoeming, in een bijzonder geval anders beslist. "

97. VV. Bijl. Hand. II 1970-1971, 10808 , nr. 6

98. Zie Hand. Il 1971-1972, p. 2757 e.v.: Geurtsen (VVD), Goudsmit (D'66), Abma (SGP)

99. Hand. II 1971-1972, p. 3082

100. A.J. Cnoop Koopmans, Rechter en politiek, NJB, 1973, p. 630-638 Zie ook: Rechler in juristenblad: rechterlijke macht is weinig links, de Volkskrant, 3 juni 1973

101. Brief van 22 maart 1972, gepubliceerd in: Gedachten over de toekomst van de rechispleging, p. 75 
met de benoeming van rechterlijke ambtenaren. ${ }^{102}$ Ruim een jaar later, op 26 mei 1973, werkt Cnoop Koopmans zijn suggestie voor een raad voor de rechterlijke macht uit in het Nederlands Juristenblad, waarin hij opnieuw de stelling verdedigt dat recht en politiek nauw verband houden, en dat dit verband in het benoemingsstelsel tot uitdrukking dient te worden gebracht. ${ }^{103}$ Om haar functie naar behoren uit te oefenen is het daarom van het grootste belang dat de rechterlijke macht het vertrouwen van de bevolking geniet:

"Een rechterlijke macht in een democratie houdt in: een rechterlijke macht die zoveel mogelijk uit de bevolking voortkomt en de meningen en opvattingen van die bevolking zo genuanceerd mogelijk in zich verenigt. Als een rechterlijke macht naar samenstelling aanzienlijk afwijkt van de samenstelling der bevolking, dan kan zij in een levende, dus kritische maatschappij haar taak op den duur niet bevredigend vervullen, al was het alleen maar, omdat het noodzakelijke vertrouwen in haar kan komen te ontbreken. " 104

Over de bestaande benoemingsprocedure merkt hij op dat de ontwikkeling van de samenstelling van de rechterlijke macht is achtergebleven bij die van de wetgevende en de uitvoerende macht: "[B]enoemde parlementen, provinciale, en gemeenteraden zijn vervangen door gekozen colleges, benoemde ministers hebben plaats gemaakt voor door het parlement aangewezene." Slechts bij de Hoge Raad is het anders, omdat daar het beginsel van coöptatie 'op gelukkige wijze' is gecombineerd met 'democratische inspraak van de burgerij'. (Dit laatste moge dan feitelijk zo worden gezien, historisch is deze verklaring voor de voordracht onjuist; zie $\$ 3.3 .1$ ). Een andere reden waarom de henoemingsprocedure volgens Cnoop Koopmans onbevredigend is, is het toegenomen beroep van de burgers op de rechterlijke macht tegen de rijks- of plaatselijke overheid. Daardoor zou bij het ministerie de neiging kunnen bestaan om rechters te passeren van wie men een uitgesproken kritisch-onafhankelijk standpunt heeft ervaren. Dit probleem speelt vooral bij de verdere benoemingen waar het ministerie - anders dan bij eerste benoemingen, die praktisch altijd door coöptatie tot stand komen - op dat moment nog nagenoeg vrijheid van handelen heeft. Om aan beide problemen - de eenzijdige samenstelling van de rechterlijke macht en de invloed van het ministerie van justitie - het hoofd te kunnen bieden, bepleit Cnoop Koopmans een verkleining van de ministeriële hevoegdheid bij het rechterlijk benoemings- en promotiebeleid en een vergroting van de invloed van de burgerij daarop. Directe verkiezingen sluit hij echter hij voorbaat uit vanwege de schadelijke gevolgen die hij daarvan in de Verenigde Staten heeft gezien. Een benoeming van rechters door de volksver-

103. Cedachten. o.c. p. 74

104. Cnoop Koopmans, o.c. p. 633 
tegenwoordiging ziet Cnoop Koopmans als een systeem met de meeste voordelen en de minste nadelen. Hij stelt daarom de instelling van een raad voor de rechterlijke macht voor, waarin qualitate qua de president van de Hoge Raad zitting heeft en waarvan de overige leden door de Tweede Kamer worden geko$z e n$, met dien verstande dat zij periodiek aftreden en herbenoembaar zijn.

De ideeën van Cnoop Koopmans zijn in 1973 - ook onder juristen - niet helemaal nieuw. Eerder, in de jaren vijftig, heeft het Nederlands Juristenblad een soortgelijk pleidooi gehouden en een lans gebroken voor een representatief benoemingsbeleid. ${ }^{105}$ In 1973 echter leidt het artikel van Cnoop Koopmans tot een stroom van reacties, waarin vooral het verband tussen 'recht' en 'politiek' bekritiseerd wordt, een gevoeligheid die wellicht kan worden verklaard uit de discussie over klassejustitie, die op dat moment net gesust lijkt. De minister van justitie (A.A.M. van Agt) noemt het pleidooi van Cnoop Koopmans 'ongenuanceerd', en meent dat deze het woord politiek gebruikt voor verschillende situaties. Toch is ook Van Agt het met Cnoop Koopmans eens dat bij rechtspraak sprake kan zijn van politiek handelen:

"Sommige werkzaamheden van de rechter hebben intussen inderdaad een verandering in maatschappelijke verhoudingen tot gevolg, en kunnen dus als politiek handelen, beter gezegd als policy-making - hiervoor heb ik geen vertaling dispomibel - worden aangemerkt. Ik zou er evenwel voor terugdeinzen onder een dergelijk politiek handelen ook partijpolitiek handelen te begrijpen. Zodra nu de relatie wordt gelegd met de vertegenwoordigende lichamen, zoals de heer Cnoop Koopmans doet. dringt zich die associatie wel op. Ik zou hem daarin, als hij dat bedoelt, niet willen volgen. Wij moeten blijven verlangen, dat iedere rechter, of hij nu lid is van een politieke partij of niet, oordeelt in volstrekte onbevangenheid en onpartijdigheid. Ik kan dan ook niet inzien, dat wij, zelfs als wij het uitgangspum van de heer Cnoop Koopmans zouden kiezen. alle politieke richtingen in de rechterlijke macht zouden moeten aantreffen. "106

De vele tegenstanders van het voorstel van Cnoop Koopmans vrezen vooral een politisering van de rechterlijke macht, en daarmee een daling van het vertrouwen in de rechtspraak. "Een rechter die van wege zijn politieke richting door een politiek gekozen college wordt benoemd is niet meer objectief. Juist vanwege zijn politieke kleur (maatstaf voor zijn benoeming) wordt van hem verwacht overeenkomstig die kleur recht te spreken en zal hij zich gebonden gevoelen aan partijpolitieke programma's en standpunten. ${ }^{107}$ Men meent dat

105. Zie $\$ 4.4 .1$

106. Hand. II 1973-1974, p. 807-808

107. L. Wichers Hoeth, NJB, 1973, p. 1209. In gelijke zin: W. de Vries, NJB, i973, p. 1212-1216 en Th. H.A.M. van Eupen, Handelingen NJV, 1975, deel 1, p. 41 
de door Cnoop Koopmans bepleite raad voor de rechterlijke macht voet geeft aan "de onjuiste gedachte dat ook in de rechtspraak wordt gestreden over levensbeschouwelijke, sociaal-economische of politieke strijdpunten." $10 \mathrm{~s}$ Anderen trekken de analyse van Cnoop Koopmans in twijfel. Zo zegt de rechtsfilosoof J.J. Loeff in zijn afscheidscollege: "Wij hebben er alle begrip voor, dat de deuren en ramen van onze eerbiedwaardige gerechtsgebouwen eens wijd worden opengezet, zodat er een frisse wind doorheen kan blazen, maar wij zijn er niet gerust op of het vertrekpunt, waarvan veel kritiek en voorstellen tot vernieuwing uitgaan, wel juist is. ${ }^{m(*)}$ Volgens J.C.M. Leijten noopt de grondgedachte van Cnoop Koopmans - meer politieke verscheidenheid onder rechters - tot een andere oplossing. Niet de ministeriële bevoegdheid dient te worden verkleind maar er moet gebroken worden met het systeem van anbevelingen. Opnieuw meent Leijten - net als in zijn oratie uit 1970 - dat 'teamgeest' als criterium bij benoemingen dient te vervallen. ${ }^{110}$ Hoewel hij zich aanvankelijk nog bijzonder sceptisch uitlaat over een raad voor de rechterlijke macht ${ }^{11}$, toont hij zich in zijn preadvies voor de Nederlandse Juristenvereniging in 1975 een voorstander van een dergelijk instituut. ${ }^{12}$

\subsection{Promotiefuncties}

Uit het voorgaande blijkt dat het recruteringsprobleem van vlak na de Tweede Wereldoorlog, en de latere kritiek op de eenzijdige samenstelling van de rechterlijke macht, heeft geleid tot twee ontwikkelingen: de institutionalisering van een opleiding voor rechterlijke ambtenaren (de raio-opleiding) en de institutionalisering van de werving en selectie van buitenstaanders, door de instelling

108. H.L. Wedeven, Taak en positie van de rechterlijke mach in onze samenleving. Handelingen NJV 1975, deel 1, p. 96-97. In gelijke zin: M. Bonger, NJB, 1973 p. 1208, en W. Schenk. Verantwoording en vooruiticht. NJB, 1974, p. 6-16

109. J.J. Loeff, Het rechl is de hoeder van de ander, 1973, p. 15, instemmend aangehaald door W.E. Haak, Ad personam, ad rem, in: 't exempel dwinght, 1975, p. 203-204

110. J.C.M. Leijten, De rechter op de schopstoel, oratie 1970, p. 23

111. J.C.M. Leijten, Rechter en politiek 1, NJB,1973, p. 1204-1205 Zie ook: J.C.M Leyten, De opleiding van de magistratuur in Nederland, in: Taak en opleiding van de magisiraat, 1973, p. 87

112. J.C.M. Leyten, De positie van de rechterlijke macht in de samenleving; in: Handelingen NJV 1975, deel 1,p. 121. Zie ook de stemming op de vergadering van de NJV op 21 juni 1975. Vraagpunt 7 luidt: 'Is het wenselijk, dat een voor tenminste de helft uit niet-leden van de rechterlijke macht bestaand college wordt ingesteld voor benoeming van rechters? Indien deze vraag bevestigend wordt beantwoord: a dient dit college dan uitsluitend adviserende bevoegdheid te hebben? $b$. behoren de leden van dit college te worden benoemd door c.q. op bindende voordracht van de volksvertegenwoordiging?' V raag 7 werd bevestigend beantwoord, evenals vraag 7a. Vraag b werd ontkennend beantwoord. 
van de Commissie aantrekken leden rechterlijke macht (aanvankelijk: Commissie-Dubbink). Doordat in beide gevallen de minister van justitie belangrijke bevoegdheden kreeg bij de samenstelling van de selectiecommissies, kon de uitvoerende macht meer en meer haar stempel drukken op het selectiebeleid. Kritiek op de potentieel uniformerende werking van de selectiecommissies bleef dan ook niet uit. ${ }^{113}$ De vermoedens over de uniformerende werking van de selectiecommissies zijn later bevestigd door het voormalig hoofd van de Hoofdafdeling Rechterlijke Organisatie van het ministerie van justitie, P. Mostert. In een interview in 1981 herinnerde hij zich de eerste tijd van de raio-selectie door de minister van justitie Samkalden.

"Hij heefi de eerste selectie duidelijk overgedaan en daarmee richtlijnen gegeven voor zijn vertegenwoordiger in de Commissie, en ik kan u zeggen dat waren heel strenge richtlijnen. Verder is het steeds zo gebleven dat alleen die kandidaten door de commissie kwamen waarmee zowel de rechterlijke macht als het departement zich konden verenigen. Als éen van de twee fundamenteel bezwaar bleef houden kwam de kandidaat er niet door, "114

Er is echter nog een ander - zeer belangrijk - terrein waar de invloed van het ministerie van justitie na de Tweede Wereldoorlog toeneemt, en dat in de literatuur ten onrechte onderbelicht blijft, namelijk de benoeming in promotiefuncties. Terwijl de critici van Rechter en politiek in 1973 zich vastbijten in de ideeën van Cnoop Koopmans over de 'democratisering' van de rechterlijke macht, signaleert deze in 1973 ook de groeiende greep van het ministerie van justitie op de promotie van de leden van de rechterlijke macht. In 1975 schrijt hij hierover:

"Terwijl de benoeming van nieuwe leden in de colleges in feite een kwestie van coöptatie is, onttrekt de verdere benoeming binnen de colleges zich thans aan hun invloed en geschiedt in hoofdzaak door het ministerie van justitie. Een situatie die zo mogelijk nog ongewenster is. De onafhankelijkheid van de rechter ten opzichte van de administratie, van de vierde macht, van het daarmee verbonden openbaar ministerie is hiermee aangetast. Een rechter zal zich in zijn dagelijkse werk licht kunnen laten beïnvloeden door de wetenschap dat zijn. 'promotie' afhankelijk is van wat het O.M. daarover aan het ministerie bericht. "115

113. Zie: Coornhert Liga, Alternatieve justitiebegroting 1973, p. 46-47. Zie in gelijke zin: P. Zonderland. Het menselijk gelaat van de Nederlandse burgerlijke rechter. Intermediair 22 april 1977, p. 47 en W.E. Haak, Rechers, wie zijn dat, en hoe kom ik er aan?. in: De magistraat in de st(r)aat, 1979, p. 57-70

114. In: De schutkleur van de rechterlijke macht, Trema, 1981, p. 163

115. Reactie op de preadviseurs, Handelingen NJV, 1975, deel 2, p. 54 
Waar Cnoop Koopmans op doelt is dat de anciënniteitsregel, die van oudsher de doorstroom naar presidents- en vice-presidentsfuncties bepaalde, na de Tweede Wereldoorlog allengs wordt vervangen door z.g. keuzebenoemingen, waarnaar gesolliciteerd kan worden. De nieuwe situatie geeft de minister een belangrijke rol bij de selectie van presidenten en vice-presidenten. De benoeming tot president rechtbank bijvoorbeeld vindt plaats na consultatie van de president van het gerechtshof in het betreffende ressort, die op zijn beurt het gevoelen van het college en dat van de Deken van de Orde van advocaten inwint. De reden voor het verlaten van de anciënniteitsregel is dat de zich uitbreidende kort gedingrechtspraak steeds meer eisen stelt aan de geschiktheid van de (fungerend) president. ${ }^{116} \mathrm{Bij}$ wijze van experiment besluit de minister van justitie (Van Agt) daarom eind 1974, ook de vacatures van vice-president rechtbank voor sollicitatie open te stellen door publikatie in het Nederlands Juristenblad. ${ }^{117}$

Een belangrijk punt van kritiek op de keuzebenoemingen was dat een herkenbare procedure ontbrak. Of, zoals de vice-president van de rechtbank Arnhem P.R. Smits het in 1989 uitdrukt: "Het departement had een belangrijke, doch onduidelijke vinger in de pap, evenals de hof-president van het ressort, de oudpresident van het college, de hoofdofficier van justitie en de procureur-generaal, de laatste twee met hun ondoorgrondelijke inlichtingenkanalen." ${ }^{118}$ Ook de commissie-Van der Velden, ingesteld door de Nederlandse Vereniging voor Rechtspraak, hekelt in 1981 de "waas van geheimzinnigheid", die zich wreekt ten aanzien van het vertrouwen van de bevolking "omdat de indruk gewekt wordt dat er wat te verbergen valt. Maar zelfs onder de leden van de rechterlijke macht zelf wordt het als merkwaardig ervaren dat bijvoorbeeld niets bekend is over de wijze waarop, met name op wier adviezen, benoeming in topfuncties in de rechterlijke macht tot stand komen. "119 Niet voor niets vergelijkt K.E. Mollema de benoeming van een rechtbankpresident in 1980 dan ook met een pausbenoeming: "Reeds maanden van te voren zwelt de geruchtenstroom aan. De één waant zich nog ingewijder dan de ander. Toch blijkt keer op keer dat de werkelijke ingewijden zich in onze residentie bevinden en aldaar in hun ivoren toren de definitieve beslissing nemen. "120

16. Rapport-Nivard, p. 370

117. MvT, Bijl. Hand. II 1975-1976, 13600, hoofdstuk VI. nr. 2, p. 43 Zie: Circulaire van 3 januari 1975 (nr. 2284, P 874)

118. P.R. Smits, Enige kanttekeningen bij de huidige procedure van benoeming van presidenten en vice-presidenten bij de rechibanken en hoven. Trema, 1989, p. 169

119. Gevraagd: een raad voor de rechterlijke mach Rapport van de commissie raad voor de rechterlijke macht aan hel bestuur van de Nederlandse Vereniging voor Rechtspraak, gepubliceerd in: Trema, 1981, p. 253

120. K.E. Mollema, De witte rook kringelt op, Trema, 1980, p. 137-138 
De kritiek op de ondoorzichtige benoeming in promotiefuncties moet worden gezien tegen de achtergrond van het gewicht van de betrokken functies. Met name de functie van (fungerend) president van de rechtbank is in belang toegenomen, in verband met zijn taak in de kort gedingrechtspraak. ${ }^{121} \mathrm{Bij}$ de Rijksbegroting 1982 vraagt het Tweede Kamerlid Faber (CDA) dan ook aandacht voor het probleem van de 'verstrengeling 'van de rechterlijke met de uitvoerende macht. "Men zou kunnen zeggen dat wij op het ogenblik hard op weg zijn naar een rechtersstaat. Ook in dit Huis moeten wij de hand in eigen boezem steken. Hoe komt het: vage wetsnormen, kaderwetgeving, algemene beginselen van behoorlijk bestuur, toegenomen mondigheid van de burger niet te vergeten, toegenomen rechtshulp, maar ook trage wetgeving!"122 Faber vraagt zich af hoe het in dit verband staat met de onafhankelijkheid van de rechterlijke macht ten opzichte van de uitvoerende macht, en welke waarborgen er zijn ten aanzien van het carrièrebeleid, om die onafhankelijkheid in de toekomst te waarborgen. ${ }^{123}$ Ook de Staatscommissie herziening rechterlijke organisatie, neemt in 1985 bovenstaand perspectief van de toegenomen overheidsbemoeienis en de bedreiging die daarvan uitgaat voor de onafhankelijkheid van de rechterlijke macht, tot haar uitgangspunt: "Naarmate het bestuur vaker direct of indirect bij geschillen betrokken is, neemt de kans op uitspraken die voor het bestuur niet gunstig zijn, toe. Het bestuur kan er daardoor belang bij hebben alleen rechters te benoemen of te bevorderen van wie te verwachten of gebleken is, dat zij de door het bestuur gestelde doelen niet zullen tegenwerken. "124 De Staatscommissie constateert een 'overheersende' invloed van de minister van justitie op de benoeming en bevordering van rechters. Hoewel zij geen enkele aanwijzing zegt te hebben dat het benoemingsbeleid ook maar enigszins tendeert in de richting dat door het bestur rechters worden benoemd of bevorderd van wie te verwachten of gebleken is, dat zij de door het bestuur gestelde doelen niet zullen tegenwerken, acht zij het wenselijk dat het bestuur een minder overheersende invloed krijgt op de benoeming van leden van de zittende magistratuur.

\subsubsection{Openstelling promotiefuncties}

De kritiek op het ondoorzichtige promotiebeleid leidt in 1981 tot de instelling van de werkgroep-Nivard, die niet alleen voorstellen doet voor een loopbaan-

121. Rappen-Nivard, o.c. p. 370

122. Hand. II 1 december 1981, p. 661

123. Hand. II 1 december 1981, p. 662

124. Eindrapport van de Staatscommisvie Herriening Rechterlijke Organisatic, deel II, 1985, p. 7 
prognosesysteem ${ }^{125}$, maar ook voor de benoeming in promotiefuncties. De werkgroep meent dat de benoemingsprocedures van met name de presidenten en vice-presidenten, zoals die in de vorige eeuw ontwikkeld zijn, minder goed hanteerbaar zijn geworden; zo zou bijvoorbeeld de anbevelingsprocedure ${ }^{136}$ zijn toegesneden op de beperkte omvang van de toenmalige rechtbanken en hoven ( 3 tot 5 leden). Het experiment met de benoemingsprocedure voor de vice-president rechtbank wenst de werkgroep te handhaven en wettelijk vast te. leggen. Ook ten aanzien van presidentsvacatures rechtbank stelt de werkgroep een open sollicitatieprocedure voor die zoveel mogelijk overeenkomsten vertoont met de procedure voor de vice-president rechtbank. De aanbeveling zal echter niet door een commissie maar door de president van het gerechtshof worden opgesteld. De president van het gerechtshof dient daarbij schriftelijk het advies in te winnen van de hoofdofficier van justitie, het desbetreffende college en de Deken van de Orde van advocaten in het arrondissement. ${ }^{127}$ De regering volgt de suggestie van de werkgroep-Nivard en in 1985 wordt de functie van president arrondissementsrechtbank opengesteld voor sollicitatie. Anders dan de werkgroep-Nivard echter had voorgesteld, geschiedt de aanbeveling niet door de president van het gerechtshof alleen, maar wormt deze een commissie, met twee ad hoc door de vergadering van rechtbankpresidenten aan-

125. Het loopbaanprognosesysteem omschreef de werkgroep enigszins houterig als "Het stelselmatig verzamelen van relevante informatie omtrent de belangstelling van rechers en vice-presidenten van rechbanken (belangstellingsregistratie), alsmede de informatie over hun verdere loopbaammogelijkheden in de ziltende magistratuur foopbaanindicatie). " (Rapport-Nivard, o.c. p. 367) De betekenis en de voordelen van het systeem - waarin een sleutelrol voor de president van het college is weggelegd - waren volgens de werkgroep-Nivard tweeledig. Volgens de werkgroep biedt het systeem de mogelijkheid van een betere onderbouwing van de aanbevelingen voor en benoemingen in rechterlijke promotiefuncties en van een verdere uitbouw van de personeelsplanning, terwijl het voor rechters en vice-presidenten meer inzicht in eigen carrièremogelijkheden en een grotere controleerbaarheid van de a anbevelings- en benoemingsprocedures creëert. Het zou bij het loopbaanprognosesysteemniet gaan om een 'methodische personeelsbeoordeling' die de huidige functievervulling tot onderwerp heeft. "De huidige functievervulling van de rechter of vice-president is in het systeem geen beoordelingsdoel op zichzelf doch slechis een aanknopingspunt voor de beoordeling van de potentiele geschiktheid." (Rapport-Nivard, o.c. p. 367) De plannen van de werkgroep-Nivard verdwenen uiteindelijk in de ijskast. Thans is bij de NVVR opnieuw een loopbaanprognosesysteem in studie.

126. N.B. Met weinig gevoel voor historiciteit noemt de werkgroep-Nivard de negentiendeeeuwse aanbevelingsprocedure 'vooruitstrevend', omdat slechts de door het college gekwalificeerde kandidaten voor benoeming in aanmerking kwamen, terwijl anderzjjds. slechts die kandidaten benoemd werden die voor het college in collegiaal opzicht aanvaardbaar waren. Bij herhaling echter is deze procedure in de vorige (en ook in deze) eeuw juist op grond van deze factoren gelaakt wegens haar conserverende invloed. Zie ook hoofdstuk 3

127. Rapport-Nivard, o.c. p. 372 
gewezen rechtbankpresidenten. Een vergelijkbare benoemingsprocedure geldt sinds 1987 voor de functie van president gerechtshof en sinds 1989 voor de functie van vice-president gerechtshof. ${ }^{128}$

\subsection{Benoembaarheidsvereisten}

In hoofdstuk 3 is er al op gewezen dat de formele benoemings- en benoembaarheidsstructuren voor rechterlijke ambtenaren sinds de invoering ervan in de vorige eeuw niet zijn gewijzigd. Na de Tweede Wereldoorlog heeft het benoemingsstelsel weliswaar onder zware kritiek gestaan, maar tot een wijziging van de uitgangspunten, die al in het begin van de vorige eeuw zijn geformuleerd, heeft dit niet geleid. In het licht van de ontwikkelingen die zich ten aanzien van het denken over de aanbeveling en - later (zie hierna) - de voordracht hebben voorgedaan is dat merkwaardig; daarbij ging het immers allereerst om een recruteringsvraagstuk, nl. om de veronderstelling dat de rechterlijke macht eenzijdig is samengesteld. Juist de benoembaarheidsvereisten zijn - misschien meer nog dan het benoemingsstelsel - bepalend voor het recruteringsperspectief. Het verhinderen, bemoeilijken of juist vergemakkelijken van de toegang tot het rechtersambt voor bijvoorbeeld niet-Nederlanders, personen die niet voltijds beschikbaar kunnen of willen zijn, niet-juristen of juristen met een specifieke opleiding, of (kandidaat-)rechterlijke ambtenaren met typische nevenfuncties, kan een belangrijke impuls betekenen voor een vernauwing of juist verbreding van de samenstelling van de rechterlijke macht. In de discussie over de bredere samenstelling van de rechterlijke macht in de jaren vijftig, zestig en zeventig, is dit probleem echter voor het grootste deel blijven liggen. Ook in de jaren tachtig en negentig, als het thema 'afspiegeling' van maatschappelijke opvattingen en stromingen in de rechterlijke macht steeds belangrijker wordt (zie hoofdstuk 6), zal de aandacht voor de benoembaarheidsvereisten achterblijven.

\subsubsection{Het vereiste van het Nederlanderschap}

De eerste, belangrijke barrière voor de toegang tot het rechtersambt vormt het vereiste van de Nederlandse nationaliteit. Vóór 1988 wordt de nationaliteitseis voor rechterlijke ambtenaren niet in de Wet RO genoemd, maar geregeld in de Wet van 4 juni 1858, regelende de benoembaarheid van vreemdelingen tot landsbedieningen, Stb. 46. ${ }^{129}$ Sinds 1989 wordt de nationaliteitseis ook in art. 29a Wet RO genoemd. Een uitzondering op de regel van art. 29a Wet RO nemen de niet-Nederlandse Molukkers in, 'die door de zorg van de Neder- 
landse regering in 1951 of 1952 in groepsverband naar Nederland zijn overgebracht, en die op het tijdstip van het in werking treden van de Wet van 9 september 1976 Stb. 468 in Nederland woonplaats of werkelijk verblijf hadden'. ${ }^{130} \mathrm{Zij}$ worden bij de toepassing van de Nederlandse wetgeving behandeld als Nederlander, en zijn in tegenstelling tot andere niet-Nederlanders, wèl tot iedere openbare dienst benoembaar, met uitzondering van de krijgsmacht. ${ }^{131}$ Ook het vereiste van het Nederlanderschap dat art. 29a Wet RO als voorwaarde stelt voor de benoembaarheid tot rechterlijk ambtenaar geldt niet voor deze categorie niet-Nederlanders, ${ }^{132}$ Voor deze bijzondere rechtspositie heeft de regering bij herhaling de 'bijzondere historische relatie' tussen de Nederlandse regering en deze bevolkingsgroep genoemd. ${ }^{133}$ Met name de Tweede Kamerfractie van de VVD heeft kritiek op deze regeling geuit, omdat zij het niet wenselijk vindt dat niet-Nederlandse Molukkers functies als rechter, burgemeester of lid van de Raad van State kunnen bekleden. ${ }^{134}$

Tot aan de Wet van 28 september 1989, Stb. 420, was de eis van het Nederlanderschap - als gezegd - niet opgenomen in de Wet op de Rechterlijke Organisatie. ${ }^{135}$ Als in 1988 de eerdergenoemde Wet van 4 juni 1858 Stb. 46 vervalt, ontstaat een situatie waarbij Nederlanders zowel als niet-Nederlanders in de rechterlijke macht benoembaar zijn, maar waarbij degene die na benoeming het Nederlanderschap verliest in verband met art. 12, eerste lid Wet RO zijn arnbt. moet neerleggen. Bij de algehele grondwetsherziening van 1983 was namelijk het tweede lid van art. 5 GW 1972 ('Geen vreemdeling is hiertoe benoembaar dan volgens de bepalingen der wet') uit de Grondwet geschrapt. ${ }^{136}$ De regering is echter van oordeel dat het bezit van het Nederlanderschap van belang is voor rechterlijke ambtenaren zowel 'als waarborg voor kemis van Nederlandse verhoudingen en maatschappelijke beleving, als uit een ongpunt van acceptatie door de justitiabelen'. Daarom stelt zij voor de nationaliteitseis in de

130. Wet van 9 september 1976, houdende regelen omtrent de positie van in Nederland wonende Molukkers die niet het Nederlanderschap bezitten (Wet betreffende de positie van Molukkers). Stb. nr. 468

131. Art. 1 Wet van 9 september 1976 , Stb. nr. 468

132. MvA. Bijl. Hand. Il 1985-1986, 19076 , or. 5, p. 6

133. MvA, Bijl. Hand. II 1989-1990, 21215 , nr. 5, p. 3. Zie ook: Nota naar aanleiding van het eindvers]ag, Bijl. Hand. Il 1986-1987, 19 076, nr. 7, p. 2-3

134. Eindverslag, Bijl. Hand. II 1986-1987, 19076 , nr. 6, p. 2, en: VV, Bill. Hand. II 1989-1990. 21215 , nr. 4, p. 2

135. Overigens wordt in art. 12, eerste lid, Wet RO het verlies van het Nederlanderschap wel als ontslaggrond aangemerkt.

136. Deze bepaling zou volgens de regering een ongewenst accent leggen op het weren van vreemdelingen. Hoewel de wetgever bevoegd is de openbare dienst gebeel of gedeeltelijk te reserveren voor de eigen staatsburgers, sluit de beperking de benoembar. heid van vreemdelingen in de openbare dienst niet uit. 
Wet RO op te nemen. ${ }^{137}$ Volgens de regering is voor het stellen van het nationaliteitsvereiste noodzakelijk dat tussen functie en Nederlanderschap sprake is van een 'zinvolle samenhang'. ${ }^{138}$ Het moet dan gaan om functies waarin een van de 'kerntaken van de staat' worden vervuld, t.w. functies waarin rechtstreeks ${ }^{139}$ publiek gezag over burgers wordt uitgeoefend, of functies die verband houden met de nationale belangen van met name de interne en externe veiligheid van de staat. ${ }^{140}$ Als voorbeeld van een dergelijke functie noemt de regering de zittende en staande magistratuur. ${ }^{141}$ Het CDA-Tweede Kamerlid Paulis merkt hierover in 1987 op dat fundamentele Nederlandse belangen vereisen dat men voor de vervulling van bepaalde functies c.q. beroepen de Nederlandse nationaliteit bezit: " $[W] i j$ moeten bij voorbeeld de situatie voorkomen, waarin een fundamentalistische islamitische rechter met de Iraanse nationaliteit een oordeel moet uitspreken over de persvrijheid in Neder. land. ${ }^{142}$ Uit het voorlopig verslag bij het wetsvoorstel nr. 20301 blijkt echter dat met name de PvdA het stellen van het nationaliteitsvereiste voor het rechterlijk ambt niet zonder meer vanzelfsprekend vindt, nu de Grondwet geen beletselen meer kent voor het benoemen van vreemdelingen. $\mathrm{Zij}$ vraagt zich af of een vreemdeling, die in Nederland de hoedanigheid van meester in de rechten heeft verworven, niet evenzeer geacht kan worden iemand te zijn die kennis heeft van de Nederlandse maatschappelijke verhoudingen en maatschappelijke beleving, en zij wijst er op dat een niet onaanzienlijk percentage van de justitiabelen uit niet-Nederlanders bestaat. ${ }^{143}$ De regering herinnert er echter aan dat de nationaliteitseis niet nieuw is, en meent dat van een rechterlijk ambtenaar onder meer het bezit van een 'grondige kennis van de Nederlandse verhoudingen' gevergd mag worden, waarvoor zij de Nederlandse nationaliteit - kennelijk - een voorwaarde acht. ${ }^{144}$ In 1990 geeft de minister van Binnenlandse Zaken, Dales, echter toe dat het bezit van de Nederlandse nationaliteit geen 'keihard blijken' is van de verbondenheid met de Nederlandse staat. Toch acht

137. MvT, Bijl. Hand II 1987-1988, 20301 , nr. 3, p. 9 Eerder werd de gedachte on de nationaliteitseis $0 . a$. voor de benoembarheid in de rechterlijke macht te handhaven. door de Tweede Kamer algemeen gesteund. Zie: VV, Bijl. hand. II 1985-1986, 19076. nr. 4, p. $1-6$

138. MvT. Bijl. Hand. II 1984-1985, 19076 , nr. 3, p. 6

139. De bijvoeging 'rechtstreeks' is van belang. Bij de totstandkoming van de Wet van 25 februari 1991 tot wijziging van enkele wetten betreffende het doen vervallen van de eis van Nederlanderschap voor bepaalde functies, Stb. 98 . stelt de regering dat het enkel uitoefenen van gezag geen criterium is voor het stellen van de eis van Nederlanderschap. MvA. Bijl. Hand. I 1990-1991, 21 215, nr. 68a, p. 2

140. MvT, Bijl. Hand. II 1984-1985, $19076, \mathrm{nr} .3$, blz. 5

141. Zie in gelijke zin: MvA. Bijl. Hand. II 1989-1990, 21 215, nr. 5, p. 5

142. Hand. II, 19 maart 1987 , p. 3201

143. VV, Bijl. Hand. $1987-1988,20301$, nr. 4, p. 3

144. MvA, Bijl. Hand. II 1988-1989, 20301 , nr. 5, p. 9 
zij het 'passend' om een 'veiligheidslijn' te trekken: "Het Nederlanderschap toont een minimale betrokkenheid bij de Nederlandse staat, die allereerst dient te worden vastgesteld." 145

\subsubsection{Het opleidingsvereiste}

Sinds $1814 / 1815$ is de tweede belangrijke voorwaarde voor benoembaarheid in de rechterlijke macht het vereiste van een bepaalde universitaire juridische opleiding geweest (thans artt. 35, eerste lid, 48, eerste lid, 64 en 86 Wet RO). Voor de toegang tot het rechtersambt in de vorige en in onze eeuw is de opleidingseis van groot belang geweest, omdat de uitsluiting van niet-academici materieel tot effect heeft gehad dat met name de lagere milieus niet in aanmerking kwamen voor een benoeming in de rechterlijke macht.

Afgezien van kleine wijzigingen ${ }^{146}$, heeft na de Tweede Wereldoorlog slechts enige discussie bestaan over de al dan niet benoembaarheid van fiscaal-juristen in de rechterlijke macht. In 1972 rijzen grote bezwaren van de kant van de universiteiten, als een uit 1957 daterende regeling, die afwijking van de algemene opleidingseis toestaat bij de benoeming van die raadsheren in de getechtshoven, die wishütend dienst zouden doen in de belastingkamers, niet wordt verlengd. ${ }^{147}$ Ten onrechte wordt de fiscaal-juridische studie als onvolwaardig beschouwd, zo betogen de tegenstanders van het ontwerp. "De ge-

145. Hand. II, 19 september 1990 , p. 71

146. Bij Wet van 7 september 1972 Stb. 461 is voor de kantonrechters-plaatsvervangerseen opleidingseis als voorwaarde voor benoembaarheid ingevoerd. In art. 64 (gerechtshoven) werd de leeftijdsgrens geschrapt en ook de eis dat de opleiding ten minste vijf (voor de raadsheren-plaatsvervangers: tien) jaar geleden moet zijn voltooid. Ook in art. 84 (Hoge Raad) werd de leeftijdseis geschrapt. Bij Wet van 17 oktober 1978, Stb. 564 werd art. 86. eerste lid, Wet RO gewijzigd, in die zin dat voor de benoembaarheid tot de Hoge Raad de eis van het verlopen van tien jaren sedert het afleggen van het doctoraal examen niet van toepassing was op eventuele aanvullende examens. Bij Wet van 14 mei 1981 schrapte de wetgever in art. 86 Wet RO het vereiste voor de benoeming van de raadsheren, de procureur-generaal, de advocaten-generaalen de griffier-generaal van de Hoge Raad dat de academische graad of hoedanigheid ten minste tien jaar voor de benoeming diende te zijn verkregen. Een soortgelijk vereiste voor de gerechtshoven (vijf jaar) was al bij de Wet van 7 september 1972, Stb. 461 afgeschaft. Na 1981 zijn de bepalingen in de Wet RO over het opleidingsvereiste tweemaal gewijzigd. Zie voor wijzigingen i.v.m. de invoering van de Open Universiteit: Wet van 14 november 1984 . houdende Wet op de Open Universiteit Stb. 1984, 573 Bij Wet van 26 juni 1986, Stb. 388 werd in de artt. 35, eerste en tweede lid, 48 , eerste en tweede lid, $59 \mathrm{~b}, 64,86$, eerste en tweede lid, en 109 Wet RO de zinsnede 'een Nederlandse universiteit of hogeschool in de zin van de Wet op het wetenschappelijk onderwijs' vervangen door: 'een Nederlandse universiteit in de zin van de Wet op het wetenschappelijk onderwijs'.

147. VV, Bijl. Hand. II 1971-1972, 10 808, nr. 9 
dachte dat voor alle rechterlijke functies dezelfde eisen van benoembaarheid moeten gelden, en wel de welke o.a. in art. 64 zijn omschreven, lijkt niet meer in overeenstemming met de huidige situatie. Het recht is zo omvangrijk geworden dat een integrale kennis daarvan aan niemand meer is gegeven. Van de jurist kan niet meer verwacht worden dan dat hij een brede algemene juridische kennis heeft, met een verdieping daarvan op bepaalde onderdelen waarvoor hij speciale belangstelling heeft. ${ }^{148}$ Men beschouwt het als een ongerijmdheid dat een strafrecht-jurist "die nooit iets meer van het belastingrecht heeft gezien dan zijn eigen aangifte, wel zonder meer benoembaar zou zijn in zowel de civiele als de belastingkamer, terwijl de fiscaal-jurist, die evenveel van het burgerlijk recht afweet als de strafrecht-jurist, niet benoembaar zou zijn in de civiele kamer, laat staan de belastingkamer". Alle meesters in de rechten, ook de fiscaal-juridische en notariële, zouden zonder onderscheid benoembaar moeten zijn in alle kamers. ${ }^{149}$

De minister van justitie (Van Agt) wijst deze kritiek echter van de hand. Hij heeft grote moeite met de gedachte om juristen die het strafrecht 'niet meer dan elementair', in het kandidaatsexamen hebben bestudeerd, toe te laten tot de strafrechtspraak. "De strafrechtspraak is een teer onderwerp. Zij raakt in vele gevallen essentiële menselijke waarden en belangen. Juist bij het strafrecht komt het althans in de meer belangrijke zaken aan op het inzicht in het hoe en waarom. Daarbij moet men bedenken, dat de strafrechtspraak in de overgrote meerderheid van de gevallen, bij de kantonrechter altijd en bij de arrondissementsrechtbanken meestal -de politierechter namelijk-, plaatsvindt in een enkelvoudige kamer. ${ }^{1150}$ Niettemin blijkt de regering bereid voor een deel aan de bezwaren tegemoet te komen. Zij neemt een viertal amendementen op het ontwerp over. De vakken burgerlijk-, en handelsrecht en strafrecht blijven verplicht op doctoraal niveau, daarnaast kan een keuze worden gemaakt tussen het Nederlands staatsrecht, administratief recht of belastingrecht. ${ }^{151}$

148. Afdeling Fiscaal en Notarieel Recht van de Faculteit der Rechtsgeleerdheid aan de Rijksuniversiteit te Leiden, Verslag van een openbaar gehoor, Bijl. Hand. II 19711972, 10808 , nr. 9, p. 1-2

149. Wetenschappelijke Staven in het Belastingrecht aan de universiteiten en hogescholen in Nederland, zie: VV, Bijl. Hand. II 1971-1972, 10808

150. Hand. II $1971-1972$, p. 3061

151. Amendement-Geurtsen, amendement-Van Schaik, amendement-Haars en amendementRoethof. Bijl. Hand. II 1971-1972, 10 808, resp. nrs. 36, 37, 38 en 39 De bezwaren tegen de niet-benoembaarheid van fiscaal-juristen zijn overigens gebleven. Zie b.v.: H.J. Hofstra, De positie van de fiscaal-jurist, Weekblad voor Fiscaal Recht, no. 5027. p. 132-137; P. Meyjes, Caveant quaestores, Weekblad voor Fiscaal Recht, no. 5027 p. 125 132; P. Meyjes, De geruststellende woorden van de minister van justitie, Weekblad voor Fiscaal Recht, no. 5036, p. 321-323; H.C.F. Schoordijk, Verouderde benoemingseisen voor de rechterlijke macht, NJB 1988 p. 286-287; De wijziging van 


\subsubsection{Incompatibiliteiten}

Terwijl de aandacht voor het nationaliteitsvereiste en de opleidingseis na de Tweede Wereldoorlog vrij marginaal is geweest, en slechts heeft geleid tot de handhaving van de bestaande benoembaarheidsstructuren, heeft de regeling van de onverenigbaarheden - in het bijzonder de regeling van de nevenfuncties vooral de laatste jaren tot veel commotie geleid. ${ }^{152}$ Op weinig plaatsen wordt het verschijnsel van wetgeving als 'reactief verschijnsel' ${ }^{153}$ zo duidelijk als bij het onderwerp van de nevenfuncties. Aanvankelijk lijkt na de Tweede Wereldoorlog ten aanzien van de nevenfuncties een liberale houding te bestaan. Zo vervalt in 1956 de bepaling in de Wet RO dat de leden van de rechterlijke macht geen 'ambt kunnen uitoefenen aan hetwelk een vast tractement verbonden is'. In plaats daarvan wordt in 1956 in de Wet RO het criterium van de 'hoofdbetrekking' ingevoerd. Hoewel het de leden van de rechterlijke macht verboden is een andere hoofdbetrekking te hebben, zijn nevenfuncties, ook die waaraan een vergoeding is verbonden, toegestaan. ${ }^{1.54}$ De liberale houding ten aanzien van nevenfuncties zet zich in onze tijd door in het rapport dat de commissie-Van Julsingha in 1980 uitbrengt ten behoeve van de NVvR, en bij de grondwetsherziening 1983. De commissie-Van Julsingha acht nog slechts een beperkt aantal functies, beroepen of ambten steeds onverenigbaar met het rechterlijk ambt, t.w. die van advocaat, procureur, notaris, belastingconsulent, deurwaarder en rechtshulpverlener. ${ }^{155}$ Wel is de commissie verdeeld over de vraag of, anders dan tol dusverre, functies in of lidmaatschappen van vertegenwoordigende lichamen met wetgevende bevoegdheid en functies in het openbaar bestuur steeds onverenigbaar moeten worden geacht:

"De rechter die zijn taak in onafhankelijkheid moet uitoefenen, behoort voor zo ver zijn taak bestaat in toetsing, uitleg en toepassing van een wettelijke regel, niet te hebben deelgenomen aan de vaststelling van deze regel, terwijlde rechter die moet oordelen over de rechtmatigheid van bestuursdaden, zowel formeel als inhoudelijk vrij moet staan ten opzichte van dit bestuursorgaan. Het beginsel van de gelijkheid van partijen laat immers niet toe dat de rechter in procedures waarbij de overheid

enige bepalingen betreffende de R.O. in de Tweede Kamer, Weekblad voor Fiscaal Recht, no. 5082, p. 381-385; Wijziging van enige bepalingen betreffende de rechterlike organisatie, Weekblad voor Fiscaal Recht, no. 5031, p. 234-235

152. Het vraagstuk van de onverenigbaarheid op grond van bloed- of aanverwantschap of zwagerschap blijft hier buiten beschouwing. In het kader van de aanhangige herziening van de rechterlijke organisatie is deze eis bij Wet van 3 juni 1992, Stb. 278 komen te vervallen.

153. De term is van Reiner de Winter, De heersende leer, 1992, p. 7

154. MvT, Bijl. Hand. Il 1954-1955, 3705, nr. 3 Vergelijk art. 8, eerste lid, Wet RO

155. Rapport Onverenigbaarheden, gepubliceerd in: Trema, 1980, p. 181 
in enige vorm betrokken is als belanghebbende, in een bijzondere relatie tot dit bestuur staat. ${ }^{156}$

Ook een minderheid van de Staatscommissie van Advies inzake de Grondwet en de Kieswet meent in 1971 dat alle met rechtspraak belaste personen - voorzover zij de rechtspraak als hoofdberoep uitoefenen - uitgesloten dienen te worden van het lidmaatschap van de Staten-Generaal. Voor het bekleden van de functie van rechter is volgens haar een andere 'instelling' vereist dan voor die van volksvertegenwoordiger. $\mathrm{Zij}$ meent dat er een principieel onderscheid is, "terug te voeren op het beginsel van de scheiding der machten"; daarnaast meent men dat "de burgers het ook niet op prijs stellen indien rechters een uitgesproken politieke functie zouden bekleden". De overige leden van de Staatscommissie en de regering delen dit inzicht echter niet. Het beroep op "het klassieke, doch achterhaalde, beginsel van de scheiding der machten" acht men allerminst overtuigend ${ }^{157}$ :

"Dat voor het ambt van rechter en voor dat van volksvertegenwoordiger een verschillende instelling zou zijn vereist, achten wij een zwak argument. Naar ons oordeel zijn er geen overtuigende staatsrechtelijke gronden aan te voeren om de gehele rechterlijke macht in al zijn geledingen in de Grondwet van het lidmaatschap van de Staten-Generaal uit te sluiten. Ook hier rijst de vraag of bij een eventuele onverenigbaarverklaring niet gedifferentieerd zou moeten worden. Het verdient de voorkeur om in de Grondwet op dit punt niets te bepalen, zodat de weigever alle vrijheid heeft om - na grondwetsherziening - de regeling te treffen, die hij eventueel zou wensen. "158

Overigens blijft de grondwettelijke incompatibiliteit voor de leden van de Hoge Raad in 1983 onveranderd. ${ }^{159}$ De regering sluit daarvoor aan bij een tweetal

156. Rapport Onverenigbaarheden, Trema, 1980 p. 181

157. Eindrapport Staatscommissie Herziening Rechterlijke Organisatie, o.c. p. 119

158. MvT, Bijl. Hand. II 1978-1979, 14 223, nr. 3, p. 20 Zie in gelijke zin het Eindrapport van de Staatscommissie Herziening Rechterlijke Organisatie in 1985.

159. Art. 97 GW 1922, voorzover hier relevant, luidt: "Een lid van de Staten-Generual kan niet te gelijker tijd zijn vice-president of lid van den Raad van State, presidem, vicepresident of lid van of procureur-generaal of advocaal-generaal bij den Hoogen Raad, noch president of lid van de Algemeene Rekenkamer, noch Commissaris des Konings in eene provincie."

Art. 99 GW 1938/1946/1948 (art. 106 GW 1953/1956/1963/1972), voorzover hier relevant, luidt: "Een lid van de Staten-Generaal kan niet te gelijker tijd zijn Minister, vice-president of lid van den Raad van State, president, vice-president of lid van of procureur-generaal of advocaat-generaal bij den Hoogen Raad, noch president of lid van de Algemeene Rekenkamer, noch Commissaris des Konings in eene provincie." Art. 57, tweede lid GW 1983, luidt: "Een lid van de Staten-Generaal kan niel levens zijn minister, staatssecretaris, lid van de Raad van State, lid van de Algemene Reken- 
historische argumenten: het opmaken van de voordracht voor de Hoge Raad door de Tweede Kamer, en de taak van de Hoge Raad bij de beoordeling van ambtsmisdrijven. ${ }^{160}$ Beide argumenten zijn overigens niet erg sterk. De voordrachtsbevoegdheid van de Tweede Kamer staat immers het lidmaatschap van de Eerste Kamer niet in de weg; het tweede argument mist kracht omdat vervolging en berechting van leden van de Staten-Generaal in de praktijk nooit is voorgekomen. ${ }^{161}$

\subsubsection{Politieke nevenfunctie van A.J. Cnoop Koopmans}

De discussie over (politieke) nevenfuncties van leden van de rechterlijke macht is tot de jaren tachtig vooral theoretisch van aard. Hoewel het verschijnsel van rechters met politieke nevenfuncties niet geheel onbekend is, hebben 'incidenten' met dergelijke nevenfuncties zich tot dan toe niet voorgedaan. Dat verandert als de Amsterdamse rechter A.J. Cnoop Koopmans in 1982, behalve lid van de Eerste Kamer voor de PvdA ook lid wordt van de gemeenteraad voor die partij in Amsterdam. Onder de kop 'Mr. Cnoop Koopmans mag van rechtbank niet in raad' bericht Het Parool op 15 juni 1982 dat bij de Amsterdamse rechtbank en bij het ministerie van justitie bezwaren zijn gerezen tegen de combinatie van beide functies. Later blijkt dat het bericht in Het Parool op een misverstand berust, maar inmiddels is al enige commotie ontstaan rondom de verkiezing van Cnoop Koopmans. Niet alleen bij collega-rechters (zie hierna), ook bij de PvdA bestaan bezwaren tegen een dergelijke combinatie van functies. ${ }^{162}$ In overleg met het ministerie van justitie geeft Cnoop Koopmans zijn baan als rechter voor tweevijfde op, met behoud van volledig salaris als vicepresident, onder de voorwaarde dat hij zijn verdiensten als raadslid afdraagt aan het Rijk. ${ }^{163}$ Zelf zegt Cnoop Koopmans later over zijn nevenfunctie het "heel vanzelfsprekend" te vinden "dat je als rechter aan politiek kunt meedoen". "Waarom zou je geen verkiezingsaffiche voor je raam kunnen hangen?

kamer of lid van of procureur-generaal of advocaat-generaal bij de Hoge Raad. "

160. MvT. Bijl. Hand. II 1978-1979, 14223 , nr. 3. p. 18. Beide argumenten waren eerder genoemd door de Staatscommissie van Advies inzake de Grondwet en de Kieswet, Eindrapport, o.c. p. 115. Vergelijk art. $119 \mathrm{GW}$ 1983: "De leden van de StatenGeneraal, de ministers en de staatssecretarissen staan wegens ambtsmisdrijven in die betrekkingen gepleegd, ook na hun aftreden terecht voor de Hoge Raad. De opdracht tot vervolging wordl gegeven bij Koninklijk besluit of bij een beshit van de Tweede Kamer. " Met art. 119 GW corresponderen art. 92 en 103 Wet RO.

161. Zie ook: C.A.J.M. Kortmann, De Grondwetsherzieningen 1983 en 1987, 1987, p. 333

162. Zie: Het Parool, 15 juni 1982, Mr. Cnoop Koopmans mag van rechtbank niet in raad 163. NRC Handelsblad, 19 juni 1982, Mr. A.J. Cnoop Koopmans Rechter en politicus bij wijze van experiment. Zie ook: De Telegraaf, 16 juni 1982. Rechter-raadslid zoekt ander werk. N.B. een deeltijdaanstelling in de rechterlijke macht is pas sinds 1989 mogelijk. Zie $\$ 2.3 .8$ 
Ik heb dat altijd gedaan. Ieder mens heeft toch zijn politieke voorkeuren? Als het maar bekend is. Maar de ganghare opvatting is juist: je mag wel je meningen hebben als rechter, als het maar niet teveel naar buiten komt. "164 Een uitgesproken voorkeur of mening over maatschappelijke of levensbeschouwelijke vraagstukken staat volgens Cnoop Koopmans de vereiste onpartijdigheid voor het rechtersambt niet in de weg. "Een rechter is een gewoon mens met gewone meningen, gewone emoties en gewone beperkingen, hoe minder mythes daarover bestaan hoe beter. ${ }^{n 165}$

De nieuwe politieke nevenfunctie van Cnoop Koopmans wordt door collegarechters en door de media, met gemengde gevoelens begroet. H.H. Kirchheiner vraagt zich in Trema af of in deze niet een wat meer "homogene werkwijze" nodig is. "Want hoe zou het zijn uitgevallen onder de vorige president van de rechtbank Amsterdam (Stheeman, MdW) en onder een andere - strengere minister van justitie? (..) moeten deze kwesties blijvend ter beoordeling zijn van de betreffende president van de rechtbank en de minister van justitie tezamen? ?160 $^{16}$ De president van de rechtbank Amsterdam, W.J. Borgerhoff Mulder vindt het "juist wel prettig als rechters zich op maatschappelijk gebied bewegen. ${ }^{1167}$ De Deken van de Nederlandse Orde van Advocaten, P. van den Hoek, noemt de combinatie van beide functies echter "ongebruikelijk": "Depositie van de rechterlijke macht in Nederland wordt sterk gerespecteerd en geniet een grote mate van acceptatie. (-) Bij zo'n dubbelfunctie bestaat de kans dat je de schijn tegen je krijgt en er twijfels kunnen rijzen over de onafhankelijkheid van de rechter en over het rechtspreken zonder aanzien des persoons. ${ }^{168} \mathrm{Be}-$ paald minder enthousiast is Het Parool, bij monde van H.W. Sandberg. Praktisch levert de nevenfunctie volgens Sandberg een 'heel geregel' op, zoals verandering van roosters en overdracht van zaken aan collega's. Ook overigens vraagt Sandberg zich af of het raadslidmaatschap van Cnoop Koopmans (principieel) wel zo wenselijk is. Zeker nu het een zo "geexponeerd gezelschap" als de Amsterdamse gemeenteraad betreft, ligt het gevaar op de loer dat de Amsterdamse rechter in het grensgebied van recht en politiek terechtkomt. "Om nu te voorkomen dat een situatie kan ontstaan waarin de rechter Cnoop Koopmans zou moeten oordelen over aspecten van een beleid waarvoor het gemeenteraadslid Cnoop Koopmans mede-verantwoordelijkheid draagt, is een

164. Bij: C. Lindo, Een iets andere rechter, interview mel A.J. Cnoop Koopmans, NJB. 1987. p. 725

165. Bij: F. Bruinsma, Rechter Cnoop Koopmans: "Onafhankelijk is niet kleurloos". Staatkundig Jaarbock. 1985, p. 13-14

166. H.H. Kirchheiner. Trema, 1982, p. 183

167. De Volkskrant, 16 juni 1982, Raadlidmatschap rechter zet collega's woor het blok

168. De Volkskrant, 16 juni 1982 , o.c. 
geforceerd geknutsel op gang gebracht ${ }^{\prime 1}{ }^{169}$ De Haagsche Courant daarentegen ziet juist voordelen in de nevenfunctie van Cnoop Koopmans: "als lid van de raad zowel als lid van de rechterlijke macht woont hij (Cnoop Koopmans, $M d W)$ in een glazen huis en allen, die met hem hebben te maken, kijken kritisch toe: de combinatie van functies zal hem er nog scherper van bewust maken, dat hij als rechter onafhankelijk moet zijn. "170

Krap anderhalf jaar later, in november 1983, wordt de politieke profilering van Cnoop Koopmans - overigens niet voor het eerst - aan een vuurprofef onderworpen. In deze periode is sprake van massale ambtenarenstakingen. Met kort gedingen trachten de betrokken werkgevers (de Staat der Nederlanden/particuliere werkgevers) een einde te maken aan de stakingen. Tegen deze handelwijze rijst felle kritiek bij de vakbeweging, die meent dat de rechterlijk macht zo voor 'politieke doeleinden' ${ }^{171}$ wordt misbruikt. De fractie-leider van de PvdA, J.M. Den Uyl betreurt het dat de overheid het oordeel van de rechter zo snel heeft ingeroepen: "De overheid behoort uitermate terughoudend te zijn. Ze mag een beroep op het algemeen belang niet gebruiken om als werkgeefster haar zin te krijgen. ${ }^{172}$ Ook in de media wordt er bij herhaling op gewezen dat de verschillende kort geding-rechters, bij gebreke aan een wettelijke regeling aangaande het stakingsrecht, 'op glad ijs schaatsen' of wordt gesproken over 'rechterlijke kruipolie'. ${ }^{173}$ Als hem in een televisie-interview met de actualiteitenrubriek van de Vara, Achter het Nieuws, op 29 november 1983 wordt gevraagd naar zijn mening over het feit dat de rechter steeds vaker wordt ingeschakeld om arbeidsconflicten op te lossen, zegt Cnoop Koopmans dit een 'bedenkelijke ontwikkeling' te vinden, "want op dic manier wordt de rechter ingeschakeld om de overheid te helpen, hand-en spandiensten te verlenen. Je krijgt de situatie dat de regering een beroep op de rechter gaat doen, om z'n gezag te handhaven. (-) Op die manier breng je de rechter in een heel hachelijke gezagssituatie en bestuursconflict, waar hij eigenlijk niet voor bedoeld is. " Het 'verbaast' Cnoop Koopmans dan ook:

"dat tot dusverre eigenlijk iedercen in dic korte gedingen die uitspraken aanvaard heeft. Op zichzelf is dat een gunstige situatie. Maar het zou me aan de andere kant ook nict verbazen als het moment komt, dat in heftige conflicten, als de rechter in het kort geding duidelijk wordt ingeschakeld om het regeringsgezag door te voeren en de regeringsbesluiten te realiseren, dat dan ook wel cens in het ongelijk gestel-

169. H.W. Sandberg, Recht'r-Gemeenteraadslid, Het Parool, 8 juli 1992

170. Haagsche Courant, 24 juni 1982, Onpartijdige rechter

171. Zie bijvoorbecld de vice-vooritter van de grootste ambtenarenbond AbvaKabo, $H$. Pont. De Volkskrant, 30 november 1983

172. Den Uyl: Acties niet tevergeefs, Het Parool, 2 december 1983

173. Deventer Dagblad, Rechterlijke kruipolie, 1 december 1983 
den, vakbonden of anderen, zouden kunnen zeggen: "Nou, die rechter kan me nog meer vertellen', en dat je daar dan hetzelfde krijgt, dat alles om gaat vallen als dominostenen en ook de rechterlijke macht niet meer het gezag heeft, omdat ze dan juist voor politieke conflicten wordt gebruikt. "174

Het interview met Cnoop Koopmans in 1983 leidt tot een storm van (verontwaardigde) reacties en trekt veel publiciteit. De presidenten van de rechtbanken Amsterdam, Rotterdam, Den Haag en Groningen reageren eensgezind geprikkeld op de wijze waarop Cnoop Koopmans zijn visie openbaar heeft gemaakt. Tussen deze presidenten bestaat echter een opvallend verschil van mening over de juistheid van het betoog van de Amsterdamse rechter. De Groningse president G. Overdiep en de Amsterdamse president B.J. Asscher kunnen zich grotendeels vinden in de kritiek van Cnoop Koopmans. Overdiep geeft toe zelf een 'impliciet wantrouwen' te koesteren jegens de tenuitvoerlegging van kort geding-vonnissen, en daarom gewoonlijk een dwangsom aan zijn uitspraken te verbinden. De Rotterdamse president, F.J.M. Nivard, daarentegen zegt uit te willen gaan van een 'impliciet vertrouwen' in partijen, en om die reden juist geen dwangsommen op te leggen. ${ }^{175}$ In Het Parool is het opnieuw H.W. Sandberg die de uitspraken van Cnoop Koopmans scherp bekritiseert. Sandberg wijst er op dat in de serie kort gedingen, de staat tot dan toe slechts een maal als eiseres was opgetreden, zodat van het verlenen van 'hand- en spandiensten' aan de regering geen sprake is. Ook constateert Sandberg een 'vrij algemene bereidheid' bij de bevolking en bij vakbonden om zich neer te leggen bij het rechterlijk oordeel. De verbazing van Cnoop Koopmans, dat de uitspraken in kort geding nog steeds aanvaard worden, noemt Sandberg 'begrip-bij-voorbaat voor het aan de laars lappen van rechterlijke uitspraken.' Een lid van de rechterlijke macht dient zijns inziens 'beter te weten' of zich tenminste anders uit te drukken. ${ }^{176}$ Dat is ook de mening van de minister-president, R.F.M. Lubbers, die in zijn wekelijkse persconferentie de uitlatingen van Cnoop Koopmans 'buitengewoon ongeloofwaardig en onverstandig' noemt. Zij zouden 'een gevaar voor de politiek en daarmee een risico voor de democratie' zijn. De vrees van Lubbers dreigt enige dagen later waarheid te worden, als chauffeurs van het Zaanse streekvervoerbedrijf Enhabo inderdaad geen gehoor geven aan het blokkadeverbod van de Utrechtse president. Volgens de Waarheid zouden stakers gezegd hebben: "Zelfs een rechter heb ik van de week op

174. Interview met Ati Dijckmeester in de actualiteitenrubriek Achter het Nietws van de Vara, 29 november 1983, integraal afgedrukt in: Het Parool, Maakt de overheid misbriik van rechters?, 6 december 1983

175. NRC Handelsblad, Rechters laken mening Cnoop Koopmans, 1 december 1983

176. H.W. Sandberg. Opinie: een rechter achter het nieuws, Het Parool, 6 december 1983 
de televisie horen zeggen dat hij niet verwacht dat die anti-actie vonnissen allemaal zomaar uitgevoerd worden. ${ }^{177}$

De zorg die Cnoop Koopmans in Achter het Nieuws uitspreekt over de rol van rechters bij stakingen is, hoewel kennelijk opzienbarend, bepaald niet nieuw. Drie jaar eerder, op 10 mei 1980, heeft de president van de Hoge Raad, C.W. Dubbink, een brandbrief gestuurd naar de opinie-pagina van NRC Handelsblad, hetgeen voor een lid van de Hoge Raad op zich al opmerkelijk is. ${ }^{178}$ Dubbink voorziet in 1980 de problemen waartoe stakingsconflicten in de toekomst kunnen leiden. In zijn brief wijst hij er op dat, bij gebrek aan overeenstemming tussen regering en parlement over een wettelijke regeling van het stakingsrecht, een 'gat' zit in het recht. "Zou de rechter dit dan mogen vullen? En hoe? Een vrijblijvende stakingscode zal hem daarbij weinig steun bieden. Men bedenke wel, dat de rechter niet kan doen wat de wetgever doet: geen beslissing nemen. Het procesrecht dwingt hem iedere zaak die hem wordt voorgelegd te beslissen." Dubbink vreest dat de rechterlijke macht het in de toekomst 'moeilijker' zal hebben dan tevoren, en vraagt zich af of de rechter op het gebied van het stakingsrecht die verantwoordelijkheid nog wel kan dragen. Ook de Leidse hoogleraar strafrecht, A.L. Melai ziet in een reactie problemen wanneer 'de politieke strijd, die aan wetgeving ten grondslag ligt, in geval van belangrijke maatschappelijke vraagstukken niet in een wettelijke regeling maar in de rechtszaal wordt beslecht'. "Een bloeiende "eigenmachtige" rechtspraak in een tijd van politieke malaise is een weinig bemoedigend perspectief, omdat daarin de aankondiging is gelegen van het verval van ons politicke stelsel. Dat de rechter zelf klaarblijkelijk niet uit is op de rol van maatschappelijke verlosser, is nog maar cen bijkomstig geluk. ${ }^{n 179}$ De opvattingen van Dubbink en Melai worden echter niet door iedereen gedeeld. Zo vraagt het Tweede Kamerlid H.J. Roethof (PvdA) zich af, of 'wie geen kritiek wil ontmoeten, zich wel voldoende van zijn verantwoordelijkheid bewust is'. "Een rechter, die midden in het maatschappelijk leven staat en toch geen kritiek wenst vermag uitsluitend op te treden tegen machtelozen want zij beschikken niet over de mogelijkheid tot het uitoefenen van dergelijke kritiek. ${ }^{n 180}$

Cnoop Koopmans wordt naar aanleiding van zijn uitlatingen door de procureurgeneraal bij de Hoge Raad, W. Berger, ter verantwoording geroepen. Enige verwarring ontstaat als de minister-president in zijn wekelijkse persconferentie

177. Enhaho-chauffeurs antwoorde'n rechter: geen hlokkade? Ditn stesken!, De Warheid, 3 december 1983

178. C.W. Dubbink, Rechtspraak in de gevarenzone, NRC Handelsblad, 10 mei 1980

179. A.L. Melai. Wetgev'e', he'stuur en de' 'cigemmachtige rechter', NRC Handelsblad. 21 mei 1980

180. H.J. Roethof, Dubhinks gevarenzone, NRC Handelsblad. 20 mei 1980 
de indruk wekt dat hijzelf opdracht heeft gegeven tot het onderzoek. Dat een minister-president tot een dergelijke opdracht bevoegd is, wordt later echter door de minister van justitie, F. Korthals Altes, die zich wellicht enigszins gepasseerd voelt, tegengesproken: "Dat hij zo'n aanwijzing kon geven? Dat is dan een staatsrechtelijke vergissing. Dat kan een minister-president niet. Zo heb ik het ook niet verstaan. Voor Berger is het volstrekt irrelevant of meneer Lubbers dat vindt. Die laat dat langs zich afglijden. Die hoeft zich van niemand iets aan te trekken. "181 In de Volkskrant schrijft de columnist 'Stoker' (Hugo Brandt Corstius):

\begin{abstract}
Onafhankelijk
(-) Niet als columnist, en zeker niet als lid van de Hoge Raad, maar strikt als privé-persoon, veroordeel ik de manier waarop de regering de Hoge Raad misbruikt om een Amsterdamse rechter de mond te snoeren. Eerst roept de premier. beschermd door CDA-knokploegen, dat wat rechter Knoopmans zei a. onwaarheid is, b. helemaal niet erg is, en c. nooit gezegd had mogen worden. En nu moet onze brave procureur-generaal Berger uitzoeken welke beschuldigingen van de premier hij tegen de Amsterdamse rechter zal gaan gebruiken. Grote kans dat Knoopmans zal zeggen: "De Hoge Raad kan me nog meer vertellen; ik zei wat ik dacht en ik ga daar mee door". ${ }^{182}$
\end{abstract}

'Stoker' blijkt te beschikken over een vooruitziende blik, want inderdaad verklaart Berger na het gesprek met Cnoop Koopmans 'geen aanleiding' te zien om de Hoge Raad om een oordeel te vragen over het televisie-interview. Ook de president van de Amsterdamse rechtbank, B.J. Asscher, ziet geen reden 'zijn' vice-president te waarschuwen. ${ }^{183}$ In een terugblik in 1987 zegt Cnoop Koopmans over het gesprek met Berger:

"Achteraf gezien was dat gesprek met de P-G Berger eigenlijk een uiterst vreemd gesprek. Hij heeft een beetje de positie ingenomen mij te willen kapittelen, terwijl. hij niets over me te zeggen heeft. Ik ben uit beleefdheid naar hem toe gegaan. maar eigenlijk had ik dat helemaal niet hoeven te doen. Toen ik tenslotte vroeg wat hij nu precies wilde zei hij: ik ga geen stappen tegen $u$ ondernemen, maar mag het nooit meer doen. Ik zei: daar hebt u niets mee te maken. Dat had hij ook

181. Bij: J. van Tijn en Max van Weezel, Korthals Altes, Vrij Nederland, 24 december 1983 182. De Volkskrant van 7 december 1983

183. In 1990 zegt Asscher: "Ik ben er ook altijd een groot voorstander van geweest dat rechter Cnoop Koopmans lid was van de gemeenteraad in Amsterdam. De rechter heeft de taak een deel te zijn van de gemeenschap. Het is mijn ambitie dat de rechierlijke macht een deel is van de samenleving. De rechter is onderdeel van het overheidsapparaat. I $k$ vind het idioot om de functie van de rechter zo hoog in te schatten. De ivoren toren wordt in stand gehouden doordat die rechters er graag op willen zitten, maar ook door het publiek dat de rechter ver boven de samenleving wil plaatsen. Bij: Bert Molenaar, Rechters, 1990 , p. $30-31$ 
niet, maar hij heeft me toch een beetje zitten dreigen dat ik zulke dingen moest laten en dat hij anders naar de Hoge Raad zou gaan. Doe dat dan maar, zei ik. Ik ben mij niet onvrijer gaan voelen sindsdien en blijf mijn mening geven over kwesties van wetgeving, politiek en regeringsbeleid. "184

De beslissing van Berger wordt overwegend instemmend begroet, al vreest De Telegraaf dat Cnoop Koopmans, die het 'delicate' van zijn dubbelfunctie als rechter en raadslid 'nog altijd' niet beseft, zijn 'vrijspraak' wellicht zal opvatten als een aanmoediging om op de ingeslagen weg verder te gaan. "Nog een paar van zulke druppels en de emmer loopt echt over", aldus De Telegraaf. ${ }^{185}$ Voor de Haagsche Courant is die emmer echter al overgelopen: "deze Amsterdamse rechter kent de grenzen niet die zijn ambt hem opleggen. Op hem is zijn eigen uitlating van toepassing: 'Deze rechter kan ons nog meer vertellen'". ${ }^{186}$ Ook NRC Handelsblad noemt de dubbelfunctie van Cnoop Koopmans 'delicaat', maar verkiest deze boven het vooruitzicht van een rechter die als 'buikspreekpop van de zittende meerderheid' optreedt. ${ }^{167}$ Trouw tenslotte noemt de felheid van de reacties 'veelzeggend', en waarschuwt dat de inhoud van de uitlatingen achter een rookgordijn dreigen te verdwijnen: "Journalisten kennen die reacties: zij beschrijven een bepaald verschijnsel uit de werkelijkheid en moeten dan prompt het verwijt incasseren dat ze beter hun mond hadden kunnen houden, want dan was het in elk geval nog steeds stil geweest. ${ }^{n 188}$

Nu Berger van een onderzoek naar de uitlatingen van Cnoop Koopmans afziet, en ook de Amsterdamse president geen waarschuwing uitdeelt, vraagt het Tweede Kamerlid Den Uyl (PvdA) aan de minister-president of deze bereid is te erkennen dat diens uitspraken, waarin hij de uitlatingen van Cnoop Koopmans scherp veroordeelt, moeten worden aangemerkt als 'onzorgvuldig gelet op de noodzaak van terughoudendheid van de uitvoerende macht ten opzichte van de rechter in ons rechtsbestel'. De minister-president ziet hiertoe echter 'geen enkele aanleiding'. "Het betrof hier niet de inhoud van een rechterlijke uitspraak. Wanneer een lid van de rechterlijke macht buiten de rechtszaal uitlatingen doet over het kabinetsbeleid, acht ik het niet onzorgvuldig daarop

184. Bij: C. Lindo, Een iets andere rechter interview met A.J. Cnoop Koopmans, o.c. p. $725-726$

185. De Telegraaf, Dubbelfunctie. 15 december 1983

186. De Kok, De rechter en de politiek, Haagsche Courant, 1 december 1983

187. NRC Handelsblad, Rechter in de publiciteit, 8 december 1983 Zie ook het pleidooi van G.J.W. van Oven, destijds plaatsvervangend officier van justitie in Amsterdam, die de grijsheid van de rechterlijke macht hekelt, en in de persoon van Cnoop Koopmans een bijdrage tot een "pluriforme rechterlijke macht" ziet. G.J.W. van Oven, Zuinig zijn op onze Cnoop Koopmansen. Het Parool, 16 december 1983

188. Trouw, De recht'r als staatsburger (2), 24 december 1983 
te reageren. ${ }^{\prime 189}$ Lubbers verschilt hierin overigens - opnieuw - van mening met de minister van justitie, Korthals Altes die meent dat kritiek op de handelwijze van Cnoop Koopmans niet op de weg van de regering ligt: "Het enige wat ik daarover te zeggen heb, is dat ik Lubbers er van tevoren op gewezen heb dat als er een verantwoordelijkheid voor de opmerkingen van de heer Cnoop Koopmans zou bestaan, die uitsluitend bij de procureur-generaal bij de Hoge Raad ligt. Het kabinet heeft geen politieke verantwoordelijkheid voor de heer Cnoop Koopmans. "190

Naar aanleiding van de uitspraken van Cnoop Koopmans, stelt Korthals Altes de retorische vraag of de combinatie van rechterschap en gemeenteraadslid wel zo gelukkig is en of er bij toekomstige (promotie-)benoemingen misschien geen rekening mee moet worden gehouden; "Het is denkbaar dat we dat moeten heroverwegen. Ik weet het nog niet. ${ }^{\prime 191}$ De Staatscommissie Herziening Rechterlijke Organisatie gaat in 1985 echter een andere kant op. Zij onderstreept dat een rechter de juridische vraagstukken ook "in hun maatschappelijke context" moet kunnen zien, en dat hij met het oog daarop liefst ook buiten zijn ambt actief aan het maatschappelijke leven moet deelnemen. ${ }^{192}$ Met een merkbaar lichte aarzeling merkt de Staatscommissie op dat geen verandering moet worden gebracht in de thans bestaande regeling van incompatibiliteiten: "Van een rechter mag immers worden verwacht dat hij met de samenleving vertrouwd is, en terwille daarvan kan het nuttig zijn dat hij naast zijn ambt als rechter andere werkzaamheden verricht. ${ }^{\prime 193}$ Terwijl een minderheid meent dat de onverenigbaarheid van het rechterlijk ambt met de beroepen van advocaat, procureur en notaris, haar geldigheid niet heeft verloren, vindt de meerderheid van de Staatscommissie toch dat het geldende verhod beter kan worden afgeschaft. In plaats van een incompatibiliteitenregeling bepleit de Staatscommissie in haar Eindrapport, net als de commissie-Van Julsingha in 1980 deed, een vorm van melding en registratie van nevenfuncties.

\subsubsection{Kwestie-Van den Biesen}

Het betrekkelijk geringe effect van de kwestie-Cnoop Koopmans op het vraagstuk van de nevenfuncties, kan wellicht daaruit worden verklaard dat van enig persoonlijk belang van Cnoop Koopmans bij zijn nevenfunctie geen sprake was. Dat ligt anders in 1986, als de president van de rechtbank Almelo (Van

189. Hand. II 1983-1984, Aanhangsel nr. 286

190. Bij: J. van Tijn en Max van Weezel. Korthals Altes, Vrij Nederland, 24 december 1983

191. Bij: J. van Tijn en Max van Weezel, o.c.

192. Eindrapport van de Staatscommissie Herziening Rechterlijke Organisatie, 1985 p. 1 en 2

193. Eindrapport van de Staatscommissie Herziening Rechterlijke Organisatie, 1985 p. 14 
den Biesen) uitspraak doet in een kort geding dat is aangespannen door de Vervoersbond FNV tegen een internationaal transportbedrijf. ${ }^{194}$ Gevraagd was om represaillemaatregelen tegen twee chauffeurs die hadden meegedaan aan de blokkadeacties, ongedaan te maken. De uitspraak, waarin de vordering wordt afgewezen, die al meteen 'opmerkelijk toornig' en zelfs 'grof partijdig' 195 wordt genoemd, leidt enige dagen later tot grote opschudding in de media, als blijkt dat de president tevens de enige en betaalde commissaris is bij de vleesverwerkende industrie HAWI in Varsseveld. Dit bedrijf heeft schade geleden door de acties, omdat drie vrachtwagens van het bedrijf vast hebben gezeten in de wegblokkades die in december 1985 door de Vervoersbond FNV waren georganiseerd. Daardoor zou Van den Biesen een (overigens niet geheel duidelijk) belang hebben bij zijn eigen uitspraak. Zelf verklaart Van den Biesen niet geweten te hebben dat het betreffende bedrijf schade had geleden. ${ }^{196}$ 'Stoker' slaat in zijn column in de Volkskrant niettemin een bijtende toon aan, die suggereert dat er sinds de Revu-enquêtes van 1967 weinig veranderd is:

\section{Rechts}

Ik vind die rechter in Almelo wel een sympathieke baas. Een slecht vonnis maken, dat kan iedereen. Maar een slecht vonnis uitspreken tegen stakers terwijl iedereen weet dat je commissaris bent van een benadeelde firma, dat vereist lef. De Almelose rechter drukt ons met de neus op de harde waarheid over de rechtspraak: rechters zijn ook maar mensen, met hun eigen vooroordelen en hun eigen belangetjes. Het vervelende is alleen dat rechters, omdat ze mochten studeren en goed verdienen, hun vooroordelen en belangen meestal vinden in een zeer beperkte bovenste laag. De rechter in Almelo was zelf commissaris, maar de rechter in Hengelo heeft een broer die commissaris is, de rechter in Boekelo een zoon die werkgever is. Wat is er tegen te doen? Elke generatie moet weer opnieuw door elkaar worden gegooid. zodat rechters niet uit een bepaalde klasse voortkomen. De middenschool had dat kunnen bevorderen, en die wordt nu vakkundig de nek ongedraaid. Niet de Almelose rechter maar de rechtsen in Nederland maken de rechtspraak onrechtvaardig. ${ }^{197}$

Ook elders in de media wordt Van den Biesen verweten tenminste de schijn van partijdigheid op zich te hebben geladen. ${ }^{198}$ Naar aanleiding van de kwestie-

194. Uitspraak van 12 februari $1986, \mathrm{KG} 1986, \mathrm{nr} .135$

195. FNV-voorzitter H. Pont in: de Volkskrant 13 februari 1986. Vonnis over wegblokkade wekt woede vakbeweging

196. Henk de Mari en Joop Udo. "Rechters moeten op hun tellen gaan passen", De Telegraaf 22 februari 1986

197. Stoker, Rechts, de Volkskrant 19 februari 1986

198. Het is opmerkelijk dat de uitspraak inzake de wegblokkades in nagenoeg alle landelijke dagbladen in verband wordt gebracht met twee andere kwesties waarbij de Almelose president betrokken was geweest. De eerste betreft een verkeerd beleggingsadvies, dat 
Van den Biesen debatteert de Tweede Kamer kort met de minister van justitie (Korthals Altes) over nevenfuncties bij de rechterlijke macht. ${ }^{199}$ Het Tweede Kamerlid Kosto (PvdA) vraagt de regering om inzicht in de mate waarin 0.a. rechterlijke ambtenaren betaalde nevenfuncties vervullen. Ook vraagt hij om een registratie van deze nevenfuncties in een openbaar register, opdat ook procespartijen daarvan op de hoogte kunnen zijn en het instrument van wraking tot zijn recht kan komen. ${ }^{200}$ De minister van justitie (Korthals Altes) antwoordt niet te beschikken over een algemeen inzicht in de aard en de mate waarin nevenfuncties vervuld worden. Omdat de Wet op de Rechterlijke Organisatie geen aanknopingspunten biedt voor melding, registratie en publikatie van nevenfuncties, en 'gelet op de staatsrechtelijke verhoudingen', is Korthals Altes van oordeel dat de minister van justitie geen onderzoek kan instellen naar de nevenfuncties van de leden van de rechterlijke macht. ${ }^{201}$ Later blijkt dat Korthals Altes ook niet werkelijk onder de indruk is geweest van deze kwestie. In 1990 zegt hij daarover: "Die zaak met rechter Van den Biesen in Almelo - die door de vakbond van belangenvermenging werd beschuldigd - is enorm opgeblazen, zo met de haren erbij gesleept. Dan kun je ook zeggen dat de Amsterdamse president geen uitspraak kan doen in een tramstaking, want hij kan die morgen wel in het verkeer hebben vastgezeten. ${ }^{202}$ Toch toont Korthals Altes zich in 1986 bereid met de Nederlandse Vereniging

de president als penningmeester van het Koningin Julianafonds zou hebben gegeven. De tweede zaak betreft de uitkomst en, vooral, de toon in een uitspraak van Van den Biesen in een kraakzaak. Daarin beschrijft hij de dramatis personae als 'geen onaardige jongen met een open gezicht' en 'een jong niemandalletje, dat het kennelijk houdt met gedaagde sub 1 en dat veel te vroeg van huis is weggegaan', terwijl de eiser 'geconfronteerd met de totale ontluistering van zijn ouderlijk huis', 'een duidelijk aangeslagen indruk' op de president makkte. Kort geding van de president van de rechtbank Almelo. 3 augustus 1983, nr. 003687-B

199. Sinds 1985 vormt het vraagstuk van de nevenfuncties een vast item bij de behandeling van de Rijksbegroting. Gevraagd naar de betaalde nevenfuncties van leden van de Hoge Raad en naar degene die toestemming moet geven voor het vervullen van betaalde nevenfuncties in de betaalde sfeer bij de rechterlijke macht, antwoordde de regering de Tweede Kamer in oktober 1985 dat zij omtrent een en ander geen gegevens had. Wel meende zij dat het 'in de rede' lag dat een rechterlijk ambtenaar die een nevenfunctie van 'enige omvang" wenste te aanvaarden, daarover overleg pleegde met zijn president respectievelijk met het hoofd van zijn parket. Nota naar aanleiding van het verslag. Bijl. Hand. II 1985-1986, 19200 hoofdstuk VI, nr. 13 p. 19

200. Hand. II 25 februari 1986, p. 3616

201. Hand. II 25 februari 1986, p. 3616

202. Bij: Bert Molenaar, Rechters, o.c. p. 77 
voor Rechtspraak in overleg te treden, om te bezien op welke wijze de regeling van onverenigbaarheden kan worden aangepast. ${ }^{203}$

\subsubsection{De NVvR over nevenfuncties}

Overeenkomstig de toezegging aan de Tweede Kamer, vindt op 8 april 1986 overleg plaats tussen het ministerie van justitie met het bestuur van de Nederlandse Vereniging voor Rechtspraak. De vereniging zegt in dat gesprek toe, te zullen inventariseren welke gedachten er leven binnen de rechterlijke macht over een regeling tot melding van nevenfuncties, en het initiatief te zullen nemen om te komen tot een regeling binnen de eigen beroepsgroep. Afgesproken wordt dat deze regeling op een later tijdstip in een ministeriële circulaire zal worden vastgelegd, al dan niet als een voorfase voor verdere codificering. ${ }^{204} \mathrm{Bij}$ brief van 26 september 1986 aan de functionele geledingen stelt het bestuur van NVvR aan haar leden een vrijwillig te aanvaarden regeling voor, waarbij alle nevenfuncties worden gemeld aan de president van het college. Het bestuur geeft de voorkeur aan een aanmeldingsplicht van nevenfuncties boven een toestemming vooraf. Toetsing van de nevenfunctie aan de hoofdfunctie vindt plaats na de aanmelding van de nevenfunctie, en voor of na de behandeling van een bepaalde rechtszaak (resp. toetsing in abstracto en toetsing in concreto). Toetsing geschiedt aan het criterium dat 'degene die een functie vervult waardoor afbreuk zou kunnen worden gedaan aan zijn onpartijdigheid in een bepaalde zaak, niet als rechter bij de beslissing in die zaak mag worden betrokken'. Indien daartoe aanleiding bestaat, vindt omtrent de onverenigbaarheid van de nevenfunctie met de hoofdfunctie overleg plaats tussen de president en de betrokken rechter. Bij verschil van mening wordt advies gevraagd aan de ombudsman van de Hoge Raad. De president houdt een register bij van alle nevenfuncties van de rechters, en geeft daarvan op verzoek inzage aan de direct betrokkenen. Opmerkelijk is overigens dat volgens de NVvR aan de nevenfunctie geen bezoldiging verbonden mag zijn. Zij gaat

203. Hand. II. 25 februari 1986 , p. 3616 Wellicht gewaarschuwd door het incident met de Almelose rechtbankpresident, vroeg de Tweede Kamer in oktober van datzelfde jaar, bij de behandeling van de Rijksbegroting 1987, de regering om een overzicht van arrondissements- en gerechtshofgriffies waar een lijst van nevenbetrekkingen op vrijwillige basis was gedeponeerd, alsmede om een overzicht van de nevenbetrekkingen van de leden van de Hoge Raad. Verslag, Bijl. Hand. II 1986-1987, 19 700, hoofdstuk VI, nr. 8 p. 8 De regering deelde mee dat bij geen der griffies lijsten van nevenbetrekkingen voor rechterlijke ambtenaren waren gedeponeerd. Wel had een aantal leden van de rechterlijke macht aan de president van het eigen college opgave gedaan van de door hem of haar vervulde nevenbetrekkingen. Ook beschikte de regering niet over een overzicht van nevenbetrekkingen van leden van de Hoge Raad. Nota naar aanleiding van het verslag, Bijl. Hand. II 1986-1987, 19700 hoofdstuk VI, nr. 14 p. 20

204. Trema 1986 , p. 287 
daarmee verder dan de wettelijke bepalingen, die een honorering niet verbieden. $^{205}$

In zijn reactie stemt E.P. von Brucken Fock in met de voorstellen van het bestuur van de NVvR. ${ }^{206} \mathrm{Hij}$ concludeert 0. a. dat de noodzaak van een toetsing in abstracto voortvloeit uit de Europese rechtspraak. Uit de zaken Piersack en De Cubber $^{207}$ zou blijken dat voor de vaststelling van de rechterlijke onpartijdigheid de subjectieve benadering niet voldoende is, maar dat deze ook een objectieve toets moet kunnen doorstaan. "Het vervullen van een bepaalde nevenfunctie kan tot gevolg hebben dat ten aanzien van een bepaalde rechter een 'legitimate reason to fear a lack of impartiality' bij de behandeling van een bepaalde zaak of een bepaald type van zaken kan ontstaan. " Tegen een toetsing in abstracto van de nevenfunctie bestaan evenwel grote bezwaren bij andere leden van de NVvR. Bezwaren bestaan ook tegen algehele of vergaande openbaarmaking van nevenfuncties. Men vreest dat de voorgestelde regeling van registratie en openbare registers zal werken als een 'boemerang':

"Leert juist het Almelose voorbeeld niet dat kenbaarheid van nevenfuncties als een boemerang kan werken? Het lid van de rechterlijke macht dat tot nu toe een geprononceerde politieke functie uit de weg is gegaan, maar achter de schermen zeer actief is in een politieke partij, moet vrezen dat zijn nevenactiviteit (en dus zijh politieke voorkeur) aan de openbaarheid wordt prijsgegeven. De rechter die in zijn vrije tijd actief is in het bestuur van een vereniging die zich bezighoudt met euthanasie moet zich gaan afuragen of hij nog wel deel kan gaan uitmaken van een strafkamer die over een euthanasiegeval moet oordelen. Zal de pers geen verbanden suggereren. ${ }^{208}$

H.F. van den Haak daarentegen noemt de aanbeveling voor een openbare registratie van nevenfuncties allerminst onbegrijpelijk en ontoelaatbaar. "De (onder meer samenlevingsgevoelige) belangen die aan de rechterlijke macht ter beoordeling worden toevertrouwd zijn te groot dan dat niet in enige vorm - aan het gewicht van die belangen evenredig - openbaarheid zou moeten bestaan over door de leden van de rechterlijke macht, het OM daaronder begrepen, vervulde nevenfuncties die op eventueel conflicterende belangen kunnen wijzen. ${ }^{209}$ Algemeen wordt tenslotte bezwaar geuit tegen een regeling van

205. Trema 1986, p. $287-292$

206. Trema, 1986 , p. 288-292

207. Resp. D \& R 47 (1986) en D \& R 86 (1984)

208. K.E. Mollema, Trema 1987, p. 2 Zie ook: J.H. Blaauw en M.E.Th. de BruijnLuikinga die menen dát door een openbaar register van nevenfuncties een algemeen wantrolowen in ons rechissysteem" wordt ingebouwd. J. H. Blaauw en M.E. Th. de Bruijn-Luikinga, Melding en openbaarmaking nevenfuncties, Trema 1987, p. 13-14

209. H.F. van den Haak, Privacy: a conflict between me and myself. Trema 1987, p. 15-16 
de onderhavige materie bij ministeriële circulaire. Het bestuur van de NVvR komt aan de verschillende bezwaren tegemoet door de abstracte toetsing achterwege te laten; eerder noemde het de subjectieve benadering 'niet voldoende'. Ook wordt de openbaarheid van het register in het nieuwe voorstel flink beperkt. ${ }^{210}$

Het voorstel tot openbaarmaking van nevenfuncties leidt tot enige discussie tijdens de najaarsvergadering van de NVvR op 14 november 1987 . Zo meent J.E.B. van Julsingha dat het voorstel een minimale, 'uitgeklede" regeling is en pleit hij er voor niet alleen aan de direct betrokkenen, maar ook aan de pers die een gemotiveerd verzoek doet, inzage te geven. Veel tijd en ruimte voor detailkritiek op het voorstel blijkt er echter niet te zijn. De najaarsweryadering is inmiddels onder zware druk gezet door een motie-Wiebenga/Soutendilk-van Apeldoorn (VVD/CDA), die enige dagen eerder, op 4 november 1987, bij de behandeling van de Rijksbegroting 1988, aan de Tweede Kamer is voorgesteld, maar waarvan de stemming, in afwachting van de uitkomst van de najaarsvergadering van de NVvR, wordt uitgesteld. In de voorliggende motie verzoekt de Tweede Kamer de regering te bevorderen dat de openbaarmaking van nevenfuncties bij de rechterlijke macht met ingang van 1 juli 1988 een feit is. De indieners van de motie menen dat elke schijn van partijdigheid dan wel belangenverstrengeling, ongunstig kan werken jegens de rechterlijke macht als geheel. ${ }^{211}$ Ook de minister stelt, naar aanleiding van de voorliggende motie, zich op het standpunt dat een 'volstrekte openbaarheid' van nevenfuncties gewenst is. Hij hoopt op een oplossing met zo min mogelijk regulering. ${ }^{21}$ Hoe aanmelding, registratie en openbaarmaking dienen te geschieden, laten zowel de Tweede Kamer als de minister vooralsnog in het midden.

Tijdens de najaarsvergadering doet de president van de Hoge Raad, H.E. Ras, aan de hand van de laatste politieke ontwikkelingen op dit punt, een klemmend

210. In de nieuwe aanbeveling van de NVvR worden alle nevenfuncties gemeld. Een met rechtspraak belast lid van de rechterlijke macht of een voor het leven benoemd lid van het openbaar ministerie meldt zijn nevenfunctie(s) aan diegene die ten aanzien van hem de bevoegdheid heeft, die in art. $14 \mathrm{Wet}$ RO is geregeld. De president/voorzitter/het. hoofd van het parket houdt een register bij van alle nevenfuncties van de leden van het betrokken college/parket en geeft daarvan op verzoek inzage aan de direct betrokkene bij de behandeling door een rechterlijk ambtenaar van een bepaalde rechtszaak. Hij doet dat op een gerichte vraagstelling, aan de hand warvan hij de relevantie aan de te verschaffen informatie toetst aan het doel waarvoor die informatie gevraagd wordt. Hij bespreekt het verzoek met de betrokken rechterlijk ambtenaar. en mede aan de hand daarvan neemt de president/voorzitter/het hoofd van het parket zijn beslissing, en bepaalt. op welk wijze informatic uit het register zal worden verstrekt. Trema, 1987, p. 294

211. Hand. II 4 november 1987 , p. 905

212. Korthals Altes, Hand. II 4 november 1987, p. 912-913 
beroep op de vergadering om tot een regeling van dit onderwerp 'in eigen huis' te kornen, en het niet te laten aankomen op 'een door de Tweede Kamer afgedwongen regeling'. Ras deelt de vergadering mee dat de Hoge Raad inmiddels in een algemene vergadering unaniem heeft besloten tot een volledige openbaarmaking van nevenfuncties. ${ }^{213}$ Kennelijk onder druk gezet ziet de vergadering af van eerdere bezwaren met betrekking tot de openbaarmaking van nevenfuncties, en geeft zij in een meningspeiling vrijwel unaniem te kennen zich te kunnen vinden in het voorstel om nevenfuncties op te nemen in een openbaar, voor een ieder toegankelijk register. Het bestuur deelt mee de uitspraak van deze vergadering op korte termijn mee te zullen delen aan de functionele groeperingen met een daarbij aangepaste aanbeveling en tevens de minister van justitie daarvan op de hoogte te zullen stellen. ${ }^{214}$ Op 17 november 1987 - dus voor de stemming over de motie - stelt de minister de Tweede Kamer in kennis van de besluiten van de Hoge Raad en van de vergadering van de NVvR, en deelt mee dat naar de verwachting van de NVvR omstreeks 1 juli 1988 dergelijke registers ter inzage zullen liggen. Met de notitie die hij hieromtrent in het vooruitzicht heeft gesteld wenst de minister te wachten totdat hij weet welk gevolg de leden van de NVvR aan de oproep van de vereniging zullen geven. ${ }^{215}$ Onduidelijk is of de minister probeert de indieners van de motie te bewegen de motie weer in te trekken. De Tweede Kamer neemt de motie-Wiebenga/Soutendijk op 15 december 1987 met algemene stemmen aan. ${ }^{216}$

Het vraagstuk van de nevenfuncties lijkt nog niet afgerond. Tot tweemaal toe hebben na 1987 politieke en commerciële nevenfuncties tot lichte opschudding in de media geleid. ${ }^{217}$ Het bestuur van de NVvR heeft er - overigens niet

213. Reeds op 2 december 1986 had de Algemene Vergadering van de Hoge Raad besloten dat nevenfuncties zouden worden geregistreerd bij de president en dat deze de gegevens beschikbaar zou stellen aan belanghebbenden. Op 12 november 1987 besloot de Algemene Vergadering tot algemene openbaarmaking, hetgeen op 16 november 1987 middels een persbericht bekendgemaakt werd. Bron: De Hoge Raad der Nederlanden een portret, 1988 p. 313 . Fijntjes vermeldt de bundel: "Daarmee (met de openbaarmaking van nevenfuncties, $M d W$ ) liep de Hoge Raad vooruit op het advies van het bestuur van de Nederlandse Vereniging voor Rechtspraak aan zijn leden in de najaarsvergadering van 14 november $1987^{\circ}$. Dat het slechts om een verschil van twee dagen gaat wordt niet vermeld.

214. Trema 1987 , p. $334-335$

215. Hand. II 17 november 1987. p. 1083

216. Hand. II 15 december 1987, p. 1807

217. Zo komt de vice-president van het Gerechtshof Amsterdam. R.H.L. Cornelissen, in 1991 in opspraak, als de besloten vennootschap waarvan bij commissaris is voor een Amerikaanse rechter wordt gedaagd, wegens oplichting bij onroerend goed-projecten in Californiè. De kwestie werd aangezwengeld door De Telegraaf, die in een reportage de nevenfunctie van de vice-president ter discussie stelt (Joost de Haas en Charles Sanders, Mag rechter koopman zijn? Amsterdamse magistraat als commissaris betrok- 
zonder effect - inmiddels bij de presidenten/voorzitters van colleges en hoofden van parketten op aangedrongen aan de uitspraak van 14 november 1987 uitvoering te geven. In de praktijk blijkt echter - zeer tegen de zin van de VVD - een regeling te zijn ontstaan die per arrondissement sterk wisselt. ${ }^{218}$ Het TweedeKamerlid Wiebenga hierover in 1991: "Dit is volstrekt onacceptabel. Vier jaar geleden heeft de Kamer een motie van mij aangenomen waarin staat dat leden van de rechterlijke macht hun nevenfuncties openbaar moeten maken. Nu blijkt dat de situatie bij iedere rechtbank anders is, moet de minister ingrijpen. Het gaat hier om een zeer gewichtige zaak. Het Nederlandse volk heeft er recht op te weten in welke particuliere ondernemingen rechters functies bekleden. Alleen zo is een goede gang van de rechtspraak en het vertrouwen daarin te garanderen. ${ }^{219}$ De voorzitter van de NVvR, A.H. van Deiden, verklaart echter dat de vereniging er naar streeft alle nevenfuncties openbaar te maken, maar dat dat enkel op basis van vrijwilligheid mag gebeuren. "Wij kunnen en zullen geen rechter dwingen zijn bijbanen bekend te maken. Persoonlijk ben ik van mening dat iedere rechter voor zich moet uitmaken of een nevenfunctie verenigbaar is

ken bij miljoenengeschil, De Telegraaf, 2 november 1991). Zie ook de vragen van het Tweede-Kamerlid Wiebenga (VVD) aan de minister van justitie, naar aanleiding van deze kwestie: Hand. II 1991-1992, Aanhangsel 179. De tweede kwestie doet zich voor als de rechtbank Roermond in 1992 de burgemeester van Hunsel, J. Houben voor de functie van rechter-plaatsvervanger op de aanbeveling plaatst. De discussie spitst zich overigens, behalve op de vraag over de verenigbaarheid van beide functies, toe op de (on)wenselijkheid dat vertrouwelijke informatie over het opmaken van de aanbeveling naar buiten komt. Zie hierover mijn bijdrage in NRC Handelsblad, 19 oktober 1992 , Er is niets mis mee als burgemeester ook rechter is. Anders: D.J. Elzinga, Onverenigbaarheden Burgemeesters moeten eigenlijk geen rechter willen worden. Binnenlands Bestuur, 16 oktober 1992, p. 29

218. In juni 1988 waren volgens de regering bij alle arrondissements-en gerechtshofgriffies, met uitzondering van Maastricht en Arnhem, dergelijke registers ingesteld. Een geactualiseerd overzicht van nevenbetrekkingen was vooralsnog niet voorhanden op het ministerie van justitie. Lijst van antwoorden. Bijl. Hand. II 1988-1989. 20800 hfdst. VI, nr. 6, p. 33; Nota naar aanleiding van het verslag. Bijl. Hand. II 1990-1991, 21 800 VI, ar. 10 , p. 27 Anders dan de regering constateerde De Telegraaf een 'chaos' rond de opgave van rechterlijke nevenfuncties. Bij twee rechtbanken was geen register aanwezig (Zwolle en Leeuwarden), terwijl de openbaarheid van de registers bij de overige gerechten varieerde van openbaar, beperkt openbaar tot niet-openbaar. Ook was er per arrondissement sprake van een ander beleid aangaande melding van nevenfuncties (wisselend van een meldingsplicht tot een vrijwillige melding). Joost de Haas en Charles Sanders, Chaos rond opgave bijbanen rechlers. De Telegraaf 9 november 1991.

219. Chaos rond rechterlijke bijbanen, De Telegraaf o.c. Zie ook het redactioneel in De Telegraaf over dit onderwerp: "Commerciële bijbanen verhogen hel risico van persoonlijke betrokkenheid bij juridische conflicten. Ook al kunnen zij zich in dat soort gevallen als rechters terugtrekken, het odium van onafhankelijkheid kan licht in het gedrang komen. " Rechters, De Telegraaf, 9 november 1991 
met het rechterlijk ambt. Waarbij ik zelf duidelijk stel dat een rechter die bijvoorbeeld in het zakenleven actief is als commissaris zoveel mogelijk op de achtergrond dient te blijven." Dat is kennelijk ook de mening van de regering. Bij de behandeling van de Rijksbegroting 1992 meent zij dat de zorg van een dergelijk overzicht van nevenfuncties behoort tot de verantwoordelijkheid van de gerechten en de leden van de rechterlijke macht. Het ministerie van justitie zou terzake geen 'bemoeiing' hebben aangezien registratie niet op een wettelijk voorschrift berust, doch geschiedt op basis van een verzoek van de NVvR waaraan op vrijwillige basis gehoor wordt gegeven. ${ }^{220}$ Wel werd bij die gelegenheid een voorstel tot wijziging van de Wet RO, dat er onder meer toe strekt dat de nevenfuncties van leden van de rechterlijke macht worden neergelegd in een openbaar register, in het vooruitzicht gesteld.

\subsection{Recente ontwikkelingen}

'Rechter getroffen door slagroomtaart'. Zo opende hoofdstuk 1 met een bericht uit NRC Handelsblad over het incident waarbij krakers hun onvrede met de vermeende partijdigheid van de Amsterdamse rechter Vrakking kenbaar maakten. Het zijn geluiden die sinds de jaren zestig en zeventig eigenlijk nog maar zelden voorkomen. Het vertrouwen in de rechter is, zo valt alom te beluisteren, 'immers' belangrijk toegenomen, al spreken de cijfers elkaar wel tegen. $63 \%$ van de Nederlanders zegt volgens een onderzoek van Intomart Quantron in 1988 meer vertrouwen in de rechter dan in de Tweede Kamer te hebben. Toch zegt dat cijfer misschien meer over het vertrouwen van de burger in het parlement, dan in de rechterlijke macht. Uit een enquête van Vrij Nederland uit 1991 blijkt immers dat $37 \%$ van de Nederlanders kennelijk ók vindt dat rechters nog steeds 'met twee maten meten', terwijl $19 \%$ zegt dat niet te weten. ${ }^{221}$

De publiekspeilingen roepen ook uit methodologisch oogpunt vragen op. Problematisch is bijvoorbeeld dat de verrichte onderzoeken naar het vertrouwen in 'de' rechterlijke macht ${ }^{22}$ of zelfs 'de' justitie ${ }^{223}$ wel erg algemeen zijn. Praten we over de politie, het openbaar ministerie of de rechterlijke macht? En over welke rechters gaat het, rechters in eerste aanleg, in beroep of in cassatie?

220. Nota naar aanleiding van het verslag, Bijl. Hand. II 1991-1992, 22300 VI, ur. 13. p. 23

221. Marc Josten en J. van Tijn. De rechterlijke macht van Nederland: een geruststellend gezelschap, Vrij Nederland, 2 november 1991, p. 20

222. Vergelijk de enquête van Vrij Nederland en de dissertatie van L.E. de Groot-van Leeuwen, De rechterlijke macht in Nederland, 1991

223. Vergelijk A.J. Hoekema, Vertrouwen in de justitie, resultaten van een vergelijkend onderzoek, 1971 
Is er verschil tussen vertrouwen in alleenrechtspraak (kantonrechter, politierechter, kinderrechter, rechter in kort geding) en rechters in meervoudige kamers? Is het vertrouwen landelijk even groot, of verschilt het per arrondissement? Over wiens vertrouwen gaat het, om dat van verdachten, partijen in een civiele procedure, of van anderen? Is er meer of minder vertrouwen bij 'winnaars' dan bij 'verliezers', of maakt dat niet uit? Hoe definieer je 'vertrouwen', en hoe meet je het? Dat zijn tamelijk essentiële vragen die tot nu toe zijn blijven liggen.

De rechterlijke macht blijkt intussen niet ontevreden met zichzelf. Zelfs critici van weleer, als Leijten en Cnoop Koopmans tonen zich content met de 'jonge binken' ("en er zijn zelfs meiden bij") in de rechterlijke macht. Leijten:

"De manier waarop rechters nu worden benoemd garandeert een bredere selectie. Er is gewoon een vrij harde opleiding waar je pas toegelaten wordt na een drastisch onderzoek. Er zitten nog steeds wel pruilbuiken tussen die rechters, maar het is een stuk beter dan vroeger. Ik hoor zo'n rechter nog zeggen tot een verdachte: (met verdraaide hoge stem) ' $O$, en bent u daar toen aangeweest'. Dat was dan een piemel of zoiets, en dan ging het verder (stem nu zeer verbaasd:) 'Ohoo, en waarom deed u dat?' Gadverdikkeme! Zeg dan gewoonweg: ben je aan het neuken geweest of gebruik voor mijn part een net woord, maar doe toch nier zo raar. ${ }^{\text {"224 }}$

Zo ook Cnoop Koopmans in 1987: "Het aantal vrouwen neemt op verheugende wijze toe - etnische minderheden zie je helaas nog niet -, er zijn rechters die in concubinaat leven of ongehuwde moeders zijn, er zijn homofielen. In dat opzicht is er de laatste jaren veel veranderd. Variatie in het huidige systeem is echter een toevalstreffer. "225 Deze verschijnselen van tevredenheid van juristen met de samenstelling van de rechterlijke macht corresponderen met de onderzoeksresultaten van L.E. de Groot-van Leeuwen over de samenstelling en denkbeelden van de zittende en staande magistratuur in Nederland. Het zelfheeld van magistraten bestaat hierin dat de rechterlijke macht 'geméleerd' is, "niet meer zo conservatief als ze was, ze is meer naar links opgeschoven maar toch netjes gebleven, en in verhouding tot de Nederlandse bevolking nog steeds vrij behoudend en religieus georiënteerd." Ten aanzien van de sociale herkomst van de rechters denken de leden van de zittende en staande magistratuur dat de rechterlijke macht van een 'elitaire club' naar een 'club van

224. Marcel Haenen en Frank Vermeulen, Mr. Leijlen, advocaat-generaal bij de Hoge Raad, waarschuw voor verharding van het strafrechl Rolzakken lellen ook mee, die horen ook bij de club, NRC Handelsblad, 25 mei 1991

225. Een iets andere rechter, interview met A.J. Cnoop Koopmans, NJB, 1987, p. 726. In gelijke zin: H. van Maarseveen, De verzekeringssiaal, NJB, 1990, p. 5 
gemengde afkomst' is geëvolueerd, al zijn de hogere lagen nog oververtegenwoordigd, en is de onderste laag nagenoeg afwezig. Bovendien denkt men dat de rechterlijke macht is samengesteld uit een groot percentage vrouwen en uit mensen met verschillende levensbeschouwelijke opvattingen en politieke overtuigingen. Toch spreken de rechters zelf van een 'homogene groep' omdat van de verschillende opvattingen en overtuigingen, het de gematigden en minst geprononceerden ('grijze muizen') zijn die deel uitmaken van de magistratuur. De werkelijke samenstelling van de rechterlijke macht en de vermoedens daaromtrent bij rechters lopen echter nogal uiteen. $\mathrm{Zo}$ is de gemiddelde leeftijd van de rechters weliswaar lager geworden, maar is de politieke en religieuze pluriformiteit eenzijdiger dan bij de Nederlandse bevolking. Ook ten aanzien van de sociale herkomst is sprake van een niet-representativiteit voor de Nederlandse bevolking. Het aandeel vrouwen in de rechterlijke macht was in 1990 $19 \%$, maar vrouwen zijn met name in de lagere rangen vertegenwoordigd. ${ }^{226}$

\subsubsection{De kwestie-Van der Burg 1991}

Komt het zelfbeeld van magistraten niet geheel met de werkelijkheid overeen, ook bij de burgers bestaat een scheef heeld van de (leden van de) rechterlijke macht. Uit een enquête van het weekblad Vrij Nederland in 1991, blijkt dat een op de vijf Nederlanders van mening is dat rechters tijdens de rechtszitting pruiken dragen. Ruim een op de vijf Nederlanders denkt dat rechters voor zwaardere misdrijven de doodstraf willen opleggen als dat zou kunnen, $62 \%$ denkt dat rechters hogere straffen en boetes onvermijdelijk vinden, en $16 \%$ meent dat rechters 'behoorlijk links' denken. ${ }^{27}$

Het vermoeden dat door een grote groep van de leden van de rechterlijke macht 'behoorlijk links' gedacht wordt, leefde in de zomer van 1991 - vóór de bekendmaking van de resultaten van de Vrij Nederland-enquête in november van dat jaar - ook bij de leden van de Tweede Kamerfractie van het CDA. Op 18 juni 1991 maakt de woordvoerder van deze fractie, V.A.M. van der Burg bekend grote bezwaren te hebben tegen de oververtegenwoordiging van mensen met een 'nieuw-liberale' levensovertuiging met een voorkeur voor D66 in de rechterlijke macht in het algemeen en in de Hoge Raad in het bijzonder. Vlak daarvoor is in een besloten vergadering van de Vaste Kamercommissie voor Justitie, waarvoor ook de president van de Hoge Raad Royer wordt uitgenodigd, de benoeming van de leden van de Hoge Raad ter sprake geweest. Bij het opmaken van de voordracht zou de Tweede Kamer de kandidaten voortaan 'inhoudelijk' moeten toetsen, aldus de CDA-fractie: "We willen gestandaardi-

226. L.E. de Groot-Van Leeuwen, o.c. p. 145,147 en 149

227. Marc Josten en J. van Tijn, o.c. p. 20 
seerde levensbeschrijvingen. Nu schrijt de een over zijn hobby en de ander over nevenfuncties en publicaties. De derde vermeldt niet eens de kerngegevens van opleiding en loopbaan. ${ }^{228}$ Van der Burg zou 'steeds indringender vragen' van zijn 53 collega's krijgen, als zij moeten stemmen over de volgorde van kandidaten op de voordracht aan de regering. "Als bij een voordracht voor de Hoge Raad de fractie vraagt 'waar komen deze mensen vandaan?' en ik kan niks zeggen, ga ik mooi onderuit. ${ }^{m 29}$

De belangstelling van de Tweede Kamer voor Hoge Raad-benoemingen in 1991 was niet nieuw. ${ }^{230}$ Eerder, in 1979 , had de Vaste Kamercommissie voor Justitie de Hoge Raad verzocht enige achtergrondinformatie omtrent de kandidaten bij de aanbeveling te voegen. Aanleiding tot het verzoek, dat door Roethof (PvdA) in de commissie aan de orde werd gesteld, "was een zeker gevoel van onbehagen dat de Kamer op het punt van de aanbeveling een recht uitoefent om de benoeming van een persoon in een uiterst belangrijke publieke functie te bevorderen, zonder de achtergronden van de betrokkene te kennen. ${ }^{m 31}$ Alle grote fracties in de Tweede Kamer (CDA, PvdA, VVD en D'66) wezen in 1979 op het belang van de informatie in verband met de rechtsvormende functie van de Hoge Raad. Men meende dat de Hoge Raad voor deze functie, waarbij het gaat om de interpretatie van regels die "ontbreken of als achterhaald worden beschouwd" of bij uitspraken in "maatschappelijk gevoelige kwesties" of wanneer de wetgever "tekort schiet in vernieuwing van

228. V.A.M. van der Burg, bij: Folkert Jensma, CDA wil strengere rechlers in Hoge Raad, NRC Handelsblad, 21 juni 1991

229. NRC Handelsblad. 21 juni 1991, CDA wil strengere rechters in Hoge Raad. Behalve met benoemingen voor de Raad van State werd de voordracht voor de Hoge Raad ook vergelcken met die voor de Algemene Rekenkamer. Marc Chavannes, Hoezo linkse rechters?, NRC Handelsblad, 3 juli 1991; R. Burgert, Politici in de Rekenkamer. NRC Handelsblad, 5 juli 1991. De teneur van Burgerts vergelijking is dat de politieke benoeming van de leden van de Rekenkamer niet in het belang is van een doelmatige werking van de staatshuishouding; in het spanningsveld tussen regering en volksvertegenwoordiging dat ontstaat bij het afleggen van verantwoording over het gevoerde financiële beleid, moeten beiden kunnen vertrouwen op de onpartijdigheid en de onafhankelijkheid van de leden van de Rekenkamer. Voorgesteld wordt de benoeming van de leden van de Rekenkamer niet al te zeer te laten verschillen van die van de Hoge Raad. Anders: Aertjan Grotenhuis, Liever een kleurloze Hoge Raad, NRC Handelsblad, 31 juli 1991. die meent dat politieke benoemingen voor de Raad van State en de Algemene Rekenkamer -anders dan voor de Hoge Raad- nog te billijken zijn.

230. Zie over deze kwestie ook mijn bijdrage in NRC Handelsblad, Politieke greep op benoemingen Hoge Raad constitutioneel taboe, 30 juli 1991; Grijpgrage politici met vurige vingers. Publiek Domein, 1991, p. 226-231 en: Afschuiven in de politiek: van de stoel van de wetgever naar het bordje van de rechter, in: Verhalen over de Grondwet, 1993

231. Hand. II 1978-1979, p. 5267 
wetgeving" een bijzondere verantwoordelijkheid draagt. Nijpels (VVD) onderstreepte bij die gelegenheid dat de Tweede Kamer niet alleen een 'recht' maar ook een 'plicht' heeft om zich ten opzichte van de kandidaten goed te informeren; "Ih/et recht van voordracht verwordt immers tot een farce als de Kamer, zoals nu veelal gebeurt, die voordracht opstelt, zonder dat men over enige kennis beschikt over de kandidaten." Nadrukkelijk waarschuwden de Tweede Kamerleden (elkaar?) er in 1979 voor de voordrachten niet in de "partijpolitieke sfeer" te trekken. Ook wenste men geen "politiek benoemingsbeleid" of een "politieke sleutelverdeling" voor de leden van de Hoge Raad. ${ }^{232}$ Anders dan de ruime aandacht die het Tweede Kamerlid Van der Burg in 1991 krijgt, trok het Tweede Kamerdebat over hetzelfde onderwerp in 1979 betrekkelijk weinig belangstelling. ${ }^{233}$ Oud-D66 Tweede Kamerlid A.M. Goudsmit, die in de jaren zestig samen met H. Singer-Dekker (PvdA) nog eens een Raad voor de rechterlijke macht voorstelde, noemde de aandacht van de Tweede Kamer in 1979 voor benoemingen in de Hoge Raad een:

"zeer ongewenste tendens, omdat het zéér voor de hand ligt dat de vraag om informatie niet beperkt zal blijven tot maatschappelijk-juridische achtergronden, maar binnen de kortste keren zal uitgroeien tot partij-politieke achtergronden; met andere woorden de kans dat aldus expliciet partij-politieke verhoudingen in de Hoge Raad weerspiegeld worden is op deze weg voortgaande reëel aanwezig. ${ }^{m 234}$

\section{Hand. II $1978-1979$, p. 5270}

233. Zie over deze kwestie: Kaner wil informatie hij vacatures: Hoge Raad te zwijgzaam, de Volkskrant, 22 maart 1979: Controle op benoeming Hoge Raad goede zaak, de Volkskrant, 24 maart 1979: F. Kuitenbrouwer, De Kamer en de onafhankelijke rechter. NRC Handelsblad, 27 maart 1979; Kamer wil praten over voordrach leden Hoge Raad, NRC Handelsblad, 19 mei 1979

234. A.M. Goudsmit, Wat zoekt de rechtzoekende?, in: De magistraat in de st(r)aat. 1979. p. 81. W.E. Haak zag. verwijzend naar het artikel van Cnoop Koopmans uit 1973 , niets in een dergelijke democratisering van de rechterlijke macht. en meende dat hier op 'verwarrende wijze' de rechterlijke macht en haar 'produkt' met elkaar werdeu verwisseld. "Immers: dat in een rechtsbeslissing de wet op democratische wijze, dat wil zeggen overeenkomstig de in de maatschappij levende opvattingen behoort te worden geinterpreteerd, impliceert niet als noodzakelijke voonwaarde, dat de makers daarvan overeenkomstig de politieke verhoudingen benoemd moeten worden." W.E. Haak, Rechters, wie zijn dat, en hoe kom ik er aan?, in: De magistraat in de st(r)aal, 1979. p. 59-60 De sociologe H. Verweij-Jonker meende daarentegen dat het een "goed demokratisch principe" is dat de overheid er naar streeft dat die organen, die ze zelf benoemt min of meer een afspiegeling te zien geven van de politieke verhoudingen. Zonder duidelijk onderscheid te maken tussen zittende en staande magistratuur, meende zij dat binnen 'de' rechterlijke macht die als overheidsorgaan "bekleed is met politieke macht (-) en die macht ook uitvoert door het al dan niet vervolgen van overtredingen van wetten ", nornaen en opvattingen zoals die leven binnen het Nederlandse volk, hun "inbreng" moeten hebben. H. Verweij-Jonker, Hoe konservatief is de rechterlijke 
Naar de achtergrond van de belangstelling van de CDA-fractie voor benoemingen in de Hoge Raad in 1991 kunnen we slechts gissen. Het argument van de wetgever-plaatsvervanger, dat in 1979 nog zo duidelijk naar voren wordt gebracht, staat in 1991 niet (alleen) voorop. Veeleer lijkt het te gaan om een meer algemene onvrede met de rechtspleging, die wordt afgewenteld op een vermeende eenzijdige samenstelling van de Hoge Raad (de rechterlijke macht?). Opmerkelijk is dat de kritiek van de CDA-fractie zo op het oog meer betrekking heeft op de rechter in eerste aanleg en in beroep, dan op de cassatierechter. Zo merkt Van der Burg op: "Er is in Nederland georganiseerde criminaliteit ontstaan waar je koud van wordt. Als er dan een rechter een verdachte op proefverlof zonder parketwacht vrijlaat, of een gerechtshof een hele stapel zaken weggooit, roept dat weerstand op. "235 Met de 'stapel zaken' die is weggegooid, doelt Van der Burg op de beslissing van het Haagse gerechtshof, dat enkele dagen eerder 45 verdachten vrijuit moet laten gaan omdat hun hoger beroep niet binnen de redelijke termijn van twee jaar kan worden afgehandeld. Op dit incident - waarvoor de minister van justitie (Hirsch Ballin) de hoge werkdruk bij de rechterlijke macht als oorzaak noemt - wordt door de fracties van alle grote partijen in de Tweede Kamer met ergernis gereageerd. ${ }^{236} \mathrm{Bij}$ de CDA-fractie bestaat bovendien twijfel of de leden van de rechterlijke macht zich nog voldoende kunnen "inleven in wat er zich in de samenleving voltrekt":

"De fractie heeft al jaren het gevoel dat de rechterlijke macht te verlicht staat tegenover criminaliteit. Zij meent dat de dader onvoldoende het leed van het slachtoffer wordt aangerekend. We vangen dat bij iedere spreekbeurt in het land op. De fractic heeft het gevoel dat delen van de rechterlijke macht erg ver van de maatschappij afstaan. Het woord nieuw-liberaal is gebruikt, ja. Is die rechterlijke macht nog wel representatief. ${ }^{237}$

Wàt de CDA-fractie nu precies van de kandidaten voor de Hoge Raad wil weten blijft onduidelijk. Het is haar blijkbaar niet om de politieke kleur van de kandidaten te doen, en ook streeft men geen 'politisering' van de Hoge Raad na. Evenmin heeft men speciaal bezwaren tegen te veel rechters die "sympathiseren' met D66. Men wenst vooral inzicht in 'maatschappelijke wortels", of

macht?, in: De magistraat in de st(r)aat. 1979, p. 48. In gelijke zin: A.J. Cnoop Koopmans, De maatschappelijke selectie: hoe komen wij aan rechters? Kiezen, uitkiezen of uitverkiezen. Trema special '80-1, p. 26-34

235. Folkert Jensma, o.c.

236. Zie: De Volkskrant van 13 juni 1991, Kamer gepikeerd over vrijlaing van 45 verdachten. De actie van het Haagse gerechtshof had het (onbedoelde?) effect dat de minister enkele dagen later aankondigde extra raadsheren aan te zullen stellen bij het Haagse gerechtshof. Zie NRC Handelsblad, 21 juni 1991, Extra raadsheren bij gerechtshof Den Haag.

237. Folkert Jensma, o.c. 
- nog vager - "Wat heeft men buiten het juridische werk gedaan, wat is het venster op de samenleving geweest". ${ }^{238}$ Hoewel de Vaste Kamercommissie voor Justitie zich kan vinden in het verzoek van het CDA om meer informatie over de kandidaatleden van de Hoge Raad, is zij aanvankelijk nog tegen het voorstel om meer greep te krijgen op de politieke samenstelling van de Hoge Raad. Zou echter de Hoge Raad een toetsingsrecht krijgen, dan 'ligt het anders', aldus Jurgens van de PvdA. "Een constitutionele toetsing impliceert een politieke taak voor de hoogste rechter, en dan is het onvermijdelijk om beter naar de politicke voorkeur van de kandidaten te kijken." De VVD ziet echter weinig heil in informatie over politieke kleur en geloofsovertuiging in de beschrijvingen van de Hoge Raad, en noemt 'kundigheid' het belangrijkste criterium bij een benoeming. Meer gewicht toekennen aan politieke of religieuze factoren is volgens de VVD onwenselijk, omdat dat een 'opstap' is naar een 'grondwetshof'. Groen Links noemt een 'terughoudende opstelling' van de Tweede Kamer ten aanzien van benoemingen in het algemeen geboden, maar vindt een raadsheer van "erg rechtse signatuur (..) toch wel eng". 239

In de media reageert met name NRC Handelsblad bijzonder fel op de aantijgingen van Van der Burg, en betitelt de 'politieke greep' die Van der Burg bepleit als 'platvloers opportunisme'. "Het rechtersambt stelt vrij sterke eisen aan afstandelijkheid en dat bepaalt het menstype, van welke politieke kleur ook, dat er in belandt. Daar moet het CDA met z'n vurige vingers afblijven. ${ }^{240}$ De rechtspleging dient volgens deze krant aan "professionele, wetenschappelijk gevormde en onafzetbare rechters" te worden opgedragen, en niet aan een "politiek of sociaal afspiegelingscollege". Ook de rechterlijke macht zèlf blijkt, bij monde van de president en een vice-president van de Hoge Raad, 'bijzonder ongelukkig' met het idee van de CDA-fractie om bij de voordracht van nieuwe raadsheren meer te letten op politieke kleur en geloofsovertuiging. ${ }^{241}$ Royer verklaart niet te weten hoeveel D66-leden er in de Hoge Raad zitten, en zegt ook geen behoefte te hebben om dat te weten:

"In het grootste deel van ons werk speelt de politiek geen enkele rol. En als het dat wel doet, dan ligt de politiek toch heel ver op de achtergrond. Het gaat om

238. NRC Handelsblad, 19 juni 1991. CDA bevreesd voor opmars van D66-leden in Hoge Raad

239. NRC Handelsblad, 20 juni 1991. Fracties tegen CDA-voorstel met Hoge Raad.

240. NRC Hañdelsblad, 20 juni 1991, Grijpgrage politici; Zie ook H.A. van Wijnen. De Hoge Raad en de politiek, NRC Handelsblad, 22 juni 1991

241. NRC Handelsblad, 20 juni 1991, 'Politieke selectie tast beroepsethiek aan'; ook: A.H. van Delden, voorzitter van de Nederlandse Vereniging voor Rechtspraak, en president van de rechtbank 's-Gravenhage in: NRC Handelsblad, 21 juni 1991, Rechters woedend na kritiek CDA-er 
beslissingen die passen in ons rechisstelsel en die maatschappelijk aanvaardbaar zijn. Die zijn nooit extreem. (-) Als je stelselmatig rechters selecteert op politieke voorkeur is het onvermijdelijk dat zij bij hun uitspraken het gedachtengoed van die partij in het oog houden. ${ }^{m 42}$

Zowel Royer als Snijders vrezen een extra barrière om kandidaten te vinden, als daar een sollicitatiegesprek met de Tweede Kamer aan vast zit, omdat de kandidaten veelal 'vooraanstaande, wat oudere mensen' zijn. "Wij stuiten steeds vaker op aarzelaars en neezeggers. De juridische top in Nederland is niet gegroeid, maar het beroep dat erop wordt gedaan door advocatenkantoren, de Raad van State en gerechtshoven is sterk toegenomen. ${ }^{1243}$ Het overgrote deel van de rechterlijke macht lijkt overigens met Royer en Snijders in te stemmen; $83 \%$ van de leden van de rechterlijke macht (staande en zittende magistratuur) zegt het oneens te zijn met de stelling dat de volksvertegenwoordiging meer zeggenschap moet hebben over de benoeming van de leden van de Hoge Raad. Slechts $8 \%$ vindt dat dit wel zo zou moeten zijn. ${ }^{244}$

\subsubsection{Steun voor Van der Burg}

Ondanks de kritiek vanuit de Tweede Kamer, de publieke opinie en de rechterlijke macht op de voorstellen van de CDA-fractie, krijgt Van der Burg in juli 1991 steun van de socioloog Bruinsma, en de juristen Brenninkmeijer en Van Maarseveen. Zij leggen, anders dan Van der Burg, wél de nadruk op het vraagstuk van het rechterlijk activisme. Bruinsma meent dat de Hoge Raad met 'een dominante functie van rechtsontwikkeling' tekort schiet op het punt van de legitimatie. De belangstelling van de gekozen volksvertegenwoordigers verschaft de Hoge Raad zijns inziens 'een klein beetje broodnodige demo-

242. Men vergelijke de uitspraken van Royer met die van de vorige presideni van de Hoge Rrad, H.E. Ras. Sprekend over de bemoeienis van de politiek in Duitsland en België met rechtersbenoemingen zegt deze in 1988: "Voor mij -en nu spreek ik als burger en niet ats president van de HR- is het aantrekkelijke, dat je hier iets van 'checks and' balances' in vindt. Macht is namelijk maar op één manier te beperken en dat is door tegenmachi te creëren. Dit sysieem zal alleen overblijven bij de gratie van de politiek. De politick zal er goed op letten of het terrein van de politieke besluitvorming in redelijke mate wordt ontzien. "Niet geheel duidelijk is welke keuze Ras maakt voor de Nederlandse situatie. De terughoudendheid van de organen die in ons land met de benoemingen zijn belast noemt Ras een 'element van onze staatkundige praktijk' waardoor 'een zeker evenwicht' is ontstaan. N.J.H. Huls en F. Bruinsma, Interview met mr. H.E. Ras, president van de Hoge Raad, NJB, 1988, p. 1578

243. Zie in gelijke zin: de voorzitter van de Nederlandse Vereniging voor Rechtspraak. A.H van Delden en de president van de Haagse rechtbank, NRC Handelsblad, 21. juni 1991, Rechters woedend na kritiek CDA-er

244. Vrij Nederland, o.c. p. 32 
cratische legitimatie'. ${ }^{245}$ A.F.M. Brenninkmeijer noemt de 'maatschappelijke oriëntatie' van rechters een 'relevant gegeven', omdat de rechter in onze samenleving een steeds belangrijker, rechtsvormende rol vervult. Brenninkmeijer bepleit een Raad voor de Magistratuur, zoals deze in 1985 is voorgesteld door de Staatscommissie Herziening Rechterlijke Organisatie:

"Een dergelijk adviesorgaan kan naar voorbeeld van de Commissie aantrekken leden rechterlijke macht breder samengesteld zijn dan de rechterlijke macht en kan enerzijds waarborgen dat de maatschappelijke oriëntatie van rechters aansluit bij de realiteit en anderzijds dat er geen directe partij-politieke invloed uitgaat op de werving en selectie van rechters. (..) Twee uitersten zijn moeilijk te verdedigen: rechters selecteren rechters en politici selecteren rechters. Zonder onafhankelijke Raad voor de Magistratuur is de rechterlijke macht kwetsbaar. ${ }^{246}$

H. van Maarseveen vindt dat de Tweede Kamer de 'grondwettelijke plicht' heeft zich zorgvuldig te verdiepen in de benoeming van de leden van de Hoge Raad. Omdat de Tweede Kamer en de regering hun 'verantwoordelijkheden in deze materie' hebben verwaarloosd, is een coöptatiesysteem ontstaan, waarbij de selectiemaatstaven vooral van 'negatieve aard' zijn. De betrokkene moet niet te uitgesproken en niet te controversieel zijn, hij mag geen aanstoot geven, niet te kritisch zijn, en moet 'goed liggen'. Hoewel de minimum-geschiktheidseisen voor de Hoge Raad volgens Van Maarseveen een goede vakbekwaamheid waarborgen, meent hij dat er in de Hoge Raad geen 'topjuristen' zitten. Daaronder verstaat hij vakbekwame juristen met een duidelijke persoonlijke profilering. Later zal hij daarover in een interview met NRC Handelsblad zeggen:

"Als de Hoge Raad het zo mooi vindt als rechtsvormer op te treden hoort daar een sterke profilering bij. Pas wanneer de Hoge Raad zijn beslissingen uitvoerig motiveert, liefst met dissenting en concurring opinions, krijg.je aanvaardbare oordelen over onderwerpen die de wetgever wegens het controversiële karakter envan aon de rechter overlaat. (-) De Hoge Raad is nu een onvoorspelbaar orakel. ${ }^{247}$

De huidige raadsheren zijn volgens Van Maarseveen 'kleurloze juristen' en 'anonimi": "Er zijn weinig leden die uitmunten door duidelijke stellingnames, door duidelijke maatschappelijke standpunten, door manifeste betrokkenheden". Daarom zouden de Tweede Kamer en de regering er goed aan doen vast te stellen welk 'juristenprofiel' men voor het lidmaatschap van de Hoge Raad 'politiek wenselijk' acht: "Op basis daarvan kun men dan voortaan, zijn politieke

245. F. Bruinsma, Van aanbeveling naar voordrach, NJB, 1991, p. 1083-1085

246. A.F.M. Brenninkmeijer, Selectie rechters. NJB, 1991, p. 1086-1087

247. NRC Handelsblad, 9 december 1991 
verantwoordelijkheid serieus nemend, zorgvuldige benoemingen doen. 248 Twee maanden eerder, in oktober 1991, geeft Van Maarseveen aan zich voor de legitimatie van de cassatierechter te oriënteren op het Amerikaanse Supreme Court, waarvan de leden worden benoemd "langs de weg van een openbaar politiek machtsspel waarin zowel hun maatschappelijke overtuigingen als hun juridische bekwaamheden grondig worden onderzocht" ${ }^{249}$ Deze vergelijking is overigens pikant, omdat precies op dat moment de affaire rond de benoeming van Clarence Thomas, een van ongewenste intimiteiten betichte kandidaat voor het Supreme Court, een hoogtepunt bereikt. De hearings van het Senate Judiciary Committee zijn op dat moment wereldwijd live op televisie te volgen, en worden als een 'bizarre' en 'gênante' vertoning gezien. ${ }^{250}$

\subsubsection{Enquête Vrij Nederland}

De affaire-Van der Burg krijgt in november 1991, tijdens de behandeling van de justitiebegroting, een vervolg als het weekblad Vrij Nederland een enquête publiceert naar de rechterlijke macht van Nederland. ${ }^{251}$ Volgens deze enquête gaat de politieke voorkeur van 39 procent van de ondervraagden uit naar D66. ${ }^{252}$ Kritiek op de medewerking van de rechterlijke macht aan de enquête komt van de Tweede Kamerfractie van de Centrumdemocraten. Medewerking had volgens haar woordvoerder, H. Janmaat, nog "vergoelijkt" kunnen worden als de enquête was uitgevoerd door Elsevier, en niet door Vrij Nederland "dat zulke uitgesproken politieke denkbeelden hanteert en interpreteert. ${ }^{253} \mathrm{Jan}$ maat staat echter alleen met zijn kritiek, ook al noemt de minister van justitie, E.M.H. Hirsch Ballin de uitslag van de Vrij Nederland-enquête "operationeel

248. Henc van Maarseveen, Politiek en Hoge Raad, NJB, 1991, p. 1087-1088

249. Henc van Maarseveen, Politiek en Hoge Raad, NJB, 1991, p. 1423

250. Paul Brill, Verhoor Thomas en Hill bizarre en soms gênante vertoning, de Volkskrant, 12 oktober 1991; zie ook: J. Leijten, Hoorzitingen Senaat pure vorm van onrecht, NRC Handelsblad, 22 oktober 1991

251. Vrij Nederland ondervroeg. met medewerking van de Nederlandse Vereniging voor Rechtspraak, meer dan 1000 kantonrechters, rechters, raadsheren, administratieve rechters, leden van de Hoge Raad, officieren van justitie en procureurs-generaal over: hun afkomst en geloof. politicke voorkeur, carrière. inkomen. maatschappelijke belangstelling en hun opvattingen over misdaad en strafmaat. Marc Josten en J. van Tijn, o.c.

252. De stemverhouding binnen de rechterlijke macht zou volgens de Vrij Nederland-enquête aldus liggen: D66: $39 \%$, PvdA: $19 \%$, CDA: $17 \%$, VVD: $16 \%$, Groen Links: $4 \%$. N.B. deze cijfers wijken af van een gelijktijdig verricht onderzoek door L.E. de Grootvan Leeuwen, De rechterlijke macht in Nederland, p. 112. Volgens het onderzoek van De Groot-van Leeuwen ging in 1988 de politieke voorkeur van $29 \%$ van de leden van de rechterlijke macht uit naar het CDA, 33\% naar de VVD, $18 \%$ naar de PvdA, $18 \%$ naar D66, $2 \%$ naar klein links, en $1 \%$ naar klein rechts.

253. Hand. II 1991, p. 994-995 
niet zo interessant". Politieke gezindheid en religiositeit lijken voor de minister bij de selectie van kandidaten voor de rechterlijke macht geen expliciete rol te spelen. Hirsch Ballin:

"Er wordt in de eerste plaats gekeken naar vakman- en vakvrouwschap. Daarna wordt er gekeken naar het engagement in de samenleving. Wij willen geen mensen voor wie het recht ophoudt bij de laatste bladzijde van hun losbladig wetboek. Zet moeten begrijpen wat voor effect regels op de samenleving hebben. Dan is niet de vraag: welke politieke overtuiging heeft $u$ ? (-) $I k$ vraag nooit naar politieke overtuiging. (-) Politieke gezindheid is geen criterium voor de benoemingen waar $i k$ verantwoordelijkheid voor heb te dragen. ${ }^{254}$

Niettemin herhaalt de Vaste Kamercommissie voor Justitie naar aanleiding van de enquête dat zij nadrukkelijker betrokken wil worden bij het benoemen van raadsheren in de Hoge Raad. Zij blijkt inmiddels unaniem van mening dat de Tweede Kamer meer informatie moet krijgen over de kandidaten die door de Hoge Raad worden aanbevolen. Sinds 19 februari 1992 geldt daarom de situatie dat de Hoge Raad bij vacatures de curricula van kandidaten in gestandaardiseerde vorm voorzien van informatie aan de Tweede Kamer zendt (zie $\S 2.3 .6 .1$ ). Eventueel kan de Vaste Kamercommissie voor Justitie een gesprek voeren met een of meer kandidaten. ${ }^{235}$ Met deze nieuwe procedure wordt volgens de kamercommissie voorkomen dat de Tweede Kamer te zeer voor 'een voldongen feit' wordt geplaatst bij de voordracht. Ook meent zij dat het 'minder pijnlijk' is indien men nog in de beslotenheid kenbaar kan maken dat men een bepaalde kandidaat minder geschikt acht. ${ }^{256}$

De nieuwe belangstelling van de Tweede Kamer voor Hoge Raad-benoemingen wordt echter - opnieuw - met argusogen bekeken door de media. Zo meent de Volkskrant naar aanleiding van de Vrij Nederland-enquête, dat er 'weinig mis' is met de 'joggende, surfende, tuinierende en huiselijke' rechters. De wenselijkheid van een grotere politieke bemoeienis met de samenstelling van de Hoge Raad is volgens de Volkskrant twijfelachtig. Volgens de Volkskrant dient het politieke milieu zich allereerst zelf te beraden op zijn eigen gebrekkig functioneren, nu de rechter op grote schaal te hulp moet komen bij de 'miserabele wetgeving'. Dat de klacht over het nieuw-liberale stemgedrag juist afkomstig is van een CDA-politicus, noemde De Volkskrant verdacht. "Tot de

254. Mare Josten en J. van Tijn, De minister is tevreden over zijn rechterlijke macht, Vrij Nederland, 2, november 1991

255. Brief van de vaste Commissie voor Justitie, Bijl. Hand. II 1991-1992, 22300 VI, nr. 37 herdruk, p. $1-2$

256. W. Swildens (PvdA), voorzitter van de vaste Kamercommissie voor Justitic. NRC Handelsblad, 30 oktober 1991 
huisstijl van deze politieke groepering behoort het streven om in alle gremia van de samenleving ruimschoots een stem in het kapittel te hebben. ${ }^{1257}$

\subsubsection{De reorganisatie van de rechterlijke macht}

De beschrijving van de ontwikkelingen die zich na de Tweede Wereldoorlog met betrekking tot de toegang tot het rechtersambt hebben voorgedaan, eindigt met de thans aanhangige herziening van de rechterlijke organisatie, die reeds deels haar beslag heeft gekregen in de Wet van 3 juni 1992. Aan deze reorganisatie, ligt volgens de regering een drietal doelstellingen ten grondslag, t.w. het verbeteren, c.q. het in stand houden van de juridische kwaliteit van de rechtspraak, het verbeteren van de 'cliëntgerichtheid van de rechtspleging, en het scheppen van evenwicht in de structuur van de rechterlijke organisatie. ${ }^{258}$ Daartoe worden in de eerste en de tweede fase nieuwe gerechten van eerste aanleg gecreëerd, waarin alle civiele en strafrechtspraak en een belangrijk deel van de administratieve rechtspraak in eerste aanleg plaatsvinden. De huidige 62 kantongerechten zullen verdwijnen, en de functie van kantonrechter wordt 'geïntegreerd' in de rechtbanken nieuwe stijl. In de derde fase wordt de herstructurering van de administratieve rechtspraak voltooid. De Wet van 3 juni 1992, Stb. 278 treft wettelijke voorzieningen met betrekking tot de personele en organisatorische integratie tot de nieuwe administratieve sectoren in de nieuwe rechtbanken.

Ten behoeve van deze reorganisatie bracht de Staatscommissie Herziening Rechterlijke Organisatic in 1984 en 1985 een Eindrapport uit. De Staatscommissie werd, als hekend, ingesteld in 1971 door de toenmalige minister van justitie A.A.M. van Agt, als een reactie op de toenmalige vertrouwenscrisis. Dat laatste is echter niet langer de (eerste) zorg van de regering. Door een 'veranderd optreden van de rechterlijke macht', zo schrijtt zij in 1989, is de aandacht meer en meer verdrongen door het probleem van "de sterk toenemende werklast van de rechterlijke macht en het daarmee samenhangende besef dat de organisatie van de <gewone $>$ en de administratieve rechtspraak in Nederland meer in het algemeen zou moeten worden aangepast aan de ont-

257. Dienand Christe. Recht en wet, de Volkskrant. 2 november 1991. Ook De Gelderlander signaleert "de geur van christen-democratisch ongenoegen over de afkalvende aanhang binnen de rechterlijke macht". Een politicke maatstaf bij benoemingen noemt De Ge!derlander "een goeddeels onbruikbaar instrument als het om beïnloeding van het straf. klimaat gaat", omdat rechtsvragen niet volgens 'partij-politicke kavelgrenzen' worden beantwoord. De Gelderlander, Linkse rechters, 2 november 1991. In gelijke zin: NRC Handelsblad, 31 oktober 1991, Veeskeuring

258. MvT. Bijl. Hand. II 1990-1991, 21967 , nr. 3. p. 3 
wikkelingen van de maatschappelijke taak en functie van de rechtspleging. "25s Juist met het oog op dat laatste is het opmerkelijk dat de regering het vraagstuk van de werving, selectie, benoeming en bevordering van rechters bij de voorgenomen herziening geheel laat liggen. In haar Eindrapport stelt de Staatscommissie in 1985 immers nog op verontruste toon dat de minister van justitie 'een overheersende invloed op de benoeming en bevordering van rechters' heeft:

"Deze invloed kan naar de mening van de staatscommissie zo worden aangewend dat de onafhankelijkheid van de rechter ten opzichte van de uitvoerende macht in gevaar wordt gebracht. In veel rechtsgedingen, ook door de gewone rechter, is het bestuur éen van de partijen. Maar ook indien de overheid niet als procespartij bij de zaak betrokken is, kan een rechterlijke beslissing voor het bestuur van groot belang zijn; men denke aan de economische en sociale gevolgen van de uitspraak in een stakingsconflict. Naarmate het bestuur vaker direct of indirect bij geschillen betrokken is, neemt de kans op uitspraken die voor het bestuur niet gunstig zijn toe. Het bestuur kan er daardoor belang bij hebben alleen rechters te benoemen of te bevorderen van wie te verwachten of gebleken is, dat zij de door het bestuur gestelde doelen niet zullen tegenwerken. ${ }^{\text {260 }}$

\subsubsection{De Raad voor de rechterlijke macht}

Zeker in het licht van het tweede deel van het Eindrapport van de Staatscommissie Herziening Rechterlijke Organisatie uit 1985, schittert het vraagstuk van de toegang tot het rechtersambt bij de (aanstaande) herziening door afwezigheid. De Staatscommissie had immers nog gepleit voor een z.g. Raad voor de rechterlijke macht die bij de werving, selectie en opleiding en benoeming (bevordering) van rechterlijke ambtenaren, adviserende bevoegdheden heeft. Al eerder hadden een subcommissie van de Staatscommissie ${ }^{261}$ en de Nederlandse Vereniging voor Rechtspraak ${ }^{262}$, om dezelfde reden een soortgelijke raad voorgesteld. De Staatscommissie streeft met haar voorstel voor een Raad voor de rechterlijke macht niet naar een 'democratisering' van de rechterlijke macht. Niettemin vormt het vertrouwen van de bevolking in de rechter wel een uitgangspunt voor de Staatscommissie en voor de andere studies. De commis-

259. Kabinetsstandpunt over het Eindrapport van de: Staatscommissie Herziening Rechterlijke Organisatie, Bijl. Hand. II 1988-1989. 21 206, nr. 2, p. 4

260. Eindrapport van de Staatscommissie Herziening Rechterlijke Organisatie, deel II, 1985 , p. 7

261. F.F. Langemeijer, Raad voor de rechterlijke mach, gepubliceerd in: Trema special '84-2

262. Namelijk de werkgroep-Saelman in 1979, De onafhankelijke rechter, gepubliceerd in Trema special, 1979-2, en de commissie-Van der Velden in 1981, Gevraagd: een raad voor de rechterlijke macht?, gepubliceerd in: Trema, 1981, p. 247-262 
sie-Van der Velden hekelt in dit verband expliciet de 'geheimzinnigheid' bij rechtersbenoemingen, die veel verder gaat dan voor de privacy van de kandidaten gewenst is: "Een Raad voor de Rechterlijke Macht kan de bevolking, d.m.v. vertegenwoordigers, in de keuken laten kijken, en daarmede het vertrouwen in de (samenstelling van de) rechterlijke macht vergroten. ${ }^{263}$

In de visie van de Staatscommissie bestaat de Raad voor de rechterlijke macht uit twaalf leden, waarvan de helft afkomstig is uit de rechterlijke macht. Naast een voor de volle werktijd fungerende voorzitter, afkomstig uit de zittende magistratuur, zullen in de raad nog drie leden uit de zittende magistratuur en twee uit de staande magistratuur zitting nemen. De andere helft van de Raad bestaat uit respectievelijk twee personen, aangewezen door de Tweede Kamer, maar niet uit die Kamer afkomstig, twee afkomstig uit de advocatuur en twee uit de wetenschap of uit maatschappelijke organisaties 'met een zekere betrokkenheid bij de rechtspleging'. Daarbij moet gewaakt worden tegen het creëren van kwaliteitszetels voor bepaalde instellingen of organisaties. De leden van de raad worden door de regering benoemd, met uitzondering van de twee leden die door de Tweede Kamer worden aangewezen. Ten opzichte van de leden afkomstig uit de rechterlijke macht en de advocatuur dient de Nederlandse Vereniging voor Rechtspraak, respectievelijk de Nederlandse Orde van advocaten een aanbevelingsrecht te hebben. Alle leden van de Raad voor de rechterlijke macht worden benoemd voor een periode van vier of zes jaar. Met uitzondering van de voorzitter zullen allen in deeltijd aan de raad verbonden zijn en daarnaast hun beroepswerkzaamheden verrichten. De instelling entaakomschrijving van de raad voor de rechterlijke macht berusten op de wet. ${ }^{264}$

De Staatscommissie ziet - als gezegd - een taak voor de Raad voor de rechterlijke macht bij de recrutering, selectie en benoeming van rechterlijke ambtenaren. Zowel de werkzaamheden van de huidige Commissie aantrekken leden rechterlijke macht als de activiteiten van de raio-selectiecommissie worden aan de raad toebedeeld. Ook de selectie van gegadigden voor promotiebenoemingen is een taak voor de Raad. Een uitzondering vormt de selectie van leden van de Hoge Raad. De Staatscommissie acht het raadzaam om de huidige gang van zaken, waarbij de Hoge Raad zelf de voor een benoeming in aanmerking komende kandidaten selecteert, en de Tweede Kamer uit de aanbevolen kandidaten een voordracht samenstelt, te handhaven. ${ }^{265}$ Bij eerste benoemingen zal de minister zich bij zijn beslissing zowel door de Raad als door de colleges moeten laten adviseren. De huidige ongeschreven regel dat iemand die de selectie niet is gepasseerd niet wordt benoemd dient in de wet te worden

263. Gevraagd: een raad voor de rechterlijke macht?, o.c. p. 253

264. Eindrapport (deel 2), o.c. p. 10 en 11

265. Eindrapport (deel 2), o.c. p. 9 
vastgelegd. De minister moet een van het standpunt van de Raad afwijkend oordelen motiveren. Iemand die is geselecteerd maar niet door een college wordt aanbevolen moet zich tot de Raad kunnen wenden. Alvorens de Kroon bij verdere benoemingen beslist, dienen de colleges waarin een benoeming moet plaats hebben, een aanbeveling op te stellen, waarna de Raad zich over de aanbevolen kandidaten dient uit te laten. $\mathrm{Bij}$ bevorderingen acht de Staatscommissie het gewenst dat het initiatief inzake de advisering in handen van de raad komt te liggen. De Staatscommissie ziet tenslotte een bemiddelende rol weggelegd voor de Raad voor de rechterlijke macht bij niet-benoeming of -bevordering, alsmede bij de aanwijzing van rechters in bepaalde functies zoals die van kinderrechter of rechter-commissaris. Zij benadrukt echter dat in al deze gevallen de Raad optreedt als adviesorgaan; hij zal geen beslissingen nemen. Niettemin zal volgens de Staatscommissie de invloed van de Raad groot zijn, omdat de adviezen richtinggevend zullen zijn voor de minister, die, bij niet-opvolging, door de volksvertegenwoordiging ter verantwoording zal kunnen worden geroepen; tevens zullen de adviezen richtsnoer zijn voor de betrokken colleges. ${ }^{260}$

De voorstellen voor een Raad voor de rechterlijke macht zijn intussen een zachte dood gestorven, want bij de thans aanhangige herziening van de rechterlijke organisatie, keren zij niet terug. De minister van justitie E.M.H. Hirsch Ballin meent in 1990 dat er geen 'dringende behoefte' is aan een dergelijke raad. "Als je kijkt naar de gevaren van politisering van de rechtspraak in andere samenlevingen dan kan je je voorstellen dat daar veel eerder dan bij ons de behoefte aan een raad voor de magistratuur is opgekomen. ${ }^{1267}$ Topambtenaar Demmink van het ministerie van justitie voorzag eerder al dat een Raad voor de rechterlijke macht een 'permanente frustratie' zou worden, die:

"allerlei warm onderschreven standpunten inneemt en vervolgens de constatering dat er niets van terecht komt. (-) Het zou het zoveelste adviescollege zijn en dit keer dan van de rechterlijke macht. Nou, dat is aardig, die worden dan een keer gehoord, iedereen leest dat beleefd en zegt dan: tjonge, de raad voor de rechterlijke macht vindt er dat van. En vervolgens gaat men over tot de orde van de dag. "208

266. Eindrapport (deel 2), o.c. p. 9-10

267. Een prof op justitie. Trema, 1990, p. 88

268. Waar het sneller kan, moet het sneller. Trema. 1989, p. 180 


\subsection{Nabeschouwing}

Dit hoofdstuk beschreef de ontwikkelingen die zich na de Tweede Wereldoorlog ten aanzien van het vraagstuk van de toegang tot het rechtersambt hebben voorgedaan. Het poogde, uitgaande van de vooronderstelling in hoofdstuk 1, dat er een samenhang bestaat tussen de factoren die de toegang tot het rechtersambt bepalen (werving, selectie, benoeming, bevordering en benoembaarheid), een lijn aan te geven in de ontwikkeling van (en tussen) de verschillende deelonderwerpen. Dat laatste is maar zeer ten dele gelukt. De opeenvolging van ontwikkelingen kan weliswaar beredeneerd worden, maar van een samenhang tussen deze ontwikkelingen lijkt geen sprake. Veeleer is sprake van ogenschijnlijk technische ingrepen, met niettemin verstrekkende gevolgen. Een voorbeeld is het begrip 'selectie' van rechters dat allengs in ons staatsrecht is geslopen. Ik herinner eraan dat in de eerste jaren na de Tweede Wereldoorlog een Permanent College van Advies werd voorgesteld, met als doel het hoofd te bieden aan het toenmalige recruteringsprobleem. Als gevolg van de weerstand tegen een college, waarvan de leden door de Kroon en niet door de rechterlijke macht worden benoemd, werden de plannen afgeblazen, en afgezwakt tot een algemene maatregel van bestuur met betrekking tot de opleiding en vorming van rechterlijke ambtenaren, die later uitmondt in de huidige raioopleiding. Intussen - de Wet RO zwijgt hierover - is iemand die voldoet aan alle wettelijke benoembaarheidsvereisten, maar niet aan de kwalificatie van oud-raio of buitenstaander, niet benoembaar in de rechterlijke macht. De regering hanteert immers sinds de vertrouwenscrisis in de jaren zeventig alls beleidslijn dat de leden van de rechterlijke macht voor maximaal $50 \%$ uit oudraio's, en voor minimaal $50 \%$ uit buitenstaanders worden gerecruteerd. Aldus is een blokkade opgeworpen voor de toegang tot het rechtersambt, die het systeem van de Wet RO, dat de rekrutering en selectie van rechterlijke ambtenaren middels de aanbevelingen overlaat aan de gerechten zelf, frustreert.

\subsubsection{Twee perspectieven}

In hoofdstuk 1 werd nog als hypothese geformuleerd dat aan het ontstaan en de ontwikkeling van een selectiestelsel principiële keuzes ten grondslag liggen. In hoofdstuk 3 is echter reeds gebleken dat deze stelling voor wat het ontstaun van het benoemings- en benoembaarheidsstelsel betreft niet opgdat; aan het bestaande 'stelsel' ligt vooral het toeval ten grondslag. Maar ook voor de verdere ontwikkeling van dat stelsel na de Tweede Wereldoorlog, kan moeilijk worden volgehouden dat de ontwerpers zich hebben laten leiden door een visie die verder strekt dan een regeling per deelonderwerp. De vraag hoe een onderdeel zich verhoudt tot het geheel - wat eigenlijk het 'geheel' is - welke bevoegdheden bij wie moeten worden neergelegd en waarom, wordt veelal niet gesteld. Dit correspondeert met de bevindingen in hoofdstuk 2, waar bleek dat de grond- 
wettelijke verankering van begrippen als werving, selectie, benoeming en bevordering van rechters, bepaald problematisch is.

Hoewel het ontstaan en de ontwikkeling van de onderwerpen die de toegang tot het rechtersambt regelen, zich als willekeurig laten karakteriseren, loopt het sociologische begrip 'personele samenstelling' van de rechterlijke macht vooral sinds de Tweede Wereldoorlog als een rode draad door deze deelonderwerpen. Eind jaren zestig gaat het daarbij nog om de vermeende eenzijdigheid van de rechterlijke macht (vergelijk de vertrouwenscrisis). Allengs verplaatst het perspectief op selectie zich echter naar een discussie over de diversiteit van de rechterlijke macht in verband met haar taak bij de rechtsvorming (zie ook hoofdstuk 6). Daarbij is niet zelden sprake van wat in het Duits misschien wel een Inzidenzfalldiskussion heet. Incidenteel vindt in de Tweede Kamer, in de literatuur of in de media, een betrekkelijk chaotische discussie plaats over de benoeming van rechters (in het bijzonder over raadsheren in de Hoge Raad), zonder een bezinning op de factoren die werkelijk de toegang tot het rechtersambt, en daarmee de samenstelling van de rechterlijke macht bepalen. Opmerkelijk is ook dat de commotie en verontwaardiging die bij tijd en wijlen optreedt (vergelijk de kwesties rond Cnoop Koopmans, Van den Biesen en Van der Burg), geen gelijke tred houdt met de feitelijke, institutionele ontwikkelingen die te zelfdertijd plaatsvinden. Sterker, die ontwikkelingen staan zelfs haaks op de geuite kritiek. Zo geven de belangrijkste ontwikkelingen ten aanzien van de werving, selectie, benoeming en promotie, die zich de laatste 20 jaar hebben voorgedaan, juist een concentratie van bevoegdheden te zien bij met name het ministerie van justitie, terwijl in de discussie over het rechterlijk activisme en het toetsingsrecht juist grote bezwaren worden ingebracht tegen zo'n overheersende rol van hetzij het ministerıe hetzij de rechterlijke macht (zie ook hoofdstuk 6).

De tegenstelling tussen de maatschappelijke discussie over de samenstelling van de rechterlijke macht enerzijds, en de feitelijke, institutionele regeling van het onderwerp anderzijds valt waarschijnlijk deels te verklaren doordat de betreffende regelingen buiten het zicht van het parlement, middels circulaires, zijn ontstaan. Het ministerie heeft, zoals in hoofdstuk 2 al werd opgemerkt, zijn bevoegdheden immers niet zozeer gekregen als wel genomen. Toch rijst ook het vermoeden dat de belangstelling van het parlement, de rechtswetenschap en de media voor het vraagstuk van de toegang tot het rechtersambt niet erg diep gaat. Als bij voorbeeld in april 1970 - naar aanleiding van alle commotie rond de vertrouwenscrisis -, de Commissie aantrekken leden rechterlijke macht wordt ingesteld, die tot taak krijgt voortaan niet minder dan de helft van alle toekomstige rechters te selecteren, moet de regering de Tweede Kamer een jaar later nog van het bestaan en het doel van deze commissie op de hongte bren- 
gen. ${ }^{269}$ Inmiddels heeft deze commissie, die ooit als een experiment begon, waardoor zelfs de meest elementaire voorzieningen (samenstelling, zittingsperiode, rapportage) niet geregeld zijn, geruisloos een permanente status gekregen. En van de bezorgdheid die de Tweede Kamer tijdens de kwestie-Van der Burg tentoonspreidt, valt enkele maanden later, in weerwil van de waarschuwingen van de Staatscommissie herziening rechterlijke organisatie, bij de behandeling van de eerste fase van de reorganisatie van de rechterlijke macht, niets meer te vernemen.

\subsubsection{De rechterlijke organisatie in de toekomst}

Intussen rijst de vraag of inderdaad met een gerust hart op de ingeslagen weg kan worden voortgegaan. Geheel in de geest van de huidige reorganisatie werd, naar aanleiding van de bevindingen van het organisatiebureau Berenschot, de aanbevelingsprocedure voor rechters al eens als louter 'werkbelasting' afgedaan. De aanbevelingsvergadering legt immers "een onevenredig beslag op de tijd van de rechter. Een (-) brede oordeelsvorming lijkt in het algemeen niet nodig om tot een adequate aanbeveling te komen", concludeert de Projectgroep Werkbelasting Gerechten in 1985 . Zij stelt daarom voor de huidige regeling te vervangen door de bepaling waarbij de president van een college slechts één kandidaat aan de regering aanbeveelt. ${ }^{270}$ Onduidelijk is of deze 'technische' voorstellen ook zullen worden overgenomen, maar de regering heeft zich daarover reeds positief uitgelaten. ${ }^{271}$ Wat daar vanuit het oogpunt van een efficiënte bedrijfsvoering misschien ook voor te zeggen valt, het vraagstuk van de toegang tot het rechtersambt dreigt inmiddels wel iedere principiële relevantie te verliezen. Om bij het voorstel van de Projectgroep te blijven: een 'benoeming' door de president van een college zou niet geringe staatsrechtelijke effecten hebben, omdat mèt het verdwijnen van een keuzemogelijkheid voor de minister, ook de ministeriële verantwoordelijkheid voor een benoeming in de praktijk zal wegvallen. Hij zou, zoals reeds in de vorige eeuw bij herhaling werd benadrukt, gaan 'leunen' op de aanbeveling. ${ }^{272}$ De pendant van die verantwoordelijkheid, de controlerende functie van het parlement, wordt daarmee feitelijk illusoir. Het uitgangspunt van coöptatie dat aldus wordt binnengehaald in de rechterlijke macht is, getuige de discussies in de vorige en in deze eeuw, hovendien - zacht gezegd - niet onproblematisch. Elders lijkt de Projectgroep zich trouwens bewust van de impact van haar voorstellen. Als zij de afschafting moet beredeneren van de wettelijke advieshevoegdheid bij aanbevelingen van

269. Hand. II 1970-1971, 10808, nr. 7, p. 11

270. Prujectgrnep werkbelasting gerechten, Onderzoek functioneren rechte rlijke organisatie, 29 januari 1985

271. MvT, Bijl. Hand. II 1990-1991, nr. 3, p. 10

272. Zie $\$ 3.7 .2$ 
de officier van justitie, stelt zij niet alleen dat deze zijn tijd wel beter kan besteden, maar ook dat 'daarnaast' nog argumenten aan het staatsrecht zijn te ontlenen, "die er juist voor pleiten de invloed van het OM op de benoeming van rechters af te remmen. ${ }^{173}$

Het gebrek aan een meer principiële bezinning op het vraagstuk van de toegang tot het rechtersambt bij de aanhangige reorganisatie, is zowel in historisch, systematisch als in toekomstig perspectief verbazingwekkend. In historisch en toekomstig opzicht is het opmerkelijk dat de problemen die de aanleiding voor deze reorganisatie waren daarin - ten onrechte, zie hieronder - niet terugkeren. In systematisch opzicht staan, zo volgde al uit hoofdstuk 2, vitale onderdelen van ons staatsrecht, in het bijzonder het ontbreken van een wettelijke grondslag voor de Commissie aantrekken leden rechterlijke macht en de selectie bij promotiebenoemingen, op gespannen voet met grondwettelijke en verdragsrechtelijke bepalingen. In $\S 2.2 .2$ werd er bovendien op gewezen dat het begrip 'integratie', t.w. de opheffing van de kantongerechten, in verband met de benoeming voor het leven ex art. 117, eerste lid, GW niet zonder problemen is. Deze situatie wordt doorgezet in de aanhangige herziening van de rechterlijke organisatie. Hoewel die zich, als gezegd, verre houdt van een grondslagendiscussie, bevat zij wel degelijk zeer principiële elementen die de toegang tot het rechtersambt raken. Wat bijvoorbeeld de benoembaarheid van rechters betreft, valt op dat in de eerste fase de onverenigbaarheid op grond van bloedof aanverwantschap (voorheen art. 10 Wet RO) is weggevallen, zonder dat een discussie over de eerder aangekondigde afschaffing van onverenigbaarheden in het algemeen werd afgewacht. ${ }^{274}$ Ten aanzien van de interne selectie, t.w. de vorming en bezetting van de enkelvoudige en meervoudige kamers binnen de gerechten, zijn uit oogpunt van de 'stroomlijning', 'vereenvoudiging' en 'uniformering' van de rechterlijke organisatie, de presidenten van de colleges bevoegd gemaakt. ${ }^{275}$ Uit dezelfde koker is de nieuwe management-structuur voor de gerechten afkomstig, die vooralsnog op convenanten is gebaseerd. Het is de vraag welke invloed de directeur gerechtelijke organisatie - waaraan nu reeds een adviesrecht toekomt bij de aanbeveling van rechtbankpresidenten in de toekomst op de werving en selectie van rechterlijke ambtenaren gaat krijgen. ${ }^{276}$

"Het bestaande, geschakeerde rechterlijke bestel is niet de vrucht van een bewuste organisatorische keuze op een gegeven moment in de tijd, maar het

273. Onderzoek functioneren rechterlijke organisatie, o.c. p. 4

274. MvT, Bijl. Hand. II 1990-1991, 21976 , nr. 3, p. 16

275. MvT, Bijl. Hand. II 1990-1991. 21 976, nr. 3. p. 10

276. Zie hoofdstuk 2 
resultaat van de ontuikkeling in de afgelopen 200 jaren $^{2277}$, zo stelt de regering terecht naar aanleiding van het rapport van de Staatscommissie herziening rechterlijke organisatie. Het is echter jammer dat die keuze, maar nu kennelijk bewust, opnieuw niet gemaakt wordt. De voorliggende reorganisatie is immers, althans op het punt van de toegang tot het rechtersambt, een technocratisch project dat zelfs geen begin van een serieus antwoord geeft op vragen die reeds in de zeer nabije toekomst te verwachten zijn. "Deze hele gang van zaken roept het beeld op van een reorganisatie die primair beschouwd wordt als een interne aangelegenheid tussen de regering, de rechterlijke macht en uiteraard de Staten-Generaal" aldus het GPV-Tweede Kamerlid Schutte. ${ }^{278}$ Opmerkelijk is inderdaad dat met geen woord gerept wordt over de maatschappelijke discussie over het 'rechterlijk activisme', of over het toetsingsrecht. Het is zeer de vraag of bij invoering daarvan werkelijk volstaan kan worden met de nu omhelsde uitgangspunten van unusrechtspraak en met een dominante positie van de president of een d.g.o. bij de aanbeveling en benoeming van rechters, of bij de vorming en bezetting van kamers. Het debat over de staatkundige vernieuwing bijvoorbeeld, dat zich overigens gelijktijdig met dat over de reorganisatie heeft afgespeeld. heeft, zo zal uit hoofdstuk 6 blijken, inmiddels anders uitgewezen. Het technocratische perspectief wordt in dat hoofdstuk geconfronteerd met het democratische perspectief, dat - zoals in hoofdstuk 1 al werd aangegeven - haar probleemstelling concentreert op het thema bevoegdheid versus democratische legitimatie, waarbij legitimatie wordt vertaald in de wijze van aanstelling van rechters. Om die discussie op voorhand reeds iets meer reliëf te geven, wordt in het volgende hoofdstuk een selectiemethode onderzocht, waarin het begrip 'democratische legitimatie' par excellence lijkt te zijn geïncorporeerd, namelijk de verkiezing van rechters in de Amerikaanse deelstaat New York.

277. Bijl. Hand. II 1988-1989, 21206, nr. 2, p. 9

278. Hand. II. 26 maart 1992 , p. $4111-4112$ 


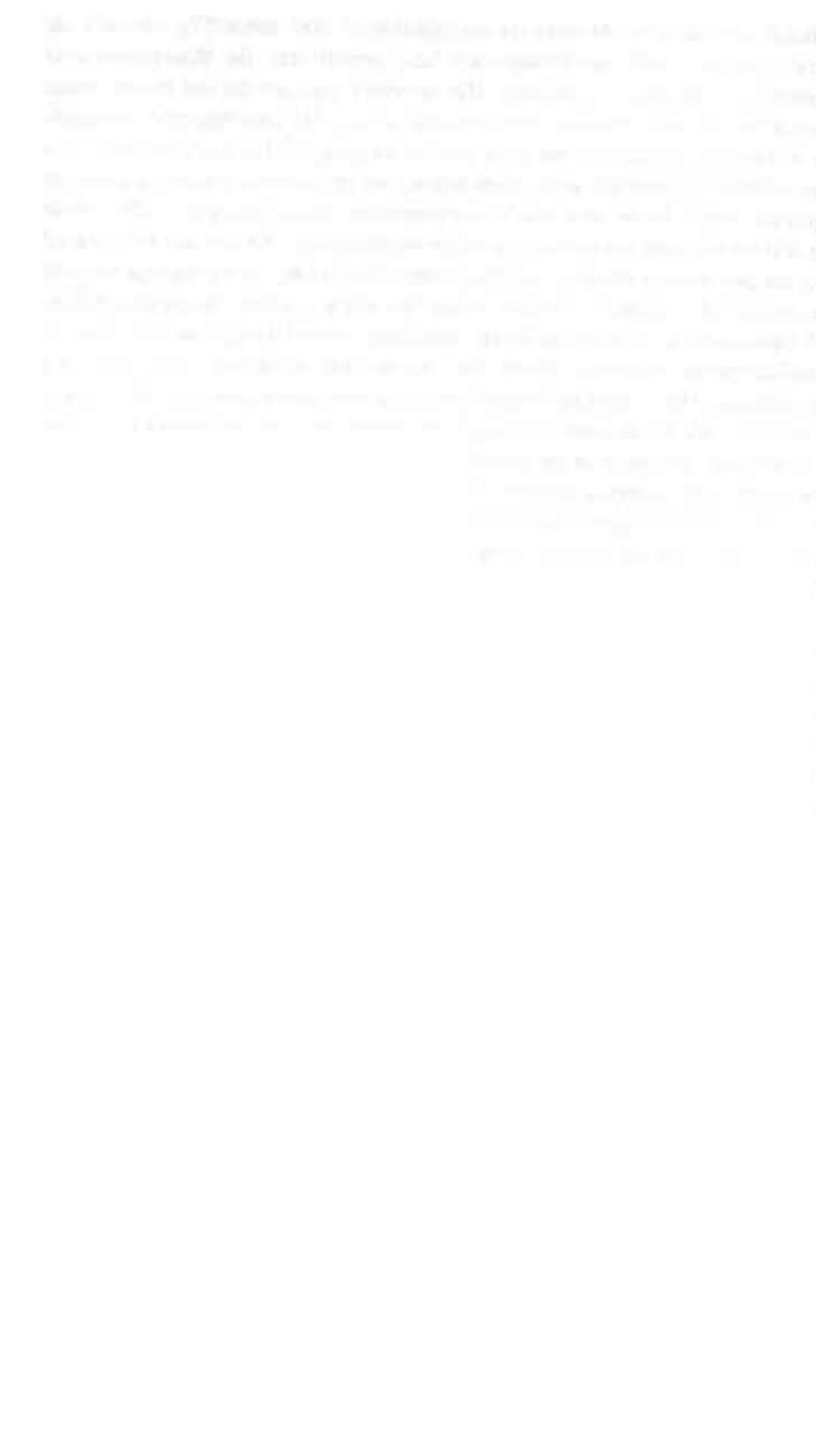




\section{Leel IV}

\section{Het democratische perspectief}




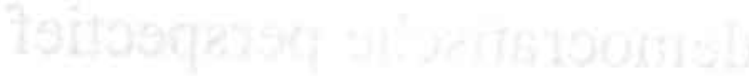




\section{De toegang tot het rechtersambt in de Amerikaanse deelstaat New York}

\subsection{Inleiding}

In een interview in 1990 zegt de oud-president van de Amsterdamse rechtbank B.J. Asscher:

"Dat de kwaliteit van de rechterlijke macht door zoveel mensen hoger wordt geacht dan de kwaliteit van politici verbaast mij niets. Simpelweg omdat de ene groep benoemd wordt en de andere gekozen. Als je rechters moet kiezen krijg je zoiets als Asscher for President. Dan moet ik me elke vier jaar waar maken. Dan laat ik mijn haar wat bijkleuren om jonger te lijken, dan ga ik spraaklessen nemen en naar een psycholoog om op tijd met mijn vuistje te zwaaien als ik iets belangrijks te zeggen heb. Maar dan leg ik het hoe dan ook af tegen een glamour-boy van 42, of die nu beter is of niet. In een stelsel waar mensen worden gekozen spelen andere factoren mee dan alleen kwaliteit. ${ }^{n 1}$

Asscher laat in het midden wat er eigenlijk tégen is dat een oudere rechter het 'aflegt' tegen een 'glamour boy van 42' - mits deze niet 'slechter' is -, en waarom niet meer factoren 'dan alleen kwaliteit' bij de selectie van rechters mogen meespelen. Het is natuurlijk even wennen, maar waarom zou - onder het motto 'het oog wil ook wat' of, voor het noodzakelijke vertrouwen - het uiterlijk (of de uitstraling) van een rechter bij zijn benoeming geen rol mogen spelen. Uit het een (de favoriete glamour boy) volgt immers niet noodzakelijk het ander (een onbenullige rechter); Asscher zèlf trouwens, heeft naar verluidt de presidenten in kort geding ooit eens de 'Chippendales van de rechterlijke macht' genoemd. De verkiezing van een onbenullige glamour boy heeft bovendien nog als voordeel, dat men er na vier jaar met een beetje geluk weer van af is, iets wat men niet kan zeggen na een slechte benoeming. Belangrijker is echter dat in het bovenstaande de weerzin wordt vertolkt die van oudsher in ons land - en daarbuiten - heeft bestaan tegen rechtersverkiezingen. B.D.H. Tellegen, een van de weinige pleitbezorgers van zulke verkiezingen in ons land, wijst er in 1883 al terecht op dat hier niet zelden met twee maten wordt gemeten; "Niets is gemakkelijker dan de schaduuzijde van den rechter door keuze

1. Bert Molemar, Rechters De opkomst van de zwarle mach, 1990, p. 29 
in 't licht te stellen, daar zij meer in 't oog springt dan de nadeelen aan de Koninklijke benoeming verbonden." 2 De enkele verwijzing naar het Amerikaanse 'schrikbeeld' van rechtersverkiezingen - het is al opgemerkt - geldt, tot in onze tijd, als een nogal gemakkelijk argument tegen 'politieke' benoemingen, en de tegenstanders (en dat is nagenoeg iedereen) zullen zelden de moeite nemen om hun afkeer te beargumenteren, laat staan om het Amerikaanse verkiezingsstelsel serieus in studie te nemen. Zij lopen daarmee een belangrijke medestander mis. Sinds de invoering van het stelsel van rechtersverkiezingen in New York in 1846, wordt in de Amerikaanse literatuur immers met toenemende felheid, en - naar het zich laat aanzien - met steeds meer succes, gepleit voor de afschaffing van rechtersverkiezingen en voor de invoering van een specifieke vorm van rechtersbenoemingen (merit selection). Met enige jaloezie wordt in de Amerikaanse staten gekeken naar de federale en Europese carrièrerechters, wier (vermeende) deskundigheid en onafhankelijkheid het gevolg zouden zijn van 'vernieuwende' denkbeelden over coöptatie, anciënniteit en esprit de corps, verschijnselen waarover wij - in beschaafd gezelschap - niet eens meer hardop durven te praten.

Ik loop inmiddels enigszins vooruit op de conclusies over rechtersverkiezingen die inderdaad somber gestemd zijn. Toch is het - om met Tellegen te spreken te gemakkelijk om zulke verkiezingen a priori te ridiculiseren. Vanuit staatsrechtelijk oogpunt zijn de Amerikaanse rechtersverkiezingen immers een boeiend experiment (geweest), waarmee al in een vroeg stadium van de opkomst van democratische bewegingen is gebroken met bestaande (Engelse) conventies over de benoeming voor het leven. Voor ons zijn rechtersverkiezingen in het bijzonder interessant, omdat zij de grenzen tussen theorie en praktijk van de (representatieve) democratie, in relatie tot het vraagstuk van de toegang tot het rechtersambt, zo pijnlijk scherp hebben aangeven. De toepassing van begrippen als volksinvloed, afspiegeling en representatie, blijkt - in Amerika althans - niet in staat geweest haar wat populistische appel op 'de wil van de meerderheid' te ontstijgen. Opmerkelijk is bovendien dat veel Amerikaanse burgers inmiddels deze zeepbel van schijn-democratie willen doorprikken, en spreken over een illusion of democracy. "We must stop perpetuating the myth that judicial elections give us a democratic choice. They do not and will not", aldus de Commission on Government Integrity in 1989.

2. B.D.H. Tellegen, preadvies, Handelingen der Nederlandsche Juristen-Vereniging, 1883. p. 103 


\subsection{Rechterlijke organisatie in de staat New York}

De rechterlijke organisatie in de staat New York is "the largest, busiest and most expensive in the world", aldus een opschepperige Peter J. Galie. ${ }^{3}$ Critici voegen daaraan toe dat het tevens "one of the most inefficiently organized systems in the nation" is. ${ }^{4}$ In elk geval is het stelsel niet erg overzichtelijk, en kan het de vergelijking met het vroegere Nederlandse labyrint van 'gewone' en administratieve rechtsgangen, met glans doorstaan. De bevoegdheid tot inrichting van de rechterlijke organisatie in de 50 Amerikaanse deelstaten vloeit niet voort uit de Amerikaanse Grondwet, maar steunt op de grondwetten van de afzonderlijke deelstaten. De constitutionele basis voor de rechterlijke organisatie van de staat New York wordt gevormd door art. VI New York State Constitution. De inrichting van de rechterlijke organisatie is nader uitgewerkt in een organieke wet: de Judiciary Law c.a. ${ }^{5}$ De staat New York is juridisch-geografisch ingedeeld in 4 judicial departments ${ }^{6}$ die zijn onderverdeeld in 11 judicial districts. De districten zijn weer verdeeld in counties. ${ }^{7}$

De structuur van de New Yorkse rechterlijke organisatie is vergelijkbaar met de Nederlandse. Men onderscheidt tussen trial courts (instanties van eerste aanleg) en intermediate appellate courts (beroepsinstanties). Daarboven staat een hoogste rechtscollege, het Court of Appeals (niet te verwarren met het Supreme Court dat in New York slechts een instantie van eerste aanleg is). De instanties van eerste aanleg oordelen over het bewijs, stellen de feiten vast en passen daarop het recht toe. Men onderscheidt rechterlijke instanties van eerste aanleg naar civiel- en strafrecht, en voorts naar absolute competentie (trial courts met superior dan wel lesser jurisdiction), en naar relatieve competentie (statewide en citywide trial courts). Statewide courts zijn het Supreme Court, het Court of Claims, het Family Court, het Surrogate's Court en de County Courts. Citywide courts zijn 1) de instanties wier jurisdictie zich enkel over het eerste departement (New York City) uitstrekt, te weten de Civil en Criminal Courts in New York, of waarvan 2) de jurisdictie is beperkt tot een village, town of city buiten de stad New York: Village Courts, Town Courts, City Courts. De beroepsinstanties worden gevormd door de County Courts, de Appellate Divisions, de Appellate Terms van het Supreme Court en tenslotte het Court of Appeals. De beroepsinstanties zien toe op de juiste toepassing van het

3. Peter J. Galic, The New York State Constitution a reference guide, 1991, p. 116

4. Commiltee for Modern Courts, Legislative brief, 1992

5. Zie: Court of Claims Act, Uniform Justice Court Act, Family Court Act, New York City Civil Court Act, New York City Criminal Court Act, Uniform City District Court Act, Uniform City Court ACl, Indian Law

6. Art. VI, Section 4, New York State Constitution

7. Art. VI, Section 6, New York State Constitution 
recht; in principe worden in beroep geen feiten vastgesteld. Veruit de belangrijkste instantie in eerste aanleg is het Supreme Court, dat in iedere county zetelt, maar dat formeel eén rechtscollege is. De regeling van het Supreme Court is om een tweetal redenen verwarrend; het Supreme Court in New York is - als gezegd - niet, zoals in alle andere Amerikaanse staten, de hoogste rechterlijke instantie maar slechts de hoogste rechterlijke instantie in eerste aanleg. Verwarrend is ook de algemene bevoegdheid van het Supreme Court, dat in principe in alle zaken in eerste instantie mag oordelen met uitzondering van die zaken waartoe speciale instanties als het Family Court, het Surrogate's Court, het Housing Court, het Court of Claims of de Federal Courts (mede) bevoegd zijn. De competentieafbakening is echter onduidelijk geregeld. Het Supreme Court heeft overigens ook zogenaamde Appellate Divisions; leden van het Supreme Court fungeren hier als beroepsrechter. ${ }^{8}$

\subsection{Rechtersverkiezingen in de staat New York}

Een groot aantal rechters in de staat New York wordt gekozen (zie schema 1). De procedure voor de verkiezing van rechters is nader uitgewerkt in een organieke wet, de Election Law. Deze wet is van toepassing op alle verkiesbare publieke ambten in de staat New York. ${ }^{9}$ Voor een goed begrip van de New Yorkse Kieswet - en van rechtersverkiezingen - is het van belang om te weten dat de politieke partijen in de staat New York voor hun inrichting onderworpen zijn aan een strak publiekrechtelijk regime ${ }^{10}$ In grote lijnen verloopt een rechtersverkiezing als volgt. Indien zich een verkiesbare rechtersvacature voordoet wijst de judicial nominating commission van een partij een kandidaat aan ('designation' ${ }^{11}$ ). Afhankelijk van de functie, geschiedt de kandidaatstelling op voordracht van de state committee ${ }^{12}$ of de county committee ${ }^{13}$ van de betreffende partij. In de betreffende commissie heeft in de praktijk het partijkader zitting. Meestal wordt de kandidaat vooraf onderzocht door een screening commission van de partij; deze laatste commissie heeft geen wettelijke grondslag, maar is vrijwillig ingesteld. Daarna wordt de kandidaat, als het goed is (en meestal is het goed) gekozen en genomineerd voor de verkiezingen door de judicial nominating convention ${ }^{14}$ van de betreffende partij in het desbetreffende district. De gedelegeerden op deze conventie worden geselecteerd door de partijtop, en gekozen tijdens een z.g. primary (voorverkiezing).

8. Art. VI. Section 4. New York State Constitution

9. \$1-102 Election Law

10. Zie $\$ 2$ Election Law (Party Organization)

11. \$ 1-104, sub 7, Election Law jo. $\$ 1-104$, sub 11. Election Law

12. $\$ 6-104$, eerste lid, Election Law

13. \$ 6-108 Elecrion Law

14. $\$ 6-124$ jo. §6-126 Election Law 
Schema 1: Benoeming en verkiezing van rechterlijke ambtenaren in de deelstaat New York ${ }^{15}$

\begin{tabular}{|c|c|c|c|c|}
\hline & $\begin{array}{l}\text { type } \\
\text { gerecht }\end{array}$ & benoeming & verkiczing & ambtstermijn \\
\hline $\begin{array}{l}\text { Suprene } \\
\text { Court }\end{array}$ & $\begin{array}{l}\text { instantie } \\
\text { van eerste } \\
\text { aanleg en } \\
\text { beroeps- } \\
\text { instantie }\end{array}$ & $\ldots$ & $\begin{array}{l}\text { door kiezers } \\
\text { betreffende } \\
\text { district }\end{array}$ & $\begin{array}{l}14 \text { jaar (art. VI } \\
\text { Section } 4 \text { New York } \\
\text { State Constitution) }\end{array}$ \\
\hline $\begin{array}{l}\text { Appellate } \\
\text { Terms } \\
\text { van het } \\
\text { Supreme } \\
\text { Court }\end{array}$ & $\begin{array}{l}\text { Supreme } \\
\text { Court als } \\
\text { beroeps- } \\
\text { rechter }\end{array}$ & $\begin{array}{l}\text { gouverneur } \\
\text { benoemt chief } \\
\text { justice en de } \\
\text { overige rechters } \\
\text { uit de gekozen } \\
\text { rechters van het } \\
\text { Supreme Court }\end{array}$ & -- & $\begin{array}{l}\text { chief justice: } \\
\text { ambtstermijn is } \\
\text { gelijk aan zittings- } \\
\text { gouverneur; } \\
\text { overige rechters: } \\
5 \text { jaar (art. VI } \\
\text { Section } 6 \text { New York } \\
\text { State Constitution) }\end{array}$ \\
\hline $\begin{array}{l}\text { Court of } \\
\text { Claims }\end{array}$ & $\begin{array}{l}\text { instantic } \\
\text { van eerste } \\
\text { aanleg }\end{array}$ & $\begin{array}{l}\text { door gouverneur, } \\
\text { na advies en } \\
\text { goedkeuring } \\
\text { Senaat }\end{array}$ & $\ldots$ & $\begin{array}{l}9 \text { jaar (an. VI } \\
\text { Section } 10 \\
\text { New York Siate } \\
\text { Constimution }\end{array}$ \\
\hline $\begin{array}{l}\text { Family } \\
\text { Court }\end{array}$ & $\begin{array}{l}\text { instantic } \\
\text { van eerste } \\
\text { aanleg }\end{array}$ & $\begin{array}{l}\text { in New York } \\
\text { City: door } \\
\text { burgemeester, na } \\
\text { advies mayor's } \\
\text { commiltee }\end{array}$ & $\begin{array}{l}\text { buiten New York } \\
\text { City: door kiezers } \\
\text { van de betreffende: } \\
\text { county }\end{array}$ & $\begin{array}{l}10 \text { jaar (art. VI } \\
\text { Section } 13 \\
\text { New York State } \\
\text { Constitution }\end{array}$ \\
\hline $\begin{array}{l}\text { Sur- } \\
\text { rogate's } \\
\text { Couri }\end{array}$ & $\begin{array}{l}\text { instantie } \\
\text { van eerste } \\
\text { aanleg }\end{array}$ & - & $\begin{array}{l}\text { door kiezers } \\
\text { betreffende county }\end{array}$ & $\begin{array}{l}\text { in New York } \\
\text { City: } 14 \text { jaar, } \\
\text { daarbuiten } 10 \text { jaar } \\
\text { (art. VI Section } \\
12 \text { New York } \\
\text { Stare Constitution }\end{array}$ \\
\hline $\begin{array}{l}\text { Counny } \\
\text { Court }\end{array}$ & $\begin{array}{l}\text { instantie } \\
\text { van eerste } \\
\text { aanleg }\end{array}$ & - & $\begin{array}{l}\text { door kiezers } \\
\text { betreffende county }\end{array}$ & $\begin{array}{l}10 \text { jaar fart. VI } \\
\text { Section } 10 \text { New } \\
\text { York Siate } \\
\text { Constitution }\end{array}$ \\
\hline $\begin{array}{l}\text { Court of } \\
\text { Appeals }\end{array}$ & $\begin{array}{l}\text { beroeps- } \\
\text { instantie en } \\
\text { hoogste } \\
\text { rechts- } \\
\text { college }\end{array}$ & $\begin{array}{l}\text { door gouverneur } \\
\text { op aanbeveling } \\
\text { van Commission } \\
\text { on Judicial Nomi- } \\
\text { nation, na advies } \\
\text { en goedkeuring } \\
\text { door de Senaat }\end{array}$ & - & $\begin{array}{l}14 \text { jaar (art. VI } \\
\text { Section } 2 \text { New } \\
\text { York State } \\
\text { Constitution }\end{array}$ \\
\hline
\end{tabular}

15. Niet opgenomen in dit schema zijn de rechters van het Disirict Courl, alsmede het Town, Village en City Court, die eveneens worden gekozen. 
Ten aanzien van de verkiesbaarheid c.q. benoembaarheid van rechterlijke kandidaten, bevatten de New York State Constitution, de Judiciary Law en de Election Law een aantal voorschriften. De New York State Constitution bepaalt dat kandidaten, afhankelijk van het betreffende ambt, gedurende een periode van tenminste vijf c.q. tien jaar zijn toegelaten tot de rechtspraktijk. De Election Law stelt bovendien het vereiste van het Amerikaanse staatsburgerschap en stelt voorwaarden aan de beschikbaarheid van de kandidaat. ${ }^{16}$ Overigens verklaart de New York State Constitution een groot aantal ambten en functies onverenigbaar met de rechterlijke functie. ${ }^{17}$ Een kandidaat heeft, om verkiesbaar te zijn, behalve een nominatie door een politieke partij, een groot aantal steunbetuigingen van partijleden nodig. Handtekeningen voor deze designating petitions worden door de kandidaat zelf en door andere actieve partijleden onder partijleden geworven. ${ }^{18}$ Overigens voorziet de Election Law ook in de mogelijkheid van een onafhankelijke kandidaatstelling (independent nomination), door een onafhankelijk lichaam (independent body). ${ }^{19}$ Indien de judicial nominating commission meer kandidaten aanwijst, dan er functies zijn, wordt de nominatie niet gemaakt door de partijconventie, maar tijdens een primary $^{20}$ (voorverkiezing). Kiesgerechtigd voor een primary zijn de leden van een politieke partij. Na de nominatie, hetzij door de partijconventie, hetzij door de primary, volgt in november de general election (algemene verkiezing), waarin de kandidaten van de (meestal twee grote) politieke partijen om de vacante plaats strijden. Kiesgerechtigd voor deze verkiezing zijn alle burgers die voldoen aan de kiezerskwalificaties. ${ }^{21}$ De verkiezing vindt - om praktische redenen - meestal plaats in combinatie met de verkiezing voor andere publieke ambten, zoals presidents-, gouverneurs-, burgemeesters- en andere verkiezingen.

\subsubsection{Kritiek op het verkiezingsproces}

In het verleden is in New York, net als in de meeste andere Amerikatanse stdten, sprake geweest van een groot aantal problemen bij zowel de kandidaatstelling als de verkiezing van rechters (zie $\S 5.3 .4$ ). De belangrijkste kritiek op rechtersverkiezingen richt zich echter op het proces dat aan de kandidaatstelling vooraf gaat. Dat proces kan worden onderverdeeld in twee stadia: de aanwijzing ('designation') van een of meer kandidaten door de judicial nominating commission van een politieke partij, en de ratificatie van die keuze door de

16. \$6-122 Election Law

17. Art. VI, Section 20, New York State Constihtion

18. \$6-136 Election Law

19. \$1-104 jo. \$ 6-138 en \$ 6-142 Election Law

20. \$ 6-160 Election Law

21. Art. II, Secrion 1, New York State Constitution 
judicial nominating convention van die partij ('nomination'). De judicial nominating commission bestaat uit een klein aantal (ongeveer vijf tot zeven) kaderleden van een van de vier partijen: de Democratic Party, Republican Party, Liberal Party en Conservative Party. In het verleden is gebleken dat deze commissie de juridische deskundigheid van een kandidaat niet als eerste - en ook niet als tweede of derde - in aanmerking neemt. Dat komt omdat de nominatie voor een rechtersfunctie vooral wordt bezien vanuit het perspectief van de partij, en minder vanuit het gezichtspunt van een efficiënte rechtspleging: "no political leader has been given the mandate to improve the judiciary, and that really isn't on the political leader's agenda", aldus Sol Wachtler, de oud-president van het hoogste rechtscollege in New York, het Court of Appeals. ${ }^{22}$ De nominatie van een kandidaat is in de meeste Amerikaanse deeistaten in de eerste plaats een reward, een beloning voor trouwe dienst aan de partij; "It's well-known to everyone in the legal community that judicial nominations are often doled out as prizes to lawyers who have put in their time working for the party", aldus een hoofdartikel in The Buffalo News in 1993. ${ }^{23}$

In 1966 bleek uit een onderzoek met de veelzeggende titel Behind closed doors, dat de judicial nominating commissions van de verschillende partijen hun kandidaten selecteren op grond van een viertal overwegingen: 1) omdat de kandidaat wordt gesteund door een of meer partijleiders, 2) als beloning voor de inzet van de kandidaat voor zijn partij, 3) uit etnische overwegingen en 4) op grond van de juridische deskundigheid van de kandidaat. ${ }^{24}$ Er zijn geen aanwijzingen dat die situatie inmiddels is gewijzigd. Zo deelt rechter William Ritzholtz in 1980 laconiek aan een verslaggever mee: "I always wanted to be a judge. That's why I joined the Democratic club, carried (election) petitions, knocked on doors. I expected that my turn would come some day and when my turn would come I would be nominated by the party and I would run. I ran and I won. "s Het verhaal van Ritzholtz wordt bevestigd door het rapport van de Commission on Government Integrity, die in 1989 een onderzoek instelt naar corruptie in het New Yorkse ambtenarenapparaat (zie ook hierna). De leider van de Queens Democratic Party verklaart tegenover deze commissie:

"It's (de nominatie, MdW) based on friendships, relationships built up over the years. For example, there's a young man that goes to my Church - I've known him since he was a Little Leaguer, so now he's a lawyer, and he also belongs to my

22. D. Feerick en Cyrus Vance, Becoming a judge: Repon on the Failings of Judicial Elections in New York State, gepubliceerd in: Pace Law Review, 1989, p. 212

23. The Buffalo News, Consolidate state courts, select judges for merit Election system rewards party service, bosses, hoofdartikel, 29 juni 1993

24. E. Costikyan, Behind closed doors, 1966, p. 175-183

25. New York Daily News, 22 december 1980 
political club, and I sort of look to the day when I will be able to nominate him for a judgeship, you know. So that's a particular personal relationship. If you run out of friends, then you look to see other considerations. Obviously, the only requirements that I know of for being a judge is having been admitted for ten years, and I don't even know of any other objective test besides that. I don't know of any other official requirement. So if you have been admitted to practice and you are without any experience of a negative nature, I assume that on the face of it, that qualifies you to become a judge. ${ }^{m 6}$

\subsubsection{De nominatie}

Behalve het proces van aanwijzing (designation) door partijleiders, wordt ook de ratificatie van die keuze (nomination) zwaar bekritiseerd. "Supreme Court judges come from judicial nominating conventions, which are to local politics what professional wrestling is to sports", schrijft New York Newsday in $1991 .{ }^{27}$ Gedoeld wordt op de weinig subtiele wijze waarop dergelijke partijconventies van begin tot einde door de partijleiding gedirigeerd worden. De gedelegeerden voor de judicial nominating convention worden in de praktijk door de partijleiding geselecteerd en - zonder tegenkandidaten - gekozen tijdens partijbijeenkomsten (party-slates). Vlak voor de conventie worden de gedelegeerden van hun verkiezing op de hoogte gesteld, waardoor zij zonder enige voorkennis van de kandidaten de conventie bezoeken. Pas na de nominatie krijgen de gedelegeerden de gelegenheid om de kandidaten te ontmoeten. ${ }^{28}$ Vrijwel automatisch neemt de conventie de voordracht van de judicial nominating commission over. De onvrede onder Amerikaanse burgers met het 'ondemocratische' karakter van deze conventies is groot. Na de nominatie van vijf Democratische kandidaten voor een verkiezing van het Supreme Court in Brooklyn, schrijft Gail Collins:

"Yesterday, in a burst of efficiency seldom seen in any other area of local government, the Brooklyn judicial convention, nominated five Supreme Court judges in 14 minutes flat. (-) Yes! They were created last night, while you were sitting in front of the TV, waiting to hear whether Rebecca would have Sam's baby. I'll bet you had no idea. I'll bet in fact that if your child sidled up to you and said: "Mommy/Daddy, where do judges come from?" you would just stand there gaping, like a failed "Jeopardy" contestant. But each State Supreme Court job pays \$95,000 annually for a 14-year term. While you were watching "Cheers" last night, people, somebody was investing $\$ 1.33$ million of your money (plus

26. D. Feerick en Cyrus Vance, o.c. p. 215

27. Gail Collins, Where do judges come from?. New York Newsday, 20 september 1991

28. D. Feerick en Cyrus Vance, o.c. p. 210 
fringe benefits) in a recycled city councilman, in the attorney for the state racing commission, and in many variations on the theme of clubhouse lawyer. ${ }^{129}$

Behalve door de judicial nominating convention, kunnen kandidaten voor een verkiezing ook worden genomineerd door een voorverkiezing onder de partijleden (primary). Een primary vindt echter pas plaats indien er meer kandidaten dan vacante rechtersfuncties zijn. In de praktijk komen primaries slechts in een kwart van de gevallen voor, niet omdat er onvoldoende kandidaten zijn, maar omdat er slechts een beperkt aantal kandidaten wordt voorgedragen door de judicial nominating commission. ${ }^{30}$ De reden daarvoor is eenvoudig; door de kandidaatstelling in eigen huis te houden, kan de partijleiding haar invloed op de selectie van rechterlijke ambtenaren consolideren. Overigens is vór de Tweede Wereldoorlog wel gepoogd de overheersende invloed van partijbonzen te breken, door voor alle rechtersverkiezingen een primary voor te schrijven. Dit middel is echter erger dan de kwaal gebleken, omdat bij de direct primary iedere controle op de (kwaliteit van de) kandidaatstelling ontbrak (zie ook $\S$ $5.6)$.

\subsubsection{Campagnevoering}

In de Verenigde Staten voeren rechters, net als alle andere kandidaten voor verkiesbare publieke ambten, betrekkelijk 'agressieve' verkiezingscampagnes. Men moet daarbij allereerst denken aan foldermateriaal en affiches, waarmee de kandidaten, al dan niet gesteund door bar associations of maatschappelijke groeperingen, zichzelf aanprijzen als 'fair', 'energetic', 'innovative', 'hardworking', 'tough' of 'experienced'; maar ook wordt gebruik gemaakt van geluidswagens, telefoon-acties en commercials op de lokale radio- en televisiestations. Hoewel de verkiezingscampagnes van kandidaten voor rechterlijke functies qua vorm veel overeenkomsten met verkiezingen voor andere functies vertonen, verschillen zij aanzienlijk waar het de inhoud betreft. Met het oog op een just debate bij de campagnevoering, is een tweetal beroepscodes ingevoerd, te weten de Fair Campaign Code en de Code of Judicial Conduct. Canon 7 van de Code of Judicial Conduct luidt: "A Judge Should Refrain from Political Activity Inappropriate to His Judicial Office", en ziet grotendeels op de wijze van campagnevoering. De Fair Campaign Code verbiedt politieke spionage, het

29. Gail Collins, o.c.

30. Uit onderzuck van het Fund for Modern Courts naar de verkiezingen voor het New York Civil Cuurt blijkt dat de dominante (Democratische) partij in de periode 19801985, voor de nominatie van een kandidaat, slechts in 24 van de $85(28 \%)$ verkiezingen een primary vooraf lict gaan. In $72 \%$ van de gevallen vond dus geen primary plaats. Bron: Fund for modern courts, The illusion of democracy New York City Civil Court Elections 1980-1985, 1986 
dwarsbomen van tegenkandidaten en het vervalsen van opiniepeilingen. Klachten worden behandeld door de New York State Board of Elections. ${ }^{31}$ Rechterscampagnes worden voorts nauwlettend in de gaten gehouden door de New York State Bar Association's Committee on Judicial Election Monitoring.

Door de beroepscodes, waarvan de juridische status niet geheel duidelijk is, kunnen rechterskandidaten zich, anders dan kandidaten voor andere verkiesbare ambten, niet uitspreken over sociale en maatschappelijke vraagstukken. In het verleden is dit overigens toch regelmatig gebeurd. Campagnemateriaal bevatte bijvoorbeeld slogans als: 'The issue is rape!' of: 'I am violently opposed to abortion! ${ }^{\prime 32}$ Ook anderszins hebben verkiezingscampagnes in het verleden tot stuitende taferelen geleid. Als in 1983 vier zittende Democratische rechters in het Supreme Court in de Bronx hun herverkiezing ingaan, zendt de Liberale Partij een radiocommercial uit, waarin een huilende vrouw (een actrice) zich wanhopig afvraagt of de moordenaars van haar vader wel een eerlijk proces zullen krijgen, als de zittende rechters worden herkozen. Deze 'corrupt' en 'organized crime picking and fixing judges' spelen 'immers' onder een hoedje met de - eveneens corrupte - advocaat van de moordenaars. De Democratische Partij laat zich echter niet onbetuigd, en jaagt in een eigen commercial de zwarte en Spaanse bevolking van de Bronx de stuipen op het lijf, door in te spelen op haar angst voor de Liberale kandidaten, die als 'big downtown lawyers' van Wall Street worden beschreven. ${ }^{33}$

Problemen hebben zich, behalve ten aanzien van de inhoud van verkiezingscampagnes, vooral voorgedaan met betrekking tot het verwerven van campagnegelden. De Election Law bevat uitgebreide voorschriften voor het aantrekken van campagnegelden, dat tijdens zogenaamde fund raising diners gebeurt. ${ }^{34}$ Het doneren van geld voor verkiezingscampagnes, is van groot belang voor (potentiële) kandidaten voor een verkiesbare rechterspost, omdat het een van de manieren is om een staat van trouwe dienst bij hun partij op te bouwen. Voor zittende rechters is het van belang dat zij de nominatie voor hun herverkiezing op tijd weten veilig te stellen, iets waar men gewoonlijk de dag na de verkiezingen mee begint. Een rechter mag echter volgens $\$ 17-162$ Election Law geen contributies aan rechterskandidaten maken, tenzij - en daar biedt de wet een kleine maar niet onbelangrijke opening - hij zelf kandidaat (in spe) is voor een herverkiezing. Via schijnsollicitaties bij hun partij - waarbij zittende rechters solliciteren op een vooralsnog onbereikbare functie - omzeilen zij het verbod om fund-raising dinners van andere (rechters-)kandidaten bij te wonen.

31. $\$ 6201.3$ Election Law

32. Sara Mathias, Electing Justice: A Handbook of Judicial Election Reforms, 1990, p. 32

33. Bronx Judgeship Campaign Is Heated. New York Times, 2 november 1983

34. \$14 Election Law 
Een staaltje van verbluffende openhartigheid - dat waarschijnlijk nooit het daglicht had mogen zien - levert de sollicitatiebrief van een rechter op, die schrijft aan zijn partij: "Don't get angry, I know I'm not going to get the nomination, but I'm going to send out the letter to say I'm a candidate so that I can give money. " Desgevraagd noemt Sol Wachtler, de oud-president van het hoogste New Yorkse rechtscollege, het Court of Appeals, deze praktijken 'perverse' en "a distortion of the ethical canons - there are judges who haven't missed a political dinner any year during their term of office as judge. ${ }^{135}$

Geld is overigens een belangrijk probleem aan het worden bij verkiezingscampagnes, al valt dat in New York nog mee. ${ }^{36}$ De kosten van verkiezingscampagnes zijn in het afgelopen decennium in heel Amerika enorm opgelopen. Een extreem voorbeeld is de campagne voor een zetel in het Texas Supreme Court in 1990, die de drie kandidaten gezamenlijk zes miljoen dollar kostte. ${ }^{37}$ Het verbaast niet dat velen zich zorgen maken over deze ontwikkeling. "Judicial elections have entered a new era, one which I like to characterize as noisier, nastier and costlier than ever before", aldus de hoogleraar Roy Schotland. ${ }^{38}$ Het geld voor campagnes is grotendeels afkomstig van grote advocatenpraktijken. Zorgen maakt men zich daarom vooral over de verwachtingen die bij deze sponsors leven, en het effect dat contributies hebben op de onafhankelijkheid van de rechter. ${ }^{39}$ "Lawyers don't contribute to judicial campaigns for altruistic reasons. They do it to gain influence", aldus een New Yorkse advocaat. "Nobody really gives a damn if a judge gets a $\$ 100$ contribution from a law firm. But if a judge receives $\$ 10,000$ from one lawyer or a fund raiser brings in $\$ 50,000$, are we as confident that nothing is expected in return? What does'nt matter when it amounts to peanuts becomes very troublesome when big money is involved. " Omgekeerd kunnen advocaten, die weigeren bij te dragen aan een verkiezingscampagne voor een rechter, evenzeer in de problemen komen: "Given the system we have to work with, if you are asked

35. D. Feerick en Cyrus Vance, o.c. p. 219

36. In New York City zijn de kosten voor het New York City Civil Court in de periode 1980 - 1985 met $330 \%$ (van $\$ 12,150$ tot $\$ 40,001$ ) gestegen. Advocaten namen $20 \%$ tot $36 \%$ van de kosten voor hun rekening. Fund for modern courts, The illusion of democracy New York City Civil Cour Elections 1980-1985. 1986, p. 18-19

37. Voor dezelfde zetel werd in Pennsylvania in 1989 door de 'winnaar' 1,4 miljoen dollar uitgegeven, en in Ohio 2.7 miljoen dollar (1986). California houdt nog steeds het nationale record met 11.4 miljoen dollar (1986, drie kandidaten). Ook in de dunbevolkte staten wordt veel geld uitgegeven aan campagnevoering. Een zetel in het Supreme Court 'kost' in Montana gemiddeld $\$ 250,000$ (1986) en in Arkansas: $\$ 500,000$ (1990). Mark Hansen, The high cost of judging, American Bar Association Journal, 1991, p. 44

38. Mark Hansen, o.c. p. 45

39. Mark Hansen, o.c. p. 45 
to make a contribution to a judicial candidate's campaign, you may have a problem if you don't send a check and the canditate wins. ${ }^{40}$

\subsubsection{De verkiezing}

Het bovenstaande lijkt er op te wijzen dat in de Verenigde Staten het werkelijke probleem met rechtersverkiezingen niet gelegen is in de eigenlijke verkiezing, maar in het proces van nominatie dat daaraan vooraf gaat. Toch worden ook de verkiezingen zèlf in hoge mate gemanipuleerd door partijen. Het districtenstelsel in New York heeft ertoe geleid dat een tweetal grote politieke partijen (in New York City is dat de Democratische Partij, in de rest van de staat New York is dat de Republikeinse Partij) een nagenoeg absoluut electoraal overwicht hebben, waardoor bij (rechters)verkiezingen veelal geen sprake is van serieuze oppositie. In de periode 1980-1985 bijvoorbeeld, wonnen de Democraten 83 van de 85 verkiezingen voor het New York Civil Court. ${ }^{41}$ Niet voor niets zijn de gekozen rechters in het eerste district vrijwel allemaal lid van de Democratische Partij. ${ }^{42}$

Verkiezingen kunnen worden geclassificeerd aan de hand van drie kenmerken: uncontested elections, d.w.z. er is geen tegenkandidaat of de twee grote partijen nomineren dezelfde kandidaat, competitive elections, d.w.z. de uitkomst van de verkiezing, of van de primary, staat niet van tevoren vast, en noncompetitive elections, d.w.z. de verkiezing is contested, maar de uitkomst ligt al bij voorbaat vast, omdat in het betreffende district slechts een partij de dienst uitmaakt. ${ }^{43}$ Wanneer een tegenkandidaat ontbreekt, hebben de rivaliserende partijen of vooraf de buit onderling verdeeld (zie hierna bij de Brooklyn Deal; $\S 5.5 .5$ ), òf steunen beide partijen dezelfde kandidaat ('bi-partisan nomination' of 'cross-endorsement'). Dit laatste komt vooral bij herverkiezingen voor, wanneer men een hooggekwalificeerde kandidaat niet tot inzet van een verkiezingsstrijd wil maken. Het gevolg van de bovenbeschreven situatie is dat voor verkiezing van een rechter, de kiezer geen rol van betekenis speelt. Afhankelijk

40. Fund for modern courts, The illusion of democracy New York City Civil Court Elections 1980-1985. 1986, p. 19 Zie ook: Marion P. Ames, Judicial elections in New York Voler participation and campaign financing of state supreme court elections 1978, 1979 and 1980. Fund for Modern Courts. Inc 1982

41. Fund for modern courts, The illusion of democracy, o.c. p. ix

42. In 1962 werd geschat dat $93 \%$ van alle rechters in New York lid waren van de Democratische Partij. Dorothy W. Nelson, Variations on a theme-selection and tenure of judges, Southern California Law Review, vol. 36 (1962), p. 11

43. In de periode 1980-1985 waren slechts 4 van de 85 verkiezingen comperitive, 59 verkiezingen waren non-competitive en 22 verkiezingen waren uncontested. Fund for modern courts. The illusion of democracy, o.c. p. 14 
van het district, wordt de verkiezing van een rechter bepaald door de nominatie van de grootste partij. Om die reden wordt de verkiezing van een rechter wel gezien als een partijbenoeming.

\subsubsection{Invloed van verkiezingen op vertegenwoordiging van vrouwen en minderheden}

Het systeem van rechtersverkiezingen trekt, zo volgt uit het voorgaande, waar het de selectie van rechters betreft, in de praktijk een hoge wissel op het oordeelsvermogen van een zeer beperkt aantal personen (al zullen de fervente voorstanders van dit systeem niet nalaten te vermelden dat Benjamin Cardozo, een voormalig lid van het U.S. Supreme Court, zijn carrière ooit is begonnen als gekozen rechter in New York ${ }^{44}$ ). Het beperkte oordeelsvermogen van deze meestal niet-juristen klemt te meer nu zij de juridische deskundigheid van de kandidaten niet als belangrijkste criterium hanteren voor een nominatie. De verkiezing van rechters heeft er dan ook toe geleid dat - anders dan bij federale rechters - openlijk wordt getwijfeld aan de kwaliteiten van de leden van de rechterlijke macht in de deelstaten.$^{45}$ Om tegemoet te komen aan deze kritiek hebben sommige afdelingen van politieke partijen in het verleden vrijwillig zogenaamde screening commissions ingesteld, die de kandidaten aan een spervuur van vragen onderwerpen. Zo beschikken de New York County Democratic Committee en de Manhattan New Democratic Coalition over een dergelijke commissie, die over de drie "most highly qualified candidates" voor elke vacature rapporteren. Toch moeten ook deze gremia het in de media ontgelden, omdat zij zich in de praktijk hebben ontwikkeld tot special interest groups, waarin vertegenwoordigers van vrouwen, etnische minderheden, joden, gehandicapten en organisaties voor homosexuele mannen en lesbische vrouwen, op drammerige wijze elk hun eigen kandidaten naar voren schuiven. ${ }^{46}$ De belangstelling van deze belangengroeperingen voor rechtersverkiezingen kan overigens daaruit worden verklaard, dat in de Verenigde Staten - anders dan in ons land - de (onder)vertegenwoordiging van vrouwen en minderheden in de rechterlijke macht een hot issue is (zie §5.8).

44. Zie bijvoorbeeld bij Harold Laski. The technique of judicial appointment, in: Studies in Law and politics, 1932, p. 165. Laski was overigens zelf geen voorstander van gekozen rechters: zie hierna bij merit selection.

45. Bron: interview met Maurice Rosenberg, 16 april 1992. New York

46. Fund for modern courts, The illusion of democracy New York Ciry Civil Court Elections 1980-1985, 1986, p. 26. Zie ook: New York Times, Party Panels Get Criticism From Judges, 16 april 1987 en New York Newsday, Goetz Case Judge Fights for Nomination, 15 september 1989 


\subsubsection{Belang bij rechtersverkiezingen}

Het mag niet verbazen dat, gezien de bovenstaande kritiek op rechtersverkiezingen, bij herhaling is gepoogd om het verkiezingsstelsel voor rechters af te schaffen en te vervangen door een alternatief benoemingsstelsel. Alle pogingen in het verleden om via grondwetswijziging te komen tot de afschaffing van rechtersverkiezingen zijn - met uitzondering van die voor het Court of Appeals in 1977 - steeds tevergeefs geweest (zie hierna). Daardoor rijst de vraag waarom politieke partijen zo gebrand zijn op dergelijke verkiezingen. Een mogelijke verklaring zou kunnen zijn, dat bij veel politici het vermoeden bestaat dat gekozen rechters 'liberaler' zijn dan benoemde, terwijl men verwacht dat gekozen rechters van een bepaalde politieke partij, ertoe neigen, bijvoorbeeld in huur- of vakbondszaken, de 'underdog' in het gelijk te stellen. Nagel (University of Illinois) concludeert in 1973 bijvoorbeeld, op basis van empirisch onderzoek, dat gekozen rechters inderdaad liberaler zijn in uitspraken over economische zaken dan hun benoemde collega's, en minder liberaal waar het de uitleg van grondrechten betreft. Het verschil tussen gekozen Democratische en Republikeinse rechters is echter verwaarloosbaar:

"The explanation for the greater liberalism of elected judges possibly lies in the fact that elected judges may be more likely to be lawyers who have risen up from the political ranks and who have characteristics more like those of the general population or at least the more liberal elements in the general population. Appointed judges, on the other hand, may be more likely to be lawyers who formerly worked for top conservative law firms from which they were appointed to judgeships. " Over de uitleg van grondrechten zegt Nagel: "This lack of civil libertarianism may be due to majoritarian public pressures to play down the rights of radical speakers and minority racial groups. ${ }^{\mathrm{W} 7}$

Een meer aanwijsbaar belang van partijleiders bij rechtersverkiezingen, is dat zij daarmee een greep krijgen op de Surrogate. Deze rechter wijst de advocaten aan, die zijn belast met het beheer van nalatenschappen waarmee soms exorbitant hoge honoraria gemoeid zijn. Van rechters wordt, na hun verkiezing, verwacht dat zij hun nominatie aan de partij 'terugbetalen' door het toewijzen

47. Stuart S. Nagel, Comparing Elected and Appointed Judicial Systems, 1973, p. 9-12 Uit jurisprudentic-onderzoek van Evan Haynes (University of California) uit 1944 blijkt. evenwel het tegenovergestelde. Over de benoemde federale rechters zegt Haynes: "The judges sitting on the federal bench during the last half-century or so have indispulably a better record, from the liberal point of view, than that of their elected brethren in the state courts; and the great majority of the federal judges of this period were appointed by conservative Presidents, and confirmed by conservative Senates. " Evan Haynes. The selection and tenure of judges, 1944, p. 185. 
van lucratieve zaken aan advocaten van hun eigen politieke partij. ${ }^{48}$ Dit geldt ook voor de bevoegdheid van rechters om law clercs aan te stellen; ook hier wordt terugbetaling verwacht in de vorm van het aanstellen van een bevriende partijgenoot. Omdat partijen er veel aan gelegen is om hun invloed op rechtersfuncties te consolideren, dragen zij vaak zittende rechters uit lagere rechtbanken voor een nominatie voor. Dit heeft enerzijds als voordeel dat de kandidaten al eens een screening gepasseerd zijn, maar bovendien ontstaat op die manier een extra vacature, die ook weer opgevuld moet worden. Zeker wanneer een partij in een gebied een groot electoraal overwicht heeft, zijn dergelijke promoties (z.g. twofers: two judgeships from one) erg lucratief.

\subsection{Rechtersbenoemingen in de staat New York}

De staat New York kent - zoals gezegd - naast gekozen, ook benoemde rechters. De benoemende autoriteiten zijn de governor of the State of New York (verder te noemen: gouverneur) en in de stad New York de mayor of the City of New York (verder te noemen: burgemeester). De gouverneur wordt terzijde gestaan door de Commission on Judicial Nomination en de Judicial Screening Commissions, de burgemeester door de Mayor's Committee. De gouverneur en de burgemeester benoemen uit de voordracht van de adviescolleges. De adviescolleges werden in 1962 - aanvankelijk op vrijwillige basis - ingesteld door gouverneur Nelson Rockefeller en burgemeester Richard F. Wagner, als een wapen tegen "boss collusion, selling judgeships and future corruption."

De New York State Constitution voorziet ten behoeve van de benoeming van de leden van het hoogste rechtscollege, te weten de chief judge en de associate judges van het Court of Appeals, sinds 1977 in de Commission on Judicial Nomination ${ }^{50}$, die tot taak heeft "[t]o consider and evaluate the qualifications of candidates for appointment". De leden van de Commission on Judicial Nomination mogen geen gekozen ambt of een functie in een politieke partij bekleden. ${ }^{51}$

48. Zie bijvoorbeeld Leonard Levitt, Courting favors Faithfuls eam right to wear robe, New York Newsday, 16 juni 1992: "The (Democratic, MdW) party also controls the selection of the Bronx surrogate, who is in charge of probating all wills in the borough and appointing lawyers to look after the interests of those lacking proper representation. With few exceptions, those jobs, and the lucrative fees that come with them, are reserved for party-connected attorneys."

49. Journal of the American Judicature Society. New selection plans announced for New York judges, 1962, p. 288 e.v.

50. Art. VI, Section 2, New York State Constitution. De Commission on Judicial Nomination is nader geregeld in $\S 3$-a 62 , eerste lid, Judiciary Law

51. § 3-a 63, sub 1, Judiciary Law 


\begin{tabular}{|c|c|c|c|c|c|}
\hline & taak & $\begin{array}{l}\text { aantal } \\
\text { leden }\end{array}$ & $\begin{array}{l}\text { wijze van } \\
\text { samenstelling }\end{array}$ & $\begin{array}{l}\text { zittings- } \\
\text { termijn }\end{array}$ & status \\
\hline $\begin{array}{l}\text { Commission } \\
\text { on Judicial } \\
\text { Nomination }\end{array}$ & $\begin{array}{l}\text { voordracht aan de } \\
\text { gouverneur van de } \\
\text { chief judge en de } \\
\text { associate judges } \\
\text { van het Court of } \\
\text { Appeals }\end{array}$ & 12 & $\begin{array}{l}4 \text { leden gekozen } \\
\text { door de gouverneur, } \\
4 \text { door chief judge } \\
\text { van het Court of } \\
\text { Appeais, } 2 \text { door de } \\
\text { Assembly, } 2 \text { door de } \\
\text { Senaat }\end{array}$ & 4 jaar & $\begin{array}{l}\text { Art. VI } \\
\text { Section } 2 \\
\text { New York } \\
\text { State Con- } \\
\text { stitution }\end{array}$ \\
\hline $\begin{array}{l}\text { Judicial } \\
\text { Screening } \\
\text { Committees }\end{array}$ & $\begin{array}{l}\text { voordracht van } \\
\text { kandidaten die } \\
\text { door gouverneur } \\
\text { worden benoemd }\end{array}$ & 9 & $\begin{array}{l}4 \text { leden gekozen } \\
\text { door de gouverneur, } \\
2 \text { door chief judge } \\
\text { van het Cour of } \\
\text { Appeals, } 1 \text { door het } \\
\text { Appellate Division } \\
\text { van het betreffende } \\
\text { departement, } 2 \text { door } \\
\text { de Speaker van de } \\
\text { Assembly, de presi- } \\
\text { dent van de Senaat } \\
\text { en de minderheids- } \\
\text { leiders uit beide } \\
\text { huizen }\end{array}$ & $\cdots$ & $\begin{array}{l}\text { Mario M. } \\
\text { Cuomo, } \\
\text { Executive } \\
\text { Order no. } \\
9,7 \text { maart } \\
1983\end{array}$ \\
\hline $\begin{array}{l}\text { Mayor's } \\
\text { Committee }\end{array}$ & $\begin{array}{l}\text { voordracht van } \\
\text { kandidaten die } \\
\text { dooi burgemeester } \\
\text { worden benoemd }\end{array}$ & 27 & $\begin{array}{l}13 \text { leden gekozen } \\
\text { door de burgemees- } \\
\text { ter, } 2 \text { door de } \\
\text { dekanen van } 2 \\
\text { rechtenfaculteiten, } \\
\text { de overige leden } \\
\text { door de presidenten } \\
\text { van de } \\
\text { Appellate Divisions }\end{array}$ & 2 jarar & $\begin{array}{l}\text { Edward I. } \\
\text { Koch, } \\
\text { Executive } \\
\text { Order no. } \\
10,11 \\
\text { april } 1978\end{array}$ \\
\hline
\end{tabular}

De commissie is breed samengesteld om te voorkomen dat één partij de cominissie zou domineren en om het publieke vertrouwen in haar onafhankelijkheid 'n onpartijdigheid te vergroten. $:$ Indien in het Court of Appeals een pladis openvalt, maakt de commissie binnen 120 dagen een voordracht van drie (bij een vaciture van associate judge) respectievelijk zeven kandidaten (bij een vacature van chief judge) op, die wordt aangeboden aan de gouverneur."

52. Peter J. Galie. The New York State Constitution, 1991, p. 120

53. § 3-a-63, tweede lid sub a en b, Judiciary Law 
Alvorens de kandidaten voor een gesprek uit te nodigen dienen zij een uitgebreide vragenlijst te beantwoorden. De gouverneur benoemt uit de voordracht, die pas na 15 dagen wordt bekendgemaakt, waarna de Senaat binnen 30 dagen de benoeming kan bekrachtigen. De commissie gaat er prat op dat zij in het verleden kandidaten van zeer diverse pluimage, zoals zittende rechters, advocaten, hoogleraren en personen uit de overheidssfeer heeft genomineerd. ${ }^{\$ 4}$ Aan de bekrachtiging van de benoeming gaat een openbare hoorzitting vooraf door een onderzoekscommissie van de Senaat.

Ten behoeve van de benoeming van alle andere door hem te benoemen rechters, stelde gouverneur Mario M. Cuomo in 1983 drie zogenaamde Judicial Screuning Committees in; de State Screening Commission voor het Court of Claims, de Departmental Screening Committees voor de vier Appellate Divisions departments, en de County Screening Committees voor de County Courts, de Surrogate Courts en de Family Courts. Deze screening committees hebben - anders dan de Commission on Judicial Nomination - geen grondwettelijke of wettelijke status, maar berusten op een Executive Order van de gouverneur. ${ }^{55}$

Voor de benoemingen door de burgemeester van de leden van het Family Court en van de rechters van de Civil en Criminal Courts, werd in 1962 de Mayor's Committee ingesteld ${ }^{56}$, die in haar huidige vorm sinds 1978 bestaat. ${ }^{57}$ De Mayor's Committee heeft net als de Judicial Screening Committees geen grondwettelijke of wettelijke status. De leden van de Mayor's Committee worden geselecteerd met het oog op "broad community representation"..$^{98}$ De taak van de Mayor's Committee omvat de recrutering en selectie van kandidaten voor een eerste of herbenoeming en de nominatie van kandidaten aan de burgemeester. ${ }^{59}$ Kandidaten dienen een uitgebreide vragenlijst in te vullen en op te

54. Persbericht Commission on Judicial Nomination, 9 maart 1992

55. Mario M. Cuomo, Executive Order No. 9. 1983. Al eerder -in 1975- had de vorige. gouverneur Hugh L. Carey dergelijke judicial nominating commintees ingesteld.

56. Met de instelling van de Moryor's comminte in 1962 loste Wagner zijn verkiezingsbelofte uit 1961 in. Zic voor een exposé over de totstandkoming van de Mayor's commiltee: Maurice Rosenberg. The qualities of justices - are they strainable? Texas Law Review vol. 44 (1966), p. 1074-1075. Er is overigens veel kritiek geweest op de integriteit en het functioneren van de Mayor's Committee onder Wagner, Lindsay en Beame. Zie: hierover: The League of Women Voters of New York State. The Judicial Maze, 1986 p. $22-24$

57. Edward 1. Koch, Executive Order, No. 10, 11 april 1978

58. "The membership shall include men and women, lawers and non-lawyers, and members of minority and other groups, who are qualified to perform the functions of the Committee." Edward I. Koch, Executive Order, No. 10, 11 april 1978, $\$ 5$

59. Edward I. Koch, Executive Order. No. 10, 11 april $1978 \S 2$ 
sturen. Daarna houdt de Mayor's Committee gesprekken met de kandidaten. De burgemeester benoemt binnen 90 dagen uit de drie voorgedragen kandidaten. ${ }^{60}$ De vorige burgemeester van New York, David N. Dinkins, breidde de Mayor's Committee in 1990 uit met de Corporation Counsel, die tot taak heeft de Mayor's Committee en de burgemeester nader te adviseren met betrekking tot de geschiktheid van kandidaten. ${ }^{61}$ Op de Mayor's Committee lijkt meer kritiek te bestaan dan op de Commission on Judicial Nomination. Zij zou zich te weinig aantrekken van het lot van met name de Spaans sprekende minderheid in New York. "We voted for the mayor but we're not getting anything in return", aldus een advocaat, die er in 1993 op wijst dat van de 41 benoemingen die Dinkins sinds zijn aantreden gemaakt heeft, het slechts in drie gevallen hispanics betreft. $^{62}$

\subsubsection{De Association of the Bar of the City of New York}

Een belangrijke, zij het niet-wettelijk geregelde, taak in het selectieproces van kandidaten voor rechterlijke functies, zowel bij verkiezingen als bij benoemingen, wordt vervuld door de bar associations (juristenverenigingen). Thans telt alleen de staat New York al 140 van dergelijke verenigingen, waarbij vooral het sterk verzuilde karakter van deze organisaties, zowel geografisch als naar etniciteit, opvalt. De oprichting van de bar associations in de Verenigde Staten geschiedde tegen het einde van de negentiende eeuw, als een reactie op de misstanden bij rechtersverkiezingen (zie hierna). De bar associations houden interviews met de kandidaten en hanteren hun eigen vragenlijsten. Met name aan de screenings van de oudste en grootste vereniging, de Association of the Bar of the City of New York (ook wel: New York City Bar Association) wordt zeer veel gewicht toegekend. Praktisch betekent een negatief oordeel van deze vereniging over een kandidaat dat deze niet in aanmerking komt voor een benoeming door de gouverneur of de burgemeester.

De New York City Bar Association werd in 1870 opgericht en telt 19.000 leden. De vereniging kent een Judiciary Committee, bestaande uit 27 leden, die worden benoemd voor een periode van drie jaar. Indien zich een vacature voordoet wordt door de Judiciary Committee een sub-commissie gevormd, samengesteld uit een lid van de Judiciary Committee, een lid van de betreffende (Civil, Criminal, Federal) Court Committee van de vereniging, en een lid van de County Bar Association waar de vacature zich voordoet. De sub-commissie

60. Edward 1. Koch, Executive Order, No. 10, 11 april $1978 \$ 4$

61. David N. Dinkins, Executive Order, No. 18, 19 september 1990

62. Michael H. Cottman, Dinkins Defense Aides react to Latino attack over judges, New York Newsday, 28 maar 1993 
heeft de beschikking over het dossier van de kandidaat. Ook hier dient de kandidaat weer een vragenlijst in te vullen en te verschijnen voor de subcommissie. De sub-commissie toetst de kandidaat op "integrity, intellectual ability, knowledge of the law, industriousness, and judicial demeanor and temperament". ${ }^{63}$ De kwalificaties lopen van 'approved as highly qualified' tot 'not qualified'. ${ }^{64}$ Daarna worden de betrokken personen, de kandidaat, het rechterlijk college, de burgemeester of de gouverneur schriftelijk van de beslissing op de hoogte gesteld. Tegen de beslissing is 'beroep' mogelijk op het Executive Committee van de vereniging. De werkzaamheden van de Judiciary Committee zijn strikt vertrouwelijk, tenzij het een kandidaat voor een verkiesbaar ambt betreft. In dat geval wordt de beslissing gepubliceerd. ${ }^{65}$ Op de activiteiten en de macht van de City Bar Association wordt overigens ook wel kritiek geleverd. Advocaten zouden een te groot machtsmiddel in handen hebben om rechters die hen niet zinnen te weren. Een enkele maal overspeelt de vereniging haar hand; in 1990 deed zij een poging om een absoluut vetorecht te verkrijgen over bepaalde rechtersbenoemingen. Een dergelijke bevoegdheidsoverdracht aan een privaatrechtelijke organisatie werd echter als ongerijmd beschouwd. ${ }^{66}$ De vaak indringende bemoeienissen van de City Bar leiden soms tot irritaties bij oudere rechters, die zich kandideren voor een herverkiezing. ${ }^{67}$

63. Association of the Bar of the City of New York, General Procedures and the Evaluation Process of Candidates, 1988; Guidelines used by the Committee on the Judician: for evaluating candidates for judicial office, 1992

64. In 1991 werd ongeveer $15 \%$ van de kandidaten "not qualified" bevonden. Bron: interview met Maureen Moralla (New York City Bar Association), 8 mei 1992, New York

65. De beoordelingen van de City Bar worden gepubliceerd in de New York Law Joumal, en -voorzover het een positief oordeel betreft- in het campagne-materiaal van de betrokken kandidaat. De City Bar Association motiveert haar oordeel niet. De kritiek op beoordelingen van de Bar Association is dat de screenings pas platsvinden na de. partijnominatie. Problemen doen zich voor indien verschillende bar associations tegenstrijdige aanbevelingen doen, of indien beide kandidaten worden afgekeurd. Het effect van deze beoordelingen is onduidelijk. In de periode 1980-1985 bleken in New York 10 kandidaten voor het Civil en Criminal Courts die "approved" waren, gekozen te worden, evenals 3 kandidaten dic "not approved" waren; 7 goedgekeurde kandidaten verloren echter. Bron: The illusion of democracy, o.c. p. 26-27: zie echter ook: John A. Stookey en George Watson (Arizona State University), Meril retention elections: can the bar infuence voters?. Judicature The Journal of the American Judicature Society, 1980, p. 234-241. Zij concluderen dat dergelijke evaluaties wel degelijk het sterngedrag van kiezers beinvloeden.

66. Dispute Boils About Judging the Judges, New York Newsday, 3 januari 1990

67. Zo bijvoorbeeld de negenenzestigjarige chief judge van het Brooklyn Supreme Court, Leonard E. Yoswein in 1989, die het vragenformulier weigerde te ondertekenen, en sprak van "an arrogant request". Yoswein werd overigens -zij het ietwat zuinig- 


\subsubsection{Het Fund for Modern Courts}

Een andere, invloedrijke organisatie die zich bezighoudt met de New Yorkse rechterlijke organisatie, is het Fund for Modern Courts (ook wel: Modern Courts). Deze watchdog-organisatie, die is samengesteld uit leken, werd opgericht in 1955. De achtergrond voor de oprichting van Modern Courts moet, net als die van de New York City Bar Association, worden gezocht in de onvrede van burgers met de rechtspleging in het algemeen, en met de gebrekkige selectie van rechters in het bijzonder. Modern Courts stelt zich ten doel de verbetering van de selectie van rechters en het opheffen van inefficiënte en publieksonvriendelijke werkwijzen bij de rechtbanken. ${ }^{68}$ Modern Courts verricht sociologisch onderzoek ${ }^{69}$, steunt scholingsprojecten en beschikt over z.g. court monitoring groups. Court monitoring geschiedt door vrijwilligers, die steekproefgewijs de verschillende gerechten bezoeken, en die hun bevindingen aan Modern Courts rapporteren:

"The monitors praised the judges for their performance on the bench, but criticized them for taking the bench late, arriving on average at 10 a.m., and for taking long lunch hours" (Queens County). "They also recommended that representation of minorities on juries be improved" (Rensselaer County), "the monitors found that several of the judges they observed treated court proceedings as though they were "private conversations" between attorneys, litigants and the judge. They urged the judges to make proceedings audible to the public as a safeguard that the rights of the accused are not violated. They also urged the town governments to provide adequate court facilities." (Ulster County). ${ }^{70}$

Helemaal zonder invloed lijkt dit court monitoring overigens niet te zijn. Zo schrijft Sol Wachtler, de oud-president van het Court of Appeals, het hoogste rechtscollege van New York, naar aanleiding van een rapportage, in een brief

"approved" bevonden door de Association. B'lyn Judge Spars With Bar Group, New York Newsday, 17 december 1989. Soms (in 1991: 10\%) weigert een kandidaat voor de commissic te verschijnen; bijvoorbeeld als hij bij voorbaat weet dat hij -bij verkiezingen- niet kan winnen. In dat geval is hij automatisch 'not qualified'. Bron, interview met Maureen Moralla, o.c.

68. Maureen Moralla, o.c.

69. Zie: Judicial elections in New York voter participation and campaign financing of state supreme court elections, 1982: The success of women and minorities in achieving judicial office, the selection process, $1985 \mathrm{en}$ : The illusion of democracy New York Cin civil court elections 1980-1985, 1986

70. Fund for Modern Courts, Minutes, 24 maar 1992 
aan het Fund for Modern Courts: "I will see to it that the judges are instructed with respect to the necessity for more public and audible proceedings. ${ }^{.71}$

\subsection{Rechtersverkiezingen: historische achtergronden}

"fOJur Constitution is not a creation, but a growth", zo relativeert Charles $\mathrm{Z}$. Lincoln, in 1906 de constitutionele geschiedenis van de staat New York:

"The sources of our constitutional history are in old-world institutions. The principal and most familiar features of our Constitutions, so far as they are fundamental in character, are, in the main. institutions of the Netherlands or of England, transplanted to the new world, and modified to adapt them to changes incident to colonial conditions. The powers, customs, and traditions of organized society, developing through centuries of fluctuating experience, have been crystallized in our written Constitutions. ${ }^{\text {} 72}$

Elders is Lincoln - die de constitutionele geschiedenis van New York toch het liefst met de Engelse Magna Charta in 1230 en niet met de komst van de WestIndische Compagnie in 1621 laat beginnen $^{73}$ - echter veel minder vleiend over de Hollandse invloed op het New Yorkse staatsrecht. De Hollandse gouverneur beschikte volgens Lincoln over ongehoord grote bevoegdheden, die de Hollanders zelf thuis nooit gepikt zouden hebben ${ }^{74}$, en een beetje zuur merkt hij op: "It did not seem practicable to transplant to America all the political rights and institutions which were enjoyed at home." De 'primary object' van de Compagnie was tenslotte 'commercial rather than political ${ }^{75}$, maar ach, wat kon men wok verwachten, "Dutchmen were Dutchmen still (-) after they crossed the ocean and began laying the foundations of a new society in a new world. "76

De koloniale geschiedenis van de staat New York is onderverdeeld in drie perioden: de Hollandse, die begint met de ontdekking van Manhattan door Henry Hudson in 1609. en duurt tot de Engelse verovering in 1664, de periode

71. Brief van 17 maart 1992. Zie over court moniloring: Fund for Modern Courts, Court monitoring manual en Court Monitoring Project Final Report. 1976

72. Charles Z. Lincoln. The constitutional history of New York, 1906, vol. 1, p. 3

73. Lincoln, o.c. p. 62

74. "It is a curious and noteworthy fact that this colonial officer should have been clothed with such irresponsible authority by a govermment which would not have tolerated it for a moment in its own country. "Lincoln, o.c. p. 12

75. Lincoln, p. 16

76. Lincoln, o.c. vol. 1, p. 4 Ook anderen achten de betekenis van de Hollandse bezetling voor de ontwikkeling van het Amerikaanse constitutionele recht gering. Zie bijvoorbeeld: Julius Goebel, The Courts and the law in colonial New York, History of the state of New York, p. 5-6 
onder het bewind van de Hertog van York van 1664 tot 1685 (inclusief een interval van 1673 tot 1674 waarin de kolonie tijdelijk terugvalt aan de Hollanders), gevolgd door een periode die begint met de troonsbestijging van de Hertog van York in 1685, en voortduurt tot de Amerikaanse revolutie van 1775. In 1776 wordt de Declaration of Independence door de toen nog 13 staten getekend, en in 1777 krijgt de staat New York zijn eerste grondwet. Een tweede, derde en vierde grondwet van de staat New York volgen respectievelijk in 1821,1846 en 1894.

De eerste rechters in New York - toen nog New Netherlands - werden, in naam van de Staten-Generaal van de Verenigde Nederlanden, benoemd bij proclamatie door de Hollandse gouverneur. Ook na de Hollandse periode, eindigend in 1664, worden rechters nog benoemd door een gouverneur, maar nu na raadpleging van en goedkeuring door een Raad van Benoeming. ${ }^{77}$ Problemen rijzen als na de Engelse revolutie van 1688 een Assemblee met wetgevende bevoegdheden wordt gevestigd. Als in 1743 onenigheid ontstaat tussen de gouverneur en de Assemblee over het benoemingsbeleid, bepaalt de Assemblee dat het salaris van iedere rechter afzonderlijk bij wet moet worden vastgesteld. Feitelijk is het daardoor onmogelijk voor de gouverneur om rechters te benoemen tegen de zin van de Assemblee. Het verhaal wil dat een chief justice die door gouverneur Colden tegen de zin van de Assemblee werd benoemd, jaren na zijn benoeming, stierf (maar waarschijnlijk niet van de honger) zonder ooit een cent van de Assemblee te hebben gekregen. ${ }^{78}$

Als de staat New York, na de ratificatie van de Declaration of Independence op 9 juli 1776, overgaat tot de vorming van een regering, gaan als een reactie op de benoemingsperikelen tussen de Engelse gouverneur en de Assemblee, stemmen op om het volk invloed te geven bij de selectie van alle ambtsdragers. Toch wordt dit denkbeeld tegen het einde van de achttiende eeuw nog verworpen, als zijnde 'too democratic', en wordt op voorstel van John Jay - we zullen hem later nog tegenkomen - in New York de beruchte Council of Appointment opgericht, die alle ambtenaren inclusief de leden van de rechterlijke macht benoemt. ${ }^{79}$ Met deze constructie hoopt men zowel de macht van de gouver-

77. Charter of Liberties and Privileges, 1683: Art. 2: "THAT The Exercise of the Chiefe Magistracy and Administracion of the Govermment over the said province shall bee in the said Governour assisted by a Councell with those advice and Consent or with at leasi four of them he is to rule and Governe the same according to the Lawes thereof."

78. Glenn R. Winters, Selection of judges in New York and in other States, 1944, p. 6

79. Art. XXIII New York State Constitution 1777: "IOfficers, how appointed.1- That officers other than those who, by this Constitution, are directed to be otheruise appointed, shall be appointed in the manner following, to wit: The assembly shall, once in every year, openly nominate and appoint one of the senators from each great district, 
neur, als die van de wetgever te beteugelen. ${ }^{\infty}$ Het experiment mislukt echter, omdat het nu de Council of Appointment is die, met voorbijgaan aan de gouverneur, de benoemingsbevoegdheid feitelijk aan zich trekt, en slechts haar welgezinde rechters benoemt. Al in 1787 schrijft Alexander Hamilton over de Council of Appointment:

"The council of appointment consists of from three to five persons, of whom the governor is always one. This small body, shut up in a private apartment, impenetrable to the public cye, proceed to the execution of the trust committed to them. It is known that the governor claims the right of nomination upon the strength of some ambiguous expressions in the Constitution; but it is not known to what extent, or in what manner he exercises it; nor upon what occasions he is contradicted or opposed. (-) And while an unbounded field for cabal and intrigue lies open, all idea of responsibility is lost. ${ }^{\mathrm{ml}}$

Overigens huilde Hamilton hier dikke krokodilletranen, want het waren de Federalisten zelf geweest die de Council of Appointment als eersten hadden gecorrumpeerd. ${ }^{82}$ Als gevolg van zijn slechte reputatie, wordt de Council of Appointment tenslotte door de Constitutional Convention van $1821 \mathrm{met}$ algemene stemmen afgeschaft. In de periode 1821-1846 worden alle rechters, na raadpleging van en goedkeuring door de Senaat, benoemd. ${ }^{83}$

which senarors shall form a council for the appointment of the said officers, of which the governor for the time being, or the lieutenant governor, or the president of the senase (when they shall respectively administer the government), shall be president, and have a cassing voice, but no other vote, and, with the advice and consent of the said council, shall appoint all of the said officers; and that a majority of the said council be a quorum; and further, The said senators shall not be eligible to the said council for two years successively."

80. J.M. Gitterman, The council of appointment, in: Political Science Quarterly, 1892. p. 90

81. Federalist Papers, no. 77

82. Gitterman, o.c. p. 95

83. Art. IV $\$ 7$. New York State Constitution 1821 (voorzover relevant): "The governor shall nominate, by message, in writing, and with the consent of the senate, shall appoint, all judicial officers, except justices of the peace" De justices of the peace worden sinds de grondwetswijziging van 1826 gekozen door de bevolking van de verschillende steden. 
Schema 3: Benoeming en verkiezing van rechters in New York, vanaf de kolonisatie in 1609 tot en met de Grondwet van 1846

\begin{tabular}{|c|c|}
\hline periode & benoeming/verkiezing \\
\hline $\begin{array}{l}\text { Hollandse } \\
\text { periode } \\
(1609-1664)\end{array}$ & benoeming van alle rechters door gouverneur \\
\hline $\begin{array}{l}\text { Engelse } \\
\text { periode } \\
(1664-1775)\end{array}$ & $\begin{array}{l}\text { benoeming van alle rechters door gouverneur, na raadpleging en goedkeuring } \\
\text { van een Councell (art. } 2 \text { Charter of Liberties and Privileges ( } 1683 \text { ) }\end{array}$ \\
\hline $\begin{array}{l}\text { Grondwet } \\
1777\end{array}$ & $\begin{array}{l}\text { benoeming van alle rechters door de Council of Appointment (an. } 23 \mathrm{New} \\
\text { York State Constitution 1777) }\end{array}$ \\
\hline $\begin{array}{l}\text { Grondwel } \\
1821\end{array}$ & $\begin{array}{l}\text { henoeming yan alle rechters door gouverneur, na raadpleging en goedkeutring } \\
\text { van de Senaat (art. IV } \$ 7 \text { New York State Constitution 1821); verkiezing van } \\
\text { justices of the peace (art. VI } \$ 7 \text { New York State Constitution 1826) }\end{array}$ \\
\hline $\begin{array}{l}\text { Grondwet } \\
1846\end{array}$ & $\begin{array}{l}\text { verkiezing van de rechters van het Court of Appeals, het Supreme Court, de } \\
\text { County Courts, en van de surrogates en justices of the peace (art. VI } \$ 12-17 \\
\text { New York State Constitution 1846) }\end{array}$ \\
\hline
\end{tabular}

\subsubsection{Invoering verkiczingsstelsel in New York 1846}

De Amerikaanse literatuur is erg vaag over de grondwetswijziging die heeft geleid tot de invoering van rechtersverkiezingen in $1846 . "$ Lincoln wijst in het algemeen op de stagnatie in deze dagen van de rechtspleging in New York, als gevolg van de groeiende commerciële activiteiten ${ }^{85}$, maar efficiency zal zeker de laatste reden zijn geweest voor de invoering van een verkiezing van rechters. Een andere, vagere verkJaring, is die van de 'wave of democracy' die in de jaren dertig en veertig over het land spoelt. Hampden Dougherty bijvoorbeeld schrijft in 1911:

"The democratic movement that swept over America within the succeeding twenty years (sinds 1826, MdW), and were felt in Europe also, produced a creed that declared frequent popular election the solvent for all political ills. The incumbent of every office should be elected by the people, and to preserve responsibility to

84. Zie bijvoorbeeld: J. Hampden Dougherty, Legal and judicial history of New York, 1983 en: Joseph Story, Commentaries on the constitution of the United States, 1858

85. Charles Z. Lincoln, The constitutional history of New York, 1906, vol. II, p. 140 
the electors, the tenure of office should be short. The new cult attacked the judiciary. ${ }^{n 86}$

Pas in 1966 werpt Russell D. Niles licht op deze 'democratische ontwikkelingen'. ${ }^{87} \mathrm{Hij}$ beschrijft hoe in de Nieuwe Wereld, althans in de staat New York, tot ver in de negentiende eeuw, een feodaal leenstelsel heeft bestaan, in een tijd dat dergelijke stelsels op het Europese continent alweer verdwenen zijn. Nazaten van grootgrondbezitters als Van Rensselaer en Livingston verpachten in deze dagen grote stukken land onder haast middeleeuwse condities aan Europese kolonisten. Zij weten hun economische positie onder andere te consolideren door een sterke greep op het staatsbestuur, en op de rechterlijke macht. Aanvankelijk (tot 1821) is sprake van een censuskiesrecht in New York, dat slechts de z.g. frecholders stemrecht verleent ${ }^{88}$. Na 1821 wordt het kiesrecht weliswaar uitgebreid voor alle blanke, mannelijke belastingplichtigen ${ }^{89}$,

86. Ziv in gelijke zin: Albert $\mathrm{S}$. Bard, Some observations on the primary and election laws of the slate of New York with special reference to the nomination and election of judges, 1914. p. 1. Zie verder Landis New York State Bar association, proceedings, 1933, p. 215, en Glenn R. Winters, Selection of Judges in New York and in other States, 1944

87. Russell D. Niles, The Popular Election of Judges in Historical Perspective, in: The Record of the Association of the Bar of the City of New York, vol. 21 (1966). p. 523-538

88. Art. VIII New York Constitution 1777 (Qualifications of voters): "That every male inhabiant of full age, who shall have personally resided within one of the counties of this state for six months immediately preceding the day of election, shall, at such election, be entitled to vote for representatives of the said count in assembly; if, during the lime aforesaid, he shall have heen a freeholder, possessing a freehold of the value of twenty pounds, within the said county, or have rented a tenement therein of the yearly value of forty shillings, and been rated and actually paid taxes to this state: Provided always, That every person who is now a freeman of the city of Albany, or who was made a freeman of the city of New York, on or before the fourteenth day of October, in the year of our Lard one thousand seven hundred and seventy-five, and shall be actually and usually resident in the said cities respectivety, shall be entilled to vat for represeniatives in assembly within his said place of residence."

89. New York Constimtion 1821 Article II Section 1. (voorzover relevant): "Every male citizen of the age of twenty-one years, who shall have been an inhabiant of this State one year preceding any election, and for the last six months a resident of the town or county where he may offer his vote; and shall have, wilhin the year next preceding the election, paid a lax to the State or county, assessed upon his real or personal property; or shall by law be exempled from taxation; or being armed and equipped according to law, shall have performed within that year military duty in consequence of being a freman in any city, town, or village in this State; and also, every male citizen of the age of twenty-one years, who shall have been, for three years next preceding such election, an inhabitant of this State; and for the last year a resident in the town or county where he may offer his vote; and shall have been, within the last year (-)." 
maar enkel de freeholders kunnen tot 1846 benoemd worden in de Senaat ${ }^{50}$, en juist voor de rechtersbenoemingen door de gouverneur is de goedkeuring van dit orgaan vereist ${ }^{91}$. Zodoende blijft tot 1846 de selectie van rechters feitelijk in handen van een aantal rijke families. Deze families hebben groot belang bij de rechtersbenoemingen, omdat juist de rechters moeten oordelen in de pachtgeschillen tussen de freeholders en de pachters.

Rond 1820 begint het verzet tegen het feodale systeem (Anti-Rent movement) onder leiding van Dr. Smith Boughton (bijgenaamd: Big Thunder) te groeien. In 1845 escaleert de situatie als 10.000 gewapende boeren de rijke families de toegang tot hun eigen land beletten. Aan dit oproer (de zogenaamde 'Rent Wars') komt een einde als Dr. Boughton wordt gearresteerd, omdat hij, vermomd als Indiaan een sheriff, zou hebben beroofd. Boughton wordt zonder borg gevangengezet, iets wat als ongehoord wordt beschouwd. De Anti-Renters zagen, als we Niles mogen geloven, het proces dat volgt tegen Boughton als een farce: "The Anti-Renters and their political sympathisers were convinced that the court was packed in favor of the patrician establishment, and that Big Thunder had very little chance of escaping the wrath of the political and judicial officers who were beholden to the establishment. ${ }^{22}$ Tijdens het proces lopen de emoties zo hoog op, dat Boughton's advocaat, Ambrose Jordan, op de vuist gaat met de openbare aanklager, John Van Buren; beiden worden daarop - wegens contempt of court - een nacht vastgezet. Voor Boughton maakt het echter allemaal weinig meer uit; de jury oordeelt hem schuldig en Boughton wordt tot levenslange gevangenisstraf veroordeeld.

Het proces van Dr. Bougthon zal uiteindelijk leiden tot de verkiezing van rechters (al had het ook kunnen leiden tot de afschaffing van het jury-systeem). Merkwaardig genoeg leidt het proces niet tot een burgeroorlog, maar tot een politieke machtsgreep, via de weg van het kiesrecht, door de Anti-Renters. Pogingen om via wetgeving een einde te maken aan het feodale stelsel hebben mondjesmaat succes. Van groot belang is echter de invloed die van de AntiRent Movement uitgaat op de grondwetsherziening van 1846. Met de uitbreiding van het kiesrecht bij de grondwetswijziging van 1821 - zie hiervoor - was

90. New York Constitution 1821: Article I Section 2. "The senate shall consist of thirty-two members. The senators shall be chosen for four years, and shall be freeholders. The assembly shall consist of one hundred and twenty-eight members, who shall be annually elected."

91. New York Constitution 1821, Article IV Section 7: "The governor shall nominate, by message, in writing, and with the consent of the senate shall appoint, all judicial officers, except justices of the peace."

92. Niles, o.c. p. 525. Zie over deze periode ook: Edward P. Cheyney, The antirent movement and the constitution of 1846, in: History of the state of New York, 1934 
de overwegende invloed van de freeholders reeds een eerste, gevoelige klap toegebracht. De conventie van 1846 is daardoor de eerste waarvan de gedelegeerden op basis van min of meer algemeen kiesrecht gekozen werden, en die niet wordt gedomineerd door de land-aristocratie. Een van de belangrijkste onderwerpen op de conventie is de organisatie van de rechterlijke macht, en de selectie van rechters. Niles:

"The political consequences of the rent wars, culminating in the trial of Dr. Boughton, were dramatic-both for New York State and the United States. Reform already was in the air. The Jacksonian demands for equality, elimination of privilege and election of all officers were widespread in the states. A desire to change the personnel of the courts, and to simplify the law itself, were part of the battle cry-since the mystery of the law created and perpetuated a judicial elite. (-) The specific grievance concerned the judges themselves, since the tenant farmers needed a sympathetic judiciary to void the oppressive leases. But, more generally, the delegates were caught up in the spirit of the day. All privileges, and all appointive systems which took control from the people, were to be condemned. Even qualifications for admission to the bar were attacked as creating a "privileged class. ${ }^{193}$

De conventie kon kort zijn over de verkiezing van publieke ambtenaren, waaronder rechters. Het overtuigende argument schijnt te zijn gekomen van Swackhamer: "Abolish the appointing power, and you will have no more scrambling to get on nominating committees. You will elect good men to office, and politicians by trade will not exhaust their patriotism in serving on committees without pay. " De nieuwe grondwet voorziet in een aantal bepalingen dat de verkiezing van sommige ambtenaren, waaronder rechters, dwingend voorschrijft. ${ }^{94}$ John van Buren, de openbare aanklager waarmee Ambrose Jordan tijdens het proces van Boughton op de vuist ging, raakt hij de eerste verkiezing na de conventie zijn positie kwijt aan Jordan. Hoe het met Boughton afliep vermeldt Niles niet. ${ }^{95}$

\subsubsection{Rechtersverkiezingen in federaal perspectief}

Het voorbeeld van de rechtersverkiezingen in New York vindt in de eerste helft van de vorige eeuw grote navolging, ook al is New York niet de eerste (maar wel de meest toonaangevende) staat die een verkiezing voor rechters invoert. ${ }^{\text {wh }}$ In 1856 worden de rechters in 15 van de - toen nog - 29 staten gekozen.

93. Niles, o.c. p. $525-526$

94. Zie artt. VI $\$ 12-17$ New York State Constitution 1846

95. Niles, o.c. p. 527

96. Al in 1832 had de staat Mississippi een verkiezingsstelsel voor rechters ingevoerd 
Sommige staten echter, zoals Massachusetts, New Jersey en Connecticut, zullen nooit tot een verkiezing van rechters overgaan. Gezien de kennelijke populariteit van rechtersverkiezingen, rijst de vraag, of deze verkiezingen - zoals in New York het geval lijkt - uitsluitend voortspruiten uit een emotionele oprisping, of dat daar wellicht ook meer theoretische gronden voor hebben bestaan. De staatsinrichtingen van de Verenigde Nederlanden, en van het Engelse Koninkrijk boden in elk geval geen voorbeeld. Opmerkelijk is echter wel, dat de conceptie van rechtersverkiezingen zich opvallend goed verhoudt met ideeën over machtenscheiding en machtsevenwicht, zoals deze aan het einde van de achttiende eeuw door bijvoorbeeld De Montesquieu worden gepropageerd. In De l'Esprit des Lois, het werk van De Montesquieu dat grote invloed heeft gehad op o.a. het denken over de inrichting van de Amerikaanse rechterlijke organisatie, pleit deze immers expliciet voor een vorm van periodieke verkiezingen van rechters, zoals deze plaatsvond in de Atheense democratie, en wijst hij carrière-rechtspraak af:

"La puissance de juger ne doit pas être donnée à un sénat permanent, mais exercée par des personnes tirées du corps du peuple, dans certains temps de l'année, de la manière prescrite par la loi., pour former un tribunal qui ne dure qu'autant que le nécessité le requiert. De cette façon, la puissance de juger, si terrible parmi les hommes, n'étant attachée ni à un certain état, ni à une certaine profession, devient pour ainsi dire, invisible et nulle. Onn'a point continuellement des juges devant les yeux; et l'on craint la magistrature, et non pas les magistrats. ${ }^{n-9}$

Men kan zich echter afvragen hoe breed deze gedachten werden gedeeld, en waarom een kleine zestig jaar eerder, bij de totstandkoming van de Amerikaanse Grondwet (in de periode 1787-1789) voor de selectie van federale rechters geen verkiezingsstelsel werd ingevoerd. Voorzover mij bekend laten Amerikaanse schrijvers deze vragen liggen; in het algemeen trouwens behandelt de literatuur de discussie over de totstandkoming van het selectieproces van de federale rechters en de rechters in de deelstaten als scherp gescheiden zaken (als zij al aandacht aan het probleem in de deelstaten besteedt). Deze lacune is opmerkelijk, omdat beide selectiemethoden, waar het de totstandkoming betreft, in tijd dicht bij elkaar liggen, terwijl beide constituties elkaar onmiskenbaar moeten hebben beïnvloed. John Jay, de eerste chief justice van het U.S. Supreme Court, was zowel betrokken bij de totstandkoming van de eerste New Yorkse grondwet (hij deed in 1777 het voorstel voor de Council of Appointment), als bij de totstandkoming van de eerste grondwet van de Verenigde Staten en de ratificatie daarvan in de staat New York in 1787. De slechte ervaringen met de Council of Appointment in de periode 1777-1787 in New York 
hebben in 1789 als argument gediend om federale rechters te benoemen door een persoon (de president), terwijl omgekeerd de Council of Appointment in New York in 1821 wordt afgeschaft en - naar federaal model - een persoon (de gouverneur) bevoegd wordt gemaakt voor de benoeming van rechters.

De keuze van de staat New York in 1846 voor een stelsel van rechtersverkiezingen, lijkt echter - gezien de debatten over de selectie van de federale rechters - betrekkelijk 'exotisch' te zijn geweest, en ook de overeenkomst met de theorieën van De Montesquieu berust waarschijnlijk op toeval. Uit de aantekeningen van James Madison blijkt namelijk dat er bij de totstandkoming van de Amerikaanse Grondwet in 1787 tussen de gedelegeerden weliswaar onenigheid bestond over de wijze waarop de leden van het Supreme Court benoemd moesten worden, maar dat een verkiezing van rechters nooit serieus is overwogen. Veeleer werd gesproken over het toekennen van de benoemingsbevoegdheid aan een groot wetgevend lichaam, dan wel aan een enkele persoon. De Conventie besloot uiteindelijk tot een compromis, waarin rechters, na raadpleging van en goedkeuring door de Senaat, door de president worden benoemd. ${ }^{98}$ Ook bij de ratificatie van de Amerikaanse Grondwet in 1789 blijkt dat de gedachte aan rechtersverkiezingen zowel door de voor- als door de tegenstanders van de federatie wordt afgewezen. In de Federalist papers schrijft Alexander Hamilton:

"Periodical appointments, however regulated, or by whomsoever made, would, in some way or other, be fatal to their necessary independence. If the power of making them was committed either to the executive or legislature there would be danger of an improper complaisance to the branch which possessed it; if both, there would be an unwillingness to hazard the displeusure of either; if to the people, or to persons chosen by them for the special purpose, there would be too great a disposition to consult popularity to justify a reliance that nothing would be consulted but the Constitution and the laws." ${ }^{n 9}$

De Anti-Federalisten schijnen het -althans op dit punt- met Hamilton eens te zijn geweest. Hoewel we bij een Anti-Federalist als 'Brutus' een sterk pleidoni vinden voor een democratische controle (popular control) van de rechterlijke macht, was ook hij geen voorstander van rechtersverkiezingen; "it would be improper that the judicial should be elective, because their business requires that they should possess a degree of law knowledge, which is aquired only by

98. Notes of debates in the federal convention of 1787 reported by James Madison, With an introduction by Adrienne Koch, 1984, p. 68 Art. II Section 2 U.S. Constitution (voorzover hier relevant) luidt thans: "The presiden (-) shall nominale, and by and with the Advice and Consent of the Senate, shall appoint (-) Judges of thi' supreme Court (-)."

99. Federalist Papers, no. 77 
a regular education, and besides it is fit that they should be placed, in a certain degree in an independent situation, that they may maintain firmness and steadiness in their decisions. ${ }^{n 100}$

\subsubsection{Problemen met rechtersverkiezingen: invloed van Tammany Hall}

De Amerikaanse literatuur is het oneens over de ervaringen met de verkiezing van rechters in de eerste twintig jaren die volgen op de grondwetswijziging van 1846. Landis en Winters beschrijven deze periode als 'either satisfactorily or unsatisfactorily"101, maar Francis Lieber meent in 1859 toch dat "The most attentive observation, extensive perusal of public journals, consultation of lawyers and statesmen, have not brought to my knowledge a single opinion in favor of an elective judiciary. ${ }^{" 10}$ En ook D.B. Eaton herinnert zich in 1873 duidelijk de 'dissatisfactions, scandals and a revulsion of popular feeling. ${ }^{103}$ Hoe het ook zij, de omslag in de publieke opinie ten aanzien van rechtersverkiezingen volgt in de jaren zeventig van de vorige eeuw, als de Democratische partij en de Society of Tammany (samen beter bekend onder de naam: 'Tammany Hall ${ }^{104}$ ) onder leiderschap van 'Boss' William Marcy Tweed, een overheersende rol in het stadsbestuur van New York krijgt. Men ontkomt moeilijk

100. Bij: Herbert J. Storing, The Anti-Federalist, 1985 p. $187-188$

101. J. M. Landis, Selection of judges in New York, New York State Bar Association p. 217 en 247. Winters, o.c. p. 10

102. Francis Lieber, On civil liberty and self-govemment, 1859, p. 227-229. Zie in gelijke zin: Rüttimann, Das Nordamerikanische Bundessfaatsrecht verglichen mit den polititischen Einrichtungen der Schweiz, 1e deel. 1867, p. 337 e.v.

103. D.B. Eaton, Should judges be elected? Or the Experiment of an Elective Judiciary in New York, pamphlet, 1873, p. 1

104. De naam 'Tammany Hall' verwijst naar de Indiaanse wijsgeer en weldoener, Chief Tammany (of: Tammanend) uit Delaware. In 1789 werd de Society of Tammany, een vereniging met sociale doeleinden opgericht door William Mooney. In haar begindagen vertegenwoordigt Tammany Hall de oppositie van de middenklasse tegen de "aristocratische" denkbeelden van de Federale Partij. Tammany zette zich in voor de rechten van blanke, bezitloze mannelijke burgers. Na 1805 otstaat tussen de Society of Tammany en de Democratische Parij een personele unie. Tammany Hall wordt gezien als het schoolvoorbeeld van 'bossism' en 'patronage'; de organisatiecultuur werd gedomineerd door partijbonzen, en leunde sterk op de gedachte van solidariteit cussen de leden. Aan de enorme macht van deze beweging in de $19 \mathrm{e}$ en in het begin van de 20 e eeuw. komt een einde in 1932, als Tammany weigert de New Deal van president Roosevelt te steunen: de invloed en status van Tammany worden daama gereduceerd tot die van de county orgamization die zij feitclijk was. Door toedoen van de New Yorkse burgemeesters Fiorello H. La Guardia (1933-45) en John V. Lindsay (1966-73) is de invloed van Tammany verder afgenomen. Men leze uitgebreider bij: Myers. The history of Tammany Hall, en bij Alexander Flick, History of the state of New York: postwar problems and political reformers the rise of Tammany Hall. 
aan de indruk, dat de discussie in New York over de verkiezing van rechters, zoals die sindsdien - tot op de dag van vandaag - voortduurt, sterk is beïnvloed door de lange reeks politieke schandalen waartoe het New Yorkse overheidsapparaat aanleiding heeft gegeven. Bij Flick lezen we over deze periode, die nog steeds als een van de meest corrupte in de geschiedenis van de staat New York te boek staat:

"The history of politics in New York State and City during the post-Civil War period, though instructive, is not altogether pleasant reading. That the strife of parties, considering the depth of feeling aroused by the late hostilities, should be bitter is easily understandable. But it was also marked in the Empire State, as practically everywhere in the Union, by a corruption seldom if ever equaled in the Annals of our Republic. ${ }^{\text {mos }}$

Het machtscentrum binnen Tammany Hall wordt in de jaren zeventig van de vorige eeuw, behalve door Tweed, gevormd door John T. Hoffman en A. Oakey Hall, die met de hulp van Tweed respectievelijk gouverneur en burgemeester van de staat, respectievelijk de stad New York worden, en door Richard B. Connolly en Peter B. Sweeney. De belangrijkste bron van inkomsten van de Tweed Ring bestond uit het zogenaamde 'contract padding'; de rekeningen van de stad New York werden opgehoogd met fictieve posten, en vervolgens goedgekeurd door de beheerder van de schatkist, Connolly. $\mathrm{Na}$ uitbetaling aan de crediteuren verdwijnt het surplus in de zakken van de Tweed Ring. Geschat wordt dat in deze periode 54 miljoen dollar donr de Tweed Ring aan de schatkist wordt onttrokken, en - zo gaat althans het verhaal - deels onder de armen werd verdeeld. Het mag niet verbazen dat het New Yorkse overheidsapparaat in de volksmond al snel de bijnaam (koosnaam?) The Forty Thieves verwerft. De invloed van de Tweed Ring strekt zich ook uit over de henoemingen in de New Yorkse rechterlijke macht. Dit is mogelijk doordat partijleiders de nominatie van rechters door hun partij in hun greep hebben. Een van de beruchtste 'Tweed-rechters' schijnt George G. Barnard te zijn geweest, die het met de hulp van de Tweed Ring tot lid van het Supreme Court van New York had gebracht. Over deze Barnard wordt later geschreven: "Few public records are worse than that of this Yale graduate (-) the decisions of this venal jurist gave necessary aid to the Tweed Ring." 100

De misstanden waartoe de organisatie van het New Yorkse stadsbestuur, en in haar kielzog de organisatie van de rechterlijke macht, hebben geleid, trckken niet alleen nationale, maar ook internationale belangstelling. In $\S 3.8 .1 .2$ is er reeds op gewezen dat Nederlandse auteurs, als B.C.J. Loder en

105. Flick, o.c. p. 139

106. Flick, o.c. p. 148 
G.J.Th. Beelaerts van Blokland, in de jaren zeventig van de vorige eeuw aan de New Yorkse rechtersverkiezingen argumenten ontlenen tegen de idee van volkssouvereiniteit of de voordrachtsbevoegdheid van de Tweede Kamer voor vacatures in de Hoge Raad. Overigens bestond in ons land niet de verwachting dat de slechte ervaringen met deze verkiezingen de Amerikanen tot 'inkeer' zou brengen. Met vooruitziende blik schrijft Beelaerts van Blokland in 1869:

"Toch mag het twijfelachtig genoemd worden, of men, ook al doen de bezwaren zich gevoelen, het noodlottig beginsel spoedig zal laten varen. Immers de veranderde positie van den rechter is geen geisoleerd feit; zij is veeleer een logisch gevolg van de meer en meer in de Unie veldwinnende neiging, om de democratie zoo zuiver mogelijk toe te passen. Men streeft er naar, alle machthebbers in den Staat rechtstreeks van het volk afhankelijk te maken, en elke instelling te wijzigen die de verwezenlijking van den volkswensch des oogenbliks zoude kunnen belemmeren. " 107

\subsubsection{Oprichting van de Association of the Bar of the City of New York}

In 1870, op een moment dat het aanzien van de rechterlijke macht 'the lowest $e b b^{\prime}$ heeft bereikt, wordt in New York de Association of the Bar of the City of New York opgericht. De oprichting van deze vereniging, thans een van de meest prestigieuze en invloedrijke jur istenverenigingen in de Verenigde Staten, is een rechtstreeks gevolg geweest van de onvrede die op dat moment onder New Yorkse juristen leeft met de politieke selectie van de leden van de rechterlijke macht. In 1871 neemt de vereniging een resolutie aan, waarin zij overweegt: "In the present disastrous condition of the City, it is the duty of every citizen and of every Association to do all in their power to rescue the City from the hands of those who have fattened on her spoils. "108 In de periode 18711881 wordt een viertal commissies ingesteld dat tot taak krijgt het verkiezingsstelsel nader te onderzoeken en aanbevelingen te doen. ${ }^{109}$ De Special Committee on Nominations for Judicial Offices in the City of New York) concludeert in 1881 "that the feeling has gathered strength that all public offices are rather rewards for political activity than places of trust to be filled by those best quali-

107. G.J.Th. Beelaerts van Blokland, De bevoegdheid van den amerikaanschen rechter iof ongrondwettigverklaring eener wet, in: Nieuwe Bijdragen voor Rechtsgeleerdheid en Wetgeving, 1869 , p. 41-43

108. Extract of Meeting of Bar Association, held October 10, 187I

109. Zie de Committee of Fifteen, de Committee of Fourteen en de Committee of Thirteen Bron: Association of the Bar of the City of New York, verslag Meeting of October 17, 1871 en: Extract from Minutes of Bar Association, Meeting held September 24, 1872 
fied. ${ }^{\prime 110}$ Kennelijk - zo merkt de commissie enigszins smalend op - is het meest ideale profiel van een rechter, dat van een "honest gentleman, against whom no 'charges' can be justly made." Ik herinner hier aan het eerder genoemde citaat uit het rapport van de Commission on Government Integrity uit 1989, waarin een van de leiders van de Queens Democratic Party zijn motieven voor een nominatie aldus toelicht: "IIt's based on friendships, relationships built up over the years. (-) So if you have been admitted to practice and you are without any experience of a negative nature, I assume that on the face of it, that qualifies you to become a judge. "111 Van de kant van de onverschillige burgerij verwachtte de commissie van 1881 bitter weinig - "What impression can a busy, hard-worked society of lawyers hope to make on a apathetic public? What influence can we hope to exercise in a realm where King Caucus has for years ruled supreme?" - en jaloers werpt zij een blik op het Franse carrière-stelsel, waarin rechters pas na een opleiding voor het leven benoemd worden. ${ }^{12}$ Toch zijn haar eigen suggesties - waarschijnlijk om haalbaarheidsredenen - veel minder ambitieus. Voorgesteld wordt om de rechterssalarissen te verhogen, teneinde corruptie tegen te gaan, en om de ambtstermijn voor rechters te verlengen tot 14 jaar. In de tussentijd dient de New York City Bar Association zich actief met de kwaliteit van de selectie bezig te houden, onder andere door zelf kandidaten te nomineren:

"Any active participation in a canvass for judicial office, would be distasteful to us, but it has been necessary in the past and it may be necessary in the future. (-) We value our building and our library, and the social advantages of our Association. We spend money gladly for both. But it is more important than these to the Bar, that Judges of experience, learning, integrity and discrimination, should decide upon our clients' causes. "113

De pogingen van de New York City Bar Association in de jaren tussen 1881 en $1898 \mathrm{om}$ meer invloed op partijnominaties te krijgen sorteren echter weinig effect. Hoewel deze pogingen niet altijd 'unsuccessful ones' zijn, beperken zij zich steeds tot een toetsing achteraf (nl. tot die gevallen waarin reeds een nominatie heeft plaatsgevonden), terwijl haar invloed niet verder reikt dan die

110. Association of the Bar of the City of New York. Report 1881, p. 3-4

111. John D. Feerick en Cyrus Vance, o.c. p. 215

112. "In France, the judiciary is almost a separate profession. A man is educated for the position of Judge of the lowest court, just as his brother goes 10 a military school. Each enters at the lowest grade, and may hope to be promoted to the highest. "Association of the Bar of the Ciry of New York Report 1881. p. 4

113. Association of the Bar of the City of New York Report 188I, p. 9 
kandidaten die 'manifestly unfit' zijn voor het rechtersambt. ${ }^{\text {It }}$ In 1898 wordt daarom opnieuw een commissie ingesteld, met vooraanstaande leden als Henry W. Taft en Elihu Root, die onderzoekt op welke wijze de vereniging haar invloed op het nominatieproces kan vergroten. Deze commissie bepleit een toetsing van rechterskandidaten voorafgaand aan de verkiezing (vergelijk de huidige evaluations of endorsements), maar wijst overigens de gedachte van een door de balie te nomineren onafhankelijke kandidaat af. In haar bevindingen klinkt een zekere moedeloosheid door, waar zij enerzijds erkent dat in de bestaande situatie "the selection of candidates for judicial offices ultimately rests in the hands of the principal political parties", maar toch meent dat,

"except under most unusual circumstances, such as do not exist at this moment, an attempt to subvert this order of things (-) would be neither practical nor prudent. (-) Neither does your Committee believe that it would be wise or expedient to attempt to influence the nomination by either political party of particular persons selected, either directly or through the Committee on Judicial Nominations, by this Association. ${ }^{n 15}$

\subsubsection{Onregelmatigheden bij rechtersverkiezingen}

Ilet is mij niet hekend of de ideeën van de Special Committee van 1898 konden rekenell op een ruime steun van de leden van de Association of the Bar of the (ity of New York. Een feit is in elk geval dat de vereniging twee maanden na het rapport van de Special Committee toch overging tot steun van een onathankelijke kandidaat. Dit gebeurt naar aanleiding van - alweer - een politiek schandaal, dat nationaal de aandacht trekt. In 1898 verhindert de toenmalige Tammany-leider Richard Croker, de nominatie van de zittende rechter Joseph P. Daly. Daly die tijdens zijn ambtstermijn heeft geweigerd een Tammany-lid tot lawclerk te benoemen, moet daarvan nu wegens "lack of subservience" de zure vruchten plukken. Brutaal verklaart Croker: "Justice Daly was elected by Tammany Hall after he was discovered by Tammany Hall and Tammany Hall had a right to expect proper consideration at his hands. "116 De Commission on Judicial Nominations van de New York City Bar Association, veroordeelt het optreden van de Democratische Partij, en stuurt haar een petitie ondertekend door 3500 juristen. Daarna wordt een Committee of Hundred Citizens gevormd,

114. Association of the Bar of the City of New York, Report of the special comminte appointed under resolution of january 11th, 1898, to consider measures for increasing the influence of the association in the matter of judicial nominations, 1898, p. 3-4

115. Association of the Bar of the City of New York Report 1898, p. 6

110. Landis, o.c. p. 222 Als de Mazel Commintee in 1899 een onderzoek instelt naar de 'handel' in vacante rechtersfuncties, blijkt dat kandidaten bereid zijn $\$ 10,000$ voor een nominatie te betalen. 
die - na een massabijeenkomst in Carnegie Hall - Daly nomineert als onafhankelijke kandidaat. De vereniging overweegt daarbij:

"That the refusal to nominate Judge Daly is a direct attack upon the independence of the bench, because he was rejected for the reason that he would not permit his official action as a judge to be controlled by the personal direction of a political manager, and because the nominating convention obeyed the direction of that political manager, against the claims of faithful service and proved fitness, against a great public demand and against the plain public interest. That to resent this attack, and to defeat it, is an imperative duty on the part of every member of the bar and every citizen who desires that his rights shall be protected by an independent, courageous and honest judiciary. "117

Daly lijdt echter - zoals gezien het electorale overwicht van Tammany Hall eigenlijk wel te verwachten valt - een zware nederlaag tegen de democratische kandidaat, maar de Association legt dit verlies anders uit: "the refusal to renominate Justice Daly upon the grounds stated for that refusal, attracted universal attention in the city and through out the State and was urged by others in the press and in political meetings as a ground for condemning the party whose representatives were responsible for it". ${ }^{118} \mathrm{Na} 1898$ signaleert de pers met enige regelmaat soortgelijke kwesties als die met Daly. De publieke verontwaardiging over de selectie van rechters in New York bereikt in de jaren dertig van deze eeuw echter een - let wel - voorlopig hoogtepunt met de zogenaamde 'Brooklyn-Deal'. Als in 1931 het Supreme Court in het district Brooklyn wegens de hoge werkdruk met zes leden moet worden uitgebreid, kunnen de vertegenwoordigers van de Democratische en de Republikeinse partij, die moeten oordelen over het wetsvoorstel, het niet eens worden over de 'sleutelverdeling' van de nieuwe posten in het Supreme Court. Uiteindelijk sluiten beide partijen de rijen, en wordt afgesproken om het aantal rechters niet op zes maar op twaalf te brengen; de Republikeinen 'krijgen' er 5 en de Democraten 7. In goed overleg selecteren en nomineren beide partijen de twaalf kandidaten (overigens zonder dat men zich erg druk maakte over de

117. Association of the Bar of the Ciry of New York Report, 1898, p. 93

118. Association of the Bar of the City of New York Report, p. 94. Zie hierover ook: Glenn R. Winters, o.c. p. 12. Soortgelijke schandalen als die bij Daly herhalen zich in de opvolgende jaren met enige regelmaat. Zo weigert Tammany bijvoorbeeld de herbenoeming van rechters als Newburger (1919). Merrell (1923) en Cohalan. Zie hierover Henry W. Taft, voordracht voor New York State Bar Association, in: Association of the Bar of the City of New York Repont 1933, p. 56-57 
kwaliteit van de kandidaten), die, zonder enige tegenstand, in de daaropvolgende verkiezing worden gekozen. ${ }^{119}$

De nominatie van bevriende rechters door partijleiders is echter nooit een doel np zichzelf geweest, maar dient steeds een 'hoger' partijbelang. Het rapport van de ber(uemde onderzoekscommissie onder leiding van rechter Samuel Seabury, signaleert in 1932 hoe met name in de lagere rechtscolleges (de toenmalige Magistrute's Courts) gritfiers, advocaten en zedenpolitie steekpenningen voor zeden- en gokdelicten onderling verdelen. Seabury:

"Whatever the motives of the magistrates may have been in sitting back and permitting this outrageous spectacle to be enacted before them doy in day out, the effect of it is not in doubt; it permitted the lawyers, the fixers, and the bondsmen who operated in these courts to reap a rich harvest. What I am criticizing is the supineness of the magistrates in the face of palpably perjurious testimony by police officers. ${ }^{120}$

In de jaren veertig van deze eeuw wordt (opnieuw) duidelijk dat sommige leden van de New Yorkse rechterlijke macht connecties met de maffia onderhouden. Nadat de Democratische Conventie op 23 augustus 1943, Thomas A. Aurelio op voorspraak van Frank Costello - een gangster met veel invloed binnen Tammany Hall - nomineert voor het Supreme Court, onderschept de officier van justitie, Frank S. Hogan, een dag later geheel bij toeval, een telefoongesprek tussen Aurelio en Costello. In het telefoongesprek bedankt Aurelio Costello voor zijn inspanningen:

-Costello: "Congratulations. It went over perfect. When I tell you something is in the bag you can rest assured."

-Aurelio: "It was perfect (-) right now I want to assure you of my loyalty for all you have done. It's undying."

-Costello: "I know. I'll see you soon."

Als Aurelio weigert zijn kandidatuur voor het Supreme Court in te trekken, matakt Hogan het telefoongesprek openbaar, en ontketent daarmee een nationale rel, waarbij - voor de zoveelste maal - van verschillende kanten een pleidooi klinkt voor een andere selectie van rechters. Gouverneur Dewey van New York dringt in 1944 in zijn jaarlijkse bondschap voor de wetgever, aan op de in-

119. City Club of New York, Selection of Judges, 1932. p. 1; de City Club stelt voor in het vervolg de nominaties te laten opmaken door de gouvemeur. Zie over de Brooklyn Deal ook: Henry W. Taft, o.c. p. 57-58

120. Bij: Herber Mitgang. The man who rode the tiger The life and times of Judge Samuel Seabury, 1963, p. 189 
voering van het Missouri Court Plan (zie hierna) ${ }^{121}$, en in No more Aurelios, schrijft de New York Herald Tribune in een hoofdartikel:

"It is not compatible with either the usefulness or the dignity of the Bench that its members engage in public contests for their posts; their function is not a party function, nor even, in the narrow sense, a political function. (-) It was not alone the specific choice of Aurelio which showed that system to be at fault; the whole atmosphere of secret vote trading, of catering to special groups and interested individuals demonstrates that the bi-partisan system of judiciary nominations has failed. Centralized and open responsibility is the answer-judges must be appointed by an elected executive. "122

Tot op de dag van vandaag wordt de discussie over rechtersverkiezingen gedomineerd door de onregelmatigheden die daarbij plaatsvinden, al wordt tegenwoordig een deel van de kritiek, door de instelling van de verschillende screening- en selectie-commissies (zie hiervoor), ondervangen. Toch zijn ook de jaren tachtig, als New York opnieuw te maken krijgt met een golf van politieke schandalen, door Cyrus R. Vance - lid van de New York Commission on Government Integrity - omschreven als "the worst since the days of Tammany Hall", en "the most scandal-ridden in the history of the State of New York. " De corruptie laat ook nu weer de rechterlijke macht niet ongemoeid, en menige rechter stapt - als hij tenminste niet in de gevangenis verdwijnt of zelfmoord pleegt $^{123}$ - in een sfeer van verdachtmakingen op. De Commission on Government Integrity, die in 1987 door gouverneur Cuomo wordt ingesteld, zoekt (en vindt) de oorzaak voor de problemen met corrupte rechters vooral in het selectiesysteem; haar conclusies ten aanzien van rechtersverkiezingen zijn dan ook vernietigend:

"Under current law, most of our judges are chosen by elections that are almost totally controlled by politicalleaders, a system which clashes with the fundamental

121. Judicial Selection Improvement Studied in New York, in: Judicature The Journal of the American Judicalure Society, 1944, p. 155 Tot vecl meer dan een uitgcbreide studie heeft het voorstel van Dewey overigens niet geleid, zie: New York Selection Campaign Resumed, in: Judicature The Journal of the American Judicature Society, 1945, p. 154 Ook het Citizens Committee on the Courts (waarin voorvechters van merit selection als Samuel Seabury, Edward R. Finch, Allen T. Klots, Frank S. Hogan, George Z. Medalie en Whitney Seymour) stelde in 1946 de invoering van merit selection voor. Zie: Citizens Commintee on the Courts, Inc, Oulline of Program, 1946

122. No more Aurelios, Herald Tribune, 2 november 1943. De New York Times stelt voor een benoeming door de gouverneur met een tweederde goedkeuring door de Senaat, en ook de World-Telegram ziet in de Aurelio zaak "the need of better methods of selecting, scrutinizing and appraising candidates for the bench."

123. Zie bijvoorbeeld: Alex Michelini, Ex-judge: 9 months in jail, New York. Daily News, 11 mei 1988, Top Court on scandal, New York Newsday, 28 april 1989 
objective of an independent and nonpartisan judiciary. By encouraging political favoritism and rewarding party loyalty, judicial elections enhance political leaders' influence over judges, discourage' lawyers without political connections from seeking judgeships, and undermine public confidence in the integrity of our judicial system. (...) We must stop perpetuating the myth that judicial elections give us a democratic choice. They do not and will not. ${ }^{124}$

\subsection{Voorstellen tot grondwetswijziging na 1846}

Het mag inmiddels niet meer verbazen dat de onvrede met het stelsel van rechtersverkiezingen in New York, sinds het einde van de vorige eeuw, groeiende is geweest. Aan verzet tegen de verkiezing van rechters heeft het in New York trouwens nooit ontbroken. Reeds vóór de grondwetsherziening van 1846, werd van verschillende kanten gewaarschuwd tegen de desastreuze gevolgen die een verkiezing van rechters zou hebben op de integriteit van de leden van de rechterlijke macht. Kirkland, merkt al met vooruitziende blik op de Conventie van New York van 1846 op: "Will not the judge be apt to remember the man who greatly promoted, perhaps secured his election? (-) In view of re-election, will he be sure to do impartial and exact justice in a controversy between the powerful and the powerless? Between him who may control many votes and him who can control none?"125 Een gelijksoortige opmerking wordt zeven jaar later, in 1853, opgetekend uit de mond van Rufus Choate, een afgevaardigde op de Conventie van Massachusets:

"So nominated, the candidate is put through a violent election; abused by the press, abused on the stump, charged ten thousand times over with being very little of a lawyer, and a good deal of a knave or boor; and after being tossed on this kind of blanket for some uneasy months, is chosen by a majority of ten votes out of a hundred thousand, and comes into it breathless, terrified, with perspiration in drops on his brow, wondering how he ever got there. to take his seat on the bench. And in the very first cause he tries, he sees on one side the counsel who procured his nomination in caucus, and has defended him by pen and tongue before the people. and on the other, the most prominent of his assailants; one who has been denying his talents, denying his learning, denying his integrity, denying him every judicial quality, and every quality that may define a good man, before half the counties in the state. ${ }^{m 126}$

Hoewel de weerstand om rechters te kiezen in de Verenigde Staten sinds het begin van deze eeuw steeds grotere vormen aanneemt, is bij de verschillende

124. John D. Feerick en Cyrus Vance, o.c. p. 201

125. Bij Niles, o.c. p. 526 ,

126. Bij Niles, o.c. p. 534 . 
Constitutional Conventions van de staat New York na 1846 nooit substantieel verzet geweest tegen het stelsel van rechtersverkiezingen. Een uitzondering vormt misschien de Conventie van 1867 waar het vraagstuk dermate controversieel blijkt, dat besloten wordt de vraag over de selectie van rechters in een referendum aan de bevolking voor te leggen. Met overgrote meerderheid spreekt de bevolking zich in 1873 echter uit vór het behoud van het verkiezingsstelsel. ${ }^{127}$ Landis meent dat het grote succes in 1873 mede te danken is geweest aan de inspanningen van de Committee of Seventy, die ten doel had de macht van de Tweed Ring te breken. "This housecleaning of the judiciary through the use of the ballot must undoubtedly have been deemed a vindication of the system and have contributed largely to its second popular vindication in 1873. "28 Op de Conventie van 1890 blijft het onderwerp rechtersselectie echter onbesproken, net als bij de grondwetsherziening van 1894. In 1915 worden verschillende voorstellen gedaan om te komen tot een ander selectiestelsel, maar de conventie nam daarvan - op een kortstondige discussie na geen notitie. Veelzeggend is de verklaring van de Tammany Society op de Conventie van 1915 :

"The power of the people to elect those who are to sit in judgment upon their liberty and their property rights should never be abrogated; least of all should that power be placed in the hands of a privileged and exclusive coterie, whether composed of lawyers or laymen. In the undisguised effort being made to deprive our citizens of the right to be judged by judges of their own selection, we perceive an inevitable return to the days of Jeffreys-those black and despairing times when a favored sycophant passed upon the life and liberty of the masses, at the behest of the power selected him to wreak its private vengeance. (-) The power of selecting judges should never be placed in the hands other than those of the people themselves. Therefore, and in no uncertain terms, we decry the effort to bring about the appointment rather than the election of judges. ${ }^{\mathrm{m} 29}$

Niettemin wordt in 1915 zware druk uitgeoefend op de Conventie om een wijziging in het bestaande selectiesysteem te brengen. Met name Elihu Root, een

127. Het referendum in 1873 is overigens wat merkwaardig. omdat de kiezers al in 1869 de kans hadden gekregen om zich over de rechtersverkiezingen uit te spreken. Henry W. Taft meent dat het referendum grotendeels te danken was aan de sterke lobby van de advocatuur om een benoemingssysteem in te voeren. Henry W. Taft, New York State Bar Association, Proceedings, 1933, p. 51

128. Landis, o.c. p. 219

129. Landis, o.c. p. 224-227 
van de voormannen van de Short Ballot Movernent ${ }^{130}$, zegt Tammany Hall op de Conventie van 1915 de wacht aan:

"Whether it be a president appointing a judge, or a governor appointing a superintendent of public works, whatever it may be, the officer wants to make a success, and he wants to get the man selected upon the ground of his ability. How is it about the boss? What does the boss have to do? He has to urge the appointment of a man whose appointment will consolidate his power and preserve the organization. There has been hardly a day for the last sixteen years when I have not seen those two principles come in conflict."

In weerwil van de kritiek van Root besluit de Conventie echter dat, hoewel een benoeming door de gouverneur in theorie wellicht de voorkeur heeft, dat het toch niet zo is dat "the elective system had not been satisfactory and had not resulted in the selection of scholarly, competent, industrious, impartial and incorruptible judges. ${ }^{131}$ Uitspraken van gelijke strekking komt men tegen op de Conventies van 1921 en $1938 .{ }^{132}$

Dat er in het begin van deze eeuw - anders dan de Conventies rapporteren - wel degelijk grote problemen zijn geweest met rechtersverkiezingen, blijkt - behalve uit de bovenbeschreven politieke schandalen - ook uit de invoering van de direct primary in 1911, waardoor kandidaten voor rechterlijke functies rechtstreeks, dus zonder tussenkomst van een nominatie, gekozen kunnen worden. Door deze wijziging in de Kieswet hoopt men enerzijds de macht van de partijbonzen te breken, en anderzijds het electoraat meer bij rechtersverkiezingen te betrekken. Het experiment mislukt echter jammerlijk, omdat met dit systeem - dat uitgaat van het vrije marktprincipe - nagenoeg iedereen, met 10 jaar praktijkervaring, zichzelf verkiesbaar kan stellen voor het rechtersambt. Als gevolg van de chaos die dreigt te ontstaan, en om te voorkomen dat volstrekt incompetente rechters worden gekozen, gaan de verschillende juristenverenigingen reeds maanden voor de verkiezingen zelf op pad met petities, om de herverkiezing van ervaren rechters te waarborgen. "Of all the evils which are supposed to be a cure for all evils the direct primary is the worst. ", constateert William

130. De Short Ballot Movement streefde ernaar het aantal verkiesbare ambten te beperken tot die ambten die voldoende in het oog lopen om een reële verkiezing mogelijk te maken. Woodrow Wilson was de president van de National Short Ballot Organization: onder de leden bevonden zich Theodore Roosevelt, Charles E. Hughes Henry L. Stimson en Elihu Root.

131. Landis, o.c. p. 226-227

132. Zie: Judiciary Constitutional Convention of 1921, Report to legislature, p. 7 en: Constitutional Convention of 1938. Joumal and documents, Document no. 8, p. 2 
H. Taft, en in 1921 keert de New Yorkse wetgever terug tot het conventie-systeem. ${ }^{133}$

Maar ook in onze tijd, wanneer de gebreken van, en de problemen met het stelsel van rechtersverkiezingen zo evident zijn geworden, stelt de Temporary Commission on the Courts zich, voorafgaand aan de (laatste) Conventie van 1967 nog altijd op het standpunt, dat er geen reden tot ongerustheid is: "Certainly there has been no convincing demonstration that the present elective method should be abandoned in favor of any of the modified or different proposals which have been advanced. The Commission recommends against the abandonment of the elective system and against the substitution of some new or different system for it. ${ }^{134}$ Met name de activistische rol van het Court of Appeals zou deze procedure rechtvaardigen. Zo stelt de Temporary Commission on the state court System:

"As the highest court in the state, the court of appeals is often called upon to determine social policy as well as to settle litigation. In this respect, the Commission believes that the election process is more likely to insure a judiciary responsive to changing social views than the appointing method. (-) The political parties have generally nominated qualified candidates, the bar associations have informed screening procedures that the parties generally follow, and there is probably less chance of an unfit person becoming a member of the court of appeals than of any other high elective office. ${ }^{m 135}$

\subsection{Merit selection}

Terwijl in de Verenigde Staten, in de periode na 1846 in 'de' politiek slechts sprake is geweest van enig lauw verzet tegen het stelsel van rechtersverkiezingen, barst daarbuiten vanaf 1870 de kritiek in alle hevigheid los. Hoewel in de

133. Men leze hierover bij: William D. Gutbrie, in: Joumal of the American Bar Association. 1921, p. $514-515$

134. Temporany Commission on the Courts, Report, 1956, p. 70-71. Zie ook: New York's Triumph of political ineptilude, in: Judicature, 1967. p. 77. Opnieuw wordt van verschillende zijden met klem aangedrongen op een wijziging van het bestaande verkiezingsstelsel. Zie bijvoorbeeld: de burgemeester van New York, John V. Lindsay, die, naar aanleiding van zijn ervaringen met de door hem ingestelde Mayor's commillee, een systeem van merit selection voorstaat. Association of the Bar of the City of New York, The record, 1966, p. 514-522. Zie ook het advies van de Special Committee on the Constitutional Convention van de Association of the Bar of the City of New York, Selection of judges, Report 1967, waarin een drastische verandering van het verkiezingsstelsel (meril selection) wordt voorgesteld.

135. ...And Justice for all, deel II, 1973, p. 53 In gelijke zin: Lewis M. Isaacs, One third of a govermment, The Record, Association of the Bar of the City of New York, 1965 
meerderheid van de Amerikaanse staten op dit moment nog steeds sprake is van de een of andere vorm van rechtersverkiezingen, berust het voortbestaan daarvan bepaald niet op een breed draagvlak binnen de Amerikaanse samenleving. Kritiek op rechtersverkiezingen, zoals ik die in mijn inleiding heb beschreven, treft men aan bij zeer diverse groeperingen, zoals de rechterlijke macht, de advocatuur, de universitaire wereld, het bedrijfsleven, de vrouwenbeweging, bij vertegenwoordigers van etnische en andere minderheden, bij burgerbewegingen, kerken en media. ${ }^{136}$ Deze kritiek heeft geresulteerd in een stortvloed aan hervormingsvoorstellen. De grote 'lijn' in deze voorstellen loopt van het Albert Kales-Plan in 1914, via het California Court Plan in 1934 naar het Missouri Court Plan in 1940; alle ideeën die na 1940 in en buiten New York over rechtersselectie zijn geopperd, betreffen variaties op het thema merit selection (merit: verdienste), zoals dat in deze jaren op basis van het Kales Plan is ontwikkeld. Merit selection - het begrip laat zich helaas niet kernachtig vertalen - is het compromis tussen de verkiezing en de benoeming van rechters. Kandidaten voor rechterlijke functies worden, na voordracht door een (ook) juridisch deskundig adviescollege, benoemd door - meestal - de gouverneur. $\mathrm{Na}$ een of twee jaar vindt een verkiezing of referendum plaats (retention election), waarin de kiesgerechtigde bevolking zich voor of tegen het behoud van de zittende rechter kan uitspreken. Is het oordeel positief, dan vangt een nieuwe zittingsperiode aan (meestal 12 jaar), na afloop waarvan opnieuw een herverkiezing plaatsvindt.

De voorstanders van merit selection stellen dat dit systeem het goede uit twee kwaden naar boven haalt: enerzijds biedt merit selection een reële mogelijkheid dat rechters worden geselecteerd op juridische deskundigheid (benoemingsaspect), anderzijds dwingt het rechters 'publieke verantwonrding' af te leggen voor hun functioneren (verkiezingsaspect). Merit selection vond - in deze

136. In New York bijvoorbeeld hebben de volgende groeperingen zich in het verleden sterk gemaakt voor de een of andere vorm van merit selection: Modern Courts, League of Women Voters of New York Siate, Cirizens Union, The Association of the City of New York, The New York City Parnership, The City Club of New York, Stale Communities Aid Association, the Women's City Club of New York, The New York State Council of Churches, The New York State Bar Association, New York State Common Cause. American Association of University Women, American Jewish Congress, The Children's Aid Society, Citizens Commintee for Children, Citizens Committee for New York City, Citizens Crime Commission, Correctional Association of New York, Institute of Judicial Adminisiration, Judicial Process Commission, New York State congress of Parents and Children, New York Women in Criminal Justice 
vorm - voor het eerst plaats (voor sommige rechtersfuncties) in Missouri, en vindt thans plaats in 33 staten. ${ }^{137}$

\subsubsection{Albert Kales-Plan 1914}

De grondgedachte van merit selection is afkomstig van Albert M. Kales (Northwestern University) de toenmalige directeur van de American Judicature Society, die tijdens een voordracht voor de Minnesota State Bar Association in 1914, een revolutionair voorstel deed met betrekking tot de hervorming van rechtersverkiezingen ('Albert Kales-Plan'). ${ }^{138}$ Kales was de eerste directeur van de American Bar Association, die in 1913 werd opgericht o.a. ten behoeve van de vebetering van de selectie van rechters. In zijn betoog wijst Kales erop dat de facto alle rechters worden 'benoemd', hetzij door een benoemende autoriteit, hetzij (bij verkiezingen) door de inspanningen van een partijleider. Van een verkiezing van rechters door het volk is zijns inziens - en hij stond daarin niet alleen ${ }^{139}$ - nergens sprake:

"There is, speaking generally, only one method of selecting judges, and that is by appointment. (-) It is one of our most absurd bits of political hypocrisy that we actually talk and act as if our judges were elected whenever the method of selection is, in form, by popular election. (-) They are appointed. The appointing power

137. Ten aanzien van de rechterlijke organisatie in de 50 Amerikaanse deelstaten geldt: zoveel hoofden zoveel zinnen. Binnen een staat worden veclal verschillende selectiemethoden voor verschillende rechtersfuncties gebruikt. Men onderscheidt tussen benoemingen (door de wetgever, de gouverneur of de burgemeester) verkiezingen (partisan elections: partijgebonden verkiezingen of non-partisan elections) en merit selection (benoerning door gouverneur op voordracht van een benoemingscommissie, gevolgd door herverkiezing). Een of andere vorm van merit selection voor bepaalde rechterlijke functies vindt men thans in AJabama, Alaska, Arizona, Colorado, Connecticut, Delaware, D.C. Florida, Georgia, Hawaii, Idaho, Indiana, Iowa, Kansas, Kentucky, Maryland, Massachusetts, Minnesota, Missouri, Montana, Nebraska, Nevada, New Mexico, New York, North Dakota, Oklahoma, Pennsylvania, Suth Dakota. Tennessee, Utah, Vermont, Wisconsin, Wyoming. Daarbij moet worden aangetekend dat de belangrijkste selectiemethode voor rechters nog altijd de verkiezing is; 39 staten hanteren -al dan niet naast een stelsel van merit selection- een verkiezingsstelsel. Bron: American Judicature Society, Judicial Selection in The United States, juni 1993

138. Albert M. Kales, Methods of selecting and retiring judges, Journal of the American Judicature Society, 1938, p. 133 c.v.

139. Al enkele jaren eerder, in 1906, hadden Roscoe E. Pound (toen: University of Nebraska) en William Howard Taft (toen: ex-president van de Verenigde Staten en toekomstig Chief Justice van het U.S. Supreme Court) zware kritiek geuit op de rechtersverkiezingen. Pound zei in een voordracht voor de American Bar Association: "Putting courts into politics and compelling judges to become politicians, in many jurisdictions has almost destroyed the traditional respect for the bench. "The Cause of Popular Dissatisfaction with the Administration of Justice, 46 Judicature 66 (1962). 
is lodged with the leaders of the party machines. These men appoint the nominees. (-) If you wish to test the soundness of these conclusions inquire your way to a judgeship in such a district or listen to the experiences of the men who have found their way to a judgeship or have tried to obtain the office and failed. In almost every case the story is one of preliminary service to the organization, recognition by the local organization chief and through him recognition and appointment by the governing board of the party organization. Those who do not go by this road do not get in. "140

Toch mag men volgens Kales deze misstand de partijleiders niet al te zeer aanrekenen. De kieswetten van de staten dwingen met de judicial nominating conventions immers tot deze praktijken, want het enige alternatief, de rechtstreekse verkiezing (de direct primary) zou slechts tot politieke chaos leiden. Kortom: "The party organization leaders only exercise the appointing power the way it is to be expected that men in their position would do. ${ }^{\prime 41}$ Deze relativering van de invloed van partijleiders lijkt niet onbelangrijk. Men kan hun greep op rechtersverkiezingen - zoals hiervoor steeds gedaan is - exclusief benaderen vanuit de misstanden waartoe dit geleid heeft, maar omgekeerd zijn 'corruptie' en 'eerlijkheid' slechts betrekkelijke begrippen in de harde samenleving die de Amerikaanse - zeker aan het einde van de vorige eeuw - was. Niet voor niets heeft Tammany Hall in New York steeds zoveel dankbare stemmers getrokken. "Niemand behalve de 'bosses' deed iets voor de immigranten. De 'machine' zorgde voor een baantje voor een neef, een mud kolen in tijden van werkloosheid, een kalkoen met kerstmis en een nette begrafenis als daarvoor geen geld was. Kleine diensten misschien, maar voor de immigrant vaak het eerste en voorlopig het enige houvast in de nieuwe wereld", aldus Maarten van Rossem. ${ }^{142}$

Voor Kales zijn er twee reële opties: een benoeming van rechters door de gouverneur, met het voordeel dat deze, als gekozen ambtsdrager, direct verantwoordelijk is ten opzichte van zijn electoraat, maar met als bezwaar dat zijn kennis van de rechtspleging veelal zeer beperkt is, en de benoeming van rechters door een hoogste rechtscollege. Als voordeel van dat laatste ziet Kales het esprit de corps en de coöptatie in rechtscolleges, die z.i. een belangrijke waarborg vormen voor een goede rechtsbedeling: "The fact that judges are part of an organization with a chief over them who is responsible to some extent for their behavior, and the esprit de corps of the court as a whole, are important safeguards against arbitrariness and lack of judicial temper on the part of

140. Kales, o.c. p. 134-135

141. Kales, o.c. p. 138

142. M. van Rossem, De Verenigde Staten in de twintigste eeuw, 1984, p. 16-17 
individual judges. ". ${ }^{143}$ Een bezwaar is echter dat een benoemend rechtscollege aan zware politieke druk bloot zou komen te staan, terwijl de verantwoordelijkheid voor benoemingen ontbreekt. De gedachten van Kales gaan tenslotte uit naar een combinatie van factoren, zodat enerzijds een deskundige selectie van rechters wordt gewaarborgd, en anderzijds een verantwoordingsplicht voor rechters wordt geschapen. Hij stelt voor rechters te laten benoemen door de chief justice van het hoogste rechtscollege in het district waar de vacature openvalt; periodiek zou de chicf justice worden gekozen voor een termijn van vier of zes jaar. De aldus benoemde rechter dient na een bepaalde termijn herkozen te worden. Om te voorkomen dat deze herverkiezingen worden gedomineerd door een handjevol partijleiders, vervalt de nominatie, en wordt bij een herverkiezing enkel de vraag gesteld: "Shall the judge be continued in office?", waarop de kiezer slechts met Yes/No kan antwoorden.

De ideeën van Kales, bestaande uit een benoeming van rechters door een gekozen ambtsdrager, en een periodieke herverkiezing van aldus benoemde rechters, hebben tot op de dag van vandaag grote invloed op de discussie over de juiste selectiemethode voor rechters. Van de schier eindeloze reeks varianten die op zijn Plan zijn voorgesteld, is de invloedrijkste die van de politicoloog Harold Laski uit 1926 geweest, die voorstelde de benoeming niet door een chief justice maar door de gouverneur, bijgestaan door een breed samengestelde adviescommissie, te laten doen. ${ }^{144}$ Deze variant werd na 1936 officieel gepropageerd door de American Bar Association, en werd bekend onder de naam Kales-Laski-Plan. ${ }^{145}$ Ook in New York is de invoering van dit

143. Kales, o.c. p. 143-144

144. Harold Laski, The technique of judicial appointment, in: Michigan Law Review, 1926, p. 539 e.v.

145. Resolutie van 6 januari 1937: "WHEREAS, The importance of establishing methods of Jualicial Selection that will be most conductive to the maintenance of a thoroughly qualified and independent judiciary and that will take the state judges out of politics as nearly as may be, is generally recognized; and WHEREAS, In many states movements are under way io find accepiable substitutes for direcl election of judges; now therefore, he it RESOLVED, By the House of Delegates of the American Bar Associalion. That in its judgment the following plan offers the most acceptable substitute available for direct election of judges:

(a) The filling of vacancies by appointment by the executive or other elective official or officials, but from a list named by another agency, composed in part of high judicial officers and in part of other citizens, selected for the purpose, who hold no other office. (b) If further check upon appointment be desired, such check may be supplied by the requirement of confirmation by the State Senate or other legislative body of appointments made through the dual agency suggested.

(c) The appointee after a period of service should be eligible for reappointment periodically, thereafier, or periodically go before the people upon his record, with no opposing candidate, the people voting upon the question 'Shall Judge Blank be retained 
Plan bij herhaling bepleit ${ }^{146}$, al is deze staat nooit overgegaan tot merit selection, met uitzondering van de selectie van de leden van het Court of Appeals, die sinds 1977 door de Commission on Judicial Nomination worden voorgedragen aan de gouverneur.

\subsubsection{California Court Plan 1934}

In 1934 nemen de kiezers van California, overigens met een zeer krappe meerderheid ${ }^{147}$, een voorstel tot grondwetswijziging aan, dat een nieuw regime voor de hogere en hoogste rechtscolleges voorschrijft. Sinds 1934 worden de rechters in deze colleges benoemd door de gouverneur, na goedkeuring van een Commission on Judicial Appointments. ${ }^{148}$ De benoeming geschiedt, afhankelijk van het betrokken rechtscollege, voor een periode van zes of twaalf jaar. Het California Court Plan was oorspronkelijk een voorstel van de Commonwealth Club van San Francisco uit 1912, en werd gesteund door de California State Bar Association en de California Chamber of Commerce. ${ }^{149}$ Het experiment in California zal echter geen doorslaand succes blijken; drie jaar later $\mathrm{al}$, in 1937 wordt van de zijde van de advocatuur geconstateerd dat het project is mislukt. De Commission on Judicial Appointments zou slecht

in office?' A.B.A. Standing Committee on Judicial Selection, Tenure and Compensation.

146. In heel Amerika werd tussen 1914 en 1934 een zestiental voorstellen voor de een of andere vorm van merit selection gedaan. In New York stelde de Short Ballot Organization in 1914 een verkiezing voor met een nominatierecht voor de gouverneur; de Association of the Bar of the City of New York deed in 1915 een voorstel voor nietpartijgebonden verkiezingen voor rechters; een andere juristenvereniging stelde in 1915 een benoeming voor, met een goedkeuringsrecht voor de Senaat; de City Club stelde in 1921 een benoeming door de gouverneur voor, in 1932 deed de Ciry Club hetzelfde voorstel als de Short Ballot Organization uit 1914: in datzelfde jaar kwam de City Bar met het voorstel voor een benoeming door de gouverneur. met goedkeuringsrechi voor de senaat. Dit voorsiel werd in 1933 gesteund door de New York State Bar Association.

147. Voor: 810,320 stemmen, tegen: 734,857 stemmen. Bron: Effect of New California Amendment, Journal of the Judicature Society, 1934, p. 142

148. Art. VI Section 7 California State Constitution luidt thans: "The Commission on Judicial Appointments consists of the Chief Justice, the Attorney General, and the presiding justice of the court of appeal of the affected district or, if there are 2 or more presiding justices, the one who has presided longest or, when a nomination or appointment to the Supreme Court is to be considered, the presiding justice who has presided longest on any court of appeal."

Art. VI Section 16 sub (d) tweede alinea: "The Governor shall fill vacancies in those courts by appointment. An appointee holds office until the Monday after January I following the first general election at which the appointee had the right to become a candidate or until an elected judge qualifies. A nomination or appointment by the Governor is effective when confirmed by the Commission on Judicial Appointments."

149. Henry J. Abraham, The judicial process, 1986, p. 37 
functioneren, omdat de gouverneur uitsluitend rechters van zijn eigen partij benoemt. ${ }^{150}$ Bovendien worden enkel apert ongeschikte kandidaten door de commissie weggestemd. ${ }^{151}$ Ook is - zo menen de critici - geen sprake van een werkelijke check door de kiezers op het selectieproces; sinds 1934 zijn namelijk alle zittende rechters herkozen. ${ }^{152}$

\subsubsection{Missouri Court Plan 1940}

In de periode na de invoering van het California Court Plan in 1934 is in de verschillende Amerikaanse staten opnieuw sprake van een hausse aan voorstellen om te komen tot een andere wijze van selectie van rechters. ${ }^{153} \mathrm{Het}$ is

150. "No one of the appointments has been a strong one. Several have been obviously weak. The appointments undoubtedly have been dictaled by political considerations. Certainly the bar is not at all satisfied with the run of the appointments made." Califormia Selection Plan Criticized, Journal of the American Judicature Society. 1937, p. 175. Vrij algemeen wordt aangenomen dat na de benoeming van Earl Warren tot gouverneur van Califomia in 1949 de selectieprocedure sterk is verbeterd.

151. Tot nu toe heeft de commissie slechts eenmaal een kandidaat afgestemd; dit gebeurde in 1941 met Max Radin (University of Berkeley) omdat hij "too liberal" zou zijn geweest.

152. Een uitzondering op het ontbreken van een check vormt de herverkiezing van Rose Elizabeth Bird, de Chief Justice van het California Supreme Court in 1986. Bird was in 1977 door gouverneur Jerry Brown voorgedragen, en werd na een 2-1 goedkeuring van de Commission on Judicial Appointments benoemd. Rondom Bird rezen, in het jaar voorafgaande aan haar herverkiezing, grote (nationale) controverses: Bird -een voormalig secretary of state- werd door collega's beschouwd als een indringer. "moving too rapidly in reordering past practices" . Bird werden bovendien links-liberale sympathieën verweten, omdat zij consequent tegen de doodstraf, en voor de 'underdog' in civieleen strafzaken stemde. Aan haar herverkiezing in 1978 gingen felle campagnes van vooren tegenstanders vooraf, die sterk op de persoon van Bird gericht waren. De Law and Order Campaign van senator Bill Richardson tegen Bird kostte 1 miljoen dollar. Met 51.7\% de smalste marge in de geschiedenis van het California Court Plan-werd Bird herverkozen. Zie: John H. Culver en John T. Wold, Rose Bird and the politics of judicial accountability in Califormia. Judicature 1986 p. 80-89. Over de herverkiezing van Rose Bird verscheen in 1981 een lijvig boekwerk van Preble Stolz. Judging Judges. The Investigation of Rose Bird and the California Supreme Court.

153. Behalve in California werd in deze periode ook in een groot aantal andere staten een of andere vorm van meril selection in studie genomen, n.l. in Florida, Georgia, Illinois. Indiana, Iowa, Kansas, Kentucky, Michigan, New York, Ohio, Oklahoma, South Dakota, Utah, Washington en Wisconsin. In 1934 hield de American Bar Association een enquête om de mening te peilen onder haar leden over de meest wenselijke vorm van rechtersselectie. Uit de reacties, die afkomstig waren uit 35 staten, bleek dat juristen in staten waar rechters werden benoemd door de gouverneur of gekozen. werden door de wetgever, sterk gekant tegen een verandering: in staten waar rechters door de bevolking werden gekozen, bleken juristen ontevreden te zijn met het selectiesysteem. Bron: Journal of the American Bar Association. 1934, p. 526-532 
echter de staat Missouri waar in 1940 een voorstel voor invoering van merit selection aan de kiezers wordt voorgelegd. De problemen met de selectie van rechters in Missouri waren vergelijkbaar met die in vele andere staten waar verkiezingen werden gehouden. Met name in St. Louis en Kansas City werd op soortgelijke wijze als in New York de kandidaatstelling en de verkiezing van rechters door partijleiders gemanipuleerd. Bovendien hadden na 1919 de verkiezingen voor rechters geheel in het teken gestaan van nationale issues; Republikeinse rechters, die tijdens de presidentiële verkiezingen waren gekozen, werden ten gunste van Democratische rechters niet herkozen bij de verkiezingen voor het Congres, en omgekeerd. Slechts twee maal was een rechter van het Supreme Court herkozen. ${ }^{154}$ Onder aanvoering van de georganiseerde advocatuur en The Missouri Institute for the Administration of Justice, voerden juristen en belangengroeperingen (waaronder The League for Women Voters), gesteund door de media (destijds vooral de kranten), een intensieve campagne voor een hervorming van het selectiesysteem. ${ }^{155}$ In het Missouri Court Plan (ook wel: non-partisan plan) is gepoogd om de problemen zoals die zich in California hadden voorgedaan, te ondervangen. Het Missouri Court Plan gaat, net als het California Court Plan uit van een benoeming door de gouverneur, maar de benoeming geschiedt - en daar ligt het grote verschil met het California Plan - uit een lijst van drie personen, opgemaakt door een voordrachtscommissie. De benoeming geschiedt voor een termijn van 12 maanden, na afloop waarvan de rechter zich voor een termijn van 12 jaar verkiesbaar kan stellen. In dat geval wordt, zoals in het Albert Kales-Plan, aan het publiek de volgende vraag gesteld: "Shall Judge $X$ be retained in office? Yes/No." 156

154. Laurance M. Hyde, Selection and tenure of judges, in: American Bar Association Joumal. 1941 , p. 763

155. Laurance M. Hyde. The Missouri Method of Choosing Judges, in: Joumal of the American Judicalure Society, 1957, p. 74-77. Hyde zelf was een van de eerste rechters die met deze nieuwe methode in Missouri benoemd werd.

156. Section 25 (a) Missouri State Constitution: "Whenever a vacancy shall occur in the office of judge of any of the following courts of this state, to wit: The Supreme Courl, the court of appeals or in the office of circuit or associate circuit judge within the city of St. Louis and Jackson county, the governor shall fill such vacancy by appointing one of the three persons possessing the qualifications for such office, who shall be nominated and whose names shall be submitted to the governor by a noripartisan judicial commission established and organized as hereinafter provided. If the governor fails to appoint any of the nominees within sixty days after the list of nominees is submitted, the nonpartisanjudicial commission making the nomination shall appoint one of the nominees to fill the vacancy. " 


\subsubsection{Ervaringen met het Missouri Court Plan}

De ervaringen met het Missouri Court Plan worden in de Amerikaanse literatuur overwegend positief beoordeeld. De meeste schrijvers hebben hun aanvankelijke reserves tegenover merit selection laten varen, en stellen dat Missouri van een Show-Me State een Show-Them State is geworden. In de eerste jaren van zijn bestaan werd het Missouri Court Plan nog met argusogen gevolgd door de Dallas Morning News in het nabijgelegen Texas, maar in 1948 rapporteert Richard M. Morehead enthousiast:

"Experience has shown that a judge with a short tenure and the necessity to spend large sums in campaigning for his post becomes a judge who is forced to keep one eye on politics and the other eye on the law. Judges who are appointed without accountability to the electorate become arrogant, sometimes, and dispense justice as if it were royal favor. (-) Missouri has hit upon a plan, however, which combines the successful selection of the ablest lawyers for the lawyerly job of judge with the successful check by popular election upon any tyrannical or corrupt action on the part of the court. ${ }^{157}$

Het enthousiasme voor het Missouri Court Plan spreekt echter niet helemaal voor zich, omdat - net als onder het California Court Plan - in de eerste tien jaar na de invoering nooit rechters werden benoemd van een andere politieke partij dan die van de gouverneur. Toch is dat voor de voorstanders nooit het doorslaggevende criterium geweest. In 1960, twintig jaar na de invoering van het Plan in Missouri, schrijft Harry Gershenson, oud-president van de Missouri Bar (St. Louis):

"Our experience in Missouri has likewise shown that judges who originally went on under political umbrellas and through political organizations have become fine non-partisan judges, since the pressure of politics is off their backs. They need not worry about the next election or about the committeemen. While we know that many fine judges were elected under the oid system, we feel in Missouri that the independence of the jutges, both politically. financially and in the matter of tenure and retirement, is of such great importance and has been so effective that our judiciary has improved in stature and in the quality of its work. ${ }^{n 158}$

157. Richard M. Morehead, Missouri court plan, A series of articles on how Missouri gets and keeps able judges, Dallas Morning News, compilatie 1948, p. 2

158. Harry Gershenson, Experience in Missouri with Judicial Selection under the NonPartisan Plan, in: American Bar Association Journal, 1960, p. 289; In gelijke zin: Glenn R. Winters. Non-Partisan Selection of Judges in Missouri, in: Journal of The American Judicature Society, 1953, p. 99 en: Warren E. Hearnes, de gouverneur van Missouri, Twenty-Five Years Under The Missouri Court Plan, in: Joumal of the American Judicature Society, 1965, p. 104 


\subsubsection{Kritische kanttekeningen bij merit selection}

Op dit moment wordt het Missouri Court Plan in veel Amerikaanse staten als een modelvoorbeeld voor de selectie van rechters gezien. Als echter bij de 25ste verjaardag van het Missouri Court Plan, de ervaringen met het stelsel worden geëvalueerd, kan een enkeling niet verhullen dat zich in de praktijk ook problemen met het Plan hebben voorgedaan, of dat er nadelen aan het Plan verbonden zijn. Een eerste - hardnekkig - bezwaar tegen merit selection is vooral van rechtspolitieke aard, en komt er op neer dat rechtersbenoemingen het publiek de kans ontnemen om rechters, die uitspraken doen in zaken "which affect virtually every aspect of citizen's lives", via verkiezingen op hun daden aan te spreken. ${ }^{159}$ De redenering die daaraan traditioneel vooraf gaat, komt dicht in de buurt bij de pleidooien die binnen en buiten de Nederlandse Tweede Kamer zijn gehouden, voor meer politieke controle op benoemingen van leden van de Hoge Raad. De rechterlijke macht dient volgens sommige auteurs, als "final decisionmaking branch of government", onderworpen te zijn aan de 'wil van het volk':

"Judges, when the theory trappings are removed, are, after all, human beings; political and social beliefs influence their decisions no less than those of legislators, administrators and members of the electorate. They cannot isolate their decisions from their total social, political and cultural background. (...) Because of the great authority vested in judges it must be accepted as a fact that they formulate public policy. It seems logical, therefore, that judicially determined political policies should and must conform to the will of the people. The will of the people cannot be peacefully expressed in any other manner than in partisan elections. Under a nonpartisan judicial selection system, control over their judiciary does not rest in any way, shape or form with the people; it is in stead asserted by an anonymous and politically nonresponsible group controlled by vested interests within the various state bar associations. ${ }^{n 160}$

Hoewel men deze opvattingen - onder hoongelach van de voorstanders van merit selection - tot voor kort slechts schoorvoetend aantrof in de meer 'serieuze' Amerikaanse rechtsliteratuur, valt - gesteund door een uitspraak van het U.S. Supreme Court uit 1991 (zie $§ 5.8$ ) - een hernieuwde belangstelling waar te nemen voor rechtersverkiezingen. Overigens staat daarbij - anders dan het bovenstaande suggereert - de laatste jaren niet zozeer de activistische rol

159. Susan B. Caron. Judicial retention elections: Are they serving their intended purpose?, in: Judicature The Joumal of the American Judicature Society, 1980, p. 216

160. Ray M. Harding. The case for partisan election of judges, in: American Bar Association Joumal, 1969, p. 1163 Zie in gelijke zin: Warren Burnelt, Observations on the direcy-election method of judicial selection, in: Texas Law Review, 1966, p. 1098-1102 
van de rechter bij de rechtsvinding voorop, alswel de vervreemding die zou ontstaan wanneer bepaalde groepen uit de samenleving - in het bijzonder vrouwen en etnische minderheden - structureel (getalsmatig) ondervertegenwoordigd zijn in de rechterlijke macht. Constance B. Motley, een rechter uit het federale District Court in New York, schrijft hierover in 1993:

"The issue involves more than a concern for the composition of the bench. It implicates a concern far more fundamental: the representation of the governed among those who do the governing, be it in the legislative, executive or judicial branches of our government. For our newly emerging pluralistic and diverse society to remain a viable democracy, all groups must feel as if they are an integral part of society and that their concerns are represented by those in positions of power. Excluding minority candidates from judicial posts because merit selection as currently practiced fails to fairly consider them breeds alienation. Alienation from government breeds the feeling on the part of the disenfranchised that government serves not to represent them but to control them. The belief, as was so tragically evident in Los Angeles recently, has grave implications for society as a whole. ${ }^{n 161}$

Met dat laatste doelt Motley op de 'rassen'rellen in Los Angeles, die uitbraken nadat een blanke jury op 30 april 1992 vier blanke politieagenten niet schuldig verklaarde aan mishandeling van een zwarte arrestant, Rodney G. King.

\subsubsection{Citizen knowledge}

Terwijl het standpunt van Motley snel terrein lijkt te winnen (zie hierna), geeft het geen antwoord op een van de belangrijkste bezwaren die traditioneel tegen rechtersverkiezingen (en herverkiezingen: lees merit selection) worden aangevoerd, t.w. het (vermeende) gebrek aan deskundigheid van de burger (citizen knowledge) om een keuze voor of tegen een kandidaat-rechter te maken. Sociologisch onderzoek heeft in het verleden aangetoond dat slechts een zeer beperkt aantal kiezers bij rechtersverkiezingen in staat is zich luttele minuten na de stemming zelfs maar de naam van de kandidaat te herinneren waarvoor hij zojuist gestemd heeft. Zo kon in 1955 slechts 19\% van de kiezers in New York City zich een of meer kandidaat-rechters herinneren waarvoor zij gestemd hadden, tegen $8 \%$ in 1966 . Opmerkelijk is dat kiezers in kleine(re) plaatsen - anders dan werd (en wordt) aangenomen - niet beter bekend zijn met de kan-

161. Constance B. Molley, U.S. Judge Speaks Oui On Judicial Diversity, in: New York Law Journal, 28 juni 1993 
didaat-rechters, dan kiezers in grotere gemeenten. ${ }^{162}$ Veel kiezers geven overigens zelf aan onvoldoende te zijn geïnformeerd om een stemkeuze te bepalen. Uit een onderzoek in Washington en Oregon uit 1982 bleek dat 44,3\% van alle kiezers het gevoel had onvoldoende te zijn geïnformeerd om een afgewogen keuze voor of tegen een kandidaat-rechter te maken; $32,2 \%$ zei zelfs geen enkele informatie te hebben gehad. ${ }^{163}$ Overigens wordt het informatiegebrek deels in de hand gewerkt doordat rechters verplicht zijn zich in hun campagne ten aanzien van sociale kwesties op de vlakte te houden (zie hiervoor). De desinteresse van het kiezerspubliek - al dan niet wegens het ontbreken van expertise - voor rechtersverkiezingen zou er de oorzaak van zijn dat bij herverkiezingen de zittende rechters in het overgrote deel van de gevallen worden herkozen. ${ }^{164}$

Door de onbekendheid van het publiek met rechters is het roll-off percentage voor rechtersverkiezingen hoog. Dit is het percentage kiezers dat bij een verkiezing wel stemt op een presidents-, of gouverneurskandidaat, maar niet op een kandidaat voor een rechtersfunctie. In Queens bijvoorbeeld, verzuimde $28 \%$ van de kiezers die wel opkwamen voor de presidentsverkiezingen in november 1993, op hetzelfde stembiljet een keuze te maken voor de verkiezing van het Supreme Court. ${ }^{165}$ Amerikaanse politieke wetenschappers verklaren het roll-off percentage onder andere uit de lengte van het gemiddelde Amerikaanse kiesbiljet; die zou een belangrijk gedeelte van de kiezers ontmoedigen om te stemmen voor 'minder belangrijke' ambten. Nagel vond in 1973 dat $90 \%$ van alle kiezers ook voor rechterstuncties stemmen indien het kiesbiljet slechts een beperkt aantal namen bevat. ${ }^{1(x)}$ Volgens de critici gelden dergelijke bezwaren tegen verkiezingen a fortiori voor herverkiezingen bij merit selection, omdat deze, bij gebrek aan campagnes, nog minder tot de verbeelding spreken dan 'normale' rechtersverkiezingen. ${ }^{167}$ Overigens gaat het bij de

162. How much do voters know or care abour judicial candidates?, Judicante The Journal of the American Judicathre Sociely, 1955 p. 141 en Citizens Union, Judges by popular inattention, 1967

163. Sara Mathias, o.e. p. 17

164. In de periode 1980-1985 was dit percentage $95 \%$ voor New York City Civil Court rechters die zich kandidaat stelden voor een herverkiezing. Dit ligt overigens weer aanmerkelijk anders voor rechters die ad interim door de gouvemeur of de burgemeester zijn benoemd, en zich daama laten herverkiezen. In de periode 1980-1985 was dit percentage $50 \%$ voor Civil Court rechters die zich na hun benoeming kandidaat stelden voor een tweede termijn. Fund for Modern Courts, The illusion of democracy New York City Civil Court elections 1980-1985, p. 20

165. Cathy Woodruff, Few voters cast ballots for justices, Schenectady Gazette, 20 december 1993

166. S. Nagel, o.c. p. 37

167. Zie: Philip L. Dubois, From Ballot to Bench, 1980, p. 244 
bezwaren van de geringe epertise bij het publiek natuurlijk om een pikant argument, omdat de conclusies veel verder zouden kunnen strekken dan enkel de verkiezing van rechters. De (vermeende) desinteresse bij, en de ongeschiktheid van de burger om publieke ambtenaren te kiezen, houdt - goed beschouwd - niet op bij rechtersverkiezingen, maar zijn evenzeer argumenten tegen verkiezingen in het algemeen. Dat dergelijke - weinig sympathieke vragen niet worden gesteld, is een opmerkelijke lacune in de Amerikaanse literatuur.

\subsubsection{Selectiecriteria}

Afgezien van meer principiële bezwaren tegen merit selection, is er bij de selectie van rechters in het algemeen (verkiezing/benoeming/merit selection) veel onduidelijkheid over hoe screening committees te werk moeten gaan, welke de criteria zijn die moeten gelden voor de toegang tot het rechtersambt, en of dergelijke criteria eigenlijk wel te meten zijn. Maurice Rosenberg toont zich, naar aanleiding van zijn ervaringen in de New York Mayor's Committee, buitengewoon sceptisch over de effecten van screening van kandidaten aan de hand van tevoren bepaalde criteria. ${ }^{168}$ Terwijl iedereen het volgens hem in grote lijnen eens is over de formele voorwaarden voor benoembaarheid van een rechter (staatsburgerschap, woonplaats, leeftijd, ervaring), bestaat over de persoonlijkheidsvereisten slechts onenigheid en verwarring. Rosenberg meent dat aan dat laatste dan ook niet al te veel aandacht moet worden besteed. Persoonlijke deugden komen slechts negatief in aanmerking, namelijk als gronden voor een afwijzing, en moeten niet dienen als positieve criteria, waaraan iedere kandidaat moet voldoen, alvorens benoembaar te zijn. Anderen zien meer in een intellectuele benadering. Zo stelt Peter G. Fish voor dat selectiepanels een 'open debat' aangaan met de kandidaten, aan de hand van vragen als: "Would you say the several States are sovereign?", "Would you agree with Socrates in Plato's Crito that a citizen always has an obligation to obey the laws of the State?" of: "Do you think that the concepts of liberty and equality are more likely to be harmonious, disharmonious, or something in beween?"169

168. Maurice Rosenberg. The qualities of justices-are they strainable?. Texas Law Review, 1966 , p. $1063-1080$

169. Peter G. Fish, Questioning judicial candidates: what can meril selectors ask?, in: Judicature The Journal of the American Judicature Society, 1978 p. 15. De suggesties van Rosenberg en Fish hebben overigens weinig invloed gehad. In 1984 gaf de American Judicature Society een draaiboek voor het functioneren van screening-panels uit. De vereniging noemt als belangrijke criteria: "Suitable Age, Good Health, Impartialiy, Industry, Integrity, Professional Skills, Community Contacts, Social Awareness"; voor rechters in beroepsinstanties voegt zij daaraan toe: "Collegiality, Writing Ability". De screening panels wordt geadviseerd aan de hand van een vragenlijst de kandidaten te ondervragen. Bij "Impartiality" vinden we vragen als: "Can this person listen to the 
Ruim vijfenzeventig jaar na de introductie van het Albert Kales-Plan, lijkt in de Verenigde Staten thans in brede kring consensus te zijn ontstaan, over de wenselijkheid van invoering van een of andere vorm van merit selection voor rechters in de deelstaten. ${ }^{170}$ Recent kwam daar een belangrijk argument bij. In zijn rapport van 29 januari 1992 concludeert de Task Force on Judicial Diversity, die in 1991 door de gouverneur van New York, Mario M. Cuomo is ingesteld ${ }^{171}$, dat het New Yorkse verkiezingsstelsel vrijwel zeker in strijd is met art. 2 van de Federal Voting Rights Act 1965 (1982). De Task Force heeft goede gronden om aan te nemen dat de rechtersverkiezingen in New York strijdig zijn met art 2 Voting Rights Act, omdat het U.S. Supreme Court in zijn uitspraak van 20 juni 1991 in Chisom $v$. Roemer ${ }^{172}$ in een zes tegen drie beslissing de Federal Voting Rights Act ook op verkiezingen van rechters van toepassing heeft verklaard.

De casus in Chisom v. Roemer was als volgt. Het Louisiana Supreme Court bestaat uit zeven rechters. Conform de Louisiana State Constitution worden vijf rechters in het Supreme Court gekozen uit vijf z.g. Supreme Court Districts, die overwegend uit blanken of zwarten bestaan (single-member districts), en twee uit een 'gemengd' district (multimember districts). De telling geschiedt per gemeente. Het gemengde Supreme Court District omvat de gemeenten Orleans Parish, St. Bernard, Plaquemines en Jefferson. Terwijl Orleans Parish de helft van de bevolking uit het betreffende District herbergt, waarvan de meerderheid $(52 \%)$ zwart is, bestaat het gemengde District in zijn geheel voor $68 \%$ uit blanken en voor $32 \%$ uit zwarten. Chisom betoogt, als vertegenwoordiger van de zwarte bevolking, dat de onderhavige regeling 'impermissibly dilutes minority voting strength' in strijd met art 2 Voting Rights Act. Bovendien zou de wijze van verkiezing van de twee rechters uit het multimember

arguments of all paries before making up his/her mind completely on the determination of legal issues?". "Will this person's rulings be free from racial bias? religious bias? ethnic bias? bias based on sex? bias based on social status of the farties? bias hased on the economic status of the parties?" Bron: Maria N. Greenstein, Handbook for Judicial Nominating Commissioners, American Judicature Society, 1984, p. 69

170. Onlangs stelde de American Judicalure Society de Hunter Award in, een aanmoedigingsprijs die wordt toegekend aan personen en organisaties die zich hebben ingzet voor "significant achievement in improving judicial selection". De eerste Hunter Award werd toegekend aan Milton L. Henry jr., directeur van het Fund for Modern Courts in New York. Bron: American Judicature Society, Report to members, april/mei 1992.

171. Mario M. Cuomo, Executive Order No. 149. 23 september 1991

172. Chisom v. Roemer, 111 S.Ct. 2354 (1991). Men leze uitgebreider over de voorgeschiedenis van deze kwestie bij: Judith Haydel, Section 2 of the Voting Rigts ACt of 1965: a challenge to state judicial election systems, Judicature, 1989, p. 68-73 
district in strijd zijn met het veertiende en vijftiende amendement van de Amerikaanse Grondwet, dat discriminatie in het algemeen door de wetgevers in de staten, en bij de uitoefening van het kiesrecht in het bijzonder, op grond van 'race, color, or previous condition of servitude' verbiedt. ${ }^{173}$

Het betoog van Chisom is - kennelijk - gebaseerd op de vooronderstelling dat blanken en zwarten de voorkeur zullen geven aan een kandidaat uit de eigen gelederen, en gaat er dus van uit dat kiezers hun stem baseren op etniciteit en niet (alleen) op politieke voorkeur. Van belang is dat het Louisiana Supreme Court altijd exclusief uit blanken heeft bestaan. De eisers hopen er op dat het multi-member district zal worden verdeeld in twee aparte single-member districten. De verdediging - de staat Louisiana - voerde (onder andere) aan dat de Voting Rights Act niet van toepassing was op rechtersverkiezingen omdat rechters geen "representatives" in de zin van de Voting Rights Act zouden zijn. De meerderheidsopinie van het Supreme Court luidt evenwel: "We think, however, that the better reading of the word "representatives" describes the winners of representative, popular elections. If executive officers, such as prosecutors, sherrifs, state attorneys general, and state treasurers, can be considered "representatives" simply because they are chosen by popular election, then the same reasoning should apply to elected judges. "Het Supreme Court ontleent daarvoor bovendien een argument aan een eerdere uitspraak uit 1991, waarin hij vaststelt dat rechters betrokken zijn bij "policymaking at some level". ${ }^{174}$ Het Supreme Court overwoog verder:

"that ideally public opinion should be irrelevant to the judge's role because the judge is often called upon to disregard, or even to defy, popular sentiment. The Framers of the Constitution had a similar understanding of the judicial role, and

173. Art. 2 van de Federal Voting Rights Act 1965 (1982):

(a) No voting qualification or prerequisite to voting, or standard, practice, or procedure shall be imposed or applied by any State or political subdivision to deny or abridge the right of any citizen of the United States to vote on accounl of race or color, or in contravention of the guarantees set forth in section $4(0)(2)$, as provided in subsection (b).

(b) A violation of subsection (a) is established if, based on the totality of circumstances, it is shown that the political processes leading to nomination or election in the State or political subdivision are not equaly open to participation by members of a class of citizens protected by subsection (a) in that its members have less opportunity than other nembers of the electorate to participate in he political process and to elect representatives (accentuering van mij, $\mathrm{MdW}$ ) of their choice. The extent to which members of a protected class have been elected to office in the State or political subdivision is one circunstance which may be considered: Provided, That nothing in this section establishes a right to have members of a protected class elected in numbers equal to their proportion in the population.

174. Gregory v. Ashcroft, 111 S.Ct.2395, 2404, L.Ed.2d (1991) 
as a consequence, they established that Article III judges would be appointed, rather than elected, and would be sheltered from public opinion by receiving life tenure and salary protection. Indeed, these views were generally shared by the States, during the early years of the Republic. Louisiana, however, has chosen a different course. It has decided to elect its judges and to compel judicial candidates to vie for popular support just as other political candidates do. The fundamental tension between the ideal character of the judicial office and the real world of electoral politics cannot be resolved by crediting judges with total indifference to the popular will while simultaneousty requiring them to run for elected office. When each of several members of a court must be a resident of a separate district, it seems both reasonable to characterize the winners as representatives of that district. (-) Louisiana could, of course, exclude its judiciary from the coverage of the Voting Rights Act by changing to a system in which judges are appointed, and in that way, it could enable its judges to be indifferent to popular opinion. The reasons why Louisiana has chosen otherwise are precisely the reasons why it is appropriate for $\S 2$, as well as $\S 5$, of the Voting Rights Act to continue to apply to its judicial elections."

In zijn dissenting opinion, die gedeeld werd door Justices Rehnquist en Kennedy, meent Scalia dat het Supreme Court in de Voting Rights Act slechts heeft gelezen wat hij heeft willen lezen. De conclusie van het Hof dat rechters "representatives" zijn noemt Scalia echter "quite out of accord with that usual practice":

"There is little doubt that the ordinary meaning of "representatives" does not include jua'ges, see Webster's Second New International Dictionary 2114 (1950). The court's feeble argument to the contrary is that "representatives" means those who "are chosen by popular election." (...) On that hypothesis, the fan-elected members of the baseball All-Star teams are "representatives"-hardly a common, if even a permissible, usage. Surely the word "representative" connotes one who is not only elected by the people, but who also, at a minimum, acts on behalf of the people. Judges do that in a sense-but not in the ordinary sense. As the captions of the pleadings in some States still display, it is the prosecutor who represents "the People"; the judge represents the Law-which often requires him to rule against the People."

In haar commentaar bekritiseert de Harvard Law Review zowel de analyse van de meerderheid van het Supreme Court, als die van Scalia c.s., omdat beide te zeer leunen op grammaticale argumenten. ${ }^{175}$ De Harvard Law Review meent daarentegen dat voor het begrip 'reprsentatie' aansluiting moet worden gezocht bij de politieke realiteit; "one must analyze contemporary judicial activity from a realistic perspective."

175. Harvard Law Review, leading cases, 1991, p. 409-418 
"Most would agree that, unlike legislators and executive officials, who should pursue the advancement of their constituents' interests, the ideal judge should interpret the law impartially and vigorously abstain from establishing public policy. In reality, however, a degree of lawmaking inheres in the judicial role-and lawmaking is, by definition, an extremely political activity. Furthermore, some judges are bewitched by the seductive appeal of the political arena and actively pursue ideological agendas. Accepting those realities, one should not be surprised that the appointment and selection of judges, even at the highest levels, has become a supremely political affair."

De Harvard Law Review meent dat, nu benoemde rechters "political actors" zijn, gekozen rechters "even more so" kunnen worden beschouwd als "representatives", en wel "[t]o the extent that the interests of their constituency guide and define their decisionmaking processes". Daaruit volgt volgens de Harvard Law Review dat deze rechters gekozen moeten worden "in a manner that allows the full and effective participation of all citizens." Dit heeft tot consequentie, aldus de Harvard Law Review, dat het kiesrecht meer inhoudt dan "mere access to the ballot" en "numerically fair representation." "True effective voting requires that there be a fair apportionment of group power among all groups, whether or not a particular group can elect its own candidates. (...) Such an approach would move all minorities closer to the ideal of full and effective participation in the political arena." En daarmee bereikt de Harvard Law Review dan, zij het dan vanuit een ander perspectief, dezelfde conclusie als de meerderheid van het Supreme Court, namelijk dat het rechtersambt een 'representatief' karakter heeft.

De opvatting van de meerderheid van het Supreme Court komt er in de kern op neer dat - wat men ook moge vinden van rechtersverkiezingen - de staat Louisiana nu eenmaal die keuze heeft gemaakt, en dat daaraan dus ook consequenties moeten worden verbonden: "The fundamental tension between the ideal character of the judicial office and the real world of electoral politics cannot be resolved by crediting judges with total indifference to the popular will while simultaneously requiring them to run for elected office." Zeker nu de selectie van rechters niet alleen de uiterlijke verschijningsvorm van normale verkiezingen heeft, maar rechterlijke ambtenaren bovendien dezelfde functie als politici lijken te hebben, is toepassing van het begrip 'representatives' volgens het Supreme Court gerechtvaardigd. De Harvard Law Review volgt een soortgelijke weg waarbij eveneens wordt aangesloten bij de politieke realiteit. De aansluiting bij de politieke realiteit is echter - om drie redenen: feitelijk, historisch en theoretisch - niet sterk. Feitelijk niet omdat het U.S. Supreme Court en de Harvard Law Review wel wat erg gemakkelijk voorbij gaan aan een andere politieke realiteit, namelijk dat rechtersverkiezingen niet kunnen worden beschouwd als verkiezingen; van enige 'volksinvloed' is, noch waar 
het hetreft de kandidaatstelling, noch waar het de uitslag hetreft, immers sprake, het voorgaande moge daarvan het bewijs zijn. Historisch is het bovendien zeer de vraag of men - gezien de (aard van de) totstandkoming rechtersverkiezingen over dezelfde kam mag scheren als andere verkiezingen; het is immers hoogst twijfelachtig dat de New Yorkse grondwetgever de bedoeling heeft gehad voor de rechterlijke macht een representatief stelsel in te voeren. En al zou dat zo zijn, dan rijst tenslotte de vraag - en daarmee bereiken we de kern van het tegenargument van de dissenters - wat de reikwijdte van het begrip 'representative' is; is daarvoor voldoende een passieve representatie (enkel gekozen door het volk) of moet daarbij tevens sprake zijn van actieve representatie: handelen namens het volk? Scalia meent - zonder daarvoor argumenten aan te dragen - het laatste, en concludeert daaruit dat van representatie geen sprake is.

\subsubsection{Proefprocessen en voorstellen tot grondwetswijziging}

De uitkomst van Chisom v. Roemer, en de hint van de Task Force on Judicial Diversity hebben de discussie over merit selection niet ongemoeid gelaten. Bij het afsluiten van dit document (voorjaar 1994) is een drietal processen aanhangig tegen de wijze waarop rechters in (bepaalde delen van) de staat New York worden gekozen. Het Center for Constitutional Rights begon op 30 maart 1992 een proefproces tegen de staat New York (France v. Cuomo ${ }^{176}$ ), gevolgd door een tweetal andere processen: Del Toro $v$. Cuomo en Healy $v$. Cuomo. Tevens is een voorstel tot grondwetsherziening aanhangig gemaakt, dat behalve in de integratie van de rechterlijke instanties in eerste aanleg (court merger), ook in merit selection voor de leden van het Supreme Court voorziet. ${ }^{177}$ Deze z.g. governor's Bill werd aanvankelijk door een groot aantal belangengroeperingen gesteund, maar daar is sinds de proefprocessen verandering in gekomen. Terwijl het er tot zeer recent naar uitzag dat de ontwikkelingen met betrekking tot merit selection uiteindelijk via een grondwetswijziging hun beslag zouden krijgen, lijkt de weg op het allerlaatste moment af te buigen, umdat minderheden alsnog hun hoop gevestigd hebben op een gunstige uitkomst van een van de drie rechtszaken, zodat de wetgever gedwongen wordt tot een andere indeling van de districtsgrenzen.

De ironie van Chisom v. Roemer - waarin het U.S. Supreme Court uitdrukkelijk zijn scepsis uitspreekt over een verkiezing van rechters - is dat het een bres heeft geslagen in de aanvankelijke onverdeelde steun voor merit selection.

176. United States District Court Somthern district of New York, 92 Civ. No. 1144 (JES), 30 maart 1992

177. Voorstel tot grondwetsherziening van de senatoren Goodman, Connor, Leichter, Marchi, Montgomery, Ohrenstein, 11 februari 1992. S.6991-A.10427. 
Hoewel het éen (invoering van merit selection) het ander (een andere indeling van districtsgrenzen) niet uitsluit, lijkt de discussie over de toegang tot het rechtersambt zich meer dan ooit toe te spitsen op de persoon van de rechter, en niet op diens professionele kwaliteiten. Wellicht biedt, behalve de uitkomst van Chisom v. Roemer, de scepsis ten opzichte van rechtersbenoemingen, die traditioneel juist van de kant van etnische minderheden heeft bestaan, een andere verklaring voor deze tactische zet. Er bestaat onder deze groepen een groot wantrouwen tegen benoemingscommissies, die de gouverneur of burgemeester adviseren, omdat zij door hun (vermeende) eenzijdige samenstelling, de toetreding van vrouwen en etnische minderheden tot de rechterlijke macht negatief zouden beinvloeden. ${ }^{178}$ Ook bij merit selection worden steeds vaker vraagtekens gezet, en recent is de term 'The Fraud of Merit Selection' gevallen. ${ }^{179}$ De New Yorkse rechters William C. Thompson en Constance B. Motley, spreken in dit verband over de 'elitist tendencies' van merit selection:

"It tends to select in large part from the major law firms, where the vast majority of the attorneys are white and white-shoe. It focuses on candidates of a certain class and social background and ignores the diversity which now exists among attorneys. (-) Without a commitment to affirmative action that would force merit selection committees to carefully consider qualified African-American, Latino and Asian candidates of both genders, the federal bench will remain homogeneous and unreflective of the larger population. ${ }^{m 80}$

Uit onderzoek uit 1985 van het Fund for Modern Courts blijkt echter dat deze vrees ongegrond is. Een aanzienlijk groter aantal vrouwen en leden van etnische minderheden bereikt het rechtersambt na benoeming $(17.9 \%$ ) of onder een stelsel van merit selection (17.1\%) dan na verkiezing (11.7\%). Voor de Verenigde Staten in het algemeen geldt volgens onderzoek uit 1993 zelfs, dat $32 \%$ van de zwarte rechters door merit selection benoemd wordt, tegen $11 \%$ van de rechters die gekozen worden. "There is no reason why properly constituted nominating commissions should be called "elitist" and no proof presented (-) that they in fact are.", aldus Elizabeth B. Hubbard van Modern Courts. ${ }^{181}$

178. Judicial Selection and the Black Experience, in: Judicature The Journal of the American Judicature Society, 1975, p. 441. Zie ook: Meade Esposito. de Democratiche leider in Brooklyn in 1983: "Under a merit system from Wall Street, you would'nt have any llalians, you would'nt have any women or blacks or Hispanics." New York Post. 6 oktober 1983 .

179. William C. Thompson, Open Letter to the Black \& Puerto Rican Caucus: The Fraud of 'Merit Selection', New York Law Journal, 24 juni 1993

180. U.S. Judge Speaks Out On Judicial Diversity, New York Journal, 28 juni 1993

181. Elizabeth B. Hubbard, Merit Selection System For Judges Defended, New York Law Journal, 1 juli 1993. Al eerder werd echter getwijfeld of rechtersverkiezingen in het voordeel van etnische minderheden werken: Michael David Smith, Race versus robe: 


\subsection{Nabeschouwing}

In hoofdstuk 1 werd rechtsvergelijking, net als rechtshistorisch onderzoek, tricky business genoemd, omdat elders een glibberig pad wordt bewandeld, waarbij tal van sociaal-culturele en economische gevoeligheden niet (direct) onderkend worden, of waarmee om redenen van tijdgebrek of expertise geen rekening kan worden gehouden. Bovendien rees de vraag naar de relevantie van rechtsvergelijking, - 'wat koop je ervoor' - een vraag die, daar zijn veronderstellingen voor, aanvankelijk nog luchtig gepareerd kon worden met de opmerking dat het 'confronteren van ogenschijnlijke extremen tot relativering en zelfinzicht leidt'. 'Kan leiden' zou ik nu van dat laatste willen maken, en: 'op termijn wellicht'. Dat het pad glibberig was staat vast, dat sommige gevoeligheden niet onderkend zijn valt niet te ontkennen, en dat we over extremen praten is evident. Maar dat dit ook tot relativering en zelfinzicht heeft geleid, daar ben ik nog niet zo zeker van. Wie verzekert mij dat niet - zoals dat de psycholoog Heymans overkwam - de echte geleerden straks met de onderzoeksgegevens aan de haal gaan? Het voorgaande geeft de Nederlander immers alle reden voor een geamuseerd hoofdschudden ('het valt hier dus allemaal nog wel mee'). Ten onrechte; een authentieke verbazing mag de lezer niet ontzegd worden - dat effect is hier en daar voor de leesbaarheid zelfs nagestreefd - maar iedere consequentie die men er voor eigen land aan wil verbinden, is niet alleen - zoals Heymans ${ }^{182}$ voorzichtig opmerkte - voor eigen rekening, maar ook onjuist, al was het maar omdat dit hoofdstuk over Amerika ging, en niet over Nederland.

Als er bij het voorgaande, in vergelijking met ons land, iets opvalt dan is het wel dat in de Verenigde Staten de functie van de rechtspleging - soms letterlijk - op straat wordt uitgevochten, iets wat mogelijk wijst op een grotere betrokkenheid van de burger. Dat is geen bijzondere verdienste van de Amerikaanse samenleving, want die 'betrokkenheid' lijkt vooral te worden ingegeven door de noodzaak het eigen hoofd boven water te houden. Bovendien gaat die betrokkenheid blijkbaar ook weer niet zover dat men zich, voordat het er echt op aankomt, nl. in het stemhokje, (voldoende) informeert over een rechterskandidaat. Maar duidelijk is wel dat, wat het vraagstuk van de selectie van rechters betreft, sprake is van een brede publieke discussie, tussen vakgenoten, in de pers, waardoor publieke opinie en staatkundige werkelijkheid elkaar minder snel mislopen dan hij ons. In hoofdstuk 4 is er reeds op gewezen dat, nadat in ons lind in april 1970 bij Koninklijk Besluit de Commissic aantrekken leden rechterlijke macht was ingesteld, die tot taak kreeg voortaan niet minder

the dilemma of black judges, 1983, p. 108

182. G. Heymans, Psychologie der vrouwen, 1920, p. 12-13 
dan de helft van alle toekomstige rechters te selecteren, de regering de Tweede Kamer een jaar later nog van het bestaan en het doel van deze commissie op de hoogte moest brengen. ${ }^{18.3}$ En inmiddels heeft deze commissie, die ooit als een experiment begon, waardoor zelfs de meest elementaire voorzieningen (samenstelling, zittingsperiode, rapportage) niet geregeld zijn, geruisloos een permanente status verkregen. Zoiets zou in de Verenigde Staten ondenkbaar zijn. Al ver voordat van de instelling van zo'n commissie zelfs maar sprake zou zijn, zouden er al tientallen claims liggen; hoe en door wie is die commissie samengesteld en welke status heeft zij, hoe lang is de zittingsperiode van de leden, waarover, aan wie en wanneer rapporteert de commissie, en hoeveel gaat het kosten? Is daarmee, in positieve of in negatieve zin iets gezegd over Nederland of over Amerika? Laten we het er op houden dat de conceptie van parlementaire en publieke controle, in relatie tot de rechterlijke macht, een andere is.

Met het voorgaande is gepoogd de discussie over het democratische perspectief, dat het vraagstuk van de toegang tot het rechtersambt in ons land lijkt te domineren, op voorhand enig reliëf te geven. Het democratische perspectief oriënteert zich voor zijn probleemstelling, zoals we nog zullen zien, op de vermeende controverse tussen de benoeming en de verkiezing van rechters, om de democratische legitimatie van de rechter te bepalen. Uit het voorgaande moge blijken dat, in de Verenigde Staten althans, die controverse - op grond van de praktische ervaringen die met rechtersverkiezingen zijn ongedaan - al sinds de invoering van die verkiezingen, sterk gerelativeerd wordt. Dat we het bij de selectie van rechters in ons land, allereerst hebben over de professionele kwaliteiten van de kandidaat - welke dat ook moge zijn -, en niet (of pas in laatste instantie) over de betreffende persoon is een vanzelfsprekendheid die niemand hoeft te worden toegelicht. Omgekeerd zijn selectiecriteria als 'integriteit, 'ervaring', en 'deskundigheid', onafhankelijkheid en onpartijdigheid, die bij ons behoren tot de ingesleten clichés, begrippen waar men in de Amerikaanse deelstaten - kennelijk - niet eens aan toekomt. De discussie over de democratische legitimatie van de rechter lijkt daardoor, zo zal in het volgende hoofdstuk worden betoogd, op grond van deze ervaringen, inmiddels een stap verder dan die in Nederland. 



\section{Het democratische perspectief}

\subsection{Inleiding}

Nadat in de hoofdstukken 3 en 4 de vraag naar de teitelijke regeling van de toegang tot het rechtersambt, en naar de overwegingen die aan die regeling ten grondslag liggen, aan de orde is gekomen, wordt in dit hoofdstuk onderzocht welke tendensen ten aanzien van dat vraagstuk zijn waar te nemen, en hoe deze moeten worden gewaardeerd. Hoofdstuk 4 eindigde onder andere met de opmerking dat de maatschappelijke discussie over de toegang tot het rechtersambt in ons land geen gelijke tred houdt met de institutionele ontwikkelingen op dat punt. Terwijl de onderwerpen die feitelijk de toegang tot het rechtersambt macht bepalen (werving en selectie) door een technocratisch perspectief worden beheerst, zagen we dat op een ander niveau in toenemende mate een meer principiële benadering van met name het vraagstuk van de benoeming van rechters valt waar te nemen, dat hier het democratische perspectief wordt genoemd. Het gaat daarbij om een vaste - bijna dwingende - route, die een Jrietal stappen omvat: de vooronderstelling van een bepaalde conceptie van de trias politica $(\$ 6.2$ ), het daaruit voortvloeiende legitimiteitsgebrek van de rechter bij een hepaalde rechterlijke taakopvatting ( $\$ 6.3$ ), en het aannemen van een verband tussen de legitimatie van de rechter en de wijze van aanstelling van de leden van de rechterlijke macht $(\S 6.4)$. Anders dan het technocratische perspectief, neemt het democratische perspectief wèl een verband aan tussen de rechtsprekende taak van de rechter en de wijze waarop de rechterlijke macht wordt samengesteld. Toch kleven aan het democratische perspectief, zo zal hierna blijken, zowel wat zijn uitgangspunten als zijn uitkomsten betreft, ook niet geringe bezwaren.

\subsection{De trias politica: machtenscheiding}

De eerste stap in het democratische perspectief is het uitgangspunt dat de pladts van de rechter in het staatshestel moet worden beheerst door 'de' trias politica, die wordt opgevat als de scheiding van de staatsmacht in een wetgevende, een uitvoerende (of besturende) en een rechterlijke macht. 'The oracle who is always consulted and cited on this subject is the celebrated Montesquieu', schrijft Publius alias James Madison in 1787 verveeld, alsof er (tven al) niets nieuws 
meer over dit onderwerp te zeggen valt. ${ }^{1}$ Ten onrechte, zal hierna blijken, machtenscheiding is slechts éen variant van de leer van de trias politica. Toch hanteren de regering, het parlement en de media slechts een vrij beperkt begrip van de trias politica, dat vooral het aspect van machtenscheiding accentueert, en waarin het ideale uitgangspunt lijkt te zijn dat de rechter 'niet aan politiek doet'. ${ }^{2}$ Of, zoals De Werd weinig genuanceerd opmerkt naar aanleiding van de commotie rond een aanbeveling van de rechtbank Roermond": "De Trias Politica vooronderstelt een strikte scheiding van wetgevende, uitvoerende en rechtsprekende macht". ${ }^{4}$ Het jargon dat gebruikt wordt is veelzeggend, en sluit naadloos aan op de positie die men de rechter in het staatsbestel idealiter toedenkt. Hij dient bij voorkeur niet op de 'stoel' van de wetgever of van het bestuur plaats te nemen - net zo min als de wetgever en het bestuur iets 'op het bordje van de rechter' mogen afschuiven - en betreedt de rechter onverhoopt toch het 'terrein' van een van beide anderen, dan spreekt men over een 'wetgever-plaatsvervanger' die in 'politiek vaarwater' terecht komt. ${ }^{5}$

Bovenstaande triasconceptie valt de laatste jaren met grote regelmaat te beluisteren. Het is de dominante visie geweest die onder meer heeft geleid tot de afwijzing van het toetsingsrecht bij de grondwetsherziening van 1983, die er op haar beurt weer de oorzaak van was dat een discussie over de toegang tot het rechtersambt uitbleef (zie hierna). De Staatscommissie Herziening Rechterlijke Organisatie noemt het heginsel van machtenscheiding in 1985 'van zo groot helang' dat zij een alternatief benoemingsstelsel voorstelt. ${ }^{6}$ De laatste jaren komt men de nadruk op de machtenscheiding tegen in tal van politiekstaatkundige analyses over 'de plaats van de rechter in het rechtsbestel'. Zo warrschuwt minister-president Lubbers in 1990 in zijn 'Nijmeegse rede' voor "de dreigende vermenging en daarmee verfloddering van de onderscheiden delen van de trias politica. Een goed functionerende trias politica vraagt om een helder onderscheid van taken van wetgeving, van die van het bestuur en die van de rechterlijke macht. ${ }^{\text {"7 }}$ Ook de bijzondere commissie Vraagpunten (commissie-Deetman) redeneert in 1990 langs dezelfde lijn. Door de 'toenemende bemoeienis van de overheid' zijn de organen van de democratische rechtsstaat

1. Federalist papers, no. XLVII

2. Vergelijk: W.J. Witteveen, De retoriek in het recht Over retorica en interpretatie, staatsrecht en democratie. 1988 , p. 272

3. Zie over deze kwestie $\$ 4.9 .9 .3$

4. Henk Schroen, "De commotie in Roermond heeft ook positieve kanten", De Limburger, 10 oktober 1992

5. Vergelijk mijn bijdrage in: Verhalen over de Grondwet, 1993, Afschuiven in de politiek: van de stoel van de wetgever naar het bordje van de rechter, p. 136-141

6. In de vorm van een Raad voor de rechterlijke macht. Zie $\$ 4.10 .2 .1$

7. Gepubliceerd in: Nederlandsche Staatscourant, 4 september 1990 
- de wetgever, het bestuur en de rechterlijke macht - onder druk komen staan, en is de balans tussen wetgeving, bestuur en rechtspleging, de trias politica, 'verstoord':

"Het is de vraag of deze ontwikkeling zich verdraagt met de uitgangspunten van onze staatsinrichting. Deze uitgangspunten houden toch in, dat wetgeving, bestuur en rechtspleging elk afzonderlijk krachtens de aan ieder van hen afzonderlijk opgedragen grondwettelijke taak zorgdragen voor de oplossing van problemen en geschillen die zich in onze samenleving voordoen. Naarmate de kwaliteit van wetgeving en bestuur beter worden, zal de noodzaak om de rechter in te schakelen, afnemen. Uitgangspunt is dat overheidsoptreden op zichzelf legitiem behoort te zijn. ${ }^{m 8}$

De commissie gaat nog niet zover om te zeggen dat het optreden van de rechter (soms) niet-legitiem is, maar zij trekt wel een duidelijke - zij het nogal willekeurige - grens bij het rechterlijk toetsingsrecht. Invoering daarvan zal moeten samenhangen met de wijze van benoeming van een Constitutioneel Hof. In dit verband wijst de commissie-Deetman er op dat de Hoge Raad, in verband met de voordracht van de Tweede Kamer, zijn legitimiteit ontleent "aan een zekere mate van inspraak van (een deel van) de volksvertegenwoordiging bij de benoeming van hen, aan wie de toetsing van wetten aan de Grondwet zou worden toevertrouwd. "9 Met dat laatste - de koppeling tussen het vermeende legitimiteitsgebrek van de rechter en de wijze van samenstelling van de rechterlijke macht - lopen we echter vooruit op de derde stap in het democratische perspectief. Eerst wordt bezien hoe in het democratische perspectief een legitimiteitsprobleem ontstaat.

\subsection{De taak van de rechter versus de legitimatie van de rechterlijke macht: het toetsingsrecht}

Traditioneel vormt de bovenstaande (enge) conceptie van de trias politica de aanzet tot het klassieke argument - ook: 'democratieargument' - tegen de bevoegdheid van de rechter om wetten aan de Grondwet te toetsen (toetsingsrecht), dat door Cliteur eerder aldus werd samengevat: "Een wet in formele zin is het produkt van de democratisch gecontroleerde wetgever (-), en wanneer de rechter als een niet democratisch gecontroleerd orgaan vervolgens die produkten van de wetgever zou gaan toetsen dan is dat te beschouwen als een inbreuk op de democratiegedachte. ${ }^{m 10}$ Het verbod tot toetsing van de formele wet aan de Grondwet is neergelegd in art. $120 \mathrm{GW}$. Dit verbiedt de rechter de grond-
8. Bijl. Hand. II 1990-1991, 21427 , nr. 3, p. 6
9. Bijl. Hand. II 1990-1991, 21427 , nr. 3, p. 40
10. P.B. Cliteur, Argumenten voor en tegen constitutionele toetsing, NJB, 1989, p. 1369 
wettigheid van wetten en verdragen te beoordelen. Volgens de Hoge Raad omvat dit verbod ook de toetsing van de totstandkoming van wetten en verdragen aan de Grondwet ${ }^{11}$, en de toetsing van wetten en verdragen aan ongeschreven rechtsbeginselen. Dit laatste besliste de Hoge Raad in het z.g. Harmonisatiewet-arrest ${ }^{12}$, onder verwijzing naar de handhaving van het toetsingsverbod bij de grondwetsherziening van 1983 (zie ook hierna). Bovendien moet volgens de Hoge Raad in aanmerking worden genomen dat een ruim toetsingsverbod 'wezenlijk' is voor de 'traditionele plaats van de rechterlijke macht in ons staatsbestel en dat niet kan worden gezegd dat over de wenselijkheid daarin verandering te brengen in brede kring overeenstemming bestaat." Het is overigens opmerkelijk dat de Hoge Raad twee jaar later, zoals we nog zullen zien, als hij positief adviseert aan de regering inzake het toetsingsrecht, weinig belang meer hecht aan deze opvattingen uit de 'brede kring'.

Het 'toetsingsverbod' in art. $120 \mathrm{GW}$ laat intussen veel toetsing overeind, zóveel dat materieel vrijwel hetzelfde effect bereikt kan worden als bij een grondwettelijke toetsingsbevoegdheid voor de rechter. Zo bepaalt de Grondwet sinds 1953 (art. 94) dat binnen het Koninkrijk geldende wettelijke voorschriften geen toepassing vinden, indien deze toepassing niet verenigbaar is met een ieder verbindende bepalingen van verdragen en van besluiten van volkenrechtelijke organisaties. Daarmee is het toetsingsverbod van art. $120 \mathrm{GW}$ goeddeels omzeild, want in internationale verdragen zijn soortgelijke grondrechten als in de Grondwet neergelegd. Het probleem van de toetsing van de grondwettigheid van (de totstandkoming) van wetten en verdragen aan ongeschreven rechtsbeginselen blijft echter overeind. ${ }^{13}$ Wèl mag de rechter regelgeving van lagere wetgevers dan de formele wetgever toetsen aan de Grondwet, en ook acht 'de' ${ }^{14}$ rechter zich bevoegd lagere regelgeving te toetsen aan algemente rechtsbeginselen.

11. HR 27 januari 1963, NJ 1963, 248

12. HR 14 april 1989, AB 1989, 207

13. Maar dat probleem zou met een toetsingsbevoegdheid voor de rechter ook niel automatisch zijn weggenomen.

14. De bevoegdheid tot toetsing van andere algemeen verbindende voorschriften dan de formele wet aan hogere algemeen verbindende voorschriften en algemene rechtsbeginselen is in de jurisprudentie ontwikkeld. Daarbij moet worden onderscheidentussen de administratieve rechters dic al sinds 1935 aan ongeschreven rechtsbeginselen toetsen (een uitzondering vormde tot 1988 de Arob-rechter) en de gewone rechter die pas sinds 1971 toetst aan algemene rechtsbeginselen. Zie hierover F.A.M. Stroink, Rechterlijke organisatie en rechtspraak in beweging, 1993, p. 36 e.v. 


\subsubsection{Het toetsingsrecht en de legitimatie van de rechter}

Het toetsingsverbod wordt thans door veel auteurs om een veelheid van redenen verworpen. ${ }^{15}$ Het meest gehoorde bezwaar tegen het toetsingsverbod werd hiervoor al genoemd, en behelst de inconsequentie dat de rechter een formele wet wel buiten toepassing mag (moet) laten wegens strijd met een ieder verbindende verdragsbepalingen maar niet met de Grondwet. Dit bezwaar is echter niet het sterkste. Het sluit weliswaar aan bij de gegroeide praktijk dat het toetsingsverbod feitelijk omzeild wordt via art. $94 \mathrm{GW}$, maar geeft geen antwoord op de principiële vraag die aan het democratieargument ten grondslag ligt, nl. welk orgaan voor de beoordeling van de grondwettigheid van wetten en verdragen gelegitimeerd is. En juist door die vraag wordt (werd) de discussie over het toetsingsrecht (en later die over het rechterlijk activisme) traditioneel gedomineerd.

Reeds bij de invoering van het toetsingsverbod in $1848^{16}$ koppelt het Tweede Kamerlid Sloet de bevoegdheid tot interpretatie van grondwetsbepalingen aan de democratische legitimatie van de Staten-Generaal, of - omgekeerd - verwerpt hij de bevoegdheid tot toetsing van de formele wet aan de Grondwet door de rechter wegens het ontbreken van die legitimatie bij de rechterlijke macht:

"Na hetgeen ik de eer had te ontvouwen, behoef ik niet te verklaren dat de regtstreeksche deelneming des volks aan de wetgeving bij mij geenen tegenstand ontmoet. (-) De wetgevende magt is als de eerste in den Staat te beschouwen. Wat zij verordent, moet voor allen verbindend wezen, door allen geëerbiedigd worden. Niemand, zelfs niet eene der andere magten, mag daar inbreuk op maken. De rijks-wetten moeten onschendbaar wezen. De regterlijke magt moet niet in eene beoordeeling der innerlijke waarde treden. Doet zij dit, dan verheft zij zich boven haar standpunt en er zoude eene regterlijke almagt ontstaan, meer te vreezen dan de grootste aanmatiging van wetgeving of uitvoering. Wat dezen verkeerd mogten doen, is voor herstel vatbaar; wat een regterlijk gewijsde, dat ook onschendbaar is, bederft, kan niet veranderd worden. ${ }^{17}$

Sloet had kennelijk nog een onbegrensd vertrouwen in een soepele werking van het parlementaire stelsel, en hij stond daarin niet alleen. Hoewel de grond-

15. Zie P.B. Cliteur, o.c. p. 1369 e.v.

16. Art. $115 \mathrm{GW}$ 1848: "Alle voorstellen van wet, door de Koning en de beide kamers der Staten-Generaal aangenomen, verkrijgen kracht van wet en worden door den Koning afgekondigd.

De wetlen zijn onschendbaar. "

17. Hand. II, $1847-1848$, p. 890 
wetsherziening van 1848 over het toetsingsrecht verre van helder is ${ }^{18}$, moet het wantrouwen tegen de rechter - als we G.J.T. Beelaerts van Blokland mogen geloven - ook aan de opstellers van deze grondwetsbepaling hebben voorgestaan. Uit zijn prive-correspondentie met J.M. de Kempenaer, een van de voormannen van de grondwetsherziening 1848, weet hij in een polemiek met Opzoomer het volgende citaat op te diepen:

"De woorden de wetten zijn onschendbaar, aan art. 115 der Grondwet toegevoegd, zijn van D. Donker Curtius afkomstig. Hij keurde het af wanneer de rechters niet ex lege maar ex cerebrina quadam aequitate hunne uitspraken putten; meer nog, wanneer zij zich boven den wetgever plaatsten en in stede van recht te spreken tusschen den man en zijnen naaste, zich opwierpen tot rechters over den wetgever, en zijne wetten beoordeelden en veroordeelden. Dikwerf hoorde ik hem zeggen: de rechterlijke tyrannie is de ergste van allen. (-) De wetten moeten door allen, zonder onderscheid, in den Staat worden geëerbiedigd en nageleefd. (-) Houdt men dat beginsel niet gestreng vast, dan worde de rechterlijke macht niet onder of zoo men liever wil naast, maar boven de wetgevende macht geplaatst, en haar een gezag toegekend, zeer nadeelig voor de orde, zelfs zeer nadeelig voor de rust in den staat. ${ }^{19}$

Het beroep op de brief van De Kempenaer is - dit terzijde - voor Beelaerts van Blokland waarschijnlijk een noodsprong geweest, want in de hoofdstukken hiervoor bleek dat hijzelf in het algemeen aanzienlijk meer vertrouwen had in de rechter dan in de wetgever. ${ }^{20}$ Het argument heeft 123 jaar later, in 1971, echter weinig aan kracht verloren, want de beperkte legitimatie van de rechter (en op de achtergrond wellicht ook de vrees voor een 'dikastocratie'? ${ }^{21}$ ) vormt nog steeds de hoofdreden voor de meerderheid van de Staatscommissie van Advies inzake de Grondwet en de Kieswet om slechts een beperkte toetsingsbevoegdheid (nl. toetsing aan de klassieke grondrechten) te adviseren:

"Interpretatie van grondwetsbepalingen dient naar het oordeel van de staatscommissie in laatste instantie aan de wetgever te worden overgelaten. Immers, de wetgever is bij uitstek het orgaan, dat politieke verantwoordelijkheid draagt.

18. De memorie van toelichting merkt over de zinsnede: 'De wetten zijn onschendbaar' slechts op: "De onschendbaarheid der welten heeft eene driedubbele beteekenis. Zij plaatst de wet boven alle bedenking; zij waarborgt haar tegen alle aanranding zoowel van de uitvoerende en regterlijke magt, als van de plaatselijke autoriteiten, aan wie, alleen behoudens de wet, het vaststellen van plaatselijke verordeningen is toegekend." MvT, Bijl. Hand. Il 1847-1848, XLIX, nr. 6, p. 345

19. G.J.T. Beelaerts van Blokland, De onschendbaarheid der wet, 1868, p. 209

20. Zie $\$ 2.8 .1 .2$, $\$ 3.8 .2$ en $\$ 5.5 .3$

21. Zie bijvoorbeeld: Erik Jurgens, Onbegrijpelijk vonnis van Haagsche president Wie is de baas: de rechter of het parlement? in: De Tijd, 19 augustus 1988 
Invoering van het rechterlijk toetsingsrecht op het gehele terrein van de Grondwet zou de rechter in optima forma op het gebied van de politieke strijdvragen brengen." ${ }^{\text {t22 }}$

Met het ontbreken van 'politieke verantwoordelijkheid' bij de rechter doelt de Staatscommissie op beslissingen die tot stand komen "in de geheime raadkamers van de niet-verantwoordelijke rechterlijke hiërarchie, waarbinnen de doorstroming veel trager verloopt dan in de vertegenwoordigende colleges." Ook de regering - die het advies van de Staatscommissie volgt - meent: "Het inhoud geven aan dergelijke begrippen (klassieke en sociale grondrechten, $M d W)$ behoort meer thuis bij het democratisch gekozen parlement en de aan dat parlement verantwoording schuldige Regering. "23

Bovenstaande bezwaren vormen traditioneel niet het enige, maar wel het belangrijkste argument tegen ${ }^{24}$ het toetsingsrecht, al wordt het bezwaar van het ontbreken van democratische legitimatie tegen de invoering van het toetsingsrecht de laatste jaren meer en meer gerelativeerd. Waar de Hoge Raad in 1970 nog aan de regering adviseert dat "toetsing van de wet aan de Grondwet de rechter [zou] kunnen betrekken in een politicke strijd waarin hij met het oog op zijn positie niet thuis hoort ${ }^{\text {"25 }}$, noemt hij in 1991 het bezwaar dat de rechter, "wegens zijn wijze van benoeming en onafhankelijkheid minder gelegitimeerd is te oordelen over bij de beoordeling van wetgeving betrokken politieke vragen dan de wetgever, waarvan de gekozen volksvertegenwoordiging een belangrijk element is, tenwijl uiteindelijk verantwoording moet worden afgelegd aan de kiezers (-) weinig sprekend". Niet kan immers worden gezegd, aldus de Hoge Raad,

22. Eindrapport van de Staatscommissie van Advies inzake de Grondwet en de Kieswet, 1971 , p. 254

23. Hand. II 1974-1975, 12944 , OCV p. 395

24. Overigens heeft het 'democratieargument' in het verleden juist ook wel dienst gedaan vóor constitutionele toetsing. Van Haeften ziet in 1911 grote voordelen in een toetsingsrecht voor de rechterlijke macht, "die eerder wit hoogstaande, ethisch denkende menschen, dan uit scherpzinnige, dikwijls maar al te spitsvondige juristen, moet bestaan". "Als eene instelling, die rekening houdt met de rechtsovertuiging, in het volk levende, is het loetsingsrecht ongetwijfeld eene democratische; doch uitgeoefend door een hoogstaanden rechterlijken stand, voorkomt het, dat de meerderheid van het volk haar wil doordrijf, doet het, wat werkelijk recht is heerschen, en is als zoodanig een uiting van aristocratische democratie." C.H.J. van Haeften, Rechter en Grondwet in verband met vrije rechtspraak, 1911, p. 60-61

25. Advies van de Hoge Raad der Nederlanden naar aanleiGing van het Tweede rapport van de Staatscommissie van advies inzake de Grondwet en de Kieswet, met name wat betreft het daarin voorgestelde artikel 14, gericht aan de Minister van Justitie, gepubliceerd in: Ned. Stcrt. 23 maart 1970, nr. 57 
"dat het daarbij in de regel gaat om vragen die eerder bij de wetgever thuis horen, of dat het gaat om belangen die zwaarder wegen of om gevolgen die dieper ingrijpen dan die welke in het algemeen aan de orde zijn bij de rechtsvormende taak die op andere gebieden aan de rechter is toevertrouwd. Men denke zowel aan rechtsvorming op de gebieden die geheel aan de rechter zijn overgelaten aan de hand van vage normen of door hemzelf te vormen ongeschreven recht (-) als aan de uitleg van wetten en verdragen op het terrein van de mensenrechten ". ${ }^{26}$

Hoewel de stellingname van de Hoge Raad meer pragmatisch dan principieel was, zette zij onmiskenbaar de toon voor de vergadering van de NJV in 1992. Prakke bijvoorbeeld - die in zijn proefschrift uit 1972 nog schrijft dat: "the allocation of the inevitably politically sensitive function of checking the lawmakers to a non-elected, non responsible judicial hierarchy, is clearly at odds with democratic principles of governmental power distribution" 27 - noemt het democratieargument in zijn preadvies uit 1992 niet eens meer. ${ }^{28}$

Toch wordt het democratieargument ook nu nog wel gehanteerd. ${ }^{29}$ Opmerkelijk is echter dat de legitimiteitsvraag niet wordt opgeworpen bij de toetsing door de rechter van de produkten van andere gekozen wetgevers (men denke alan verordeningen van gemeenteraad en provinciale staten). Het 'primaat' van de (formele) wetgever, waar de tegenstanders in de discussie over het toetsingsrecht zich veelal op beroepen, lijkt te worden verward met de omstandigheid dat 'lagere' regelgeving evenzeer burgers bindende rechten en verpliclitingen in het leven roept. Evenmin speelt het legitimiteitsprobleem bij de toetsing van formele wetten aan een ieder verbindende bepalingen van verdragen en aan besluiten van volkenrechtelijke organisaties, terwijl het toch wat wonderlijk is dat de principiële bezwaren tegen het toetsingsrecht, als gevolg van de enkele bevoegdheidstockenning in art. $94 \mathrm{GW}$, ten aanzien van verdragen en volkenrechtelijke organisaties, opeens niet meer bestaan. ${ }^{30}$ Tenslotte lijkt het legitimiteitsprobleem ook voor de toetsing van wetten aan internationale verdragen door (ook niet-Nederlandse) rechters niet te bestaan. ${ }^{31}$ En ook dat is merkwaardig, want als we, zoals het democratische perspectief doet (zie hierna), aannemen dat er een verband is tussen de legitimatie van de rechters en de

26. Advies van de Hoge Raad aan de minister van Justitie, brief van 31 oktober 1991

27. L. Prakke, Toetsing in het publiekrecht, 1972, p. 53

28. L. Prakke, Bedenkingen tegen het toetsingsrecht, preadvies, Handelingen NJV, 1992. p. $1-33$

29. Zie bijvoorbeeld: A.M.H. Dölle. Constitutionele toetsing, in: P.B. Cliteur en M.R. Rutgers, De trias onder spanning. 1990, p. 96 en P.W.C. Akkermans en A.K. Koekkoek, De Grondwet een artikelsgewijs commentaar, 1992, p. 1037-1038

30. De toetsing aan het EG-recht gaat zelfs buiten art. $94 \mathrm{GW}$ om

31. Men denke aan het Hof van Justitie en aan het Europese Hof voor de Rechten van de Mens 
wijze waarop de rechterlijke macht wordt samengesteld, dan schort het in niet geringe mate ook aan de legitimiteit van deze rechter. De leden van het Hof van Justitie bijvoorbeeld worden in onderlinge overeenstemming door de Regeringen van de Lid-Staten voor zes jaar benoemd'. ${ }^{32}$ Een voordrachtsbevoegdheid voor bijvoorbeeld het Europees Parlement, ter vervulling van vacatures in het Hof, zoals we dat in Nederland voor de Tweede Kamer kennen, ontbreekt. ${ }^{33}$

\subsubsection{Administratieve rechtspraak}

Een soortgelijke standpuntbepaling als bij het toetsingsrecht, treffen we aan in een heel andere discussie, namelijk in die over de bevoegdheid van de rechter tot administratieve rechtspraak. Ook hier wordt de rechtsprekende bevoegdheid van de rechter gekoppeld aan de (wijze van) samenstelling van het rechtsprekende orgaan. Deze discussie heeft echter, na de instelling van administratieve kamers bij de rechtbanken in $1992^{34}$, veel van haar relevantie verloren. Ik beperk mij, bij wijze van voorbeeld, daarom tot de bekendste tegenstander van de administratieve rechtspraak, A.A.H. Struycken, die in zijn pamflet Administratie of rechter uit 1910, het bezwaar van de gebrekkige legitimatie van de rechter wegens het ontbreken van een democratische samenstelling van de rechterlijke macht, aldus samenvat:

"Bovendien, het is reeds zoo dikwijls herhaald, de leiding van de administratie brengen bij den administratieven rechter, zou zijn, haar toevertrouwen aan een niet deskundig orgaan, niet deskundig in sociaal, niet deskundig in technisch opzicht. In sociaal opzicht niet deskundig is hij, die niet gedwongen is, mee te leven in de ontwikkeling der sociale ideeën, zooals deze in het ingewikkelde democratische stelsel ten slotte door de vertegenwoordigende organen worden voortgebracht; een verlicht rechter kàn dat doen, maar hij kan ook, als de jaren klimmen, trotsch op zijne zelfstandigheid, sociale ideeën trachten te verwezenlij$k e n$, behoorende tot de generatie, die aan de onze voorafging. Het zou eene zwakheid zijn onzer democratische cultuur, indien wij in arren moede, om der gerechtigheidswille, de leiding der administratie zouden moeten toevertrouwen aan een stand, die zich meer dan eenig andere kan sluiten buiten de ontwikkeling van de sociale ideeën der gemeenschap. ${ }^{\text {35 }}$

32. Art. 168a, derde lid, EEG-verdrag

33. De leden van het Europese Hof voor de Rechten van de Mens worden gekozen door de Raadgevende Vergadering uit een lijst van personen die wordt ingediend door de Leden van de Raad van Europa. Zie: art. 39, eerste lid, EVRM

34. Wet van 3 juni 1992 , Sib. 278

35. A.A.H. Struycken, Administratie of rechter, 1910, p. 43-44 (zie ook Struycken, o.c. p. 93) 
Elders stelt Struycken de vraag: "Is het onafzetbaar rechtercorps (-) waar de benoeming en de bevordering voor een goed deel worden bepaald door ancienniteit en connectie, het aangewezen organisme, om die leiding der administratie zich te zien toevertrouwd? ${ }^{136}$ Een retorische vraag, want Struycken is een van de weinige auteurs die de validiteit van waarborgen ${ }^{37}$ voor de onafhankelijkheid van de rechter(lijke macht) in twijfel trekken. In elk geval zijn het volgens Struycken niet déze waarborgen die de rechter gunstig van de administratie onderscheiden "waar toch de benoeming, verplaatsing en de bevordering geheel van de Regeering afhangen."

"Niet hare onafzetbaarheid, maar de algemeene moraliteit, de interne waarborgen voor eene behoorlijke rechtspraak, waaronder vooral de openbaarheid en de collegialiteit, gepaard aan de telkens wisselende bezetting der Regeering, behoeden de rechterlijke macht voor Regeeringscorruptie. ${ }^{38}$ De onafzetbaarheid heeft ten onzent thans m.i. geen andere beteekenis, dan dat door haar de discipline onder de leden der rechterlijke macht geheel in haar zelve besloten blijft, voor zoover ten minste die discipline niet door de Regeering als een gevolg van haar recht tot benoeming, overplaatsing en bevordering tevens kan worden uitgeoefend. Of de nadeelen van dit stelsel niet tegen de voordeelen opwegen, is eene ernstige, niet alleen in ons land in den laatsten tijd meer dan eens gestelde vraag. ${ }^{{ }^{339}}$

Dit laatste is natuurlijk een impliciete verwijzing naar de discussie over de merites van het voordrachten- en aanhevelingenstelsel, die al in het derde houfdstuk ter sprake kwam, al komt deze verdachtmaking aan het adres van de rechterlijke macht Struycken - gezien de strekking van zijn betoog - natuurlijk uitstekend van pas. Toch komt men in deze jaren dergelijke geluiden vaker tegen. Eerder, hij de invoering van de Bervepswet in 1902, zegt het Tweede Kamerlid Van Idsinga:

36. Struycken, o.c. p. 92

37. Hij noemt de regeling bij wet van de benoeming voor het leven, bet ontslag en de rechtspositie van de leden van de rechterlijke macht met rechtspraak belast

38. Opmerkelijk is de overeenkomst tussen (de volgorde in) deze passage bij Struycken en een alinea in de brochure van J. Pols Over het wetsvoorstel tot verandering in de wijze van benoeming van leden van de regterlijke magt, 1878, p. 5. Ook Pols is vol scepsis over de onafzetbaarheid van de rechter ("Moge dit bij andere volken anders aijn, wie kan een glimlach onderdrukken, wanneer dat beginsel ook ten onzent als het palladium van 's regteis onafhankelijkheid geroemd wordt? "), en ook hij zoekt de oplossing in de omstandigheid dat "onzen regeringsvorm en de invloed der openbare meening hier te lande de meest mogelijke waarborgen opleveren, dat niet ligtvaardig tot iemands ontslag zal worden overgegaan." Zie verder over de openbaarheid bij benoemingen: de interpellatie Hoynck van Papendrecht, \$3.7.1

39. Struycken, o.c. p. $47-48$ 
"Het is inderdaad te betreuren, dat de rechtspraak in onze landen allengskens ten eenenmale onttrokken is aan de directe medewerking van het geheele volk, en bijkans uitsluitend overgegaan is in handen van gestudeerde personen, die meerendeels uit bepaalde klassen worden gerecruteerd. Waarborg tegen standsvooroordeel en ambtenaarsopvattingen is, ook al staan de rechters individueel nòg zoo hoog, niet in voldoende mate aanwezig. ${ }^{40}$

Gezien het kennelijk geringe vertrouwen in de rechter is het opmerkelijk dat - als het er op aankomt, namelijk bij de (sterk verbrokkelde) invoering van de administratieve rechtspraak ${ }^{41}$ - juist over de benoeming van administratieve rechters een principiële discussie uitblijft. De waarschuwende woorden van Struycken over de neiging van het benoemingsstelsel tot een sociaal eenzijdig georiënteerde samenstelling van het rechterscorps, hebben weinig indruk gemaakt. ${ }^{42}$ Integendeel, de benoeming en de benoembaarheid van de leden van de raden van beroep en de Centrale Raad van Beroep, van de ambtenarengerechten, van het College van Beroep voor het Bedrijfsleven, de leden van de Afdeling Rechtspraak van de Raad van State ${ }^{43}$, en de leden van de Afdeling

\section{Hand. II 1901-1902, p. 1648}

41. Ik beperk mij tot de 'grote' administratieve rechters, t.w. de ambtenarenrechters (1929), en de leden van het College van Beroep voor het Bedrijfsleven (1954), de Afdeling Rechtspraak van de Raad van State (1975) en de Afdeling Geschillen van Bestuur (1987)

42. Ten onrechte overigens; zie de vertrouwenscrisis. en de achtergronden daarvan, in $\$ 4.5$

43. De invoering van de Afdeling Rechtspraak dateert van 1 mei 1975 Stb. 283. De benoemingseisen zijn gelijk aan die voor de Hoge Raad. Bij de invoering van de Afdeling Rechtspraak van Raad van State, meent de regering dat bij het toekomstig regeringsbeleid 'duidelijk aandacht' geschonken moet worden aan een bezetting in de Raad zodat voor de Afdeling 'bekwame leden' gevonden kunnen worden (MvT, Bijl. Hand. II 1970$1971,11280 \mathrm{nr} .3$ p. 10). Bij Nota van wijzigingen wordt daarom een aanbevelingsbevoegdheid voor de Raad toegevoegd (Bijl. Hand. II 1973-1974, 11 280, nr. 4 p. 2), waartegen echter kritiek rijst in de Tweede Kamer, omdat deze inspraak in de vorm van cen aanbeveling zou rieken naar 'coöptatie' (PvdA). Ook wenst de PvdA de zware opleidingseisen in het wetsvoorstel te laten vervallen. De regering kwam echter aan geen van beide verlangens tegemoet. Overigens werden in 1985 door de Staatscommissie Herziening Rechterlijke Organisatie bezwaren geuit tegen de (politieke) wijze van selectie van leden van de Raad van State, die bij hun aanwijzing al lid zijn van de Raad van State: "Omdat de hoofdtaak van de Raad ligt in zijn adviesfunctie over de wetgeving, wordt bij benoeming van de leden er zorg voor gedragen dat zij behoren tot, of zich verwant voelen aan, een van de grotere politieke partijen, zodat de Raad van State een zo goed mogelijke afspiegeling vormt van de politieke verhoudingen in met name de Tweede Kamer der Staten-Generaal. Tevens wordt er op gelet welke bestuurlijke of andere functie de te benoemen persoon in het maatschappelijk leven heeft gehad en welke ervaring hij aldus bij de genoemde adviestaak van de Raad kan inbrengen. De geschiktheid om een rechterlijke functie te kunnen gaan uitoefenen, staat bij een en ander niet altijd centraal. " Eindrapport Herziening Rechterlijke Organisatie, 1985, deel I, p. 25 
Geschillen van Bestuur ${ }^{44}$, is sterk geënt op het model van aanbeveling, benoeming en benoembaarheid van de leden van de (gewone) rechterlijke macht. Wel moet worden gewezen op het z.g lekenelement; bij de invoering van de raden van beroep in 1902, de Ambtenarenwet 1929 en het College van Beroep voor het Bedrijfsleven in $1954^{45}$, was voorzien in lekenrechters. ${ }^{46}$

In 1992, bij de invoering van de administratieve rechtspraak in de rechterlijke macht, hebben bovenstaande bezwaren goeddeels aan relevantie verloren, al blijft er volgens het PvdA-Tweede Kamerlid Jurgens, met een verwijzing naar Struycken, toch "een spanning tussen een ontwikkeling in de richting van een algehele juridisering van de samenleving, en de oude opvatting dat de rechter niet op de stoel van het bestuur moet gaan zitten, dat immers democratisch gelegitimeerd is. ${ }^{m 7}$

\subsection{De legitimatie van de rechter en de toegang tot het rechtersambt}

De gedachte dat het probleem in de discussie over de toetsingsbevoegdheid (wetgever of rechter?) en over de bevoegdheid van de (gewone) rechter tot administratieve rechtspraak (administratie of rechter?) zich toespitst op de legitimiteit van het toetsende orgaan, terwijl 'legitimatie' in verband wordt gebracht met (om niet te zeggen: afhankelijk wordt gesteld van) het vraagstuk van de toegang tot het rechtersambt, vormt de hottle neck in veel discussies over het rechterlijk toetsingsrecht en het rechterlijk activisme. J.M. Baren-

44. Opmerkelijk is dat de regering bij de invoering van deze administratieve rechter nauwelijks aandacht besteedt aan de bezwaren van de Raad van State en van de Tweede Kamer-fractie van de VVD, dat de voorgestelde Tijdelijke Wet Kroongeschillen geen voorziening treft dat in de Afdeling geschillen van bestuur niet-juristen geen zitting meer zullen hebben. In de Nota naar aanleiding van het verslag zegt de regering slechts "dat hel op termijn wenselijk is dat de rechtsprekende functie van de Raad van State alleen door juristen wordt uitgeoefend. " Nota naar aanleiding van het verslag, Bijl. Hand. II 1986-1987, 19947, nr. 5, p. 26

45. De Wet van 16 september 1954, Stb. 416 kende nog 'gewone' en 'bijzondere leden'. Voor de bijzondere ledengold een bijzondere procedure, waarin de product-. hoofdbedrijfen bedrijfschappen een voordrachtsbevoegdheid hadden. Volgens de regering vereiste deze functie bij de rechter o.a. 'inzicht in de sociaal-economische achtergrond van het optreden der bedrijfsorganisaties' (MvT, Bijl. Hand. II 1951-1952, 2493, nr. 3, p. 9). Deze bepaling verviel bij de Wet van 12 maart 1986. Stb. 99

46. Zie hierover bij N.H.M. Roos, Lekenrechters Een empirisch onderzoek naar hel functioneren van de lekenrechters bij de Raden van Beroep voor de sociale verzekeringen, 1982 , p. 13 e.v.

47. Hand. II 26 maart 1992 , p. 4133 
drecht vat de discussie op dit punt in zijn preadvies over het toetsingsrecht in 1992 aldus samen:

"Een uitgangspunt lijkt te zijn dat de rechter fundamentele beslissingen over de inrichting van de maatschappij neemt en dat deze beslissingen op éen of andere manier democratische legitimatie behoeven. In de gedachtengang van velen kan dat niet anders dan door de samenstelling van het beslissende orgaan een afspiegeling te laten zijn van die maatschappij. Het kiesstelsel waarborgt dat het parlement zo'n afspiegeling is. Het ligt wellicht voor de hand om ook een rechterlijk college als de Hoge Raad op een dergelijke manier te doen samenstellen. Ook daar kan dan uit de 'choc des opinions' een democratische beslissing tot stand komen. ${ }^{\text {"48 }}$

Dat het kiesstelsel een afspiegeling van de maatschappij 'waarborgt', valt gezien de bezwaren die daartegen eerder in hoofdstuk 1 werden ingebracht, moeilijk vol te houden. Van belang is hier echter slechts dat zelden van het door Barendrecht gesignaleerde perspectief wordt afgeweken. Niet zozeer de gemaakte stappen worden betwist als wel de onverbiddelijke, mechanische uitkomst van die stappen. Laat men in laatste instantie de interpretatie van grondwetsbepalingen over aan de rechter, of kent men anderszins een belangrijke taak toe aan de rechter bij de rechtsvorming ${ }^{49}$, dan kan het legitimiteitsconflict - zo lijkt het - slechts via de weg van de wijze van samenstelling van de rechterlijke macht worden opgelost. Hier ligt tevens het breekpunt in de discussie over het toetsingsrecht, want in het democratische perspectief kan het legitimiteitsconflict, zoals Barendrecht al aangeeft, 'logisch' gezien enkel worden opgeheven door voor de rechterlijke macht een analoge selectieprocedure in te voeren als die voor 'de' wetgever. ${ }^{50}$ Hier scheiden de wegen tussen de schrijvers die een 'afspiegeling' in de rechterlijke macht voorstaan, en zij die wijzen op de dreigende teloorgang van de onafhankelijkheid en onpartijdigheid van de rechter, wanneer deze in 'politieke strijdvragen' wordt betrokken. De uiterste consequentie - de verkiezing van rechters - wordt evenwel door niemand getrokken.

48. J.M. Barendrecht, Het constitutionele toetsingsrecht van de rechter, preadvies, Handelingen, NJV, 1992, p. 126

49. Zie bij 'rechterlijk activisme', $\$ 6.5$

50. En daarmee worden dan uitsluitend bedoeld de rechtstreekse verkiezingen voor de Tweede Kamer, en niet de getrapte verkiezingen voor de Eerste Kamer laat staan het stelsel van erfopvolging van de Koning. 
Kenmerkend voor de gedachtengang, die een verband aanneemt tussen de legitimiteit van de rechter en de toegang tot het rechtersambt, is de redenering van de eerdergenoemde Staatscommissie van Advies inzake de Grondwet en de Kieswet. Bij de algehele grondwetsherziening van 1983 wijst zij een algemene toetsingsbevoegdheid af omdat volgens haar de rechter dan 'op de stoel van de wetgever' zal plaatsnemen, en:

"dit zou dan kunnen impliceren, dat bijvoorbeeld overeenkomstig het voor de Staten-Generaal geldende representatieve stelsel ook de benoeming van rechters niet zonder volksinvloed zou mogen plaatsvinden. Daarbijkan dan gedacht worden aan een stelsel van verkozen rechters, zoals men dit in de meeste deelstaten van de U.S.A. vindt. ${ }^{\mathrm{m} 1}$

Die opmerking - zo moet de Staatscommissie gedacht hebben - zou de schrik voor een volledige toetsingsbevoegdheid voor de rechter er wel in krijgen. Maar evenmin als in het rapport van de Commissie-Deetman de stap van het toetsingsrecht naar de voordracht van de Tweede Kamer wordt beargumenteerd, zo wordt ook hier de stap van het toetsingsrecht naar rechtersverkiezingen thegelicht. Dat zou overigens ook niet meevallen. $Z_{o}$ is de verwijzing door de Stadtscommissie naar rechtersverkiezingen in de Verenigde Staten geen steekhoudend argument tegen een toetsingshevoegdheid voor benoemde rechters in ons land. Het toetsingsrecht van de Amerikaanse rechter is historisch immers geen reden geweest voor de invoering van dergelijke verkiezingen. Omgekeerd levert de aanwezigheid van rechtersverkiezingen trouwens ook geen argument voor het toetsingsrecht op. De (slechte) ervaringen die in Amerika zijn opgedaan met deze verkiezingen, hebben juist een argument opgeleverd, om de discussie over de taak van de rechter niet te voeren aan de hand van een al dan niet 'democratische' wijze van samenstelling van de rechterlijke macht. Het referentiekader voor de legitimatie van rechters, zoals dat in ons land gangbaar is, behoeft daarom enige nuancering.

\subsubsection{Relativering van het referentiekader}

Terwijl in het democratische perspectief een verband wordt aangenomen tussen de wijze van samenstelling van de rechterlijke macht en de bevoegdheid van de rechter tot grondwetstoetsing of tot administratieve rechtspraak, valt bij nadere beschouwing het begrip democratische legitimatie uiteen in twee onderdelen: de $k$ waliteit van het orgaan waaraan de aanstelling van rechters wordt overgela-

51. Eindrapport van de Staatscommissie van Advies inzake de Grondwet en de Kicswit, 1971 . p. 271 
ten en de periodiciteit van de aanstelling. Het gebrek aan democratische legitimatie vloeit immers niet enkel voort uit het ontbreken van verkiezingen maar ook uit het feit dat de benoeming van een rechter in ons land 'voor het leven' geschiedt. Door het ontbreken van periodieke verkiezingen wordt burgers - zoals Koopmans in zijn preadvies over het toetsingsrecht schrijft - de mogelijkheid onthouden om een rechter 'ter verantwoording' te roepen. Koopmans noemt dit het 'hoofdbezwaar tegen een grotere macht voor de rechter' (het toetsingsrecht):

"Het hoofdbezwaar tegen een grotere macht voor de rechter schuilt niet zozeer in de omstandigheid dat hij niet gekozen is (de minister van Justitie, de burgemeester van Amsterdam en de Nationale Ombudsman zijn dat ook niet), maar dat hij niet ter verantwoording kan worden geroepen. Als gewichtige maatschappelijke vragen door regering of kamers verkeerd worden aangepakt, zullen de politici dat merken bij de volgende stembusuitslag; en als een politicus zelf niet meer verkiesbaar is, zullen de kiezers hun gram verhalen op zijn partij. Burgemeesters en andere (halfambtelijke) bestuurders worden bedreigd met niet her-benoeming. Tegen een hoogste rechter die foute of impopulaire beslissingen neemt is echter weinig te ondernemen. Ressentiment van kiezers zal dan een andere uitweg zoeken. In de VS wordt vaak aangenomen dat het gebrek aan populariteit van vele rechterlijke beslissingen over rassenintegratie - bijv. met betrekking tot het 'bussen' van blanke schoolkinderen naar scholen in zwarte buurten - in het nadeel heeft gewerkt van de toen regerende Democraten. Republikeinse presidentskandidaten als Nixon en Reagan hebben in elk geval tijdens hun campagnes op deze ontevredenheid ingespeeld. ${ }^{\mathrm{s} 2 \mathrm{2}}$

Het is echter de vraag of - zoals het democratische perspectief veronderstelt verkiezingen voor rechters het referentiekader bij uitstek zijn om de democratische legitimatie van een rechter te bepalen. Terwijl bij een benoeming onder ministeriële verantwoordelijkheid de minister door de volksvertegenwoordiging voor de benoeming verantwoordelijk is, bestaat bij een verkiezing van rechters (uiteraard) geen verantwoordingsplicht voor degene die de keus bepaalt (de kiezer) aan een volksvertegenwoordigend college. Juist dit verschil is in de Verenigde Staten van groot praktisi h belang gebleken. Anders dan bij verkiezingen, kan onder een stelsel van ministeriële verantwourdelijkheid namelijk een benoemingsbeleid worden gevoerd (regering) c.q. worden afgedwongen (volksvertegenwoordiging), waardoor meer gestructureerd een debat plaatsvindt (zou kunnen plaatsvinden) over de wenselijke uitgangspunten bij benuemingen. $\mathrm{Bij}$ rechtersverkiezingen ontbreekt echter een controle op het aanstellende orgaan (de kiezer). Dit heeft zoals we in hoofdstuk 5 zagen, belangrijke gevolgen voor de kwaliteit van de rechterlijke macht, omdat slechts weinigen 
zich geroepen voelen om het niveau van de kandidaatstelling te controleren, terwijl door het gebrek aan onderscheidend vermogen van de kiezer, van een serieuze keuze tussen de kwaliteiten van de ene en de andere rechter(-skandidaat) geen sprake is. Daarom oriënteren alternatieve selectiemethoden zich minder op de methode (benoeming of verkiezing) voor de samenstelling van de rechterlijke macht, dan op het effect van die methode (vergelijk de discussie over merit selection).

\subsubsection{De verkiezing versus de benoeming van rechters als schijncontroverse}

De Amerikaanse literatuur beschouwt, gezien de ervaringen die met rechtersverkiezingen zijn opgedaan, de vermeende controverse tussen de benoeming en de verkiezing van rechters als uitgangspunt voor het debat over de democratische legitimatie van de rechter, meer en meer als een valse tegenstelling. Overigens moet men daarbij in het oog houden dat - in de deelstaten - voor het bepalen van de democratische legitimatie van de rechter, niet de rechtstreekse volksinvloed op zijn aanstelling, maar de professionele kwaliteit van de magistratuur allengs het doorslaggevende criterium lijkt te zijn geworden; het ene schijnt, in de Amerikaanse situatie althans, niet samen te gaan met het andere. Het debat over merit selection in de Verenigde Staten, laat de evolutie in het denken over de wijze van aanstelling van rechters haarscherp zien. Terwijl in het oorspronkelijke Albert Kales-Plan uit 1914 de politieke verantwoordelijkheid voor een rechtersbenoeming nog ligt bij de chief justice, die slechts door een (her)verkiezing ter verantwoording kan worden geroepen ${ }^{53}$, verschuift die verantwoordelijkheid in de loop der jaren naar een 'ministeriële' verantwoordelijkheid van de gouverneur in het California- en later in het Missouri-Court Plan. ${ }^{\$ 4}$ Daarbij moet eerlijkheidshalve wel worden gewezen op de omstandigheid dat ook onder een systeem van merit selection, naast de benoeming onder ministeriële verantwoordelijkheid, een (zij het sterk afgezwakte) vorm van verkiezingen wordt gehanteerd.

Evenmin als men rechtersverkiezingen dus kan verklaren uit het toetsingsrecht van de Amerikaanse rechter (of het toetsingsrecht kan verklaren uit rechtersverkiezingen) kan men zeggen dat periodieke verkiezingen het referentiekader bij uitstek zijn voor de democratische legitimatie van een rechter. Het 'zelfreinigende effect' van verkiezingen is immers een illusie gebleken. "Too much thought has been given to the matter of getting less judges off of the bench. The

53. Door de periodieke (her-) verkiezing van de chief justice was overigens wel in enige verantwoordelijkheid van het benoemende orgaan voorzien.

54. Zie $\$ 5.7$ 
real remedy is not to put them on", stelt Roscoe Pound dan ook in 1944, in een voorwoord bij het standaardwerk van Evan Haynes over rechtersselectie (het voorwoord werd tragisch genoeg beroemder dan het boek zellf):

"Want of clear and definite individual responsibility for nominations or appointments has been behind a falling off in the quality of the bench in more than one jurisdiction in the present century. Despite occasional unfortunate appointments, the quality has held up best in jurisdictions where there is manifest responsibility on some person, if not to make the best choice possible, at any rate not to make conspicuously poor choice. ${ }^{\text {s5 }}$

Dit zijn overigens geen nieuwe geluiden voor ons land. We herkennen hierin immers de scepsis die in de vorige eeuw tegen de voordracht van de Tweede Kamer voor vacatures in de Hoge Raad en tegen de aanbevelingen van de gerechten werd ingebracht (zie hoofdstuk 3). "Het is in beide in zekere mate eene ondervanging van de verantwoordelijkheid van de instellingen, die de keuze zullen moeten doen", aldus het Tweede Kamerlid Van Eck in $1860^{56}$, en om die reden verwerpt ook Beelaerts van Blokland in 1886 de verkiezing van raadsheren in de Hoge Raad door de (toen nog 86 leden tellende) Tweede Kamer:

"Ik vraag het $U$, Mijne Heeren, wie onzer gevoelt zich aansprakelijk als na stemmingen en herstemmingen eene voordracht is opgemaakt, waartoe men in het gunstigste geval voor 1/86 heeft medegewerkt, en die men wellicht voor 1/86 heeft trachten te keeren, wanneer onze keuze op anderen was gevallen? (-) Er moet iemand zijn op wien de schande voor eene slechte benoeming terugvalt, die zich daardoor zou compromitteren." ${ }^{57}$

Overigens moet men zich van die veel geroemde ministeriële verantwoordelijkheid voor rechtersbenoemingen, in de Nederlandse verhoudingen althans, (nog) niet al te veel voorstellen. Tot op heden is zij voor de benoeming van een rechter nog nooit ingeroepen, hetgeen - afgaande op de woorden van de minister van justitie De Ruiter, in 1981 ook niet echt verbaast. Gevraagd naar de betekenis van de ministeriële verantwoordelijkheid voor rechtersbenoemingen, maakt deze ter plekke nieuw staatsrecht, door te verklaren dat de Tweede

55. Evan Haynes, The selection and tenure of judges, 1944, p. xii-xiii

56. Hand. II, 1860-1861. p. 170

57. Hand. II 1886-1887, p. 1602 Zie ook: J.T. Buijs: "Is om die reden het groote recht, hier aan de Tweede Kamer vegekend, ook in hare handen betrekkelijk veilig, dat het daar veiliger zou liggen dan in handen van de Regeering zal ik warlijk niel beweren, ondat men dan toch in den verantwoordelijkheid van den minister waarborgen vindt, die in eene groote, geheel onverantwoordelijke, politieke vergadering vruchteloos worden

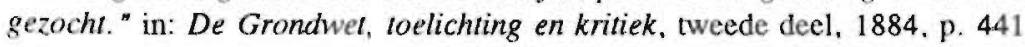


Kamer "niet het aangewezen controle-orgaan' is om hem ter verantwoording te roepen voor concrete benoemingen in de rechterlijke macht. ${ }^{158}$ Wie in dezen dan wél het aangewezen controle-orgaan is, verzuimde de (wellicht verbouwereerde) vragensteller, het Tweede Kamerlid Faber (C.DA), helaas te vragen.

\subsection{Rechterlijk activisme}

Kan men zeggen dat de discussie over het vraagstuk van de toegang tot het rechtersambt bij het toetsingsrecht een hypothetisch probleem betreft (invoering (netsingsrecht blijft - in beginsel ${ }^{\$ 9}$ - immers uit), een werkelijk probleem rijst wanneer de rechter - in termen van het democratische perspectief - de grens tussen recht en politiek overschrijdt, ook wel 'rechterlijk activisme' gennemd. De discussic over het 'rechterlijk activisme' is voor (onderdelen van) het vrdagstuk van de toegang tot het rechtersambt van groot belang geweest, omdat het de ideeën daaromtrent in een stroomversnelling heeft gebracht. Zoals de vertrouwenscrisis in de jaren zestig de aanzet vormule voor een pleidnoi vonr een 'bredere' samenstelling van de rechterlijke macht, en uitmondde in de insteliing van de Commissie aantrekken leden rechterlijke macht, zo is de discussie over het rechterlijk activisme in de jaren tachtig en negentig de katalysator geweest bij ontwikkelingen die zich hebben voorgedaan ten aanzien van de benoemingsprocedure van de leden van de Hoge Ridad. bij de henoeming in promotiefuncties en de toelaatbaarheid van neventuncties. ${ }^{\text {at }}$

Intussen valt het - anders dan bij het toetsingsrecht - niet mee aan te geven waar het bij 'rechterlijk activisme' precies over gaat. "The clearest definition I could give you is what Justice Potter Stewart said about obscenity. He said he could not define it, but he knew it when he saw it. I know activism when I see it, and I would define it by saying that if a question is unanswered in the law, and a judge is called upon to provide an answer, he or she should do it with the least possible exercise of power", aldus Griffin Bell, in een radio-interview in 1981. ${ }^{61}$ Hoewel dit meer een opvatting dan een definitie is, komt Bell toch dicht in de buurt van de definitie van de vergadering van de NJV, die in 1975 sprak over "zaken die hij (de rechter, MdW) niet kan beslissen, zonder

58. Hand. I1, 2 december 1981, p. 739

59. Zie echter het reeds genoemde art. $94 \mathrm{GW}$ dat (de rechter) verplicht wettelijke voorschriften buiten toepassing te laten, indien die toepassing niet verenigbaar is met een ieder verbindende bepalingen van verdragen en van besluiten van volkenrechtelijke organisaties.

60. Zie verder hoofdstuk 4

61. John Charles Daly, Whom do jud'ges represent?, publikatie van een radiouitzending op i juni 1981 , p. 22 
een standpunt in te nemen ten aanzien van vragen die in de samenleving fel omstreden zijn en waarop hij geen duidelijk antwoord in het positieve recht windt. ${ }^{\prime 62}$ Rechterlijk activisme kan in deze visie dus de concrete toetsing van wetten aan de grondwetsbepalingen omvatten, maar omgekeerd is grondwets(grondrechts-)toetsing niet per definitie 'activistisch'. Dat blijkt ook wel als in $199158 \%$ van de Nederlandse rechters zegt voorstander te zijn van het toetsingsrecht, terwijl $85 \%$ van alle rechters tevens meent dat de wetgever te veel 'politiek moeilijke problemen' overlaat aan de rechterlijke macht. ${ }^{63}$

Onder de term rechterlijk activisme gaat een veelheid van rechtsvorming, door verschillende soorten (gewone en administratieve) rechters, in verschillende hoedanigheden (rechters in eerste aanleg, in beroep en in cassatie) schuil. Het kan bij rechterlijk activisme gaan om de toetsing van algemeen verbindende voorschriften (inclusief de formele wet) aan internationaal recht $^{64}$, en de toetsing van lagere regelgeving dan de formele wet aan de Grondwet. Maar rechterlijk activisme omvat $606 \mathrm{k}$ de invulling van open wettelijke rechtsnormen als 'redelijkheid' en 'billijkheid' in het burgerlijk recht, en ók de rechtsvorming die niet rust op een expliciete wettelijke toetsingsopdracht (men denke hier bijvoorbeeld aan de toetsing aan ongeschreven rechtsbeginselen, zoals die - eerst door de administratieve rechter, en in de jaren tachtig vooral ook door de gewone rechter - is ontwikkeld). Het is - niet helemaal terecht - vooral die laatste categorie die als een blikvanger fungeert, en waaromheen de discussie over rechterlijk activisme in verband met de samenstelling van de rechterlijke macht zich afspeelt. Enkele 'klassieke' voorbeelden van deze soort activisme, en de problemen die daarbij met betrekking tot het vraagstuk van de toegang tot het rechtersambt kunnen rijzen, kwamen reeds in hoofdstuk 4 aan de orde, zoals b.v. het stakingsrecht (zie de kwesties-Van den Biesen en -Cnoop Koopmans). Te denken valt ook aan de discussie over euthanasie of de gelijke behandeling van alternatieve samenlevingsvormen.

De term 'rechterlijk activisme' krijgt, in samenhang met uitdrukkingen als 'wetgever-plaatsvervanger', die zoals we zagen rechtstreeks afkomstig lijkt te zijn uit de machtenscheiding, gemakkelijk een ongunstige betekenis, als zou het gaan om een chique vorm van landjepik. Die opvatting moet echter worden genuanceerd. Nog afgezien van de omstandigheid dat een rechter volgens art.

62. Vragpunt 1 op de vergadering van de NJV 1975. Handelingen NJV, 1975

63. Genoemd worden: het stakingsrecht, euthanasie, gelijke behandeling van homosexuelen en het toekennen van rechten/plichten aan diverse samenlevingsvormen. Zie: Marc Josten en J. van Tijn, De rechterlijke macht van Nederland: een geruststellend gezelschap, Vrij Nederland, 2 november 1991, p. 32

64. Met name moet gewezen worden op de jurisprudentie van het Europese Hof voor de Rechten van de Mens en van Het Hof van Justitie van de EG 
13 Wet Algemene Bepalingen niet mag weigeren 'regt te spreken, onder voorwendsel van het stilzwijgen, de duisterheid of de onvolledigheid der wet' (hij kan daarvoor zelfs vervolgd worden wegens rechtsweigering ${ }^{65}$ ), ligt de toetsingsopdracht veelal in de wet zelf besloten (zie hiervoor). De rechter maakt zichzelf niet alleen 'breed', maar wordt, zoals J.Th.J. van den Berg opmerkt, ook breed gemaakt. ${ }^{66}$ Niet zelden beroept de regering zich bij het uitblijven van wetgeving op het argument dat aldus een gevoelig vraagstuk kan 'uitkristalliseren' in de rechtspraak. En komt het bij zulke vraagstukken - ik denk aan euthanasie en gelijke behandeling - toch tot wetgeving, dan lijkt al voordat het voorstel het Staatsblad heeft bereikt, mét de toetsingsopdracht aan de rechter, tevens het legitimiteitsconflict waarin de rechter onvermijdelijk terecht zal komen gegeven.

\subsubsection{Analoge probleemstelling}

De aard van het legitimiteitsprobleem bij rechterlijk activisme is intussen in grote delen dezelfde als bij het toetsingsrecht. Ook hier rijst - blijkens de literatuur - redenerend vanuit de machtenscheiding een legitimiteitsconflict, veroorzaakt door een gebrekkige ('ondemocratische') wijze van aanstelling van rechterlijke ambtenaren. Bij het vonnis van de Haagse president Wijnholt in 1988 bijvoorbeeld, waarin deze uitspreekt dat wetten getoetst kunnen worden aan het Statuut voor het Koninkrijk, schrijft de Volkskrant dat Wijnholt 'de pijlers onder het constitutionele bestel heeft weggeslagen': "De Montesquieus model van de trias politica -de onderscheiding van staatsfuncties in wetgevende, uitvoerende en rechterlijke macht- lijkt afgedaan te hebben. (-) De rechter neemt plaats op de stoel van de wetgever. ${ }^{n 67}$ De hoogleraren Prakke, Jurgens en Degenkamp reageren in soortgelijke bewoordingen: "je moet geen democratische waarborgen -de macht van de volksvertegenwoordiging- door niet gekozen, onafzetbare rechters onderuit laten halen" (Prakke). ${ }^{6} \mathrm{Net}$ als bij de discussie over het toetsingsrecht wordt de oplossing voor het legitimiteitsprobleem gezocht in de wijze van aanstelling van rechterlijke ambtenaren, en ook hier wordt het meest voor de hand liggende alternatief: rechters-

65. Art. 13 Wet AB De wet zegt overigens niet door wie vervolging wordt ingesteld

66. J.Th.J. van den Berg. De rechter als Derde Macht, in: Rechters en politiek, 1993, p. 25 e.v.

67. Presiden toetst harmonisatiewet op deugdelijkheid van bestuur Haagse rechter wijst revolutionair vonnis tegen Deetman, De Volkskrant, 12 augustus 1988

68. Bij: Gijs Schreuders, Prof. mr. Prakke: 'Van rechter moet je niet 'n soort vermomde politicus maken', Utrechts Nieuwsblad, 30 augustus 1988 Zie in gelijke zin: Erik Jurgens, Wie is de baas: de rechter of het parlement?. De Tijd, 19 augustus 1988 en J. Th. Degenkamp, Rechters moeten geen staat in de staat gaan vormen, Haagsche Courant, 22 juni 1992 
verkiezingen, afgewezen. 'Lex Dura' (Vrij Nederland) laat, naar aanleiding van het vonnis van Wijnholt, het democratische perspectief nog eens in volle omvang de revue passeren:

"Elk wettelijk systeem tobt met het probleem van de soevereiniteit, tenminste zolang er een idee van machtenscheiding leeft. Als wetten mogen worden vastgesteld door gekozen vertegenwoordigers, en voor die gedachte is heel wat gunstigs te zeggen, en als rechters ook een oordeel mogen geven over de inhoud van wetten en buiten beschouwing mogen laten wat zij daarin voor onjuistheden aantreffen. dan zullen rechters ook gekozen moeten worden in plaats van benoemd. Maar aan de gekozen rechter kleven veel bezwaren, en daarom is die onafhankelijk en onafzetbaar gemaakt. De keerzijde daarvan is, systematisch bezien volstrekt terecht, dat de rechter met zijn vingers van wetten behoort af te blijven. ${ }^{169}$

\subsubsection{Afspiegeling}

De discussie over het rechterlijk activisme is in zekere zin veel interessanter dan die over het toetsingsrecht, omdat er geen tijd en plaats is voor een patstelling tussen voor- en tegenstanders, terwijl het forum aanzienlijk breder is (al levert dit weinig nieuwe gezichtspunten op). Het enkele verweer dat de rechter tot 'activisme' niet gelegitimeerd en bevoegd is - vergelijk de discussie over het toetsingsrecht -, plaatst de tegenstander buiten het debat, en maakt bovendien zijn zaak er niet sterker op. Immers, rechterlijk activisme heeft in hoge mate het karakter van een fait accompli, of - onaardiger gezegd - van een overval; nog voordat vastgesteld is dat de rechter niet democratisch gelegitimeerd is, en hij -zoals Lex Dura het stelt- dus ook 'met zijn vingers van wetten behoort af te blijven', is het 'kwaad' al geschied, en wordt men geconfronteerd met een rechterlijke uitspraak, veelal in kort geding. Het fait accompli dat het rechterlijk activisme, anders dan het toetsingsrecht, is zet de discussie over de legitimatie van de rechter, en daarmee kennelijk ook die over de benoeming van rechters, onder zware druk (zie bijvoorbeeld de kwestie-Van der Burg). Wellicht heeft deze dwangpositie meegewerkt aan de ontwikkeling van het idee van 'afspiegeling' zoals dat met name in de laatste jaren school heeft gemaakt.

Afspiegeling is, net als rechterlijk activisme, een (bewust?) uiterst vage conceptie, waarvan de strekking al in 1887 door de liberaal De Ranitz aldus onder woorden werd gebracht: "De Hooge Raad behoort niet te zijn eene coterie, die geheel staat buiten het volk; tusschen dat volk en dien Raad moet een band zijn, die Raad mag niet geheel vreemd blijven aan hetgeen in de natie omgaat. Eenige terugslag van hetgeen in het volk leeft en werkt, mag niet 
gemist worden in het hoogste rechterlijk college. ${ }^{m 70}$ In grote lijnen gebruikt de discussie over rechterlijk activisme nog altijd de probleemstelling uit Rechter en politiek uit 1973 van A.J. Cnoop Koopmans, waarin de verwevenheid van recht en politiek als het ware in een democratisch benoemingsstelsel wordt verdisconteerd. ${ }^{71}$ Aanvankelijk is het begrip afspiegeling vooral gebruikt in verband met de 'democratisering' van de rechterlijke macht in de jaren zestig en zeventig ${ }^{2}$; recent wordt het echter vooral gebruikt om het vermeende legitimiteitsgebrek van de rechter bij rechterlijk activisme te ondervangen. De wijziging van de voordrachtsprocedure voor vacatures in de Hoge Raad in $1992^{73}$ onderstreept hoe de Tweede Kamer, redenerend via de stappen van het democratische perspectief, zoekt naar mogelijkheden om het gebrek aan legitimatie van de rechter te ondervangen. De nieuwe taak(-stelling) van de rechter zèlt staat niet meer ter discussie; veeleer lijkt het er op dat de Tweede Kamer via een omweg haar greep op de rechtsontwikkeling probeert terug te krijgen. Wat De Ranitz in 1887 nog 'enige terugslag van hetgeen in het volk leeft en werkt' noemt, heet vandaag 'het venster op de samenleving' of 'inzicht in maatschappelijke wortels'. ${ }^{74}$

Maar ook elders, namelijk in de jurisprudentie van de Commissie voor de Rechten van de Mens, lijkt het begrip 'afspiegeling' voet aan de grond te krijgen. Zo merkt de Commissie in de zaak Crociani over de verkiezing van de leden van het Italiaanse Constitutionele Hof door het parlement op, dat deze 'politieke' (wijze van) samenstelling van een rechterlijke instantie op zich niet in strijd is met het vereiste van de onpartijdigheid van rechters, maar voegt daaraan toe dat daarbij wel sprake zou moeten zijn van een zekere 'afspiegeling': "It considers that political sympathies, at least in so far as they are of different shades, do not in themselves imply a lack of impartiality towards the parties before the court. "75 Van Dijk/Van Hoof interpreteren deze uitspraak aldus:

"En hoewel ook rechters doorgaans een bepaalde politieke voorkeur zullen hebben en een bepaalde levensbeschouwing zullen aanhangen, en het goed is dat de verschillende politieke richtingen en levensbeschouwingen ook binnen de rechterlijke macht 'vertegenwoordigd' zijn, mag het niet zo zijn dat het voor de betrokkene een

70. Hand. II $1886-1887$, p. 1606

71. Zie hoofdstuk 4

72. Vergelijk de voorstellen voor een Raad voor de rechterlijke macht, $\$ 4.10 .2 .1$

73. Zie $\$ 2.3 .6 .1$ en $\$ 4.10 .1$

74. Vergelijk de uitspraken van V.A.M. van der Burg, bij Folken Jensma, CDA wil strengere rechters in Hoge Raad. NRC Handelsblad, 21 juni 1991

75. Crociani v. Italië D \& R 22 (1981), p. 222 
wezenlijk verschil maakt, of hij door een rechter met de ene dan wel met de andere voorkeur wordt berecht. ${ }^{m 76}$

\subsubsection{De onafhankelijkheid van de rechter}

Het zou onjuist zijn de indruk te wekken dat de ontwikkelingen die hiervoor gesignaleerd werden, en die gemakshalve (en dus ten onrechte) werden gereduceerd tot een 'democratisch perspectief', louter voorstanders zou kennen. Integendeel zou ik bijna zeggen, want de institutionele ontwikkelingen gaan, zoals we eerder zagen een andere richting uit, en de deining die bij de kwestieVan der Burg ontstond deed al vermoeden dat er ook (en veel) aperte tegenstanders van de afspiegelingsgedachte zijn. Wat die laatsten betreft is hiervoor al gesteld dat veelal ook door hen het legitimiteitsvraagstuk wordt erkend, maar dat zij niet bereid zijn daar ook consequenties uit te trekken voor de aanstelling van rechters. Dit leidt dan bijvoorbeeld tot een afwijzing van het toetsingsrecht of administratieve rechtspraak voor de rechter. Hun belangrijke troef is de gevreesde teloorgang van de onafhankelijkheid van de rechter, als het 'partijpolitieke element' in de rechtspleging wordt gehaald, en zij sluiten zich aan bij de huidige situatie van niet-politieke benoemingen, waarbij de onafhankelijkheid en de onpartijdigheid van de rechter maximaal gewaarborgd zouden zijn. Toch vormt het inroepen van de onafhankelijk(heid) van de rechter(lijke macht) slechts een mager tegenargument tegen de afspiegelingsgedachte.

De eis van een onathankelijke en onpartijdige rechter wordt beschouwd als een van de elementen van de rechtsstaat. ${ }^{77}$ Hier wordt, in navolging van art. 6 EVRM, onderscheiden tussen de onafhankelijkheid en de onpartijdigheid van de rechter. Onpartijdigheid staat tot onafhankelijkheid in een doel/middelverhouding. Het laatste schept het staatsrechtelijke kader waarin het eerste tot zijn recht kan komen, of zoals de Commissie voor de Rechten van de Mens bijvoorbeeld in Malmström zegt: "there is a functional relationship between independence and impartiality, the former being essentially a precondition for the latter. "78 De term 'onafhankelijkheid' is echter - zo mag inmiddels duidelijk zijn - misleidend. De rechter/de rechterlijke macht is in staatsrechtelijk opzicht immers verre van 'onafhankelijk'. Uit art. 116, eerste lid, GW blijkt reeds dat de wetgever 'de inrichting, samenstelling en bevoegdheid van de rechterlijke

76. P. van Dijk en G.J.H. van Hoof, De Europese Conventie in theorie en praktijk, 1990 , p. 373. Hier rijst overigens de vraag of er ook een plicht is tot een evenredige/diverse samenstelling van de rechterlijke macht, hetgeen juist bij verkiezingen moeilijk te verwezenlijken valt, en of een dergelijke plicht ook voor benoemingen zou gelden.

77. Zie bijvoorbeeld: M.C. Burkens. H.R.B.M. Kummeling en B.P. Vermeulen, Beginselen van de democratische rechtsstaal, 1992, p. 34

78. Rapport van 12 december 1983, Malmström, 1983, p. 38 
macht' regelt. Alleen al ten aanzien van de werving, selectie, benoeming en promotie van rechterlijke ambtenaren geldt -zie hoofdstuk 2- dat zij rusten op een groot aantal regelingen, neergelegd in de Grondwet, de Wet op de Rechterlijke Organisatie, de Wet op het Nederlanderschap, de Wet betreffende de positie van Molukkers, de Eedswetten 1911 en 1916, het reglement van orde van de Tweede Kamer, diverse algemene maatregelen van bestuur, ministeriële besluiten, circulaires en gewoonte(-recht?). Met andere woorden, er is nauwelijks een Rijksorgaan denkbaar dat niet direct of indirect betrokken is bij vitale onderdelen die de toegang tot het rechtersambt bepalen. Staatsrechtelijk betekent de eis van onathankelijkheid dan ook niet meer dan de norm dat gezocht moet worden naar die constellatie van bevoegdheden die het beste de onpartijdigheid van de rechter kan waarborgen. Hoe die constellatie er uit moet zien, en welke gevolgen dit heeft voor het vraagstuk van de toegang tot het rechtersambt, laat 'de' rechtsstaat echter in het midden.

Toch bestaat, als gezegd, in de literatuur over 'de onafhankelijkheid van de rechter' een betrekkelijk grote consensus. Er is letterlijk geen handboek in het staatsrecht te vinden, waarin de benoeming voor het leven bij koninklijk besluit, en de regeling van het ontslag en de rechtspositie bij formele wet, al dan niet gekoppeld aan een beschouwing over de rechtsstaat, geen 'waarborgen' voor de onafhankelijkheid van de rechter worden genoemd, al klinkt bij een enkeling (zie hiervoor bij Pols en Struycken) toch ook duidelijk scepsis door. Het is opmerkelijk (om niet te zeggen: verdacht) hoe zeer de conceptie van de rechtsstaat voor dit onderdeel naadloos past op de bestaande Nederlandse situatie ${ }^{79}$, zeker wanneer men in aanmerking neemt dat de invoering en handhaving van het bestaande stelsel in de vorige eeuw, betrekkelijk willekeurig, althans zeker niet vanuit het perspectief van de moderne rechtsstaat is geschied. In hoofdstuk 2 werd er al op gewezen dat in ons land noch in historisch noch in systematisch opzicht, sprake is van een coherent benoemingsstelsel. De voordrachtsbevoegdheid van de Tweede Kamer voor de Hoge Raad werd 'geleend' van de Republiek, en hoorde eigenlijk niet thuis in een eenheidsstaat. Het stelsel van aanbevelingslijsten in de Wet RO 1827 stond haaks op de ideeën die daarover ontwikkeld waren in de grondwetscommissie 1813/ 1814, terwijl de benoembaarheidsvereisten (nationaliteit, opleiding en onverenigbaarheden) slechts met horten en stoten konden worden ingevoerd, na herhaalde klachten over de vermeende inconstitutionaliteit van de regelingen. Meer in het algemeen geldt dat de ministeriële verantwoordelijkheid voor rechtersbenoemingen pas in 1848 onder het bestaande 'stelsel' is gelegd. Maar

79. De benoeming voor het leven en de benoeming bij koninklijk besluit is immers voorgeschreven in art. 117, eerste hid, GW, de regeling bij wet van het ontslag in art. 117, tweede en derde lid, GW en de regeling van de rechtspositie bij formele wet in art. 117 , vierde lid, GW 
ook voor latere ontwikkelingen is er op gewezen dat, zacht gezegd, geen blijk is gegeven van een afstemming met het constitutionele kader. ${ }^{80}$

Het wekt dan ook verbazing dat er in de literatuur kennelijk zoveel consensus bestaat over bijvoorbeeld het uitgangspunt van het bestaande benoemings- en benoembaarheidsstelsel. Niet duidelijk is waarom juist dit uitgangspunt de onafhankelijkheid en de onpartijdigheid van de rechter waarborgt. De motivering bijvoorbeeld van de regering bij de grondwetsherziening 1983, dat de "waarborgen voor de onafhankelijkheid voor de hier bedoelde functionarissen daarin [zijn] gelegen, dat hun benoeming bij koninklijk besluit plaatsvindt" ${ }^{\text {"81 }}$ is wat wonderlijk, omdat historisch de institutionele waarborgen voor de onafhankelijkheid van de rechterlijke macht steeds gezocht zijn in regelingen die de leden van de rechterlijke macht juist tegen de regering beoogden te beschermen. Is omgekeerd, iedere andere selectiemethode, bijvoorbeeld een stelsel van verkiezingen, of een gecombineerd stelsel van benoemingen en verkiezingen (vergelijk de voordracht van de Tweede Kamer bij vacatures in de Hoge Raad) in strijd met de rechtsstaat? De Europese Commissie meent vooralsnog dat dit niet het geval is, en acht bijvoorbeeld ook de verkiezing van rechters in overeenstemming met het vereiste van een onafhankelijke en onpartijdige rechter in art. $6 \mathrm{EVRM}^{82}$, net als een beperkte ambtstermijn. ${ }^{83}$

\subsection{Terug naar de eerste stap: machtenscheiding of evenwicht van machten?}

De discussie over rechterlijk activisme deelt, op het punt van de legitimatie van rechters, niet alleen dezelfde probleemstelling van die over het rechterlijk toetsingsrecht, maar ook dezelfde impasses. Zoals beide zich afzetten tegen de (overigens door iedereen onwenselijk geachte) rechtersverkiezingen, zo ligt ook bij beide het breekpunt bij de wijze waarop rechterlijke ambtenaren worden aangesteld. Een belangrijk probleem in het democratische perspectief is dat nagenoeg alle deelnemers bereid zijn niet alleen elkaars idioom, maar ook elkaars vooronderstellingen te delen. De dwingendheid van de stappen: het uitgangspunt van de machtenscheiding, het legitimiteitsconflict en het zoeken naar

80. Zie de hoofdstukken 2 en 4

81. MvT, Bijl. Hand. II, 16162 , nr. 3, p. 19

82. Crociani v. Italië D \& R 22 (1981), p. 222

83. Zo zegt zij in de Zand-zaak, "that according to the principles of the rule of law in democratic states which is the common heritage of the European countries, the irremovability of judges during their time of office, whether it be for a limited period of time or for lifetime, is a neccessary corollary of their independence from the Administration and thus included in the guarantees of Article $6(I)$ of the Convention. "Rapport van 12 oktober 1978, Z:and, D\&R 15 (1979) p. 82 
alternatieve selectiemethoden (in die volgorde) lijkt daardoor onontkoombaar, maar uit de Amerikaanse situatie blijkt al dat het referentiekader onzuiver is. Men kan echter nòg een stap terugdoen, en de aandacht van het legitimiteitsconflict verleggen naar de - kennelijke - bron van dat conflict: de machtenscheiding. Het probleem van het toetsingsrecht en rechterlijk activisme ligt immers steeds -zo is de vooronderstelling in het democratische perspectief althans- op het snijvlak van drie gescheiden staatstaken: rechtspraak enerzijds en wetgeving of bestuur anderzijds.

In de staatsrechtelijke, politicologische en bestuurskundige literatuur bestat, anders dan het bovenstaande doet vermoeden, al lang veel kritiek op deze benadering van de trias politica (zie hierna), terwijl historisch zelfs kan worden betwijfeld of de machtenscheiding inderdaad - zoals steeds wordt aangenomen wel aan onze staatsorganisatie ten grondslag ligt. De privé-aantekeningen van de leden van de grondwetscommissie van 1814 laten ons hier echter in de steek. Van belang is wel de totstandkoming van de Wet op de rechterlijke organisatie 1827, in het bijzonder de rede van de minister van justitie Van Maanen op 10 april van dat jaar. Van Maanen - hij maakte deel uit van de grondwetscommissies van 1814 en 1815 , en heeft dus enig recht van spreken stelt bij die gelegenheid dat men in de Grondwet 'geen schijn of schaduw' van de leer van de machtenscheiding tegenkomt, sterker, deze leer moet in ons koninkrijk als 'geheel ongrondwettig' worden beschouwd:

"Veel is er gezegd om die leer ingang te doen vinden, welke men zelfs een politiek axioma heefi genoemd, en met het gezag van den beroemden Montesquieu heefi willen bevestigen, daartoe aanhalende eene zinsnede uit zijn voortreffelijk werk; in hetwelk hij voorwaar niets minder dan dat beginsel, veelmin als een axioma behandelt, maar alleen betoogt, dat een Koning nimmer regter behoort te zijn, en te vonnissen in strafzaken waarin zijne onderdanen betrokken zijn. Maar al ware het, dat de beroemde man het gewilde beginsel als goed had voorgesteld, en als bij uitnemendheid dienstig ter bevestiging van de burgerlijke vrijheid tegen alle overmagt, dan nog zoude zijne leer niet anders kunnen beschouwd worden dan als het gevoelen van een te regt beroemd man; maar de verwezenlijking van die leer en van die beginselen in de Nederlandsche Grondwet (en dit is toch het punt, waarop het ten deze alleen aankomt), zoude daaruit geenszins voortvloeijen. ${ }^{\text {"I4 }}$

Tegen machtsmisbruik waakt volgens Van Maanen in onze Grondwet niet de leer der machtenscheiding, maar een systeem dat bescherming biedt: "tegen mogelijke overschrijding van het Koninklijk gezag, en daarom palen gesteld heeft aan deszelfs uitvoering of misbruik; en dit is juist het voorregt van grondwettelijke Monarchie, waaronder wij het geluk hebben te leven. Zoo heeft zij 
aan den Koning het regt niet toegekend om alleen wetten te maken. Zoo heeft zij hem het regt niet toegekend om alleen regtbanken in te stellen, ter beslissing van eenige regtszaken hoegenaamd. "85 Overigens is het bewijs dat Van Maanen aandraagt voor zijn bewering niet bijster sterk. Hij beroept zich op het systeem van de Grondwet 1815 , in het bijzonder op de naamgeving van de hoofdstukken. Zo heet het tweede hoofdstuk 'Van de Koning', en niet 'Van de uitvoerende macht'; het derde hoofdstuk 'Van de Staten-Generaal', en niet 'Van de wetgevende macht' en het vijfde hoofdstuk 'Van de justitie', en niet 'Van de rechterlijke macht'. ${ }^{86}$

\subsubsection{Evenwicht van machten}

Van meer belang voor de huidige situatie is dat de machtenscheiding, strikt opgevat, feitelijk niet is gerealiseerd (hetgeen - zie Van Maanen - historisch ook verklaarbaar is) en, ook minder strikt opgevat, voorbij gaat aan de staatkundige werkelijkheid van het bestaan van andere machten ${ }^{87}$ of aan de omstandigheid dat de wetgevende en de uitvoerende (besturende) macht inmiddels sterk verweven zijn. ${ }^{88}$ In toenemende mate wijst de literatuur een rigide interpretatie van de machtenscheiding dan ook af, hoewel zij zich paradoxaal genoeg voor het bepalen van de legitimiteit van de rechter, juist exclusief op een strikte scheiding van machten beroept (zie hiervoor). Naar de oorzaak van die paradox kan men slechts gissen. Een - zij het weinig plausibele - verklaring zou kunnen zijn dat ontwikkelingen uit het ene forum niet in het andere doordringen.

Om tegemoet te komen aan de problemen, waar het uitgangspunt van een strikte machtenscheiding toe leidt, stelt W.J. Witteveen in zijn oratie Evenwicht van machten een interpretatie van de trias politica voor, die niet zozeer de scheiding, maar het evenwicht van machten voorop stelt. De grondslag van de trias politica (het beschermen van de vrijheid van de burger door het tegengaan van machtsconcentratie) en de daarin onderscheiden functies van wetgeving, uitvoering en rechtspraak blijven bestaan, maar de onderlinge verhouding tussen

85. Hand. II $1826-1827$, p. 363

86. De vijfde afdeling van het derde hoofdstuk van de Grondwet 1815 heet overigens wel 'Van de wetgevende magt', terwijl de term 'regterlijke magt' veelvuldig wordt gebruikt in het vijfde hoofdstuk

87. Zie R. Crince Le Roy, De vierde macht Een hemieuwde kennismaking, derde herziene druk, 1976

88. C.W. van der Pot, De verdeling der staatstaak, 1921, p. 8, S.O. van Poelje, Verscheidenheid en eenheid, 1966, p. 7-8. S.W. Couwenberg, De trias voorbij? Een alternatieve visie op machtenscheiding en machtsevenwicht, in: De Trias onder spanning, 1990, p. 111 e.v. 
deze functies dient te worden bepaald door het principe dat de ene macht de andere zonodig 'afstopt' (bij De Montesquieu: 'le pouvoir arrête le pouvoir ${ }^{\prime} .^{89}$ Dit uitgangspunt heeft als gevolg dat de speelruimte van met name de rechterlijke macht - waarvoor in de traditionele trias-opvatting slechts een bescheiden rol was weggelegd - vergroot, ten koste van de politiek - die voorheen op grond van haar democratische legitimatie een primaat toekwam - wordt vergroot:

"Evenwicht van machten matigt de absolute aanspraken op gehoorzaamheid uit het idee van het primaat van de politiek. Dit betekent uiteraard niet dat dit primaat overboord wordt gezet. De meerderheidsregel is éen van de elementen van de democratische rechtsstaat. Maar het primaat van de politiek krijgt een topische status: het wordt een legitiem gezichtspunt naast andere legitieme gezichtspunten. In de omstandigheden van het geval wordt het gewicht tussen de topische waarden vastgesteld. ${ }^{m 00}$

Optimisme kan Witteveen niet ontzegd worden, want wie zoveel waarde toekent aan het debat, en meent dat het gezichtspunt van 'de' politiek even legitiem is als dat van bijvoorbeeld de rechter, moet wel erg veel vertrouwen hebben in de deelnemers aan dat debat, of verwacht tenminste dat niet-legitieme gezichtspunten (op tijd!) worden onderkend en publiekelijk worden ontmaskerd. We zijn hier wel erg ver vandaan van de zo vertrouwde opvatting over democratische legitimatie. De vraag rijst welke rol Witteveen nog ziet weggelegd voor selectiemethoden in het algemeen. Als de legitimiteit van een gezichtspunt niet langer verbonden is met de (wijze van) samenstelling van het betrokken orgaan, maar enkel met de kracht van het betrokken argument, waarom zou bijvoorbeeld een parlement dan nog gekozen moeten worden (waarom zou er eigenlijk nog een parlement zijn?). En hoe valt in zo'n situatie eigenlijk nog gezag uit te oefenen; wie mag er knopen doorhakken, en wie moet het? Of bedoelt Witteveen slechts dat alleen het omgekeerde - dat wil zeggen het gezichtspunt van het niet-gekozen orgaan - niet noodzakelijk een niet-legitiem gezichtspunt is? Mag van het, al dan niet tegengestelde, gezichtspunt van de rechter, niet gezegd worden dat het niet-legitiem is, alleen omdat het niet 'democratisch gelegitimeerd' is?

Behalve groot optimisme, gaat er echter ook een grote slagvaardigheid uit van de gedachte aan machtsevenwicht, en dat is de alantrekkelijke kant ervan. Star vasthouden aan de machtenscheiding - en ik beperk mij nu tot de positie van de rechterlijke macht - gaat voorbij aan het feit dat inmiddels een andere koers is ingezet, waarop, al zou men willen, niet meer kan worden teruggekomen. Hier-

89. Witteveen, o.c. p. 70

90. W.J. Witteveen, Evenwicht van machten, 1993, p. 73 
voor werd over het overval-karakter van rechterlijk activisme gesproken. Het is geen toeval dat veel van de rechtspraak die wij thans onder 'rechterlijk activisme' rangschikken zich in kort geding heeft ontwikkeld. Controversiële vraagstukken blijken steeds vaker van spoedeisend belang (of worden als zodanig gepresenteerd), en op dat punt kan de - zoals dat tegenwoordig heet 'stroperige' wetgeving niet concurreren met een (alleensprekende) rechter, die, desnoods in pyjama, vonnis kan wijzen.

\subsubsection{Evenwicht van machten en de samenstelling van de rechterlijke macht}

Maar ook als we het uitgangspunt van het evenwicht van machten omhelzen, blijft de vraag overeind welke consequenties dit heeft voor het vraagstuk van de toegang tot het rechtersambt. Valt met de eerste stap van het democratische perspectief (de machtenscheiding) vanzelf de vraag naar de legitimiteit van de rechter weg, of stelt het uitgangspunt van het machtsevenwicht zijn eigen eisen aan de legitimiteit van de rechter? Witteveen laat deze vraag liggen, en lijkt de legitimatie van de rechter vooral te zoeken in de motivering van vonnissen en obiter dicta:

"hoe meer het Nederlandse staatsrechtelijke bestel feitelijk als een stelsel van machtsevenwicht wordt ervaren, hoe meer het nodig zal blijken dat de betrokkenen zich van tijd tot tijd openlijk rekenschap geven van de verhoudingen van de acteurs in het scenario. De rechter kan er, in de marge van beslissingen ter beslechting van conflicten - beslissingen die vaak een rechtsvormend karakter hebben - toe bijdragen dat deze reflectie niet al te vrijblijvend geschiedt. ${ }^{n 91}$

De Amerikaanse auteur Erwin Chemerinsky redeneert in dezelfde trant als Witteveen, maar gaat een stap verder, en wijst de centrale vooronderstelling van het democratische perspectief - het rechtstreekse verband tussen de legitimiteit van de rechter en de toegang tot het rechtersambt - expliciet af. ${ }^{22}$ Chemerinsky meent dat het beroep op het gebrek aan 'democratische legitimatie' van de rechter wegens het ontbreken van verkiezingen (majoritarianism), op dit moment slechts als een dekmantel fungeert voor het U.S. Supreme Court om zich aan bepaalde keuzes te ontirekken. Dit leidt op termijn tot een vanishing Constitution, een situatie waarin de bescherming van grondrechten en de institutionele grondwettelijke bepalingen worden uitgehold:

91. Witteveen, o.c. p. 91

92. Erwin Chemerinsky, The vanishing Constitution, in: Harvard Law Review, 1989. p. 44-104 
"Fewer clauses of the Constitution, whether dealing with the structure of the government or with individual liberties, are being enforced. Majoritarianism is a jealous philosophy that tolerates little judicial review. If judges can intervene only when there are clear "objective" standards, wholly apart from the views of the individual Justices, judicial review will serve primarily to uphold and legitimate legislative and executive decisions."

Chemerinsky bestrijdt dat niet-gekozen rechters 'ondemocratisch' zijn, en spreekt over The False Priority of Majoritarianism. ${ }^{93}$ In zijn visie zijn beslissingen van gekozen gremia niet superieur aan die van de rechterlijke macht, en vloeit de legitimatie van de rechter, net als bij Witteveen, voort uit de controleerbaarheid van de (totstandkoming van de) rechterlijke uitspraak. Voor het (soms al te botte) controle-mechanisme dat de meerderheidsregel (in de vorm van een verkiezing) kennelijk is, stelt Chemerinsky ter legitimatie van de rechtspraak, het publieke debat in de plaats: "As such, Justices should openly explain and defend their value choices, and thus persuade observers of the best way to understand and apply the Constitution. "94 Hij pleit daarom uitdrukkelijk voor concurring en dissenting opinions: "Written judicial opinions reinforce this notion and facilitate public and scholarly discussion about constitutional issues. The Court has the chance to persuade and, at the same time, the Court's reasoning can be criticized and the Court can be persuaded to change its mind." Chemerinsky lijkt hiermee aan te sluiten bij William Brennan, die in In Defense of Dissents de publicatie van afwijkende minderheidsoordelen sterk heeft verdedigd, al voegt deze er wijselijk aan toe dat "No one has any duty simply to make noise":

"At the heart of that function (bedoeld is de functie van dissenting en concurring opinions, MdW) is the critical recognition that vigorous debate improves the final product by forcing the prevailing side to deal with the hardest questions urged by the losing side. In this sense, this function reflects the conviction that the best way to find the truth is to go looking for it in the marketplace of ideas. It is as in the opinions of the Court - both for majority and dissent - were the product of a judicial town meeting. ${ }^{195}$

Het uppel van Chemerinsky op het wetenschappelijke èn het publieke discours is niet zonder betekenis. Dat de controle op het functioneren van de rechter vooral wok een public's business is, en niet (alleen) een zaak die met een gerust hart kan worden overgelaten aan 'ofticiële instanties', is een notie die in Amırika (heldas) vanzelfsprekender is dan bij ons. Hiervor zagen we dat niet

93. Chemerinsky, o.c. p. 76

94. Chemerinsky, o.c. p. i02

95. William J. Brennan, In defense of dissents, in: The Hastings Law Journal, 1986, p. 430 
alleen professionele organisaties, zoals de bar associations, hun oorsprong ontlenen aan de onvrede met de rechtspleging, maar ook tal van organisaties variërend van het Fund for Modern Courts tot kerken en belangengroeperingen. De rol van het publieke debat moet voor het vraagstuk van de toegang tot het rechtersambt in Amerika, ook vanuit praktisch oogpunt niet uit het oog worden verloren. Wie de milde opvattingen van de volksvertegenwoordigers op de Constitutional Conventions over rechtersverkiezingen legt naast de overweldigende kritiek die daarop elders in de Amerikaanse samenleving bestaat, begrijpt dat iedere aanzet tot hervorming kansloos zou zijn geweest als bijvoorbeeld de dagbladpers niet voortdurend op de feilen van het systeem had gewezen.

\subsubsection{Dissenting en concurring opinions}

Het loslaten van het directe verband tussen de legitimatie van de rechter en de wijze waarop hij wordt aangesteld, zoals we dat hiervoor bij Chemerinsky en Witteveen tegenkwamen, is interessant, omdat daarmee de impasse wordt doorbroken over de weinig inspirerende vraag of rechters nu wel of niet op 'politieke wijze' (afspiegeling) moeten worden benoemd. Door de legitimatie van de rechter te verbinden met bijvoorbeeld de publikatie van dissenting en concurring opinions, wordt een einde gemaakt aan de idee dat de legitimatie van rechters, per se een constellatie van publiekrechtelijke bevoegdheden vooronderstelt. In het democratische perspectief wordt de legitimatie van de rechter immers steeds benaderd vanuit een visie waarin (volks-)invloed via verkiezingen kan worden opgelegd of door benoemingen (via de ministeriële verantwoordelijkheid) kan worden afgedwongen. Het ontkoppelen van de legitimatie van de rechter van het vraagstuk van de toegang tot het rechtersambt geeft een nieuwe inhoud aan het begrip publieke controle, waarin het wetenschappelijke en publieke debat een vooruitgeschoven post innemen.

In de Nederlandse literatuur is een relativering van 'het' democratische perspectief niet geheel onbekend. Snijders bijvoorbeeld, noemt het 'overdreven' om principieel een verband te leggen tussen de toeneming van rechtsvorming en "democratie, legitimatie van de rechter en een evenwichtige verdeling van overheidsfuncties" ${ }^{\prime 6}$ Anderen zien dat verband blijkbaar nog wel, maar zoeken - voor het antwoord op het probleem van het toetsingsrecht en rechterlijk activisme - de oplossing evenmin (alleen) in de wijze van samenstelling van de rechterlijke macht. Engels bijvoorbeeld meent dat een zich expliciet op rechtsstatelijke beginselen oriënterende rechter zich reeds om die reden mag

96. W. Snijders, De rechter als dictator?, in: De rechter als dictator Dynamiek in de trias. Verschuivingen in de verhouding regelgeving, hestuur en rechtspraak, 1987, p. 140-141 
verheugen in een groeiend gezag. ${ }^{97}$ Ook Koopmans relativeert, in zijn eerder genoemde preadvies over het toetsingsrecht, het ontbreken van een politieke verantwoordelijkheid van de rechter, door te wijzen op de 'grote troef' waarover rechterlijke besluitvorming beschikt, "namelijk een procesgang waarin ieder argument naar voren kan worden gebracht in een sfeer van onbevangenheid, en een beslissing waarin de argumenten onbevooroordeeld tegen elkaar worden afgewogen. Zit een rechterlijke beslissing goed in elkaar, dan kunnen partijen en alle andere belangstellenden zien hoe de redenering van de rechter in elkaar steekt. ${ }^{\text {mo8 }}$ De Winter meent dat rechters hun legitimatie achteraf - op grond van hun uitspraken - moeten verwerven, en niet vooraf door politieke benoemingen. Hij stelt voor het verwerven van legitimatie uitdrukkelijk aan rechters op te dragen, door het stellen van extra motiveringseisen, het toestaan van dissenting en concurring opinions en z.g. amicus curiae briefs. ${ }^{99}$

De voor- en de nadelen van dissenting opinions zijn in ons land in de jaren dertig uiteengezet door J.P. Fockema Andreae ${ }^{100}$ (zelf bepleitte hij dit systeem voor de cassatierechter) en de voordelen zijn - onder meer als een uitvloeisel van de discussie over klassejustitie - verdedigd door J.C.M. Leijten in 1972. ${ }^{101}$ De argumenten bleven door de jaren heen grotendeels dezelfde; tegen dissenting en concurring opinions pleiten de noodzakelijke overtuigingskracht van de rechterlijke beslissing, de vrees dat het gezag van de rechter zal afnemen en de verwachting dat de aandacht zich vooral op controversiële zaken zal richten, al ziet Fockema Andreae dat allemaal niet zo somber: "openbaarheid [is] het krachtigste middel om aan iedere autoriteit gezag en eerbied te verzekeren, en bij het publiek grooter vertrouwen in en meer belangstelling voor haar werk te wekken." 102 Vandaag kan aan de tegenargumenten een tweetal praktische problemen toe worden gevoegd, nl. het feit dat de ontwikkelingen in de rechtspleging tenderen naar unusrechtspraak (zie hoofdstuk 4), waardoor de functie van dissenting en concurring opinions zich lijkt te beperken tot het hoger beroep en cassatie, en de vraag naar het effect van dissenting opinions. Met name in spoedeisende zaken, waar door een alleensprekende rechter een 'voorlopige' voorziening wordt getroffen (kort

97. J.W.M. Engels, Constitutionele toetsing en machtenscheiding, in: De trias onder spanning, 1990, p. 106

98. Koopmans, o.c. p. 83

99. Reiner de Winter. De benoeming van raadsheren in: Publiek Domein, 1991, p. 231-233

100. J.P. Fockema Andreae, Het geheim van de raadkamer Beschouwingen over het bekend maken van de gevoelens der minderheden in rechterlijke colleges, 1934

101. J.C.M. Leyten. Dissenting opinion (1) en Dissenting opinion (2), resp. NJB, 1972, p. 697-707 en p. 731-741 Zie ook de preadviezen uit 1973 over dit onderwerp van $H$. Drion en $O$. de Savornin Lohman voor de Nederlandse Juristen-Vereniging

102. Fockema Andreae, o.c. p. 68 
geding), schiet het instituut zijn doel voorbij. Overigens kan dit laatste behalve als een - praktisch, en daarom weinig sprekend - argument tegen dissenting opinions, ook als een bezwaar tegen alleenrechtspraak in het algemeen worden opgevat. Historisch is bijvoorbeeld het kort geding voor de (fungerend) president van de rechtbank ook niet ontwikkeld tegen de achtergrond van controversiële vraagstukken ${ }^{103}$, en juist bij deze zaken lijkt alleenrechtspraak - al was het maar omdat onderlinge tegenspraak uitblijft - onwenselijk. Wat het effect van dissenting opinions betreft, rijst, net zoals dat in hoofdstuk 1 gebeurde ten aanzien van pleidooien voor gedemocratiseerde benoemingen, de vraag of er wel een relatie mag worden aangenomen tussen het vertrouwen van de burger in de rechter en de publikatie van minderheidsoordelen, en of ook hier niet meer beloofd dan waargemaakt wordt. Overigens moet voor het klassieke bezwaar, dat dissenting opinions tot meer aandacht voor het benoemingsbeleid leiden, worden gewezen op het feit dat wetenschappelijke analyse van dissenting en concurring opinions juist tot het inzicht heeft geleid dat de impact van een benoemingsbeleid op de koers van het U.S. Supreme Court betrekkelijk is. In de stemverhouding van 'Democratische' en 'Republikeinse' rechters in het U.S. Supreme Court zijn minder aanwijsbare 'patronen' te vinden dan verwacht werd. Zo is bijvoorbeeld de verwachte 'ruk naar rechts' na de benoeming van Clarence Thomas in het U.S. Supreme Court niet opgetreden ${ }^{104}$, al concluderen Smith en Johnson, aan de hand van Thomas' dissents, dat "Id/espite his relatively modest impact during his first term, Thomas may become an influential justice as his career progresses. ${ }^{105}$

Men kan zich echter afvragen of de argumenten tegen dissenting opinions intussen niet door de feiten zijn ingehaald. Met name het argument van wat Leijten in 1972 noemt 'de Fortbildung van het recht ${ }^{\circ 106}$ heeft sterk aan belang toegenomen. Fockema Andreae schrijft al in 1934, ver vó́r de discussie over rechterlijk activisme:

"Er zit toch iets kunstmatigs, iets onbegrijpelijks, ja, iets beangstigends in, dat rechterlijke vogels van diverse pluimage zich gelijkelijk behagelijk en tevreden

103. Zie de totstandkoming van de bepaling over het kort geding in het Wetboek van Burgerlijke Regtsvordering, Bijl. Hand. 1836-1837, XI, nr. 3

104. Christopher E. Smith en Scoll Patrick Johnson. The first-term performance of Justice Clarence Thomas, in: Judicature The Journal of the American Judicature Society, 1993, p. $172-178$

105. Smith en Johnson, o.c. p. 178 Zie ook Kathleen M. Sullivan die aan de hand van een analyse van de jurisprudentie van het U.S. Supreme Court aantoont dat de relatie tussen de politieke achtergrond en de juridische opvatting van rechters veel complexer is dan wel wordt aangenomen; Foreword: The Justices of Rules and Slandards, in: Harvard Law Review, 1992, p. 24-123

106. Leijten, o.c. p. 732 
gevoelen te midden van een ingewikkeld samengesteld netwerk van rechtsoverwegingen, waaronder men hier leeft. Of gevoelen zij zich als gevangenen, die daarin zijn verstrikt en vleugellam werden?

Zouden, als de deuren van de raadkamer werden opengezet, de frissche wind der openbaarheid en de verschillende stroomingen, die dan voor den draad komen en het tegen elkander gaan opnemen, soms een aantal van de dufste argumenten wegvagen en een herziening van het leerstuk der wetsuitlegging bewerken? ${ }^{n 107}$

Dissenting opinions geven bovendien een indicatie omtrent de kwaliteit van de discussie binnen de rechterlijke macht, en kunnen, behalve op onderlinge meningsverschillen, wijzen op knelpunten in de rechtspleging in het algemeen. De botte constatering dat de rechterlijke macht voor de oplossing van controversiële vraagstukken - zoals dat heet - 'niet geëquipeerd' is, zal daardoor wellicht worden vervangen door de veel interessantere vraag hoe de rechterlijke macht dan wel zodanig geëquipeerd kan worden.

\subsection{Nabeschouwing}

Het vraagstuk van de toegang tot het rechtersambt, zo zette ik in de inleiding van dit hoofdstuk uiteen, wordt grofweg benaderd vanuit twee invalshoeken: een technocratisch perspectief, dat in het derde en vierde hoofdstuk is besproken, en een democratisch perspectief, dat hiervoor aan de orde kwam. Het democratische perspectief is opgezet vanuit een vaste, ogenschijnlijk dwingende route. Uitgaande van de gedachte aan machtenscheiding, ontstaat in het democratische perspectief bij een bepaalde taakstelling/taakopvatting van de rechter (de scheidslijn is niet altijd even duidelijk), een legitimiteitsprobleem, dat ogenschijnlijk slechts kan worden opgelost door te kiezen voor een methode van aanstelling van rechters, die analoog is aan die voor 'de' wetgever, waarmee bedoeld wordt de rechtstreekse verkiezing van de leden van de Tweede Kamer. Betoogd werd dat deze stappen niet voor zich spreken. Allereerst zijn

107. Fockema Andreac, o.c. p. $85 \mathrm{Hij}$ kon dit trouwens makkelijk zeggen, want "/v/oor een revolutie behoeft men niet bang te zijn, - daarvoor zijn te veel bezadigde krachten aan het werk". al "/warel eenige verjonging niet kwaad". Vergelijk J.C. Van Oven die twee jaar eerder. in 1932, over de "leiders der rechtsontwikkeling, deze rechtsvinders bij uitnemendheid" in de Hoge Raad schrijft: "Mij dunk, voor hen gelden de motieven voor een tijdig afscheid nog meer dan voor anderen. Laat ons niet in het abstracte blijven, maar een voorheeld noemen: men leze eens de namen der raadsheeren die de arresten over art. 1401 B.W. geveld hebben in de jaren vór 1919, met die, welke het befaamde arrest van 31 Jamuari van dat jaar hebben gewezen, en beantwoorde dan de vraag of deze heilzame nieuwe rechtspraak, die a.h.w een nieuw hoofdstuk in de ontwikkeling van ons privaatrecht heeft geopend, niet 'n jaar of tien vroeger zou zijn aanvaard, indien voor den H.R. de 65-jarigen leefrijdsgrens had gegolden. "J.C. van Oven, De leeftijdsgrens: niet 70, maar 65, NJB, 1932, p. 633-637 
verkiezingen als referentiekader voor het aannemen van de legitimatie van de rechter onzuiver. Te zeer oriënteert men zich in ons land voor de legitimiteit van de rechter op de methode zonder een bezinning op het effect van de methode. In de Amerikaanse literatuur is de tegenstelling tussen de benoeming en de verkiezing van rechters inmiddels ontmaskerd als een schijncontroverse. Het traditionele tegenargument tegen 'politieke' benoemingen, de dreigende teloorgang van de onafhankelijkheid van de rechter biedt overigens weinig soelaas; de bestaande conceptie van onafhankelijkheid legt minder duidelijk een claim op het vraagstuk van de toegang tot het rechtersambt dan veelal wordt aangenomen.

Aan het vraagstuk van de toegang tot het rechtersambt komt het democratische perspectief goed beschouwd echter niet toe, omdat de eerste stap, het uitgangspunt van de machtenscheiding, inmiddels lijkt te zijn ingehaald door dat van het machtsevenwicht. In de visie van Chemerinsky wordt het verband ontkend tussen de legitimiteit van de rechter en de wijze waarop de rechterlijke macht wordt samengesteld. Deze benadering sluit goed aan op de herwaardering van het element van machtsevenwicht in de trias politica, waardonr (zie bij Witteveen) de expanderende taak van de rechtspraak op zich-elf niet leidt tot een legitimatieprobleem. Door de legitimatie van de rechter te verbinden met bijvoorbeeld dissenting en concurring opinions, en met - zie hoofdstuk 7 de openbaarheid van de rechtspleging in het algemeen, wordt een einde gemaakt aan een denkpatroon, waarin publieke controle per se een constellatie van publiekrechtelijke bevoegdheden vooronderstelt. In het democratisch perspectief wordt publieke controle immers steeds benaderd vanuit een visie waarin (volks-)invloed via verkiezingen kan worden opgelegd of door benoemingen (via de ministeriële verantwoordelijkheid) kan worden afgedwongen. Het ontkoppelen van legitimatie en de wijze van samenstelling geeft een nieuwe inhoud aan het begrip publieke controle. Die controle ruimt ook plaats (en verantwoordelijkheden!) in voor het publieke en wetenschappelijke juridische debat. 


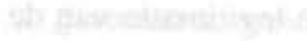

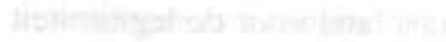

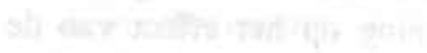

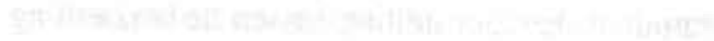

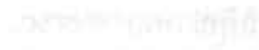


Deel V

Slot 



\section{Epiloog}

Het jaarlijkse Raio-congres, op 3 april 1993, bleek om meer dan én reden verontwaardigde reacties uit te lokken. Terwijl de minister van justitie, Hirsch Ballin, de 'in de zeventiger jaren opgeleide garde' van de rechterlijke macht, een te liberaal strafklimaat verweet', en daarmee het ongenoegen van de pers over zich afriep, maakte Dorien Pessers zich boos over een cabaretlied, waarin drie vrouwelijke raio's, op de melodie van Let's Talk About Sex, Baby, op de slotavond hun verlangen naar de verdachte in zedenzaken bezongen. Het zou hier een knipoog betreffen naar het soms welwillende oor van rechters in deze zaken. ${ }^{2}$ In de Volkskrant noemt Pessers het lied kwetsend voor verdachten en slachtoffers van seksuele delicten, en meent zij dat het past in de 'tijdgeest'. Deze wordt 'immers' gekenmerkt "door de schaamteloosheid waarmee mensen hun intieme, persoonlijke en seksuele leven breeduit etaleren. " Pessers juicht het toe dat de functie en de persoon van de rechter verregaand zijn geritualiseerd, geneutraliseerd en geanonimiseerd, en vindt dat dit vooral zo moet blijven: "De rechter behoort recht te spreken achter een masker. Niet de verwijzing naar de seksuele persoon van de rechter wekt dus het onbehagen, maar het afrukken van zijn masker en het belasten van procespartijen met het driftleven van degene die over hen moet oordelen." ${ }^{3}$

Het pleidooi van Pessers is opmerkelijk. ${ }^{4}$ Niet omdat zij vindt dat er fatsoensgrenzen zijn overschreden, maar omdat zij denkt dat het vertrouwen van

1. Vergelijk de rede van de minister van justitie Hirsch Ballin op 1 april 1993 te Zutphen voor het vijfde Raio-congres, waarin deze suggereert dat de bescherming van de burger tegen criminaliteit voor de 'in de zeventiger jaren opgeleide garde' van de rechterlijke macht een dubieus thema is. Gepubliceerd in Stcrt, 2 april 1993, p. 1 en 6

2. Elma Drayer en Mare Josten, De jonge hoeders van rechl en orde reageren laww op de tijdgeest. Vrij Nederland 10 april 1993. p. 656. Het lied vangt aan met de tekst: 'Ik geil het meest op zedenzaken/maar doe altijd eerst mijn toga aan/ik lees en tik me door de stukken/zet zoemend m'n vibrator aan.' Gepubliceerd in: Dorien Pessers, Demasquë der Rechters, de Volkskrant, 20 april 1993

3. Dorien Pessers, o.c.

4. Elders wordt het lied 'hilarisch' genoemd; vergelijk Elma Drayer en Marc Josten, o.c. In gelijke zin Marcel Haenen, Juristen bespreken de normen na een nacht vol 'headbangen', NRC Handelsblad, 3 april 1993 
de burger in de rechter zal toenemen door hem in de anonimiteit terug te dringen. Mèt het kind dreigt nu immers ook het badwater te worden weggegooid. De kritiek op de rechtspleging na de Tweede Wereldoorlug heefi zich (zie de jaren zestig) immers allereerst geconcentreerd op de geslotenheid en de (vermeende) eenzijdige samenstelling van de rechterlijke macht, al kan men zich afvragen of kritiek op rechters, buiten hun rechtsprekende functie, bijvoorbeeld in de beslotenheid van een raio-congres, wel gerechtvaardigd is. Los van het antwoord op die (normatieve) vraag, roept gedrag van rechters, privé of in functie, - kennelijk - reacties op, en wordt zo (mede)bepalend voor de beeldvorming van de rechterlijke macht bij het publiek. De vraag is welke positie het staatsrecht hierin moet kiezen. Slaat Pessers met haar pleidooi voor volledige anonimiteit de plank faliekant mis, snijdt het misschien toch hout, of mogen tussen volstrekt anonieme rechtspraak en uitdrukkelijke profilering van rechters, nog nuances worden onderscheiden? Een terugblik en een nabeschouwing.

\subsection{De toegang tot het rechtersambt: terugblik}

Deze studie onderzocht het constitutionele kader van de toegang tot het rechtersambt, en beschreef de parlementaire geschiedenis, die aan het ontstaan van dit stelsel en aan de wijzigingen die daarin later zijn opgetreden, ten grondslag heeft gelegen. Voorts poogde deze studie de relevante aspecten van het vraagstuk van de toegang tot het rechtersambt voor het moderne staatsrecht in kaart te brengen, en deze te waarderen. De 'toegang tot het rechtersambt' in Nederland kenmerkt zich door de drempels die door het positieve recht worden opgeworpen tegen een benoeming in de 'gewone' rechterlijke macht. Daarbij werd onderscheiden tussen de fasen voorafgaande aan een benveming (bevordering) in de rechterlijke macht, nl. de werving en de selectie van rechterlijke ambtenaren, en de benoembaarheid van kandidaatleden in de rechterlijke macht, die wordt bepaald door de vereisten van de Nederlandse nationaliteit en een juridische opleiding, alsmede de afwezigheid van bepaalde onverenigbaarheden.

De veronderstelling was in hoofdstuk 1 dat bij de invoering en de verdere ontwikkeling van het stelsel van benoeming en benoembaarheid in de rechterlijke macht. bij de (grond-)wetgever in de vorige eeuw een visie met betrekking tot de toegang tot het rechtersambt heeft voorgestaan, die gerelateerd is aan de tadk van de rechter. De vraag rees of inmiddels, bij een andere taakstelling (-opvatting) van de rechter, het bestaande stelsel vanuit staatsrechtelijk oogpunt wijziging behoeft. Voor het antwoord daarop moesten drie hoofdvragen beantwoord worden, nl. 1) hoe is de toegang tot het rechtersambt thans feitelijk geregeld, en hoe verhoudt die regeling zich tot het constitutionele kader, 2) welke overwegingen liggen historisch aan deze regeling ten grondslag en 3) 
welke tendensen doen zich ten aanzien van de taak van de rechter in relatie tot de toegang tot het rechtersambt voor.

Wat de tweede hoofdvraag betreft (over de eerste kom ik hieronder te spreken), werd in de hoofdstukken 3 en 4 uiteengezet, dat van een samenhang tussen de factoren uit het positieve recht, die de toegang tot het rechtersambt bepalen, noch waar het de invoering noch waar het de verdere ontwikkeling betreft. sprake is. Uit hoofdstuk 3 blijkt dat een duidelijke visie van de (grond)wetgever, op het type rechter dat door het stelsel wordt geselecteerd - laat staan een nadere nuancering van het type rechter dat wordt benoemd in relatie tot de functie of de taak waarvoor hij wordt aangesteld - ontbreekt. De verklaring voor deze situatie is drieërlei. Allereerst dient men te beseffen dat het bestaande stelsel van benoeming en henoembaarheid van rechters nagenoeg geheel uit het begin van de vorige eeuw dateert, toen de taakstelling (en -opvatting) van de rechter, zich grotendeels beperkte tot strikte wetstoepassing. Aan de rechtsvormende of zelfs normstellende rol van de rechter is daarom weinig belang gehecht door de wetgever, zodat de belangstelling voor de persoon van de rechter zich beperkte tot het stellen van randvoorwaarden als de vereisten van het Nederlanderschap en een juridische opleiding, en de afwezigheid van bepaalde onverenigbaarheden. Het gebrek aan interesse voor de persoon van de rechter in de vorige eeuw, zal zeker ook veroorzaakt zijn door de omstandigheid dat rechters, o.a. als gevolg van het vereiste van een juridische opleiding, tot vrij recent slechts uit een kleine groep werden gerecruteerd, die zich beperkte tot een (welgestelde) bovenlaag van de hevolking. Bovendien stond - zeker als het ging om vacatures in afgelegen gebieden - lang niet iedereen te dringen om een (slecht bezoldigde) positie bij de rechterlijke macht. Uit hoofdstuk 3 blijkt tenslotte dat de belangstelling voor de (diverse) samenstelling van de rechterlijke macht, en in het verlengde daarvan voor de toegang tot het rechtersambt, van recente datum is; in elk geval heeft zij niet aan de (grond-)wetgever uit de vorige eeuw voor ogen gestaan. Zo zijn de twee belangrijkste selectiecriteria - het eigen vermogen en verder de uitsluiting van de vrouwelijke sekse - nooit gepositiveerd. Wat het eigen vermogen aangaat geldt dat de perceptie (bij sommigen zelfs tot ver in deze eeuw) van de onathankelijkheid en onpartijdigheid van de rechter was gekoppeld aan de financiële zelfstandigheid van de rechter, omdat de kans op omkoping daardoor gereduceerd werd.

Wat de ontwikkeling van de toegang tot het rechtersambt na de Tweede Wereldoorlog betreft, werd in hoofdstuk 4 gewezen op een tweetal tendensen, aangeduid als een technocratisch en een democratisch perspectief. Het technocratische perspectief op de toegang tot het rechtersambt behelst de optiek van het hestuur (de regering). De vervulling van rechtersvacatures wordt in deze visie veelal beschouwd als een louter technisch-organisatorische aangelegenheid. Wijzigingen in het bestaande benoemings- en benoembaarheids-'stelsel' (zoals 
de invoering van selectiecommissies, de regeling van benoeming in promotiefuncties, of de discussie over het nationaliteitsvereiste, de juridische opleiding of de incompatibiliteiten) worden niet als samenhangende problemen gezien, die een belangrijk effect kunnen hebben op de toegang tot het rechtersambt en daarmee op de samenstelling van de rechterlijke macht. Het technocratische karakter van deze voorschriften wordt onderstreept door de lage status van de betrokken regelingen (koninklijk of ministerieel besluit, circulaires). De fragmentarische en ondoorzichtige regeling van de toegang tot het rechtersambt verklaart de problematische verhouding van onderwerpen als de werving, selectie en promotie van rechterlijke ambtenaren tot het constitutionele kader, in het bijzonder tot het vereiste van een wettelijke grondslag in art. 116, eerste lid, GW. In hoofdstuk 2 werd, naar aanleiding van de eerste hoofdvraag van dit onderzoek, geconcludeerd dat de regeling met betrekking tot de toegang tot het rechtersambt in ons land voor een belangrijk deel op gespannen voet staat met de Grondwet.

Het democratische perspectief op de toegang tot het rechtersambt, de tweede tendens die werd onderscheiden, ontstaat met name na de Tweede Wereldoorlog, en wordt veroorzaakt door de groeiende belangstelling voor de persoon van de rechter en de samenstelling van de rechterlijke macht. Aanvankelijk wordt die belangstelling ingegeven door een vertrouwenscrisis, en gaat het om een negatieve benadering van de rechterlijke macht, die slechts eenzijdig zou zijn samengesteld uit een bovenlaag van de samenleving. Deze 'beschuldiging' (hieruit blijkt reeds een breuk met het verleden waarin die eenzijdigheid juist positief werd gewaardeerd) wordt, bij gebrek aan empirisch onderzoek niet hard gemaakt, maar is niet zonder grond. De geringe toegankelijkheid van de universitaire studie in het algemeen, de (onbezoldigde) weg naar het rechtersambt via de griffie, en de mogelijk afwerende cultuur binnen de rechtbanken die de aanbevelingen opmaken, maken de rechterlijke macht tot ver in de jaren vijftig een nagenoeg onneembare vesting voor de lagere sociale klassen.

In een nagenoeg vloeiende lijn verlegt de discussie over de persoon van de rechter zich in de jaren zeventig en tachtig naar een positieve belangstelling voor de samenstelling van de rechterlijke macht. De geluiden over klassejustitie verstommen, zo wordt aan het einde van hoofdstuk 4 opgemerkt - hoewel men zich ernstig kan afvragen of zij werkelijk zijn verdwenen -, en de rechtspraak lijkt het voortouw te nemen in tal van heikele, maatschappelijke kwesties. Vooral ten aanzien van het rechterlijk activisme, rijst nu de vraag of de rechter voor die nieuwe taak wel gelegitimeerd en geëquipeerd is. In die discussie wordt, voor de samenstelling van de rechterlijke macht, een analogie gemaakt met de rechtstreekse verkiezing van de leden van de Tweede Kamer. Opvallend is overigens de wijze waarop de discussie over de toegang tot het rechtersambt zich steeds ontwikkelt, nl. aan de hand van incidenten (relletjes) die bij toeval 
de media weten te halen. De (keuze van) berichtgeving door de media, en de wijze waarop die plaatsvindt, lijkt een cruciale, en onderschatte rol voor de beeldvorming van de rechterlijke macht te vervullen. Die berichtgeving heeft niet alleen invloed op de beeldvorming van de rechter bij het publiek, maar heeft ook een aanwijsbare impact op het staatsrecht. De aanzet voor veel ontwikkelingen in de inrichting van de rechterlijke organisatie blijkt niet zelden te komen van buiten-parlementaire zijde. Zo was de vertrouwenscrisis uit de jaren zestig wellicht nooit serieus genomen door de Tweede Kamer als zij niet door de Revu-enquêtes op het probleem opmerkzaam was gemaakt, en de crisis zou wellicht nooit door de wetenschappelijke literatuur zijn opgepikt als de pers niet zoveel aandacht had besteed aan de processen naar aanleiding van de Maagdenhuisbezetting. Ook de commotie rond het Tweede Kamerlid-Van der Burg in 1991 heeft zich, net als die over de nevenfuncties van Cnoop Koopmans en Van den Biesen, grotendeels in de pers afgespeeld, en kreeg pas daarna een vervolg in de vorm van regelgeving.

Het democratische perspectief, blijkt in hoofdstuk 6 een hardnekkig misverstand, dat men aantreft op die plaatsen waar de (traditionele taak van de) rechter op gespannen voet komt te staan met de (traditionele taak van de) wetgever of (van) het bestuur, in het bijzonder bij onderwerpen als het toetsingsrecht, de administratieve rechtspraak en het rechterlijk activisme. Uitgaande van de gedachte aan machtenscheiding, ontstaat in het democratische perspectief bij een bepaalde taakstelling/taakopvatting van de rechter (de scheidslijn is niet altijd even duidelijk), een legitimiteitsprobleem, dat ogenschijnlijk slechts kan worden opgelost door te kiezen voor een methode van aanstelling van rechters, die analoog is aan die van 'de' wetgever, waarmee bedoeld is de rechtstreekse verkiezing van de leden van de Tweede Kamer. Deze noties worden, eerst voor wat betreft de vermeende controverse benoeming-verkiezing, later wat het uitgangspunt van de machtenscheiding aangaat, in hoofdstuk 6 gerelativeerd. Om deze discussie op voorhand enig reliëf te geven, is in hoofdstuk 5 de methode van verkiezing van rechters, en de discussie daarover, in de Amerikaanse deelstaat New York beschreven. Mede aan de hand daarvan, wordt aan het einde van het zesde hoofdstuk het probleem van de legitimatie van de rechter, in verband met zijn taak(stelling/opvatting), afgebogen van het vraagstuk van de toegang tot het rechtersambt. Door de legitimatie van de rechter te verbinden met bijvoorbeeld dissenting en concurring opinions, en meer in het algemeen met de openbaarheid van de rechtspleging, wordt een einde gemaakt aan een denkpatroon, waarin publieke controle per se een constellatie van publiekrechtelijke bevoegdheden (benoeming/verkiezing) vooronderstelt. Het ontkoppelen van legitimatie en de wijze van samenstelling geeft een nieuwe inhoud aan het begrip publieke controle. Die controle ruimt ook plaats in voor het wetenschappelijke en maatschappelijke debat. 


\subsection{Nabeschouwing}

Aan het eind van deze studie gekomen, blijkt het onderzoeksobject - de benoeming van rechters - een overschat onderwerp in het staatsrecht. Voor de ijverige onderzoeker, die zijn onderzoeksterrein (en zichzelf) graag onmisbaar maakt, valt het niet mee zoiets te moeten constateren. Toch voert het voorgaande ontegenzeggelijk tot de conclusie dat voor de uiteenlopende vraagstukken die in het verleden aan de toegang tot het rechtersambt hebben geraakt -het probleem van personeelsvoorziening, het vertrouwen in de rechter en het rechterlijk activisme-, de benoeming van rechters weinig te bieden heeft. Die ietwat zure uitkomst zegt vooral iets over het gebrekkig functioneren van het forum, dat ons in de afgelopen jaren op een dwaalspoor heeft gezet. De waardering van ontwikkelingen die zich terzake van de rechtspleging voordoen, en het signaleren van de problemen die daarbij (kunnen) rijzen, stellen (kennelijk) in toenemende mate hoge eisen aan 'de' politiek, 'de' rechtswetenschap, en 'de' pers. Als uit de beschrijving van de discussie over de toegang tot het rechtersambt iets duidelijk wordt, dan is het wel dat die discussie op alle fronten onvolledig gevoerd wordt, terwijl al die fragmenten samengenomen nog steeds geen compleet beeld opleveren van het probleem.

()m met het probleem van personeelsvoorziening te beginnen, al sinds het eerste hoofdstuk mag duidelijk zijn dat benoeming en (personeels-)selectie van rechterlijke ambtenaren geen synoniemen zijn. Het formele benoemingsbesluit is inmers de allerlaatste fase van een complexe reeks hindernissen die samen het selectieproces vormen. Een serieuze discussie over selectie begint daarom, zo zagen we in het eerste hoofdstuk, al bij de vraag naar de rekrutering van rechterlijke ambtenaren, die op haar beurt weer samenhangt met de toegang (t)egankelijkheid) tot het hoger onderwijs. Wie gaan er studeren, en vooral: wie niet en waarom niet'? Aan die vraag 'hangt' zoals dat heet, een 'prijskaartje'. Wie praat over gelijke toegang tot het rechtersambt, praat uiteindelijk ook over studiefinanciering en tweede kans onderwijs, over het gericht enthousiasmeren van die groepen die (traditioneel) minder snel geneigd zijn te gaan studeren of te opteren voor een loopbaan in de rechterlijke macht, over voorzieningen voor gehandicapten en over kindercrèches.

Evenmin als men het benoemingsvraagstuk mag overschatten, mag men dat trouwens doen met het selectievraagstuk. Zowel in binnen- als in buitenland, staan de betrokken selecteurs immers te dringen om als eerste de betrekkelijkheid van een selectiesysteem aan te geven ${ }^{5}$. De waarde van een selectiemethode is daarom beperkt. In positieve zin mag men hoogstens verwachten dat 
selectie er toe leidt dat professionele, goed gekwalificeerde rechters worden binnengehaald (een garantie dat dat ook inderdaad gebeurt ontbreekt echter). In negatieve zin zal men ervoor moeten waken dat selectie geen ongewenst afwerend effect heeft op de toegang van bepaalde groepen in de samenleving tot het rechtersambt. Zo gesteld, kan iedereen in die opvatting wel iets van zijn gading in vinden - wie is er niet vórr 'goede' rechters en tégen 'ongewenste' effecten -, maar het wordt ingewikkelder wanneer we moeten bepalen wie niet professioneel gekwalificeerd is voor de rechterlijke macht, welke groepen - anders dan uit oogpunt van professionaliteit - niet mogen worden toegelaten tot het rechtersambt, en wie aan het selectieproces niet mogen deelnemen.

Met die laatste vraag is een strategisch probleem verbonden. Bevoegdheden - in het bijzonder de concentratie van bevoegdheden - dragen altijd het gevaar in zich van misbruik. Toch vallen, op dat punt, bij de benoeming en selectie van rechters nauwelijks problemen te verwachten. Een interessant (zij het historisch volstrekt onbedoeld) aspect van de bestaande situatie, is dat zij - zoals in $\$ 2.4 .2 .1$ werd opgemerkt - weinig systeem bevat. Noch de uitvoerende, noch de rechterlijke macht zijn - door de veelheid aan medebeslissers - in staat gericht hun stempel op de personele samenstelling van de rechterlijke macht te drukken; rechtstreekse beïnvloeding - 'beleid' (of erger: een complot) - valt moeilijk te realiseren. Tegelijk blijkt dat dit gebrek aan systeem de samenstelling van de rechterlijke macht niet ongevoelig maakt voor maatschappelijke veranderingen. De kritiek op de samenstelling van de rechterlijke macht, nú en in het verleden, en vooral het vóor willen zijn en blijven van die kritiek, lijkt de deelnemers aan het selectieproces (de selectiecommissies, de rechterlijke macht, de regering) niet onberoerd te laten. Alom wordt immers geconstateerd dat er 'veel verbeterd' is, dat de samenstelling van de rechterlijke macht 'diverser' is, en dat de persoon van de rechter 'een andere' is dan vroeger. Het onuitgesproken verlangen dat art. $3 \mathrm{GW}$ uitdrukt, $\mathrm{nl}$. dat Nederlanders van diverse herkomst niet alleen benoembaar zijn, maar ook benoemd worden in de rechterlijke macht, lijkt werkelijkheid te worden. Het zou potsierlijk zijn deze historisch gegroeide chaos een geraffineerd stelsel van checks and balances te noemen, maar naar het effect gemeten dringt de gedachte eraan zich wel op. Het bestaande stelsel sluit de ogen niet voor het feit dat rechtspraak mensenwerk is, maar het maakt tegelijk de samenstelling van de rechterlijke macht niet tot inzet van een bloedgroependiscussie.

Of deze weinig gestructureerde situatie ook overigens wenselijk is valt echter te betwijfelen. Uit het uitblijven van een complot mag men niet afleiden dat er dus een garantie is dat in ieder stadium behoorlijk met bevoegdheden wordt omgesprongen. Integendeel, het ontbreken van inzicht, laat staan van toezicht, biedt in elk stadium van het selectieproces ruimte voor willekeur of ondeskundigheid. Ook is er weinig kans dat verschillen van inzicht over selectie en 
selectiecriteria - tussen RPD Advies en de selectiecommissies, tussen de selectiecommissies onderling, tussen de selectiecommissies en de rechterlijke macht, tussen de rechterlijke macht en het parlement of de regering - aan het licht komen, laat staan dat deze opgelost worden. Het constitutionele probleem dat in $\S 2.2 .3$ werd geconstateerd, namelijk het gebrek aan onderlinge afstemming van de factoren in het positieve recht die de toegang tot het rechtersambt bepalen, bestaat dan ook niet zozeer uit een juridisch-technische inconsequentie, als wel uit hetgeen waar zo'n inconsequentie staatsrechtelijk voor staat, namelijk voor een ondoorzichtige en daardoor oncontroleerbare procedure.

Ik bereik daarmee de kern van het probleem waar het staatsrecht zich bij de regeling van de toegang tot het rechtersambt voor geplaatst ziet. Enerzijds is in het verleden steeds gezocht naar een mogelijkheid om reeds vooraf, met een 'ideale' selectiemethode een scala aan behoeften te bevredigen ${ }^{6}$, anderzijds ziet het institutionele recht zich voor het probleem gesteld dat iedere poging om invloed uit te oefenen op de feitelijke praktijk van de werving, selectie en benoeming (bevordering) van rechterlijke ambtenaren, per definitie tekort schiet, omdat de aard en de omvang van toekomstige problemen niet kan worden overzien. Een schrale troost is misschien dat elders (vergelijk de Verenigde Staten) met dezelfde problemen wordt geworsteld, al kan men wellicht daar 6́6 terecht voor de eerste stap naar de oplossing van het probleem. Met name de meer algemene notie uit de discussie over merit selection, dat bij de toegang tot het rechtersambt niet zozeer de methode an sich maar vooral het effect van de methode telt, lijkt belangrijk. Weliswaar kan het staatsrecht niet meer dan gebrekkig tegemoetkomen aan de vele, zeer uiteenlopende aspecten die met het vraagstuk van de toegang tot het rechtersambt zijn verbonden, het kan wel zorgen dat knelpunten op tijd gesignaleerd worden, opdat erger (een vertrouwens- of legitimiteitscrisis) wordt voorkomen. Controleerbaarheid lijkt - zoals in nagenoeg het gehele staatsrecht - ook hier het sleutelwoord te zijn.

Een eerste stap om de inzichtelijkheid van de toegang tot het rechtersambt te vergroten, zou zijn de bestaande procedure, die slechts met veel kunst- en vliegwerk kan worden ge(re?)construeerd, te codificeren (een noodzaak die overigens reeds uit de Grondwet voortvloeit). Men kan daarbij denken aan regeling in de Wet RO zelf, of - gezien de gevoeligheid van het onderwerp, en de noodzakelijke publiciteit - in een algemene maatregel van bestuur. Dit heeft als gevolg (en als bijkomend voordeel) dat onder parlementariërs, tussen het parlement en de regering, onder de betrokken rechters en bij juristen, vrij snel

6. Zoals een diverse samenstelling van en vertrouwen in de rechterlijke macht, de legitimatie van de rechter en de rechterlijke uitspraak, of de selectie van 'goede' en professionele rechters. 
een discussie zal ontstaan over de vraag naar de taken en bevoegdheden van de organen in het selectieproces, en meer in het algemeen over de wenselijkheid om bepaalde drempels voor de toegang tot het rechtersambt te slechten of juist op te richten. Met het verlangen naar overzichtelijkheid heeft men in het verleden een van de weinige kansen om de verbanden en dwarsverbanden van een vraagstuk als het onderhavige te doorgronden, laten schieten.

Codificatie alléen is echter niet voldoende. Zij biedt weliswaar inzicht in de structuur en de bevoegdheden van de betrokken organen, maar verschaft geen duidelijkheid over hun werkzaamheden. Meer inzicht in het feitelijk functioneren van deze organen zou veel (potentiële) achterdocht over de motieven bij selectie en benoemingen weg kunnen nemen - een probleem dat (zie hieronder) in de nabije toekomst mogelijk opnieuw zal gaan spelen -, en brengt bovendien de discussie over de toegang tot het rechtersambt vanzelf op een hoger niveau. Reeds de publikatie van een betrekkelijk eenvoudig te realiseren (zonodig geanonimiseerd) overzicht van de aanmelding, toelating en afwijzing van kandidaten voor de selectiecommissies, en voor eerste en verdere benoemingen, laat immers zien dat de toegang tot het rechtersambt veel meer om het lijf heeft dan de enkele benoeming, terwijl van deze openbaarheid een effect zal uitgaan op de betrokken selecteurs, die zullen anticiperen op mogelijk gerechtvaardigde kritiek.

Behalve als een technocratisch-strategisch probleem, wordt het vraagstuk van de toegang tot het rechtersambt vandaag vooral als een rechtstheoretisch probleem gezien, in het bijzonder als een instrument om de rechter democratische legitimatie te verschaffen. In hoofdstuk 6 werd betoogd dat de redenering die hierachter schuilgaat berust op een dwangargumentatie. Bovendien is, sprekend over afspiegeling in de rechterlijke macht, de eenzijdige belangstelling voor de benoemingsfase (zie hiervoor) weinig subtiel te noemen. In dat opzicht heeft de voordrachtsbevoegdheid van de Tweede Kamer een debiliserend effect gehad. Zij verleidt slecht geïnformeerd volksvertegenwoordigers tot een simplificatie van de problematiek, en maakt de samenstelling van de Hoge Raad tot inzet van (veelal niet ter zake doende) beschouwingen over de rechterlijke macht. Ook zonder voordrachtsbevoegdheid zou de Tweede Kamer haar controlerende taak kunnen uitvoeren, beter zelts. Dror het activeren van de ministeriële verantwoordelijkheid voor de toegang tot het rechtersambt, zou in het parlement, aan de hand van gegevens over de in- en doorstroom in de rechterlijke macht (zie hierboven) en van de aanbevelingslijsten van de rechtscolleges, een oneindig veel genuanceerder debat over de samenstelling van de rechterlijke macht gevoerd kunnen worden.

Toch vermoed ik dat juist de belangstelling vour de benoeming van rechters - zuals we die eerder in bijvoorbeeld bij de kwestie-Van der Burg tegenkwa- 
men - in de toekomst sterk zal groeien. Gedachten als zouden wij moeten voorkomen dat - ik doe een greep uit een onuitputtelijke bron van potentiële conflicten - een fundamentalistische islamitische rechter een oordeel uitspreekt over de Nederlandse persvrijheid ${ }^{7}$, zullen in de zeer nabije toekomst aan invloed winnen (al zullen aanspraken van islamitische zijde op gelijke toegang tot het rechtersambt, nádat ons angstbeeld van 'de' buitenlander is genuanceerd, op termijn even legitiem blijken als die van vrouwen destijds). Bovendien zal mèt de grotere speelruimte van de rechter, de angst dat die vrijheid wordt 'misbruikt' toenemen, en zal de discussie zich vaker toespitsen op de achtergrond en de persoon van de rechter. Met name vraagstukken rond criminaliteit en rechtshandhaving, en uit de medisch (technologisch)-ethische hoek dragen het gevaar in zich dat zij de samenstelling van de rechterlijke macht uiterst gevoelig maken voor claims van belangengroepen. De kwestie-Van der Burg zal daarom niet een bedrijfsongelukje blijken, maar heeft veeleer de toon gezet voor een sterke polarisatie. In dit verband is het interessant (dat is niet altijd hetzelfde als bemoedigend) dat de huidige minister van justitie, Hirsch Ballin, dergelijke gedachten actief lijkt te voeden, waar hij meent dat de rechtsbescherming van de verdachte 'te ver doorgeschoten is', als gevolg van een te liberale samenstelling van de rechterlijke macht. ${ }^{8}$

Het is echter van tweeën één: men kan niet een belangrijk deel van de normstelling willen overlaten aan de rechterlijke macht, en tegelijkertijd hadar geloofwaardigheid ondermijnen. De vraag is daarom of het staatsrecht - en ik knoop hier aan bij het slot van het zesde hoofdstuk - hovenstaande ontwikktlingen ook moet ondersteunen. Dient de legitimiteit van de rechter en de rechterlijke uitspraak inderdaad te worden verbonden met het botte instrumentarium van de benoeming van rechters, of moeten we die simplificatie een stap vóór zijn, en aansluiten hij een verfijnder controlemechanisme (vergelijk de pleidooien in hoofdstuk 6 voor bijvoorbeeld dissenting en concurring opinions)? Ik opteer - de woordkeuze 'bot' versus 'verfijnd' laat wat dat betreft ook niets aan verrassing over - voor dat laatste.

\subsection{Slot}

Een epiloog is voor volhouders, voor een select gezelschap dat, na-pratend op een veel te laat feestje, toch nog een fles wijn opentrekt. De schrijver roept iets meer dan hij werkelijk waar kan maken, en de lezer doet daar iets minder moeilijk over dan hij anders zou doen. In de kern vormt de uitkomst van deze

7. Vergelijk het CDA-Tweede Karnerlid Paulis, Hand. II, 19 maart 1987, p. 3201; ik verder $\$ 4.9 .1$

8. Zie de inleiding bij dit hoofdstuk 
studie - tegen beter weten in - immers een appèl op de alertheid van de welingelichte, redelijk argumenterende, en geïnteresseerde burger. Dit beroep op het publieke debat is een onzeker experiment, dat zeker niet mag worden overschat. Zolang zelfs kwaliteitskranten in ons land de term 'rechtsstaat' consequent met één 's' te weinig blijven spellen, is waakzaamheid geboden. De vraag is echter of er werkelijk veel keuze is, en of men - zie het pleidooi van Dorien Pessers aan het begin van dit hoofdstuk - de zaak nog kan beslechten door de rechter eenvoudig terug te dringen in de anonimiteit van toga en raadkamer $^{9}$. Jerome Frank heeft er al op gewezen dat in de (burgerlijke) overheidsdienst alleen liftjongens en telefonistes geüniformeerd gaan ${ }^{10}$, en hij waarschuwt voor de beschutting die de toga opwerpt, "to shield the judges and their ways from rational inquiry. (-) The robe, as ceremonial costume, functions as part of a rite, and rites have deep roots in the tabu. An institution ritually protected by tabu is fenced off from the attack of critical reason. "11 Gezag - rechterlijk gezag - legitimeert zichzelf niet, maar ontleent zijn bestaansrecht slechts uit de kracht van zijn argumenten. Moeten wij misschien, net als in Engeland het geval is, een lijst publiceren van 'enge rechters', die 'onvergetelijke diepten van afschuwelijkheid' hebben bereikt? "In Nederland voorulsnog ondenkbaar vanwege de verplichte eerbied", meldt de Volkskrant met weinig historisch besef. " Hopelijk ook niet nodig, voeg ik er daarom aan toe, maar de boodschap is helder. Voor zijn legitimatie zal de rechter zich allereerst op zijn feitelijk functioneren moeten beroepen.

9. Ja, zeggen inmiddels ook de oud-president van de rechtbank Amsterdam B.J. Asscher, en de journaliste An Salomonson. als zij er op wijzen dat de symbolische waarde van de toga -'het gezag als beeld, als heilzame functie'- ten onrechte wordt onderschat. An Salomonson, Witte jas als symbool van autoriteit, NRC Handelsblad, 27 juli 1993 en: B. J. Asscher, Witte jas als symbool van schuldloosheid. NRC Handelsblad, 17 juli 1993

10. Mijn vertaling is bij nader inzien beduidend seksistischer dan de oorspronkelijke tekst die slechts spreekt van 'operators' en 'elevator-starters'. Zie: Jerome Frank, Courts on trial Myth and reality in American justice, 1949, p. 256

11. Jerome Frank, o.c. p. 256

12. Henk Strabbing, Opnieuw een lijst met enge rechters, de Volkskrant, 9 april 1994 


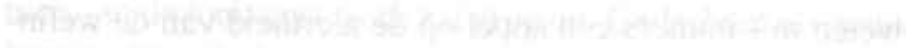

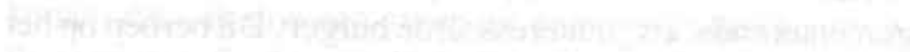

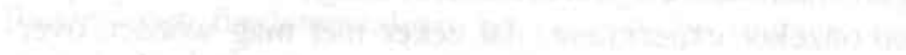

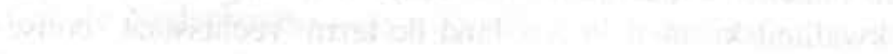

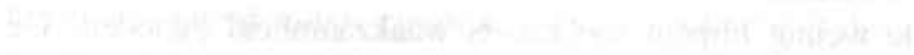

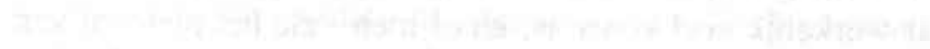
(n)

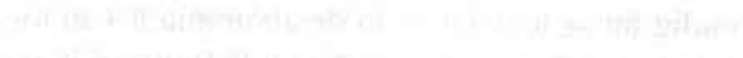

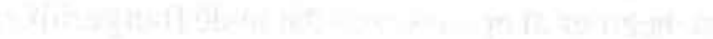




\section{Bijlage 1: Benoeming}

\section{Kantonrechter}

Vacatures kantonrechter of kantonrechter-plaatsvervanger worden gepubliceerd in het Nederlands Juristenblad. Sollicitaties dienen te worden gericht aan de Koningin, en worden gestuurd naar het ministerie van justitie. De binnengekomen sollicitaties worden met een verzamellijst, toegezonden aan de president van de rechtbank in het ressort waarin de vacature ontstaat. Door de president van de rechtbank wordt een vergadering belegd met de officier van justitie, hoofd van het arrondissementsparket, en de rechters van de kantons in het arrondissement, met uitzondering van degenen, die naar de opengevallen plaats mochten mededingen (art. 36a Wet RO). De vergadering doet aan de president van en de procureur-generaal bij het gerechtshof, tot welks ressort het arrondissement behoort, een lijst van aanbeveling van drie kandidaten toekomen, welke lijst, alfabetisch ingerieht, aan de Koning wordt aangeboden, om daarop zodanig acht te slaan als Hij zal dienstig oordelen. De aanbevelingslijst wordt niet gepubliceerd. De aanbevolen kandidaten worden voor een gesprek uitgenodigd op het ministerie van justitie; afhankelijk van de vacature vindt een gesprek plaats met de minister of met de secretaris-generaal van het departement. De vacature kantonrechter of kantonrechter-plaatsvervanger is in de praktijk een promotie-benoeming ('verdere benoeming) en staat slechts open voor de rechters in een arrondissementsrechtbank.

\section{Rechter arrondissementsrechtbank}

Vacatures van rechter, rechter-plaatsvervanger of griffier in een arrondissementsrechtbank worden gepubliceerd in het Nederlands Juristenblad. Sollicitaties dienen te worden gericht aan de Koningin, en worden gestuurd naar het ministerie van justitic. Art. 52 Wet RO bepaalt dat wanneer een plaats van rechter, rechter-plaatsvervanger of griffier openvalt, de rechtbank, de officier van justitie, die is benoemd tot hoofd van het arrondissementsparket daaronder begrepen, aan de president en procureur-generaal van het gerechtshof, tot welks ressort zij behoort, een lijst van aanbeveling zendt van drie kandidaten, welke lijst, alfabetisch ingericht, aan de Koning wordt aangeboden om daarop zodanig acht te slaan, als Hij zal dienstig oordelen. De aanbevelingslijst wordt niet gepubliceerd. De aanbevolen kandidaten worden voor een gesprek uitgenodigd op het ministerie van justitie; afhankelijk van de vacature vindt een gesprek plaats met de minister of met de secretaris-generaal van het departement. De vacature rechter of rechter-plaatsvervanger in een arrondissementsrechtbank is in de praktijk een z.g. 'eerste benoeming'.

\section{Raadsheer gerechtshof}

Vacatures raadsheer of raadsheer-plaatsvervanger worden gepubliceerd in het Neder!ands Juristenblad. Sollicitaties dienen te worden gericht aan de Koningin, en worden gestuurd naar het ministerie van justitie. Art. 63 Wet RO bepaalt dat wanneer een plaats van raadsheer of raadsheer-plaatsvervanger openvalt, het hof, de procureur-generaal daaronder begrepen, een lijst van aanbeveling van drie kandidaten opmaakt, welke lijst, alfabetisch ingericht, aan de Koning wordt aangeboden, otn daarop zodanig acht te slaan als $\mathrm{Hij}$ zal dienstig oordelen. De aanbevelingslijst wordt niet gepubliceerd. De aanbevolen kandidaten worden voor een gesprek uitgenodigd op het ministeric van justitie; athankelijk van de vacature vindt een gesprek plaats met de minister of met de secretarisgeneraal van het depariement. De vacature raadsheer of raadsheer-plaatsvervanger is in de praktijk 
een promotie-benoeming ('verdere benoeming) en staat slechts open voor rechters in een arrondissementsrechtbank of kantonrechters.

\section{Raadsheer Hoge Raad}

De leden van de Hoge Raad der Nederlanden worden benoemd uit een voordracht van drie personen, opgemaakt door de Tweede Kamer der Staten-Generaal. ${ }^{1}$ Wanneer een platats van raadsheer in de Hoge Raad openvalt, zal de Hoge Raad daarvan kennis geven aan de Tweede Kamer der Staten-Generaal, en daarbij inzenden een door die Raad, de procureur-generaal daaronder begrepen, bij besloten briefjes en met meerderheid van stemmen opgemaakte aanbevelingslijst van 6 kandidaten, waarop de Tweede Kamer bij het maken van haar nominatie zodanig acht zal slaan als zij zal dienstig oordelen. ${ }^{2}$ De leden der hoven en der arrondissementsrechtbanken, mitsgaders de leden van het openbaar ministerie bij dezelve, welke deze hun ambtsbedieningen met lof en ijver hebben waargenomen, zullen bij het opmaken dier lijst meer bijzonderlijk in aanmerking komen. ${ }^{3}$ De Hoge Raad stuurt de curricula van de kandidaten op de aanbevelingslijst in gestandaardiseerde vorm voorzien van informatie naar de Tweede Kamer. De president van de Hoge Raad voorziet iedere aanbevelingslijst vân een aparte toelichting. In die toelichting zet hij uiteen wat de motieven zijn van de Raad om te komen tot de aanbeveling. De aanbevelingslijst, de curricula en de toelichting worden gelijktijdig gestuurd aan de Voorzitter van de Tweede Kamer en aan de voorzitter van de Vaste Kamercommissie voor Justitie. Indien de lijst of de toelichting aanleiding vormen tot het vragen van nadere inlichtingen, dan zal de Commissie een gesprek kunnen aangaan met de president en de procureur-generaal. Spreekt de Commissie daarna de wens uit, dan kan zij een gesprek voeren met een of meer kandidaten, in het bijzonder met de personen die voor het eerst op de aanbevelingslijst zijn opgevoerd. ${ }^{4}$ De door de Hoge Raad aanbevolen kandidaten worden niet voor een gesprek uitgenodigd op het ministerie van justitie.

\section{President rechtbank}

Vacatures president rechtbank worden sinds 1986 voor sollicitatic opengesteld door middel van publikatie in het Nederlands Juristenblad. Sollicitaties, gericht aan Hare Majesteit de Koningin, dienen, vergezeld van een curriculum vitae, te worden ingediend bij het ministerie van justitie. Een afschrift daarvan dient rechtstreeks te worden gezonden aan de president van het gerechtshof in het ressort waarvan de onderhavige rechtbank is gelegen. De binnengekomen sollicitatierekesten worden met een verzameilijst aan de president van genoemd gerechtshof gezonden. De sollicitatietermijn sluit drie weken na datum van de publikatic in het Nederlands Juristenblad. Er is een commissie van aanbeveling die bestaat uit de president van het genoende gerechtshof en twee rechtbankpresidenten. De vergadering var, rechtbankpresidenten wijst in beginsel de voorzitter van die vergadering en een rechtbankpresident uit het ressort van het onderhavige hof aan. Indien een sollicitant vice-president is van of rechter in een rechtbank waarvan de president deel uitmaakt van de commissie van aanbeveling, laat deze president zich in beginsel als zodanig door een collega. aan te wijzen door voornoemde vergadering, vervangen. Evenzo laat de hofpresident zich in beginsel vervangen door een collega wanneer een lid van zijn hof sollicitant is. De. rechtbank waarin de vacature bestaat stelt voordat de vacature wordt opengesteld een profielschets op en. doet

1. Art. 118, eerste lid, GW. Zie ook: Reglement van Orde van de Tweede Kamer, art. 123-136.

2. Art. 85, eerste lid, Wet $\mathbf{R O}$

3. Art. 85 , tweede lid, Wet RO

4. Brief van de vaste Commissie voor Justitie, Bijl. Hand. II 1991-1992, 22300 VI, nr. 37 herdruk p. 1-2

5. Circulaire van 19 november $1985 \mathrm{nr}$. 2168 P 885 . Gewijzigd bij circulaire van 24 november 1992 nr. 263662/892 
deze aan de commissie van aanbeveling toekomen. De commissie van aanbeveling wint inlichtingen in bij voorkeur volgens een vast stramien, met een vaste vraagstelling en beperkt tot bepaalde functionarissen, zoals de president van de rechtbank waaraan de sollicitant verbonden is en eventueel de president van het hof indien het een radsheer betreft. Indien de adviezen daartoe aanleiding geven staat het de commissie van aanbeveling vrij nadere inlichtingen in te winnen. De voorzitter van de commissie van aanbeveling doet afschrift van de binnengekomen inlichtingen toekomen aan de overige leden van de commissie alsmede aan de voorzitter van een delegatie van in beginsel 5 personen uit de rechtbank die het vertrouwen heeft van dit college en welke als een afspiegeling daarvan kan worden aangemerkt (het afspiegelingscollege), die deze stukken vertrouwelijk onder zich houdt en ze na het uitbrengen van het advies aan de voorzitter van de commissie van aanbeveling terugzendt. De leden van het afspiegelingscollege en de overige hierna te noemen insprekers kunnen bij de voorzitter van het afspiegelingscollege inzage verkrijgen. De sollicitant heeft het recht kennis te nemen van de zakelijke inhoud van de inlichtingen. Het afspiegelingscollege onthoudt zich van het inwinnen van schriftelijke inlichtingen. De commissie van aanbeveling heeft het recht om, indien haar dit in bijzondere omstandigheden gewenst voorkomt, bijvoorbeeld omdat zich zeer veel sollicitanten hebben gemeld, uit de sollicitanten een voorselectie te maken van degenen die naar haar mening voor de vervulling van de vacature in aanmerking lijken te komen. De commissie hoort in ieder geval alle sollicitanten indien deze dat wensen, behoudens wanneer een kandidaat niet an de formele vereisten voor de benoeming voldoet. $Z_{i j}$ geeft de namen van alle sollicitanten, alsmede de eventueel door haar gemaakte voorselectie, door aan de insprekers.

Insprekers zijn het afspiegelingscollege, de hoofdofficier van justitie, de directeur gerechtelijke ondersteuning, het hoofd gerechtelijke ondersteuning en de deken van orde van advocaten in het arrondissement. Op welke wijze de D.G.O. en de H.G.O. hun inspraakrecht uitoefenen staat te hunner beoordeling. Zij kunnen dit gezamenlijk doen, maar het is ook mogelijk dat de H.G.O. zich aansluit bij het afspiegelingscollege. Iedere inspreker moet contact kunnen hebben met de kandidaten. Het afspiegelingscollege heeft binnen een door de commissie gestelde termijn het recht de commissie te laten weten dat het ook andere dan de voorgeselecteerde sollicitanten in de verdere selectie wil betrekken. De commissie kan hierover met het afspiegelingscollege in overleg treden. Indien dit zijn wens handhaaft worden bedoelde sollicitanten in de verdere selectie betrokken. Vervolgens bericht de commissie aan de sollicitanten die niet in de verdere selectie zijn betrokken dat aan hun sollicitatie geen verder gehoor zal worden gegeven. Voorts bericht de commissie de overige sollicitanten en de insprekers welke sollicitanten nog als zodanig zullen optreden. De insprekers brengen op verzoek van de commissie van aanbeveling hetzij schriftelijk hetzij mondeling advies uit, maar hebben steeds de bevoegdheid schriftelijk te adviseren en, indien schrificlijk advies is uitgebracht, en mondelinge toelichting daarop aan de commissie van aanbeveling te geven. Het afspiegelingscollege adviseert zonder last of iuggespraak. De adviezen zijn strikt vertrouwelijk en blijven voor de sollicitanten en de andere insprekers geheim, behoudens de vrijheid van de commissie van aanbeveling om met toestemming van de betrokken inspreker de inhoud ervan met andere insprekers en/of soliicitanten te bespreken wanneer de adviezen daartoe aanleiding geven. De aftredende of afgetreden president geeft ten behoeven van de commissie van aanbeveling een kenschets van de door hem (te) verlaten rechtbank en brengt deze in relatie met bovengenoemde profielschets. Voorts kan hij inlichtingen verstrekken omtrent de sollicitanten die aan de door hem (te) verlaten rechtbank verbonden zijn. Hij onthoudt zich van een advies of aanbeveling. De aanbeveling bevat zo mogelijk meer dan een naam, met een maximum van drie, in volgorde van voorkeur. De commissie van aanbeveling zendt de aanbeveling, vergezeld van een toelichting, de originele rekesten van de sollicitanten, alle binnengekomen adviezen alsmede de inlichtingen met betrekking tot de aanbevolen kandidaten uiterlijk drie maanden na sluiting van de sollicitatietermijn aan het ministerie van justitie. Aan de sollicitanten en aan de insprekers wordt bericht hoe de aanbeveling, inclusief volgorde van voorkeur, luidt. De aanbeveling wordt niet gepubliceerd. In de praktijk is de benoeming tot president rechtbank een promotie-benoeming en komen slechts in aanmerking vice-presidenten rechtbank. 


\section{Vice-president rechtbank}

Vacatures vice-president rechtbank worden sinds 1975, behoudens in bijzondere gevallen, gepubliceerd in het Nederlands Juristenblad..$^{6}$ Over de vraag of in een bepaald geval openstelling van de vacature achterwege dient te blijven, wordt overleg gepleegd met de hieronder te noemen aanbevelingscommissie. Bij de publikatie wordt zo enigszins mogelijk vermeld of aan de kandidaten bijzondere eisen moeten worden gesteld. Sollicitaties worden gericht aan de Koningin. De binnengekomen sollicitaties worden met een verzamellijst toegezonden aan de president van de rechtbank waarin de vacature ontstaat. De minister kan tevens een beschouwing bijvoegen omtrent de uitgangspunten voor het te volgen benoemingsbeleid. Door een aanbevelingscommissie, bestaande uit de president gerechtshof in het ressort waar de vacature ontstaat (tevens voorzitter), de president van de betrokken rechtbank en de hoofdofficier in het betreffende arrondissement (leden) wordt een aanbeveling opgesteld welke in, volgorde van voorkeur, zo mogelijk meer dan één naam met een maximum van drie dient te bevalten. Alvorens de aanbeveling op te stellen, stelt de commissie de vice-presidenten van de desbetreffende rechtbank in de gelegenheid om terzake gezamenlijk schriftelijk advies uit te brengen (dit zijn de zogenaamde insprekers). Dit advies wordt met de aanbeveling meegezonden naar de minister. De commissie zendt een afschrift van deze bescheiden aan de desbetreffende procureur-generaal. De aanbeveling wordt niet gepubliccerd. Van de presidenten van de gerechtshoven wordt, zo zij niet achter de aanbeveling staan, niet verwacht dat zij een officieel minderheidsadvies zullen uitbrengen. In de praktijk is de benoeming vicepresident rechtbank een promotie-benoeming en komen slechts in aanmerking rechters in een rechtbank.

\section{President gerechtshof}

Vacatures president gerechtshof worden sinds 1987 voor sollicitatie opengesteld door middel van publikatie in het Nederlands Juristenblad. ${ }^{7}$ Sollicitaties gericht aan Hare Majesteit de Koningin, dienen te worden toegezonden aan het ministerie van justitie. De binnengekomen sollicitatierekesten worden met een verzamellijst toegezonden aan de president gerechtshof in welk rechtsgebied de vacature zich voordoet. De aanbeveling, welke zo mogelijk meer dan één naam, met een maximum van drie, in volgorde van voorkeur dient te bevatten, wordt opgesteld door een commissie, bestaande uit een door de vergadering van hofpresidenten aan te wijzen president van een gereehtshof en twee ad hoc door de vergadering van rechtbankpresidenten aan te wijzen presidenten van arrondissementsrechtbanken, onder wie éen rechtbankpresident uit het ressort waarin de vacature zal openvallen e.q. is opengevallen. Alvorens de aanbeveling op te stellen doch nadat de commissie zich een eerste oordeel heeft gevormd, vraagt zij in een vertrouwelijk gesprek de visie van de aftredende of afgetreden president, de procureur-generaal bij het desbetreffende gerechtshof, en de deken van de orde van advocaten in het arrondissement, waarin het gerechtshof is gevestigd. In dat gesprek beperkt de commissie zich tot het noemen van de namen van diegenen die naar har mening voor de vervulling van een vacature het meest in aanmerking lijken te komen. Daarnast stelt de commissic een delegatic uit het gerechtshof welke als een afspiegeling daarvan kan worden aangernerkt, en de griffier van het college in de gelegenheid schriftelijk advies uit te brengen. Indien de wens daartoe nadrukkelijk wordt uitgesproken kan de aanbevelingscommissie aan de delegatie uit het college toestaan dat, naast de kandidaten die reeds zijn genoemd, ten hoogste éen andere kandidaat in het advies wordt betrokken. De aanbevelingscommissie zendt de aanbeveling, vergezeld van een toelichting, inhoudende onder meer de visie van diegenen die ter zake gehoord zijn, en de schriftelijk uitgebrachte adviezen met de (originele) rekesten van de sollicitanten, naar het ministerie van justitie. Van de plaatsing op de aanbeveling wordt door de commissie aan de

6. Circulaire van 3 januari 1975 nr. 2284 P 874

7. Circulaire van I juli $1987 \mathrm{nr} .1271$ P 887 
betrokkene(n) mededeling gedaan. In de praktijk is de benoeming president gerechtshof een promotie-benoeming en komen slechts in aanmerking vice-presidenten gerechtshof.

\section{Vice-president gerechtshof}

Vacatures vice-president gerechtshof worden sinds 1989 voor sollicitatic opengesteld door middel van publikatie in het Nederlands Juristenblad. ${ }^{8}$ Over de vraag of in een bepaald geval openstelling van een vacature achterwege dient te blijven, wordt overleg gevoerd met de hieronder te noemen aanbevelingscommissic. Bij de publikatie wordt zo enigszins mogelijk vermeld of aan de kandidaten bijzonder eisen moeten worden gesteld. Sollicitaties, gericht aan Hare Majesteit de Koningin, dienen te worden ingediend bij het ministerie van justitie. De binnengekomen sollicitatierekesten worden met een verzamellijst toegezonden aan de president van het gerechtshof in welks gerechtsgebied de vacature zich voordoet. De aanbeveling, welke zo mogelijk meer dan een naam, met een maximum van drie, dient te bevatten, wordt in volgorde van voorkeur opgesteld door een commissic, bestaande uit de president van het betrokken gerechtshof alsmede een door de vergadering van rechtbankpresidenten aan te wijzen president van een arrondissementsrechtbank. Alvorens de aanbeveling op te stellen, stelt de commissie de vice-presidenten van het desbetreffende gerechtshof in de gelegenheid om ter zake gezamenlijk schriftelijk advies uit te brengen. De griffier van het desbetreffende gerechtshof wordt in de gelegenheid gesteld met betrekking tot de voorziening in de vacature advies uit te brengen. De aanbevelingscommissie zendt de aanbeveling, vergezeld van een toelichting, en de schriftelijk uitgebrachte adviezen met de (originele) rekesten van de sollicitanten, naar het ministerie van justitie. Van de plaatsing op de aanbeveling wordt door de commissie aan de betrokkenen mededeling gedaan. De aanbeveling wordt niet gepubliceerd. Vacatures vice-president gerechtshof zijn in de praktijk promotie-benoemingen waarvoor slechts in aanmerking komen raadsheren in een gerechtshof.

8. Circulaire van 25 januari $1989 \mathrm{nr} .142$ P 889

9. De samenstelling van de aanbevelingsvergadering is gewijzigd bij circulaire van 21 februari 1989, nr. 307 P 889. De circulaire uit 1987 schreef voor dat de aanbevelingsvergadering was samengesteld uit de president van het betrokken gerechtshof, de procureur-general bij dat gerechtshof alsmede cen door de vergadering van rechtbankpresidenten aan te wijzen president van een arrondissementsrechtbank. 


\section{Bijlage 2: Selectie}

\section{De selectieprocedure voor aspirant-raio's}

Tweemaal per jaar (in mei en november) worden selectieronden gehouden, middels advertenties in het Nederlands Juristenblad, Intermediair en enkele landelijke dagbladen. Na inzending van een aanmeldingsformulier en een sollicitatiebrief worden alle sollicitanten onderworpen aan een formele toetsing door de afdeling Personeel van het Directoraat-Generaal Rechtspleging van het ministerie van justitie. De sollicitanten die aan de eisen voor toelating voldoen worden door R.P.D. Advies uitgenodigd voor een psychologisch onderzoek. Het eerste testgedeelte van dat onderzoek wordt schriftelijk afgenomen, het tweede omvat naast een schriftelijk gedeelte een gesprek met een psycholoog. Toelating tot het tweede testgedeelte is afhankelijk van de resultaten van het eerste deel. R.P.D. Advies brengt een eindadvies uit over die kandidaten die beide delen van de test hebben afgelegd. Geteste kandidaten hebben het recht het doorsturen van het eindrapport te verhinderen. R.P.D. Advies deelt dit aan het Ministerie mede. In dat geval wordt de sollicitatie niet verder behandeld. Alle sollicitanten die tot het tweede testgedeelte zijn toegelaten, komen in aanmerking voor een gesprek met de raio-selectiecommissie.

Van de kandidaten die een gesprek met de raio-selectiecommissie zullen hebben, worden de referenties (maximal vier) aangeschreven en verzocht schriftelijk te reageren. De selectiegesprekken vinden in de regel ongeveer een maand nadat de kandidaat het tweede gedeelte van het psychologisch onderzoek heeft afgelegd plaats. De sollicitanten worden uitgenodigd voor een subcommissie van de raio-selectiecommissie, in beginsel samengesteld uit: een president van een arrondissementsrechtbank als voorzitter; een ander lid van de zittende magistratuur; een lid van de staande magistratuur; een hoofdambtenaar van het ministerie van justitie; een lid, niet behorende tot de rechterlijke macht en niet zijnde een departementsambtenaar. De subcommissies worden bijgestaan door een secretaris (een ambtenaar van het ministerie van justitie). De voorzitter voert in elk geval een gesprek met de sollicitant (een half uur), de overige leden van de subcommissie kunnen de kandidaat in (wisselende) combinaties van twee leden voor een gesprek ontvangen.

In totaal vinden drie gesprekken plats. Na afloop van de gesprekken met de kandidaten beraadt de subcommissie zich over de vraag of deze al dan niet geschikt worden geacht voor een functic binnen de rechterlijke macht en aanbevolen kunnen worden voor toelating tot de raio-opleiding. $Z \mathrm{ij}$ doet dat aan de hand van de door de kandidaat verschafte informatie op het sollicitatieformulier en in de sollicitatiebrief, van de door de referenten verstrekte inlichtingen, van de inhoud van de selectiegesprekken en van het resultaat van de psychologische test. De voorzitter van de subcommissie beschikt 's morgens voor de aanvang van de selectiegesprekken over het psychologisch rapport; de overige leden van de subcommissie worden pas in de eindfase van de oordeelsvorming door de voorzitter van de inhoud van dat rapport op de hoogte gesteld. Aan kandidaten die door de commissie niet geschikt worden geacht, wordt dit binnen enkele dagen na de selectiezitting schriftelijk meegedeeld. Zij kunnen pas na twee jaar opnieuw solliciteren.

De selectiecommissie richt haar gesprekken in op basis van vier factoren: a) motivatie, b) juridische kwaliteiten, c) contactuele en andere persoonlijke eigenschappen en d) matschappelijke activiteiten/betrokkenheid. De commissie biedt een in rangorde opgestelde 'voordracht' aan, aan de 
minister van justitic. De plaats in de rangorde wordt aan de kandidaten niet meegedeeld. Wel wordt een indicatie gegeven van de kans op daadwerkelijke benoeming: a: de kans op benoeming is zeer groot, b: de kans op benoeming is aanwezig en $\mathrm{c}$ : benoeming moet vrijwel worden uitgesloten. Het (plaatsvervangend) hoofd van het Directoraat-Generaal Rechtspleging ontvangt de geschikte kandidaten en beslist namens de minister of een kandidaat daadwerkelijk in dienst wordt genomen. Wanneer het aantal beschikbare plaatsen is bezet worden de audienties stopgezet. De geschikt geachte kandidaten die op grond van hun plaats in de rangorde niet kunnen worden benoemd, krijgen hiervan schriftelijk bericht. Zij kunnen bij de eerstvolgende gelegenheid opnieuw solliciteren en dienen de gehele selectieprocedure opnieuw te doorlopen. Kan een kandidaat ook in tweede instantie niet worden benoemd, dan kan hij pas na twee jaar opnieuw solliciteren. ${ }^{10}$

\section{De selectieprocedure voor 'buitenstaanders'}

Van buitenstaanders die in aanmerking willen komen voor een rechterlijke functie, wordt verwacht dat zij: voldoen aan de vereisten voor benoembaarheid ex artt. 48 en 35 Wet RO, zij bij voorkeur ouder dan 30 en jonger dan 50 jaar zijn, beschikken over een ruime maatschappelijke ervaring en een juridische praktijkervaring bezitten van tenminste 6 jaar, en bereid zijn op termijn in tenminste twee van de drie (civiel-, straf,- en bestuursrechtelijke) sectoren werkzaam te zijn. Het toetsingscriterium van de Commissie is "een goede intelligentie en over karaktereigenschappen, die voor een rechter noodzakelijk zijn." $\mathrm{Er}$ is een normale selectieprocedure voor kandidaten die cen overstap op korte of langere termijn naar een vaste rechterlijke functie willen maken, en een verkorte procedure voor kandidaten voor een honoraire functie, dat wil zeggen voor hen, die (kanton)rechter-plaatsvervanger willen worden, maar niet op afzienbare termijn naar een vaste rechterlijke functie willen solliciteren. Voor hen is vereist dat op grond van hun juridische kennis en ervaring verwacht mag worden dat zij op korte termijn bij het rechterlijk werk kunnen worden ingeschakeld. Ten aanzien van deze honoraire kandidaten geldt niet de gestelde leeftijdsgrens van 50 jaar. Bij de inlichtingenstaat dienen zij een schrijven toe te voegen, waaruit blijkt dat een rechterlijke instantie positief staat tegenover de benoeming van de betreffende kandidaat. In de normale procedure worden allereerst omtrent de kandidaat ambtsberichten ingewonnen bij de hoofdofficier van justitie van het arrondissement, waarin de betrokkene woont, en inlichtingen gevraagd aan in beginsel alle -tenminste drie- door hem of haar opgegeven referenten, waaronder bij voorkeur twee uit de werksfeer. Omtrent advocaten worden bovendien ambtshalve inlichtingen ingewonnen bij de president van de rechtbank in het arrondissement, waarin de betrokkene is ingeschreven, en bij de deken van de Orde van Advocaten in dat arrondissement. Daarna stelt RPD Advies een onderzoek in en brengt advies uit, waarbij vooral wordt gelet op de intelligentie, de produktiviteit, de stabiliteit, het sociaal gedrag en de taalbeheersing van de betrokkene.

$\mathrm{Na}$ voltooiing van het psychologisch onderzoek volgt een onderhoud met een beoordelingscommissie, doorgaans gevormd door zes leden van de Commissie. Gedurende telkens een half uur spreekt de kandidaat met twee commissieleden gezamenlijk. In totaal vinden drie gesprekken plaats. De commissieleden nemen pas kennis van het RPD Advies-rapport, nadat zij zich op grond van de ambtsberichten, de inlichtingen en de gevoerde gesprekken een voorlopig oordeel hebben gevormd. Het oordeel van de Commissie, dat in de regel een week na het onderhoud schriftelijk aan de kandidaat wordt meegedeeld, kan luiden dat zij: a) cen positieve verwachting koestert omtrent de geschiktheid van de betrokkene voor een rechterlijke functie (dit advies gaat in de regel vergezeld van de aanbeveling tot benoeming in een opleidingsfunctie), b) bereid is betrokkene toe te laten tot de cursus maken vonnissen, c) nog niet tot een oordeel is gekomen, of d) tot de conclusie is gekomen niet in positieve zin te kunnen adviseren omtrent de geschiktheid van de betrokkene voor een rechterlijke functie. In het geval onder c) vindt een ambtshalve revisie plaats, met een tweede, 
uit zes andere leden van de Commissie bestaande beoordelingscommissie. In het geval onder d) genoemd kan de kandidaat zelf een revisie verzoeken. Revisie wordt in de regel niet toegestaan, indien de eerste beoordelingscommissie unaniem in negatieve zin oordeelde. Indien de commissie tot de slotsom komt, dat nog geen oordeel kan worden gegeven over de geschiktheid van de kandidaat voor het rechterlijk werk -bijvoorbeeld indien de aard en/of de duur van de (juridische) ervaring niet voldoende wordt geacht-kan zij degenen, die opteren voor een rechterlijke functie. in de rechtspraak, in de gelegenheid stellen deel te nemen aan de cursus maken vonnissen. Bij de verkorte procedure worden inlichtingen ingewonnen. Een onderzoek door RPD Advies vindt in beginsel niet plaats. De kandidaten verschijnen voor een kleine beoordelingscommissie, bestaande uit de voorzitter, een van de secretarissen en een ander lid van de Commissie. Het met goed gevolg doorlopen hebben van de selectieprocedure geeft geen recht op benoeming tot rechter-plaatsvervanger. Daarvoor dient de kandidaat eerst door een rechtbank op de aanbeveling te worden geplaatst (zie hierna) en door de regering als rechter-plaatsvervanger te worden benoemd. ${ }^{11}$

11. Gegevens: Brochure De toetreding tot de rechterlijke macht via de Commissie antrekken leden rechterlijke macht 
The appointment of judges

\begin{abstract}
Access to judicial offices in the Netherlands and in New York State
\end{abstract}

This study investigates the constitutional framework that governs access to judicial offices in the Netherlands and gives a historical description of how Dutch parliament shaped the genesis and the later development of this framework. This study is also an attempt to explore relevant aspects of the system of access in relation to modern constitutional law, and to assess these. 'Access to the judiciary' in the Netherlands is characterised by the barriers which are put up in positive law to a judicial appointment. We distinguish the stages that precede a judicial appointment (or promotion), i.e. the recruitment and selection of judges, from the eligibility of judicial candidates. In the Netherlands the latter is restricted by the requirements of Dutch citizenship, a university degree in law, and the absence of certain incompatibilities.

Chapter 1 takes as its hypothesis that (constitutional) legislators in the 19thcentury, when they created and further developed the system of judicial appointment and eligibility, were guided by a clear vision of access to the judiciary that was related to a specific idea of its task. This raises the question whether recent changes in our definition and understanding of the judge's role in society make it necessary to reform the existing system. In order to answer this we need to know the answers to three key questions: 1) what does the present access system actually look like, and how does it reflect the constitutional framework; 2) what considerations historically shaped this system; and 3) what recent developments are there in the way we define and understand the task of a judge in relation to access to the judiciary.

The discussion of the second question in Chapters 3 and 4 (see below for the first question) shows that the various factors in positive law that have developed over time to govern access to the hench lack any coherence. Chapter 3 shows that (constitutional) legislators have never had a clear vision of what kind of judge the system is designed to select, let alone that they have thought through how judicial appointments should reflect the function and task a judge 
is supposed to fulfil. The explanation for this is threefold. First, one should realise that most if not all of the existing system of judicial appointment and eligibility dates back to the early 19th century, when judges were supposed to limit themselves to merely applying the law. The precedent-setting or even normative role of the judiciary was therefore very much ignored. This explains why legislators were not particularly interested in the person behind the judge and why they limited themselves to such general requirements as Dutch citizenship, a university degree in law, and the absence of certain incompatibilities. Another explanation for this lack of interest in the judge's personal characteristics is undoubtedly the circumstance, partly because of the requirement of a degree in law, that judges were until fairly recently recruited from a small well-off elite. Moreover, not everyone was keen to take up a poorlypaid job in the judiciary, especially when the vacancy was in a far-off corner of the country. Finally, Chapter 3 also shows that the diversity of the bench and the related issue of access have only recently become topics of public interest, and that they were far removed from the minds of 19th-century (constitutional) legislators. The two key selection criteria, for instance, i.e. financial independence and the exclusion of women, have never been enshrined in positive law. As far as financial independence is concerned, this criterium was thought necessary (a belief that persisted well into this century) as a sateguard against bribery, thus securing the impartiality of the bench.

Discussing the post-war history of judicial access, Chapter 4 distinguishes two main trends. They are defined as the technocratic and democratic perspectives. The technocratic perspective on judicial access is the perspective adopted by the government, which sees the filling of vacancies in the judiciary first and foremost as an administrative matter. Reforms of the existing appointment and eligibility regulations (such as the introduction of selection committees, the laying-down of rules guiding promotion, or the debate over the citizenship requirement, the law degree requirement, or the incompatibilities) are therefore not seen as related problems, which could have a significant impact on the access to judicial posts, and therefore on the diversity of the judiciary. That these regulations are mainly technocratic in nature is underlined by their low legal status (royal decrees, ministerial orders or circular letters). The fragmentedness and obscurity of the access system explains the problematic relationship between judicial recruitment, selection and promotion regulations and the constitutional framework, in particular Article 116, Section 1 of the Dutch Constitution, which requires all regulations to be anchored in basic law. In reference to the first key question, Chapter 2 concludes that significant parts of the judicial access system are at odds with the Dutch Constitution.

The second trend, the democratic perspective on judicial access, is the result of a growing interest after World War II in the individual characteristics of a 
judge and in the make-up of the judiciary. Initially this interest is prompted by a crisis of confidence in the judiciary, which is said to draw its members exclusively from an upper-class elite in society. This negative approach towards the judiciary marks a break with the past, which considered the bench's lack of diversity as an advantage. Although there is no empirical evidence to substantiate this claim, it does seem to be legitimate. Limited access to the university; the unpaid position of clerk of the court, which in the Netherlands used to precede a position on the bench; and possible class prejudice inherent in the culture of the magistracy that draws up the list of recommendations: this all contributes to making the judiciary until well into the Fifties an almost impregnable fortress to the lower classes.

During the Seventies and Eighties the focus of the debate shifts slowly and almost imperceptibly to a more positive interest in the make-up of the judiciary. As is pointed out at the end of Chapter 4 , the critical voices that once complained about class justice have now fallen silent - whether they have really disappeared still remains to be seen - and the judiciary appears to take the lead in all sorts of controversial social issues. This new judicial activism raises the question whether the magistracy has the legitimacy and capacity to take upon itself such a pioneering role. An analogy is drawn between the selection and promotion of judges and the way in which members of the Dutch Lower Chamber of Parliament are elected in a direct ballot. Looking at how this debate on judicial access has developed in recent years, one is struck by its incidental and arbitrary nature. The agenda is being set by controversies that happen to make headlines. It seems to me that the (selection of) news items in the media, and the way in which these are reported, play a crucial and often underestimated role in our perception of the judiciary. What's more, there is clear evidence to suggest that media reporting also has an impact on constitutional law. Many developments in the organisation of the judiciary are instigated by institutions outside parliament.

Chapter 6 shows that the democratic perspective is a persistent misconception that arises wherever (the traditional job of) the judiciary comes into conflict with (the traditional job of) the legislature or the administration, especially over issues such as constitutional review, administrative law, and judicial activism. Trying to take into account recent changes in the definition and understanding of the task of the judiciary, and taking as its premise the principle of separation of powers, the democratic perspective is inevitably faced with a problem of legitimacy. This, it believes, can only be solved by adopting the system of selection that is used to select the legislature, i.e. the direct election of members of the Dutch Lower Chamber of Parliament. Chapter 6 puts these notions into perspective, focusing first on the controversy between the appointive and elective systems, and then on the principle of the separation of 
powers. To shed some initial light on these issues, Chapter 5 discusses the system of judicial election in New York State, and the debate surrounding it. This and other evidence enables us at the end of Chapter 6 to separate the problem of legitimacy of the judiciary in relation to recent changes in the way we define and understand its task, from the issue of access. By linking judicial legitimacy to, for instance, dissenting and concurring opinions, and to the wider principle of open and public administration of justice, we are able to leave behind us the school of thought which says that public control necessarily presupposes a constellation of public (appointive/elective) powers. Disconnecting legitimacy and judicial access gives new meaning to the concept of public control, and opens up new opportunities for scholarly and social debate.

Translation: Henk van Appeven 
Abraham, H.J., The judicial process, vijfde druk, Oxford University Press New York Oxford 1986

Akkermans, P.W.C. en A.K. Koekkoek, De Grondwet Een artikelsgewijs commentaar, tweede druk, W.E.J. Tjeenk Willink Zwolle 1992

Anderson, K., Ethical Problems of Lawyers and Judges in Election Campaigns, in: American Bar Association Journal, volume 50, 1964, p. 819-822

Andreae, J.P. Fockema, Het geheim van de raadkamer Beschouwingen over het bekend maken van de gevoelens der minderheden in rechterlijke colleges, Boekhandel H. de Vroede Utrecht 1934

Anoniem, De verdediging der wet op de instelling der regterlijke magt van den minister van justitie getoetst aan en wederlegd uit de Grondwet: het belang des Konings en dat der natie, M. de Lyon 's Gravenhage 1827

Asscher, B.J., Meesters der metamorfose, Uitgeverij Balans 1989

Association of the Bar of the City of New York, Report, 1871

Association of the Bar of the City of New York, Report, 1872

Association of the Bar of the City of New York, Report, 1881

Association of the Bar of the City of New York, Report, 1898

Association of the Bar of the City of New York, Year Book 1911

Association of the Bar of the City of New York, Report, 1932, volume 5

Association of the Bar of the City of New York, Report on Consideration of New Methods to Select Judges, 1952

Association of the Bar of the City of New York, The Record, volume 10, 1955

Association of the Bar of the City of New York, The citizens and the courts A report

by The Special Committee on the Administration of Justice on A Proposed Simplified State-Wide Coun System, 1955

Association of the Bar of the City of New York, Report on special commitree in judicial selection and tenure, 1963

Association of the Bar of the City of New York, The Record, volume 20, 1965

Association of the Bar of the City of New York, The Record, volume 22, 1966

Association of the Bar of the City of New York, Report of the Special Commitree on

the Constitutional Convention Selection of Judges, 1967

Association of the Bar of the City of New York, The Record, 1974

Association of the Bar of the City of New York, Committee On State Courts of

Superior Jurisdiction Governor Carey's Judicial Reform Proposals, 1976

Association of the Bar of the City of New York, The Record, 1978

Association of the Bar of the City of New York, The Record, 1979 
Association of the Bar of the City of New York, The Record, 1980 Association of the Bar of the City of New York, The Record, 1989

Baars, John van, Over de rechtshistorie van het eedsvraagstuk in Nederland sinds 1910, deel I en II, in: Nederlands Juristenblad 1969, p. 357-366 en 381-391

Baars, John van, Het Ontwerp Eedswet 1969 en de Eedsvorm, in: Nederlands Juristenblad 1970, p. 629-639

Bannier, G.W., Grondwetten van Nederland Teksten der achtereenvolgende staatsregelingen en grondwetten sedert 1795, met verschillende andere staatstukken, historische toelichtingen en eenige tabellen, N.V. Uitgeversmaatschappij W.E.J. Tjeenk Willink Zwolle 1936

Bard, A. S., Some observations on the primary and election laws of the State of New York with special reference to the nomination and election of judges, Association of the Bar of the City of New York, 1914

Barendrecht, J.M., Het constitutionele toetsingsrecht van de rechter, preadvies, Handelingen Nederlandse Juristen-Vereniging, W.E.J. Tjeenk Willink Zwolle 1992 , p. $89-172$

Beaufort, Henriette L.T. de, Gijsbert Karel van Hogendorp Grondlegger van het Koninkrijk, Ad. Donker Rotterdam 1979

Bell, C., The Supreme Court of New York During the Revolunionary Period and under the Constitution of 1777, in: The American Lawyer, Volume XI, 1903, p. 289-293

Bentinck, U.W., M.M. Beins, A.H. Kist, Th. L. Lind (red.), Kabaal in Holland, Gouda Quint bv Arnhem 1993

Bentley, F., The Process of Government, The Belknap press of Harvard University Press Cambridge Massachusetts 1967

Bergh, G. van den, De Rechterlijke Macht als grondwettelijk begrip, in: Nederlands Juristenblad 1950, p. 193-413

Berkson, L., Women on the bench: a brief history, in: Judicature The Journal of the American Judicature Society, volume 65, no. 6, 1982, p. 286-293

Bernstein, I., The New York City Draft Riots, Oxford University Press New York Oxford 1990

Besier, A.P., en P.A.J.T. van Teeffelen, Enquête onder de raio's (Een onderzoek naar het functioneren van de raio-opleiding), in Nederlands Juristenblad, 1972, p. $621-628$

Buckley, R.F., New York Elects a Chief Judge, Judicature The Journal of the American Judicature Society, volume 57, no. 6, 1974, p. 237-241

Binnerts, T., Wetstoepassing en rechterlijke macht (II), in: Weekblad voor Privaat recht, Notaris-ambt en Registratie 1918 (no. 2530), p. 293-295

Blokland, G.J.Th. Beelaerts van, De onschendbaarheid der wet, S.C. van Doesburgh Leijden 1868

Blokland, G.J.Th. Beelaerts van, De bevoegdheid van den Amerikaunschen rechter tot ongrondwettigverklaring eener wet, in: Nieuwe bijdragen voor regtsgeleerdheid en wetgeving 1869 , p. 5-61

Böcker, B.F.N., Onze rechterlijke macht onder verdenking, in: Nederlands Juristenblad, 1967 , p. $285-289$ 
Boissevain, J.H.G., Staatsregt van Nederland, Arnhem G.J. Thieme en J.G. Stenfert Kroese 1851

Bordewijk, F., De laatste cer Grafreden, Em. Querido's Uitgeverij b.v. Amsterdam 1976

Boven, M.W., De rechterlijke instellingen ter discussie De geschiedenis vern de wetgeving op de rechterlijke organisatie, Gerard Noodt Instituut 1990

Brauw, L. de, Vertrouwen in de rechterlijke macht, in: Trema 1981, p. 245-246

Brand, G.E., Selection of Judges - The Fiction of Majority Election, Joumal of the American Judicature Society, volume 34, 1951, p. 136-143

Brennan, William J., In Defense of Dissents, in: The Hastings Law Joumal, 1986, p. $427-438$

Brenninkmeijer, A.F.M., Selectie rechters, in: Nederlands Juristenblad, 1991, p. 1086-1087

Brongersma, E.. De openbaurheid van de rechtspraak, I en II, in: Nederlands Tijdschrift voor Criminologie, 1962, p. 61-83 en p. 93-107

Bruchem, Jean Philippe Théodore du Quesne van, De bevoegdheid der regterlijke magt met opzigt tot wetten die de Grondwet schenden Eene staatsregtelijke proeve naar aanleiding van Arı. 115 al. 2 Grdwt. Stoomdrukkerij P.W. van de Weijer Utrecht 1867

Bruinsma, F., Rechter Cnoop Koopmans: "Onafhankelijk is niet kleurloos", in: Staatkundig Jaarboek 1985, Kobra/Amsterdam 1985

Bruinsma, F., De paradox van de afspiegelingshenoeming, in: Nederlands Juristenblad, 1986, p. 1205

Bruinsma, F., Cassatierechtspraak in civiele zaken Een rechtssociologisch verslag, tweede druk, W.E.J. Tjeenk Willink Zwolle 1988

Bruinsma, F., Van aanbeveling naar voordracht, in: Nederlands Juristenblad, 1991. p. 1083-1085

Buckley, R.F., New York Elects a Chief Judge, in: Judicature The Journal of the American Judicature Society, volume 57, no. 6, 1974, p. 237-241

Buijs, J.T., De Grondwet Toelichting en kritiek, Arnhem P. Gouda Quint 1884

Burgh. J.P.C., Opmerkingen over des rechters toetsingsbevoegdheid, Zuid-Hollandsche boek- en Handelsdrukkerij 1905

Carbon, S.B., Women in the judiciary: an introduction, in: Judicature The Journal of the American Judicature Society, volume 65, no. 6, 1982, p. 285

Carbon, S.B, Houlden, P, en Berkson, L., Women on the state bench: their characteristics and attitudes about judicial selection, in: Judicature The Joumal of the American Judicature Society, volume 65, no. 6, 1982, p. 294-305

Cau, J.P., Solliciteeren, in: Weekblad van het Recht, 1921 (no. 10721) p. 4

Centrum voor Staatkundige Vorming, Reorganisatie van rechtspraak in Nederland, 's Gravenhage 1950

Cheney, P., The Antirent Movement and the Constitution of 1846, in: History of the State of New York, Columbia University Press New York 1934

Childs, R.S., Elective judges in New York, in: Massachusetts Law Quartely, 1922, p. 137-139

Citizen Committee on the Courts, Outline of Program, 1946 
Citizens Union, Who picks our judges?, in: The Searchlight, volume XLIII, 1953, p. $2-7$

City Club of New York, Selection of judges, 1932

City Club of New York, The Magistrates Court, 1932

Chemerinsky, E., Interpreting the Constitution, Praeger New York Westport Connecticut London 1987

Chemerinsky, E., The vanishing Constitution, in: Harvard Law Review 1989/1 p. 44104

Cliteur, P.B., Argumenten voor en tegen constitutionele toetsing, in: Nederlands Juristenblad 1989, p. 1369-1375

Cluysenaer, O.J., De geschiktheid der Vrouw voor de Rechterlijke Macht, preadvies voor de Nationale Vrouwenraad van Nederland, Drukkerij N.V. "Leidsch Dagblad" Leiden 1933, p. 13-39

Cnoop Koopmans, A.J., Vormen van klassejustitie, in: Nederlands Juristenblad 1969, p. 421-423

Cnoop Koopmans, A.J., Rechter en politiek, in: Nederlands Juristenblad, 1973, p. 630-638

Cnoop Koopmans, A.J., De maatschappelijke selectie: hoe komen wij aan rechters? Kiezen, uitkiezen of uitverkiezen, in: Trema special 1980, p. 26-34

Colenbrander, H.T., Ontstaan der Grondwet, Martinus Nijhoff 's-Gravenhage 1908 Comisky, M., Patterson, P.C., Taylor, W.E., The Judiciary - Selection, Compensation, Ethics, and Discipline, Quorum Books New York Westport Connecticut London 1987

Cook, B.B., in: Judicature The Joumal of the American Judicature Society, volume 65 , no. 6,1982 , p. $314-326$

Coolen, W.A., De historische ontwikkeling der Grondwet beschouwd in het licht der geschriften van Mr. J.R. Thorbecke, Van Heusden 's-Hertogenbosch 1872

Coornhert-Liga, Alternatieve justitiebegroting 1973, Ars Aequi Utrecht 1972 Kluwer Deventer 1972

Crince Le Roy, R., De vierde macht Een hernieuwde kennismaking, derde herziene druk, Vuga-Boekerij 's Gravenhage 1976

Crockett, G.W., Judicial Selection and the Blach Experience, in: Judicature The Journal of the American Judicature Society, volume 58, no. 9, 1975, p. 438-442.

Curtius, Dirk Donker, Proeve eener nieuwe Grondwet, C.A. Thieme Arnhem 1840

Daly, John Charles, Whom do judges represent?, American Enterprise Institute for Public Policy Research Washington and London 1981

Delfgaauw, B., Recht en politiek, in: Nederlands Juristenblad 1970, p. 794-800

Denniston, Lyle W., The reporter and the law Techniques of covering the courts, Columbia University Press New York 1992

Dougherty, J. Hampden, Legal and judicial history of New York, volume II, William S. Hein \& Company, Buffalo, New York 1983

Drabbe, L.W.M.M., De vrouw in de rechterlijke macht, in: Themis 1963, p. 532-548 Drion, H., preadvies, in: Handelingen 1973 der Nederlandse Juristen-Vereniging deel 1, eerste stuk, W.E.J. Tjeenk Willink 1973, p. 31-48 
Dijckmeester, H.J., Handhaving van de zelfstandigheid en onafhankelijkheid der Regterlijke magt, tegen daarmede strijdende uitleggingen van art. 160 der Grondwet, in: Nederlandse Jaarboeken voor regtsgeleerdheid en wetgeving, 1846, p. 281-296

Dijk, P. van en G.J.H. van Hoof, De Europese Conventie in theorie en praktijk, derde druk, Ars Aequi Libri 1990

Does, A.M.I., De toegang tot de hoogste rechter Onderzoek naar certiorari en andere methoden om de toegang tot de hoogste rechter te beperken in de Verenigde Staten, Kluwer Deventer 1990

Donner, A.M., Rechtspraak en politiek, een verlate bijdrage tot de discussie, in: Nederlands Juristenblad, 1975, p. 850-853

Doomen, J., Hoe maak je carrière in de magistratuur? Een rechter is ook maar een sollicitant, in: Account april 1992, p. 22-32

Dubois, P.L., Judicial elections and the quest for accountability, University of Texas Press Austin and London 1980

Dubois, P.L., Financing trial court elections: who contributes to California judicial campaigns?, in: Judicature The Journal of the American Judicature Society, volume 70, no. 1, p. 8-16

Dubois, P.L., The Analysis of Court Reform, Lexington Books D.C. Heath and Company Lexington Massachusetts Toronto 1982

Eaton, D.B., Should judges be elected? Or the experiment of an elective judiciary in New York, John W. Amerman Printer New York 1873

Elzinga, D.J., Onverenigbaarheden Burgemeesters moeten eigenlijk geen rechter willen worden, in: Binnenlands bestuur 16-10-1992

Engstrom, R.L., When blacks run for judge: racial divisions in the candidue preferences of Louisiana, Judicature The Journal of the American Judicature Society, volume 73 , no. 2 , p. $87-89$

Enschedé, Ch. J., Rechterlijke onafhankelijkheid en ministeriële verantwoordelijkheid Over werving, keuze en opleiding van toekomstige magistraten, in: Nederlands Juristenblad, 1977, p. 823-827

Escovitz, S.S., Judicial selection and tenure, American Judicature Society Chicago 1975

Feerick, J.D. en C. Vance, Becoming a judge: Report on the Failings of Judicial Elections in New York State, in: Pace Law Review, 1989 p. 199-241

Finch, E.R., in: Journal of the American Bar Association, 1934, p. 144-147

Fish, P.G., Questioning judicial candidates: what can merit selectors ask?, Judicature

The Journal of the American Judicature Society, volume 62, no. 1, 1978, p. 8-17

Flick, A.C., History of the State of New York, Published under the auspices of the New York Stare Historical Association

Fockema, R.A., Het ontwerp tot ontbinding van de Rechtbanken te Zierikee en Heerenveen, in verband met het gemis aan raadpleging van de rechterlijke macht, in: Themis 1923, p. 232-235

Frenkel, F.E. (red.), Provo Kanttekeningen bij een deelverschijnsel, Polak en Van Gennep Amsterdam 1967 
Fruin, Robert, Geschiedenis der staatsinstellingen in Nederland uitgegeven door H.T. Colenhrander, Martinus Nijhotf' 's-Gravenhage 1901

Fund for Modern Courts, Court Monitoring Project Final report, 1976

Fund for Modern Courts, Court Monitoring Manual, 1976

Fund for Modern Courts, Judicial elections in New York, Voter participation and campaign financing of state Supreme Courts 1978, 1979 and 1980, 1982

Fund for Modem Courts, The success of women and minorities in achieving judicial office: the selection process, 1985

Fund for Modern Courts, The illusion of democracy, New York Ciry Civil Court Elections 1980-1985, 1986

Fund for Modern Courts, Annual Report, 1991

Fund for Modern Courts, Minutes, 24 maart 1992-15 oktober 1993

Furtwangler, A., The authority of Publius, Cornell University Press, 1984

Galie, Peter J., The New' York State Constitution A reference guide, Greenwood Press New York Westport Connecticut London 1991

Gibson, E.M., New York legal research guide, William S. Hein \& Co. Inc. Buffalo New York 1988

Giltay Veth, D., De rapporten-Bloemarts en -Witsen Elias, deel I en II, in: Nederlands Juristenblad 1970, p. 1061-1072 en p. 1120-1131

Gitterman, J.M., The council of appointment, in: Political Science Quarterly, volume 7, 1892

Goldstein, C., Fundraising by judges: ethical restrictions on assisting civic, charit able and other organizations, Judicature The Joumal of the American Judicature Society, volume 70, no. 1, 1986, p. 27-30

Goudsmit, J.E., De Goesche zaak, in: Weekblad van het Regt, 1870 (no. 3200)

Grasserie, Raoul de la, De la justice en France et a l'étranger au xxe siècle, Librairie de la société du recueil Sirey Ane Mon Larose \& Forcel Paris 1914

Gratama, L. Oldenhuis, Welk is het thans voor Nederland aangewezen stelsel van regterlijke organisarie?, in: Nieuwe bijdragen voor rechtsgeleerdheid en wetgeving 1879 , p. $77-92$

Greenberg, F., The task of judging the judges, Judicature The Journal of the American Judicature Society volume 59, no. 59 p. 458-467

Greenstein, M.N., Handbook for Judicial Nominating Commissioners, American Judicature Society Chicago 1984

Griend, P.C. van de, Kunnen rechers mensen zijn?, in: Trema exclusief 3, 1979

Griftiths, J., Het interessante van de Hoge Raad, in: Recht der Werkelijkheid, 1989, p. $80-99$

Grinnell, F.W., The opening argument in opposition to an elective judiciary before the Commitre' on Constitutional Law of the Massachuserts Legislature, in: Massachusetts Law Quarterly, 1922, p. 122-136

Gront-van Leeuwen, L.E. de, en C.C.M. Kester en J.G.C. Kester, De loophaanontwikkeling van vrouwen en manne'n in de rechterlijke' macht: beeld en werkelijkheid, in: Mens en maatschappij 1991 (no. 1), p. 54-64

Groot-van Leeuwen, L.E. de, Vrouwen en aanzien van de rechterlijke machr, in Trema 1990, p. 307-313 
Groot-van Leeuwen, L.E. de, De rechterlijke macht van Nederland, Gouda Quint bv Arnhem 1991

Gutter, Cor, Ons strafrecht, verkenning van een achtergebleven gebied, in: Mooi rood is niet lelijk, Universitaire Pers Rotterdam 1969

Haagse Post, HP enquête Klassejustitie in Nederland ja of nee?, 24 mei 1969 Haak, W.E., Ad personam, ad rem Ethisch-filosofische aspekten van rechterlijke specialisatie, in: 'T exempel dwinght, W.E.J. Tjeenk Willink Zwolle 1975

Haan, C.J. de, Taak en opleiding van de jurist, in: Nederlands Juristenblad, 1958, p. 81-87 (deel I) en Nederlands Juristenblad, 1958, p. 97-103 (deel II)

Haeften, C.H.J. van, Rechter en Grondwet in verband met de vrije rechtspraak, J. Dz. Veen Amersfoort 1911

Hage, Gert, Vrouwe Justitia, in: Intermediair 1990 (no. 19), p. 33-39

Hale, F.D., The Cour's Pereception of the Press, Judicature The Journal of the American Judicature Society, volume 57, no. 5, 1973, p. 182-189

Hansen, M., The high cost of judging, in: American Bar Association Journal, 1991 p. $44-47$

Harley, H., Judge Finch's Plan for Non-Political Veto Council on Judicial Character and Fitness Deserves Study - Need for Best Material on Bench, in: Journal of the American Bar Association, 1934, p. 246-247

Harvard Law Review, Leading cases, vol. 105, no. 1, 1991, p. 409-418

Haydel, J., Section 2 of the Voting Rights Act of 1965: a challenge to state judicial election systems, in: Judicature The Journal of the American Judicature Society, volume 73 , no. 2 , p. $68-73$

Haynes, E., The selection and tenure of judges, The national conference of judicial councils, 1944

Heemskerk, A., Boekbeoordelingen en verslugen. Nederlandsche litteratuur, in: Themis Regtskundig tijdschrift 1876, p. 454-460

Heemskerk, J., De praktijk onzer Grondwet, J.L. Beijers Utrecht 1881

Heemskerk Azn, J., Welke bepalingen omtrent de justitie zijn in de Grondwet onmisbaar?, preadvies, in: Nederlandsche Juristen-Vereniging, Handelingen 188.3, Gebroeders Belinfante 's Gravenhage 1883, p. 34-79

Heide, J. ter, De onafhankelijkheid van de rechterlijke macht Een functioneelanalytische beschouwing, Agon Elsevier Amsterdam/Brussel 1970

Henschen, B.M, R. Moog en S. Davis, Judicial nominating commissioners: a national profile, in: Judicature The Journal of the American Judicature Society, volume 73 , no. 6,1990 , p. $328-334$

Heringa, A.W., C.H.A. Litjens, R.E. de Winter (red.), Verhalen over de Grondwet, Sdu Juridische \& Fiscale Uitgeverij 's-Gravenhage 1993

Heymans, G., Die Psychologie der Frauen, Carl Winter's Universitätsbuchhandlung Heidelberg 1910

Heymans, G., Psychologie der vrouwen, vertaald door J. van Hees, derde druk, Maatschappij voor goede en goedkoope lectuur Amsterdam 1920

Hoefnagels, G.P., Rituelen ter terechtzitting Een voorstudie van emoties, attituden en interacties tijdens het strafproces en terechtzitting, Kluwer Deventer 1987 
Hoefnagels, G.P. (red.), De goede jurist Vierentwintig feestredes van oude meesters voor jonge meesters in de rechten over hun beroep, Gouda Quint bv (S. Gouda Quint - D. Brouwer en zoon) Amhem 1991

Hoekema, A.J., Vertrouwen in de justitie Resultaten van een vergelijkend onderzoek, Samson Uitgeverij nv, Alphen aan den Rijn 1971

Hoekema, A.J., G.E. Langemeyer en H. Bianchi, Opstellen en stellingen over klassejustitie, JFAS en Machiavelli Amsterdam 1969

Hofland, H.J.A., Tegels lichten of ware verhalen over de autoriteiten in het land van de voldongen feiten, Contact 1972

Hogendorp, G.K., Bijdragen tot de huishouding van staat in het Koningrijk der Nederlanden verzameld ten dienste der Staten-Generaal door Gijsbert Karel grave van Hogendorp, tweede druk, Zalt-Bommel Joh. Noman en Zoon 1854

Huart, F.J.A., De grondwetsherziening 1917 en 1922, Arnhem S. Gouda Quint 1925 Hugenholz, P.H., Klassejustitie: realiteit!, in: Intermediair (19) 1969, p. 3-7

Hulsman, L.H.C., Onbehagen over het recht, De Gids, 1967, p. 260-266

Idsinga, J.W.H.M. van, De eedsquaestie Open brief aan Mr. J.A. Levy, W.P. van Stockum \& Zoon 's Gravenhage 1882

Ingelse, P., Op zoek naar een nieuwe president Verslag van het Amsterdamse afspiegelingscollege, in: Trema 1993 (7), p. 294-298

Jackson, D.W. en J.W. Riddlesperger, Money and politics in judicial elections: the 1988 clection of the chief justice of the Texas Supreme Court, in: Judicature The Joumal of the American Judicature Society, volume 74, no. 4, 1991, p. 184-189 Jellinek, Georg, Allgemeine Staatslehre, Verlag von Julius Springer Berlin 1929

Jonge, W.A.C. de, De wetten zijn onschendbaar, in: Themis Regtskundig tijdschrift 1849 , p. $353-364$

Jonge, W.A.C. de, Bijdrage tot de geschiedenis der Grondwet (1830-1848) met eenige onuitgegeven stukken als Bijlagen, 's Gravenhage Gebroeders Belinfante 1883

Josten, Marc en J. van Tijn, De rechterlijke macht van Nederland: een geruststellend gezelschap, in: Vrij Nederland (44), 2 november 1991

Joumal of the American Bar Association, New York experience shows need for better methods of choosing judges, redactioneel, volume 29, 1943, p. 690-695

Journal of the American Bar Association, How much do Voters Know or Care about Judicial Candidates?, redactioneel, volume 38, no. 5/6, 1955, p. 141-143

Joumal of the American Judicature Society, Judicial Selection Improvement Studied in New York, volume 27, 1944, p. 153-156

Journal of the American Judicature Society, New York Judicial Selection Campaign Resumed, volume 28, 1945, p. 154-157

Joumal of the American Judicature Society, New Selection Plans announced for New York Judges, redactioneel, 1962, p. 288-289

Judicature The Joumal of the American Judicature Society, New York's "Triumph of Political Ineptitude", redactioneel, volume 51 no. 3, 1967, p. 76-77 
Judicature The Joumal of the American Judicature Society, The Voting Rights Act and judicial elections: an update on current litigation, volume 73, no. 2, p. 74-81

Kales, A.M., Methods of Selecting and Retiring Judges, Minnesota State Bar Association, 1914

Kappeyne van de Copello, N.J.C. M., Staatkundigehervomingen Rapport uitgebracht aan het genootschap voor den rechtsstaat, H.D. Tjeenk Willink \& zoon N.V. Haarlem 1946

Kemper, J. de Bosch, Handleiding tot de kennis van het Nederlandsche stalsrecht en staatsbestuur, Amsterdam Johannes Müller 1865

Kirchheiner, H.H., 'Bij wijze van experiment', in: Trema 1982, p. 183

Klots, A.T., The selection of judges and the short ballot, in: Joumal of the American Bar Association, volume 38, no. 5/6, 1955, p. 134-140

Knap, M., Worden rechters wel op "democratische" wijze benoemd?, in: Nederlands Juristenblad 1969, p. 1080-1083

Koopmans, T., Constiturionele toetsing, preadvies, in: Handelingen Nederlandse Juristen-Vereniging, p. 39-84, W.E.J. Tjeenk Willink Zwolle 1992

Kooten, Hugo van, Alex Meijer, Hanneke Moons, Mappie Veldt, Kornelis Vos, Rechter en politick, Ars Aequi Nijmegen 1992

Koppen, P.J. en J. ten Kate, Tot raadsheer benoemd Anderhalve eeuw benomingen in de Hoge Raad der Nederlanden, Gouda Quint Amhem 1987

Kortmann, C.A.J.M., De Grondwersherieningen 1983 en 1987, Kluwer Deventer 1987

Kortmann, C.A.J.M., Constitutioneel recht, Kluwer Deventer 1990

Langemeyer, G.E., De toekomst van de rechterlijke macht, in: Nederlands Juristenblad, 1945, p. 281-291

Langemeijer, G.E., Klassejustitie: realiteit?, in: Intermediair (19) 1969, p. 1 en 7

Langemeijer, G.E., De onafhankelijke rechter op de schopstoel, in: Nederlands Juristenblad, 1971, p. 801-813

Langemeijer, G.E., De tockomst van onze rechtspleging, in: Nederlands Juristenblad 1973 , p. $61-67$

Langemeijer, G.E., Wetgever en rechter, in: Nederlands Juristenblad 1974, p. 1-5

Langemeijer, F.F., Raad voor de rechterlijke macht, in: Trema special 1984

Laski, Harold J., Studies in law and politics, George Allen \& Unwin Ltd. London 1950

Lasser, William, The limirs of judicial power The Supreme Court in American Politics, The University of North Carolina Press Chapel Hill \& London 1988

League of women voters, Seeds of failure, A Political Review of New York State's 1967 Constitutional Convention, 1973

League of women voters of New York State, The judicial maze, The Court System in New York State

Levy, J.A., De rechter, zelfstandig drager der koninklijke rechtsmacht (rechterlijke aanbevelingen), in: Nieuwe bijdragen voor rechtsgeleerdheid en wetgeving 1877, p. $93-147$

Leyten, J.C.M., De rechter op de schopstoel, oratie, Kluwer Deventer 1970 
Leyten, J.C.M., De rechterlijke organisatie, deel I en II, in: Nederlands Juristenblad 1971 , p. 589-603 en Nederlands Juristenblad, 1971, p. 627-637

Leyten, J.C.M., Dissenting opinion, deel 1 en 2, in: Nederlands Juristenblad 1972, p. $697-707$ resp. $731-741$

Leyten, J.C.M., De opleiding van de magistratuur in Nederland, in: Taak en opleiding van de magistraat, Gent 1973

Leijten, Jan, De verschrikkelijke eenzaamheid van de inbreker, Uitgeverij Balans 1992

Leijten, Jan, Brullen als een nachtegaal, Uitgeverij Balans 1993

Lieber, Francis, On civil liberty and self-government, J.B. Lippencott and co. Philadelphia 1859

Lincoln, C. Z., The Constitutional History of New York, The Lawyers Co-operative Publishing Company 1906

Lindo, Caroline, Een iets andere rechter Interview met A.J. Cnoop Koopmans, in: Nederlands Juristenblad 1987, p. 725-727

Loder, B.C.J., De leer der volkssouvereiniteit in hare ontwikkeling, aanbeveling en bestrijding historisch-kritisch beschouwd, proefschrift, P. Somerwil Leiden 1873

Lohman, A.F. de Savormin, Onze Constitutie, Utrecht Kemink \& Zoon (Over den Dom) 1901

Lohman, O. de Savornin, preadvies, in: Handelingen 1973 der Nederlandse JuristenVereniging deel 1, eerste stuk, W.E.J. Tjeenk Willink 1973, p. 49-78

Loke, J.J., Ook een woord voor het behoud der aanbevelingen bij vacaturen in de regterlijke magt, Rotterdam H.A. Kramers \& Zoon 1876

Maanen, C.F. van, Aanteekeningen van het verhandelde over de Grondwet van 1814 gehouden door C.F. van Maanen, Dordrecht Blussé en Van Braam 1886

Maarseveen, Henc van, Politiek en Hoge Raad, in: Nederlands Juristenblad 1991, p. 1087-1088

MacIver, R.M., The modern state, Oxford university press London 1926

Madison, J, A. Hamilton en J. Jay, The Federalist Papers, Penguin Books 1987

Malefijt, J.J. de Waal, De eed ter beslissing van het geding, proefschrift, F. Wentzel \& Co. Utrecht 1907

Martin, E., Women on the federal bench, in: Judicature The Journal of the American Judicature Society, volume 65, no. 6, 1982, p. 306-313

Martin, E., Men and women on the bench: vive la difference?, in: Judicature The Journal of the American Judicature Society, volume 73, no. 4, 1990, p. 204-209

Martin, R.A., Giving Light to the People: Public Relations for the Courts, in: Judicature The Joumal of the American Judicature Society, volume 57, no. 5, 1973, p. $190-193$

Mazel, P.E., In naam van het recht De Hoge Raad en de Tweede Wereldoorlog, Gouda Quint bv-Amhem 1984

McDuff, R., The Voting Rights Act and judicial elections lirigation: the plaintiffs' perspective, in: Judicature The Journal of the American Judicature Society, volume 73 , no. 2,1989 , p. $82-85$

McKinney's, Consolidated laws of New York annotated, West Publishing Co. St. Paul Minn. 
Melvin, E.J., Judicial activism - the violation of an oath, Catholic Lawyer, volume 27, 1982, p. 283-300

Meyes, P., Caveant quaestores, in: Weekblad voor Fiscaal Recht 1971, p. 125-137

Meyes, P., De geruststellende woorden van de Minister van Justitie, in: Weekblad voor Fiscaal Recht 1971, p. 321-323

Miller, B.K., Assessing the functions of judicial conduct organizations, in: Judicature The Journal of the American Judicature Society, volume 75, no. 1, 1991, p. 16-19 Miller, J.R., Judges - or politicians, in: This Week, 1947, p. 5 en 25

Ministerie van justitie, Gedachten over de toekomst van de rechtspleging Rapport van de werkgroep heriening rechterlijke organisatie ingesteld bij beschikking van de Minister van Justitie van 23 december 1971, Staatsuitgeverij 's-Gravenhage 1972 Ministerie van justitie, Wetenschappelijk Voorlichtings-en Documentatiecentrum, De rol van de rechter in de samenleving Een beschrijvend literatuurrapport, 1973

Ministerie van justitie, Wetenschappelijk Onderzoek- en Documentatiecentrum, De rol van de rechter in de samenleving een aanvullend literatuuronderzoek ten behoeve van de Staatscommissie Herziening Rechterlijke Organisatie, 1977

Mitgang, H., The Man Who Rode The Tiger - the life and times of judge Samuel Seabury, J.B. Lippincott Company Philadelphia \& New York 1963

Molenaar, Bert, Rechters, Aramith Uitgevers Bloemendaal 1990

Moley, R., Tribunes of the People The Past and Future of the New York Magistrates' Courts, New Haven Yale University Press London Humphrey Milford Oxford University Press 1932

Mollema, K.E., De witte rook kringelt op, in: Trema 1980, p. 137-138

Montesquieu, Ch. S. de la Brède et de, De l'esprit des lois, Gamier frères, LibrairesEditeurs Paris 1874

Moons, Ch. Y.M., Het laatste woord over benoemingen van leden van de Hoge Raad bij de Tweede Kamer?, in: Ars Aequi 1980, p. 7683

Nagel, S. S., Compairing Elected and Appointed Judicial Systems, Sage Publications Beverley Hills London 1973

Nederlands Juristenblad, Afscheidsrede Mr. Feber, 170, p. 410-414

Nederlandsche Juristen-Vereniging, Handelingen 1975, deel I en deel II, W.E.J. Tjeenk Willink Zwolle 1975

Nederlandse Vereniging voor Rechtspraak, De onafhankelijke rechter Rapport van een werkgroep van de afdeling rechterlijke organisatie van de Nederlandse Vereniging voor Rechtspraak, in: Trema special 1979

Nederlandse Vereniging voor Rechtspraak, Rapport onverenigbaarheden, in: Trema 1980, p. $177-186$

Nederlandse Vereniging voor Rechtspraak, Verdere vorming van leden van de rechterlijke macht, in: Trema special 1981

Nederlandse Vereniging voor Rechtspraak, Gevraagd een rand voor de rechterlijke macht? Rapport van de commissie raad voor de rechterlijke macht aan het bestuur van de Nederlandse Vereniging voor Rechtsprauk, in: Trema 1981, p. 247-262 New York State Bar Association, Reports for 1932 
Nicholson, M.A en B.S. Weiss, Funding judicial campaigns in the Circuit Court of Cook County, Judicature The Journal of the American Judicature Society, volume 70, no. 1, 1986, p. $17-25$

Niles, R.D., The Popular Election of Judges in Historical Perspective, in: The Record of the Association of the Bar of the City of New York, vol. 21 (1966), p. 523-538

Nord, H.R., Historische ontwikkeling en beteekenis van de representatiegedachte in het Staatsrecht, Eduard IJdo N.V. Leiden 1944

O'Connor, A. en M.L. Henze, "During good behavior" Judicial Independence and Accountability, The Jefferson Foudation 1984

Oppenheimer-Belinfante, D.R.E., De geschiktheid van de vrouw voor de Rechtcrlijke Macht, in: Weekblad van het Recht 1933 (no. 12591)

Opstall, S.N. van, De aanstelling van den rechter voor zijn leven, in: Nederlands Juristenblad 1932, p. 653-658

Opzoomer, C.W., Aanteekening op de Wet houdende Algemeene Bepalingen der wetgeving van het Koninkrijk, vierde druk, Gebr. Belinfante 's Gravenhage 1884

Oven, J.C. van, De leeftijdsgrens: niet 70 maar 65!, in: Nederlands Juristenblad 1932, p. 633-637

Oven, J.C. van, De klassieke opleiding der toekomstige juristen, in: Nederlands Juristenblad 1958, p. 117-122

Perry, Barbara A, A "Representative" Supreme Court? The impact of race, religion, and gender on appointmants. Greenwood Press New York Westport Connecticut London 1991

Pieterman, R., De plaats van de rechter in Nederland Politiek-juridische ideeënstrijd over de scheiding van machten in de staat, proefschrift, Gouda Quint Amhem 1990

Pinner, J., Bijdrage tot de reorganisatie der regterlijke magt, in 't bijzonder der kantongerechten, J.C. Loman Jr. Amsterdam 1851

Pinto, A. de, Handleiding tot de Wet op de Regterlijke Organisatie en het beleid der jusititie, J. Belinfante 's Gravenhage 1844

Pinto, A.A. de, Staatsexamens voor magistratuur en balie, in: Themis Regtskundig Tijdschrift 1874 , p. 347-375

Pinto, A. A. de, Handleiding tot de Wet op de Regterlijke Organisatie en het beleid der justitie, tweede druk, W.E.J. Tjeenk Willink Zwolle 1880

Pinto, A.A. de, Een verjongingskuur der Nederlandsche magistratuur., in: Themis Verzameling van bijdragen tot de kennis van het Publiek- en Privaatrecht 1905, p. $589-603$

Pitkin, Hanna Fenichel, The concept of representation, Univerity of California Press Berkeley Los Angeles London 1972

Pols, J., Over het wetsvorstel tot verandering in de wijze van benoeming van leden der regterlijke magt, H.A. Kramers \& Zoon Rotterdam 1876

Popper, K.R., The poverty of historicism, London Routledge \& Kegan Paul, 1957

Pot, C.W. van der, Wie behoren tot "de rechterlijke macht"?, in: Nederlands Juristenblad 1950, p. 353-358 
Prakke, L., Toetsingsrecht Preadvies uitgebracht voor de Nederlandse Vereniging voor Rechtsvergelijking, Kluwer Deventer 1971

Prakke, L., Toetsing in het publiekrecht, Van Gorcum \& Comp. N.V. - Dr. H.J. Prakke \& H.M.G. Prakke Assen 1972

Prakke, L., Bedenkingen tegen het toetsingsrecht, preadvies, in: Handelingen Nederlandse Juristen-Vereniging, p. 3-33, W.E.J. Tjeenk Willink Zwolle, 1992

Raio-congres, De magistraat in de st(r)aat Raio-congres 11 en 12 oktober 1979, W.E.J. Tjeenk Willink Zwolle 1979

Raio-congres, De rechter als dictator? Dynamiek in de trias. Verschuivingen in de verhouding regelgeving, bestuur en rechtspraak, J.B. van den Brink \& Co. Lochem 1987

Randwijck, A.J. van, De geschiedenis der zeven en twintig ontwerpen van wet tot herziening der Grondwet in 1847-1848, P.J. Kraft 's Gravenhage 1979

Ras, H.E., De onafhankelijkheid van de rechterlijke macht, in: Nederlands Juristenblad 1989 , p. 1242-1244

Redactie Nederlands Juristenblad, De vastgelopen herziening van de rechterlijke organisatie, Nederlands Juristenblad 1955, p. 641-652

Redactie Nederlands Juristenblad, Nogmaals de herziening van de rechterlijke organisatie, Nederlands Juristenblad 1955, p. 770-774

Redactie Nederlands Juristenblad, De "Revu "-enquête, Nederlands Juristenblad 1967, p. $467-469$

Reesema, W. Siewertsz van, Zamenstelling der regterlijke magt, in: Nieuwe bijdragen voor regtsgeleerdheid en wetgeving 1853, p. 154-167

Rifkind, S.H., When the Press collides with Justice, in: Joumal of the American Bar Association, volume 34, 1950, p. 46-52

Roe, R.A., Korte geschiedenis van de personeelsselektie, Technische Hogeschool Delft Onderafdeling der Wijsbegeerte en der Maatschappijwetenschappen Vakgroep Psychologie 1982

Roe, R.A., Grondslagen der personeelsselektie, Van Gorcum Assen 1983

Röell, J., Kantreekeningen op de regeerings-ontwerpen tot Herziening der Grondwet,

H. de Voogd van der Straaten Hzn 's Gravenhage 1887

Roessingh, P.H., De eedsiraag, S.L. van Looy Amsterdam 1901

Rood, M.G., Rechters en politiek, W.E.J. Tjeenk Willink Zwolle 1993

Roos, N.H.M., Juristerij in Nederland, Kluwer Deventer 1981

Roos, N.H.M., Lekenrechters Een empirisch onderzoek naar het functioneren van de lekenrechters bij de Raden van Beroep voor de sociale verzekeringen. Kluwer Deventer 1982

Rosenberg, M., The qualities of justices - are they strainable, in: Texas Law Review 1966, p. 1063-1097

Rossem, M. van, De Verenigde Staten in de twintigste eeuw, H\&S uitgevers/Utrecht 1984

Rijksen, R., Meningen van gedetineerden over de strafrechispleging, Van Gorcum \& Comp. N.V. - G.A. Hak \& Dr. H.J. Prakke Assen 1958

Ruiten, G.A. van, Uitgangspunten bij een enquête onder de rechterlijke macht, in: Ars Aequi 1970, p. 518-524 
Ruiter, J. de, Oude en nieuwe taken van de burgerlijke rechter, tweede druk, Calvinistische juristen vereniging 1970

Rüttimann, Das Nordamerikanische bundestautsrecht verglichen mit den politischen Eimrichrungen der Schweiz, Verlag von Drell, Füßli und Comp. 1867

Scheltema, F.G., De' geschiktheid der Vrouw voor de Rechterlijke Macht, preadvies voor de Nationale Vrouwenraad van Nederland, Drukkerij N.V. "Leidsch Daghlad" Leiden 1933, p. 3-13

Schenk, W., Verantwoording en vooruitzicht, in: Nederlands Juristenblad 1974, p. 6-16

Schoordijk, H.C.F., Verouderde benoemingseisen voor de rechterlijke macht, in: Nederlands Juristenblad 1988, p. 286-287

Simons, D., Vroun'e'n bij de rechterlijke macht, deel I en II, In: Weekblad van het Recht no. 9773 (1915) en no. 9775 (1915)

Simons, D., Vrouwen in de rechterlijke macht, in: Weekblad van het Recht no. 12135 (1930)

Singer-Dekker, H., Het voordrachten- en benoemingenbeleid bij de Re'chterlijke Macht, in: Nederlands Juristenblad 1971, p. 68-73

Sloot, B.P., Officielle uitsluiting van vrouwen in juridische heroepen Fragmenten van cen geschiedenis, in: Nederlands Juristenblad 1980, p. 1186-1195

Slooten, G. van, Het ambt van den rechter, A.W. Sijthoff's uitgeversmaatschappij Leiden 1921

Slotnick, E.E., Media coverage of Supreme Court decision making: problems and prospects, Judicature The Journal of the American Judicature Society, volume 75, no. 3,1991 , p. $128-143$.

Smith, M.D., Race versus Robe, The Dilemma of Black Judges, National University Publications, Associated Faculty Press, inc. Port Washington New York 1983

Smits, P.R., Enige kanttekeningen bij de huidige procedure van benoeming van presidenten en vice-presidenten bij rechtbanken en hoven, in: Trema 1989, p. 168175

Sonsbeeck, H. van, Proeve over de zelfstandigheid en onafhankelijkheid der regterlijke magt, $\mathrm{H}$. As. Zoon Doijer 1829

Spaeth, E.B., Reflections on a judicial campaign, Judicature The Journal of the American Judicature Sociery, volume 60, no. 1, 1976, p. 10-20

Stason, E. Blythe, Judicial selection around the world, in: Journal of the American Bar Association, volume 41, no. 5, 1958, 134-141

State of New York. The Plan of the temporary commission on the courts for a simplified state-wide court system, 1956

State of New York, Report to the temporary commission on the courts A study of methods and proposals as to the selection of judges, 1956

State of New York, Temporary State Commission on the Constitutional Convention Introductory Report: 1967 Convention Issues, 1966

State of New York, Temporary State Commission on the Constitutional Convention The Judiciary, 1967 
State of New York, Temporary State Commission on the Costitutional Convention, Studies in the judiciary, judges, Study no. 1 Selection of judges, confidential draft, 1967

State of New York, And Justice for All, 1973

State of New York, Report of the joint legislative Committee on Court Reorgani zation, legislative document, no. 24, 1973

State of New York, Public Papers of Hugh L. Carey, fifty-first Governor of the State of New York 1977, Alhany, 1987

State of New York, Public Papers of Governor Mario M. Cuomo 1983, Albany, 1987

State of New York, Commission on Judicial Nomination, Questionnaire for candidates for associate judge of the Court of Appeals, 1992

Stheeman, U.W.H. en B.W. van Houten, Pers en rechtspraak, in: Nederlands Juristenblad, 1974, p. 17-19

Stoetwegen, C.W. Wttewal van, De freule vertelt, Bosch \& Keuning n.v. Baam 1973

Stolz, P., Judging Judges, The Free Press, A Division of MacMillan Publishing Co. Inc, New York 1981

Storing, H.J., The Anti-Federalist, The University of Chicago Press, Chicago and London 1985

Story, J., Commentaries on the Constitution of the United States: with a preliminary review of the constitutional history of the colonies and States, before the adoption of the Constitution, third edition, Boston: Little, Brown and Company 1858

Straelen, F.W.M. en P.A.J.Th. van Teeffelen, Toekomst in de rechterlijke macht een tweede enquête onder de raio's, in: Nederlands Juristenblad 1977, p. 978-981

Stroink, F. A.M., De plaats van de rechter in het staatsbestel, W.E.J. Tjeenk Willink Zwolle 1990

Stroink, F.A.M., Rechterlijke organisatie en rechtspraak in beweging, W.E.J. Tjeenk Willink Zwolle 1993

Struycken, A.A.H., Administratie of rechter Beschouwingen over de moderne rechtsstaatsgedachte naar aanleiding van de aanhangige ontwerpen tot regeling der administratieve rechtspraak, S. Gouda Quint Amhem 1910

Struycken, A.A.H., Het staatsrecht van het Koninkrijk der Nederlanden, Amhem S. Gouda Quint 1915

Taft, H.W., Selection of judges, New York State Bar Association, 1932, p. 44-65 Trollope, A., North America, Allen Sutton Gloucester Hippocrene Books inc New York 1987

Tellegen, B.D.H., Wolke bepalingen omtrent de Justitie sijn in de Grondwet onmisbaar?, preadvies, in: Nederlandsche Juristen-Vereniging. Handelingen 1883, Gebroeders Belinfante 's Gravenhage 1883, p. 81-120

Tellegen, B.D.H., Overzicht van het tor stand komen der Grondwet van 1814, proefschrift, M. de Waal Groningen 1912

Thorbecke, J.R., Aanteekening op de Grondwet, Johannes Müller Amsterdam 1839 en 1840

Thorbecke, J.R., Bijdrage tot de herzicning der Grondwet, Leiden P.H. van den Heuvell 1848 
Toqueville, A. de, De la Démocratie en Amérique, Gallimard 1980

Twaalfhoven, D.F.M., De part-time leden van de rechterlijke macht, in: Nederlands Juristenblad 1985, p. 347-351

Uelmen, G.F., Supreme Court Retention elections in California, Santa Clara Law Review, volume 28, no. 2, 1988, p. 333-377

Veen, Jac. van, De rechten van de mens De mensen van recht, Van Gennep Amsterdam 1971

Veen, Jac. van, Journalist in de rechtszaal, Van Gennep Amsterdam 1988

Veltman, Cees, Vrouwe justitia, in: Hervormd Nederland, 28 maart 1992

Verburgh, M.J.P., De rechterlijke macht ter diskussie, in: Nederlands Juristenblad 1975 , p. $741-751$

Verloren, J.P., Over art. 163 van de Grondwet, in: Themis Regtskundig tijdschrift 1877 , p. $165-187$

Versluijs, F. van Reigersberg, Rechter en Grondwet in de Vercenigde Staten van Noord-Amerika, Dekker \& Van de Vegt N.V. Nijmegen Utrecht 1938

Volcanseck-Clark, M., Why lawyers become judges, in: Judicature The Journal of the American Judicature Society, volume 62, no. 4, p. 166-175

Voorduin, J.C., Geschiedenis en beginselen der Nederlandsche wetboeken volgens de beraadslagingen deswege gehouden bij de Tweede Kamer der Staten-Generaal, Rohert Natan Akademic-boekhandelaar Utrecht $183 \mathrm{~T}$

Wardwell, A., Selection of judges in New York, in: Judicature The Journal of the American Judicature Society, volume 28, 1944, p. 8-19

Weber, R.E., The Voting Rights Acr and judicial elctions litigation: the defendant states' perspective, in: Judicature The Journal of the American Judicature Society, volume 73 , no. 2 , p. $85-86$

Werd, M.F.J.M. de, Grijpgrage politici met vurige vingers De Tweede Kamer en de voordracht voor de Hoge Raad, in: Publiek Domein (7/8) 1991, p. 226-231

Werd, M.F.J.M. de, Politieke greep op benoemingen Hoge Raad constitutioneel taboe, in: NRC Handelsblad 30 augustus 1991

Werd, M.F.J.M. de, Openheid nodig bij benoeming rechters, in: de Volkskrant 16 oktober 1991

Werd, M.F.J.M. de, Er is niets mis mee als burgemeester ook rechter is, in: NRC Handelsblad 19 oktober 1992

Werd, M.F.J.M. de, Afschuiven in de politiek: van de stoel van de wetgever naar her bordje van de rechter, in: Verhalen over de Grondwet, Sdu Juridische \& Fiscale Uitgeverij 's-Gravenhage 1993 p. 136-141

Wesser, R.F., A response to progressivism: The Democratic Party and New York Parry and New York Politics, 1902-1918

White, R.A., New approach to Financing Judicial Campaigns, in: American Bar Association Journal, volume 59, 1973, p. 1429-1433

Winter, R.E. de, Vertrouwen in de rechter, in: Binnenlands Bestuur 28-10-1988, p. 20 
Winter, R.E. de, Nota bene De benoeming van raadsheren, in: Publiek Domein (7/8) 1991 p. 231-233

Winter, R.E. de, De overheid, Sdu Juridische en Fiscale Uitgeverij Den Haag 1991

Winter, R.E. de, De heersende leer, Sdu Juridische \& Fiscale Uitgeverij 's-Gravenhage 1993

Winters, G.R., Selection of judges in New York and in other states, 1944

Winters, G. R., Selected Readings Judicial Selection and Tenure, American Judicature Society Chicago 1967

Wintgens, W., Advies over regterlijke organisatie, Gebroeders Belinfante 's Gravenhage 1860

Wintgens, W., Redevoeringen over regterlijke organisatie, 's Gravenhage Gebroeders Belinfante 1861

Witteveen, W.J., De retoriek in het recht Over retorica en interpretatie, staatsrecht en democratie, W.E.J. Tjeenk Willink Zwolle 1988

Witteveen, W.J., Evenwicht van machten, W.E.J. Tjeenk Willink Zwolle 1991

Wyers, Th. R.J., De vorming van de rechter, Ars Aequi 1954, p. 185-190

Zonderland, P., Het menselijk gelaat van de Nederlandse burgerlijke rechter, in: Intermediair, 1977 (16), p. 45-47 


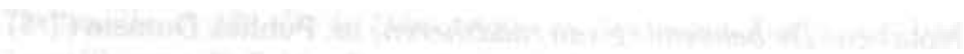

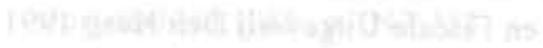

-

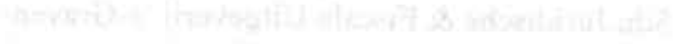


Aanbeveling $5-8,16,20,39,43,46-48$, $50-54,56,67,74,81,84,85,100-104$, $106-111,114-116,120,123,137,146$, $151,160,175,176,194-197,201,206$, $212,215-217,225,284,293,294$

Aanbevelingsvergadering 47, 50, 215

Aanwijzing $33,56,58,59,66,86,131$, $174,188,212,226,228,293$

Administratieve rechtspraak 24, 209, 291 , $293,294,296,305,325$

Afspiegeling $7,21,22,26,51,149,150$, $152,176,202,222,293,295,303$, $304,313,329$

Afspiegelingscommissie 50

Algemene Rekenkamer 17, 55, 95, 182, 201

Ambtseed 67-69

Anciënniteit 60-62, 150, 157, 222, 292

Anti-Rent Movement 246

Association of the Bar of the City of New York 238, 239, 245, 252-255, 261, 266

Benoembaarheid 4, 11, 12, 24, 25, 44, 45, $67,74-76,86,88,89,91,92,124,126$, $128,129,131,132,133-135,138,139$. $141,176-180,213,216,226,273,293$. $294,322,323$

Benoemingen

Eerste benoeming $5,46,50,57,65$, 169,211

Verdere benoeming $6,39,44,48-50$, $53,56,57,64,65,169,172,212,329$

Benoeming voor het leven 12, 14, 21 , $33,35-38,41,77,216,222,292,306$

Benoeming in deeltijd 58

Beroep $11,20,43,56-58,60-62,68,73$, $96,109,124,125,161,164,169,182$, $185,196,198,203,205,224,239$. $288,293,294,301,311,314,331$

Bi-partisan nomination 232
Big Thunder 246

Brooklyn Deal 232, 256

Buitenstaanders $7-9,42-46,63,64,73$, $123,143,144,146,156,157,166-168$, 171,213

Burgemeester 6, 7, 16, 18, 177, 197, 225, $235-239,251,261,263,272,279,297$

California Court Plan 262, 266-269

Campagne $231,239,268,272$

Chippendales 221

Circulaire $17,31,48-51,64,100,101$, $173,193,195$

Code of Judicial Conduct 229

Commissie aantrekken leden rechterlijke macht $8-10,24,38,40,42-46,65,74$, $166,167,172,206,211,214,216$, 280,300

Commission on Government Integrity 222, $227,253,257$

Commission on Judicial Nomination 24, 235-238, 266

Committee of Seventy 259

Constitutional Convention 243, 260, 261

Council of Appointment 242-244, 248, 249

Court of Appeals 223, 225, 227, 231, $234-236,240,244,261,266,268$

Court Packing Plan 13, 15, 37

D.G.O. 52,217

Delegatie $38,40-42,51$

Democratisch perspectief $305,316,317$, 323

Dissenting opinions $312,314-316$

Esprit de corps 11, 152, 159-161,222, 264

Euthanasic 9, 194, 301, 302

Evenwicht van machten $309-311$

Fair Campaign Code 229

Fund for Modern Courts 24, 229, 231-233, $240,272,274,279,313$ 
Gerechtsauditeur $8,42,44,45,48$

Gerechtssecretaris 147,152

Gouverneur 225, 235-239, 241-244, 246, $249,251,256,257,260,262-269,272$, $274,279,298$

H.G.O. 52

Hof van Staat 112, 113

Hoge Raad 5, 7, 12, 13, 16, 19, 20, 23, $24,32,33,35,37,38,45,47-49$, $53-56,65,67,68,74,76,77-82,84-$ $87,89-91,94-97,100,102,103,106$, $110-117,119-123,125,128-131,138$, $139,144,148,149,167,169,170$, $179,182,183,187-190,192,193,195$, $196,199-208,211,214,252,270,285$, $286,289,290,293,295,299,300$, $304,306,307,316,329$

Hoofdbetrekking 67,181

Incompatibiliteiten $34,45,74,86,87,181$, 190,324

Insprekers 50-53

Integratie $14,24,34,36,209,216,278$

Inzidenzfalldiskussion 214

Judicial Nominating Commission 224. 226-229

Judicial Nominating Convention 224, 227-229

Kwestie-Van der Burg 8, 54, 200, 215, $303,305,329,330$

League of Women Voters 237, 262

Leeftijdsgrens $13,14,34,139,179,316$

Legitimatie $3,16,18-20,205-207,217$. $281,283,285,287-291,294-298,303$, $304,307,310-314,317,325,328,329$, 331

Machtenscheiding $80,248,283,284$, $301-303,307-311,314,316,317,325$

Mayor's Committee 225, 235-238, 261, 273

Media

Buffalo News 227

de Gelderlander 164, 209

Haagsche Courant $185,189,302$

De Limburger 142, 284
New York Daily News 227, 257

New York Newsday 228, 233, 235. $238,239,257$

New York Times 230, 233, 257

NRC Handelsblad 3, 7, 19, 63, 142, $183,186,187,189,197-199$, 201-209, 304, 321, 331

Het Parool 164, 165, 183-186, 189

De Telegraaf $183,189,191,196,197$

Trouw 107, 189

Utrechts Nieuwsblad 7, 302

de Volkskrant $6,155,158,164,168$, $184,185,188,191,202,203$, $207-209,302,321,331$

Vrij Nederland $11,20-23,188,190$, 198, 200, 205, 207, 208, 301. 303,321

de Waarheid $133,186,187$

Merit selection 4, 222, 233, 257, 261-263, $266-274,278,279,298,328$

Minderheden 22, 199, 233, 262, 271, 278, 279,314

Missouri Court Plan 257, 262, 267-270

Nationale Vrouwenraad 132-134

Nationaliteit $8,44,67,74,87,176,178$, 306,322

Nederlandse Vereniging voor Rechtspraak $43,62,148,173,192,193,196,204$, $205,207,210,211$

Nevenfuncties $8,45,67,90,96,176,181$, $183,190,192-198,201,300,325$

New Deal 13, 15, 250

New York State Constitution 223-226, 235, $236,242-244,247$

Nominatic $77,78,80-85,106,113,115$, $121,226-230,232-235,237,251,253$, $254,256,260,265$

Onafhankelijkheid $7,12,15,23,31,33$, $35-38,41,65,66,75,81,96,113,114$, $119,120,122,142,160,172,174$, $181,184,197,201,210,222,231$, $236,281,289,292,295,305-307,317$, 323

Onpartijdigheid $117,121,129,141,143$, $170,184,193,194,201,236,281$, 295, 304-307, 323

Ontslay 12, 22, $34,36,37,39,40,45$, $131,136,292,306$ 
Onverenigbaarheden $67,74,86,88,181$, $182,193,197,216,306,322,323$

Opleiding $7,8,11,39,42-45,58,65,67$, $74,95-97,99,135,143,145-147$, $151-153,156,167,171,176,179,199$, $201,210,213,253,306,322-324$

Party-slates 228

Permanent College van Advies 146, 148, $149,151,213$

Personeelsmanagement $15,16,64$

Promotie $12,31,39,40,45,46,48,53$, $99,166,172,190,214,306,324$

Provincialc Hoven $76,78,79,81,82$, $84-86,90,108,109,119,139$

Provinciale Staten $16,77-81,84,89,90$, $114,115,290$

Raad van advies voor de Zittende Magis tratuur 166, 167

Raad voor de rechterlijke macht 169-171, $173,202,210-212,284,304$

Raio-selectiecommissie 8, 9, 42, 74, 211

Rechterlijk activisme 205, 214, 217, 287, $294,295,300-304,307,308,311,313$. $315,324-326$

Rechterlijke macht $3-12,14-16,18,20-24$, $26,31-47,53,55,57-59,61,62,64-$ $68,74-77,80,83,85,86-89,93,95-$ $99,101,104-106,110,114-116,121-$ $130,132,133,135,136,138,141$, $143-174,176-189,192-195,197-200$, $202-217,221,233,242,245,247,249$, $251,252,256-258,262,270,271$, 278-281, 283-289, 291, 292, 294-298, 300-302, 304, 305, 307, 309-313, 316, $317,321-330$

Rechtersverkiczingen 116-118, 122, 221, $222,224,226,229,232-234,238,241$, $244,247-250,252,254,257-264$, 270-275, 277-279, 281, 296-298, 303. 307,313

Rechtsstiat 7, 12, 20, 23, 122, 123, 144, $164,284,305-307,310,331$

Recrutering $40,46,95,143,153,166$, 211,237

Rent wars 246, 247

Republiek 75, 76, 78-80, 96, 108, 116, 139,306
Screening commission 224, 337

Selectic $6-10,12,13,15-18,24,25$, $31-33,38-43,52,63-69,143,145,147$. $151-153,155,156,158,168,171-173$. $199,203,204,206,208,210,211$. $213,214,216,221,229,233,237$, $240,242,246-249,252,253,255-257$, $259,263,265,266-268,270,273,277$, $280,281,283,293,306,322,324$, $326,327,328,329$

Short Ballot Movement 259, 260

Souvereine Vorst 75, 77-79, 81, 87

Staatscommissic Herziening Rechterlijke Organisatic $39,59,60,66,153,163$, $174,182,190,206,209,210,215$, $217,284,293$

Stakingsrocht $185,187,301$

Supreme Court $13,15,24,74,80,83$, $207,223-225,228,230-233,239,240$, $244,248,249,251,255,256,263$, $266-268,270,272,274-278,311,315$ Surrogate's Court 223, 224

Tammany Hall 250, 251, 254-257, 260, 264

The Forty Thieves 117,251

Toetsingsrecht $122,204,214,217$, 284-291, 294-298, 300-303, 305, 307. $308,313,314,325$

Trias politica $7,283-285,302,308,309$, 317

Tweed Ring 251, 259

Tweede Kamer 3, 5-8, 17-20, 23, 32, 35, $53-56,67,74,76-79,82-86,891-93,96$, $98-100,102,103,105,106,108-117$, $119-123,128,130,131,135,137,139$, $143,147,148,149,151-153,155,159$, $161,168,170,178,181,183,192$, $193,195,196,198,200-206,208,211$, $214,215,252,270,281,285,291$, $293,294-296,299,300,304,306,307$, $316,324,325,329$

Twofers 235

U.S. Supreme Cour 13, 15, 233, 248, $263,270,274,277,278,311,315$

Vertrouwenscrisis $22,153,209,213,214$, $293,300,324,325$ 
Voordracht $5,7,20,32,38,53-56,74$, $78-82,112-115,119-123,159,162$, $167,169,171,176,183,200-202,204$, $206,208,211,224,228,235-237,255$, $262,263,285,296,299,307$

Vrouwen $10,12,25,59,61,124-138,145$, $199,200,233,271,279,280,330$
Werving $7,31,39-41,46,47,63,64,66$, $67,69,171,206,210,213,214,216$, $283,306,322,324,328$

Wettelijke grondslag $38-41,49,69,216$. 224,324

Zelfselectie 15,65 


\section{Personenregister}

Abraham, H.J. 79, 266

Appeven, H. 344

Asscher, B.J. 186, 188, 221, 331

Aurelio, A. 256,257

Baars, J. van 68

Bard, A.S. 245

Barendrecht, J.M. 295

Beaufort, H.L.T. de 80

Beelaers van Blokland, G.J.Th. 117, 121, $122,252,288,299$

Bergh, G. van den 35, 36

Bird, R.E. 267

Blythe Stason, E. 27

Boer, Th.M, de 26, 27

Bordewijk, F. 141, 142

Brauw, L. de 102

Brennan, W.J. 312

Brenninkmeijer, A.F.M. 7, 205, 206

Brongersma, E. 156

Bruinsma, F. 20, 21, 184, 205

Buijs, J.T. 14, 35-37, 79, 299

Burg, V.A.M. van der $7,8,19,54,56$, 200-205, 207, 214, 215, 303-305, 325, 329,330

Carbon, S.B. 124

Chemerinsky, E. 20, 311-313, 317

Cliteur, P.B. 285, 287, 290

Cluysenaer, O.J. 132-134

Cnoop Koopmans, A.J. 19, 158, 159 , $168-173,183-190,199,202,214,301$, 304,325

Colenbrander, H.T. $75,81,82,86,87$

Costello, F. 256

Cuomo, M.M. 236, 237, 257, 274, 278

Delden, A.H. van 197, 204, 205

Demmink, J. 5, 212

Dinkins, D.N. 238
Donker Curtius, D. 112, 120, 288

Drion, H. 314

Dubbink, C.W. 167, 172, 187

Dubris, P.L. 272

Eaton, D.B. 118,250

Feerick, J.D. 227, 228, 231, 253, 258

Fish, P.G. 273

Flick, A.C. 250, 251

Fockema Andreae, J.P. 314-316

Frank, J. 199, 256. 257, 331

Gershwin, G. 25

Giltay Veth, D. 157,158

Gitterman, J.M. 243

Grasserie, R. de la 16, 124

Gregory, A.F.L. 115, 116, 275

Groot-van Leeuwen, L.E. de 198-200, 207

Haak, W.E. $171,172,194,202$

Haeften, C.H.J. van 289

Hamilton, A. 4, 80, 243, 249

Hampden Dougherty, J. 244

Haynes, E. 234, 299

Heemskerk, A. 107, 108, 114-117, 119. 120,128

Heemskerk Azn, J. 114, 117

Heide, J. ter $66,160,161$

Hermesdorf, B.H.D. 76

Heymans, G. 127, 132-137, 280

Hoefnagels, G.P. 142

Hoekema, A.J. 159, 198

Holland, H.J.A. 153, 154

Hogan, F.S. 256, 257

Hogendorp, G.K. van 75, 78-82, 86, 96

Houten, B.W. van 83, 115, 120-122, 164

Hoynck van Papendrecht, A. 100, 101 , $106,116,292$

Hubbard, E.B. 24, 279 
Hugenholz, P.H. 159,160

Hulsman, L.H.C. 160

Idsinga, J.W.H.M. van 292

Ingelse, P. 50-52, 63

Jay, J. 242,248

Josten, M. 11, 20, 198, 200, 207, 208, 301,321

Jurgens, E.C.M. 204, 288, 294, 302

Kalcs, A.M. 4, 262-265, 268, 274, 298

Kate, J. ten $47,55,56,74,114,120,122$, 123

Kirchheiner, H.H. 184

Klots, A.T. 257

Koch, E.I. 236-238, 249

Koupmans, T. 19, 158, 159, 168-173, $183-190,199,202,203,214,297$. $301,304,314,325$

Koppen, P.J. 47, 55, 56, 74, 114, 120, 122, 123

Korthals Altes, F. 188, 190, 192, 195

Kortmann, C.A.J.M. 3, 4, 16, 41, 55, 183

Kuitenbrouwer, F. 142, 202

Kummeling, H.R.B.M. 18, 305

Langemeijer, G.E. $144-146,158,160$, 161,210

Laski, H.J. 4, 17, 233, 265

Lasser, W. 13

Lee, N.J. van der 8-10, 24, 43

Leijten, J.C.M. 10, 12, 66, 158, 160, $161,171,199,207.314,315$

Levy, J.A. $116,115,116$

Lieber, F. 250

Lincoln, C.Z. 79, 241, 244

Lindo, C. 184,189

Loder, B.C.J. 117, 251

Loke, J.J. 105, 106, 108, 109

Maanen, C.F. van 75, 80-82, 87, 308, 309

Maarseveen, $H$. van $20,135-138,199$, 205-207

Madison, J. 249, 283

Mszel, P.E. 144

Melai, A.L. 187

Mitgang, H. 256

Molenaar, B. $188,192,221$

Motley, C.B. 26, 271, 279
Nagel, S.S. 234, 272

Nijpels, E. 20, 201

Niles, R.D. 245-247, 258

Nivard, F.J.M. 142, 173-175, 186

Noyon, J.T. $12,129,130,132$

Oppenheimer-Belinfante, D.R.E. 133, 134

Opzoomer, C.W. 288

Oven, J.C. van $13,151,189,316$

Perry, B.A. 74

Pessers, D. $321,322,331$

Pieterman, R. 79

Pinner, J. 95

Pinto, A. de $79,83,92,95,96$

Polak, C.H.F. $156,157,162$

Pols, J. 100, 106-109, 292, 306

Pompe, W. 138

Popper, K.R. 25

Pot, C.W. van der 36, 37, 309

Pound, R. 263. 299

Prakke, L. 290, 302

Ras, H.E. $65,66,195,196,205$

Rehwinkel, J.P. 18

Rijksen, R. 154

Roc, R.A. 15, 63, 73

Rocthof, H.J. 20, 180, 187, 201

Roos, N.H.M. 11, 294

Rout. E. 254, 259, 260

Rosenherg, M. 10,11,24, 233, 237, 273

Rossem, M. van 264

Ruiter, J. de 161, 299

Savornin Lohman, A.F. de 111, 121

Savornin Lohman, O. de 314

Scheltema, F.G. 132, 133

Seabury, S. 256, 257

Simons, D. 125-127, 132, 145

Singer-Dekker, H. 155-158, 202

Slooten, G. van 73

Smits, P.R. 49, 173

Stheeman, U.W.H. $155,163,164,184$

Stolz, P. 267

Storing, H.J. 250

Story, J. 244, 264

Stroink, F.A.M. 3, 59, 286

Struycken, A.A.H. 291-294, 306 
Taft, H.W. 254-256, 259, 261, 263

Tellegen, B.D.H. 75, 81, 114-116, 118 , 221,222

Thorbecke, J.R. 78-82, 112, 113, 120

Tijn, J. van $11,20,188,190,198,200$, $207,208,301$

Trollope, A. 117,118

Twaalfhoven, D.F.M. 59

Uyl, J.M. den $158,185,189$

van Boven, M.W. $76,78,80$

Vance, C.R. 227, 228, 231, 253, 257, 258
Veen, Jac. van 164,165

Verloren, J.P. 35-37

Wichers Hoeth, L. 170

Winter, R.E. de $3,181,314$

Winters, G.R. 242, 245, 250, 255, 269

Wintgens, W. 95

Witteveen, W.J. 284, 309-313, 317

Wtcwat Stoetwegen, C.W. van 136, 137

Zonderland, P. 172 



\section{Curriculum vitae}

Marc de Werd werd op 11 september 1962 geboren te 's-Hertogenbosch. In 1982 haalde hij het VWO-diploma aan het Monseigneur Zwijsen College te Veghel, en in 1989 behaalde hij het doctoraal examen in de studierichting Nederlands Recht aan de Katholieke Universiteit Nijmegen. In 1989 werd hij assistent in opleiding bij de vakgroep Publiekrecht van de Faculteit der Rechtsgeleerdheid van de Rijksuniversiteit Limburg. In het voorjaar van 1992 deed hij ten behoeve van zijn dissertatie onderzoek aan Columbia University School of Law in the City of New York. Sinds 1994 is hij als universitair docent staats- en bestuursrecht aan de vakgroep Publiekrecht van de RL verbonden. 


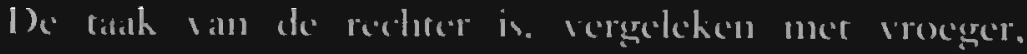
belangrijk veranderd. We hex.e'n de krant mair opent te

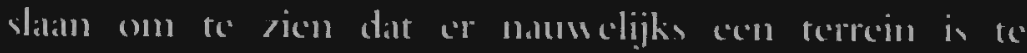
bedenken walrep de rechter zich niet heweegt. Al unel rịjte de valagy of de rechterlijhe macht voror dic talah wel voldoxende galegitimeerd is. W ie is dic rechter eigenlijh. dat hij zich soms als ene "wetgeror-platetsors anger"

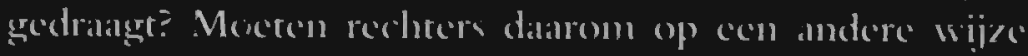
worden benosend. mocten ハ misschien gekozen worden: ()f ligt daar niet het echte probleem:

Deze studic pougt de reled ante aspecten van het waing-

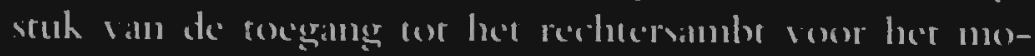

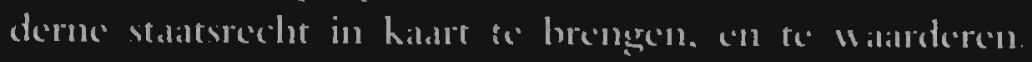

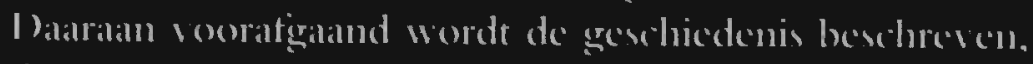
die: alan het ontstam vill dit stelscel ten grondslang heceft gclegents.

(1) de discusic over de toxgang tiet het rechersimbt. 'n wer de legitiniteit valn de rechter, relieft te geven, wordt in dit bock andache besteed an de rerkicying van rechters in de Amerikamse dechatalt New York. 